A 969852

Krzysztof Jakubczak

\title{
POZA BYTEM I NIEBYTEM FILOZOFIA BUDDYJSKA WOBEC ZARZUTU NIHILIZMU
}

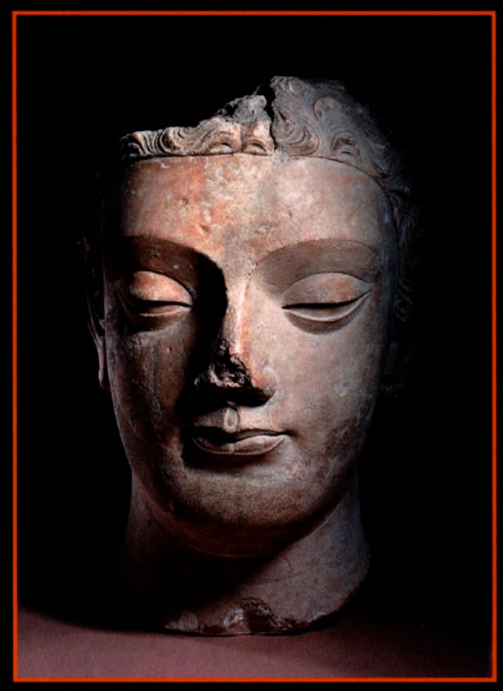

K S I E GAR N I A A K A D E M I C K A 



\section{POZA BYTEM I NIEBYTEM}

Filozofia buddyjska wobec zarzutu nihilizmu 


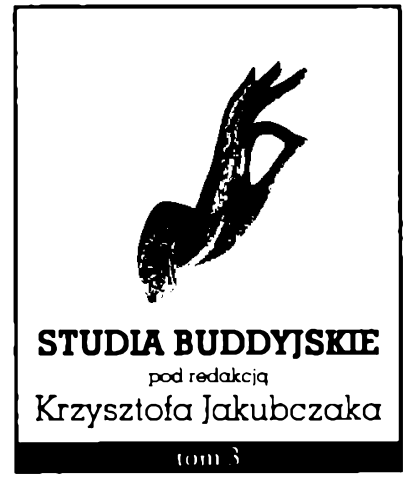

Rada naukowa:

dr hab. Krzysztof Kosior (prof. UMCS)

dr hab. Joanna Grela (prof. UJ)

dr hab. Przemysław Szczurek (prof. UWr) 
Krzysztof Jakubczak

\title{
POZA BYTEM I NIEBYTEM
}

\author{
Filozofia buddyjska \\ wobec zarzutu nihilizmu
}


Copyright by Krzysztof Jakubczak @ , 2019

Recenzent

dr hab. Krzysztof Kosior

Redakcja

Marta Stęplewska

Projekt okładki

Igor Stanisławski

Zdjęcie na okładce: Głowa Buddy Siakjamuniego, Gandhara lub Afganistan IV w., stiuk (Los Angeles County Museum of Art, domena publiczna)

Publikacja dofinansowana przez Wydział Studiów Międzynarodowych i Politycznych Uniwersytetu Jagiellońskiego

ISBN 978-83-8138-115-4 (druk)

ISBN 978-83-8138-188-8 (online, PDF)

https://doi.org/10.12797/9788381381888

\section{WYDAWNICTWO KSIĘGARNIA AKADEMICKA}

ul. św. Anny 6, 31-008 Kraków

tel./faks: 124312743,124211387

e-mail: akademicka@akademicka.pl

Ksiegarnia internetowa: https://akademicka.pl 
Mojej córce, Michalinie, kroczącej wlasna ściezka, po której szlo już wiele(-u). 
nayidam bhikkbave brabma-cariyam vussati jana-kubanattham na jana-lapanattham na läbha-sakkāra-silokānisamsattham na iti mam jano jänātū-ti. atba kbo idam bhikkbave brabma-cariyam vussati samviaratthaññeva pabānatthañcā-ti.

Mnisi, żyje się tym świątobliwym życiem nie dla zwodzenia (kubanā) ludzi, nie dla schlebiania (lapanā) ludziom, nie dla korzyści (läbba), zaszczytu (sakkära), sławy (siloka), zasługi (anisamsa), [myśląc:] „Niechaj mnie ludzie tak poznają”. Zaprawdę, mnisi, żyje się tym świątobliwym życiem tylko dla powściągnięcia (saṃvara) i porzucenia (pabāna).

Budda

Pierwsze kazanie o niezwodzeniu (Pațama-nakubana-sutta), Iti-vuttaka 35/28 


\section{Spis treści}

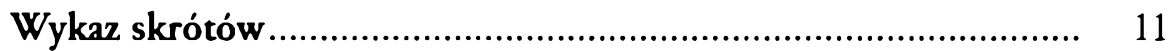

Literatura źródłowa .............................................................. 11

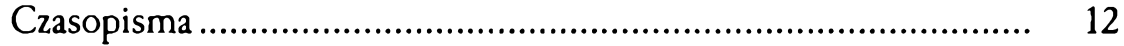

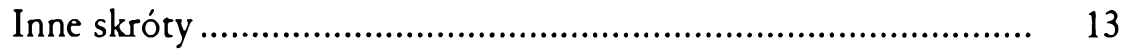

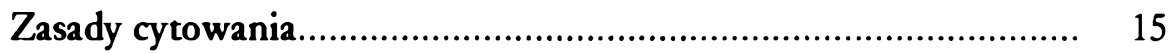

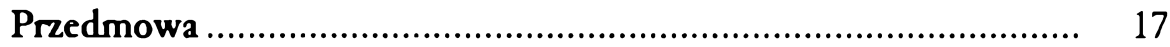

\section{Wprowadzenie}

1. Problem nihilizmu ................................................................ 21

1.1. Nihilizm jako kategoria deskryptywna i ewaluacyjna............. 25

1.2. Różne rodzaje nihilizmu ................................................... 28

2. Problem buddyjskiego nihilizmu .............................................. 31

2.1. Budda jako nihilista ......................................................... 31

2.2. Nihilizm madhjamaki..................................................... 34

3. Założenia metodologiczne ........................................................ 43

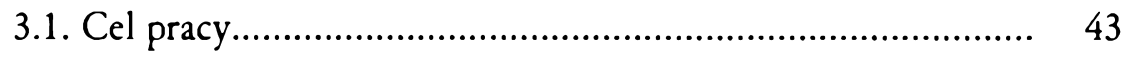

3.2. Jaki materiał będzie badany................................................. 47

\section{Część pierwsza „JEŻELI BYTU NIE MA..." BUDDYZM JAKO FILOZOFLA NICOŚCI?}

1. Poza istnieniem i nieistnieniem, czyli o rozumieniu dharmy Buddy

1.1. Droga środka w Kazaniu do Katjajany 
1.2. Idea świata w myśli Buddy......................................... 56

1.3. Dwa krańce - istnienie i nieistnienie .............................. 67

1.4. Widzenie powstawania i ustawania jako remedium na istnienie i nieistnienie

1.5. Zasada zależnego powstawania jako środkowa droga............ 92

1.5.1. Ontologia fundamentalna a ontologia dystrybutywna .. 96

1.5.2. Antyrealizm Buddy........................................... 104

1.5.3. Nauka o zależnym powstawaniu ............................ 123

2. Poza bytem i niebytem, czyli droga środka w madhjamace Nagardzuny .................................................................. 153

2.1. Znaczenie Kazania do Katjajany w myśli Nagardżuny........... 153

2.2. Istnienie i nieistnienie we wczesnej literaturze mahajany ...... 155

2.3. Środkowa droga jako pustka ....................................... 190

\section{Część druga \\ PRAWDA JAKO PRZEDMIOT LGNIECCIA POZA ABSOLUTYZMEM I NIHILIZMEM EPISTEMOLOGICZNYM}

1. Nauka Buddy jako sceptycyzm..

1.1. Poznanie, widzenie, mądrość

1.2. Czym jest sceptycyzm?

1.3. Sceptyczne tendencje we wczesnym buddyzmie 270

1.4. Prawda a kwestia nastawienia poznawczego. 276

1.5. Lgnięcie do prawdy jako problem epistemologiczny.... 285

1.5.1. Spór jako sposób wyrażania się lgnięcia 304

1.5.2. Wątpienie jako sposób wyrażania się lgnięcia.. 312

1.5.3. Zarzut wewnętrznej sprzeczności

1.5.4. Jaką rolę odgrywa pogląd jako przedstawienie?.

1.5.5. O języku nauczania

1.6. Dlaczego Nagardżuna nie posiada własnych poglądów?

1.7. Dlaczego buddyzm nie ma nic wspólnego ze sceptycyzmem?..

2. Widzenie pustki a doświadczenie mistyczne

2.1. Buddyzm jako mistycyzm

2.2. Cechy doświadczenia mistycznego

2.3. Madhjamaka jako mistyka

2.4. Pustka a Nicość 
2.5. Sens milczenia w madhjamace.

2.6. Dlaczego poznawcze doświadczenie jogiczne nie jest doświadczeniem mistycznym?

Uwagi końcowe 401

\section{Dodatki}

Apendyks 1. Kazanie do [pewnego] bramina (Brābmana-sūtra) ........ 407

Apendyks 2. Kazanie do Katjajany (Kätyayana-sütra)...................... 409

Bibliografia 413

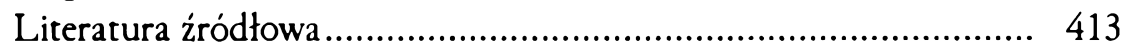

Literatura buddyjska..................................................... 413

Indyjska literatura niebuddyjska ..................................... 422

Nieindyjska literatura..................................................... 423

Literatura ogólna ................................................................. 423

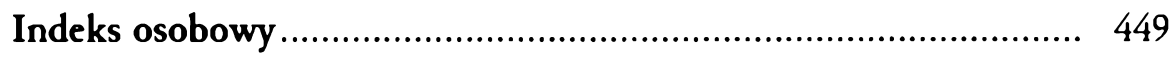

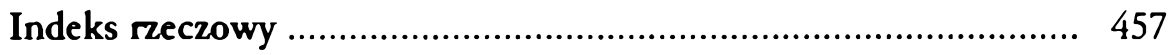

Summary. Beyond being and non-being. Buddhist philosophy against the charge of nihilism. 



\section{Wykaz skrótów}

\section{Literatura źródłowa}

(w nawiasie transkrypcja polska)

AK - Abbidbarma-kośa (Abbidharmakosia)

AKB - Abbidharma-kośa-bhassya (Abbidbarmakosiabhaszja)

AM - Adversus mathematicos (Przeciw matematykom)

AN - Anguttara-nikaya (Anguttaranikaja)

AS - Așta-säbasrikāa-prajña-pāramita-sūtra (Asztasabasrikapradżniaparamitasutra)

BĀU - Brhad-aranyakopanișad (Bribadaranjakopaniszad)

ChU - Chändogyopanisad (Czhandogjopaniszad)

CS - Catub-stava (Czatubstawa)

CŚ - Catub-śataka (Czatubsiataka)

DhP - Dhamma-pada (Dhammapada)

DhS - Dhamma-sañgani (Dhammasangani)

DN - Digha-nikaya (Dighanikaja)

KP - Kásyapa-parivarta-sūtra (Kasjapapariwartasutra)

MMK - Müla-madhyamaka-karikā (Mulamadbjamakakarika)

MN - Majjhima-nikaya (Madżdżbimanikaja)

MU - Mandükyopanișad (Mandukjopaniszad)

NidSa - Nidana-samyukta (Nidanasanjukta)

$\mathrm{PH} \quad-$ Pyrrboniae hypotyposes (Zarysy pirrońskie)

PP - Prasanna-pada (Prasannapada)

PVS - Pañca-vimíati-sābasrika-prajña-pāramitā-sūtra (Pańczawińsiatisabasrikapradżniaparamitasutra) 
$\mathrm{RA} \quad-$ Ratnavalī (Ratnawali)

RGS - Prajñā-paramitā-ratna-guna-samcaya-gātbāa(Pradìniaparamitaratnagunasańczajagatba)

RV - Rg-veda (Rigweda)

$\mathrm{SA}$ - Samyuktāgama (Sanjuktagama)

SK - Sämkbya-kärikä (Sankbjakarika)

SN - Samyutta-nikāya (Sanjuttanikaja)

Sn. - Sutta-nipata (Suttanipata)

ŚS - Ś̄nyata-saptati (Siunjatasaptati)

$\mathrm{T}$ - Taishō Tripitaka

Ud. - Udāna (Udana)

VC - Vajra-cchedikā-prajñ̄a-pāramitāa-sūtra (Wadizraczczbedikapradżniaparamitasutra)

VM - Visuddbi-magga (Wisuddbimagga)

VP - Vinaya-pitaka (Winajapitaka)

YṢ - Yukti-șaștikä-kärikā (Juktiszasztikakarika)

VV - Vigraba-vyavartanī (Wigrabawjawartani)

\section{Czasopisma}

$\mathrm{AM}$ - „Asia Major”

AO - „Acta Orientalia”

APh - „Asian Philosophy”

ARIRIAB $-{ }_{n}$ Annual Report of the International Research Institute for Advanced Buddhology"

BSOAS - „Bulletin of the School of Oriental and African Studies”

BSR - „Buddhist Studies Review”

$\mathrm{CB}$ - "Contemporary Buddhism"

HR - "History of Religions”

IHQ - "Indian Historical Quarterly"

IIJ - „Indo-Iranian Journal”

JAOS - "Journal of the American Oriental Society"

JCBSSL - "Journal of the Centre for Buddhist Studies, Sri Lanka”

JChP - "Journal of Chinese Philosophy"

JLABS - "Journal of the International Association of Buddhist Studies" 


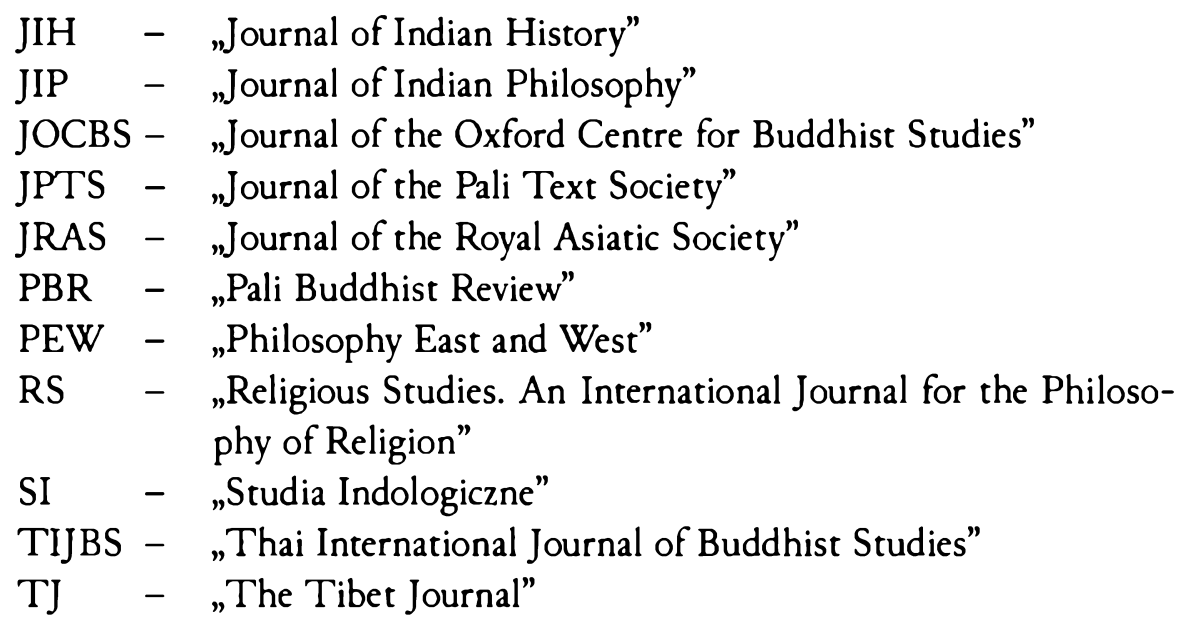

\section{Inne skróty}

p. - pali

s. - sanskryt

t. - tybetański 



\section{Zasady cytowania}

Teksty kanonu palijskiego przytaczam w oparciu o redakcje Pali Text Society. W opisie DN, MN, SN i AN cyfra rzymska oznacza tom, arabska zaś numer strony. W DN i MN tam, gdzie to było wskazane, podałem w nawiasie także numer sutty. SN przywołałem kilka razy, podając numer sanjukty i po kropce sutty. Sn. i DhP przywołuje podając numer strofy zgodnie z całościową i jednolitą numeracją wszystkich strof $\mathrm{w}$ tekście. Ponadto $\mathrm{w}$ wypadku $\mathrm{Sn}$. często podaje też, rozdzielając kropkami, numer rozdziału (cyfrą rzymską), sutty oraz numer strofy w sutcie, a w wypadku DhP numer rozdziału (cyfrą rzymską) i po przecinku numer strofy w rozdziale. Ud. cytuję, podając numer strony. AS przywołuję, podając numer strony według redakcji Rājendralāli Mitry. RGS cytuję, podając numer rozdziału (cyfra rzymska) i numer strofy (cyfra arabska). KP przytaczam, podając numer paragrafu według redakcji Alexandra von Staël-Holsteina. MMK, RĀA AK oraz kilka innych tekstów o analogicznej strukturze przywołuje, podając rozdziat (cyfra rzymska) i po przecinku numer strofy (cyfra arabska). MMK przytaczam zasadniczo w oparciu o redakcję Jana Willema de Jonga, chociaż, tam gdzie ma to znaczenie, uwzględniam także inne redakcje. CŚ cytuję, podając numer hymnu (cyfra rzymska) według redakcji Christiana Lindtnera oraz numer strofy (cyfra arabska). Pozostałe teksty Nagardżuny przytaczam, podając numer strofy. PP przywołuję, podając numer strony według redakcji Louisa de la Vallée Poussina oraz tam, gdzie to niezbędne, po kropce numer wiersza. Drobne różnice w tekście w stosunku do 
tej redakcji, takie jak przecinki, są wynikiem uwzględnienia redakcji Parashuramy Lakshmany Vaidyi. Sposób cytowania innych tekstów nie powinien sprawiać większych trudności, jeżeli chodzi o umiejscowienie przywoływanych fragmentów w tekstach źródłowych. Różnice w sposobie przywoływania tekstów (np. stosowanie znaków zapytania, przecinków, kropek bądź dandy, tj. pojedynczej lub podwójnej pionowej kreski) wynikają $z$ różnych zasad ich pierwotnego redagowania. Czasami, choć sporadycznie, te zasady zmieniałem. Tym, z czego całkowicie zrezygnowałem, przywołując tekst oryginalny, są wielkie litery, które w niektórych redakcjach pojawiają się w zapisie nazw własnych i słów otwierających zdania. Sanskryt i pali ich nie znają, a niemal zawsze cytaty z tekstu źródłowego opatruję przekładem, więc w braku wielkich liter nie widzę żadnej straty. Tam, gdzie tekst na to pozwalał, w związku z brakiem zmian sandhicznych, starałem się wydzielać poszczególne słowa w zbitkach, wprowadzając dywiz. 


\section{Przedmowa}

Filozofowanie jest zajęciem głęboko intymnym. Przynajmniej dla mnie zawsze takim było. Przemiany, jakie dokonują się we współczesnej kulturze naukowej, pogłębiały moją niechęć do tego, aby tę intymność przeliczać na punkty. To jest bodaj gtówny powód, dla którego od momentu pojawienia się pomysłu niniejszej książki do jego ucieleśnienia $w$ druku upłynęło wiele czasu. Zdecydowanie zbyt wiele, jeśli mierzyć w kategoriach akademickich standardów. Żadne jednak akademickie wymogi nie były w stanie zmotywować mnie do przyspieszenia pracy. Ponadto do pewnych idei trzeba dojrzeć. Przeświadczenie to potęgowało się w zetknięciu z przesłaniem, jakie niesie myśl dwóch postaci, które w niniejszej książce zajmują dominującą pozycję - Buddy i Nagardżuny.

Proces dojrzewania zapewne by jeszcze trwał, gdyby los nie wziął sprawy we własne ręce i nie skonfrontował mnie boleśnie $z$ doświadczeniem nietrwałości. Dopiero konieczność zaakceptowania utraty większości z tego, co przez wiele lat było dla mnie najcenniejsze, stanowiła impuls na tyle silny, abym podjął wysiłek zobiektywizowania intuicji i przekonań, jakie od dawna mi towarzyszą podczas lektury tekstów wiązanych ze wspomnianymi myślicielami.

W ostatnich trzech latach w związku z osobistą sytuacją nurtowało mnie pytanie o cenę, jaką płacimy za nasze myśli, słowa oraz czyny. Podejrzewam, że refleksja nad tym dylematem odcisnęła piętno na treści niniejszej publikacji. Mam jednak nadzieję, że udało mi się ją 
wpisać $\mathbf{w}$ uniwersalny wymiar prowadzonej w niej analizy. Zresztą pobrzmiewający, być może, w niektórych miejscach osobisty ton, nie stanowi dla mnie wielkiego problemu ze względu na sposób traktowania filozofii. Kilkakrotnie jednak powątpiewałem w sens dzielenia się tymi intuicjami i przemyśleniami. Dzięki wsparciu, jakie w tym czasie otrzymałem od paru osób, udało mi się tę wątpliwość przezwyciężyć. Niech ta książka będzie formą podziękowania za Waszą życzliwość. Była i jest dla mnie bezcenna. 


\section{Wprowadzenie $>+4)-60$}





\section{Problem nihilizmu}

Zarzut nihilizmu jest, przynajmniej w potocznym odczuciu, najcięższym oskarżeniem, jakie można postawić filozofii - oskarżeniem, którym, począwszy od końca XVIII w., szermowano w myśli i kulturze europejskiej nader często. Toteż niewielu filozofów gotowych jest otwarcie się do nihilizmu przyznawać, a ci, którzy to czynią, zwykle deklarują ograniczenie jego zasięgu do obszaru aksjologii, etyki czy też po prostu kwestii sensu życia.

Chociaż sam termin „nihilizm” zaczął robić karierę w kulturze europejskiej późno, bo dopiero w XIX w., to postawy i przekonania, które desygnuje, mają długą historię sięgającą $\mathrm{V}$ w. p.n.e. Za patrona europejskiego nihilizmu uznać można bez wątpienia Gorgiasza z Leontinoi (ok. 483-374 r. p.n.e.) ${ }^{1}$, który swoimi trzema tezami głoszącymi, iż nic nie istnieje, jeżeli coś istnieje, to nie może być poznane, a jeżeli może być poznane, to nie może być wyrażone, otworzył obszar refleksji, który zdaniem wielu myślicieli, szczególnie o platońskich inklinacjach, miał nieść ogromne zagrożenie dla kultury europejskiej, a nawet dla samego człowieczeństwa. Zwykle podkreśla się, że chociaż tezy owe są bezkompromisowe i obrazoburcze, nie jest pewne, jak sam Gorgiasz do nich się ustosunkowywał. Wielu afirmacja nieistnienia niczego w kontekście doświadczenia codziennego wydaje się absurdalna, stąd sądzą, iż stanowi ona jedynie retoryczny kalambur. Inni gotowi są twierdzić, iż Gorgiasz głosił swoje przekonania z całą powagą. Bez

Zob. J. Gajda, Sofiści, Warszawa 1989, s. 230-231. 
względu na to, czy grecki filozof z pełnym przekonaniem afirmował nicość, czy też oddawał się tylko intelektualnej prowokacji, nie ma wątpliwości, iż bezpośrednim adresatem jego krytyki była koncepcja Parmenidesa (koniec VI - poł. V w. p.n.e.) z jej naczelną tautologicznie brzmiącą tezą o byciu bytu i niebyciu niebytu. Wykorzystując (być może tylko utylitarnie) tę samą co Parmenides i jego eleaccy uczniowie ufność pokładaną w logosie i dialektyce, Gorgiasz bronił radykalnie przeciwstawnego obrazu świata, w którym to nicość - a nie byt - jawiła się jako bardziej oczywista. Tu tkwi źródło oskarżeń tego myśliciela o nihilizm - przekreślając byt, Gorgiasz miał wykreślać z ludzkiego doświadczenia wszelkie stałe, a tym samym realne i ostateczne punkty odniesienia, wobec których powinniśmy się orientować zarówno w życiu indywidualnym, jak i społecznym. Na pierwszy plan wysuwał on praktykę życia codziennego zrelatywizowaną, zdaniem krytyków, do przygodnych i przede wszystkim egoistycznych celów jednostek. Parmenides sformułował pierwszą metafizyczną koncepcje bytu, Gorgiasz zaś jako pierwszy przeciwstawił jej metafizyczny nihilizm, który pociągał za sobą nihilizm epistemologiczny.

Bezpośredni atak na eleatów stawiał pośrednio problem rozumienia niczego. Piszę „pośrednio”, gdyż sam Gorgiasz, jak się wydaje, nie zadawał sobie takiego pytania. Swoimi tezami, w których bytowi przeciwstawiał nic, prowokowat jednak do postawienia pytania o możliwość rozumienia niczego, które to pytanie pojawi się dobitnie w Platońskim Sofiście.

Gdyby range problemu filozoficznego mierzyć liczbą słów wypowiedzianych na jego temat w dziejach, to kwestię rozumienia niczego, nicości i niebytu należałoby uznać w myśli europejskiej za wiodącą. Oczywiście ma to związek z tym, że zagadnienie nicości jawi się jako lustrzane odbicie pytania o byt. Refleksje nad tym ostatnim w metafizyce europejskiej będzie się zwykle postrzegać jako naznaczoną brakiem, jeżeli pomija ona bądź lekceważy problem nicości.

Czy jednak wiemy, o czym mówimy, gdy mówimy o niczym? Czy o niczym (nicości) można w ogóle sensownie cokolwiek powiedzieć? 
Jednej z najgłośniejszych i w związku z tym najczęściej przywoływanych negatywnych odpowiedzi na te pytania udzielił na początku XX w. Henri Bergson (1859-1941) w książce Ewolucja twórcza². W czwartym rozdziale owej słynnej pracy autor obszernie dowodzi, że pojęcie nicości jest faktycznie pojęciem pozornym, tzn. nie jest pojęciem w ogóle, tylko pustym słowem, pod którym kryją się treści ujawniające przy skrupulatnej analizie swoją wewnętrzną sprzeczność.

W argumentacji Bergsona pojawiają się co najmniej dwa uzupetniające się wątki. Po pierwsze francuski filozof stara się przedstawić proces konstytuowania się pojęcia nicości i wskazać momenty, w których dokonuje się nieuprawniony przeskok myśli. Dzięki z jednej strony władzy pamięci, a z drugiej zdolności wybiegania myślą w przyszłość umysł może odnieść obraz stanu obecnego do obrazu stanu minionego i pojąć to odniesienie jako unicestwienie stanu przeszłego przez obecny. Owo poczucie unicestwienia i nieobecności znajduje wzmocnienie $\mathbf{w}$ uświadomieniu sobie, że stan obecny nie jest stanem oczekiwanym, a zatem jest „niczym”. Rozciągając to poczucie na wszelkie możliwe stany czy przedmioty, na całość rzeczywistości, uzyskuje sį̨ „pojęcie” nicości rozumiane jako zniweczenie wszystkiego. Problem polega na tym, mówi Bergson, iż to rozciągnięcie jest $w$ istocie pozorne, a zniweczenie czy unicestwienie zachodzi tylko dla nas. Jest pozorne, ponieważ z możliwości myślenia zniweczenia każdej rzeczy po kolei, wnosi się błędnie możliwość przypuszczenia, iż zniweczone mogą być wszystkie rzeczy naraz. Błąd ma charakter logiczny, twierdzi Bergson, i jest analogiczny do sprzeczności tkwiącej w nazwie kwadratowego koła. Co więcej, unicestwienie zachodzi tylko względem naszych oczekiwań i wspomnień, faktycznie mamy do czynienia nie z nicestwieniem jednego stanu przez drugi, z usuwaniem jednej rzeczy przez drugą, lecz z zastępowaniem jednej pełni przez drugą. Wątek ten można by, jak sądzę, podsumować stwierdzeniem, iż Bergson

2 H. Bergson, Ewolucja twórcza, thum. F. Znaniecki, Kraków 2005 (1 wyd. 1907). 
głosi, że warunkiem myślenia nicości jest istnienie i jest to warunek nieusuwalny pod zakazem logicznym ${ }^{3}$.

Przeświadczenie to znalazło rozwinięcie $\mathrm{w}$ drugim wątku argumentacji Bergsona, którego treścią jest analiza przeczenia i negacji. Punktem wyjścia uczynił francuski filozof twierdzenie Immanuela Kanta głoszące, że pojęcie istnienia nie wnosi żadnej jakościowej treści w pojęcie przedmiotu. Kant na owym twierdzeniu zbudował rozumowanie wykazujące błędność dowodu ontologicznego na istnienie Boga. Bergson natomiast posłużł się nim, aby wykazać, że przeczenie jest sądem drugiego stopnia, tzn. tylko pośrednio odnoszącym się do rzeczywistości, bezpośrednio zaś - zawsze do jakiegoś sądu twierdzącego, który wprost ujmuje pewien aspekt rzeczywistości. Ponadto przeczenie ma charakter pedagogiczny i społeczny, gdyż ukierunkowane jest zawsze na kogoś jako rodzaj ostrzeżenia i przestrogi przed popełnieniem błędu wyrażającego się w sądzie twierdzącym. W konsekwencji stwierdzanie nieistnienia jest zawsze tylko stwierdzaniem różnicy między stanem faktycznym, a stanem przez kogoś błędnie domniemanym ${ }^{4}$.

Argumenty Bergsona uderzają przede wszystkim w możliwość myślenia nicości jako „stanu” bezwzględnego ${ }^{5}$. Można mieć jednak wątpliwości, czy taki sposób jej pojmowania dominował w filozofii europejskiej. Poniekąd już Parmenides twierdził przecież, że niebytu jako całkowitego przekreślenia bytu nie ma i nie może być on nawet sensownie pomyślany. Jeżeli więc próbujemy myśleć niebyt, to zbaczamy $z$ drogi prawdy. Problem Parmenidesa polegat jednak na tym,

$\mathrm{Na}$ temat pierwszego argumentu zob. ibidem, s. 226-230.

Ibidem, s. 230-239; zob. także W. Stróżewski, Ontologia, Kraków 2003, s. $162-165$.

5 Warto w tym miejscu zaznaczyć na marginesie, że krytyka i odrzucenie możliwości sensownego myślenia nicości jest $w$ filozofii Bergsona tylko fragmentem integralnie związanym ze znacznie obszerniejszą krytyką obejmującą wiele klasycznych pojęć metafizyki, takich m.in. jak byt, ciało, jakość, forma, istota czy ruch. Rozważając wartość krytyki nicości, często się o tym fakcie zapomina. 
że o ile bezwzględną nicość łatwo było zdyskredytować, jako że zdaje się kłócić z codziennym doświadczeniem, to bezwzględny, absolutny, statyczny byt pozostawał $\mathrm{z}$ tym doświadczeniem $\mathrm{w}$ konflikcie $\mathrm{w}$ stopniu nie mniejszym. Filozof z Elei niedogodność tę zdecydował się usunąć w sposób tyle przejrzysty, co pozorny - stwierdzit, iż w obszarze zmiennego doświadczenia codziennego dostęp do prawdy jest zamknięty, a sfera zjawisk jest wyłącznie sferą mniemania. Jako że mniemanie uchwytuje tylko zjawiska, nigdy nie uzyska waloru prawdy, czyli stałości i niezmienności. Rozwiązanie to jest pozorne, gdyz unieważniając poznawczą wartość codziennego doświadczenia, nie odpowiada na pytanie, jak w ogóle w świecie niezmiennego bytu możliwe jest zrealizowanie się obszaru codziennej praktyki i jaki faktycznie jest jego bytowy status.

Napięcie między bytem a niebytem leży u podstaw myślenia buddyjskiego. Rewolucyjność myśli Buddy będzie polegała na sposobie, w jaki potraktuje on to napięcie, a konkretnie na sposobie, w jaki uzna za stosowne je unieważnić. Wcześniej jednak, zanim ten sposób poddamy analizie, wypada dookreślić znaczenie samego terminu „nihilizm".

\subsection{Nihilizm jako kategoria deskryptywna i ewaluacyjna}

W pierwszym zdaniu tekstu opublikowanego pod koniec XIX wieku Caroline A. F. Rhys Davids zauważyła: „Należy się spodziewać, że ze względu na niedostępność dla ogólnego czytelnika, a nawet w pewnym stopniu także dla indianisty, starożytnej literatury z zakresu filozofii buddyjskiej, w odniesieniu do natury buddyjskich idei i praktyki dominować będą pochopne uogólnienia i jednostronne wnioski"ø. Jako przykład określeń, które są „w znacznym stopniu mylące czy

- C. A. F. Rhys Davids, On the Will in Buddhism, JRAS 1 (1898), s. 47: It is only to be expected, while the ancient literature of Buddhist philosopby is inaccessible to the general critic, and still to some extent also to the Indianist, that many 
też wręcz całkowicie fałszywe" autorka wyliczyła: pesymizm, panteizm, ateizm, nihilizm, kwietyzm, apatheia. Sądzę, iż wskazując źródło owego niekorzystnego dla buddyzmu stanu rzeczy w braku dostępu do oryginalnej literatury, wybitna badaczka wykazała się nadmiernym optymizmem. Podstawą mojej opinii nie jest fakt, iż wymienione określenia ciągle jeszcze znajdują użytkowników, mimo że od chwili wydania tekstu upłynęło niemal 120 lat, podczas których wskazana dotkliwa luka została wypełniona.

Dzisiaj dysponujemy zarówno krytycznymi edycjami, jak i tłumaczeniami na dominujące języki europejskie większości zachowanych wczesnych tekstów buddyjskich oraz wieloma późniejszymi dziełami. Powodem, dla którego optymistyczna sugestia Rhys Davids nie mogła znaleźć spełniania, nie jest brak źródeł, nie jest nawet zła wola ich potencjalnych czytelników, lecz ontologiczne uwikłanie samych językowych kategorii. Język, którym się posługujemy, ma swoją historię i to ona $w$ znacznym stopniu określa znaczenie używanych słów. Nasze deskryptywne kategorie stosowane do opisu zjawisk z obszaru obcych kultur i obcych struktur myślowych odzwierciedlają dyskurs, w ramach którego zostały wypracowane, są obrazem wewnętrznej struktury tego dyskursu, obrazem napięć, jakie go ukonstytuowały. Nie mają zatem uniwersalnego, ponadkulturowego znaczenia. Ich użycie prowadzi często do niekończących się dyskusji i sporów, które nie rokują na pozytywne rozstrzygnięcie. Klasycznym przykładem takiej sytuacji jest dyskusja na temat religijności buddyzmu. Innym, aczkolwiek powiązanym z pierwszym, nie mniej wymownym przykładem jest spór wokół buddyjskiego ateizmu. Buddyzm w kwestii boga nie zawiesza głosu, nie zajmuje stanowiska agnostycznego, jak twierdzą niektórzy. Możemy się zastanawiać, dlaczego przedstawiciele tradycji filozoficznej otwarcie odrzucający idę̨ boga stwórcy, boga jako bytu koniecznego, oponują, gdy stykają się z oskarżeniem o ateizm. Otóż czynią

basty generalizations and one-sided conclusions concerning the nature of Buddhist ideals and discipline should continue to prevail. 
tak dlatego, że stykają się właśnie z oskarżeniem. Nazwanie buddyzmu ateizmem nie jest bowiem wyłącznie diagnozą faktycznego stanu buddyjskiej ontologii, lecz rzutuje jednocześnie na tę ontologię obcą jej i przez nią niepodzielaną aksjologię. Buddyjski ateistyczny filozof nie głosi bowiem, jak często sugerują użytkownicy owej etykiety, że życie nie podlega żadnym etycznym zasadom, że zasady słusznego moralnego postępowania nie mogą być w żaden sposób umocowane. Odrzucając ideę boga koniecznego, buddyjski myśliciel nie zostaje „bezbożnikiem" i nie widzi konieczności, aby takie absurdalne konsekwencje zaakceptować. Innymi słowy, w strukturze buddyjskiej racjonalności nie ma napięcia między ideą konieczności i przygodności, a tym samym buddysta nie uważa za racjonalne akceptacje konsekwencji, jakie płyną $\mathrm{z}$ wykreślenia pierwszej $\mathrm{z}$ owych idei.

$\mathrm{Z}$ analogiczną sytuacją mamy do czynienia w wypadku kategorii nihilizmu. Deskryptywna wartość tejże jest pochodną dyskursu, w ramach którego kategoria ta została wypracowana. Co więcej, rzadko kiedy jest ona używana wyłącznie w funkcji deskryptywnej. Zwykle jej użytkownicy posługują się nią dla scharakteryzowania stanu opatrywanego tym określeniem jako nośnika pewnych wartości, a zatem stosują ją ewaluatywnie. Można wręcz odnieść wrażenie, że ewaluacyjny aspekt tej kategorii jest dla nich jeśli nie ważniejszy, to przynajmniej równie ważny jak deskryptywny. Jej użycie służy często zdeprecjonowaniu określanego nią stanu rzeczy. Sytuacja taka bez wątpienia miała miejsce na przełomie XVIII i XIX w., kiedy termin ten wchodził do użytku. Friedrich Heinrich Jacobi, odpowiedzialny za jego spopularyzowanie, posługując się nim na określenie statusu świata $\mathrm{w}$ pokantowskim transcendentalnym idealizmie, dokonywał negatywnej oceny idealistycznego odchylenia ze względu na to, iż prowadziło ono w jego opinii do ateizmu. Realność świata, nawet jeżeli ten świat całkowicie kryje sį̧ pod zjawiskami i jest rozumowi niedostępny, była niezbędnym korelatem realności boga. A na tego w świecie idealnym, konstytuowanym przez transcendentalny podmiot nie ma zapotrzebowania. 
Dlatego, kiedy analizujemy nihilizm w jego historycznych wystąpieniach, powinniśmy za każdym razem zapytać „dla kogo?”. Nihilizmem jest się bowiem zawsze wobec opozycyjnego stanowiska, które samo dla siebie jest, zaryzykuję takie określenie, „afirmatyzmem”. Nierzadko zatem możemy mieć do czynienia z paradoksalną sytuacją, w której dwa różne afirmatyzmy oskarżają się wzajemnie o nihilizm. Klasycznym przykładem takiej sytuacji były oskarzenia o nihilizm kierowane $\mathrm{w}$ przeciwstawne strony na linii sporu między Friedrichem Nietzschem a chrześcijaństwem. „Zatem termin «nihilizm» - pisze William Slocombe - historycznie odnosi się raczej do postrzegania czegoś, co istnieje w opozycji do konkretnych ideologii niż do bycia ideologią owego nibil [nicości] jako takiego"?

\subsection{Różne rodzaje nihilizmu}

Pytanie o to, co znaczy termin "nihilizm”, jest nie mniej problematyczne od pytania o to, co zasługuje na to miano. Słowo to stało się tak wieloznaczne, a przez to tak pojemne, że posługiwanie się nim powoli traci sens. Praktycznie każde stanowisko, o tyle, o ile wiąże się z negacją czegoś, może stać się w relacji do jakiegoś punktu odniesienia, czyli w relacji do stanowiska, które to coś akurat afirmuje, nihilizmem. Potencjalnie, ujmując sprawę od strony czysto formalnej, nihilizmów jest tyle, ile przedmiotów negacji. Nikt jednak jak dotychczas nie był gotowy kruszyć kopii w obronie istnienia chrumpli. Dlatego nie sposób znaleźć chrumplowych nihilistów. To, ile rodzajów nihilizmu się wyróżnia, związane jest $\mathrm{z}$ historią, dynamiką oraz pojęciową strukturą toczonych w kulturze dyskursów. Liczba nihilizmów świadczy o kul-

W. Slocombe, Nibilism and the Sublime Postmodern. The (Hi)Story of a Difficult Relationship from Romanticism to Postmodernism, New York-London 2006, s. 2: Thus, the term "nibilism" refers historically to a perception of something that exists in opposition to particular ideologies, rather than being an ideology of the nihil [notbingness] as such. 
turowej randze danych zagadnień. Na potrzeby tej książki przyjąłem podział przedstawiony przez Karen L. Carr ${ }^{8}$, który choć niewyczerpujący i budzący różne zastrzeżenia bywa powtarzany w innych pracach?, gdyż ujmuje wiodące formy, dając poczucie uporządkowania i przejrzystości. Autorka ta wyróżniła pięć rodzajów nihilizmu: epistemologiczny, aleteologiczny, metafizyczny/ontologiczny, etyczny/moralny i egzystencjalny/aksjologiczny.

W przeciwieństwie do Carr charakterystykę nihilizmów zacznę od nihilizmu metafizycznego, a nie epistemologicznego. Zważywszy na Gorgiasza, jest to forma historycznie pierwsza, poza tym w swojej skrajnej postaci jest formą pierwszą logicznie, wszystkie pozostałe rodzaje nihilizmu są pochodne względem owej skrajnej postaci. W niej nihilizm metafizyczny głosi bowiem dosłownie, że „nic nie jest, nic nie istnieje". Jakkolwiek stwierdzenie takie wydawałoby się absurdalne, to jest możliwe do sformułowania i miało przynajmniej jednego swojego rzecznika. Świadome utrzymywanie tego twierdzenia wymaga albo intelektualnej brawury popartej retoryczną sprawnością, albo braku rozsądku. Ponieważ w powszechnym odczuciu jego gtoszenie świadczy raczej o tym drugim, to standardowo metafizyczny nihilizm sprowadza się do postaci słabszej, która wyraża się w twierdzeniu „nic nie jest realne". Tak rozumiany neguje nie istnienie jako takie, co pewien sposób rozumienia istnienia, standardowo nazywany realnym.

Kolejne dwa nihilizmy, epistemologiczny i aleteologiczny, mogą, choć nie muszą, sprowadzać się do jednego. Wszystko zależy od tego, jak rozumiemy poznanie. W wypadku rozumienia klasycznego, czyli wówczas, gdy poznanie pojmowane jest jako posiadanie uzasadnionego prawdziwego przekonania, stanowią one jedność. Są wtedy po prostu nihilizmem epistemologicznym, który wyraża się w twierdzeniu, że „nie istnieje poznanie”. Współcześnie jednak, np. w falibilizmie,

K. L. Carr, The Banalization of Nibilism. Twentieth-Century Responses to Meaninglessnes, Albany 1992, s. 17-18.

Zob. W. Slocombe, op. cit., s. 4-7. 
poznanie rozumie się słabiej jako posiadanie przekonań tylko uzasadnionych. Do bycia przekonaniem uzasadnionym nie potrzebna jest pewność, a tym samym prawda, wystarcza np. zgoda uczestników danego dyskursu. W takim wypadku można być zdeklarowanym nihilistą aleteologicznym, głoszącym, że prawda nie istnieje, i jednocześnie bronić się przed zarzutem nihilizmu epistemologicznego, utrzymując, że poznanie jest możliwe. Oczywiście dla zwolennika klasycznej koncepcji poznania falibilistyczna wizja poznania będzie formą zamaskowanego nihilizmu epistemologicznego. Dla porządku tylko wspomnę jeszcze, że możliwa jest sytuacja odwrotna. Jeżeli oddziela się prawdę od poznania, to można być zdeklarowanym nihilistą epistemologicznym i obstawać przy kategorii prawdy ${ }^{10}$.

Nihilizm etyczny/moralny sprowadza się do twierdzenia, że nie istnieją żadne wartości moralne, co w wypadku etyki oznacza, iż żadne sądy o dobru nie dają się uzasadnić. Zwykle w tym kontekście zwraca się uwagę na problem związany $z$ motywacją podejmowanego działania. Jeżeli nie można osadzić działań w wartościach, to - podkreśla się - pozostaje egotyzm bądź przemoc. Z sądu o nieistnieniu wartości nie wynika wszakże logicznie przekonanie, że wszelkie działanie jest uprawomocnione. Bez wątpienia jednak przekonanie o nieistnieniu wartości stanowi podstawę dla uprawomocnienia psychologicznego.

Ostatnia forma nihilizmu, czyli nihilizm egzystencjalny - zauważa Carr - jest tą, z którą zjawisko to jest zwykle kojarzone. Jest to przekonanie, że życie nie ma żadnego sensu. Nihilizm ten zrobił furore w kulturze europejskiej nie z powodu prostej logicznie deklaracji braku sensu w życiu, lecz ze względu na kojarzone z nią medialnie nośne psychiczne stany znudzenia, wyczerpania i beznadziei, od XIX w. analizowane oraz barwnie i licznie prezentowane w literaturze i sztukach wizualnych. 


\section{Problem buddyjskiego nihilizmu}

\subsection{Budda jako nihilista}

Wydaje się, że zarzut nihilizmu musiał być Buddzie stawiany często. Wskazuje na to liczba odniesień do tego oskarżenia w różnych miejscach wczesnego kanonu buddyjskiego zwanego Trójkoszem (p. Ti-pitaka, s. Tri-pițaka) oraz zwłaszcza ustandaryzowany sposób radzenia sobie z nim przez twórcę buddyzmu, ewentualnie przez późniejszą buddyjską tradycję. Owa standaryzacja polegała na przewrotnym i ironicznym potraktowaniu tego zarzutu, co niewątpliwie miało osłabiać jego sił̨̨ rażenia. W kilku miejscach (VP I, 235; VP III, 2-3; AN IV, 174-175; AN IV, 182-183) Budda odnosi się do posądzenia o nihilizm według analogicznego wzorca. Przyznaje przewrotnie, iż istnieje sens, w którym zgodnie z prawdą można o nim powiedzieć, że np. naucza doktryny unicestwienia (uccheda-väda), gdyż mówi o unicestwieniu trzech skalań umysłu: pragnienia (rāga), awersji (dosa) i omroczenia (moba), a także licznych złych i niewłaściwych jakości (anekavibitānam päpakānam akusalānam dhammānam). Podobnie też akceptuje pozornie oskarżenie o bycie wenajiką" (venayika), czyli nihilistą/sofistą, gdyż, jak zaznacza, naucza o niszczeniu tych samych umysłowych czynników.

1 Na podstawie skojarzeń dźwiękowych znaczenie terminu venayika jest $w$ tym wypadku wywodzone ze słowa vinasati znaczącego 'niszczy'. Stąd tekst sugeruje, że termin ten znaczy 'niszczyciel', zob. także podrozdział $1.3 \mathrm{w}$ części drugiej. 
Alexander Wynne zauważa, że taki sposób potraktowania zarzutu nihilizmu nie mówi niczego o faktycznym kontekście i powodzie jego postawienia' ${ }^{2}$. Nie wiemy, jaki dokładnie był sens tego zarzutu. Niejasność tę do pewnego stopnia można starać się rozświetlić analizą sytuacji, w których to Budda formułuje analogiczne w treści zarzuty, kierując je do swoich filozoficznych oponentów. Tak jak bowiem jego oskarżano o nihilizm, tak też i on zarzut ten stawiał niektórym ze współczesnych mu myślicieli. Jak zobaczymy w kolejnych dwóch częściach tej książki, zarzut anihilacjonisty (uccheda-vādī) będzie wiązał się $\mathrm{z}$ zagadnieniem rozumienia istnienia jaźni, a konkretnie z zagadnieniem domniemanej utraty owego realnego istnienia, podczas gdy zarzut nihilisty/sofisty (venayika) będzie wyraźnie wskazywał na kontekst epistemologiczny, a konkretnie na zajmowanie nieprecyzyjnej postawy w kwestii możliwości rozstrzygnięcia poznawczej wartości pewnych, a w niektórych wypadkach nawet wszystkich sądów. Można więc podejrzewać, że kontekst owych oskarżeń pod adresem Buddy mógł być analogiczny. $Z$ jednej strony stanowisko twórcy buddyzmu w kwestii jaźni, czyli brak wyraźnej deklaracji afirmującej jej istnienie, będzie wzbudzało oskarżenia o anihilacjonizm, które to stanowisko można będzie rozumieć jako pewną formę metafizycznego nihilizmu, z drugiej strony brak wyraźnej deklaracji negującej istnienie jaźni będzie prowokowat podejrzenie o kluczenie w tej kwestii, co ostatecznie będzie prowadziło do zarzutu nihilizmu epistemologicznego.

Opinię tę zdaje się potwierdzać skierowany pod adresem Buddy zarzut nihilizmu, jaki został przytoczony w MN I, 140. Przebudzony oznajmia, iż jest niesłusznie oskarżany o to, że naucza o unicestwieniu istniejącego bytu. Stwierdza się tam: „Asceta Gotama jest zwodzicielem/sofistą, który naucza o unicestwieniu, zniszczeniu i ustaniu istniejącego bytu" (venayiko samano gotamo, sato sattassa ucchedam vināsam vibbavam paññapeti). Oba wspomniane aspekty postawy Buddy zosta-

12 A. Wynne, Early Buddhist Teachings as Proto-śünyavada, JOCBS 11 (2015), s. 217. 
ły tutaj scalone w jedno oskarżenie, do czego wróç jeszcze w drugiej części pracy. Postaram się pokazać, że w istocie w wypadku Buddy nie mamy do czynienia $z$ dwiema postawami, lecz z jedną, która swoje ugruntowanie będzie znajdywała w rewolucyjnym na tle całej filozofii indyjskiej potraktowaniu zagadnienia istnienia i nieistnienia.

Nowatorstwo stanowiska Buddy z trudem będzie przebijało się do świadomości indyjskich filozofów. Tak jak w starożytności wyrazem niezrozumienia tego podejścia był zarzut nihilizmu, tak też $\mathbf{w}$ dobie współczesnej wraz z zapoczątkowaniem badań nad buddyzmem w XIX w. zarzut ten powróci zarówno w opiniach badaczy ${ }^{13}$, jak też i w nieprzychylnych buddyzmowi publikacjach przybierających nierzadko formę pamfletów. Za przykład może posłużý opinia Hendrika Kerna, który uznał $\mathrm{w}$ zgodzie $\mathrm{z}$ innym badaczem, że myśl buddyjska w kształcie, w jakim zaprezentowana została w Trójkoszu, jest formą idealistycznego nihilizmu typu Berkeleyowskiego. Szybko jednak, wraz z odkryciem relatywności wszelkich poznawalnych przedmiotów będących jedynie wytworem ego i ograniczeń poznania, myśl ta przekształciła się w nihilizm zdający się wykluczać poznanie oraz istnienie zarówno boga, jak i absolutnego bytu ${ }^{14}$. W podobnym duchu Otto Franke twierdził dwadzieścia lat później, że we wczesnym buddyzmie mamy do czynienia wyłącznie $z$ negatywizmem ${ }^{15}$. Tego

13 Przejrzysty przegląd stanowisk w kwestii buddyjskiego nihilizmu formułowanych w związku z zagadnieniem rozumienia nirwany przez pięć kolejnych generacji badaczy do połowy XX w. znaleźć można w: G. R. Welbon, On Understanding the Buddbist Nirvana, HR 5/2 (1966), s. 300-326.

14 H. Kern, Manual of Indian Buddhism, Strassburg 1896, s. 50. Kern potwierdzenie nihilizmu znajduje np. w Sn. 1070, gdzie Budda stwierdza: „będąc wspartym o [poznanie] "to nie istnieje» przekrocz rozlewisko" (nattbïti nissäya tarassu ogham) oraz w Sn. 1113, gdzie mówi się, że doskonały „widzi, iż nic nie istnieje ani wewnątrz, ani na zewnątrz" (ajjbattañ ca babiddha ca nattbi kiñcīti passato).

15 R. O. Franke, Der „Negativismus” in der alten Buddhalebre, [w:] Aufsditze zur Kultur - und Sprachgeschichte vornebmlich des Orients. Ernst Kubn zum 70. Geburtstage, Breslau 1916, s. 336-344. 
typu opinie stały się pożywką dla obrońców europejskiej chrześcijańskiej racjonalności, którzy nierzadko w sposób dosadny wytaczali przeciwko myśli buddyjskiej najostrzejsze zarzuty nihilizmu. Również w języku polskim tego typu publikacje pojawiły się stosunkowo szybko. Klasycznym przykładem takiego pamfletu jest ciągle wznawiana książeczka Władysława M. Dębickiego ${ }^{16}$.

Wypada jednak zauważyć, że zarzut nihilizmu wzbudzał także sprzeciw w gronie badaczy. Przybierał on różną formę - od zawieszania opinii, co wiązało się z metodologicznym postulatem skrupulatnego badania historii buddyjskich idei w indo-buddyjskim kontekście ${ }^{17}$, poprzez wskazywanie na niejasne stanowisko Buddy w kwestii jaźni, co sugerowało, że negacja tejże może dotyczyć tylko pewnych jej wyobrażeń ${ }^{18}$, a tym samym, że oskarżenie o nihilizm jest bezpodstawne, po otwartą deklarację utrzymującą, że Budda odrzucał wyłącznie utożsamianie jaźni z tym, co zjawiskowe zarówno w sensie fizycznym, jak i umysłowym, a niezrozumienie tego faktu doprowadziło późniejszą tradycję monastyczną do nihilizmu. Caroline A. F. Rhys Davids, rzeczniczka ostatniej z tych postaw, broniąc myśli Buddy przed oskarżeniem o nihilizm, w swoim zapale polemicznym posunęła się nawet do sugestii, że Przebudzony miał pozytywny stosunek do idei boga ${ }^{19}$.

\subsection{Nihilizm madhjamaki}

Żadnej innej tradycji buddyjskiej nie oskarżano o nihilizm z takim wigorem jak madhjamaki (madhyamaka). Zarzut ten stawiali przed-

16 W. M. Dębicki, Filozofia nicosci. Rzecz o istocie buddyzmu, Warszawa 1896. Ostatnie znane mi wydanie tej publikacji pochodzi z $2019 \mathrm{r}$.

17 Wyrazicielem tej postawy był Louis de La Vallée Poussin, zob. G. R. Welbon, op. cit., s. 315-317.

18 E. J. Thomas, The Life of Buddha as Legend and History, London 1927, s. 203.

19 C. A. F. Rhys Davids, To Become or Not to Become, London 1937, s. 134. 
stawiciele abhidharmicznych szkół buddyjskich, w tym idealistycznej jogaczary (yogācāra), jak też powszechnie formułowali go indyjscy oponenci buddyzmu. Znajduje on także swoich licznych rzeczników w gronie współczesnych badaczy.

Twórca madhjamaki, Nagardżuna (Nāgārjuna, druga poł. II pocz. III w.), był w pełni świadomy tego zarzutu. Dał temu wyraz w swoim gtównym dziele - Podstawowe strofy madbjamaki (Müla-madhyamaka-kärikā), gdzie w licznych wypowiedziach wkładanych w usta oponenta określa zasadniczy sens tego oskarżenia. Sprowadza się on do przekonania, że o niczym nie można mówić sensownie, jeśli uznaje się pustkę wszystkiego. Pustka wszystkiego bowiem w opinii krytyków madhjamaki oznacza nieistnienie niczego. Dobrze widać to w poniższym sformułowaniu. W MMK XIII, 4ab oponent zadaje pytanie:

kasya syäd anyathā-bhāvạ̣ svabbāvaś cen na vidyate |

Czego dotyczyć będzie zmiana, jeśli samobyt nie istnieje?

Warunkiem sensowności orzekania zmiany według oponenta jest istnienie tego, o czym zmiana jest orzekana; warunkiem orzekania istnienia jest posiadanie samobytu. Madhjamaka orzeka pustk̨ rozumianą jako brak samobytu; orzekanie tak rozumianej pustki o wszystkim musi oznaczać nieistnienie niczego. Orzekając pustkę wszystkiego, madhjamik zatem opowiada się za nicością, nawet jeżeli nie chce tego otwarcie przyznać. Dlatego w MMK XXIV, 6-11 oponent mógt wytoczyć pod adresem Nagardżuny najcięższe oskarżenie - twierdzenie o pustce wszystkiego niszczy naukę Buddy, a w MMK XXV, 1 dodał $\mathrm{w}$ tym samym duchu, że pojęcie pustki wszystkiego niszczy samą idę̨ nirwany.

Siłę sprzeciwu wobec twierdzenia o pustce wszystkiego widać też wyraźnie w drugim ważnym dziele Nagardżuny, Odwróceniu kryty$k i$ (Vigraba-vyāvartanī), jedynym zachowanym z autokomentarzem. $\mathrm{W}$ zasadzie całe to dzieło jest wielką polemiką z zarzutem nihilizmu, 
przy czym w tym wypadku oponent, wyciągając konsekwencje z nauki o pustce wszystkiego dla możliwości poznania, formułuje zarzut nihilizmu epistemologicznego. Jeżeli wszystko jest puste, stwierdza w VV 1-20, to nie jest możliwa żadna wiedza, albowiem ta jest zawsze wiedzą o czymś. Twierdzenie o pustce wszystkiego oznacza jednak, że nie istnieje nic, czego wiedza może dotyczyć. Co więcej samo to twierdzenie albo nie ma sensu, wówczas niczego faktycznie nie stwierdza i nie warto się nim zajmować, albo sens ma, co prowadzi jednak do unieważnienia samego siebie. Jeśli bowiem twierdzenie to ma sens, to znaczy, że jest czymś, a zatem ono samo już puste nie jest, czyli wypada poza duży kwantyfikator. Sens może mieć tylko wtedy, gdy orzeka o czymś. Nie jest bowiem możliwe orzekanie o niczym. Innymi słowy, warunkiem negacji jest ostatecznie realne istnienie czegoś. Metafizyczny nihilizm madhjamaki pociąga za sobą nihilizm epistemologiczny.

Przekonanie, że nauka o pustce jako o braku samobytu rzeczy oznacza faktycznie nieistnienie owych rzeczy, daje się dostrzec w wypowiedzi Wasubandhu (Vasubandhu, IV-V w.), który w Komentarzu do "Skarbnicy abbidbarmy" (Abbidbarma-kośa-bbāsya) zauważył: "Jedni uznają pojęcie osoby, inni uznają pojęcie nieistnienia żadnych [dharm]" (ya eṣa ekeșām pudgala-grāba ekeșām sarva-nāstitāa-grābaḅ) ${ }^{20}$.

Jeszcze wyraźniej przekonanie to uwidacznia się w wypowiedzi Asangi (Asañga, IV w.) pochodzącej z Bodbi-sattva-bbūmi. Mamy tam ${ }^{21}$ :

yena bi śūnyam tad asadbbãvāt | yac ca súnyam tat sadbbàvācchūnyatā yujyeta | sarväbbāvāc ca kutra kim kena śūnyam bhaviṣyati | na ca tena tasyaiva śūnyatā yujyate |

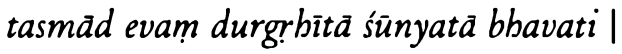

20 Wypowiedź ta znajduje się w tzw. dziewiątym rozdziale Abbidbarmakosiabbaszji, zob. Vasubandhu, Abhidharmakośabhāsyam, French trans. L. de la Vallée Poussin, English trans. L. M. Pruden, vol. 4, Berkeley 1991, s. 1338, 1373, przyp. 111.

21 Bodhisattvabhumi, ed. N. Dutt, Patna 1966, s. 32. 
Ponieważ to, pod względem czego coś jest puste, nie istnieje i ponieważ to, co jest puste, istnieje, pustka ma sens. Jeśli jednak nic nie istnieje, gdzie, co i jak będzie istniało puste? Pustka nie ma sensu, jeśli coś jest puste pod względem samego siebie. Takie pojęcie pustki jest błędne.

W wypowiedzi Asangi pojawia się jeszcze jeden ważny wątek. Orzekanie pustki jest orzekaniem braku, czyli nieistnienia. W ten sposób brak mogę orzekać tylko pod jakimś względem, np. mogę orzec nieistnienie słonia w pokoju, czyli pustkę pokoju pod względem słonia. Nie sposób orzec pustki czegoś pod jego własnym względem, to bowiem oznacza nic innego jak orzekanie jego nieistnienia. Gdy w ten sposób orzekam pustkę wszystkiego, to orzekam nieistnienie niczego, czyli nicość. Takie orzekanie pustki nie ma żadnego sensu. Musi zatem istnieć jakaś realna podstawa orzekania braku. Asanga jest wyrazicielem odmiennej, można by rzec, realistycznej koncepcji pustki. Koncepcję tę można by też nazwać fundacjonalistyczną - jakiekolwiek orzekanie, pozytywne czy negatywne, wymaga ostatecznie uznania istnienia ontycznego fundamentu.

Wszystkie zarzuty nihilizmu kierowane pod adresem madhjamaki będą bazowały na tym samym przekonaniu, bez względu na to, gdzie ten fundament będą lokowały. Dla realistycznych tradycji njaji-wajsiesziki (nyāya-vaišssika) i mimansy (mìmāmsāa) tym fundamentem będą realne, dostępne poznawczo w codziennym doświadczeniu, konkretne, jednostkowe rzeczy. Dla idealistycznej adwajtawedanty (advaita-vedānta) będzie to absolutny byt dostępny poznawczo w szczególnych, wykraczających poza codzienne, formach poznania ${ }^{22}$.

Analogiczne przekonania kierowały badaczami, którzy od połowy $\mathrm{X} D \mathrm{X}$ w. kwalifikowali madhjamakę do grupy koncepcji nihilistycz-

22 Przegląd zarzutów nihilizmu pod adresem madhjamaki formułowanych w bramińskich tradycjach, począwszy od njaji, przez mimansę, po różne formy wedanty znaleźć można w: J. Westerhoff, On the Nibilist Interpretation of Madbyamaka, JIP 44 (2016), zwt. s. 340-346; zob. także G. J. Darling, An Evaluation of the Vedantic Critique of Buddhism, Delhi 1987. 
nych. Grono to otwiera Eugène Burnouf, który nazwał myśl Nagardżuny „scholastycznym nihilizmem”23. Hendrik Kern określił madhjamików „kompletnymi nihilistami”24. Arthur Berriedale Keith uznał, że madhjamaka przedstawia rzeczywistość jako „absolutną nicość"25. Według tej teorii nieistnienia zjawiskowego świata nie orzeka się względem prawdy absolutnej, czyli względem absolutnego bytu; o świecie zjawiskowym nie sposób orzec nawet istnienia fenomenalnego ${ }^{26}$.

Taka ocena filozofii madhjamaki była powszechnie utrzymywana aż do 1927 r. ${ }^{27}$, kiedy to Theodor Stcherbatsky opublikowat prace The Conception of Buddhist Nirvana. Przedstawił w niej mahajanę, w tym madhjamakę, jako idealistyczną, monistyczną i mistyczno-absolutystyczną rewolucję względem wcześniejszej buddyjskiej myśli podpadającej pod skłaniający się ku realizmowi pluralizm ${ }^{28}$. Różnica między jogaczarą a madhjamaką miała się sprowadzać według rosyjskiego badacza do różnicy w sposobie poznania domniemanego absolutu. Jogaczara rozwinęła koncepcję absolutu jako zbiorczej świadomości, korzystając $z$ naturalnych metod poznania, w tym zwłaszcza $\mathrm{z}$ wnioskowania. Madhjamaka miała negować możliwość poznania absolutu logicznymi metodami i opowiadać się wyłącznie za mistyczną intuicją ${ }^{29}$. Aby uniknąć skojarzeń $z$ ideą nicości, badacz proponowat

23 Zob. E. B ur nou f, Introduction to the History of Indian Buddbism, trans. K. B u ffetrille, D. S. Lopez, Chicago-London 2010, s. 509: scholastic nibilism. 24 H. Kern, op. cit., s. 126: complete nibilists.

25 A. B. Keith, Buddbist Philosophy in India and Ceylon, Oxford 1923, s. 261: absolute notbingness.

26 Ibidem, s. 240.

27 Zob. J. W. de Jong, Emptiness, JIP 2 (1972), s. 71; zob. także R.-P. Droit, The Cult of Nothingness. The Philosophers and the Buddha, trans. D. Streight, P. Vohnson, Chapel Hill 2003.

28 T. Stcherbatsky, The Conception of Buddbist Nirvana, Leningrad 1927, s. 40-50.

29 Ibidem, s. 61. Przekonanie, że madhjamaka jest formą monizmu, pokutuje do dnia dzisiejszego, zob. M. Scarborough, Comparative Theories of Nonduality. The Search for a Middle Way, London-New York 2009, s. 14-23. 
przekładać termin śūnyatā, nie jak było i jest powszechnie przyjęte jako „pustka”, lecz jako „względność” (relativity) ${ }^{30}$. Możliwe, że w tym pomyśle kierował się propozycją Daisetsu Teitaro Suzukiego, który ów kluczowy termin z tych samych powodów tłumaczył już wcześniej jako „stan uwarunkowania” (conditionality) ${ }^{31}$.

Praca Stcherbatsky'ego zapoczątkowała falę pozytywnych interpretacji madhjamaki. Poważną rolę $\mathrm{w}$ tym procesie odegrali również polscy uczeni ze Stanisławem Schayerem na czele ${ }^{32}$. Wykładnia absolutystyczna zyskała sporą popularność wśród indyjskich uczonych, gdyż pozwalała im włączyć na powrót myśl buddyjską w nurt refleksji upaniszadowej ${ }^{33}$. W tym kontekście warto przywołać prace Harsha Naraina, który od lat sześćdziesiątych ubiegłego wieku głosił zdecydowanie w opozycji do absolutystycznych tendencji, iż madhjamakę należy rozumieć jako nihilizm ${ }^{34}$.

Narain pozostawał osamotniony przez trzy dekady. Dopiero od lat dziewięćdziesiątych XX w. daje się wyraźnie zauważyć ponowny wzrost popularności nihilistycznych wykładni madhjamaki ${ }^{35}$. Proces ten

30 T. Stcherbatsky, op. cit., s. 42-43.

31 D. T. Suzuki, Outlines of Mabayana Buddbism, London 1907, s. 173.

32 Zob. zwł. S. Schayer, Ausgewäblte Kapitel aus der Prasannapada, Kraków 1931. Schayer z jednej strony krytykował Stcherbatsky'ego za tendencje do odczytywania madhjamaki w duchu Kantowskim, z drugiej strony proponował absolutystyczną interpretację, w której podkreślał jej mistyczno-sceptyczny charakter, zob. ibidem, s. XXIX-XXXIII oraz ide m, Anityatd. Zagadnienie nietrwatości bytu w flozofii buddyjskiej, [w:] ide m, O filozofowaniu Hindusów, red. M. Mejor, Warszawa 1988, s. 248.

33 Klasyczną pracą jest T. R. V. Murti, The Central Pbilosopby of Buddhism, London 1955. Zob. także J. W. de Jong, Absolut w myśli buddyjskiej, thum. K. Jakubczak, „Nomos” 18/19 (1997), s. 23-30.

Zob. H. Narain, Súnyavada. A Reinterpretation, PEW 13/4 (1963), s. 311338; idem, The Nature of Madbyamika Thought, [w:] Mädbyamika Dialectic and the Philosophy of Nagarjuna, ed. Samdhong Rinpoche, Sarnath 1985, s. 227-256 oraz zwł. ide m, The Madbyamika Mind, Delhi 1997.

35. Przejrzysty przegląd nienihilistycznych oraz nieabsolutystycznych interpretacji madhjamaki można znaleźć w: R. P. Hayes, Nāgarjuna's Appeal, JIP 22 
zapoczątkował Thomas E. Wood, który w obszernej pracy dowodzit, że według madhjamików „nic nie jest realne" ${ }^{\text {" }}$. W tórował mu Claus Oetke, który przyznał, że podziela podobną opinię ${ }^{37}$. Duży rozgłos uzyskała praca Davida Burtona, w której wykazywał, że „Nagardżuny filozofia pustki, tj. powszechnego braku swabhawy, prawdopodobnie pociąga nihilizm" 38 oraz że ostatecznie, zgodnie z zarzutem przywołanym przez samego Nagardżunę w MMK XXIV, 1-6, filozofia pustki niszczy buddyjską ścieżkę ${ }^{39}$. W późniejszych pracach badacz ten był już mniej powściągliwy, gdyż otwarcie głosił, że: „Filozofia madhjamaki, można stwierdzić, przede wszystkim nie jest środkową drogą. Popada ona w skrajność nihilizmu”“0.

Jedną z ostatnich prac dyskutujących kwestię nihilizmu w madhjamace jest obszerny artykuł Jana Westerhoffa, w którym autor próbuje wykazać, że „nihilistyczna interpretacja madhjamaki daje się obronić tekstualnie oraz filozoficznie”, chociaż nie jest to „jedyna możliwa czy też nawet koniecznie najlepsza interpretacja we wszelkich kontekstach" " ${ }^{1}$. Warto też wspomnieć o tekście wobec powyższego polemicznym, którego autor dowodzi, że „uważna ocena antyrea-

(1994), s. 337-356.

36 T. E. Wood, Nägäriunian Disputations. A Philosophical Journey through an Indian Looking-Glass, Honolulu 1994, s. 266: nothing is real.

37 C. Oetke, "Nibilist" and "Non-nibilist" Interpretations of Madbyamaka. Review article of: Thomas E. Wood, Nagärjunian Disputations, Honolulu 1994, AO 57 (1996), s. 57-104.

38 D. Burton, Emptiness Appraised. A Critical Study of Nägärjuna's Pbilosophy, Richmond 1999, s. 209: Nagarjuna's philosophy of emptiness, i.e. universal absence of svabhāva, probably does entail nibilism, zob. też s. 109-111.

39 Ibidem, s. 211.

40 Idem, Is Madhyamaka Buddhism Really the Middle Way? Emptiness and the Problem of Nibilism, CB 2/2 (2001), s. 181: The Madhyamaka philosophy, it can be claimed, is not the Middle Way after all. It bas fallen into the extreme of nibilism; zob. takze ide m, Buddhism, Knowledge and Liberation. A Philosophical Study, Aldershot-Burlington 2004, s. 96-98.

${ }^{41} \mathrm{~J}$. Westerh off, op. cit., s. 370: [...] nibilist interpretation of Madhyamaka is both textually and philosophically defensible. Yet I do not want to claim that it 
listycznych sposobów odczytywania [madhjamaki] ujawnia, że są one logicznie nieodróżnialne od wykładni nihilistycznych" i dlatego ostatecznie „musimy zrozumieć, że najwyższa prawda [dla madhjamaki] jest poznaniem czegoś realnego"‘2.

is the only possible interpretation, or even necessarily the best interpretation in all contexts.

42 G. Ferraro, Realistic-Antimetaphysical Reading Vs Any Nibilistic Interpretation of Madhyamaka, JIP 45 (2017), s. 95: a careful evaluation of antirealistic readings shows that they are logically indistinguishable from nibilistic ones oraz dalej: we must think that supreme truth is the cognition of something real; zob. takzie ide m, A Criticism of $M$. Siderits and J. L. Garfield's "Semantic Interpretation" of Nagarjuna's Theory of Two Trutbs, JIP 41 (2013), s. 195-219. 



\section{Założenia metodologiczne}

\subsection{Cel pracy}

W pewnym sensie niniejszą książkę można traktować jako analizę oraz obszerny i wielowątkowy komentarz do jednej krótkiej mowy Buddy, wygłoszonej, jeśli wierzyć tradycyjnemu przekazowi, do bramina Katjajany (s. Kātyāyana/Mahākātyāyana, p. Kaccāna/Kaccānagotta/ Kaccāyanagotta), który w późniejszym czasie będzie zaliczany do grona najbliższych i najwybitniejszych uczniów Buddy. Ze względu na adresata mowa ta znana jest pod tytułem Kazania do Katjajany (s. Kätyāyana-sūtra, p. Kaccānagotta-sutta) ${ }^{43}$. W niej to w sposób skondensowany Przebudzony zaprezentował właściwy mu sposób rozumienia zagadnienia istnienia $\mathrm{i}$ nieistnienia. Zrobił to $\mathrm{w}$ nawiązaniu do pytania Katjajany o rozumienie właściwego poglądu (s. samyag-drsțti, p. samma-dițthi). Postawę ujmowania doświadczenia w kategorie istnienia i nieistnienia Budda potraktowat jako wyraz lgnięcia (upadāna). Warunkiem wyzwolenia się związanego $z$ widzeniem rzeczy, jakimi są, jest wyzbycie się owego lgnięcia.

Analiza Kazania do Katjajany pozwala mi zrealizować dwa cele, jakie stawiam sobie w tej pracy - pierwszy ma charakter ogólny, natomiast drugi szczegółowy. Celem ogólnym jest rekonstrukcja i obrona buddyjskiego stanowiska $w$ odpowiedzi na najbardziej klasyczny

${ }^{43}$ Adnotacje do tego kazania podaję w przyp. 1 części pierwszej. 
zarzut, jaki był stawiany już Buddzie, a mianowicie zarzut nihilizmu. Rozpatruje go w dwóch kontekstach - ontologicznym i epistemologicznym. Całkowicie pomijam dyskusję toczącą się wokół zarzutu nihilizmu etycznego, aczkolwiek sądzę, że ten był Buddzie stawiany najczęściej i w pewnym sensie można go uznać za najbardziej pierwotną wersję kierowanego pod adresem twórcy buddyzmu oskarżenia o nihilizm. Pomijam jednak to oskarżenie, gdyż uważam, że było ono formułowane jako wniosek $\mathrm{z}$ analizy antropologicznego i ontologicznego stanowiska Buddy. W obliczu tego wniosku deklaracje Przebudzonego o uznawaniu moralnej odpowiedzialności, co w kontekście indo-buddyjskim oznaczało uznawanie prawa karmana, traktowane były jako zapewnienia bez pokrycia.

Podstawą dla sformułowania takiego wniosku było zdaniem krytyków niejasne stanowisko Buddy w kwestii jaźni, czyli w kwestii podmiotu moralnej odpowiedzialności. W okresie formowania się wykładni abhidharmicznej owo niejasne stanowisko uległo ujednoznacznieniu i sprowadzało się do stwierdzenia nieistnienia żadnej jaźni. Za to stwierdzenie przyszło jednak tradycji abhidharmicznej zapłacić wysoką cenę, którą były rozstrzygnięcia w obszarze najbardziej fundamentalnym, a mianowicie w kwestii rozumienia kategorii istnienia i nieistnienia. Budda wobec istnienia i nieistnienia zachowywał, używając eufemizmu, daleko idącą wstrzemięźliwość. Najbardziej dobitnym jej przykładem jest właśnie Kazanie do Katjajany. Ratując się przed zarzutem nihilizmu w obliczu negacji istnienia jaźni, tradycja abhidharmiczna uznała obiektywną wartość orzekania istnienia tak zwanych dharm, czyli ostatecznie prostych, tj. niepodlegających dalszej redukcji, realnych składników rzeczywistości. $Z$ nich mają być konstruowane przedmioty naszego codziennego doświadczenia, które jako skonstruowane nie istnieją obiektywnie; co ważniejsze w oparciu o realność relacji zachodzących między dharmami można odeprzeć zarzut nihilizmu zarówno etycznego, jak i ontologicznego. Abhidharma uległa presji bytu i na tej podstawie mogła się stać partnerem w dyskusji dla całej bramińskiej tradycji, która mimo wewnętrznego 
zróżnicowania w jednym pozostawała zgodna - ostatecznie coś realnie istnieje.

Nic więc dziwnego, że wzrost popularności nauki o pustce wszystkiego jako nowej wykładni stanowiska buddyjskiego wywołał ataki ze strony zarówno tradycji pozabuddyjskich, jak i buddyjskich szkół abhidharmicznych. Nurt madhjamaki, który stał się ostatecznie głównym rzecznikiem tej wykładni, spotkał się z frontalnym oskarżeniem o nihilizm wszelkiej możliwej maści. Zarzut nihilizmu pod adresem tej szkoły nie jest wyłącznie zjawiskiem historycznym. Jak wskazywałem wcześniej, powrócił on we współczesnych dyskusjach nad statusem nauki madhjamaki. Wyrażenie sprzeciwu wobec narastającej od lat dziewięćdziesiątych ubiegłego wieku fali nihilistycznych interpretacji myśli madhjamaki stanowiło pierwotną motywację do napisania tej książki.

W pracach stawiających madhjamace zarzut nihilizmu uderza niemal zupełny brak odniesien do wczesnego oskarżenia o nihilizm kierowanego pod adresem Buddy ${ }^{44}$. Wręcz przeciwnie, niektórzy autorzy formułują swój zarzut $\mathrm{w}$ nawiązaniu do wcześniejszej buddyjskiej tradycji, tak jakby nauka o pustce wszystkiego stanowiła na tym tle rodzaj jakiejś ontologicznej aberracji, która nieuchronnie musi się wyrazić również $w$ aberracji epistemologicznej. Jest to związane $z$ utrzymywanym przez nich przeświadczeniem, że abhidharmiczna wykładnia myśli Buddy jest jedyną prawomocną, a to przeświadczenie $\mathrm{z}$ kolei ugruntowane jest ostatecznie $\mathrm{w}$ realistycznym sposobie rozumienia istnienia.

Wbrew temu przekonaniu twierdzę, że zarzut nihilizmu stawiany madhjamace jest nierozerwalnie powiązany $z$ analogicznym zarzutem formułowanym pod adresem Buddy. Wynika to ze ścisłego związku wykładni madhjamaki z pierwotnymi intuicjami twórcy buddyzmu

${ }_{44}$ Wyjątkiem pod tym względem jest książa T. E. Wooda (op. cit., s. 15-45), aczkolwiek należy zauważyć, że $\mathrm{w}$ swoim rozumieniu wczesnej myśli buddyjskiej podąża on za jej abhidharmiczną wykładnią przedstawioną w książce: K. N. Jayatilleke, Early Buddhist Theory of Knowledge, London 1963. 
w kwestii istnienia i nieistnienia. Wykazanie takiego związku stanowi właśnie drugi szczegółowy cel tej pracy. Nie sposób bowiem mówić o deskryptywnej wartości kategorii pustki wszystkiego w oderwaniu od czy też wręcz z pominięciem analizy rozumienia kategorii istnienia i nieistnienia. Innymi słowy, nie sposób zrozumieć wykładni madhjamaki, ignorując jedyny wyraźny drogowskaz, jaki Nagardżuna w swoich pracach umieścił, a jest nim Kazanie do Katjajany.

Za poważny metodologiczny błąd uważam rozpatrywanie madhjamaki wyłącznie na tle tradycji abhidharmicznej. Nie mam wątpliwości, że filozofia Nagardżuny jest reakcją na zyskującą w jego czasach na znaczeniu i przede wszystkim na precyzji myśl abhidharmy. Powinniśmy jednak zapytać, dlaczego filozof ten zdobył się na tak bezkompromisową jej krytykę. Wątpliwość tę możemy rozstrzygnąć na dwa sposoby: albo przyjmiemy, że proponuje on nowatorską, rewolucyjną wykładnię myśli buddyjskiej, albo uznamy, że nawołuje do powrotu do tego, co uważa za pierwotną intuicję w myśli Buddy. Jestem przekonany, że przywołując z tytutu tylko jeden raz jedyne kazanie Buddy twórca madhjamaki w tej kwestii nie pozostawia żadnych wątpliwości.

Jeszcze większym metodologicznym błędem jest ujmowanie madhjamaki w kontekście późniejszych tybetańskich sporów. Oczywiście nie twierdzę, że tego typu badania nie mają sensu. Sądzę tylko, że nie są w stanie odpowiedzieć na zasadnicze pytanie o motywację $\mathrm{Na-}$ gardżuny. Wynika to z prostego faktu braku w kanonie tybetańskim najwcześniejszych tekstów buddyjskich. Trudno oczekiwać w związku z tym, aby wykładnia tybetańska była w stanie przekroczyć pojęciowy horyzont wyznaczony przez abhidharme i wczesne sutry mahajany. Jeszcze mniejsze poznawcze nadzieje mam wobec dominującej obecnie postawy, która dąży do wyrażenia myśli Nagardżuny w ramach dyskursu typowego dla dwudziestowiecznej filozofii analitycznej. Interpolacja taka choć może budzić zainteresowanie i do pewnego przynajmniej stopnia nieunikniona ${ }^{45}$, lokując filozofię madhjamaki

45 Nie sposób bowiem w dążeniu do zrozumienia abstrahować od filozoficznego języka, w którym jest sį̨ zadomowionym. Samo rozumienie traktujধ jako 
w całkowicie odmiennym kontekście filozoficznego dyskursu, gubi motywację Nagardżuny, a tym samym, co będę starał się wykazać, także Buddy.

\subsection{Jaki material będzie badany}

Osią tej książki jest Kazanie do Katjajany. Jego rola jest szczególnie wyraźnie widoczna w pierwszej części pracy, gdyż jej strukturę wyznaczają kolejne fragmenty tego tekstu. W trakcie analizy zwracam uwagę na pozornie drobną różnicę, jaka pojawia się w ujęciu kwestii istnienia i nieistnienia między dwoma wersjami tego kazania - palijską i sanskrycką. W pracach badawczych owa różnica jest powszechnie bagatelizowana, co należy przypisać ogromnej popularności kanonu palijskiego i słabemu utrwaleniu w świadomości faktu istnienia sanskryckich fragmentów Nidanasanjukty (Nidāna-samyukta), wśród których znajduje się też owo kazanie. W opozycji do tego podejścia będę twierdził, że różnica ta jest istotna i znamionuje dwie tendencje rozwojowe we wczesnej myśli buddyjskiej. W swojej wykładni myśli Buddy będę skłaniał się ku opinii, iż jedna z tych tendencji trafniej oddaje pierwotne intuicje twórcy buddyzmu.

Punktem odniesienia dla analiz prowadzonych w części drugiej jest Atțhaka-vagga, czwarty rozdział Suttanipaty (Sutta-nipäta). W opinii badaczy mamy podstawy, aby ten zbiór szesnastu krótkich kazań pisanych mową wiązaną (w sumie 210 strof) uważać za jedno z najstarszych kompendiów myśli buddyjskiej, które swoim początkiem może sięgać postaci samego Buddy ${ }^{46}$. Uważam, iż nauka, jaką prezentuje Atțhaka-vagga, pozostaje w ścisłym związku z Kazaniem do Katjajany. Podstawowym problemem tego ostatniego jest unieważ-

rozsuwanie ścian owego domostwa, a zatem poszerzanie obszaru, w którym jest się zadomowionym.

46 Referencje do tego tekstu podaję $\mathrm{w}$ drugiej części pracy. 
nienie kategorii istnienia i nieistnienia oraz związana z tym kwestia nielgnięcia. Podstawowym problemem Atthakawaggi jest nielgnięcie unieważniające istnienie i nieistnienie. Teksty te wzajemnie się dopełniają. Mówią dokładnie o tym samym, podkreślając dwa zespolone ze sobą aspekty. Dostrzeżenie tego ewidentnego związku przemawia za przekonaniem o niemniejszej archaiczności Kazania do Katjajany. W nawiązaniu do problemu nielgnięcia oraz istnienia i nieistnienia Atțhaka-vagga stawia kwestię prawdy i fałszu, rozwiązując ją w sposób, który w moim przekonaniu doskonale koresponduje ze sposobem rozumienia właściwego poglądu w Kazaniu do Katjajany.

Materiał ten badam w powiązaniu z całym wczesnym kanonem tekstów buddyjskich zwanym Trójkoszem. Sięgam do czterech pierwszych palijskich nikaji oraz do wybranych tekstów piątej. Korzystam z dostępnych w sanskrycie fragmentów Nidanasanjukty, a także z dostępnych w przekładzie z chińskiego wybranych sutr Sanjuktagamy (Samyuktāgama). Sporadycznie też sięgam do zbioru winaji oraz abhidhammy. Należy to podkreślić szczególnie w odniesieniu do Attbakawaggi, która często bywa rozpatrywana w oderwaniu od reszty kanonu, co skutkuje fatalnymi propozycjami interpretacyjnymi (jak choćby sugestią, że mamy w tym tekście do czynienia ze sceptycyzmem). Podejście takie motywowane jest dostrzeżeniem braku w owej kolekcji sutt wielu kluczowych pojęć charakterystycznych dla klasycznej myśli buddyjskiej, takich jak choćby cztery szlachetne prawdy i zależne powstawanie. Uważam, iż ten brak nie stanowi żadnego problemu po pierwsze $z$ tego powodu, iz treści zawarte w tym tekście znaleźć możemy także w innych partiach kanonu, co staram się pokazać, oraz po drugie dlatego, ze tekst ten pozostaje w ścisłym związku z Kazaniem do Katjajany.

Odrębną grupą tekstów, której poświęcam sporo uwagi, są wczesne, czyli poprzedzające wystąpienie Nagardżuny (druga poł. II w.), sutry mahajany. Skupiam się zwłaszcza na sutrze znanej jako Ksiega Kaśjapy (Kāśsapa-parivarta-sūtra) oraz Sutrze doskonałości mądrości $w$ ośmiu tysiącach strof (Asta-sābasrikā-prajñāa-päramitā-sūtra) wraz 
$z$ jej syntetyczną wersją wierszowaną noszącą tytuł Prajñā-pāramitā-ratna-guna-samcaya-gāthā. Wybór tych tekstów podyktowany jest przekonaniem, że w obu daje się dostrzec związek z Kazaniem do Katjajany, a konkretnie z charakterystycznym dla tego kazania sposobem rozumienia zagadnienia istnienia i nieistnienia. Co więcej ich rola w kształtowaniu się myśli madhjamaki jest niezaprzeczalna, chociaż sam Nagardzuna o nich nie wspomina. Owo milczenie nie jest jednak świadectwem braku takowych związków, gdyż Nagardżuna programowo poza Kazaniem do Katjajany nie przywołuje z tytułu żadnych innych źródeł wczesnobuddyjskich. Sporadycznie odwołuję się też do kolejnych tekstów literatury doskonałości mądrości.

Ostatnią grupą dzieł ważnych dla tej pracy są pisma twórcy madhjamaki, Nagardżuny, zwłaszcza Podstawowe strofy madhjamaki (Müla-madhyamaka-kārikā) i Odwrócenie krytyki (Vigraba-vyāvartan̄i), Czterechsetka / Czterysta [strof] (Catub-śataka) jego ucznia, Arjadewy (Āryadeva, III w.), oraz powstały w VII w. wielki komentarz Czandrakirtiego (Candrakirti) do głównego działa Nagardzuny w skrócie znany jako Jasne stowa (Prasanna-padā). Sporadycznie też przywołuję dwa ważne scholastyczne teksty tradycji abhidharmy - sanskrycką Skarbnice abbidharmy (Abbidbarma-kośa) Wasubandhu oraz palijską Ścieżke oczyszczenia (Visuddbi-magga) Buddhaghosy (Buddhaghosa, $\mathrm{V}$ w.). Analizą tekstów madhjamaki kieruje intencja, aby pokazać, że mamy $w$ nich do czynienia $z$ pierwotnymi zapoczątkowanymi przez Buddę rozstrzygnięciami, które ze względów historycznych i merytorycznych zostały ubrane w nowe szaty pojęciowe. 



\section{Część pierwsza

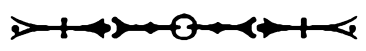

\section{„JEŻELI BYTU NIE MA..." BUDDYZM JAKO FILOZOFIA NICOŚCI?}





\section{Poza istnieniem i nieistnieniem, czyli o rozumieniu dharmy Buddy}

\subsection{Droga środka w Kazaniu do Katjajany}

W obszarze wczesnych pism buddyjskich ujętych w korpusie tekstów określanym nazwą Trójkosza (s. Tri-pitaka, p. Ti-pițaka) niewielkiemu Kazaniu do Katjajany (s. Kätyãyana-sūtra, p. Kaccānagotta-suttal Kaccāyanagotta-sutta) ${ }^{1}$ należy przypisać szczególną pozycję. O znaczeniu tego tekstu może świadczyć fakt, że jest jedynym, który Nagardżuna w swoich traktatach filozoficznych wymienia z tytułu. David J. Kalupahana uznat tę okoliczność za wystarczającą przesłankę do tego, aby wyrazić przekonanie, że główne dzieło Nagardżuny, w którym to odniesienie się pojawia, czyli Podstawowe strofy madbjamaki (Müla-madhyamaka-kārikā), stanowi w całości komentarz do tego kazania².

W kanonie palijskim jest to piętnasta sutta dwunastej powiązanej grupy Sanjuttanikaji (SN II, 16-17 [SN 12.15]). Tekst został powtórzony również w dalszej części, SN III, 134-135. W zachowanej częściowo sanskryckiej wersji analogicznej grupy kazanie to pojawia się jako sutra 19. W chińskim przekładzie jest to 301 sutra Sanjuktagamy, T 2, 85c-86a. Ponieważ w zachowanej sanskryckiej wersji imię adresata podawane jest jako Kātyāyana, a nie Kātyāyanagotra, jak często można spotkać w tekstach badawczych, których autorzy sugerują się analogią do wersji palijskiej, trzymam się tej krótszej wersji imienia.

2 D. J. Kalupahana, Nagariuna. The Philosophy of the Middle Way, Albany 1986, s. 5. Ściśle rzecz biorąc, Kalupahana twierdzit, że MMK stanowi 
Co więcej, jedno z kluczowych sformułowań tego tekstu wzmiankowane jest w mahajanistycznej sutrze Lañkāvatāra, aczkolwiek bez podania tytułu samego kazania, ponadto w dwóch różnych tekstach kazanie to przywołuje także Czandrakirti ${ }^{3}$. Jednak to nie ten fakt nadaje rangę Kazaniu do Katjajany. Jest on raczej odzwierciedleniem pozycji, jaką idee wyrażone w tym tekście zajmują w strukturze wczesnej buddyjskiej myśli. Mowa ta wiąże ze sobą trzy pierwotne buddyjskie pojęcia: właściwego poglądu (s. samyag-drști, p. sammā-ditțhi), środkowej drogi (s. madbyamā pratipad, p. majjbimā patipadā) oraz zależnego powstawania (s. pratītya-samutpāda, p. pațicca-samuppada), wszystkie je jednocześnie redefiniując $\mathrm{w}$ relacji do pojęć istnienia (s. astitā, p. atthitā) i nieistnienia (s. nāstitā, p. n'attbitā). Jest to jedyna zachowana w Trójkoszu domniemana wypowiedź Buddy, w której tak jasno i wyraźnie została określona równoważność między tymi pojęciami, a co ważniejsze, uczyniono to na tle czy też w kontekście ogólnych pojęć istnienia i nieistnienia.

Punktem wyjścia dla wykładu Buddy jest pytanie o właściwy pogląd zadane przez bramina Katjajanę $e^{4}$ w NidSa 19.3:

komentarz do palijskiej wersji tej sutry. Dalej jednak pokażę, że ze względu na różniç między wersją palijską a sanskrycką Nagardżunie zdecydowanie bliższa jest ta druga. Ta pozomie drobna rozbieżność jest faktycznie świadectwem znacznie głębszej różnicy w sposobie rozumienia madhjamaki. Zdecydowanie odrzucam jej empirystyczną interpretację proponowaną przez Kalupahanę.

3 Do tej kwestii powróç w następnym podrozdziale.

4 Sanskryckie imię Kātyāyana jest rodzajem imienia patronimicznego od Kātya (które $\mathrm{z}$ kolei jest patronimikiem od Kati) w formie zwanej yuvan, czyli "młodszy”, zob. na ten temat L. P. van den Bosch, Some Reflections on the Concept of Person in Ancient Indian Texts, [w:] Concepts of Person in Religion and Thought, ed. H. G. Kippenberg et al., Berlin-New York 1990, s. 246-247. Noszone jest przez najstarszego syna w okresie, gdy ojciec jeszcze żyje. Ponieważ w wersji palijskiej pojawia się błędna derywacja tego imienia Kaccāna, badacze mają tendencję, aby zastępować ją formą poprawną, stąd często, podając tytuł kazania, używają imienia Kaccāyana. 
samyag-drștili samyag-drștir iti bbadanta ucyate | kiyatd samyag-drsțir bbavati | kiyata tatbagatab samyag-drștim prajñapayamānạ prajñapayati|

Mówi się, Czcigodny, „właściwy pogląd, właściwy pogląd”. Jak istnieje właściwy pogląd? Jak Tathagata określa rozumienie właściwego poglądu?

Należy zwrócić uwagę na to, czego faktycznie dotyczy pytanie Katjajany. Nie docieka on treści właściwego poglądu, nie interesuje go, co głosi właściwy pogląd, lecz pyta, „jak (kiyata) istnieje (bbavati) właściwy pogląd (samyag-drștir)?". Kluczowe dla uchwycenia intencji tego pytania jest słowo kiyatā (w wersji palijskiej kittavata), które znaczy 'jak duży, jak daleko', ale też 'pod jakim względem, w jakim stopniu'. Zatem Katjajana pragnie doprecyzować to, pod jakim względem właściwy pogląd jest właściwym poglądem, czyli interesuje go jego specyfika, może wręcz natura, a nie treść. Dlatego dookreślając ukierunkowanie swojej intencji, stawia drugie pytanie o to, w jaki sposób Tathagata dosłownie „pojmuje rozumienie właściwego poglądu" (samyag-drștim prajñapayamanab prajñapayati).

Odpowiedź Buddy będzie adekwatna do zadanego pytania, tj. zwróci on uwagę na okoliczności pojawienia się właściwego poglądu, ale zanim jej udzieli, poczyni niezwykle ważny, kluczowy dla przesłania sutry, wstęp dotyczący pojęć istnienia i nieistnienia. Budda stwierdza (NidSa 19.5a1):

dvayam niśrito 'yam kâtyãyana loko yad bbūyasāstitāñ ca niśrito nästitã̃ ca | upadbyupadāna-vinibaddho 'yam katyayana loko yad utāstitañ ca niśrito nastitañ ca |

Ten świat, Katjajano, zasadniczo ufundowany jest na dwójni (dvaya): na istnieniu (astitā) i nieistnieniu (nāstita). Ten świat, Katjajano, ufundowany na istnieniu i nieistnieniu, spetany jest przywiązaniem i lgnięciem [ew. spętany jest lgnięciem do podłoża/zespołów]. 
W wypowiedzi tej powinniśmy dokładniej przyjrzeć się co najmniej czterem kwestiom - co rozumie się tutaj pod terminem „świat” (loka), czym jest wspomniana dwójnia istnienia i nieistnienia, na czym polega jej fundacyjna względem świata rola oraz jaki jest związek owej dwójni z postawą lgnięcia.

\subsection{Idea świata w myśli Buddy}

O świecie Budda wspomina we wczesnych kanonicznych tekstach wielokrotnie. Często czyni to przy okazji różnych rozważań niepoświęconych bezpośrednio temu zagadnieniu, co więcej odnosi się nieodparte wrażenie, że terminu tego używa w znaczeniu potocznym jako określenia wyrażającego naiwno-realistyczne przeświadczenie o ulokowaniu życia w obiektywnej przestrzeni. Nathan Katz zauważa, że w tym wypadku termin loka bywa sporadycznie zastępowany terminem jagat ${ }^{5}$. Ten ostatni pojawia się w nikajach trzykrotnie. W SN I, 186 mówi się o nietrwałości wszystkiego na niebie i ziemi, co „zawiera się w świecie" (jagat-ogadha). W AN II, 15 mowa jest o mnichu, który dokładnie bada zespoły „powyżej, w szerz i poniżej, tak daleko, jak rozciąga się świat" (uddham tiriyam apācinam yāvatā jagato gati). Ta sama fraza pojawia się też w AN II, 17, gdzie powiada się, że "powyżej, w szerz i poniżej, tak daleko, jak rozciąga się świat", Budda nazywany jest pierwszym. Przestrzenność zatem, jak możemy zauważyć, jest wyznacznikiem owego obiektywistycznego czy też naiwno-realistycznego pojęcia świata ${ }^{6}$.

5 N. Katz, Does the "Cessation of the World" Entail the Cessation of Emotions? The Psychology of the Arabant, PBR 4/3 (1979), s. 54.

- W póżniejszej literaturze filozoficznej i komentatorskiej ten aspekt przestrzenności określający wyobrażenie świata znajdzie swoje odzwierciedlenie w adekwatnym nazewnictwie. Wasubandhu (s. Vasubandhu, IV-V w.), który cały trzeci rozdział Abbidharmakosi (Abbidharma-kosa) poświęcit analizie zagadnienia świata, dokonał podziału na świat istot czujących (sattva-loka) 
W ogólnych opracowaniach filozofii buddyjskiej mających tendencję do zastępowania myśli Buddy utrwalonymi w późniejszej kulturze buddyjskiej interpretacjami standardowo przywoływanym kontekstem, w którym pojawia się termin „świat” (loka), jest kontekst doświadczenia medytacyjnego. W ujęciu tym świat pojmowany jest $\mathrm{z}$ jednej strony jako obiektywny korelat doświadczenia medytacyjnego, tj. sfera istnienia udostępniana $\mathrm{w}$ danym doświadczeniu, a charakterystyka pogrążonego $w$ medytacji umysłu $w$ tym stanie się znajdującego traktowana jest jako charakterystyka umystów istot w owej sferze egzystujących. Z drugiej strony taki świat rozumiany jest jako obszar potencjalnego odrodzenia, czyli realizowania się karmana, a tym samym jest ontycznym korelatem moralnej jakości czynów istot w nim się odradzających. Ściśle rzecz biorąc, ze względu na różnorodność stanów medytacyjnych oraz zróżnicowanie moralnej jakości czynów w tym kontekście mówi się o świecie w liczbie mnogiej, tj. o światach jako planach egzystencji. Sue Hamilton zauważa, że taki sposób rozumienia świata wypracowano w późniejszej myśli abhidhammicznej i nie został on wyraźnie wyartykułowany we wczesnych wypowiedziach przypisywanych Buddzie, chociaż można w nich znaleźć podstawy dla takiej psychologiczno-kosmologicznej wykładni ${ }^{7}$. Istnieje jednak grupa stwierdzeń, w których świat staje się problemem centralnym i które nadają temu terminowi swoiste buddyjskie znaczenie, decydujące o radykalnej odmienności myśli Buddy od przekonań głoszonych przez jemu współczesnych. I tym wypowiedziom się teraz przyjrzymy.

i świat-pojemnik (bbajana-loka), tj. świat nieożywionych rzeczy (zob. zwłaszcza AK III, 45 i AKB do III, 44-45). Z kolei Buddhaghosa (p. Buddhaghosa, $\mathrm{V}$ w.) przeprowadził trychotomiczny, aczkolwiek niekoniecznie rozłączny, podziat na świat istot czujących (satta-loka), świat formacji czy też uformowany (sañkbära-loka) i świat przestrzenny (okasa-loka), zob. VM 204-205.

7 Zob. S. Hamilton, The "External World”. Its Status and Relevance in the Pali Nikayas, „Religion” 29 (1999), s. 81. Przykłady takich wypowiedzi znaleźć można np. w AN II, 126-130, MN II, 37 i 194-196. 
W jednej z mów skierowanych do czcigodnego Samiddhiego (p. Samiddhi) zawartej w Sanjuttanikaji rozmówca zadał Buddzie wprost pytanie o rozumienie świata. Czytamy tam (SN IV, 39):

loko lokoti bbante vuccati | kittāvatā nu kbo bbante loko vā assa lokappaññati va ti

Mówi się, Czcigodny, „świat, świat”. Jak może, Czcigodny, istnieć świat bądź też pojęcie świata?

$\mathrm{Na}$ co Budda udzielił następującej odpowiedzi:

yattha kho samiddhi atthi cakkbum atthi rūpā atthi cakkbu-

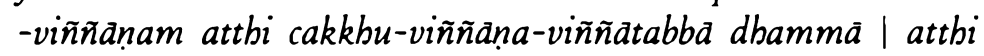
tattha loko vā loka-pañnatti va | la ||

Doprawdy, Samiddhi, gdziekolwiek istnieje oko, istnieje materialna forma, istnieje wzrokowa świadomość oraz rzeczy poznawalne przez wzrokową świadomość, tam istnieje świat bądź też pojęcie świata itd.

Analogicznie, na co wskazuje owo „itd." kończące powyższą wypowiedź, Budda wyrokuje o pozostałych zmysłach, do których zalicza także umysł (mana) jako narząd ujmowania. Zatem świat, jak można by wnosić z przywołanych słów, to nie są po prostu otaczające nas rzeczy, które można poznać, naiwnie lokowane w otaczającej nas obiektywnej przestrzeni. W kontekście, w jakim mówi o nim Budda, jest on funkcją zarówno rzeczy, jak też władz zmysłowych oraz świadomości. Innymi słowy, światem nazywa się tutaj jego złożone przedstawienie czy też może raczej, podkreślając aktywny charakter owego przedstawienia, jego wieloaspektowe doświadczenie; światem jest to, co nam się przedstawia, łącznie z tym, jak się nam przedstawia. Ponadto owe rzeczy, o których mówi Budda, też nie powinny być rozumiane potocznie. Oryginalne słowo dhammā w liczbie mnogiej, jakie tu występuje, może być bowiem rozumiane jako przedmioty doświadczenia dostępne danemu zmysłowi, czyli uchwytywane danym zmysłem zjawiska/jakości. Jeżeli któregoś $\mathrm{z}$ owych aspektów doświad- 
czenia świata zabraknie, wówczas nie ma żadnego świata, na co wskazuje dalszy ciąg wypowiedzi Buddy (SN IV, 40):

yattha ca kho samiddbi nattbi cakkbu nattbi rüpa nattbi cakkbu-viññānam natthi cakkbu-viññāna-viñ̃āatabbā dbammā | natthi tattha loko vā loka-paññatti vā | la ||

Doprawdy, Samiddhi, gdzie nie istnieje oko, nie istnieje materialna forma, nie istnieje wzrokowa świadomość oraz nie istnieją rzeczy poznawalne przez wzrokową świadomość, tam nie istnieje świat ani też pojęcie świata itd.

Rozumienie świata jako doświadczenie świata jeszcze dobitniej zostało podkreślone w wypowiedzi Anandy (p. Ānanda), zaaprobowanej następnie przez Buddę (SN IV, 95):

yena kho ãvuso lokasmim loka-saññ hoti loka-mānī ayyam vuccati ariyassa vinaye loko \|| kena cavuso lokasmim loka-saññi boti loka-mañi | cakkbunā kbo avuso lokasmim loka-saññ̄ boti loka-mānì |

Przez co jest się $w$ tym świecie, przyjaciele, postrzegającym świat, pojmującym świat, to $z$ wie się światem $w$ terminologii Szlachetnego. A przez co, przyjaciele, jest się w tym świecie postrzegającym świat, pojmującym świat? Przez oko, przyjaciele, jest się w tym świecie postrzegającym świat, pojmującym świat.

$\mathrm{Na}$ tej samej zasadzie Ananda analogicznie oświadcza o pozostałych zmysłach. Gdyby powyższą wypowiedź czytać literalnie, to można by wręcz zaryzykować wniosek, że światem jest nie tyle doświadczenie, jak to powyżej zasugerowałem, lecz to, co umożliwia owo doświadczenie, czyli sześć narządów ujmowania. Sądzę jednak, że nie należy iść tym tropem i owo stwierdzenie powinniśmy czytać w szerszym kontekście, w którym sześć narządów ujmowania uznamy nie tyle za sam świat, co za podstawy umożliwiające doświadczenie czy też przed- 
stawienie świata. Potwierdzenie tej sugestii znajdziemy $\mathbf{w}$ poniższej wypowiedzi zaczerpniętej ze 169 strofy Suttanipaty (Sn. I.9.17):

chassu loko samuppanno, hemavatã ti bhagavā chassu kubbati santhavam channam eva upädāya chassu loko vibaññati $\|$

Hemawato, [powiedział] Czcigodny, świat powstał w sześciu [narządach ujmowania], w sześciu został obznajomiony, po schwytaniu w sześciu, przez sześć świat jest dotknięty cierpieniem.

Ten sam wniosek narzuca się po lekturze poniższego cytatu, który jest o tyle interesujący, że nie tylko mowa w nim o ciele $z$ jego aparaturą poznawczą jako podstawie świata, ale przede wszystkim dlatego, że sam świat ujęty został w strukturę czterech szlachetnych prawd, co zdecydowanie potwierdza, że jest on rozumiany tutaj jako doświadczenie świata czy też $\mathrm{w}$ tym wypadku jako pole realizowania się doświadczenia cierpienia. W SN I, 62 czytamy $^{8}$ :

api kbväham avuso imasmiññeva vyamamatte kalevare saññimbi samanake lokam ca pañnapemi loka-samudayam ca loka-nirodham ca loka-nirodhagaminim patipadan-ti $\|$

Doprawdy, przyjacielu, oznajmiam, że właśnie w tym ciele długim na sążeń $z$ jego postrzeganiem i umystem jest świat, powstawanie świata, ustanie świata oraz droga prowadząca do ustania świata.

Deklarację tę Budda złożył w odpowiedzi na pytanie zadane przez Rohitassę (p. Rohitassa; SN I, 61):

\& Kazanie, w którym pojawia się ta wypowiedź (Robitassa-sutta), powtórzone zostało jeszcze dwukrotnie $w$ nieco bardziej rozbudowanej narracyjnie wersji w AN II, 47-49 oraz AN II, 49-50, a przywołane słowa znajdują się w AN II, 48 i 50. 
yattha nu kbo bbante na jayati na jìyati na mìyati na cavati na uppajjati I sakka nu kbo so bbante gamanena lokassa anto ñatum vã datțhum vā papunitum vā ti $\|$

Czy jest możliwe, Czcigodny, dzięki podróży poznać, zobaczyć, osiągnąć kres świata, w którym się nie rodzi, nie starzeje, nie umiera, nie porzuca, nie odradza?

W powyższych dwóch cytatach doskonale wybrzmiewa dwuznaczność słowa „świat” (loka), która zresztą była widoczna już w wypowiedzi Anandy z SN IV, 95. W zdaniu drugim, które w warstwie narracyjnej faktycznie otwiera suttę, Rohitassa, pytając o możliwość dotarcia do kresu (anta) świata, pyta o świat jako obszar zamieszkania, zatem używa tego słowa w potocznym znaczeniu. W cytacie wcześniejszym, będącym odpowiedzią na zadane pytanie, Budda mówi o świecie jako doświadczanym obszarze cierpienia, a kres pojmuje nie przestrzennie jako koniec sceny, na której rozgrywa się theatrum mundi, lecz czasowo jako ustanie pewnego stanu, czyli doświadczenia cierpienia ( $d u k-$ kba). Dwuznaczność tę widać jeszcze wyraźniej w poniższej wypowiedzi, w której świat i cierpienie Budda traktuje zamiennie (SN IV, 93):

nabam bbikkbave gamanena lokassa antam ñätayyam dațtbayyam pattayyan ti vadämi | na ca panābam bbikkbave apatva lokassa antam dukkbassa anta-kiriyam vadāmiti $\|$

Głoszę, mnisi, że kresu świata nie można poznać, nie można zobaczyć, nie można osiągnąć dzięki podróży. Głoszę jednak także, mnisi, że bez osiągnięcia kresu świata nie można położyć kresu cierpieniu.

Należy podkreślić, że w wypowiedziach tych nie mamy do czynienia ani z błędem ekwiwokacji, ani z wewnętrzną sprzecznością. Z ekwiwokacją nie mamy do czynienia, gdyż Budda na zadane pytanie o możliwość dotarcia do kresu świata dzięki przemieszczaniu się w przestrzeni udziela wprost jednoznacznej i negatywnej odpowie- 
dzi, która pozostaje w obszarze rozumienia świata rozmówcy, czyli uwzględnia założenia, jakie wkłada on w pojęcie „świat”: „Głoszę, że kresu świata dzięki podróży nie można poznać, zobaczyć, osiągnąć" (näbam tam gamanena lokassa antam ñateyyam dațtheyyam patteyyanti vādamīti; SN I, 61). Budda nie poprzestaje jednak na udzieleniu prostej i zrozumiałej odpowiedzi, postawienie pytania traktuje bowiem jako pretekst do przeformułowania pojęcia „świat” w kierunku zgodnym z własnym odkryciem. Tym zaś było dostrzeżenie aktywnej roli poznającego podmiotu w konstytucji świata. Świat, jaki nam się jawi, nie jest biernym umysłowym przedstawieniem, nie jest kopią zewnętrznej wobec poznającego podmiotu rzeczywistości, lecz jest przedstawieniem przez podmiot współtworzonym, zależnym zarówno od jego aparatury poznawczej, jak też i, co Budda będzie szczególnie podkreślał, odpowiadającym (czy też bardziej mającym odpowiadać) jego pragnieniom. Robi to, używając sposobu, który stanie się charakterystyczny dla późniejszej, związanej zwłaszcza z tradycją tzw. mahajany, myśli buddyjskiej, a mianowicie stosuje paradoks. $Z$ jednej strony Budda będzie twierdził, że kresu świata osiągnąć nie można, $z$ drugiej natomiast, nauczając drogi do wyzwolenia z cierpienia, będzie oznajmiał, że kres świata osiągnął. Sprzeczność, jaka się tu ujawnia, jest jednak pozorna, gdyż bierze się z zestawienia wypowiedzi utrzymanych $\mathrm{w}$ dwóch różnych porządkach, $\mathrm{z}$ których pierwszy jest porządkiem codziennego, dodajmy, naznaczonego błędem poznawczym, a tym samym sansarycznego doświadczenia, drugi natomiast porządkiem poznania tego błędu pozbawionego, czyli poznania przełamującego porządek pierwszy9. Paradoks jest narzędziem, z którego

9 Na bazie tego typu jezzykowych sytuacji kreowanych przez Buddę rozwinie się w późniejszej myśli buddyjskiej nieobecna w Trójkoszu koncepcja dwóch prawd. Chociaż tym zagadnieniem nie będę się zajmował, warto jednak zwrócić na ten fakt uwagę, aby uświadomić sobie powody, dla których późniejszym koncepcjom buddyjskim nadawano status nauk ortodoksyjnych - postrzegano je bowiem zwykle jako ukoronowanie refleksji nad praktykami samego Buddy. 
Budda robił użytek w sytuacjach wyjątkowych, kiedy szczególnie zależało mu na podkreśleniu konieczności zmiany w sposobie patrzenia, jaka musi dokonać się wraz z przebudzeniem. Gdy audytorium było tego świadome, wypowiedzi Buddy często paradoksu były pozbawione, czego przykładem może być poniższy cytat zaczerpnięty z Kazania o świecie (Loka-sutta) zamieszczony w AN II, $23^{10}$ :

loko bhikkhave tatbägatena abbisambuddho lokasmã tathagato visamyutto, loka-samudayo bbikkbave tathagatena abbisambuddho loka-samudayo tatbägatassa pabino, loka-nirodbo bbikkbave tatbagatena abbisambuddho loka-nirodbo tathagatassa sacchikato, loka-nirodba-gamini patipadä bbikkbave tatbagatena abbisambuddho loka-nirodba-gamini patipada tathagatassa bbavita.

Tathagata, mnisi, doskonale poznał (abbisambuddba) świat, Tathagata pozostaje odłączony od świata; Tathagata, mnisi, doskonale poznał powstawanie świata, Tathagata porzucił powstawanie świata; Tathagata, mnisi, doskonale poznał ustanie świata, Tathagata urzeczywistnił ustanie świata; Tathagata, mnisi, doskonale poznat drogę prowadzącą do ustania świata, Tathagata wprawił się $\mathbf{w}$ drodze prowadzącej do ustania świata.

W Sanjuttanikaji znajdziemy jeszcze jeden ciekawy i wymowny przykład równoważności cierpienia i świata. W SN II, 71-74 pojawiają się dwie identyczne pod względem struktury i niemal identyczne pod względem treści sutty, z których pierwsza dotyczy cierpienia, a druga świata, stąd ich tytuły Kazanie o cierpieniu (Dukkba-sutta) i Kazanie o świecie (Loka-sutta). Budda naucza w nich o powstawaniu (samudaya) i zaniku (atthangama) odpowiednio cierpienia i świata właśnie, przy czym w obu wypadkach podstawą pierwszego i drugiego jest

11 Kazanie to zostało powtórzone w Itiwuttace (Iti-vuttaka, s. 121-123) jako kazanie 112 zamykające cały zbiór. 
relacja między władzami ujmowania (zmysłami i umysłem) a odpowiadającymi im przedmiotami. Desygnaty zdają się być ze sobą tożsame, a oba terminy potraktowane zostały jako synonimy, które można ze sobą wymienić bez zmiany i straty znaczenia.

Skoro termin „świat” (loka) równoważny jest terminowi „cierpienie" (dukkba), to możemy przyznać, że wypowiadając się na temat świata, Budda pozostawał wierny swojej deklaracji, którą złożył w słynnym Kazaniu $w$ lesie palisandrowym (Simsapā-vana-sutta; SN V, 437-438): chociaż poznałem znacznie więcej, to nauczam tylko tego, co przynosi korzyść w realizacji ostatecznego celu, jakim jest wyzwolenie. W tekście tym czytamy (SN V, 438):

kiñca bbikkave mayā akkbatam || idam dukkban ti bbikkbave maya akkbātam \| ayam dukkba-samudayo ti mayā akkbatam \| ayam dukkba-nirodho ti maya akkbatam \| ayam dukkba-nirodha-gäminī pațipada ti mayã akkbātam \|

Czego, mnisi, nauczam? Mnisi, nauczam: „To jest cierpienie”. Nauczam: „To jest powstawanie cierpienia”. Nauczam: "To jest ustanie cierpienia”. Nauczam: „To jest droga prowadząca do ustania cierpienia".

Ciekawego przykładu, który zdaje się potwierdzać tezę głoszącą, że Budda, mówiąc o świecie, w istocie mówi o przedstawieniu czy też doświadczeniu świata, dostarcza Kazanie o kwiatach (Pupphā-sutta; SN III, 138-140). W mowie tej Budda przyznaje się do tego, z jaką opinią na temat istnienia i nieistnienia zgadza się / nie zgadza się. Nie zgadza się ze stanowiskiem głoszącym istnienie trwałych, niezmiennych zespołów (khandha), zgadza się zaś z tym, które utrzymuje istnienie zespołów nietrwałych, zmiennych, a następnie oznajmia (SN III, 139):

atthi bhikkbave loke loka-dhammo yam tathagato abbisambujjbati abbisameti | abbisambujjhitva abbisametvä acikkbati deseti paññäpeti pațthapeti vivarati vibhajeti uttanikaroti $\mid$ 
Istnieje mnisi zjawisko świata w świecie, które Tathagata w pełni doskonale poznaje i pojmuje. W pełni doskonale poznawszy i pojąwszy, omawia je, tłumaczy, oznajmia, ustala, ujawnia, analizuje, objaśnia.

Następnie, odpowiadając na zadane przez samego siebie pytanie, czym jest owo zjawisko świata w świecie, Budda wskazuje kolejno na pięć zespołów (kbandba) - to je poznat i je objaśnia.

Od razu trzeba zaznaczyć, że interpretacja interesującego nas wyrażenia „zjawisko świata w świecie” (loke loka-dhammo), jak też i całego kazania nie należy do łatwych zadań. Kazanie o kwiatacb bywa często przywoływane w dyskusji nad realizmem/antyrealizmem myśli Buddy. Co ciekawe, zawarte w nim wypowiedzi używane są jako argumenty na rzecz obu wykluczających się stanowisk. Do kwestii realizmu/antyrealizmu w kontekście tej sutty jeszcze w tym rozdziale powrócę. Teraz skupię się tylko na wskazanym wyrażeniu, aczkolwiek należy zaznaczyć, że jego interpretacja ostatecznie zależna jest od rozstrzygnięcia spornej kwestii.

Obaj thumacze obu dostępnych kompletnych przekładów Sanjuttanikaji rozumienie Kazania o kwiatach oparli o wykładnię znacznie późniejszych oddających stanowisko therawady (thera-vāda) komentarzy Buddhaghosy z V w. Frank L. Woodward, autor pierwszego thumaczenia, wyrażenie loke loka-dbammo przełożyt jako „warunek świata w świecie" "1. Bhikkhu Bodhi, autor drugiego przekładu, przetłumaczył je jako „zjawisko świata w świecie”"12. W przekładzie pierwszym nacisk został położony na rozumienie zespołu jako tego, co warunkuje świat w obszarze formowania (san்kbāra-loka). Autor przekładu drugiego unika trudności interpretacyjnych, trzymając się litery. Chociaż

1 The Book of the Kindred Sayings, vol. 3, trans. F. L. Woodward, London 1924, s. 117: in the world a world-condition.

12 The Connected Discourses of the Buddha. A New Translation of the Samyutta Nikaya, vol. 1, trans. Bhikkhu Bodhi, Boston 2000, s. 950: a world-phenomenon in the world. 
tłumaczenia te $\mathbf{w}$ warstwie dosłownej nie wykluczają antyrealistycznego rozumienia, to ewidentnie poprzez odwołania w przypisach do Buddhaghosy promują realistyczne rozumienie zarówno oddziaływania przyczynowego, jak i świata ukonstytuowanego przez pozostające w przyczynowym warunkowaniu dhammy.

Sue Hamilton thumacząca interesujące nas wyrażenie jako „zjawisko, które jest światem w świecie", postuluje, aby jego znaczenie czytać w szerszym kontekście ${ }^{13}$. Są nim wypowiedzi Buddy zrównujące świat, pięć zespołów oraz cierpienie. Zgodnie $z$ tą opinią zarówno zjawisko, jak i świat są tym, co jest nam dane w naszym doświadczeniu, a zatem użycie miejscownika „w świecie” (loke) nie wyprowadza naszego doświadczenia poza sferę subiektywności.

W identycznym tonie wypowiedział się Alexander Wynne, który uznał, że wyrażenie to, tłumaczone przez niego jako „światowe zjawisko w świecie", określa perspektywę, z jakiej Budda zajmuje się światem - patrzy on na świat po prostu jako na zjawisko ${ }^{14}$. Przekonanie to potwierdzać mają liczne przykłady, w których świat (loka) rozumiany jest jako świat doświadczenia.

Sądzę, że przywołane wcześniej cytaty stanowią bardzo mocną przesłankę na rzecz antyrealistycznej interpretacji. Jak zatem, w myśl tej wykładni, należy rozumieć wyrażenie „zjawisko świata w świecie”? Tym zjawiskiem jest, przypomnijmy, każdy z pięciu zespołów, a zespół (kbandha) to nic innego, jak kompleks zjawisk danego typu. Otóż kompleks fenomenów w obszarze danego zespołu podlega w naszym naturalnym doświadczeniu obiektywizacji i reifikacji (loka-dbammo) jako część świata, obiekt przynależny do świata (loke). Fenomeny konstytuujące formę cielesną obiektywizowane są jako realny przedmiot

13 Zob. S. Hamilton, The "External World”..., s. 81: phenomenon which is a world in the world; eade m, Early Buddhism. A New Approach. The I of the Bebolder, Richmond 2000, s. 96-97.

14 A. Wynne, Early Buddhist Teachings as Proto-śūnyavada, JOCBS 11 (2015), s. 226: worldly phenomena in the world. 
ulokowany w czasoprzestrzennym realnym świecie, zaś wszystkie pozostałe zespoły obiektywizowane są jako ulokowane w realnym ciele, a zatem także w realnym świecie. Innymi słowy, postrzeganie ciała to nic innego, jak postrzeganie kompleksu zjawisk, które obiektywizujemy, przypisując im samobytność, oraz reifikujemy, przypisując im substancjalność - i analogicznie $\mathrm{w}$ odniesieniu do pozostałych zespołów.

\subsection{Dwa krańce - istnienie i nieistnienie}

W Kazaniu do Katjajany Budda oznajmił, przypomnijmy, że świat ufundowany jest na dwójni istnienia i nieistnienia. W oparciu o przeprowadzoną powyżej analizę świata można postawić mocną hipotezę, że pojmuje on tutaj świat w sposób subiektywistyczny, jako przedstawienie świata. Światem jest nie to, co nam się, jak sądzimy naiwnie, po prostu udostępnia w doświadczeniu, lecz całość naszego doświadczenia, którą poddajemy swoistej „obróbce”. Pojęcie świata jako obiektywnej przestrzeni naszego życia jest efektem owej „obróbki” i jako takie jest pochodne względem struktury naszego doświadczenia. Oglądana z tej perspektywy dwójnia istnienia i nieistnienia okazuje się aspektem tego ostatniego w nie mniejszym stopniu niż tzw. obiektywny świat. Innymi słowy, mówiąc o istnieniu i nieistnieniu Budda ma na myśli istnienie i nieistnienie dla nas, czyli nasz sposób rozumienia tych pojęć, a ściślej rzecz ujmując, sposób, w jaki konstytuują się one w naszym doświadczeniu, oraz rolę, jaką odgrywają w strukturyzowaniu doświadczenia świata. Dodać też należy, że żadnym innym pojęciem istnienia/nieistnienia, w szczególności żadnym obiektywnym pojęciem istnienia/nieistnienia oderwanym od naszego doświadczenia czy też wychodzącym poza nasze doświadczenie w kierunku nieuwarunkowanego obserwatora, dysponować nie możemy. Jak się w dalszym ciągu tej pracy okaże, samo wyjście poza nasze uwarunkowane, czyli subiektywne doświadczenie, jest warunkiem osiągnięcia postulowanego przez Buddę wyzwolenia, a tym samym 
ma być jak najbardziej możliwe, niemniej wyjście to, na co za chwilę zwróç uwagę, będzie oznaczało zniesienie i unieważnienie pojęć istnienia i nieistnienia, a nie wzniesienie ich na poziom znaczenia obiektywnego, to po pierwsze. Po drugie wyjście to będzie oznaczało osiągnięcie nieuwarunkowanego i w tym sensie zobiektywizowanego oglądu konstytuowania się naszego subiektywnego doświadczenia, a nie jakiejś obiektywnej rzeczywistości samobytującej poza tym doświadczeniem.

Zasadnicze pytanie zatem brzmi, jak w naszym doświadczeniu kształtuje się owo naturalne poczucie obiektywności świata, to znaczy, jak to się dzieje, że doświadczając umysłowej treści, wyprowadzam tę treść w bezrefleksyjnym i w tym sensie w naturalnym odruchu poza umysł, dokonując jej obiektywizacji, czyli przypisując jej realne istnienie. Innymi słowy, na czym polega czy też jak się wyraża poczucie realności świata?

Do odpowiedzi na to pytanie przybliżyć nas może analiza różnicy w sposobie postrzegania zwykłych istot oraz przebudzonych, tj. arhatów i Tathagaty. Na różnicę tę Budda wskazał w Pouczeniu o podstawie [wszystkich rzeczy] (Müla-paryāya-sutta; MN I, 1-6). Odnośnie sposobu postrzegania zwyktych istot czytamy (MN I, 1):

idba bbikkbave assutavā putbujjano [...] pațavim paṭhavito sañjānāti | pațavim pațhavito sañnatvā pațavim maññati | pațhaviyā mañnati | pațhavito mañnati | pațhavim-me ti mannami | pațhavim abbinandati | tam kissa betu | apariññatam tassäti vadami ll

W tym wypadku, mnisi, nieuczony zwykły człowiek postrzega ziemię jako ziemię. Postrzegłszy ziemię jako ziemię, wyobraża sobie [siebie jako] ziemię, wyobraża sobie [siebie] w ziemi, wyobraża sobie [siebie] poza ziemią, wyobraża sobie ziemię jako „moją", znajduje upodobanie w ziemi. Dlaczego tak jest? Głoszę, że dlatego, iż nie poznał jej w pełni. 
W dalszym ciągu w ten sam sposób Budda wypowiada się jeszcze o postrzeganiu dwudziestu trzech przedmiotów, w tym kolejnych $\dot{z} y-$ wiołów, istot wyższych poziomów istnienia, planów ujmowania (tego, co zmysłowo i umysłowo ujmowane) oraz trzech szczególnych przedmiotów określających czy wręcz wyznaczających skłonność ku i tendencję do konkretnej ontologii, jak jedność (ekatta), różnorodność (nânatta) i wszystko/wszechcałość (sabba).

Radykalnie odmiennie postrzegają arhaci i Tathagata. Budda stwierdza (MN I, 4):

yo pi so bbikkbave bbikkbu arabam kbīnāsavo [...] sammadañ̃ãa vimutto | so pi pathavim pațhavito abbijanati | pathavim pațhavito abbiññaya pațhavim na mañnati | pațhaviyā na mañnati $\mid$ pațhavito na mañnati | pațhavim-me ti na mañnati | pațhavim nabbinandati | tam kissa betu | pariñnáatam tassati vadami $\|$

Natomiast, mnisi, mnich, który jest arhatem, który zniszczył skazy [...] wyzwolił się dzięki właściwemu doskonałemu poznaniu, całkowicie poznaje ziemię jako ziemię. Całkowicie poznawszy ziemį̨ jako ziemį, nie wyobraża sobie [siebie jako] ziemi, nie wyobraża sobie [siebie] w ziemi, nie wyobraża sobie [siebie] poza ziemią, nie wyobraża sobie ziemi jako "moja”, nie znajduje upodobania w ziemi. Dlaczego tak jest? Głoszę, że dlatego, iż w pełni ją poznał.

Różnica w postawie poznawczej istot zwykłych i przebudzonych, jak możemy stwierdzić na podstawie powyższych cytatów, polega na tym, że zwykłe istoty, gdy postrzegają (sañjānātı), dokonują obiektywizacji tego, co postrzegają w akcie obustronnego uznania w bycie przedmiotu postrzeganego i podmiotu postrzegającego. Następnie przedmiot taki staje się obiektem pojęciowego ujęcia (maññatı) czy też mniemania, domysłu, wyobrażenia, w którym podmiot dąży do określenia relacji z nim, co z kolei konstytuuje emocjonalną więź. Opowiedzenie się za jedną z czterech rudymentarnych relacji wyznacza 
podstawę, w oparciu o którą rozwijane są następnie określone typy ontologii - monistyczne, dualistyczne/pluralistyczne, panteistyczne.

Przebudzony natomiast nie postrzega, tylko całkowicie poznaje (abbijanātı). Między "postrzega" (sañjānātı), a "całkowicie poznaje” (abbijānāti) zachodzi fundamentalna jakościowa różnica, gdyż całkowite poznanie nie pozostawia miejsca na żadne mniemanie, wyobrażenie, pojęciowe ujęcie, na żaden domysł (na mañnatz) ${ }^{15}$. Przebudzony pozostaje całkowicie $\mathrm{w}$ obszarze doświadczenia, czyli w obszarze samych zjawisk, nie nadaje im statusu realnego bytu, nie buduje żadnej emocjonalnej relacji, gdyż poznaje zjawiska jako zjawiska, nie obiektywizując ich.

Analogiczny opis sposobu poznania Tathagaty zamieszczony został też w MN I, 329 (MN 49). W obu wypadkach struktura wypowiedzi jest identyczna, w treści jednak pojawiły się pewne ciekawe modyfikacje. Zamiast twierdzić, że Tathagata nie znajduje upodobania (näbbinandatı) w ziemi itd., mówi się, że nie afirmuje (nābbivadı) ziemi itd., czyli nie deklaruje jej istnienia - i analogicznie odnośnie do pozostałych przedmiotów. Zestawienie to pozwala wyciągnąć wniosek, że znajdowanie upodobania (abbinandana) oraz afirmacja (abbivadana) to dwa momenty tej samej postawy. Afirmacja istnienia wyraża się w znajdowaniu upodobania, znajdowanie upodobania zaś potwierdza afirmację.

Możemy zatem stwierdzić, że poczucie obiektywności świata charakterystyczne dla naturalnego doświadczenia jest pochodną momentu tetycznego, czyli uznania w bycie postrzeganego przedmiotu. Ważne, żebyśmy sobie uświadomili, że chociaż mówię o uznaniu w bycie, to nie jest to kwestia decyzji, czyli woli. Jeżeli w sposobie ukazywania się świata ucieleśnia się błąd poznawczy, to oznacza, że błąd poznaw-

15 W MN III, 45 dając opis osiągnięcia ustania postrzegania i uczuć, Budda podkreśla: „taki mnich niczego sobie nie wyobraża, nie wyobraża sobie w odniesieniu do czegokolwiek, nie wyobraża sobie w żaden sposób" (bbikkbu na kiñci maññati, na kubiñci maññati, na kenaci mañnatı). 
czy nam się narzuca; ma on charakter obiektywny w tym sensie, że doświadczenie świata jawi nam się jako jego odkrywanie, a nie jego tworzenie. Dlatego Budda oznajmia, że świat ufundowany na istnieniu i nieistnieniu spętany jest przywiązaniem i lgnięciem. Postawa przywiązania i lgnięcia charakteryzuje nasz naturalny sposób istnienia. Lgnięcie przybiera postać uznania w bycie tego, co nam się jawi, czyli jego ulokowania poza obszarem jawienia się, tzn. poza świadomością. W ten sposób czynię to przeciwstawnym świadomości i dlatego atrakcyjnym, wartym pożądania i dążenia ku. Aktowi uznania w bycie tego, co się jawi, odpowiada zatem w warstwie subiektywnej akt uznania w bycie "ja" jako odniesionego i dążącego do tego, co się jawi. Z buddyjskiej perspektywy uznanie w bycie "ja" oraz uznanie w bycie świata to dwa momenty czy też dwie strony tego samego aktu. Na powiązanie lgnięcia $z$ uznaniem w bycie "ja” Budda zwraca uwage w NidSa 19.5a, kojarząc trwanie w lgnięciu $z$ ideą „moja jaźñ".

Intuicja istnienia zbudowana jest na pragnieniu trwania „ja”. Istnieć to znaczy trwać w czasie dzięki sobie, w sobie znajdować podstawę swojego bytu. Kazanie do Katjajany taką wykładnię tylko pośrednio sugeruje. Potwierdzenie tego przekonania znajdziemy jednak w charakterystyce błędnych poglądów przeprowadzonej w Kazaniu o sieci Brabmy (Brabma-jäla-sutta), pierwszej sutcie Dighanikaji (DN I, 2-46), w szczególności zaś w charakterystyce pierwszych czterech błędnych poglądów głoszących eternalizm, czyli istnienie świata i jaźni rozumiane jako ich trwanie. Ważniejsze jednak jest to, że wszystkie te poglądy ugruntowane są w odczuciu (vedayita), które wyrasta z pragnienia, które wyraża zatroskanie i niepewność. Podsumowując wszystkie poglądy $z$ osobna, Budda za każdym razem powtarza to samo stwierdzenie (DN I, 40-41):

tad api tesam bhavatam samana-bräbmanānam ajānatam apassatam vedayitam tanha-gatanam paritasita-vipphanditam eva 
To jest jedynie odczucie (vedayita) tych szacownych ascetów i braminów, którzy nie wiedzą i nie widzą, obawa i wahanie owładniętych pragnieniem.

$\mathrm{Na}$ związek między poczuciem indywidualnego istnienia (p. sakkāya-dițthi, s. sat-kāya-drșţi) a sześćdziesięcioma dwoma błędnymi poglądami omawianymi w Kazaniu o sieci Brabmy, jak też i słynnymi dziesięcioma (ew. czternastoma) kwestiami, które Budda standardowo pozostawiał bez odpowiedzi (p. avyākata-vattbu, s. avyākrta-vastu), wskazuje uczeń Buddy imieniem Isidatta (p. Isidatta) w SN IV, 287. Udzielając odpowiedzi świeckiemu wyznawcy, stwierdził on dobitnie: "gospodarzu, poglądy te powstają, kiedy istnieje przeświadczenie o indywidualnym istnieniu; kiedy przeświadczenie o indywidualnym istnieniu nie istnieje, poglądy te nie powstają" (ima kbo gabapati dițthiyo sakkāya-ditṭhiya sati bonti | sakkāya-dițthiyā asati na bontī ti).

W podobnym tonie utrzymana jest odpowiedź Buddy na indagowanie ze strony Waczczhagotty (p. Vacchagotta) o to, dlaczego nie odpowiada on na pytania, na które inni mędrcy odpowiedzi udzielają. Budda zaznacza, że w przeciwieństwie do owych mędrców, którzy postrzegają poszczególne zespoły (kbandba) w relacji do jaźni, np. formę materialną uważają za jaźń lub uważają, że jaźń posiada materialną formę, lub że materialna forma jest zawarta w jaźni, lub też że jaźń zawarta jest w materialnej formie i podobnie odnośnie do pozostałych zespołów, on jako w pełni, doskonale przebudzony w ten sposób na zespoły nie patrzy (SN IV, 395-396). Nie powinien nas kłopotać fakt, że w tej konkretnej wypowiedzi nie pojawia sį̨ literalne odniesienie do poczucia indywidualnego istnienia. We wczesnej tradycji buddyjskiej wchodzenie w ową czworaką relację z pięcioma zespołami było bowiem od samego początku traktowane jako sposób wyrażania się poczucia indywidualnego istnienia. Budda dał temu jednoznaczny wyraz $w$ rozmowie $z$ jednym ze swoich uczniów, który wprost postawił pytanie: „Czcigodny, jak powstaje poczucie indywidualnego istnienia?" (katham nu kbo bbante sakkāya-dițţi botīti; SN III, 102). 
W odpowiedzi Budda przywołał właśnie ową czworaką formułę określającą postrzeganie zespołów w relacji do jaźni, co następnie podsumowat: „Tak właśnie, mnichu, powstaje poczucie indywidualnego istnienia" (evam kbo bbikkbu sakkaya-dițthi botīti).

Warto przytoczyć również wypowiedź słynnego ucznia Buddy Anandy, potwierdzającą to przekonanie. Ananda, wspominając czasy nowicjatu, przywołuje naukę starszego mnicha imieniem Punna Mantaniputta (p. Puṇna Mantāniputta), który w lgnięciu do zespołów widzi podstawę tworzenia się wyobrażenia „ja jestem” (asmît $i$; SN III, 105).

Określając rangę poczucia indywidualnego istnienia dla kształtowania się ogólnych pojęć istnienia i nieistnienia, nie sposób nie przywołać rozmowy słynnej uczennicy Buddy mniszki Dhammadinny (p. Dhammadinnā) ze świeckim wyznawcą o imieniu Wisakha (p. Visākha) zachowanej w Madżdżhimanikaji (MN I, 299-305 [MN 44]: Cūla-vedalla-sutta). Rozmowa ta jest niezwykle ciekawa dlatego, że Dhammadinna odrębnie objaśnia w niej kwestie indywidualnego istnienia (sakkāya) i poczucia indywidualnego istnienia (sakkāya-ditțhi). Zgodnie z jej wykładnią indywidualne istnienie (sakkāya) definiowane jest w relacji do pięciu zespołów. Czytamy tam (MN I, 299):

pañca kho ime āvuso visākba upadanakkbandhā sakkayo vutto bhagavata. seyyatbìdam rüpupadānakkbandho vedanupadānakkbandho saññupadanakkbandho sañkbärupädanakkbandho viññanupadanakkbandho. Ime kbo avuso visäkba pañc'upadanakkbandha sakkayo vutto bhagavata ti.

Przyjacielu Wisakho, Czcigodny indywidualnym istnieniem nazywa tych pięć zespołów dotkniętych lgnięciem, mianowicie: zespół materialnej formy dotknięty lgnięciem, zespół uczucia dotknięty lgnięciem, zespół postrzeżenia dotknięty lgnięciem, zespół dyspozycji wolicjonalnych dotknięty lgnięciem, zespół świadomości dotknięty lgnięciem. Czcigodny indywidualnym istnieniem nazywa tych pięć zespołów dotkniętych lgnięciem. 
Indywidualne istnienie, co stwierdzamy na podstawie powyższego cytatu, to nie po prostu pięć zespołów, jak można by pochopnie sądzić, a lgnięcie czy też pozostawanie $\mathrm{w}$ relacji lgnięcia do pięciu zespołów ${ }^{16}$.

W dalszym ciągu Wisakha pyta o powstawanie (samudaya), ustawanie (nirodha) i drogę (pațipadā) prowadzącą do ustania indywidualnego istnienia, czyli postępuje zgodnie ze schematem wyznaczonym przez cztery szlachetne prawdy. Dhammadinna, odpowiadając, nie tylko trzyma się tego schematu, co jest oczywiste, ale - co znacznie ważniejsze - idzie jeszcze dalej i powtarza klasyczną wykładnię czterech szlachetnych prawd ukierunkowaną na opis cierpienia (dukkba) znaną z pierwszego kazania Buddy, tj. Kazania wprawiającego $w$ ruch koto nauki (Dhamma-cakkappavattana-sutta; SN V, 420-424). Daje w ten sposób do zrozumienia, że pojęcia sakkāya i dukkba są równoważne, czyli że odnoszą się do tego samego przedmiotowego zakresu, ujmując go $z$ różnych perspektyw. Innymi słowy, istnieć indywidualnie, czyli lgnąć do pięciu zespołów, to cierpieć. Cierpienie zaś to istnienie indywidualne, czyli lgnięcie do pięciu zespołów. Do tej pary powinniśmy dodać, jeśli przypomnimy sobie wcześniejsze rozważania, trzecie pojęcie - świat (loka). Wszystkie trzy są równoważne, ujmując różne aspekty naszego doświadczenia.

W związku $\mathrm{z}$ opisem powstawania indywidualnego istnienia (sakkāya-samudaya) warto zwrócić uwagę, nieco na marginesie, na jeszcze jeden moment. W tym przypadku, tak jak w opisie powstawania cierpienia, za źródło powstawania zostaje uznane pragnienie (tanhba), które wyraża się w trzech formach: pragnienie przyjemności zmysłowych (kãma-tanhba), pragnienie istnienia (bhava-tanbāa) i pragnienie nieistnienia (vibbava-tanhā) (MN I, 299). Ponieważ termin vibbava może znaczyć 'potęga, bogactwo, dobrobyt', można spotkać się z sugestią, że trzecia forma pragnienia może być ukierunkowa-

16 Zob. też Kazanie o indywidualnym istnieniu (Sakkaya-sutta; SN IV, 259-260), w którym Sariputta (p. Sāriputta) stwierdza to samo. 
na właśnie na potęgę ${ }^{17}$. Otóż sądzę, że ze względu na wspomnianą równoważność trzech pojęć rozumienie trzeciej postaci pragnienia nie powinno nastręczać żadnych problemów, należy zdecydowanie opowiedzieć się za drugim możliwym znaczeniem tego terminu, czyli 'nieistnieniem'. Może być to nieistnienie własne, jako potencjalna odpowiedź na doświadczenie nadmiaru nieznośnego cierpienia, bądź nieistnienie czegoś innego, jako potencjalna odpowiedź na doświadczenie cierpienia związane $z$ poczuciem awersji, zagrożenia. Tak czy inaczej, chodzi o nieistnienie jako opcję względem istnienia, jako jego przekreślenie, anulowanie, unicestwienie. Żeby w pełni zrozumieć tę uwage, należy bez wątpienia czytać ją w kontekście Kazania do Katjajany, zwłaszcza w kontekście stwierdzenia o ufundowaniu świata na opozycji istnienia i nieistnienia. Te dwa pojęcia w obszarze doświadczenia sansarycznego wyznaczają zdaniem Buddy nasz horyzont jego rozumienia.

Ukontentowany Wisakha pyta w końcu o to, jak powstaje poczucie indywidualnego istnienia (sakkāya-dițthi). W odpowiedzi słyszy znaną nam już czworaką formułę określającą postrzeganie zespołów w relacji do jaźni powtórzoną pięciokrotnie w odniesieniu do pięciu zespołów (MN I, 300).

Jeszcze bodaj ciekawsze są uwagi Buddy na temat tego, jak dochodzi do pojawienia się lgnięcia w odniesieniu do pięciu zespołów wypowiedziane w Kazaniu o ekscytacji lgnięciem (Upädā-paritassanä-sutta; SN III, 15-18). Budda kolejny raz zauważa, że zwykły człowiek może postrzegać relację jaźni do zespołów na cztery sposoby, a następnie oznajmia (SN III, 16):

tassa tam rūpam viparinamati añnatba boti | tassa rūpa-viparinamañnatba-bbāva rūpa-viparinamānuparivatti viññanam boti I tassa rüpa-viparinamanuparivattajā paritassand

17 Zob. np. przekład pierwszego kazania w: M. Mejor, Buddyzm. Zarys bistorii buddyzmu w Indiach, Warszawa 2001, s. 240. 
dhamma-samuppādā cittam pariyādāya tițhanti I cetaso pariyādānā uttāsavā ca hoti vighătavā ca apekhavā ca upādāya ca paritassati ll

Ta jego materialna forma zmienia się i podlega przeobrażeniu. $\mathrm{Z}$ powodu zmiany i przeobrażania materialnej formy jego świadomość zajmuje się zmianą materialnej formy. Pozostają ekscytacja i powstawanie [umysłowych] stanów zrodzonych z zajmowania się zmianą materialnej formy, pętając jego umysł. Ponieważ umysł jest spętany, jest on przerażony, zrozpaczony, zatrwożony i ulega ekscytacji lgnięciem.

Idea istnienia/bytu, a co za tym idzie i nieistnienia/niebytu, jest wyrazem lgnięcia. Zmiana przeraża, budzi trwogę. Idea istnienia jest pozytywną odpowiedzią na lgnięcie, daje ona nadzieję na możliwość spełnienia się pragnienia przekroczenia zmiany, czyli trwania ${ }^{18}$. To jej nadaje znak dodatni. W tym ukierunkowaniu lgnięcia na istnienie rozumiane jako zniesienie, przekroczenie zmiany należy ulokować wszelkie postawy, które nakazują postrzegać czysty byt jako jednocześnie doskonały, czyli dobry i piękny. Tym samym jego zaprzeczenie, tj. czyste nieistnienie, czyli nicość/niebyt, automatycznie naznaczone zostaje znakiem ujemnym, stając się synonimem zła. Dla Buddy,

18 Doskonałej ilustracji potwierdzającej tę uwage dostarcza krótkie Kazanie o tej jazni (Eso atta-sutta; SN III, 182-183). Budda oznajmia tam: „Kiedy istnieje forma materialna, mnisi, przez lgnięcie do formy, przez przywieranie do formy, taki pogląd powstaje: To jest jaźnią, co jest światem, po śmierci będę trwały, stały, wieczny, nie podlegający zmianie" (rüpe kbo bbikkbave sati rūpam upädaya rūpam abbinivissa evam dițthi uppajjati. so atta so loko so pecca bhavissāmi nicco dhuvo sassato aviparināmadhammoti) i to samo $\mathrm{w}$ odniesieniu do pozostałych zespołów. Bezpośrednio po tym kazaniu w kolejnym Budda oznajmia, że dokładnie w taki sam sposób kształtuje sį̧ inny, w pewnym sensie przeciwstawny, gdyż oparty o idę̧ nieistnienia, pogląd (SN III, 183): „Mógtbym nie istnieć, a to mogłoby nie istnieć dla mnie; nie będę istniał, a to nie będzie istnieć dla mnie" (no cassam no ca me siya na bhavissami na me bbavissatīti). 
powtórzmy to po raz kolejny, obie opcje są nie do zaakceptowania: afirmacja istnienia, jak i w nie mniejszym stopniu afirmacja nieistnienia. Daje temu bezpośredni wyraz w Suttanipacie, gdzie czytamy (Sn. 243): „żywienie poglądu, że nic nie istnieje [...] oto skażona żywność" (natthikadițthi [...] esāmagandho).

Wyrażenie sakkaya-dițthi/sat-kaya-drști bywa różnie tłumaczone, aczkolwiek ze względu na obecność terminu dițthi/drsți zwykle pojawia się w przekładzie określenie „pogląd”. Pierwsza część tego wyrażenia to dwa słowa - p. sant (w złożeniu sak-), s. sat, drugie zaś to kāya. Pierwsze jako imiesłów czasu teraźniejszego od s. Vas (p. attbi) w znaczeniu 'być, istnieć' znaczy 'będący, istniejący, byt', drugie natomiast to 'ciało', ale też 'zbiór, nagromadzenie, grupa, zespół, korpus'. W przekładzie całości zwykle uwzględnia się jednak kontekst użycia tego wyrażenia, który każe je wiązać z poglądem o własnym osobowym, opartym o trwałą jaźń istnieniu. Stąd różne propozycje tłumaczenia, np. jako: theory of soul ${ }^{19}$, personality view ${ }^{20}$, identity view ${ }^{21}$, personality-beliefe, the view of individuality ${ }^{23}$ i wiele innych. $\mathrm{Na}$ język polski można by je przełożyć jako "pogląd o osobowym/indywidualnym istnieniu". Należy jednak odróżnić konkretne pojęcie siebie, tj. wyobrażenie na swój temat, od owego „poglądu”. Pierwsze ma charakter dynamiczny i refleksyjny, tzn. podlega zmianie pod wpływem różnych okoliczności i do pewnego stopnia może być świadomie kształtowane, a w stosunku to tego "poglądu” jest jego konkretną, tzn. jakościowo określoną manifestacją. Ten „pogląd” natomiast jest kształtującym się na poziomie przedrefleksyjnym poczuciem własnej

19 Pali-English Dictionary, ed. T.W. Rhys Davids, W. Stede, Delhi 1993, s. 661.

20 The Middle Length Discourses of the Buddha. A New Translation of the Majjhima Nikāya, trans. Bhikkhu Ñà ṇ a moli, ed. Bhikkhu B od hi, Boston 1995, s. 398.

${ }^{21}$ The Connected Discourses of the Buddha. A Translation of the Samyutta Nikaya, vol. 2, trans. Bhikkhu Bodh i, Boston 2000, s. 1565.

22 The Long Discourses of the Buddha. A Translation of the Digha Nikaya, trans. M. Walshe, Boston 1995, s. 26.

23 R. Gethin, The Foundations of Buddhism, Oxford 1998, s. 73. 
osobowej odrębności, można by powiedzieć, że jest przedrefleksyjnym poczuciem źródłowego „ja”, które następnie będzie się wyrażało w refleksyjnych aktach na temat siebie oraz na temat nie-, ,ja”, czyli świata. Dlatego zamiast mówić o poglądzie, wolę w tym wypadku mówić o przeświadczeniu czy też poczuciu, stąd „poczucie indywidualnego/ własnego/osobowego istnienia".

Warto zwrócić uwage na jeszcze jedną rzecz. W wyrażeniu akcentowane jest słowo "ciało” (kāya). Michael David Radich zauważa, że słowo to pojawia się tu w zastępstwie terminu "materialna forma" ( $r \bar{u} p a)$ i użyte jest w funkcji synekdochy, zastępując wszystkie pięć zespołów, w odniesieniu do których kształtuje się poczucie własnego istnienia ${ }^{24}$. Zapewne jest to słuszna uwaga. Niemniej sądzę, że można się w tym zabiegu dopatrzeć głębszej treści. Możliwe, że chodzi tutaj o wskazanie roli, jaką w kształtowaniu się poczucia własnej tożsamości pełni właśnie doświadczenie cielesności.

Poczuciu indywidualnego istnienia przypisuje się rolę podstawy, w oparciu o którą kształtują się błędne poglądy (p. miccbā-ditṭtbi). Anālayo koryguje jednak to przeświadczenie, zauważając, że sakkāya-ditṭbi nie daje się sprowadzić wyłącznie do tej funkcji ${ }^{25}$. Błędny pogląd skutkuje bowiem zawsze gorszymi odrodzeniami, czego nie można powiedzieć o sakkāya-dițthi. Jest to oczywiste, jeżeli pamiętamy o wspomnianej powyżej równoważności trzech pojęć: dukkba/duḅkba, loka i sakkāya/sat-kaya. W poczuciu indywidualnego istnienia wyraża się całe nasze sansaryczne doświadczenie, to, które leży u podłoża zarówno błędnych, jak też i właściwych poglądów (p. sammā-dițthi). Zważywszy na fakt, że według Buddy żywienie poglądów jako ukierunkowanie myśli na określoną treść podlega moralnej waloryzacji,

24 M. D. Radich, The Somatics of Liberation. Ideas about Embodiment in Buddhism from Its Origins to the Fifth Century C.E., [rozp. dokt.], Harvard University, Cambridge 2007, s. 103.

25 Anālayo, Sakkayadittthi, [w:] Encyclopaedia of Buddhism, vol. 7, fasc. 4, ed. W. G. Weeraratne, Colombo 2006, s. 642. 
zgodnie $\mathrm{z}$ definicją karmana jako intencjii ${ }^{26}$, to żywienie poglądów, jako szczególna forma waloryzowanego moralnie czynu, nie może wyprowadzać poza sansarę, może co najwyżej skutkować gorszymi bądź lepszymi odrodzeniami. Zatem sakkāya-ditțhi jest podstawą wszelkich poglądów. Ze względu na żeński rodzaj terminu „pogląd” w pali/ sanskrycie, można by powiedzieć, że sakkāya-dițthi to matka wszystkich poglądów, zarówno niewłaściwych, jak i właściwych. Poczucie osobowego istnienia (sakkāya-dițţhi) jest podstawą żywienia poglądów, a nie żywienia błędnych poglądów ${ }^{27}$. Budda uwydatnia ten fakt w Sn. 867, gdzie czytamy:

sātam asātan' ti yam ābu loke, tam üpanissāya paboti cbando, rüpesu disvā vibhavam bhavañ ca vinicchayam kurute jantu loke $\|$

Pragnienie/intencja (chanda) powstaje w zależności od tego, co zwą "przyjemnym" i „nieprzyjemnym” w świecie. Dostrzegając $w$ formach materialnych nieistnienie $\mathrm{i}$ istnienie, istota podejmuje decyzje [ew. dokonuje rozróżnienia, tworzy pogląd] (vinicchayam kurute) w świecie.

Dlatego żeby się wyzwolić, trzeba wyzbyć się wszelkich postaci sakkāya-dițţi, a nie tylko błędnych poglądów. Innymi słowy, trzeba wyzbyć się poglądów jako takich, czyli ugruntowanej w pragnieniu wyrażającym się w Ignięciu do zespołów postawy żywienia poglądów - afirmowania istnienia i nieistnienia.

Opinię tę zdają się potwierdzać następujące dwie strofy z Sn. 869-870:

26 W AN III, 415 Budda oznajmia: „Intencje, mnisi, nazywam karmanem. Wyraziwszy intencję, podejmuje się działanie ciałem, mową i myślą" (cetanaham bhikkhave kammam vadami; cetayitva kammam karoti kayena vacaya manasa).

27 Do zagadnienia tego wróç $w$ drugiej części niniejszej ksiąiki, dyskutując kwestį̨ domniemanego buddyjskiego sceptycyzmu. 
sătam asatañ ca kutonidaña, kismim asante na bhavanti 'b' ete, vibhavam bhavañ cāpi yam etam attham, etam me pabrübi yatonidanam $\|$

Gdzie mają swoją przyczynę przyjemność i nieprzyjemność? W związku 2 nieistnieniem czego one nie powstają? Owa rzecz, która jest istnieniem i nieistnieniem, powiedz mi, gdzie ona ma swoją przyczynę?

phassanidānam sătam asātam, phasse asante na bbavanti ' h' ete, vibbavam bhavañ cāpi yam etam attham, etạn te pabrūmi itonidānam \|

Przyjemność i nieprzyjemność ma swoją przyczynę w kontakcie. Gdy kontakt nie istnieje, one nie istnieją. Owa rzecz, która jest istnieniem i nieistnieniem, powiadam ci, ona też ma swoją przyczynę w tym.

Ponieważ uznanie istnienia, jak i negacja istnienia to nic innego jak poglądy, które mają zastosowanie w obszarze opisu sansarycznego, czyli w obszarze skażonego doświadczenia, wszelkie próby określenia statusu wyzwolonego po śmierci postulowane przez Waczczhagottę muszą zostać zdyskredytowane przez Buddę. Ściśle rzecz biorąc, o wyzwolonym nie tylko nie sposób orzekać w kategoriach istnienia i nieistnienia po śmierci, ale nie sposób tego robić również za jego życia. Nie jest to sytuacja zarezerwowana tylko dla wyzwolonego. Jeśli Kazanie do Katjajany potraktujemy poważnie, to uznać będziemy musieli, że o niczym nie można orzekać istnienia i nieistnienia w sensie ostatecznym, czyli obiektywnym, tj. niezależnym od naznaczonego błędem poznawczym doświadczenia. Jeżeli przypisujemy czemuś istnienie, odbywa się to tylko w ramach błędu poznawczego polegającego na obiektywizacji treści doświadczenia istot w błędzie pozostających. Tak należy rozumieć wypowiedź Buddy ze słynnego Kazania 
do Waczczhagotty o ogniu (Aggi-vacchagotta-sutta; MN I, 487): „Tathagata porzucił tę materialną formę, przez którą poznający Tathagatę może go poznać" (yena rūpena tathāgatam paññāpayamāno paññāpeyya tam rūpam tathägatassa pabinam), i dalej: „zaiste Waczczho Tathagata wyzwolił się z bycia definiowanym na podstawie materialnej formy [dost. z definicji/nazwy materialnej formy]" (rüpa-sañkbā-vimutto kbo vaccha tathägato). Budda nie tylko oznajmił, że przebudzony po śmierci, nie mając związku z materialną formą (oraz pozostałymi zespołami), nie może być w żaden sposób opisany na jej (ich) podstawie, ale wyraźnie sugeruje, że wszelki opis przebudzonego jest opisem z perspektywy istot błędnie go poznających, przez istoty błędnie go poznające i dla istot błędnie go poznających. Wszelki opis Tathagaty jest opisem na podstawie sposobu doświadczania pięciu zespołów przez istoty pozostające w błędzie, czyli obiektywizujące owe zespoły, afirmujące ich istnienie. Gdy zespoły te znikają z ich doświadczenia, poznające błędnie istoty skłonne są afirmować ich, a tym samym też Tathagaty nieistnienie. Ponieważ afirmacja zarówno istnienia, jak i nieistnienia są postawami naznaczonymi błędem, równie błędne musi być orzekanie oparte o ich koniunkcję oraz binegację. Sposoby te bowiem nie wyprowadzają poza semantyczny horyzont kategorii istnienia i nieistnienia.

Dokładnie takiej samej odpowiedzi na analogiczne pytania o istnienie, nieistnienie, istnienie i nieistnienie, ani istnienie, ani nieistnienie Tathagaty po śmierci udzieliła mniszka Khema (p. Khemā) królowi Pasenadiemu (p. Pasenadi) w SN IV, 376-377. Z tą różnicą, że Khema wypowiedź swoją okrasiła mocnymi, barwnymi metaforami, przyrównując porzucenie przez Tathagatę poszczególnych zespołów do odcięcia korzenia, do odcięcia dłoni i zamazania, a jego pośmiertny stan do głębokiego, niezmierzonego, niezgtębionego oceanu.

Za podsumowanie powyższych rozważań uznać można odpowiedź, jaką Budda udzielił Upasiwie (p. Upasiva) w Suttanipacie na pytanie, czy mędrzec, tj. muni, po śmierci nie istnieje czy też trwa wiecznie (Sn. 1075). Przebudzony rzekł (Sn. 1076): 
atthañ gatassa na pamanam atthi, upasīvã ti bhagavã yena nam vaju, tam tassa n' attbi, sabbesu dhammesu samūbatesu samūbata vãdapatbā pi sabbe ti ll

Upasiwo, dla tego, który odszedł, nie istnieje miara, powiedział Czcigodny. To, dzięki czemu mogą o nim mówić, nie istnieje dla niego. Gdy wszystkie zjawiska zostają usunięte, wówczas usunięte zostają też wszystkie sposoby mówienia.

Tłumacząc na początku tego rozdziału fragment NidSa 19.5al z Kazania do Katjajany, zasugerowałem możliwość dwojakiego przekładu. Przypomnijmy: „Ten świat, Katjajano, ufundowany na istnieniu i nieistnieniu, spętany jest przywiązaniem i lgnięciem [ew. spętany jest lgnięciem do podłoża/zespołów]". Zwykle badacze wybierają pierwszą możliwość, oddając upadbi jako 'przywiązanie'. Termin ten może znaczyć jednak także 'podstawa, podłoże', zwłaszcza jako podstawa istnienia, odradzania się. W tym drugim znaczeniu słowo to może m.in. desygnować zespoły (p. kbandba, s. skandba). Dlatego sądzę, że na podstawie powyższej analizy konstytuowania się poczucia istnienia w oparciu o lgnięcie do zespołów przekład nspętany jest lgnięciem do zespołów" jest jak najbardziej prawdopodobny.

$\mathrm{Na}$ koniec tej części rozważań winienem poczynić jeszcze jedną drobną uwagę. Czujny czytelnik zauważył zapewne, że pragnienie/ Ignięcie może wystąpić w dwóch funkcjach - przyczyny i skutku. Raz mówi się o pragnieniu/lgnięciu jako o źródle poczucia indywidualnego istnienia, innym razem zaś to poczucie indywidualnego istnienia przedstawiane jest $\mathrm{w}$ roli podstawy dla pojawiania się pragnienia. Może zrodzić się pytanie o to, co jest wcześniejsze: istnienie/nieistnienie czy pragnienie/lgnięcie. Pytanie to jest jednak źle postawione. W kontekście buddyjskim bowiem aktualne doświadczenie istnienia/ nieistnienia postrzegane jest jako konsekwencja uprzedniego pragnienia/lgnięcia i staje się aktualnie podstawą dla kształtowania się dalszego pragnienia/lgnięcia. 


\subsection{Widzenie powstawania i ustawania jako remedium na istnienie $i$ nieistnienie}

W poprzednim podrozdziale dążłem do pokazania, jak konstytuuje się dwójnia istnienia i nieistnienia, jaką rolę odgrywa w fundowaniu świata oraz przede wszystkim, jaki jest jej związek z postawą Ignięcia. Kolejny fragment Kazania do Katjajany w swojej pierwszej części nawiązuje do tych zagadnień w negatywny sposób, wskazując na lgnięcie wyrażające się w przeświadczeniu „moja jaźń” (ätmā me) jako na przeszkodę, którą należy przekroczyć. Budda jednak nie poprzestaje na postulacie wyzbycia się lgnięcia, lecz idzie znacznie dalej, opisując stan, który będzie skutkiem takiej realizacji. Stwierdza zatem (NidSa 19.5a2-b1):

etāni ced upadhyupādannani cetaso 'dhișthänābbinivesánuśayān nopaiti nopadatte nädhitișțhati nabbinivisaty àtmā meti | dubkbam idam utpadyamānam utpadyate | dubkbam nirudbyamanam nirudhyate |

Jeśli nie oddaje się tym [postawom] lgnięcia i przywiązania, stanowiącym skłonność umysłu do uporu i związania, nie przyjmuje ich, nie obstaje przy nich, nie trzyma się ich [mówiąc] "moja jaźñ", to powstające cierpienie powstaje, to ustające cierpienie ustaje.

Nowością w tej wypowiedzi jest ostatnia fraza, która określa sytuacje po wyzbyciu się lgnięcia. Jak rozumieć stwierdzenie: „to powstające cierpienie powstaje, to ustające cierpienie ustaje”, które odczytywane literalnie zdaje się tautologią? Klucza do interpretacji tej wypowiedzi dostarczają dwie sutry obecne zarówno w zachowanym fragmencie sanskryckiej wersji Nidanasanjukty (Nidāna-samyukta), jak też i w wersji palijskiej. Są to Kazanie do pewnego bramina (s. Bräbmaṇa-sūtra, NidSa 18; p. Añ̃atara-sutta, SN II, 75-76 [SN 12.46]) oraz Kazanie do nagiego ascety (s. Acela-sūtra, NidSa 20; 
p. Acela-sutta, SN II, 18-22 [SN 12.17]). Co ważne, w wersji sanskryckiej kazania te znajdują się w bezpośrednim sąsiedztwie Kazania do Katjajany, pierwsze je bezpośrednio poprzedza, drugie ulokowane zostało bezpośrednio po nim, a razem tworzą spójny i komplementarny przekaz. W wersji palijskiej kazania te znalazły się po Kazaniu do Kaczczanagotty i w pewnym oddaleniu od niego. Widać wyraźnie, że w wersji sanskryckiej zostały one potraktowane jako ramy dla Kazania do Katjajany. Odnoszę w związku z tym wrażenie, że układ wersji sanskryckiej jest bardziej przemyślany pod kątem wyeksponowania sensu Kazania do Katjajany niż układ wersji palijskiej. Chociaż różnie rozmieszczone, zauważyć trzeba, że obie wersje owych kazań są do siebie bardzo podobne i trudno dostrzec między nimi jakieś poważne merytoryczne różnice. Przesłanie obu tekstów też jest identyczne, aczkolwiek w Kazaniu do pewnego bramina zostało okrojone do myśli przewodniej, zgodnie z którą wszystko, co się dzieje, dzieje się bez sprawczego podmiotu. W powyższym fragmencie Kazania do Katjajany Budda oznajmia zatem, że gdy nie oddajemy sį̨ lgnięciu, wówczas widzimy powstawanie cierpienia jako powstawanie cierpienia, jego ustawanie zaś jako jego ustawanie. Widzimy zatem to, co się dzieje, jako to, co się dzieje, bez projekcji sprawczego podmiotu. W powstawaniu cierpienia i jego ustawaniu nie istnieje żaden metafizyczny podmiot, który sprawia cierpienie, który doświadcza cierpienia i wobec którego cierpienie ustaje.

W Kazaniu do nagiego ascety Kassapa (p. Kassapa, s. Kāśyapa), tytułowy nagi asceta, docieka kwestii sprawstwa cierpienia. Interesuje go zagadnienie ciągłości i tożsamości podmiotu konkretnego działania i podmiotu doświadczającego skutków owego działania w postaci cierpienia. Wyróżnia cztery możliwości. Po pierwsze pyta, „czy cierpienie stwarzane jest przez samego siebie?" (p. sayamkatam dukkbanti, s. svayamkrtam dubkbam), to znaczy, czy sam tworze cierpienie. Innymi słowy, czy ten, kto doświadcza cierpienia, jest tym, kto je tworzy, czyli czy zachowana jest tożsamość sprawcy i odbiorcy? Po drugie, „czy cierpienie tworzone jest przez innego" (p. paramkatam dukkbanti, 
s. parakrtam duḅkham), czyli czy ten, kto doświadcza cierpienia, jest kimś innym, niż ten, kto je stworzył. Słowo para może być rozumiane jako 'inny, różny od' w sensie przestrzennym oraz czasowym. Kassapie zdecydowanie chodzi o ten drugi sens, czyli 'inny' jako 'wcześniejszy, uprzedni'. Interesuje go zatem w tym pytaniu, czy tożsamość sprawcy nie jest zachowana. W takim wypadku ten, kto doświadcza skutków czynu, czyli cierpienia, byłby kimś różnym od sprawcy, gdyż sprawca uległ unicestwieniu. Jako możliwość trzecią Kassapa dopuszcza sytuację dającą się opisać koniunkcją dwóch pierwszych możliwości: cierpienie byłoby tworzone przez siebie i przez innego. Sytuacja czwarta opisywalna jest przez binegację dwóch pierwszych możliwości. Cierpienie w tym wypadku nie byłoby tworzone ani przez siebie, ani przez innego, co jest równoważne $\mathrm{z}$ przekonaniem, że powstawałoby całkowicie przypadkowo. Budda na wszystkie cztery pytania odpowiada przecząco, co wywołuje u Kassapy podejrzenie, że gotów jest on twierdzić, iż cierpienia faktycznie nie ma, gdyż w żaden sensowny sposób nie można opisać jego powstawania. Niemniej temu przypuszczeniu Budda również przeczy, oznajmiając, że cierpienie jednak jest. W związku z tym Kassapa pyta, czy nie jest przypadkiem tak, że Gotama nie poznaje cierpienia i nie widzi go. Budda jednak oznajmia, że w istocie poznaje cierpienie i widzi cierpienie (jānāmi kbvāham dukkbam passāmi kbvābam dukkbanti; SN II, 20).

Skonfundowany Kassapa prosi ostatecznie Buddę, aby ten nauczył go o cierpieniu. Spełniając prośbę, Przebudzony objaśnia konsekwencje żywienia poglądów na temat sprawstwa cierpienia. Utrzymywanie przekonania, że samemu tworzy się cierpienie, sprowadza się faktycznie do przekonania, że ten, kto stworzył cierpienie, jest tym, kto doświadcza jego skutków. Takie twierdzenie prowadzi do eternalizmu (p. sassata, s. śáśvata), gdyż akceptuje ciągłość i niezmienność podmiotu. Eternaliści głoszą konieczność przyjęcia istnienia trwałej jaźni jako warunku niezbędnego do uznania odpowiedzialności za czyny. Natomiast przekonanie, że cierpienie tworzone jest przez innego, jest równoznaczne z przekonaniem, że ten kto doświadcza cierpienia, jest kimś 
innym niż ten, kto cierpienie tworzy. Takie przekonanie prowadzi do anihilacjonizmu (p., s. uccheda), czyli do twierdzenia, że podmiot tworzący cierpienie ulega unicestwieniu ${ }^{28}$. Innymi słowy, anihilacjonista przeczy istnieniu moralnej odpowiedzialności za czyny. Tathagata nie ucieka się do tych krańców, lecz naucza „poprzez środek” (w wersji sanskryckiej poprzez środkową drogę), a jest nim (nią) nauka o zależnym powstawaniu cierpienia warunkowanego niewiedzą ${ }^{29}$.

Te same dwa krańce zostały też przywołane w Kazaniu do pewnego bramina. W mowie tej pewien nieprzedstawiony $z$ imienia bramin pyta Buddę o to, czy ten, kto działa, jest tym, kto doświadcza [skutków działania]. Budda odrzekt, że nie twierdzi, iż ten, kto działa, jest tym, kto doświadcza [skutków działania]. Nie twierdzi też, że ten, kto działa, nie jest tym, kto doświadcza [skutków działania]. Utrzymywanie pierwszego poglądu, zgodnie z sanskrycką wersją sutry, prowadzi do eternalizmu, gdyż oznacza utrzymywanie poglądu o istnieniu jaźni rozumianym jako jej trwanie. Utrzymywanie drugiego poglądu prowadzi do anihilacjonizmu, gdyż oznacza utrzymywanie poglądu o faktycznym unicestwieniu jaźni, która działała ${ }^{30}$. W NidSa 18.6-7 padają

28 Zauważyłem przed chwila, że obie wersje kazania w obu wypadkach są do siebie bardzo podobne. Jedną różniç jednak warto podkreślić. Otóż określenia

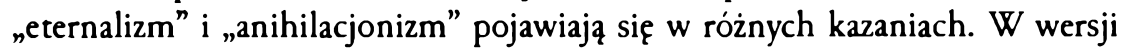
palijskiej występują one w Kazaniu do nagiego ascety. Brak ich jednak w sanskryckim jego odpowiedniku. W wersji sanskryckiej pojawiają sį̨ natomiast w Kazaniu do pewnego bramina. Nie ma ich natomiast w palijskim odpowiedniku tego kazania. Przykład ten doskonale ilustruje, na czym polegała praca zespołów redakcyjnych obu kanonów. Wczesny wspólny zasób myśli porządkowany był $w$ oparciu o różne wyobrażenia spójności przekazu.

29 Analogiczną rozmowę Budda przeprowadził $\mathrm{z}$ ascetą Timbaruką (p. Timbaruka), który pytał o powstawanie przyjemności (sukba) i cierpienia (dukkba), zob. SN II, 22-23.

30 NidSa 18.5: „[Twierdzenie]: “Ten, kto działa, jest tym, kto doświadcza [skutków działania]», prowadzi, braminie, do [poglądu o] trwałości. [Twierdzenie]: «Kto inny działa, kto inny doświadcza [skutków działania]", prowadzi, braminie, do [poglądu o] zniszczeniu" (sa karoti sa pratisamvedayatīti brabmana śasvatatve paraiti $\mid$ anyab karoty anyab pratisamvedayatity ucchede 
dokładnie te same słowa, co w Kazaniu do Katjajany (NidSa 19.8-9), które za chwilę będę analizował, o nauczaniu dharmy poprzez środkową drogę unikającą dwóch krańców oraz o zależnym powstawaniu (brak tylko zwrotu pūrvavad, tj. ,jak powiedziano wcześniej”, co jest zrozumiałe, gdyż zwrot ten ewidentnie odsyła Kazanie do Katjajany do bezpośrednio go poprzedzającego Kazania do pewnego bramina). Pojęcie eternalizmu zatem, stwierdzamy, konstytuowane jest w oparciu o wyobrażenie trwałej jaźni jako warunku moralności, pojęcie anihilacjonizmu zaś w oparciu o wyobrażenie unicestwienia istniejącej uprzednio jaźni. Akceptacja anihilacjonizmu prowadzi w konsekwencji do moralnego nihilizmu, gdyż zdejmuje z podmiotu działania poczucie odpowiedzialności za czyny, których skutków nie on będzie doświadczał.

Wprowadzanie pojęcia metafizycznego podmiotu w opis powstawania i ustawania cierpienia jest wyrazem błędu poznawczego i nie należy w związku z tym tego robić. Wszelkie pytania o to, kto działa, ostatecznie muszą zostać zdyskwalifikowane jako źle sformułowane. Myśl tę Budda wyrazit jasno w Kazaniu do Molijaphagguny (Moliyaphagguna-sutta; SN II, 12-14). W mowie tej przywołuje idę tzw. czterech pokarmów (ahara), w oparciu o które funkcjonują czujące istoty. Daje to okazje mnichowi Molijaphaggunie (p. Moliyaphagguna) do zadania pytań o to, kto spożywa pokarm świadomości, tworzy kontakt, odczuwa, pragnie. Pytania takie, oznajmia Budda, za każdym razem są niewłaściwe, nieprawomocne (no kallo pañbo), jako że on nigdy nie mówi, iż „ktoś spożywa” (äāreti), „ktoś tworzy kontakt” (phusati), „ktoś odczuwa” (vediyati), „ktoś pragnie” (tasati). Dobrze zadane pytania pytają o to, dla pojawienia się czego warunkiem jest

paraiti |). W analogicznym miejscu wersji palijskiej mamy: „[Twierdzenie]: "Ten, kto działa, jest tym, kto doświadcza [skutków działania]", to, braminie, jest jeden kraniec" (so karoti so pațisamvediyatîtī kbo bräbmana ayam eko anto; SN II, 75). Następnie zaś: „[Twierdzenie]: “Kto inny działa, kto inny doświadcza [skutków czynów]", to, braminie, jest drugi kraniec" (añño karoti añno pațisamvediyatitì kho bräbmana ayam eko anto; SN II, 76). 
świadomość, kontakt, uczucie, pragnienie. Innymi słowy, widzieć właściwie świadomość, kontakt, uczucie i pragnienie, to widzieć je $\mathrm{w}$ relacji do tego, co jest warunkiem ich pojawienia się, oraz $\mathrm{w}$ relacji do tego, dla czego one są warunkiem pojawienia się. Podobnie też widzieć cierpienie, to widzieć, jak ono powstaje i jak ustaje, bez wpisywania w nie tego, kto cierpi.

W kanonie palijskim znaleźć można niewielką suttę (SN I, 134135) opowiadającą o dylemacie, przed jakim stanęła mniszka Wadżira (p. Vajirā). Podczas medytacji zaczęły dręczyć ją pytania o to, kto i gdzie stworzył tę istotę (czyli ją), gdzie znajduje się jej twórca i gdzie ona odejdzie $w$ chwili śmierci. Formalnie rzecz biorąc, pytania te zostały włożone w usta Mary (p. Māra), który w tym wypadku ewidentnie jest personifikacją własnych pragnień Wadżiry i związanych z nimi wątpliwości. Ostatecznie mniszka uporała się z nimi, obnażając fałszywe założenia leżące u podłoża ich konwencjonalnej formy, i uświadomiła sobie faktyczny sens powstawania i ustawania. Dała temu wyraz w sposób, który doskonale koresponduje z Kazaniem do Katjajany, stwierdzając (SN I, 135):

dukkbam eva bi sambhoti $\mid$ dukkbam tițthati veti ca $\mid$

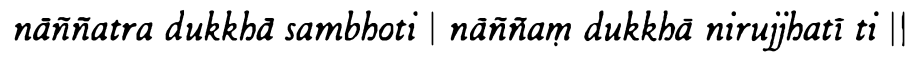

Tylko cierpienie powstaje, cierpienie trwa i zanika.

Nic tylko cierpienie powstaje, nic tylko cierpienie ustaje.

Po tych zwięzłych chociaż, jak możemy ocenić na podstawie powyższej analizy, brzemiennych w znaczenie uwagach Budda może wreszcie przejść w Kazaniu do Katjajany do odpowiedzi na fundamentalne pytanie: „Jak istnieje właściwy pogląd?”. W NidSa 19.5b2-6 czytamy:

atra cen na känksșati na vicikitsati | apara-pratyayam jñanam evasya bhavati | iyata kätyayana samyag-drștir bhavati | iyata tathagatab samyag-drsțim prajñapaymanab prajñapayati | 
Jeśli w tej kwestii nie wątpi, nie waha się, to niezwłocznie pojawia się niezależne poznanie tego. Właściwy pogląd, Katjajano, istnieje w ten sposób. Tak Tathagata określa rozumienie właściwego poglądu.

$\mathrm{Na}$ podstawie tej wypowiedzi możemy stwierdzić, że włásiwy pogląd jest tutaj rozumiany nie jako określona treść propozycjonalna afirmowana ze względu na swoją adekwatność względem stanu faktycznego, lecz jako stan czystej, tj. niezależnej poznawczej naoczności (apara-pratyaya jñāna). Właściwy pogląd to jest bycie w stanie widzenia, a nie w stanie afirmowania abstrakcyjnej treści. Kolejny fragment jeszcze mocniej podkreśla takie rozumienie właściwego poglądu. W NidSa 19.7 Budda oznajmia:

tat kasmad dhetoḅ | loka-samudayam kātyāyana yatba-bbūtam samyak-prajñaya paśyato yā loke nastitā sa na bbavati | loka-nirodham yatba-bbütam samyak-prajñaya paśyato ya loke 'stità sa na bbavati |

Dlaczego tak jest? Kto, Katjajano, dzięki właściwemu poznaniu widzi powstawanie świata takim, jakim jest (yatbā-bbūta), ten nie postrzega w świecie nieistnienia. Kto dzięki właściwemu poznaniu widzi ustawanie świata takim, jakim jest, ten nie postrzega w świecie istnienia.

W Kazaniu do Katjajany Budda właściwy pogląd (samyag-drsțti) zrównuje z właściwym poznaniem (samyak-prajñā), które definiuje jako widzenie (paśya) powstawania (samudaya) i ustawania (nirodba) świata (loka) takimi, jakimi są (yatba-bbūta). Oczywiście widzenie świata, jak zaznaczałem wyżej, jest widzeniem cierpienia. Widzenie powstawania świata zapobiega rzutowaniu na doświadczenie idei nieistnienia, czyli przeciwdziała popadaniu w nihilizm. Widzieć powstawanie bowiem to widzieć zależności, na bazie których kształtuje się doświadczenie. Widzenie ustawania z kolei ma zapobiegać rzutowaniu na doświadczenie idei istnienia, czyli popadaniu w przekonania 
eternalistyczne, a ostatecznie w absolutyzm. Widzieć ustawanie bowiem, to widzieć niesamoistność i niesamobytność wszystkiego, co sį̧ jawi. Właściwy pogląd nie polega na żywieniu, afirmowaniu prawdziwej opinii, lecz, można by rzec, na byciu w prawdzie. Być w prawdzie, czyli widzieć rzeczy, jakimi są, można tylko wtedy, gdy zaniechało się wszelkiego lgnięcia i przywiązania, w tym również lgnięcia do opinii/ poglądów jako umysłowych przedstawień, mniemań (maññatı), nawet jeżeli są to przedstawienia właściwe, czyli moralnie pozytywne i korzystne ${ }^{31}$.

Zaznaczmy, że wyrażenie samyak-prajūā, które tutaj oddaje jako "właściwe poznanie", równie dobrze można byłoby przekładać jako "właściwa mądrość", co w pewnych kontekstach byłoby może nawet trafniejsze. Niewątpliwie kontekst taki znaleźć możemy w jednym z kazań poświęconych trzem ćwiczeniom (AN I, 235), na które zwyczajowo dzielona jest szlachetna ośmioraka ścieżka, czyli ćwiczeniom w: wyższej moralności (adbisilla-siddbā), wyższym umyśle (adbicitta-siddhā) i wyższej mądrości (adbipañña-siddhā). Wyższą mądrość Budda określa jako poznawanie/pojmowanie rzeczy, jakimi są (yatbā-bbūtam pajānāti), czyli cierpienia, powstawania cierpienia, ustawania cierpienia i drogi do ustania cierpienia prowadzącej. Wyższa mądrość tak określona bez wątpienia jest właściwą mądrością.

W podobnym tonie utrzymana jest wypowiedź Buddy z Kazania o skupieniu (Samādbi-sutta; SN III, 13-15). Budda zachęca mnichów do ćwiczenia się w skupieniu i oznajmia, że ci, którzy są skupieni „poznają/pojmują rzeczy, jakimi są" (yathā-bbütam pajānātı). Tym, co jest w ten sposób pojmowane, jest powstawanie i zanik formy materialnej, uczuć, postrzeżeń, dyspozycji wolicjonalnych oraz świadomości (SN III, 13), czyli powstawanie i zanik pięciu zespołów.

31 W tej kwestii zgadzam się z Paulem Fullerem, który bodaj jako pierwszy zaproponował taki sposób widzenia właściwego poglądu, a przynajmniej pierwszy zrobił to tak wyraźnie i jednoznacznie, zob. P. Fuller, The Notion of dittthi in Theravada Buddhism. The Point of View, London-New York 2005, s. 64-65. 
Zatem ten, kto widzi rzeczy, jakimi są ${ }^{32}$, nie trzyma się pojęć istnienia i nieistnienia. Przekonanie to znalazło potwierdzenie w kilku miejscach Tipitaki. W Sn. 786ab Budda stwierdza:

dhonassa bi n'attbi kubiñci loke
pakappita dițthi bhavabbavesu

Nigdzie w świecie oczyszczony nie posiada wymyślonych poglądów na temat [rzeczy] istniejących i nieistniejących.

W związku z tym, że Tathagata nie żywi żadnych poglądów na temat tego, co istnieje i nie istnieje, to, jak oznajmia się w słynnym Kazaniu o sieci Brabmy, w przeciwieństwie do różnych ascetów i braminów, którzy namiętnie oddają się dyskusjom i sporom na różne tematy, w tym na temat bycia i niebycia, powstrzymuje się (pațivirata) on od rozmowy o byciu i niebyciu (iti-bhavabhava-kathä; DN I, 8). Podobnego motywu można dopatrzeć się też w Dhammapadzie, gdzie oznajmia się, że brahmanem, czyli świątobliwym, należy nazywać tego, dla kogo nie istnieje tamten, ten ani oba brzegi (DhP 385 [DhP XXVI, 3]).

Przywołana wcześniej mniszka Wadżira, którą dręczyły pytania o jej pochodzenie i kres, ewidentnie przestała obstawać (p. nādhițthäti, s. nädbitișţhati) przy wyobrażeniu „moja jaźñ" (p. attā me, s. ātmā me) jako tym, co miało fundować i uspójniać jej doświadczenie samej siebie. Widząc powstawanie i ustawanie cierpienia, zarzuciła wszelkie umysłowe stanowiska (p. cetaso adbițthāna, s. cetaso 'dbișthana). Wyrażenie cetaso 'dhișthana (po odsandhizowaniu cetasab adbișthana) pojawiło się w Kazaniu do Katjajany (NidSa 19.5a2), gdzie przełożyłem je jako „skłonność umystu”. Warto jednak zdać sobie sprawę z całego zakresu semantycznego terminu adbișthäna. Znaczyć on może 'stanie

32 Do kwestii rozumienia wyrażenia yatha-bbūta powróç̨ jeszcze w kolejnej części niniejszej pracy w związku z domniemanym sceptycyzmem wczesnej buddyjskiej myśli. 
na, spoczywanie na; podstawa, podłoże; położenie, stanowisko; decyzja, determinacja, upór, skłonność, zatem całe wyrażenie odczytywać można jako 'spoczywanie umysłu na, ulokowanie umysłu; umysłowe podłoże, umysłowe stanowisko; upór umysłu, skłonność umysłu'. Wyrażenie to oznacza stan umysłu, który na czymś spoczywa, znajduje w czymś oparcie, jest w czymś ulokowany, osadzony - w czymś, ku czemu jest silnie usposobiony. Są to wyobrażenia, pojęcia, mniemania, poglądy, m.in. takie jak „moja jaźń” czy też najogólniej „istnienie” i "nieistnienie”. Widzenie powstawania i ustawania świadczy o wyzbyciu się postawy lokowania-umysłu-w, zafiksowania na wyobrażeniach, pojęciach, mniemaniach, czyli postawy żywienia poglądów. Wolność od tej postawy świadczy o osiągnięciu ostatecznego celu praktyki duchowej. Potwierdza to sam Mahakaczczana (p. Mahākaccāna), prawdopodobnie adresat analizowanego tutaj Kazania do Katjajany, który już jako mnich buddyjski miał objaśniać naukę Buddy o wyzwoleniu poprzez wygaszenie pragnienia jako osiągnięciu ostatecznego celu. W'śód różnych form chorobliwego ukierunkowania-umysłu-na pięć zespołów, takich jak m.in. pragnienie, pożądanie, upodobanie, Mahakaczczana wymienia również lokowanie-umysłu-w (cetaso adbițthāna), czyli opowiadanie się za różnymi stanowiskami (w domyśle, ze względu na domniemaną tożsamość owego Mahakaczczany z Kaczczanagottą, możemy dodać: stanowiskami na temat świata i siebie samego ufundowanymi na pojęciach istnienia i nieistnienia) (SN III, 13).

\subsection{Zasada zależnego powstawania jako środkowa droga}

Ostatecznie Budda w Kazaniu do Katjajany przechodzi do określenia specyfiki swojej własnej nauki. W NidSa 19.8-9 czytamy:

ity etāv ubbāv antāv anupagamya madbyamayã pratipadā tatbagato dharmam desayati | yad utdsmin satidam bbavaty asyotpādād idam utpadyate | yad utavidyāpratyayāḅ samskārā iti pūrvavad yāvat samudayo nirodhaś ca bbavati | 
Zatem unikając tych dwóch krańców, Tathagata naucza dharmy poprzez środkową drogę: mianowicie, gdy to istnieje, to się pojawia, gdy to powstało, to powstaje, i tak formacje wolicjonalne są uwarunkowane niewiedzą, jak powiedziano wcześniej odnośnie powstawania i ustawania.

Fragment ten stanowi kulminację nauki Buddy i jednocześnie jej podsumowanie. Począwszy od pierwszego kazania, a przynajmniej od mowy, która w tradycji utrwaliła się jako pierwsze kazanie, Budda naukę swoją nazywał "środkową drogą" (s. madhyama pratipad, p. majjbima pațipadāa $)^{33}$. W Kazaniu do Katjajany odwołuje się do tego określenia, lecz nadaje mu odmienne, całkowicie nowe znaczenie. W pierwszej mowie wyrażenie to oznacza postawę unikania dwóch przeciwstawnych modeli życia - hedonizmu i ascezy w ich skrajnych postaciach. Używane jest zatem w kontekście etycznym. W Kazaniu do Katjajany pojawia się natomiast $\mathrm{w}$ innym kontekście. Środkową drogą określona zostaje nauka, która ma unikać krańców istnienia i nieistnienia, czyli - jak się domyślamy - orzekania istnienia i nieistnienia. Przy czym, podkreślić musimy, nie chodzi wyłącznie o sam fakt orzekania, a o ten aspekt naszego doświadczenia, który w orzekaniu istnienia i nieistnienia zostaje wyrażony. Chodzi o konstytuowanie się tetycznego momentu naszego doświadczenia, czyli uznania w bycie tego, co doświadczamy, w szczególności świata, chodzi o samo poczucie realności i nierealności świata.

Rodzi się jednak pytanie, jak wyrazić naukę, która nie orzeka istnienia i nieistnienia. Czy w ogóle jesteśmy w stanie cokolwiek powiedzieć bez orzekania istnienia bądź nieistnienia czegokolwiek? A może mylimy się, sądząc, że w kazaniu tym chodzi o ów moment tetyczny, może wcale nie chodzi o unikanie orzekania istnienia i nieistnienia jako takich, a o unikanie orzekania istnienia i nieistnienia wobec całkiem konkretnych przedmiotów, jakimi są np. domniemana jaźń

33 Ogólnie na temat środkowej drogi we wczesnym buddyzmie zob. K. Kosior, Droga środkowa w nikajach, Lublin 1999, zwt. s. 81-86. 
czy też pewne doświadczane przedmioty? Dotykamy tutaj najbardziej fundamentalnego problemu, przed jakim stanęli późniejsi uczniowie Buddy. Zmaganie się z nim zaowocowało w myśli buddyjskiej z jednej strony wykształceniem się nowych idei, takich jak np. idea dwóch prawd czy idea zręcznych środków, z drugiej zaś odmiennymi, konkurencyjnymi i wzajemnie się podważającymi wykładniami.

Jestem przekonany, że widomym przejawem owego zmagania sį̨ jest kształt tekstu w palijskiej wersji sutry. Zestawiając tę wersję z wersją sanskrycką, daje się zauważyć pewną różniç, która - jak sądzę - jest brzemienna w konsekwencje. Analogiczny do przywołanego powyżej fragment sutry palijskiej został poprzedzony nieobecnym w wersji sanskryckiej stwierdzeniem. Budda ponownie określa w nim treść krańców, których należy unikać, i - co ważne - jego wypowiedź, a tym samym jej sens, różni się od wypowiedzi, w której po raz pierwszy wskazał na charakter owych krańców ${ }^{34}$. Czytamy więc (SN II, 17, §7):

sabbam attbìti kho kaccāyana ayam eko anto | sabbam nattbīti ayam dutiyo anto $\|$

„Wszystko istnieje”, Kaczczajano, to jeden kraniec. „Nic nie istnieje" to drugi kraniec.

O ile w sanskryckiej wersji sutry w obu momentach, w których pojawia się odniesienie do krańców, tj. w NidSa 19.5 i 19.8, krańce rozumiane są tak samo, jako orzekanie istnienia i nieistnienia, o tyle w wersji palijskiej krańce, których należy unikać, gdy przywoływane są po raz drugi, zostają ostatecznie zredefiniowane. W wersji tej mówi się bowiem, że jeden kraniec to twierdzenie "wszystko istnieje” (sabbam atthì), drugi zaś to twierdzenie "nic nie istnieje” (sabbam natthì).

${ }^{34} \mathrm{Na}$ istnienie owej różnicy wskazał Mattia Salvini, zgłaszając postulat przemyślenia jej merytorycznych konsekwencji, czego sam niestety nie zrobił, zob. M. Salvini, The Nidanasamyukta and the Mülamadbyamakakarika. Understanding the Middle Way through Comparison and Exegesis, TIJBS 2 (2011), s. 57-95, zwł. s. 61-62. Niniejszy rozdział można traktować jako realizację tego postulatu. 
W orzekaniu istnienia bądź nieistnienia, a w orzekaniu istnienia wszystkiego bądź nieistnienia niczego wyrażają się różne postawy. Dodanie jednego słowa - sabba, czyli dużego kwantyfikatora „wszystko", radykalnie zmienia wymowę tekstu, gdyż przenosi dyskusję z poziomu fundamentalnej refleksji nad istnieniem na poziom pochodnej refleksji nad tym, co istnieje. Tekst nie odsyła już do pytania, czym jest istnienie, jak konstytuuje sį̨ poczucie i pojęcie istnienia, tylko do pytania o to, co istnieje. To drobne dopowiedzenie otwiera droge do abhidharmicznej wykładni tego kazania. Ściśle rzecz biorąc, sądzę, że pojawienie się tego dodatku związane jest z późniejszą abhidharmiczną tradycją jako późniejsza modyfikacja wprowadzona po to, aby uprawomocnić abhidharmiczną wykładnię. W wykładni tej środkowa droga przestaje być postawą wobec istnienia i nieistnienia, a staje się nauką o istniejących w zależności dharmach różnych od przedmiotów doświadczanych w codziennym doświadczeniu, na których owe przedmioty są ufundowane. Pośrednim argumentem potwierdzającym przekonanie, że w wersji palijskiej mamy do czynienia z późniejszym dopiskiem, jest fakt, że obie wersje sutry były pielęgnowane przez szkoły abhidharmiczne. Zachowany w sanskrycie fragment Nidanasanjukty pochodzi według wszelkiego prawdopodobieństwa z Sanjuktagamy (Samyuktāgama) szkoły sarwastiwady (sarvāsti-vāda). Zważywszy na to, że teoria dharm tej szkoły stanowi radykalniejszą formę stanowiska realistycznego niż teoria palijskojęzycznej therawady, szkoła ta miała wszelkie powody, aby pielegnować wypowiedź Buddy w postaci sprzyjającej abhidharmicznej wykładni. Skoro tak się nie stało, a trudno wyobrazić sobie, żeby sarwastiwada miała modyfikować tekst w kierunku dla siebie niekorzystnym, to znaczy, że w wypadku tekstu sanskryckiego mamy do czynienia z pierwotniejszą wersją kazania, któremu szkoła ta po prostu pozostawała wierna, aczkolwiek niekoniecznie pozostawała wierna zawartemu w niej sensowi ${ }^{35}$.

35 W palijskiej Tipitace duży kwantyfikator pojawia się jeszcze dwukrotnie. W krótkim Kazaniu do Dżanussoniego (Janussoni-sutta; SN II, 76-77) Budda 


\subsubsection{Ontologia fundamentalna a ontologia dystrybutywna}

Ideą środkowej drogi sformułowaną w sanskryckiej wersji sutry Budda unieważnia refleksję ontologiczną. Odrzucając poznawczą wartość kategorii istnienia i nieistnienia, czyni tym samym ową refleksje pozbawioną wartości. Jest ona bowiem refleksją nad „istnieje” i "nie istnieje”, nad „jest” i „nie jest”. Obie te kategorie zostają przez Budde unieważnione i refleksja ontologiczna zostaje sprowadzona do refleksji rozwijającej się w ramach błędu poznawczego, w ramach tego, co tradycja buddyjska nazywa niewiedzą (avidyā). Zatem idea środkowej drogi w ścisłym tego słowa znaczeniu nie jest ideą ontologiczną, jest, można by rzec, ideą ponad- czy pozaontologiczną. Jest formą unieważnienia ontologii, a nie drogą pośrednią w ramach perspektywy ontologicznej.

Wprowadzenie dużego kwantyfikatora w wersji palijskiej osłabia twierdzenie, że świat ufundowany jest na istnieniu i nieistnieniu. W stwierdzeniu bez kwantyfikatora pozostajemy na poziomie refleksji dotyczącej fundowania czy raczej konstytucji doświadczenia świata. Natomiast sprowadzając krańce do opozycji między zdaniami ogólnymi, niejako wchodzimy w ukonstytuowany już, doświadczany, świat. Poruszamy się w jego granicach, dążąc tylko do rozstrzygnięcia, co w obszarze naszego doświadczenia odnosi się do realnego, a co do nierealnego, subiektywnie projektowanego istnienia. Innymi słowy, poruszamy się w obszarze zobiektywizowanego świata. Podczas gdy w wersji sanskryckiej problemem jest sam fakt obiektywizacji, czyli

jako dwa krańce określa twierdzenia "wszystko jest” (sabbam attbi) $\mathrm{i}_{\text {"nic nie }}$ jest" (sabbam nattbi) (SN II, 76). Tathagata zaś naucza poprzez środek, czyli zależne powstawanie cierpienia. W innym krótkim Kazaniu do kosmologa (Lokäyatika-sutta; SN II, 77) Budda wyróżnia dwie pary krańców: „wszystko istnieje" i "nic nie istnieje” oraz „wszystko jest jednością" (sabbam ekattan) i „wszystko jest wielością" (sabbam putbuttan). Budda ich unika i naucza poprzez środek. Skłonny jestem sądzić, że użycie dużego kwantyfikatora w wypadkach tych podporządkowane jest palijskiej wersji Kazania do Katjajany. 
pytanie o to, jak dochodzi do doświadczenia świata jawiącego nam sį̨ jako realny i obiektywny, mówiąc kolokwialnie, jak tworzy się poczucie obiektywności owego świata. W wypadku wersji palijskiej problemem jest, co w obszarze owego doświadczenia świata traktowanego jako pewien obiektywny fakt zasługuje na miano realności, czyli w jakim stopniu się mylimy, przypisując istnienie bądź nieistnienie rzeczom owego obiektywnie doświadczanego świata. Wyrażając to skrótowo, według palijskiej wersji sutry błąd poznawczy polega na myleniu się w stwierdzaniu, co istnieje bądź nie istnieje. Według wersji sanskryckiej błąd polega na stwierdzaniu, że coś istnieje lub nie istnieje. Perspektywy te są radykalnie odmienne.

Różnica między wersjami sanskrycką a palijską to różnica między ontologią fundamentalną a ontologią dystrybutywną. Ta pierwsza docieka tego, jak konstytuuje się nasza pierwotna intuicja istnienia, czyli dotyka podstawy czy też źródła ontologicznego myślenia, druga natomiast oddziela istniejące od nieistniejącego, czyli dokonuje dystrybucji bytu. Do pierwszej odwoła się Nagardżuna, dając wyraz postawie, którą gotów jestem określić mianem rewolucyjnej ortodoksji. Będzie to postawa ortodoksyjna, gdyż Nagardżuna oprze się w całości na ideach utrwalonych w sanskryckiej Tripitace, w tym zwłaszcza na Kazaniu do Katjajany, a rewolucyjna, bowiem radykalnie i bezkompromisowo przeciwstawia się ontologii drugiej, która w obszarze myśli buddyjskiej znajdzie swoje ucieleśnienie $\mathrm{w}$ refleksji abhidharmicznej, wyładowującej się w sporach o bytowy status dharm oraz o liczbę pozycji w wykazie kategorii owych dharm. W abhidharmicznej wykładni palijskiej wersji kazania idea środkowej drogi zostaje sprowadzona do orzekania istnienia (oraz nieistnienia) konkretnych rzeczy, tj. dharm właśnie, do których zostają zredukowane rzeczy codziennego doświadczenia. Orzekanie istnienia dharm ma się więc różnić od orzekania istnienia wszystkiego i niczego, jako że dharmy nie sq̨ ani wszystkim, czemu istnienie przypisujemy, ani niczym. Sama konstytucja poczucia istnienia przestaje być problemem. Myśl abhidharmiczna bazuje na owym naturalnym, przedrefleksyjnym poczuciu 
istnienia, z jednej strony ograniczając jego zasięg, jako że istnienie rzeczy codziennego doświadczenia zostaje zanegowane, z drugiej strony rozszerzając go, jako że istnienie zostaje przypisane elementom, na bazie których rzeczy codziennego doświadczenia są konstytuowane, czyli poszczególnym zreifikowanym jakościom.

Chociaż w sanskryckiej wersji sutry Budda obnaża uwarunkowania i granice ontologicznego myślenia, skłonny jestem nazwać tę refleksję ontologią fundamentalną czy też umieścić idę̨ środkowej drogi w ramach refleksji ontologicznej ze względu na to, iż Budda próbuje zejść w swoim namyśle na poziom, na którym konstytuuje sį̧ samo poczucie istnienia, czyli najbardziej pierwotna intuicja związana z byciem i z niebyciem. Mimo że Budda unieważnia kategorie „jest” i "nie jest", robi to z perspektywy odkrywania źródeł refleksji operującej tymi kategoriami, tj. z perspektywy ujawniania fundamentu, na którym obie te kategorie się konstytuują. W tym właśnie sensie gotów jestem, mimo wcześniejszych zastrzeżeń, nazwać refleksję nad „jest” i „nie jest” czy też, ściśle mówiąc, nad światem ufundowanym na kategoriach „istnienie” i „nieistnienie” ontologią fundamentalną w przeciwieństwie do refleksji abhidharmicznej, którą nazwałem ontologią dystrybutywną.

Dobrym przykładem abhidharmicznej tendencji w sposobie rozumienia Kazania do Kaczczanagotty są uwagi Bhikkhu Bodhi wypowiedziane w komentarzu do Kazania o kwiatacb (SN III, 138-140). Bodhi uważa, że obie te mowy należy czytać łącznie, w szczególności zaś w kazaniu drugim dostrzega treści, które stanowią istotne ograniczniki dla rozumienia sensu kazania pierwszego, kazanie to - w jego opinii - „oferuje ważny kontrapunkt dla przesłania Kaczczanagottasutty"36. Tym kontrapunktem ma być m.in. słynna wypowiedź Buddy otwierająca Kazanie o kwiatach (SN III, 138):

36 Zob. uwagi Bodhiego w: The Connected Discourses..., vol. 1, s. 1085, przyp. 185: offers an important counterpoint to the message of the Kaccanagotta Sutta. 
näham bbikkbave lokena vivadämi loko ca maya vivadati | na bbikkbave dhamma-vadì kenaci lokasmim vivadati || yam bbikkbave natthi sammatam loke panditanam abam pi tam nattbi ti vadami | yam bbikkbave atthi sammatam loke panditānam abam pi tam atthïti vadämi $\|$

Nie ja, mnisi, spieram się ze światem. To świat spiera się ze mną. Żaden głosiciel dhammy, o mnisi, nie spiera się z kimkolwiek w świecie. O tym, mnisi, odnośnie do czego mędrcy w świecie zgadzają się, że nie istnieje, mówię, że nie istnieje. O tym, mnisi, odnośnie do czego mędrcy w świecie zgadzają się, że istnieje, mówię, że istnieje.

Czytając tę wypowiedź literalnie, można by odnieść wrażenie, że Bodhi ma rację. Budda przecież zdaje się zajmować stanowisko w kwestii istnienia i nieistnienia zgodne ze stanowiskiem mędrców w świecie (loke panditānam). Czy aby jednak na pewno wypowiedź ta koryguje stanowisko Buddy z Kazania do Kaczczanagotty? Żeby te kwestię rozstrzygnąć, musimy przyjrzeć się kolejnym partiom tego kazania. Odpowiadając na pytanie o to, odnośnie do czego mędrcy zgodni są, że nie istnieje, o czym on też oznajmia, że nie istnieje, Budda wskazuje na zespoły. Niektórzy przynajmniej mędrcy zgodni są, że trwałe (nicca), stałe (dbuva), wieczne (sassata), niezmienne (aviparināma) zespoły nie istnieją. Zgodni są też, że istnieją zespoły nietrwałe, naznaczone cierpieniem i zmianą. Budda w tej kwestii wypowiada się podobnie. Według Bodhiego świadczy to o tym, że Budda nie odrzuca wszystkich ontologicznych sądów, jak można by wnosić na podstawie zbyt pochopnie odczytywanego Kazania do Kaczczanagotty, "tylko te, które transcendują granice możliwego doświadczenia” ${ }^{37}$. Dalej dodaje: „Afirmacja istnienia pięciu zespołów, jako nietrwałych procesów, odpiera iluzjonistyczne teorie utrzymujące, że świat pozbawiony jest realnego bytu"38.

37 Ibidem: [...] only those that transcend the bounds of possible experience.

38 Ibidem: The affirmation of the existence of the five aggregates, as impermanent processes, serves as a rejoinder to illusionist theories, which bold that the world lacks real being. 
Nie chcę bagatelizować wartości abhidharmicznej wykładni, tym bardziej nie jest moją intencją przekreślanie w punkcie wyjścia intuicji, które mogły leżeć u podstaw jej sformułowania. Dlatego warto postarać się o ich dokładniejszą rekonstrukcję. Sądzę, że mogłaby ona wyglądać następująco. Gdy Budda stwierdza, że świat ufundowany jest na istnieniu i nieistnieniu, to według abhidharmy rozumie owe kategorie w bardzo szczególny sposób. Mówiąc o zakorzenieniu świata $\mathrm{w}$ istnieniu, ma na myśli przekonanie, iż nie sposób zrozumieć ciągłości istnienia zmiennego świata bez uznania istnienia jakiegoś trwałego, niezmiennego fundamentu, czy to w postaci jakkolwiek rozumianych dalej nieredukowalnych atomów, czy też w postaci jakiegoś niezmiennego absolutu (boga teistów, idei Platona, pierwszego poruszyciela itp.), czy też może wyłącznie trwałej, niezmiennej jaźni. Alternatywą dla takiego sposobu rozumienia istnienia $w$ świecie jest całkowity brak ciągłości w świecie, gdy taki fundament odrzucimy. $\mathrm{Z}$ jednej strony (i to jest ten drugi sposób wysłowienia krańców, jakich należy unikać) możemy więc twierdzić, że wszystko istnieje, gdy uznajemy istnienie trwałego i niezmiennego fundamentu. W tym wypadku istnienie wszystkiego jest ugruntowane $w$ istnieniu trwałego fundamentu, jego doskonałe istnienie w pewnym sensie udziela się wszystkiemu innemu - w kontekście takiego istnienia zmiana okazuje się doskonale zrozumiała i wytłumaczalna. $\mathrm{Z}$ drugiej zaś strony pozostaje nam nicość jako całkowity brak zakorzenienia w trwałości. Świat bez trwałości jest niebytem, nie sposób rozsądnie utrzymywać o nim, że istnieje. Zmianę, czyli ciągłość zmiennego świata, albo możemy wytłumaczyć odwołaniem do fundującej trwałości i niezmienności, albo musimy skończyć na uznaniu nicestwienia wszystkiego, tj. na uznaniu braku takiej ciągłości. Z jednej strony więc eternalizm (p. sassata-vāda, s. śáśvata-vāda), z drugiej zaś anihilacjonizm (p., s. uccheda-vada). Środkową drogą abhidharmików byłoby zatem, jak sugeruje Bodhi, powiązanie istnienia ze zmiennym procesem, którego ciągłość konstytuuje się w oparciu o zależności, w jakich pozostają następujące po sobie stany rzeczy. Mamy tutaj do czynienia z próbą myślenia 
procesu jako ciągłości zależności. Problem tej koncepcji polega jednak na tym, że nie jest to ostatnie słowo, jakie w tej sprawie ma do powiedzenia abhidharma. Ostatecznie bowiem tak jak istnienie danych nam w codziennym doświadczeniu przedmiotów tradycja ta redukuje do układu dyskretnych bytów, tj. dharm (p. dhamma, s. dharma), tak też i proces redukuje do następstwa owych zależnych, ale dyskretnych bytów; dyskretnych, gdyż wewnętrznie określonych, obdarzonych własną naturą, nawet jeżeli jest nią tylko jedna, konkretna jakość, oraz określonych pod względem długości trwania, co nazywa momentem (p. kbana, s. kṣana). Dokonując tej redukcji, abhidharma wprowadza nowy problem - jak pogodzić samoistność owych dharm $\mathrm{z}$ ich bytową zależnością. Kwestia ta stanie się kluczowa w ataku, jaki przypuści Nagardżuna na abhidharmiczny sposób myślenia. Tym zagadnieniem zajmę się jednak w kolejnym rozdziale. Teraz wróćmy jeszcze do Kazania o kwiatach.

Po sprecyzowaniu, z jakimi poglądami mędrców w świecie na temat zespołów Budda się zgadza, w kolejnej sekwencji kazania padają stowa o zjawisku świata w świecie (loke loka-dbammo), które przywoływałem już pod koniec podrozdziału 1.2. Warto je jednak tutaj powtórzyć (SN III, 139):

atthi bhikkbave loke loka-dhammo yam tathägato abbisambujjbati abbisameti | abbisambujjhitva abbisametvā acikkbati deseti paññapeti pațthapeti vivarati vibhajeti uttānikaroti $\|$

Istnieje, mnisi, zjawisko świata $\mathrm{w}$ świecie, które Tathagata w pełni doskonale poznaje i pojmuje. W pełni doskonale poznawszy i pojąwszy, omawia je, tłumaczy, oznajmia, ustala, ujawnia, analizuje, objaśnia.

Tymi zjawiskami świata $\mathrm{w}$ świecie, jak wspominałem, są zespoły, to je Budda w pełni doskonale poznał i pojąt, to je omawia i objaśnia. Wskazując kolejno na pięć zespołów, które poznawszy, omawia i objaśnia, za każdym razem zadaje sobie to samo pytanie (SN III, 140): 
tam abam bbikkbave balam putbujjanam andbam acakkbukam ajanantam apassantam kinti karomi $\|$

Co mogę zrobić z tym głupim, zwykłym człowiekiem, ślepym i niewidzącym, który nie poznaje i nie widzi?

Pięciokrotne powtórzenie tego pytania wydaje się ważną wskazówką. Budda zastanawia się nad tym, jak ma postępować ze ślepymi, jak do nich dotrzeć. Jak ma mówić ten, kto w pełni poznał, do tych, którzy są ślepi, którzy niczego nie poznają i nie widzą? Pytanie to stawiane $w$ tym miejscu rzuca pewne światło na kwestię należytego rozumienia wstępnej afirmacji i negacji istnienia, która zdaje się pozostawać $\mathbf{w}$ zgodzie $z$ opinią mędrców.

Zauważyć należy, że owi mędrcy nie są przebudzonymi, to nie są ci, którzy wiedzą i widzą. Są to światowi mędrcy (loke panditānam), czyli ci, którzy w swoim myśleniu i działaniu kierują się „światowymi” narzędziami, czyli obserwacją i krytyczną refleksją, są dociekliwi, badawczy (vimmamsaka; SN III, 7-8). Narzędzia te są „światowe”, gdyż nie wyprowadzają poza świat, czyli poza jego zobiektywizowane doświadczenie. Niemniej warto podkreślić, iż w oczach Buddy ich użytkownicy znajdują uznanie. Budda o tego typu mędrcach, wśród których są też asceci i bramini, wypowiada się z wyraźnym szacunkiem, nazywając ich inteligentnymi, mądrymi (viññü DN I, 163). Zdarza sį̨ nawet, że tak jak w omawianym tutaj Kazaniu o kwiatach, Budda przyznaje, iż jego nauka w pewnych aspektach potrafi być zgodna $z$ wypowiedziami owych mędrców, ale też zaznacza, że pod wieloma względami potrafi być niezgodna (DN I, 162-163). Jako nieprzebudzeni, w swoim postępowaniu pozostają oni $\mathrm{w}$ obszarze naiwnego zobiektywizowanego postrzegania świata. Są w stanie teoretycznie, w oparciu o krytyczny namysł stwierdzić i zaakceptować, że w obszarze ich doświadczenia nie ma niczego trwałego, jednak perspektywa ta jest egotyczna, traktują doświadczenie tak, jak inni ślepcy, jako kryterium istnienia. Żeby do nich dotrzeć, Budda jest zmuszony wejść w ich perspektywę, inaczej skaże się na całkowite niezrozumienie. Dla niego jednak stwierdzenie, 
że nie istnieją trwałe zespoły czy też że istnieją nietrwałe zespoły, znaczy co innego niż dla owych nieprzebudzonych. Dla nich stwierdzenie to jest wyznacznikiem obiektywnego nieistnienia/istnienia. Dla niego stwierdzenie, że nie istnieją trwałe zespoły, znaczy tylko tyle, że w obszarze doświadczenia poszczególnych zespołów nie znajduje niczego trwałego, stwierdzenie zaś, że istnieją zespoły nietrwałe, znaczy tyle, że w obszarze doświadczenia poszczególnych zespołów dostrzega tylko nietrwałość. Budda w tym wypadku, chociaż mówi o istnieniu i nieistnieniu, pozostaje wyłącznie w obszarze własnego doświadczenia, nieprzebudzeni zaś wychodzą poza ten obszar. O postawie Przebudzonego można powiedzieć, że jest fenomenologiczna, o postawie nieprzebudzonych, że jest empiryczna. Pierwszy opisuje własne doświadczenie, pozostając $w$ jego obszarze, drudzy wierzą, że opisują doświadczany świat. Późniejsza tradycja abhidharmiczna, a za nią Bodhi, poszła w owym empirycznym kierunku ${ }^{39}$. Chociaż więc Budda, mówiąc tutaj o istnieniu i nieistnieniu, wypowiada się w sposób (pozornie) zrozumiały dla mędrców, a w domyśle też dla zwykłych ludzi, to używa jezzyka opartego o powszechnie akceptowaną konwencję, w której odzwierciedla się fundamentalny błąd poznaw$\mathrm{czy}^{40}$. W wypowiedzi tej daje się dostrzec napięcie, które stanie się

39 Klasyczną, monumentalną pracą ucieleśniającą ową empiryczną perspektywę pozostaje dzieło: K. N. Jayatilleke, Early Buddhist Theory of Knowledge, London 1963. Na możliwość interpretacji postawy Buddy jako typowej dla fenomenologii w odróżnieniu od empirycznej postawy późniejszej tradycji abhidharmicznej wskazywałem już w: K. Jakubczak, Doświadczenie mistyczne $w$ tradycji buddyjskiej, [w:] Między wiara a gnozq. Doświadczenie mistyczne $w$ tradycjacb Orientu, red. M. Jakubczak, M. Sacha-Piekło, Kraków 2003, s. 234-235. W niniejszej pracy ową hipoteze przekształciłem w tezę, uważam bowiem, że faktycznie między abhidharmiczną wykładnią myśli Buddy a intuicją zawartą w przypisywanych jemu wypowiedziach zachodzi bardzo wyraźna różnica, jeśli chodzi o sposób rozumienia doświadczenia.

40 Na temat użycia konwencjonalnego jezzyka przez wyzwolonego Budda w Tipitace wypowiedział się co najmniej dwukrotnie, zob. MN I, 500: „Mnich, którego umysł jest w ten sposób wyzwolony, Aggiwessano, nie zgadza się z nikim 
charakterystyczne dla idei dwóch prawd $-\mathrm{z}$ jednej strony orzekamy coś prawdziwie $\mathrm{w}$ ramach konwencji, $\mathrm{z}$ drugiej zaś obnażamy konwencjonalny, czyli względny, a ostatecznie utylitarny charakter owej konwencjonalnej prawdy.

Stanowisko Bodhiego, a tym samym abhidharmików przypomina jedno $\mathrm{z}$ trzech stanowisk względem poglądów, jakie Budda wyróżnił w Kazaniu do Dighanakbi (Dighanakba-sutta; MN I, 497-501). Istnieją, mówi twórca buddyzmu, ci, którzy głoszą, że uznają wszystko; ci, którzy głoszą, że nie uznają niczego; oraz ci, którzy twierdzą, że niektóre przekonania uznają, innych nie uznają. Postawa Bodhiego, jeśli pominiemy uwagi wypowiadane $\mathbf{w}$ późniejszym komentarzu ${ }^{41}$, podpadałaby pod trzecią kategorię. Budda odrzuca jednak to stanowisko podobnie jak dwa pozostałe.

\subsubsection{Antyrealizm Buddy}

Bhikkhu Bodhi swoimi uwagami podprowadza nas do jeszcze jednego istotnego tematu, wokół którego już w tym rozdziale intensywnie krążłem, chociaż nie uczyniłem z niego kwestii tytułowej

i nie spiera sį̨ z nikim. Posługuje się mową używaną $\mathbf{w}$ świecie, nie chwytając się jej (evam vimutta-citto kho aggivessana bbikkbu na kenaci samvadati na kenaci vivadati, yañ-ca loke vuttam tena voharati aparämasan-ti). Por. też DN I, 202: „To są, Czitto, zwykłe nazwy, zwykłe wyrażenia, zwykłe sposoby mówienia, zwykłe określenia, których Tathagata używa, nie chwytając się ich" (itima kbo citta loka-samañna loka-niruttiyo loka-vobara loka-paññattiyo yabi tathagato vobarati aparamasan ti). Szerzej na temat jezyka we wczesnym buddyzmie zob. G. Polak, Language, Conscious Experience and the Self in Early Buddhism. A Cross-cultural Interdisciplinary Study, JOCBS 14 (2018), s. 3776; zob. też K. Kosior, op. cit., s. 60-65.

41 W komentarzu do Madżdżhimanikaji te trzy stanowiska zostały skojarzone z eternalizmem, anihilacjonizmem i połowicznym eternalizmem. Jednak w samym kazaniu mówi się wyłącznie o uznawaniu poglądów w sposób uniwersalny, zob. na ten temat uwage Bodhiego w: The Middle Length Discourses..., s. 1277 , przyp. 734. 
i jednoznacznie go nie określiłem. Jest to zagadnienie tzw. realizmu/ antyrealizmu myśli Buddy. Wszyscy badacze są zgodni, że Budda był zorientowany na analizę i opis doświadczenia. Nie jest jednak jasne, jaki charakter i, można by rzec, zakres miała ta orientacja. Bodhi w tej kwestii wypowiada się następująco:

Świat, o którym nauka Buddy traktuje przede wszystkim, to „świat doświadczenia”, i nawet obiektywny świat jest przedmiotem zainteresowania tylko $w$ takim stopniu, w jakim petni rolę koniecznego zewnętrznego warunku doświadczenia ${ }^{42}$.

W świetle tej wypowiedzi powinniśmy zapytać, czy z perspektywy Kazania do Katjajany, a konkretnie z perspektywy stwierdzenia, że świat ufundowany jest na istnieniu i nieistnieniu, uwaga Bodhiego ma sens? Z jednej strony przyznaje on, że Buddę interesuje „świat doświadczenia", z drugiej jednak to, co określa tym pojęciem, rozumie w sposób naiwno-realistyczny, jako to, co odróżnia się od świata obiektywnego. Formułując uwagę o niewielkim zainteresowaniu światem obiektywnym, Bodhi przede wszystkim pokazuje, że uznaje, iż dystynkcja na świat subiektywny i obiektywny w kontekście nauki Buddy ma sens, że odsyła do czegoś realnego. Bodhi tym samym zdaje się proponować, aby określenie „świat subiektywny” rozumieć w sposób potoczny, tzn. w sposób, w jaki mówimy czasami, że ktoś „żyje we własnym świecie”. „Żyć we własnym świecie” oznacza tutaj być pogrążonym we własnych myślach, we własnych wyobrażeniach, usensowniać doświadczenie w sposób odbiegający od normy, czyli od intersubiektywnie komunikowalnych standardów ugruntowanych w tym, co obiektywne, wyznaczających powszechnie funkcjonujące sensy. Jednym $z$ takich sensów jest właśnie intuicja istnienia i nieist-

42 The Connected Discourses..., vol. 1, s. 394, przyp. 182: The world with which the Buddha's teaching is principally concerned is "the world of experience", and even the objective world is of interest only to the extent that it serves as that necessary external condition for experience. 
nienia związana z poczuciem „ja”. Kazanie do Katjajany przynajmniej w wersji sanskryckiej pokazuje jednak, że dla Buddy zasadniczym problemem jest właśnie ta norma. Błąd poznawczy nie wyraża się w owej subiektywnej nakładce "własnego świata” okrywającej dostępny w jakimś pierwotniejszym, wiarygodnym, gdyż niezakłóconym poznaniu świat obiektywny. W obszarze doświadczenia ukonstytuowanego przez błąd poznawczy nie istnieje żadna wiarygodna perspektywa sub specie aeternitatis. Wręcz przeciwnie, właśnie przekonanie, że taka perspektywa istnieje, zdaje się twierdzić Budda, jest wyrazem błędu poznawczego. Zatem z perspektywy Kazania do Katjajany dystynkcja na to, co subiektywne i obiektywne, jako że uzyskuje sens w obszarze doświadczenia naznaczonego błędem, sama jest formą przejawiania się tego błędu.

Podobny problem pojawia się też w wypowiedzi Sue Hamilton. Badaczka ta była bodaj pierwszą, która tak wyraźnie położyła nacisk na rozumienie zespołów jako po prostu zjawisk. O ile więc Bodhi w zgodzie z tradycją therawady otwarcie broni realizmu myśli Buddy, o tyle Hamilton opowiada się za jej antyrealizmem. Świat określany przestrzennie to tylko metafora świata doświadczenia ${ }^{43}$. Poznawczy dostęp mamy tylko do tego ostatniego ${ }^{44}$, a przestrzeń i czas stanowią jego strukturę ${ }^{45}$.

Budda - twierdzi Hamilton - nie jest w ogóle zainteresowany rozstrzyganiem tego, czy realny, przestrzenny, zewnętrzny świat istnieje, czy też nie istnieje. Chce ona pokazać, że „w świetle jego nauk założenie, iż «zewnętrzny świat» musi albo istnieć, albo nie istnieć, jest fałszywe" "46. Postawę Buddy w związku z tym najlepiej opisać można jako formę idealizmu transcendentalnego bliską koncepcji Immanu-

43 Zob. S. Hamilton, The "External World”..., s. 81.

${ }_{44}$ Eadem, Early Buddhism..., s. 107-108.

45 Ibidem, s. 169-170.

46 Eade m, The "External World”..., s. 74: [...] in the light of of his teachings the premise that there must either be or not be the "external world" is a false one. 
ela Kanta ${ }^{47}$. Chociaż Hamilton przestrzega, że odwołuje się do idealizmu transcendentalnego tylko jako do modelu, to podąża za tym modelem na tyle daleko, aby zaprzeczyć swoim własnym wstępnym deklaracjom. Uznaje bowiem ostatecznie, że musi istnieć Rzeczywistość (majuskuła badaczki) poza empirycznym światem doświadczenia jako warunek moźliwości doświadczenia, oraz ustawia ową Rzeczywistość w roli przyczyny doświadczenia. Co więcej, potwierdzenie dla tego przeświadczenia znajduje w Kanonie. Jest nim słynna wypowiedź Buddy z Udany, zwykle przywoływana w kontekście dyskusji nad naturą nirwany, którą Hamilton odczytuje w nowy sposób. Brzmi ona (Ud. 80-81) ${ }^{48}$ :

atthi bbikkbave ajatam abbūtam akatam asamkhatam, no ce tam bhikkbave abhavissa ajatam abbūtam akatam asaṃkhatam, na yidha jatassa bbütassa katassa saṃkbatassa nissaranam paññayetha. yasma ca kho bhikkhave attbi ajatam abbütam akatam asamkhtam, tasma jatassa bbütassa katassa samkbatassa nissaranam paññayati 'ti.

Istnieje, mnisi, niezrodzone, niepowstałe, niestworzone, nieuformowane. Mnisi, gdyby nie było tego niezrodzonego, niepowstałego, niestworzonego, nieuformowanego, to $\mathrm{w}$ tym świecie wyjścia ze zrodzonego, powstałego, stworzonego, uformowanego nie można by poznać. Ponieważ jednak istnieje, mnisi, niezrodzone, niepowstałe, niestworzone, nieuformowane, dlatego wyjście ze zrodzonego, powstałego, stworzonego, uformowanego daje się poznać.

Chociaż w swoim rozumieniu myśli Buddy podążam za intuicjami wyrażonymi przez Hamilton, to zdecydowanie nie potrafię zaakceptować tego momentu jej argumentacji. Przeciwko zaproponowanej przez nią wykładni przywołanego tutaj fragmentu Udany wysunąć

47 Ibidem, s. 74-76, 85.

48 Tłumaczenie tego fragmentu podaje w zgodzie $z$ własnym, odmiennym od Hamilton, jego rozumieniem. Na punkt rozbieżności zwróç za chwilę uwag̨̧. 
można trzy krytyczne argumenty. Po pierwsze, badaczka wyrywa ten cytat z kontekstu, całkowicie ignorując wskazówkę, jaka pojawia sį̧ we wstępie do pierwszej sutty ósmego rozdziału Udany, i odnosi się do pierwszych czterech sutt tego rozdziału stanowiących całość. Każda bowiem kolejna sutta, począwszy od drugiej, powtarza in extenso wcześniejsze, dodając własne rozszerzenie. Przywołany fragment stanowi rozszerzenie sutty trzeciej. Zgodnie $z$ ową uwagą sutty te mówią o nirwanie, a nie - jak sugeruje Hamilton - o transcendentnej rzeczywistości jako takiej ${ }^{49}$. Badaczka traktuje metaforyczne i apofatyczne wypowiedzi o nirwanie jako apofatyczne wypowiedzi o transcendentnej wobec doświadczenia rzeczywistości. Po drugie, interpretacja cytatu jest nadmiernie spekulatywna. Hamilton poboczne znaczenie słowa nissarana uznaje za główne i zmienia logiczny porządek zdania określony strukturą gramatyczną. Słowo nissarana $\mathrm{w}$ pierwszym rzędzie ma znaczenie 'odejście, wyjście, ucieczka'. Jako że standardowo używane jest na określenie wyjścia/ucieczki ze stanu doczesności, bywa też oddawane jako 'wyzwolenie'. Jest synonimem do takich słów jak palayana ('ucieczka'), parimuccana ('ucieczka, wyzwolenie'), mutti ('uwolnienie, wyzwolenie'). Wyzwolenie jest kresem dążeń, tym, co leży na końcu praktyki, stąd metaforycznie można powiedzieć, że jest jej rezultatem, wynikiem. Słownik dopuszcza taką możliwość thumaczenia jako poboczne określenie na owo wyjście, czyli wyzwolenie ${ }^{50}$. Hamilton jednak pojmuje ów rezultat w sposób uniwersalny, umieszczając go w ogólnym kontekście przyczynowego warunkowania. Co więcej, zmienia porządek zdania, tłumacząc to słowo w funkcji przydawki dopełniaczowej, a nie rzeczownika w funkcji podmiotu zdania. W jej thumaczeniu zatem warunek sformułowany w kluczowym dla tego fragmentu drugim zdaniu wygląda następująco: „Istnieje, mni-

49 Ud. 80: „Czcigodny wygłaszał mnichom mowę zgodną z dhammą związaną $z$ nibbaną" (bbagava bbikkbū nibbanapatisaññuttaya dbammiya katbaya sandasseti).

50 Zob. Pali-English Dictionary..., s. 374. 
si, niezrodzone, niepowstałe, niestworzone, nieuformowane, bez którego, mnisi, to będącego [jego] rezultatem zrodzonego, powstałego, stworzonego, uformowanego nie można by poznać [doświadczyć]" 51 . W myśl jej wykładni istnienie niezrodzonego jest warunkiem poznania czy też istnienia zrodzonego, które to zrodzone pozostaje $\mathrm{w}$ relacji skutku do niezrodzonego. Zgodnie z porządkiem gramatycznym, który w przekładach jest powszechnie akceptowany, istnienie niezrodzonego (co by to nie miało znaczyć) jest warunkiem poznania (doświadczenia) wyzwolenia ze zrodzonego. Zatem zaproponowany przez badaczkę sposób tłumaczenia jest czystą manipulacją podporządkowaną założonemu z góry celowi. Po trzecie, w świetle wcześniejszego twierdzenia o unieważnieniu przez Buddę pytania o istnienie bądź nieistnienie zewnętrznego świata uwagą tą Hamilton sobie przeczy. Odkrywając wewnętrzną logikę myśli Buddy, brytyjska badaczka jednocześnie ją unieważnia. Hamilton uznaje bowiem, podążając tropem Kanta, że musi istnieć coś od nas niezależnego, i przekonanie to wtłacza poniekąd na siłę, wbrew wcześniejszej deklaracji, w postawę Buddy. Ostatecznie zatem na planie metafizycznym opowiada się po stronie realizmu, a $z$ racji ulokowania owej rzeczywistości względem doświadczenia można by powiedzieć, że jest to realizm abstrakcyjny ${ }^{52}$. Dostęp mamy tylko do świata przez nas skonstruowanego, o owym realnym świecie nic nie wiemy poza tym, że istnieje. Zatem na planie epistemologicznym jest to stanowisko umiarkowanego antyrealizmu kreacyjnego $^{53}$. Aczkolwiek na temat samego procesu kreacji Hamilton

st S. Hamilton, The „External World”..., s. 85: There is, bhikkhus, an unborn, an unbecome, an uncostructed, an unconditioned, without which, bhikkhus, the resultant born, become, constructed, conditioned could not be known [experienced].

\$2 Terminu „abstrakcyjny realizm” używam za Edwardem Craigiem, zob. E. Craig, Realism and Antirealism, [w:] Routledge Encyclopedia of Philosopby, vol. 8, ed. idem, London-New York 1998, s. 117.

is Na temat umiarkowanego antyrealizmu kreacyjnego zob. np. T. Szubka, Trzy formy wspótczesnego antyrealizmu, „Kwartalnik Filozoficzny” XXVI/1 (1998), zwł. s. 18-21. 
nic więcej nie mówi. Nie rozstrzyga, jaki jest zasięg owej kreacji - czy jest to tylko interpretacja i nadawanie sensu doświadczanym przedmiotom, czy faktyczna konstytucja owych przedmiotów; czy strukturyzacja świata jest przygodna i względna, co wiąże się z pewną dowolnością wyboru perspektywy, czy konieczna i uniwersalna, w związku z tym, że odzwierciedla transcendentalną strukturę podmiotu. Nie odnosi się ona też do zarzutu, który jako pierwszy został Kantowi postawiony - jak zrozumieć przyczynową relację między rzeczą w sobie a zjawiskiem, jeśli przyczynowość jest wyłącznie sposobem strukturyzowania zjawisk i poza sferą zjawisk użycie tej kategorii nie ma zadnego sensu. Właśnie to przywiązanie Kanta do realistycznej perspektywy w metafizyce zostało najszybciej zaatakowane jako pozostałość naturalnego naiwno-realistycznego przeświadczenia niespójnego z wizją transcendentalnego idealizmu. Hamilton nie dostrzega zarówno problemu, jak i wielkiej potrzeby poznawczego uprawomocnienia przekonania o istnieniu rzeczywistości w sobie. Widać to wyraźnie w następującej wypowiedzi:

To dlatego, że empiryczny świat doświadczenia jest zależnie powstały, i dlatego jest zależny, musi być coś jeszcze. Gdyby nie było, to konwencjonalny świat, świat doświadczenia musiałby być autonomiczny, co, jak stwierdza nauka Buddy implicite i explicite, nie ma miejsca ${ }^{54}$.

Ponieważ jednak Hamilton jako jedyny przykład stwierdzenia explicite owego faktu przytacza cytat z Udany, który, jak to powyżej pokazywałem, nie dowodzi tego, czego w zamierzeniu miał dowodzić, wychodzi na to, że nauka Buddy fakt istnienia transcendentnej rzeczywistości bardziej niż explicite stwierdza jednak implicite.

54 S. Hamilton, The „External World”..., s. 84: It is because the empirical world of experience is dependently originated, and therefore dependent, that there must be something else. If there were not, the conventional world, the world of experience would have to be autonomous, which the Buddha's teachings both implicitly and explicitly state is not the case. 
Jeszcze na jeden problem, w świetle Kazania do Katjajany najbardziej zasadniczy, należy zwrócić uwagę. Jeżeli mamy dostęp tylko do świata doświadczenia, który w całości zależny jest od naszych stanów epistemicznych, jak mówi Hamilton - od naszego aparatu poznawczego, to jaki sens ma orzekanie istnienia transcendentnego wobec świata doświadczenia? Jedynym sposobem, żeby kategorii istnienia transcendentnego nadać sens, jest uznanie, że dysponujemy jakimś minimalnym, ograniczonym być może tylko do tego jednego aspektu dostępem poznawczym do owej Rzeczywistości, i nie ma znaczenia, czy będzie to postrzeżenie zmysłowe, czy jakaś forma intelektualnej intuicji. Jeżeli takim dostępem nie dysponujemy, to orzekając transcendentne istnienie, kierujemy się przeświadczeniami ukształtowanymi w obszarze świata doświadczenia, a w ostateczności przeświadczeniami zakorzenionymi w naiwno-realistycznej postawie, dla owego świata doświadczenia charakterystycznej. Sądzę, że na ten właśnie moment zwraca uwagę Budda, mówiąc w Kazaniu do Katjajany o ufundowaniu świata $w$ istnieniu i nieistnieniu. Oczywiście powyższe krytyczne uwagi nie odbierają odkrywczej wartości ogólnej perspektywie, z jakiej Hamilton proponuje rozumieć myśl Buddy. Wskazują raczej na potrzebę gruntowniejszego, dokładniejszego i bardziej skrupulatnego przemyślenia całego zagadnienia.

Zadanie takie postawił przed sobą Alexander Wynne, który równie zdecydowanie co Sue Hamilton opowiada się za antyrealizmem myśli Buddy ${ }^{55}$. Chociaż wyraźnie dba o to, aby unikać niespójności w swojej

5s Sugestię, że Budda w swojej filozofii rozwija stanowisko antyrealistyczne, sformułowała również Noa Ronkin: N. Ronkin, Early Buddhist Metaphysics. The Making of a Philosophical Tradition, London-New York 2005. Czytamy w niej (s. 245): „Tym, co odrzuca Budda, jest realizm, zarówno pojęciowy, jak i ontologiczny: przekonanie, że napotkany świat składa się z odróżnialnych substancji, oraz lingwistyczna teoria głosząca, że słowa odnoszą się do owych substancji, reprezentując je; przeświadczenie, że nasz jezyk koresponduje z niezależną od umysłu rzeczywistością, czy też że ją odzwierciedla" (What the Buddha rejects is realism, conceptual and ontological alike: the notion that the 
prezentacji postawy twórcy buddyzmu, mam pewne wątpliwości, czy udało mu się w tym dążeniu w pełni wytrwać $c^{56}$.

Centralnym punktem swojej rekonstrukcji i jednocześnie punktem wyjścia dla dalszych tez Wynne uczynił zagadnienie miejsca i znaczenia we wczesnej refleksji buddyjskiej kwestii jaźni. Podejmuje on analizę głównego w jego opinii argumentu wymierzonego w wartość pojęcia jaźni zawartego $\mathrm{w}$ drugim kazaniu Buddy, który to argument kilkakrotnie został powtórzony $w$ kanonie palijskim oraz zachował się w kilku wersjach sanskryckich ${ }^{57}$. W argumencie tym Budda wykazuje bezzasadność przypisywania statusu jaźni zespołom, które są nietrwałe, a ponieważ w naszym doświadczeniu nie znajdujemy niczego trwałego, więc niczemu tego statusu nie możemy nadać ${ }^{58}$. Wynne zwraca uwag̨ na brak ze strony Buddy jasnej deklaracji o nieistnieniu jaźni ${ }^{59}$. Chociaż z owego rozumowania płynie, zdawałoby się, jednoznaczny wniosek stwierdzający nieistnienie jaźni, Budda w kazaniu tym nie orzeka tego wprost. Co więcej, w innych sytuacjach też powstrzymuje sį̨ od wyraźnej deklaracji w tej kwestii, jak ma to miejsce choćby $\mathrm{w}$ rozmowie Buddy $\mathrm{z}$ ascetą Waczczhagottą, w której Przebudzony nie odpowiada ani twierdząco, ani przecząco na pytania o ist-

encountered world is made up of distinguishable substances, and the linguistic theory that words refer to these substances which they represent; the conviction that our language corresponds to or mirrors a mind-independent reality). Tematu tego jednak nie pogtębiła.

s6 Najważniejszymi tekstami, w których Wynne wypowiada się na temat antyrealizmu myśli Buddy, są: A. Wynne, The atman and Its Negation. A Conceptual and Chronological Analysis of Early Buddhist Thought, JIABS 33/1-2 (2010), s. 103-171; idem, Buddhism. An Introduction, London-New York 2015. 57 Analizy zagadnienia jaźni, które przygotowały grunt dla tezy o antyrealizmie myśli Buddy zawarte są w dwóch tekstach, zob. idem, Early Evidence for the "No Self" Doctrine? A Note on the Second anātman Teaching of the Second Sermon, TIJBS 1 (2009), s. 64-84; idem, Miraculous Transformation and Personal Identity. A Note on the First anātman Teaching of the Second Sermon, TIJBS 1 (2009), s. 85-113.

58 Zob. np. SN III, 66-68.

59 A. Wynne, The atman and Its Negation..., s. 113, 142. 
nienie/nieistnienie jaźni (SN IV, 400-401), czy też w innej rozmowie z tym samym Waczczhagottą, w której bez odpowiedzi pozostawia m.in. pytania o istnienie Tathagaty po śmierci, jego nieistnienie, jego jednoczesne istnienie i nieistnienia oraz ani istnienie, ani nieistnienie (MN I, 484-485).

Żeby zrozumieć postawę Buddy, podkreśla Wynne, powinniśmy zdać sobie sprawę z tego, na czym polega różnica między nauką o niejaźniowości (Not-Self), a nauką o bezjaźniowości (No Self). Pierwsza ma być charakterystyczna dla Buddy, druga dla tradycji abhidharmicznej. Pierwsza wiąże się z filozofią epistemologicznego warunkowania, wyraża więc postawę antyrealistyczną, druga zaś z redukcjonistycznym realizmem charakterystycznym dla abhidharmy. Zgodnie z pierwszą nauka o niejaźni polega na wykazaniu, że o aspektach naszego doświadczenia, czyli o pięciu zespołach, nie sposób orzekać jaźni (orzekanie jaźni jest błędną konceptualizacją), nie można ich uważać za jaźń, żaden aspekt naszego doświadczenia (zespół) nie jest jaźnią. Zgodnie z drugą nauka o bezjaźniowości jest nauką o braku jaźni, o jej faktycznym nieistnieniu. Głosi ona, że w realnie istniejących zespołach nie można znaleźć jaźni, gdyż żadna jaźń nie istnieje ${ }^{60}$.

$Z$ kolei w pytaniach Waczczhagotty, pozostawionych bez odpowiedzi, nie chodzi tylko o błędne oczekiwania i założenia pytające-

60 Kwestii jaźni w buddyzmie poświęcona jest ogromna literatura. Tutaj warto wskazać tylko kilka kluczowych prac (kilka dodatkowych podaje w bibliografii): S. Collins, Selfless Persons. Imagery and Thought in Theravada Buddhism, Cambridge 1982; ide m, What Are Buddhists Doing When They Deny the Self?, [w:] Religion and Practical Reason. New Essays in the Comparative Philosophy of Religions, ed. F. E. Reynolds, D. Tracy, Albany 1994, s. 5986; J. Pérez-Remón, Self and Non-Self in Early Buddhism, The Hague 1980; P. Harvey, The Selfless Mind. Personality, Consciousness and Nirvana in Early Buddhism, Richmond 1995; idem, Dukkha, Non-Self, and the Teaching on the Four "Noble Trutbs", [w:] A Companion to Buddhist Pbilosophy, ed. S. M. Emmanuel, Chichester 2013, s. 26-45; M. Albahari, Analytical Buddhism. The Two-Tiered Illusion of Self, New York 2006; w jezyku polskim zob. K. Kosior, op. cit., s. 185-198. 
go, z powodu których każda odpowiedź Buddy zostanie zrozumiana przez niego opacznie, niezgodnie $z$ jej intencją (taką wykładnię postawy Buddy zwykle przyjmują badacze). W obu wypadkach, zarówno w sytuacji powstrzymywania się przed afirmacją nieistnienia jaźni, jak i w sytuacji nieudzielania odpowiedzi Waczczhagotcie, podstawą dla zachowania Buddy jest przekonanie, że pojęcie istnienia konstytuowane jest w zależności od umysłu; posiada ono wartość tylko w obszarze przyczynowo uwarunkowanego doświadczenia, w związku z czym wszelkie orzekanie istnienia bądź nieistnienia poza doświadczeniem nie ma najmniejszego sensu ${ }^{61}$. Jedyną rozsądną postawą, jaką można przyjąć względem pytań wychodzących poza doświadczenie, jest - zdaje się sugerować Wynne - zachowanie milczenia.

Postawa Buddy względem kwestii jaźni koresponduje z postawą, jaką ten zajmuje w Kazaniu o sieci Brabmy (DN I, 1-46). Ściśle rzecz biorąc, refleksja nad tą suttą dostarcza Wynne'owi argumentów uzasadniających postawę Buddy względem kwestii jaźni. W kazaniu tym Przebudzony przeprowadził krytykę sześćdziesięciu dwóch poglądów głoszonych przez różnych niebuddyjskich myślicieli. Niektóre $z$ tych poglądów stanowią wyraz spekulacji na temat przeszłości oraz sposobu istnienia w czasie jaźni, świata czy bogów. Inne formułują przekonania na temat świata ze względu na jego przestrzenność. Jeszcze inne rozstrzygają kwestie moralnej jakości różnych przedmiotów. Odrębna grupa dotyczy charakterystyki jaźni. Ostatnia zaś manifestuje różne poznawcze postawy względem możliwości żywienia poglądów ${ }^{62}$. Odrzuciwszy wszystkie, Budda sam nie afirmuje $w$ ich miejsce żadnego poglądu. Nie robi tego, gdyż obca jest mu perspektywa, którą wszystkie one, bez względu na swoje zróżnicowanie, podzielają. Skrupulatna analiza owej krytyki ujawnia zdaniem Wynne’a, że jej podstawą jest nieadekwatność pojęć czasu (przeszłości i przyszłości) oraz przestrzeni. Budda nie proponuje żadnego różnego od przywołanych stanowiska

\footnotetext{
61 A. Wynne, The atman and Its Negation..., s. 142.

62 Tą grupą zajmę się w drugiej części niniejszej pracy.
} 
ontologicznego, gdyż jego rozumienie nie wyraża się poprzez czasowe pojęcia. Kazanie o sieci Brabmy zatem jest świadectwem odrzucenia filozoficznego realizmu ${ }^{63}$. Wynne stwierdza, że w tym obszernym i niezwykle ważnym kazaniu Budda dał wyraz swojej unikatowej postawie, którą badacz określa filozofią epistemologicznego warunkowania.

Podsumowując swoje szczegółowe analizy Wynne oznajmia:

Budda był pierwszą osobą w historii, która odrzuciła, nie mówiąc już o jego podjęciu, przekonanie, że zewnętrzny świat ujmowany zmysłowo jest rzeczywistością niezależną od umystu ${ }^{64}$.

Z tak zarysowanego stanowiska płyną radykalne konsekwencje, które nie zostały dotychczas należycie uchwycone. Wskazując na nie, badacz dodaje:

Jeśli bowiem postrzegany świat jest pewnego rodzaju pojęciowym konstruktem, oznacza to, że przestrzeń, czas oraz jednostkowe istnienie nie są obiektywnie realne oraz że nirwana jest raczej niewystawialną prawdą o zjawiskach niż absolutną rzeczywistością poza nim ${ }^{65}$.

Ostatecznie Wynne podejmuje próbę uogólnionego zaklasyfikowania filozoficznej postawy Buddy, oświadczając:

Ogólną metafizykę [Buddy] można nazwać „skonstruowanym realizmem": " skonstruowanym" w tym sensie, że świat doświadczenia jest umystowym konstruktem; a "realizmem"

\footnotetext{
${ }^{63}$ A. Wynne, The dtman and Its Negation..., s. 148-149.

of Ide m, Buddhism..., s. 5: Buddha was the first person in bistory to reject, let alone entertain, the notion that the external world apprebended through the senses is a mind-independent reality.

65 Ibidem, s. 7: For if the perceived world is a sort of conceptual construction, it implies that space, time and individual existence are not objectively real, and that Nirvana is the ineffable truth of phenomena, rather than an absolute reality beyond it.
} 
w tym sensie, że poznawcze procesy oraz leżąca u podstaw rzeczywistość, którą one formują, są obiektywnie realne ${ }^{66}$.

W powyższej wypowiedzi powraca problem, przed jakim postawiła nas już Hamilton. Z jednej strony Wynne stanowczo oznajmia, że ze względu na skonstruowany charakter pojęcia istnienia nie sposób orzekać istnienia/nieistnienia transcendentnego względem uwarunkowanego doświadczenia ${ }^{67}$. Powstrzymywanie się przed jednoznacznym orzekaniem nieistnienia transcendentnej jaźni oraz brak odpowiedzi na pytania Waczczhagotty miały świadczyć o uświadomieniu sobie przez Buddę owej niemożliwości. Z drugiej strony jednak, wbrew własnym rozstrzygnięciom, Wynne uległ Kantowskiej manierze mówienia o leżącej u podstaw procesów poznawczych transcendentnej rzeczywistości, za którą Hamilton opowiadała się świadomie.

Trzeba jednak przyznać, że postawa Wynne'a nie należy do wyjątkowych, maniera owa we współczesnym antyrealizmie nie jest zjawiskiem odosobnionym. Można odnieść wrażenie, jakby niektórzy ze współczesnych antyrealistów żywili przekonanie, że naturalizacja Kanta, czyli usunięcie transcendentalnego wymiaru z jego filozofii, likwidowała również problem poznawczych podstaw, w oparciu o które przyjmuje się istnienie rzeczywistości samej w sobie. Zaskakuje jednak fakt, że proponując wykładnię myśli Buddy, która w swoim radykalizmie zdaje sį̨ bliższa stanowisku Nelsona Goodmana ${ }^{68}$, osta-

66 Ibidem, s. 33: The general metaphysic could be termed "constructed realism": "constructed" in the sense that the world of experience is a menatl construction; and "realism" in the sense that cognitive processes and the underlying reality that they fashion are botb objectively real.

67 Zob. ide m, The ätman and Its Negation..., s. 149, 154.

${ }_{68}$ Zestawiając w tym miejscu myśl Buddy ze stanowiskiem Nelsona Goodmana, biore pod uwag̨̨ wyłącznie kwestį̨ możliwości i sensowności orzekania transcendentnego istnienia $w$ związku z przekonaniem o skonstruowanym charakterze samego pojęcia istnienia, całkowicie pomijam natomiast zagadnienie relatywizmu. Reprezentatywną pracą dla Goodmanowskiego antyrealizmu jest: N. Goodman, Jak tworzymy świat, thum. M. Szczubiałk a, Warszawa 1997. 
tecznie badacze, gdy przychodzi do postawienia przysłowiowej kropki nad „i”, skłonni są cofać się o krok, zbliżając się do pozycji Michaela Dummetta $^{69}$ czy może bardziej Hilarego Putnama ${ }^{70}$. Przyczyn takiego postępowania, jak sądzę, należy upatrywać w obawie przed postawieniem myśli Buddy zarzutu metafizycznego nihilizmu, co prowadzi do podjęcia wyprzedzających działań, które zarzut taki mają z góry unieważnić, nawet jeżeli skutkują one niespójnością w wykładni. Możliwe, że nieświadomie historyk filozofii ustępuje $\mathrm{w}$ tym momencie miejsca apologecie. Czy jednak taka apologia ma jakąkolwiek wartość, skoro wyrasta $z$ naiwno-realistycznego przekonania o obiektywności dystynkcji między obrazem a obrazowanym, stojącego w opozycji do antyrealistycznej wykładni myśli Buddy?

Chociaż wykładnia taka pozostaje $\mathrm{w}$ niezgodzie $\mathrm{z}$ ukierunkowaną realistycznie filozofią abhidharmiczną, głosów dezaprobaty pod jej adresem jak dotychczas pojawiło się zaskakująco niewiele. Najbardziej zdecydowana krytyka tezy o antyrealizmie Buddy pochodzi od Douglassa Smitha ${ }^{71}$. Nie oznacza to jednak, żeby podnoszone przez niego argumenty były mocne i rozstrzygające. Jego krytyka, bardziej niż w sile argumentów, wyraża się w sposobie, w jaki buduje narrację, która ma odpowiadać zdroworozsądkowym intuicjom, a tym samym sugerować, że zdroworozsądkowa perspektywa rozumienia jakiejś kwestii zdaje się lepiej objawiać jej sens ${ }^{72}$. Chociaż badacz odnosi się do kilku tekstów, które odgrywają ważną rolę w uzasadnieniu wykładni antyrealistycznej, robi to w sposób raczej wybiórczy: całkowicie pomija kluczowe wypowiedzi Buddy zawarte w innych tekstach, które sugerują antyrealizm (jak choćby dotyczące „przekraczania” przestrzeni,

69 Zob. M. Dummett, Logiczna podstawa metafizyki, tłum. W. Sady, Warszawa 1998.

70 Dobrym wprowadzeniem w myśl tego filozofa w języku polskim jest: H. Pu tn a m, Wiele twarzy realizmu $i$ inne eseje, wybór i tłum. A. Grobler, Warszawa 1998.

7 D. Smith, Was the Buddha an Anti-Realist?, JOCBS 9 (2015), s. 143-178.

72 Zob. ibidem, s. 163. 
a tym samym rozumienia przestrzeni czy przede wszystkim istnienia), nie próbuje dać żadnej ich realistycznej wykładni. Stąd skłonny jestem zaryzykować stwierdzenie, że argumentacja Smitha przeciwko antyrealizmowi myśli Buddy jest w znacznym stopniu retoryczna, bardziej perswazyjna niż merytoryczna.

Niemniej, mimo tych zastrzeżeń, warto zwrócić uwage na co najmniej cztery punkty, które Smith podnosi. Po pierwsze, wskazuje, że krytycy przekonania głoszącego realizm myśli Buddy skupili się wyłącznie na realizmie substancjalistycznym i nie wzięli pod uwagę, że mogą istnieć inne rodzaje realizmu. W szczególności nie rozważyli możliwości, że mamy tutaj do czynienia z filozofią procesu. Według Smitha myśl Buddy jest realistyczną filozofią procesu, jest to realizm procesualny, a nie substancjalny ${ }^{73}$.

Po drugie, wiele momentów w wypowiedziach Buddy utrwalonych w kanonie w tekstach uchodzących za wczesne można wytłumaczyć, uwzględniwszy właściwy dla nich kontekst, czyli buddyjską teorię medytacji, w związku z czym nie tylko nie wymagają one antyrealistycznej interpretacji, ale interpretacja taka zaciera faktyczne intencje za nimi stojące. Przykładem może być charakterystyczna dla antyrealistycznej interpretacji wykładnia zawartej w czwartym rozdziale Suttanipaty zatytułowanym Ațthaka-vagga (uchodzącym za jeden z najstarszych buddyjskich tekstów) strofy 874, w której mówi się, że forma materialna przestaje istnieć dla przebywającego w szczególnym stanie opisywanym w odniesieniu do postrzegania/konceptualizacji (sañña). Wypowiedź tę po umieszczeniu jej w kontekście opisu praktyki medytacyjnej można rozumieć w sposób jak najbardziej realistyczny. Wystarczy przypomnieć sobie, że w czwartej bezforemnej dhjanie opisywanej jako stan ani postrzegania, ani niepostrzegania (neva-sañña-nāsaññayatana) forma znika dla medytującego, w związku z czym kontakt zostaje przerwany, a medytujący w ten sposób przestaje reagować odczuciem przyjemności i nieprzyjemności. Przebywając w tym stanie równowagi, zaprzestaje sporu ze światem. 
Innego przykładu ilustrującego zbędność antyrealistycznej interpretacji dostarcza Alagaddūpama-sutta (MN I, 130-142). Pojawia sį̨ w niej opis arahanta, w którym orzeka się, że bogowie, szukając wyzwolonego, nie mogą go znaleźć, gdyż jest nie do wykrycia. Antyrealistyczna interpretacja głosi, że jest tak dlatego, iż jest on poza czasem i przestrzenią. Smith ponownie odnosi się jednak do kontekstu opisów dhjany, w szczególności do stwierdzenia, że dzięki tej medytacji uchodzi się z pola widzenia Mary. Mara traci z oczu tego, kto pnie się po stopniach owej medytacji, gdyż ten odrywa się od przyjemności zmysłowych, a tym samym od pożądania. Zatem metafora niewykrywalności odnosi się według Smitha do faktu odseparowania od przyjemności, a nie do faktu bycia poza czasem i przestrzenią ${ }^{74}$.

Po trzecie, Smith odwołuje się do przeciwstawienia apofatyczny/ katafatyczny, które w wykładni Wynne'a odgrywało ważną rolę. Zaznacza, że chociaż Budda odrzuca wartość żywienia poglądów, to nie sposób nie dostrzec, że w suttach roi się od wypowiadanych przez niego opinii. Badacz sugeruje wręcz utrzymaną w zdroworozsądkowym tonie interpretację, oznajmiając, że ponieważ sutty Attbakawaggi są wczesne, być może nawet pochodzą z wczesnego okresu działalności Buddy, to charakterystyczne dla nich odrzucenie poglądów może być wyrazem zniechęcenia młodego jeszcze Buddy do uczestniczenia w sporach, wręcz zmęczenia nieustannym zabieganiem o uznanie ${ }^{75}$. Ważne jednak jest to, iż zarówno Alagaddūpama, jak i Atțhaka-vagga zawierają nauki nie tylko o charakterze apofatycznym, ale też katafatycznym. Podobnie rzecz ma się ze słynną Brabmadżalasutta, której analiza dostarczyła Wynne'owi ważnych argumentów wspierających jego wywód. W sutcie Alagaddūpama katafatyczne nauki dotyczą cierpienia i ustania cierpienia, w Brabmadżalasutcie zaś zależnego powstawania. Co więcej Budda nauki o zależnym powstawaniu nie traktuje jako sześćdziesiątego trzeciego poglądu, czyli nie stawia jej

74 Ibidem, s. 154-156.

75 Ibidem, s. 150-151. 
na tej samej płaszczyźnie, co krytykowane wcześniej przeświadczenia intelektualnych konkurentów. Właściwy pogląd nie jest bowiem uwarunkowany pragnieniem. Niemniej - twierdzi badacz - jest to pogląd metafizyczny. Zawarta w sutcie Alagaddüpama metafora tratwy według Smitha obrazuje właściwy i niewłaściwy sposób ujmowania nauki, tj. dhammy. Wspierając się na tej metaforze, badacz zgłasza przekonanie, że wiara w prawdziwość poglądu nie kłóci się z postawą nielgnięcia do niego, możliwe jest ich pogodzenie ${ }^{76}$.

Po czwarte, Smith uwypukla range kontaktu (phassa) w buddyjskim rozumieniu zmysłowego postrzegania. Standardowy opis kontaktu przedstawia go jako zajście relacji między organem zmysłem, przedmiotem zmysłowym i świadomością. Badacz oznajmia, że mówienie o nim ma sens tylko przy realistycznym założeniu faktycznego istnienia zarówno organu zmysłowego, jak i zewnętrznego przedmiotu pozostającego w relacji do organu ${ }^{77}$. Pisze na ten temat: „ «Kontakt» jest paradygmatycznie realistycznym pojęciem, ponieważ dotyczy interakcji pomiędzy odrębnymi umysłowymi i fizycznymi rzeczami"78. $\mathrm{Na}$ tej samej zasadzie uważa, że użycie zwrotu yathä-bhūtam do opisu właściwego poznania osłabia te interpretacje, które pozytywne wypowiedzi Buddy odczytują wyłącznie kontekstualnie i pragmatycznie. Zwrot ten bowiem - w jego opinii - wyraża przekonanie, że prawda/

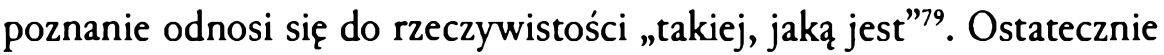
stwierdza, że stanowisko Buddy opisać można jako nierozwiniętą metafizykę i nierozwinięty realizm ${ }^{80}$.

W krytyce Smitha można wskazać kilka słabych punktów. Badacz ten sprowadza antyrealizm do twierdzenia o niewysławialności ostatecznej, tj. transcendentnej rzeczywistości samej w sobie, stąd z anty-

76 Ibidem, s. 157.

77 Ibidem, s. 160.

78 Ibidem, s. 174: "Contact” is a paradigmatically realist concept, since it involves an interaction between separable mental and physical things.

79 Ibidem, s. 168, 170.

${ }^{80}$ Ibidem, s. 175. 
realizmem ma korespondować postawa apofatyczna. W suttach jednak mamy pełno pozytywnych wypowiedzi, stwierdza, co kłóci się z ową postawą i każe spojrzeć na nią w szerszym kontekście. Przeciwko tej wykładni można wysunąć zarzut, że Smith zbyt pochopnie sprowadza antyrealizm do postawy apofatycznej, a tę traktuje jako ugruntowaną w niewysławialności transcendentnej rzeczywistości. Podobnie pozytywne wypowiedzi dlatego, że są pozytywne, nie muszą dotyczyć rzeczywistości transcendentnej. Równie dobrze mogą odnosić się do sfery zjawisk, czyli doświadczenia, co - jak sądzę - ma miejsce w wypadku Buddy. Dotyczy to również wypowiedzi o zależnym powstawaniu, do czego przejdę za chwilę.

Istotnym momentem krytyki Smitha jest zwrócenie uwagi na szczególny charakter kategorii kontaktu w buddyjskiej koncepcji postrzegania. Badacz jednak z góry przesądza, że pojęcie to ma sens tylko wówczas, gdy kontakt rozumie się jako realną relację między tym, co wewnętrzne, a tym, co zewnętrzne. Innymi słowy, ulega naiwno-realistycznemu typowemu dla naturalnego doświadczenia przeświadczeniu. Pojęcie kontaktu daje się jednak bez problemu opisać w języku doświadczenia i nie wymaga akceptacji realizmu. Podobnie też rzecz ma się z użyciem zwrotu yathā-bbūtam.

Poważnym mankamentem krytyki Smitha jest całkowity brak refleksji dotyczącej kwestii rozumienia zagadnienia istnienia i nieistnienia. Badacz ten w ogóle nie dyskutuje problemu konstytuowania się owych kategorii. Podobnie też w krytyce Smitha brak jest odniesienia do pytań pozostawionych bez odpowiedzi. Interpretacja antyrealistyczna zdaje się znacznie lepiej radzić sobie z wykładnią postawy Buddy - wszelkie pytania o istnienie, które miałoby transcendować doświadczenie świata, są pytaniami źle zadanymi, które z zasady muszą pozostać bez odpowiedzi.

Mimo tych ułomności warto jednak podkreślić również momenty cenne. Bez wątpienia jednym $z$ nich jest zwrócenie uwagi na znaczenie dla rozumienia różnych wypowiedzi kontekstu medytacyjnego oraz kwestii nielgnięcia. Pewne negatywne wypowiedzi Buddy nie muszą 
być interpretowane automatycznie z klucza wykładni antyrealistycznej, a o skłonność do takiego postępowania szczególnie można podejrzewać Wynne'a.

W opinii badaczy, którzy w myśli Buddy dopatrują się stanowiska antyrealistycznego, ukształtowanie się abhidharmicznej scholastyki oznaczało odejście od niejednoznacznej wstrzemięźliwości samego Buddy w kierunku jednoznacznych deklaracji, co wiązało się z przejściem na pozycje realistyczne. Ma to być widoczne w wielu momentach, począwszy od negatywnych rozstrzygnięć $w$ kwestii istnienia jaźni, poprzez wypracowanie jednoznacznych opinii w obszarze problematyki kosmologicznej, a skończywszy na sposobie rozumienia zespołów i, mógtbym dodać, na sposobie rozumienia i traktowania doświadczenia. Niemniej należy pamiętać, że również w myśli abhidharmy silnie zaznacza się tendencja do antyrealizmu. Abhidharma bowiem utrzymuje, zdecydowanie przeciwstawiając się realistycznemu atomizmowi filozofii wajsiesziki (vaiśeșika) i njaji (nyāya) ${ }^{81}$, że rzeczy dane nam w codziennym doświadczeniu są umysłowo skonstruowane i ostatecznie podlegają redukcji do podstawowych czynników/jakości, czyli dharm będących faktyczną treścią naszego doświadczenia. Według njaji-wajsiesziki rzeczy codziennego doświadczenia istnieją realnie jako substancje złożone $\mathrm{z}$ atomów. Ich złożoność decyduje o ich nietrwałości, ale nie o ich nierealności. Póki są substancjami złożonymi, póty są przede wszystkim substancjami, czyli stanowią realną, tj. obiektywną istotową jedność; w sensie metafizycznym są jednostkowymi bytami, których nie sposób zredukować do części składowych. Filozofia abhidharmy natomiast twierdzi, że rzeczy codziennego doświadczenia, podlegając mereologicznej redukcji ${ }^{82}$, fak-

81 Na temat atomizmu w njaji-wajsieszice i w ogóle na temat indyjskiego atomizmu zob. Encyclopedia of Indian Pbilosopbies, vol. 2: Indian Metaphysics and Epistemology. The Tradition of Nyaya-Vaiśsesika up to Gangesa, ed. K. H. Potter, Delhi 1977, zwł. s. 69-86; M. Gangopadhyaya, Indian Atomism. History and Sources, Calcutta 1980.

82 Na temat mereologicznego redukcjonizmu abhidharmy zob. M. Siderits, Buddhism as Philosopby. An Introduction, Indianapolis 2007, s. 105-111. 
tycznie nie istnieją, ich obiektywność jest wyłącznie empiryczna, a nie metafizyczna. Realnie istnieją tylko proste dharmy, czyli niezłożone i niepodzielne byty przenoszące własną, indywidualną, pojedynczą jakość. Treścią naszego codziennego doświadczenia są jednak owe całości, a nie proste byty/jakości. Siadamy przy stole, głaszczemy kota, zakochujemy się w człowieku, bawimy się z dzieckiem, mamy - żywimy takie przekonanie - do czynienia z wieloaspektowymi całościami, a nie ze skupiskami odrębnych fizycznych czy psycho-fizycznych jakości. To, jak nam owe całości są dane, i przede wszystkim to, że są nam dane, uwarunkowane jest według abhidharmy procesami poznawczymi. Sądzę, że ten antyrealistyczny aspekt filozofii abhidharmy ciągle jeszcze nie doczekał się należycie pogłębionej analizy. Badacze, jak też i - mam wrażenie - sami myśliciele abhidharmy bardziej skupiali się na realistycznej koncepcji dharm niż antyrealistycznej koncepcji świata doświadczenia. Ci drudzy, dokonawszy podziału na prawdę ostateczną (s. paramärtha-satya, p. paramattha-sacca) i konwencjonalną (s. samurti-satya, p. samvuti-sacca) ${ }^{83}$, więcej uwagi poświęcali rzeczywistości widzianej przez pryzmat prawdy ostatecznej niż naznaczonemu błędem poznawczym, a tym samym też cierpieniem, światu doświadczanemu w obszarze prawdy konwencjonalnej.

\subsubsection{Nauka o zależnym powstawaniu}

Po dywagacjach na temat antyrealizmu wczesnej myśli buddyjskiej czas powrócić do uwag kończących naukę Buddy do Katjajany i zastanowić się nad „ukształtowaniem” owej środkowej drogi, która ma unikać istnienia i nieistnienia. Obie zachowane w jezzykach indyjskich wersje sutry, chociaż różnią się $\mathrm{w}$ tym fragmencie $\mathrm{w}$ swojej narracji, zgadzają się, że drogą tą jest nauka o zależnym powstawaniu (s. pratītya-samutpāda, p. paticca-samuppada). W obu wersjach nauka ta zosta-

$83 \mathrm{Na}$ temat koncepcji dwóch prawd w tradycji abhidharmy zob. P. M. Williams, On the Abbidharma Ontology, JIP 9 (1981), s. 237-239. 
ła przywołana w sposób skrótowy, aczkolwiek w wersji sanskryckiej pojawia się odwołanie do dwóch postaci tejże - do ogólnej formuły zależnego powstawania oraz do jej standardowej egzemplifikacji prezentującej kształtowanie się cierpienia. W wersji palijskiej przywołuje się tylko samą egzemplifikację, przy czym w jej obu postaciach: wstępującej i zstępującej. Zalecenie unikania orzekania istnienia i nieistnienia jest wyrazem uświadomienia sobie sposobu formowania się intuicji, z których pojęcia istnienia i nieistnienia wyrastają. Intuicje te uwikłane są w poczucie „ja" - indywidualnej odrębności i tożsamości. Świadomość ta prowadzi Buddę do „afirmacji” postawy apofatycznej, do odrzucenia istnienia oraz nieistnienia. Jak jednak odrzucić coś, co wyrasta $z$ najgłębszych warstw doświadczenia samego siebie? Odpowiedzią na to pytanie jest nauka o zależnym powstawaniu, która wieńczy odkrycie Buddy. To ta nauka decyduje o nowatorstwie i oryginalności jego myśli. Nie biorąc jej pod uwagę, filozofię buddyjską bez wielkich problemów dałoby się sprowadzić do jeszcze jednej postaci apofatycznej refleksji upaniszadowej. W opinii samego Buddy jest to nauka głęboka (gambbira) i mająca głęboką postać (gambbirā̃vabhäsa), czyli doniosła, brzemienna w konsekwencje (DN II, 55; SN II, 92). $\mathrm{Z}$ powodu jej niezrozumienia istoty doświadczają cierpienia. Niewiedza jest bowiem, jak stwierdza Budda w dwóch bliźniaczych kazaniach o ascetach i braminach (SN II, 14-16), brakiem wiedzy o zależnym powstawaniu zjawisk (dhamma), ich ustawaniu i ścieżce prowadzącej do ich ustania. Wgląd $w$ tę naukę daje zatem wyzwolenie.

O randze tej nauki mogą świadczyć słowa Assadżiego (p. Assaji), który, jeśli wierzyć tradycji, jako ostatni z pierwszej piątki towarzyszy Buddy osiągnąt stan arhata. Pewnego razu Sariputta (p. Sāriputta), niebędący jeszcze wówczas buddyjskim mnichem, zaintrygowany jego postawą zadał mu pytanie (VP I, 40): "Jaka jest doktryna twojego szacownego nauczyciela, co on głosi?" (kimvādì panāyasmato satthā kimakkbāyatīti). Na co Assadżi odpowiedział"

${ }_{84}$ Zob. także The Book of the Discipline (Vinaya-pitaka), vol. 4: Mabavagga, trans. I. B. Horner, London 1951, s. 53-54. 
ye dhamma hetuppabhava tesam hetum tathägato äba tesañ ca yo nirodho evamvädì mabäsamano 'ti

Tathagata powiedział o przyczynie i ustaniu owych zjawisk powstających za sprawą przyczyn, oto doktryna Wielkiego Ascety.

Nauka o zależnym powstawaniu jest odpowiedzią Buddy na problem, jaki wyłania się w związku z zawieszeniem opinii na temat istnienia (ale też i nieistnienia) metafizycznego podmiotu czynu. Jest to szczególnie palący problem w kontekście etycznym, czyli w kontekście pytania o odpowiedzialność za podejmowane działania i ich konsekwencje.

W przywoływanym już Kazaniu do Molijaphagguny (SN II, 13-14) Budda, przypomnijmy, zredefiniował pytania o to, kto spożywa "pokarm" świadomości, wywołuje kontakt, czuje i pragnie. Pytania takie, oznajmia, są niewłaściwie sformułowane (no kallo pañbotz). Należy pytać o to, czego warunkiem jest pokarm świadomości, w oparciu o jaki warunek pojawia się kontakt, uczucie, pragnienie. Właściwie zadane pytanie jest pytaniem o to, jaki stan jest warunkiem pojawienia się jakiego stanu. Nie należy pytać o to, kto działa, tylko o to, w oparciu o jaki warunek pojawia się jakiś stan.

Analogicznej odpowiedzi Budda udzielit pytany o to, do kogo przynależą starość-i-śmierć, narodziny itd. (SN II, 60-63), czyli, innymi słowy, kto doświadcza starości-i-śmierci, narodzin itd. Wszystko to są "niewłaściwie zadane pytania” (no kallo pañhotı). W miejscu tym Budda poczynił jeszcze jedną ciekawą uwagę. Stwierdził mianowicie, że wypowiedzi w rodzaju: „Czym jest starość-i-śmierć i do kogo przynależy?" (katamam jarā-maranam kassa ca panidam jarä-marananti) oraz: „Starość-i-śmierć to jedna rzecz, a ten, do kogo starość-i-śmierć przynależy, to druga" (añ̃am jarā-maranam aññassa ca panidam jarä- maranantz) posiadają tę samą charakterystyczną cechę czy też wymowę (ubbayam etam ekattam vyañjanam eva nānam). Cechą tą jest podzielanie tego samego błędnego założenia dotyczącego działania, 
w tym w szczególności doświadczenia. Obie wypowiedzi są wadliwe, zarówno pytanie, jak i stwierdzenie, gdyż zakładają ontyczny podmiot. Ponieważ Budda dostrzega tę wadę we wszystkich funkcjonujących w jego czasach koncepcjach przyczynowości, wszystkie je odrzuca.

W Kazaniu do nagiego ascety koncepcje owe podzielone zostały według klucza logicznego na cztery grupy (SN II, 19-20) ${ }^{85}$. Do pierwszej należą te, które głoszą, że skutek wywołany został przez samego siebie (sayamkata), czyli że skutek i przyczyna są ze sobą tożsame albo, jak się czasami to ujmuje, że skutek tkwił już w przyczynie. Oznacza to, że w sensie metafizycznym skutek i przyczyna są tym samym bytem, chociaż różnią się w sensie empirycznym. Do drugiej zaliczone zostały te, które utrzymują, że skutek został wywołany przez coś innego (paramkata), czyli że skutek i przyczyna nie są ze sobą ontycznie tożsame, nie ma między nimi bytowej ciągłości. Do grupy trzeciej włączone zostały te, których stanowisko opisać można koniunkcją dwóch pierwszych możliwości, głoszą one zatem, że w pewnym sensie skutek wywołany jest przez samego siebie i przez coś innego (sayamkatañ ca paramkatañ ca), czyli że jest tożsamy z przyczyną i nie jest z nią tożsamy. Grupę czwartą mają stanowić koncepcje opisywalne binegacją, które głoszą, że skutek ani nie został wywołany przez samego siebie, ani nie został wywołany przez coś innego (asayamkāram aparamkāram). Innymi słowy, głoszą one całkowite niezdeterminowanie (yadicchā) skutku czy też jego przypadkowe powstawanie (adhicca-samuppäda).

Grupe pierwszą ilustruje cały wachlarz poglądów, których pierwociny znaleźć można w Rigwedzie (Rg-veda), które dojrzewały w upaniszadach, a następnie wyraziły się w kilku klasycznych bramińskich systemach, jak np. adwajtawedanta (advaita-vedānta) czy sankhja (samkbyya). Mimo różnic wszystkie one podzielają przekonanie, że skutek jest wynikiem przemian (przekształceń lub podziałów) pierwotnego bytu (czy to ujmowanego w kategoriach boga, czy bezosobowego absolutu, czy też po prostu pierwotnej substancji). Wyrazi-

${ }_{85}$ Szerzej na temat owych czterech grup zob. N. Ronkin, op. cit., s. 195-198. 
stego przykładu takiego stanowiska, pośród wielu mniej wyrazistych, dostarcza opowieść o pierwotnym podziale, jaki dokonał się w bogu/ duchu o imieniu Purusza (Puruṣa), w wyniku którego, poprzez dalsze podziały wydzielonej części, ukształtowany został świat fizyczny i społeczny (RV X, 90). Inny nie mniej wyrazisty przykład znaleźć możemy w Nasadïjasukcie (Nāsadīya-sūkta; RV X, 129), najsłynniejszym filozoficznym hymnie Rigwedy, gdzie mówi się o początku tak doskonałym, iż wyprzedzat niebyt (asat) i byt (sat), a będąc w sobie niezróżnicowanym, pozostawał jednym (eka). W nim to, w wyniku wewnętrznej dynamiki określanej mianem żarzenia się (tapas), zainicjowany został proces przemian, którego efektem było powstanie wszystkiego. Zawarta w tym hymnie idea jednego dała początek dominującej we wczesnych upaniszadach koncepcji wszechobejmującego jedynego brahmana (brabman $)^{86}$, będącego korzeniem i podstawą wszystkiego ${ }^{87}$, który w wymiarze subiektywnym udostępnia się jako jaźń-atman $(\bar{a} t m a n)^{88}$.

86 ChU VI.2.1-3: sad eva somyedam agra asid ekam evadvitiyam | [...] tadaiksata babu syam prajayeyeti („Na początku, Somjo, istniał tylko byt, jedno tylko bez drugiego. [...] To pomyślało: obym było wielością, obym się rozmnożyło"). Zob. także Upaniszady, tłum. M. Kudelska, Kraków 1998, s. 240, a także The Early Upanisads, trans. and ed. P. Olivelle, Oxford 1998, s. 246-247.

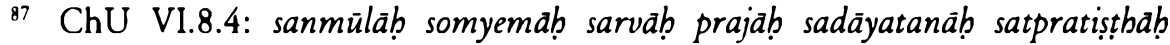
(„Te wszystkie stworzenia, Somjo, mają korzeń w bycie, siedzibę w bycie, podstawę w bycie"). Zob. także Upaniszady, s. 244, a także The Early Upanișads, s. $250-251$.

88 MU I.2: sarvam by etad brabma | ayam atma brabma ("Zaprawdę wszystko jest brahmanem. Ten atman jest brahmanem"). Datowanie upaniszady Mandukji (Mändūkya) jest problemaryczne. Badacze w swoich opiniach potrafią się różnić nawet o sześć do siedmiu wieków, lokując ją między V w. p.n.e. a II w. n.e. Niemniej w interesującym nas tutaj aspekcie upaniszada ta powtarza myśl, która pierwszoplanową pozycję uzyskała już w dwóch najstarszych (VII-VI w. p.n.e.) upaniszadach - Bribadaranjace i Czbandogji - wysławianą jako „ja jestem brahmanem” (abam brabma asmi; BĀU I.4.10) oraz „ty jesteś tym" (tad tvam asi; ChU VI.8.7). Zob. Upaniszady, s. 251 oraz The Early 
Koncepcje przynależne do grupy drugiej są w swojej treści znacznie bardziej zróżnicowane. Cechą im wszystkim wspólną jest kontestowanie wedyjskiej tradycji. Nie z tego powodu jednak Budda zalicza je do jednej grupy, zwłaszcza że jego własna nauka tę cechę z nimi podzielała. O ile przedstawiciele grupy pierwszej reprezentowali w opinii Buddy stanowisko eternalizmu ${ }^{89}$, o tyle przedstawicieli grupy drugiej uważał on za reprezentantów anihilacjonizmu ${ }^{90}$. Przypisanie anihilacjonizmu przynajmniej niektórym myślicielom z tej grupy, jak choćby adżiwice o imieniu Pakudha Kaczczajana (p. Pakudha Kaccāyana) może w pierwszej chwili zaskakiwać. Wszak uznawał on realne i niepodlegające zmianie istnienie siedmiu zasad, w tym duszy (jivva) (DN I, 56). Z perspektywy kategoryzacji poglądów z Kazania o sieci Brabmy pogląd ten stanowi wyrazistą egzemplifikację eternalizmu (DN I, 13-16). Na tym przykładzie widać, że określenia „eternalizm” i „anihilacjonizm" należy zawsze czytać uwzględniając kontekst ich pojawienia się. Stanowisko oceniane z perspektywy ontologicznej jako eternalizm, z perspektywy etycznej może jawić się jako anihilacjonizm. Z taką sytuacją mamy do czynienia właśnie w wypadku Pakudhy Kaczczajany, jak i zresztą w kilku innych wypadkach podawanych jako ilustracje poglądu o wytwarzaniu skutku przez coś innego. Standardowo przywołuje się tutaj stanowiska naturalizmu (svabhāva-vāda) i fatalizmu (niyati-vāda). Przedstawiciele pierwszego to materialiści (lokāyata,

Upanișads, s. 474-475. Zob. także Mãndūkyopanișad, tłum. B. Śliwczyń ska, SI 3 (1996), s. 131.

${ }^{89}$ SN II, 20: „Kassapo, [twierdzenie]: «ten, kto działa, jest tym, kto doświadcza [skutków działania]», przy wstępnym założeniu, że "cierpienie powstaje dzięki sobie», prowadzi do eternalizmu" (so karoti so pațisamvediyatitit kbo kassapa adito sato sayamkatam dukkhanti iti vadam sassatam etam pareti). Por. tei̇ SN II, 75 oraz NidSa 18.5.

90 SN II, 20: „Kassapo, [twierdzenie]: «kto inny działa, kto inny doświadcza [skutków czynów]", dla owładniętego uczuciem przy założeniu, że "cierpienie powstaje dzięki czemuś innemu», prowadzi do anihilacjonizmu" (añño karoti añno patisamvediyatîti kho kassapa vedanabbitunnassa sato paramkatam dukkhanti iti vadam ucchedam etam pareti). Por. też SN II, 76 oraz NidSa 18.5. 
cārvāka), drugiego - adżiwikowie (ājìvika). Chociaż pod względem ontologicznym ich przekonania podpadaja pod eternalizm, to z perspektywy rozważań o warunkowaniu traktowani są jako anihilacjoniści, gdyż na różne sposoby przeczą, abyśmy świadomym wysiłkiem byli w stanie kształtować swój los. Wszystko, co się dzieje, dzieje się w związku z koniecznością naturalną (materialiści) bądź metafizyczną (adżiwikowie), czyli na to, co się nam przydarza, nie mamy żadnego wpływu. W tym sensie owe zdarzenia, chociaż są naszym udziałem, stanowią skutek czegoś od nas różnego. W konsekwencji prowadziło to owych myślicieli do przekonania, że moralna odpowiedzialność jest czystą mrzonką, z czym Budda zdecydowanie się nie zgadzał.

Jeżeli chodzi o ilustracje trzeciego modelu warunkowania opisywanego koniunkcją, to w nikajach nigdzie nie znajdziemy jednoznacznego wskazania na przedstawicieli takiego stanowiska. Badacze jednak zdecydowanie w ten model warunkowania wpisują stanowisko myślicieli dżinijskich w związku z ich koncepcją "niejednostronności" [prawdy] (anekanta-vāda), czyli wieloaspektowości czy też wręcz względności prawdy" ${ }^{91}$ Ponieważ rzeczywistość jest złożona - twierdzą myśliciele dżinijscy - to nie sposób ująć jej w jednoznaczny sposób. W zależności od punktu widzenia akceptowalne mogą być nawet sądy sprzeczne. W związku z tym obie możliwości opisu warunkowania są w pewnym sensie trafne. Również odnośnie do modelu czwartego teksty buddyjskie nie identyfikują z imienia żadnego myśliciela, którego poglądy podpadałyby pod tę kategorię. Mówi się tylko ogólnie o istnieniu ascetów i braminów, którzy głoszą, że skutek powstaje przypadkowo (adbicca) ${ }^{92}$.

91 Na temat koncepcji niejednostronności prawdy w dżinizmie zob. P. Balcerowicz, Dizinizm. Starożytna religia Indii, Warszawa 2003, s. 239; ide m, Early Asceticism in India. Ajivikism and Jainism, London-New York 2016, s. 174-185.

92 Szerzej na temat owych czterech kategorii oraz podpadających pod nie stanowisk zob. D. J. Kalupa hana, Causality. The Central Philosophy of Buddhism, Honolulu 1986, s. 1-53. 
Wydawać by się mogło, że wyróżniając w oparciu o kryterium logiczne cztery typy przyczynowości, które zdają się wyczerpywać wachlarz teoretycznych możliwości, i odrzucając je wszystkie, Budda zamyka sobie drogę dla własnej pozytywnej propozycji. Niewątpliwie w jego oczach sytuacja taka ma miejsce w ramach perspektywy poznawczej, która operuje kategoriami istnienia i nieistnienia jako kategoriami obiektywnymi w sensie metafizycznym. Żeby zrozumieć nowatorstwo i doniosłość koncepcji Buddy, musimy zdać sobie z tego sprawę. Rozwiązanie proponowane przez twórcę buddyzmu przełamuje, a przynajmniej stara się przełamać tę metafizyczną perspektywę.

Dobre wprowadzenie do tego zagadnienia mogą stanowić uwagi na temat pojawiającej sį̨ w tym kontekście we wczesnych pismach terminologii. Miejscem pod tym względem szczególnie wartościowym jest Wielkie kazanie o podstawach zależności (Mabā-nidāna-sutta; DN II, 55-71). W nauce tej Budda postużł się stosunkowo obszernym słownikiem do opisu mechanizmu powstawania w zależności. Zaczynając od stanu starości-i-śmierci, czyli cierpienia, przypomina on, iż ogłosił, że tym co warunkuje ten stan, są narodziny, a następnie określa pozycję, jaką narodziny zajmują względem starości-i-śmierci, mówiąc (DN II, 57):

tasmāt ib' ānanda es' eva betu etam nidãnam esa samudayo esa paccayo jarä-maranassa, yadidam jäti.

Dlatego Anando właśnie to jest przyczyną, podstawą, początkiem, warunkiem starości-i-śmierci, mianowicie narodziny.

Ewidentnie w kazaniu tym cztery terminy: przyczyna (hetu), podstawa (nidãna), początek (samudaya) i warunek (paccaya), zostały potraktowane jako synonimy. Buddhaghosa do tej listy dodaje kolejne trzy: powód (kārana), powstanie (sambhava) i zalążek (pabhava) ${ }^{93}$. Noa Ronkin na podstawie analizy Trójkosza dorzuciła dalsze: środek 
[do czegoś] (upanisā), czynnik formujący (sañkbāra), korzeń/podstawa (mūla), podpora (ärammana), pokarm (āhāra), pochodzenie (samuțţhāna). Widać wyraźnie, że wczesna myśl buddyjska intensywnie krążyła wokół zagadnienia zależnego powstawania, naświetlając je $\mathrm{z}$ różnych stron. Inspirując się rozwiązaniami typowymi dla późniejszej abhidharmy, zwłaszcza dla szkoły sarwastiwady, badacze próbowali dokonać rozróżnień w znaczeniu przywołanych tu terminów. Ich uwaga skupiała się głównie na dwóch najczęściej pojawiających się we wczesnych tekstach określeniach - paccaya (s. pratyaya) i betu, które standardowo tłumaczy się jako „warunek” i „przyczyna”. Za tym thumaczeniem miała się kryć głębsza różnica, odpowiadająca faktycznemu rozróżnieniu na to, co w standardowej koncepcji przyczynowości uważane jest za przyczynę sprawczą różną od towarzyszących jej warunków. Pomysły te jednak nie znajdują w kazaniach Buddy żadnego uzasadnienia ${ }^{94}$. Wręcz przeciwnie, jeśli chodzi o dwa najważniejsze terminy, to w nikajach wielokrotnie pojawia sie pytanie: „Czym jest przyczyna, czym warunek?" (ko betu ko paccayo) (np. MN I, 285, 442, 444-445; MN II, 45, 74; SN III, 101; AN I, 55, 66, 200; AN III, 230), którego kontekst nie pozostawia żadnych wątpliwości, że użyte w nim terminy są synonimami. Powinniśmy natomiast zastanowić się: które z tych znaczeń, przyczyna czy warunek, bliższe jest intuicji samego Buddy? Nie jest to pytanie błahe. Rozstrzygnąć musimy kwestię zasadniczą, czy Budda naucza o przyczynowej sprawczości, czyli czy głosi koncepcję koniecznego związku przyczynowo-skutkowego, czy też naucza o wystarczającym warunkowaniu. Możemy to pytanie ująć jeszcze inaczej. Jaki kierunek relacji go interesuje $w$ analizie zależnego powstawania - od przyczyny do skutku czy od skutku do przyczyny? Postaram się pokazać, iż ten drugi kierunek jest dla niego zdecydowanie ważniejszy.

Zasada zależnego powstawania w nikajach sformułowana została na dwa sposoby - w postaci ogólnej jako formalna zasada warunkowania

94 Zob. D. J. Kalupahana, Causality..., s. 56-59. 
i w postaci szczegółowej będącej egzemplifikacją zasady ogólnej. Od razu należy podkreślić, iż owa egzemplifikacja, która w standardowej postaci wyrażana jest za pomocą łańcucha złożonego $\mathrm{z}$ dwunastu ogniw/podstaw (nidāna), nie jest po prostu jedną z wielu możliwych ilustracji zasady ogólnej, lecz faktycznie traktowana jest jako zasadnicza treść najważniejszego odkrycia Buddy. To ona właśnie decyduje o soterycznym potencjalne jego nauki.

Obie formuły w nikajach i Winajapitace (Vinaya-pițaka) występują wielokrotnie. Równie często przywoływane są w postaci skróconej, która zastępuje całe formuły. Z taką sytuacją mamy do czynienia właśnie w sanskryckiej wersji Kazania do Katjajany. Bez wątpienia jednak w kazaniu tym chodzi o pełną formułę, która tylko jest wzmiankowana jako podana wcześniej w innym miejscu. Co więcej, przyjąć możemy, że skrócona wersja ogólnej formuły zastępuje tutaj także jej egzemplifikację zarówno w formie pozytywnej, jak i negatywnej. Ogólna zasada w pełnej postaci głosi ${ }^{95}$ :

imasmim sati idam hoti, imass' uppadā idam uppajjati, imasmim asati idam na boti, imassa nirodba idam nirujjbati

Gdy jest to, jest tamto. Gdy to powstaje, tamto powstaje. Gdy nie ma tego, nie ma tamtego. Gdy to zanika, tamto zanika.

Pierwsza wątpliwość, jaka się pojawia w związku z tą formułą, to niepewność odnośnie jej sensu: chodzi w niej o stosunki czasowe (synchronia i następstwo) czy o typy modalności? Uważam, że analiza ogólnej zasady będzie zbyt jednostronna i niekonkluzywna (ewentualnie narażona na wyprowadzenie błędnych konkluzji), jeżeli nie uwzględnimy kształtu i charakteru konkretnego łańcucha warunko-

95 Zob. w palijskim Trójkoszu: MN II, 32; III, 63; SN II, 28, 65, 70, 78, 95, 96; VP I, 5. Ciekawym miejscem jest Wielkie kazanie o zniszczeniu pragnienia (Maba-tanha-sankbata-sutta), w którym zasada ta została rozpisana na poszczególne frazy objaśniane po kolei (MN I, 262-264). 
wania egzemplifikującego ogólną zasadę. $Z$ analizy samej zasady, o ile będziemy zbyt restrykcyjnie czytać zawartą w niej implikację, wynika, że frazy z pierwszej połowy określają relację przyczynowości pod kątem wystarczalności przyczyny, podczas gdy frazy $z$ drugiej połowy określają tę relację pod kątem jej konieczności. Późniejsza tradycja abhidharmiczna interpretowała tę zasadę $\mathbf{w}$ tym kierunku z zastrzeżeniem, że przyczynę rozumiała jako zespół warunków (hetu-samūba) ${ }^{96}$. Zgodnie $z$ tą opinią przyczyna A jest wystarczająca do pojawienia się skutku B, wtedy i tylko wtedy, gdy przyczyna A jest pełnym zestawem warunków koniecznych do pojawienia się skutku B. Innymi słowy, późniejsza tradycja interpretowała tę zasadę w sposób mocny, mianowicie: gdy jest $\mathrm{A}$, to musi być $\mathrm{B}$; gdy $\mathrm{A}$ się pojawia, to musi pojawić się $B$; gdy nie istnieje $A$, to nie może istnieć $B$; gdy $A$ zanika, to musi zaniknąć $B$.

Sądzę jednak, na podstawie analizy egzemplifikacji owej ogólnej zasady, jak też i na podstawie przekazanego przez tradycję biograficznego podania związanego z jej odkryciem, że Buddzie chodziło wyłącznie o konieczność warunku, a nie o jego wystarczalność. Podejście takie całkowicie wystarcza do realizacji celu, który mu przyświecał, i doskonale koresponduje $\mathrm{z}$ wyrażaną przez niego antyspekulatywną $i$ antymetafizyczną postawą. Tym samym czytał on tę zasadę, skłonny jestem twierdzić, w sposób słabszy jako: gdy jest $A$, to może istnieć $B$; gdy A się pojawia, to może pojawić się $\mathrm{B}$; gdy $\mathrm{A}$ nie istnieje, to $\mathrm{B}$ nie może istnieć; gdy A zanika, to B musi zaniknąć.

Żeby wykazać stuszność tej opinii, musimy przyjrzeć się owym egzemplifikacjom. Za locus classicus klasycznego schematu zasady za-

96 Zob. D. J. Kalupahana, Causality..., s. 56. W nikajach znaleźć można kilka miejsc, które uprawomocniają takie odczytanie. W dwóch z nich - SN I, 134 i SN III, 54 - pojawia się metafora nasion i wielu czynników (jak woda, żyzna ziemia, właściwy stan ziaren) niezbędnych do tego, aby wydały plon. W kilku innych (DN II, 62-63; MN I, 111-112, 190; SN II, 72-75; IV, 32-34, 66-69, 166-167) pojawia się ciekawy opis wieloczynnikowego warunkowania postrzegania zmysłowego. 
leżnego powstawania w dwunastu ogniwach (nidāna) możemy uznać pierwsze kazanie noszące tytuł Wykładnia [zależnego powstawania] (Desana) otwierające dwunasty rozdział Sanjuttanikaji w całości poświęcony przyczynowości zatytułowany Nidāna-samyutta, czyli Powiazane [kazania o] podstawach zależności. Czytamy tam (SN II, 1):

katamo ca bbikkbave paticca-samuppado | avijja-paccaya bbikkhave sañkhārā | sañkhārā-paccayà viñ̃ananam | viñ̃ãana- paccaya näma-rūpam | nāma-rūpa-paccaya salayatanam | salayatana-paccayā phasso | phassa-paccayā vedanā | vedanā-paccaya tanba | tanba-paccaya upadanam | upädana-paccayā bhavo | bhava-paccayã jäti | jati-paccaya jara-maranam soka- parideva-dukkba-domanassupayäsa sambhavanti | evam etassa kevalassa dukkbakkbandbassa samudayo hoti | ayam vuccati bikkbave samuppado II

Co to jest zatem, mnisi, zależne powstawanie? Uwarunkowane niewiedzą, mnisi, powstają dyspozycje wolicjonalne. Uwarunkowana dyspozycjami powstaje świadomość. Uwarunkowane świadomością powstają nazwa i forma. Uwarunkowane nazwą i formą powstaje sześć podstaw ujmowania. Uwarunkowany sześcioma podstawami ujmowania powstaje kontakt. Uwarunkowane kontaktem powstaje doznanie/uczucie. Uwarunkowane doznaniem powstaje pragnienie. Uwarunkowane pragnieniem powstaje lgnięcie. Uwarunkowane lgnięciem powstaje [trojakie] istnienie. Uwarunkowane istnieniem powstają narodziny. Uwarunkowane narodzinami powstają starość-i-śmierć, boleść, żałość, męka, udręka i niepokój. Tak powstaje ten cały zespół cierpienia. To zwie się, mnisi, [zależnym] powstawaniem.

Po wyliczeniu poszczególnych ogniw kazanie powtarza tę formułę w postaci negatywnej, wskazując, jaki będzie efekt, gdy kolejne ogniwa, wychodząc od pierwszego, będą zanikać. Porządek prezentacji formuły zależnego powstawania $\mathbf{w}$ dwunastu ogniwach, który zaczyna się od niewiedzy i kończy na starości-i-śmierci, nazywa się „z włosem” (anuloma). Porządek odwrotny, który przebiega w kie- 
runku odwrotnym, od ogniwa dwunastego do pierwszego, zwie sį „pod włos" (p. pațiloma, s. pratiloma) (zob. SN II, 10 i 25). Ponadto oba porządki mogą występować też w postaci negatywnej. Negatywna wersja w przód pojawia się właśnie w przytoczonym tu kazaniu jako jego druga część (SN II, 2), znajdziemy ją też w SN II, 95. Natomiast negatywną wersję wstecz znajdziemy w SN II, 11.

Zasada zależnego powstawania, sądzę, określa zależność pod względem wystąpienia warunku koniecznego, a nie wystarczającego. Ściśle rzecz biorąc, nie jest to w związku z tym zasada linearnego przyczynowego sprawstwa, a przynajmniej nie jest taką dla Buddy. Nie mówi ona, jaki stan rzeczy A wymusza powstanie stanu rzeczy B, czyli jaki stan rzeczy $A$ jest wystarczający do powstania stanu rzeczy $B$, lecz jaki stan rzeczy A jest konieczny, aby pojawił się stan rzeczy B. Rozumienie tej zasady jako opisu nieuchronnego sprawstwa prowadzi do absurdu, bo za taki można by uznać twierdzenie, że niewiedza, czyli pierwsze ogniwo w standardowej egzemplifikacji owej zasady, jako przyczyna wymusza powstanie dyspozycji wolicjonalnych / formacji karmicznych. Innymi słowy, karman byłby ukształtowany przed pojawieniem się istoty czyn popełniającej97. Równie absurdalne byłoby stwierdzenie, że świadomość jest przyczyną zaistnienia całości

97 Zasada zależnego powstawania w klasycznej myśli buddyjskiej wykorzystywana jest m.in. jako narzędzie służące do objaśniania $z$ buddyjskiej perspektywy procesu odradzania się, zob. na ten temat R. Gethin, The Foundations of Buddhism, Oxford 1998, s. 149-159. W ramach tego zastosowania dwa pierwsze ogniwa traktowane są jako związane z przeszłym żywotem, są dorobkiem, czyli skutkiem wcześniejszego życia i w tym sensie uprzedni karman uznawany jest za czynnik warunkujący życie obecne. Jednak w kwestii, jaką tutaj stawiam, chodzi o coś innego, mianowicie o to, że absurdem jest twierdzenie, iż dyspozycje wolicjonalne (czyli karmiczny bagaż) są wywoływane wprost przez niewiedzę, że niewiedza jest bezpośrednią przyczyną sprawiającą pojawienie sį̨ dyspozycji wolicjonalnych (karmana). Dwa pierwsze ogniwa są $\mathbf{w}$ istocie skrótem $z$ całego łańcucha warunkowania, u którego początków stała niewiedza, a na którego końcu pojawiły się dyspozycje. Niewiedza jest tu zatem warunkiem koniecznym do pojawienia sį̧ dyspozycji/karmana, ale nie jest ani warunkiem wystarczającym, ani bezpośrednim. 
psychofizycznej (nāma-rūpa). Podobnie na absurd zakrawałoby traktowanie narodzin jako po prostu przyczyny sprawczej cierpienia, czyli starości-i-śmierci. Na tym ostatnim przykładzie szczególnie wyraźnie widać niedorzeczność pomysłu, w myśl którego stan rzeczy ujęty w ogniwie poprzedzającym należy traktować jako wystarczającą przyczynę sprawczą stanu rzeczy ujętego w ogniwie następującym. Gdyby narodziny były wystarczającą przyczyną cierpienia, czyli pociągałyby istnienie cierpienia $\mathrm{z}$ konieczności, to przekonanie o możliwości wyzwolenia byłoby mrzonką, a dążenie do wyzwolenia byłoby z góry skazane na porażkę ${ }^{98}$. Sytuację, z jaką mamy tutaj do czynienia, dobrze obrazuje następujące stwierdzenie: woda jest niezbędnym warunkiem życia, jednak pojawienie się wody nie jest przyczyną, która wymusza pojawienie się stanu rzeczy określanego mianem „życie”. Woda w ścisłym tego słowa znaczeniu nie jest wystarczającą przyczyną życia, aczkolwiek niewykluczone, że jest jego warunkiem koniecznym.

Zasada zależnego powstawania nie ma też nic wspólnego z kosmologiczną ideą genezy. Nie chodzi w niej o opis procesu przemian bytowych, które wychodząc od jakiegoś pierwotnego stanu doprowadzity do ukształtowania się dostępnej poznawczo rzeczywistości, nie chodzi w niej nawet o opis procesu przemian bytowych człowieka (czy istoty czującej), lecz o opis kształtowania się doświadczenia, a może nawet jeszcze bardziej o opis pewnego fundamentalnego dla myśli buddyjskiej aspektu naszego doświadczenia, jakim jest zależność (bytowa pochodność) i nietrwałość. Co więcej, jako reguła zależności zachowuje ona tę samą ważność bez względu na to, czy rozpisywana jest na dwanaście ogniw, na dziesięć czy choćby na dwaa9. Jej ranga byłaby dokładnie taka sama, nawet gdyby jej egzemplifikację sprowadzić do

98 Tak jak dwa pierwsze ogniwa traktowane są jako skrócony zapis z wcześniejszego żywota, tak dwa ostatnie mają opisywać w sposób skrócony żywot kolejny, przyszły. W tym wypadku również narodziny mogą być traktowane jako warunek konieczny przyszłego cierpienia, ale niewystarczający.

99 Odnośnie do dyskusji dotyczącej kształu formuły ze względu na liczbę ogniw zob. M. Mejor, Buddyjska doktryna o powstawaniu w zależności (pratītya- 
dwóch ogniw - niewiedzy oraz tzw. starości-i-śmierci, czyli symbolicznego określenia cierpienia ${ }^{100}$. Głosiłaby ona wtedy, że warunkiem pojawienia się cierpienia jest wystąpienie niewiedzy; cierpienie nie może się pojawić bez pojawienia się niewiedzy.

Zresztą słynny uczeń Buddy Sariputta w pewnym miejscu przedstawia zasadę zależnego powstawania sprowadzoną właśnie do dwóch ogniw - cierpienia (dukkba) i kontaktu (phassa) (SN II, 32-34). Czyni to, przebywając w Radżagasze (p. Rājagaha) w odpowiedzi na pytania ascetów o sprawstwo cierpienia, które były zadawane także Buddzie. Sariputta stwierdził:

paticcasamuppannam kbo avuso dukkbam vuttam bhagavatā $\mid$ kim pațicca phassam paticica $\mid$

Przyjaciele, Czcigodny powiedział, że cierpienie powstato $\mathrm{w}$ zależności. W zależności od czego? W zależności od kontaktu.

Co ciekawe, świadkiem owego zdarzenia był inny ważny uczeń, Ananda. Po usłyszeniu tego pouczenia udał się do Buddy i zdał mu $\mathrm{z}$ niego relacje ${ }^{101}$. Mistrz zareagował $\mathrm{z}$ aprobatą, potwierdzając trafność wypowiedzi Sariputty i powtarzając jego słowa, które, jak przyznał, sam już kiedyś w tym samym miejscu w analogicznej sytuacji wypowiedziaf ${ }^{102}$. Ananda reaguje $z$ zachwytem, stwierdzając (SN II, 36):

acchariyam bhante abbhūtam bhante yatra bi näma ekena padena sabbo attho vutto bhavissati | siyā nu kbo bbante esevat-

-samutpāda) - oryginalna koncepcja samego Buddy czy późniejszy jej rozwój., SI 3 (1996), s. 118-129.

100 W SN II, 31 Budda mówi po prostu o cierpieniu zamiast o starości-i-śmierci. 101 Opowieść ta została powtórzona w kolejnym kazaniu, w którym Sariputta tym razem został zagadnięty przez czcigodnego Bhumidżę ( $p$. Bhūmija) w Sawatthi (p. Sāvatthi) (SN II, 37-39).

102 Ten sam motyw pojawia się też w krótkim Kazaniu do Upawany (Upavana-sutta; SN II, 41-42), w którym Budda oznajmia, że cierpienie powstaje w zależności od kontaktu. 
tho vitthärena vuccamāno gambhīro ceva assa gambhìravabhāso $c \bar{a} t i \|$

To cudowne, Czcigodny! To nadzwyczajne, Czcigodny! Jakżeż jednym zdaniem można wypowiedzieć całe znaczenie. Czy można, Czcigodny, to znaczenie wyrazić szczegółowo, aby było dogłębne i doniosłe?

Zachęcony przez Buddę Ananda sam udziela odpowiedzi na własne pytanie, wymieniając ogniwa zależnego powstawania w trybie wstecznym, począwszy od starości-i-śmierci i zatrzymując się na, licząc od końca, ósmym ogniwie, czyli sześciu podstawach zmysłowych. $\mathrm{Na-}$ stępnie przechodzi w drugą stronę, opisując, co się dzieje, gdy kolejne ogniwo, począwszy od sześciu podstaw zmysłowych, znika (SN II, 36-37).

Oczywiście nic nie stoi na przeszkodzie, żeby egzemplifikację zasady zależnego powstawania wzbogacić jeszcze bardziej, o więcej niż dwanaście ogniw. Kwestia ich liczby uzależniona jest w tym wypadku wyłącznie od soteriologicznej pragmatyki. Zasada zależnego powstawania określa minimum tego, z czym musimy się uporać, aby osiągnąć soteriologiczny cel. Warto podkreślić, ze tak jak znajdziemy przykład tej zasady sprowadzony do dwóch ogniw, tak też znajdziemy przykład jej rozszerzenia. We wspomnianym juz Wielkim kazaniu o podstawach zależności Budda rozszerza zakres warunkowania o nowe ogniwa. Wychodząc od doznania/uczucia (vedanā) i pragnienia (taṇbā), a następnie przechodząc przez kolejnych osiem stanów, o których nie było w ogóle mowy w standardowym dwunastoelementowym opisie zasady zależnego powstawania, pokazuje rozwój negatywnych, szkodliwych postaw, ujawniających sį̧ w codziennym życiu ${ }^{103}$.

${ }^{103}$ Chociaż analiza owego łańcucha warunkowania jest zbędna dla stawianego w tym miejscu celu, jakim jest prezentacja istoty buddyjskiej idei warunkowania, to ponieważ mamy tutaj do czynienia z niezwykle ciekawym przykładem starożytnej buddyjskiej psychologii; warto ją choćby tylko przytoczyć, zwłaszcza że w drugiej części niniejszej pracy motyw ten będzie stanowił warto- 
Wyrazisty przykład egzemplifikujący tę zasadę podaje Budda w rozmowie $z$ ascetą Waczczhagottą (MN I, 487). Czcigodny przywotuje przykład ognia. Pyta Waczczhę, co by odpowiedział, gdyby ktoś go spytał: „W zależności od czego płonący przed tobą ogień płonie?” (yo te ayam purato aggi jalati ayam aggi kim pațicca jalati). $\mathrm{Na}$ co asceta odpowiada: „Ogień płonie w zależności od paliwa z trawy i patyków” (ayam aggi tina-kațthupādānam pațicca jalati). Trawa i patyki są warunkiem koniecznym płonięcia ognia, nie są jednak jego przyczyną sprawczą, nie są warunkiem wystarczającym do tego, aby on zapłonął. Rozmowa ta ma swoją jeszcze ciekawszą kontynuację. Budda pyta bowiem, jak należałoby odpowiedzieć po zgaśnięciu ognia na pytanie o to, gdzie ten odszedł, w jakim udał się kierunku. Waczczha stwierdza, że takie pytanie byłoby niewłaściwe. Ogień płonie bowiem w zależności od paliwa, gdy paliwo się skończy, uważa się, że ogień gaśnie, czyli przestaje płonąć. Pytanie o kierunek jego odejścia jest bez sensu. W ten sam sposób, oznajmia Budda, należy myśleć o Tathagacie. Wyzwolił się on od bycia opisywanym poprzez kategorie zespołów, nie można o nim niczego powiedzieć jako o żyjącym, tym bardziej nie będzie można o nim niczego powiedzieć po jego śmierci. W szczególności pytanie o to, czy i jak się odrodzi, jest kompletnie bez sensu.

ściowe uzupełnienie rozważań nad rozumieniem poglądu w obszarze wczesnej buddyjskiej myśli. Czytamy więc (DN II, 58-59): „A zatem, Anando, uczucie warunkuje pragnienie, pragnienie warunkuje poszukiwanie, poszukiwanie warunkuje posesywność, posesywność warunkuje wyróżnianie, wyróżnianie warunkuje ukierunkowanie żądzy, ukierunkowanie żądzy warunkuje przywiązanie, przywiązanie warunkuje chwytanie, chwytanie warunkuje zachłanność, zachłanność warunkuje strzeżenie [własności], a w związku ze strzeżeniem [własności] powstają łapanie za kij i broń, kłótnie, sprzeczki, spory, konflikty, oszczerstwa, kłamstwa oraz inne złe, szkodliwe zjawiska" (iti kbo ananda vedanam pațicca taṇba, tạnbam pațicca pariyesana, pariyesanam pațicca labbo, läbham pațicca vinicchayo, vinicchayam pațicca chandarägo, chandarägam pațicca aj̄josānam, aj̄hosānam pațicca pariggabo, pariggabam pațicca macchariyam, macchariyam pațicca ärakkho, arakkbädhikaranam dậ̣ädāna-satthädäna-kalaba-viggaba-vivāda-tuvamtuvam-pesuñna-musā-vādā aneke pāpakä akusalā dhammä sambbavanti). 
W Kazaniu o nasieniu (Bīja-sutta; SN III, 54-55) Budda przedstawia złożony obraz warunkowania na przykładzie ziarna. Do wydania plonów potrzeba ziarna, żyznej gleby i wody, ale i ziarno musi być w odpowiednim stanie (niepołamane, nieuszkodzone). Konsekwencją niespełnienia któregoś z warunków jest brak plonów. Podobnie jest z powstawaniem cierpienia. Jeżeli któryś warunek niezbędny do powstania cierpienia nie zostanie spełniony, to cierpienie się nie pojawi, czyli nastąpi wyzwolenie. Opis ten doskonale pokazuje, jaki jest kontekst nauki o powstawaniu w zależności. Potwierdza też przekonanie, że formuła dwunastu ogniw ma pragmatyczny charakter, jej struktura podporządkowana jest celowi soteriologicznemu.

Kazaniem, któremu warto się przyjrzeć jest Upanisā-sutta (SN II, 30-32). Budda daje w nim opis "transcendentalnego zależnego powstawania”, tj. zależnego powstawania na ścieżce do wyzwolenia. Łańcuch zależnego powstawania na ścieżce do wyzwolenia stanowi przedłużenie zależnego powstawania cierpienia z cierpieniem jako warunkiem pojawienia się kolejnego stopnia - wiary czy może lepiej zaufania (saddhā), od którego zaczyna się ścieżka transcendentalna. Opis transcendentalnego zależnego powstawania jest dobrym przykładem na to, że Buddzie nie chodzi o przyczynową sprawczość i wystarczalność, lecz o konieczność, czyli niezbędność. Cierpienie bowiem nie jest sprawczą przyczyną zaufania, lecz jego warunkiem koniecznym. Gdyby cierpienie było warunkiem wystarczającym zaufania, a ten pozostawałby w łańcuchu wystarczających warunków prowadzących do wyzwolenia, to z konieczności wszystkie sansaryczne istoty, jako że dotknięte są niewiedzą, a w związku z tym cierpieniem, dązyłyby do wyzwolenia, a być może nawet powinny być już wyzwolone. Wynika to z prostej dedukcji. Gdy przyczyna A jest wystarczająca do pojawienia się skutku B, to skutek B jest w swoim istnieniu względem przyczyny A konieczny, czyli nie może nie zaistnieć, gdy istnieje przyczyna. Stąd mamy paradoks - każdy, kto ogarnięty jest niewiedzą, z konieczności musi dążyć do wyzwolenia (jest wyzwolony). 
Możliwe jednak, że najmocniejszy argument na rzecz przekonania, że Buddzie w ogóle nie chodzi o wystarczalność przyczyn, a o ich konieczność, znajdziemy w kazaniu noszącym tytuł Gotama, wielki mędrzec Sakjów (Mabā Sakyamuni Gotamo; SN II, 10-11). W kazaniu tym pojawia się wątek biograficzny związany z okolicznościami odkrycia i sformułowania zasady zależnego powstawania. Kwestia owych okoliczności wzbudzała wśród badaczy wiele kontrowersji, gdyz w tradycji buddyjskiej zachowały się trzy różne podania na temat czasowego ulokowania owego zdarzenia względem przebudzenia, zgodnie z którymi odkrycie to poprzedzało moment przebudzenia, było jego treścią, miało miejsce już po przebudzeniu ${ }^{104}$. Sprawa ta jednak w żaden sposób nie wiąże się z naszym zagadnieniem. Tym, co nas tutaj interesuje, jest pierwotny kształt formuły zależnego powstawania, przy założeniu, że podanie to pod tym względem jest wiarygodne.

Budda przyznaje się, że absorbowało go doświadczenie cierpienia i poszukiwanie możliwości wyzwolenia. W związku z tym postawił sobie fundamentalne dla zrozumienia owej zasady pytanie (SN II, 10): „W związku z istnieniem czego, powstaje starość-i-śmierć? Czym starość-i-śmierć jest uwarunkowana?" (kimbi nu kbo sati jarā-maranam boti kim-paccayā jarā-marananti). Zwróćmy uwagę, że pyta nie o to, co sprawia, wywołuje starość-i-śmierć, tylko o to, na podstawie czego starość-i-śmierć powstaje, co jest warunkiem pojawienia się starości-i-śmierci. Następnie udziela odpowiedzi: „Gdy istnieją narodziny, powstaje starość-i-śmierć. Warunkiem starości-i-śmierci są narodziny" (jātiyā kbo sati jarāmaranam hoti jātipaccayā jarā-maranan ti). $\mathrm{Na}-$ stępnie $w$ analogiczny sposób postępuje $z$ narodzinami, pytając o to, w związku z czym one powstają, czym są uwarunkowane ${ }^{105}$. W ten

${ }^{104}$ Zob. M. Mejor, Buddyjska doktryna..., s. 122-123. W niniejszym kazaniu zdarzenie to ulokowane jest przed przebudzeniem.

$105 \mathrm{~W}$ przywoływanym juz w tej pracy kilkakrotnie Wielkim kazaniu o podstawach zależnosci Budda naucza Anandę o zależnym powstawaniu w identyczny sposób, cofając się od starości-i-śmierci i pytając o warunek jej (a następnie kolejnych ogniw) powstania, zob. DN II, 55-56. 
sposób przechodzi przez kolejne ogniwa aż do niewiedzy. Po dotarciu do niej, dokonuje reasumpcji w odwrotną stronę. To jednak nie kończy kazania. W dalszym ciągu stawia sobie pytanie o to, w związku z nieistnieniem czego starość-i-śmierć nie powstanie, i odpowiada, że będzie to nieistnienie narodzin. Analogicznie postępuje $\mathrm{z}$ dalszymi ogniwami, schodząc w dół. Po dotarciu do niewiedzy, dokonuje reasumpcji zasady $w$ drugą stronę.

$\mathrm{Na}$ czym polega dowodowa wartość tego kazania? Otóż musimy zdać sobie sprawę ze znaczenia pytania, jakie Budda zadaje, oraz z pierwotnego kształtu samej formuły zależnego powstawania. Ogólną, formalną formułę zależnego powstawania należy odczytywać przez pryzmat owego pytania. Zaczynając od cierpienia i pytając o jego warunek powstania, Budda pyta o to, co do jego powstania jest niezbędne. Gdy, mając określony skutek, pytamy o jego przyczynę, to pytamy o jej konieczność. Jaki zatem stan rzeczy jest konieczny, aby powstało cierpienie? Dzięki odpowiedzi na to pytanie Przebudzony potrafi wskazać czynnik, którego brak uniemożliwi powstanie cierpienia. $\mathrm{Na}$ tej podstawie jest $\mathrm{w}$ stanie określić następnie postępowanie, które ma doprowadzić do wyzwolenia. Pierwotną formułą zależnego powstawania jest formuła wsteczna, „pod włos” (patiloma), i to w obu jej wydaniach - pozytywnej i negatywnej. To proste stwierdzenie jest brzemienne w konsekwencje. W wersji pozytywnej zasada ta określa, co jest konieczne do powstania danych stanów rzeczy, w wersji negatywnej - usunięcie czego jest wystarczające do zapobieżenia powstaniu danych stanów rzeczy. Samo dokonanie reasumpcji, czyli prześledzenie tej zasady w drugą stronę, czyli „z włosem” (anuloma), niczego już nie zmienia w charakterze relacji między przyczyną a skutkiem. Przyczyna dalej pozostaje tylko konieczna względem skutku, a jej brak wystarczający do tego, żeby skutek nie zaszedł. Uświadomienie sobie soteriologicznego kontekstu odkrycia zasady zależnego powstawania oraz jej pierwotnego kształtu pozwala nam zrozumieć, dlaczego ogólna, formalna formuła nie jest formułą opisującą przyczynowe sprawstwo rozumiane pod kątem wystarczalności. Innymi słowy, wbrew 
pozorom wynikającym z nadmiernie restrykcyjnego czytania implikacji, formuła ta mówi, co jest konieczne do pojawienia się jakiegoś zjawiska, a nie co jest wystarczające ${ }^{106}$.

Kilku wspomnianych przeze mnie cech zasady zależnego powstawania można dopatrzeć się w Kazaniu o rozpatrywaniu zagadnienia w parach (Dvayatãnupassanā-sutta; Sn. III.12). Punktem wyjścia dla tej mowy są uwagi na temat czterech szlachetnych prawd, które Budda ujmuje w dwie pary. Ci, którzy nie znają owych dwóch par, skazani są na doświadczanie narodzin i starości (Sn. 724-725). Na zagadnienie cierpienia, stwierdza Budda, można spojrzeć też poprzez inne pary. W sumie tych szczególnych par wylicza jedenaście. Ściśle rzecz biorąc, to wylicza ich więcej, ale owych jedenaście łączy ta sama kwestia, a mianowicie stwierdzenie, od czego zależy istnienie cierpienia i czego brak przyniesie skutek w postaci ustania cierpienia. Owo wyliczenie, podkreślmy to, nie jest ujęte w łańcuch warunkowania, jak

106 Jeżeli moje spostrzeżenia w tej kwestii są trafne, to stwierdzić możemy, że późniejszy rozwój teorii przyczynowości w abhidharmie stanowi wyraz sprzeniewierzenia się intencjom samego Buddy, nie tylko bowiem poza nie wykraczał, ale w pewnym sensie im się też przeciwstawiał, gdyż wiązał się z przerostem spekulacji całkowicie zbędnej z perspektywy realizacji poszukiwanego soteriologicznego celu. Sądzę, że rozwój ten był bardziej związany z klimatem czasów i dążeniem do przeciwstawienia się koncepcjom przyczynowości rozwijanym w tradycjach pozabuddyjskich. Ulegając jednak temu klimatowi i interpretując ogólną zasadę zależności jako zasadę opisującą równoważność przyczyny i skutku, czyli konieczność i wystarczalność przyczyny względem skutku, abhidharma stworzyła problem, od którego koncepcja Buddy była wolna, a mianowicie problem determinizmu. Jeżeli wszystko podlega tak ścisłemu warunkowaniu zarówno w sferze fizycznej, jak i umysłowej, to jak sensownie wythumaczyć możliwość sprzeniewierzenia się owej determinacji, która miałaby ostatecznie doprowadzić do wyzwolenia? Już całkiem na marginesie można zauważyć, że dokładnie przed takim samym problemem stała dualistyczna szkoła sankhji (samkbya), która w fakcie istnienia $\mathbf{w}$ sferze naturalnej determinacji (prakrti) dạżności do przebudzenia widziała mocny argument na rzecz konieczności uznania istnienia transcendentnego i niezmiennego ducha (purusa), zob. SK 17. 
w standardowym schemacie. Budda po prostu wskazuje na jedenaście czynników mających wpływ na powstawanie cierpienia, ujmując je w odrębne pary z niewiedzą jako skutkiem i z poszczególnymi czynnikami jako z przyczynami koniecznymi, lecz niewystarczającymi do jej powstania. Wśród tych czynników siedem pojawiło się w standardowym schemacie dwunastu ogniw (tj. niewiedza [avijjā], dyspozycje wolicjonalne [samkbāra], świadomość [viñnāna], kontakt [phassa], doznanie/uczucie [vedanā], pragnienie [tanbā] , Ignięcie [upädāna]), cztery jednak były nowe (podłoże [upadbi], wysiłek [ärambba], pożywienie [äbāra], rozchwianie [iñjita]). Na tym przykładzie widzimy, że zarówno sama formuła dwunastu ogniw, jak też i wyliczenie w niej konkretnych stanów rzeczy nie jest sztywną strukturą, lecz stanowi bardziej narzędzie służące uzmysłowieniu głębszej prawdy, że nie ma nieuwarunkowanego stanu rzeczy. To odkrycie stanowi źródło buddyjskiej nadziei - skoro cierpienie jest uwarunkowane, to można na nie wpłynąć aż po jego likwidację. Zależność, uwarunkowanie jest sposobem „istnienia” sansarycznej egzystencji, czyli sposobem, w jaki jej doświadczamy. Wyzwolenie zatem musi oznaczać uzyskanie niezależności. Tę myśl Budda stwierdza w Sn. 752, gdzie czytamy:

anissito na calati, nissito ca upädiyam itthabāvañnatbābhāvam samsāaram nātivattati $\|$

Niezależny pozostaje niewzruszony, lgnący do bytu w tym lub innym świecie nie przekracza sansary.

Na pytanie, co tworzy ów byt (bhāva), do którego sansaryczna istota lgnie, odpowiada strofa Sn. 759:

rūpā saddā rasā gandhä phassā dhammā ca kevalä ițțha kantā manäpa ca yāvat' atthi ti vuccati $\|$

Formy, dźwięki, smaki, zapachy, kontakty (wrażenia) oraz wszystkie umysłowe zjawiska są pociągające, przyjemne i powabne, dopóty twierdzi się: „One istnieją”. 
Odpowiedź ta ważna jest $\mathrm{z}$ dwóch powodów. Wylicza się tutaj zjawiska, tj. nie mówi się o przedmiotach codziennego doświadczenia, tylko o samych doświadczeniach danych w obszarze sześciu narządów ujmowania, tj. pięciu zmysłów i umysłu. Co ważniejsze, ich atrakcyjność zostaje powiązana $\mathrm{z}$ aktem uznania ich istnienia. Dopóki uznajemy wartość kategorii istnienia do ich opisu, dopóty tkwimy w zależności. W uznaniu istnienia bowiem, jak to wcześniej wskazywałem, wyraża się egotyczne odniesienie do tego, co poza „ja”. Tym sposobem powracamy do podstawowego zagadnienia Kazania do $\mathrm{Ka}$ tjajny - ujmowanie doświadczenia w kategoriach istnienia i nieistnienia jest wyrazem błędu poznawczego i leży u podstaw doświadczenia cierpienia. Odpowiedzią na ten błąd jest nauka o zależnym powstawaniu. W jakim jednak sensie jest to odpowiedź? Wszak standardowo, tj. realistycznie, przyczynowość, powstawanie w zależności rozumiane jest jako wchodzenie $w$ istnienie bądź wychodzenie $z$ niego. W wypadku nauki Buddy wraz z odrzuceniem deskryptywnej wartości kategorii istnienia i nieistnienia taka możliwość rozumienia przyczynowości została wykluczona. Jak zatem należy tę naukę pojmować? Otóż sądzę, że Budda przy pomocy dostępnych mu środków językowych stara się podprowadzić nas tą nauką do uświadomienia sobie całkowitej płynności i pochodności naszego doświadczenia. Przebudzony wyraża w ten sposób intuicje stojące w całkowitej opozycji wobec fundującego ontologię przekonania, że myśl i byt to jedno. Nie sposób jednak mówić o czymkolwiek, nie zakładając jakiegoś tego istnienia, czyli jego tożsamości, a to znaczy bytu. Nawet gdy mowa jest o zależnym powstawaniu, to ustanawiamy przyczynę i skutek oraz wpisujemy w nie konkretne zjawiska, którym przypisujemy istnienie, czyli postępujemy wbrew intencji owej nauki. Dlatego Budda ostatecznie przyznaje w Sn. 764, że nauka ta leży poza zasięgiem pojmowania sansarycznych istot:

bhava-ragga-paretehi bbava-sotānusāribi

märadheyyanupannebi nāyam dhammo susambudbo \| 
Owładnięci pragnieniem istnienia, podązający strumieniem istnienia, poddani władzy Mary, nauki tej nie rozumieją.

Zauważmy jednak, iż niezrozumienie owej nauki nie bierze się z jakiejś przyrodzonej tej nauce tajemniczości czy też z faktu, że transcenduje ona doświadczenie, lecz jest pochodną umysłowej postawy poznających istot. Problemem jest postawa poznawcza. Myśl tę Budda uwypuklił w Kazaniu o szlachetnym poszukiwaniu (Ariya-pariyesanā-sutta) opowiadającym historię jego duchowych peregrynacji po odejściu w bezdomność, gdzie czytamy (MN I, 167):

alayaramaya kbo pana pajāya ãlayaratãya alayasammuditaya duddasam idam thanam yadidam idappaccayata pațiccasamuppado

Doprawdy ludziom znajdującym przyjemność w doczesności [dost. w tym, czego pragną], cieszącym się doczesnością, radującym się doczesnością, trudno jest zobaczyć ten stan, mianowicie bycie warunkowanym, zależne powstawanie.

Problemem jest zawężenie i ograniczenie poznawczych możliwości przez czynnik afektywny. Zmiana owej postawy, tj. osłabianie owego afektywnego czynnika aż po jego całkowitą neutralizację, jak będzie powtarzał Budda, otwiera drogę do poznania, do widzenia rzeczy, jakimi są.

Podsumujmy zatem. Sensem formuły zależnego powstawania nie jest stwierdzenie nieuchronności skutku, tylko uznanie, że nic nie istnieje z własnej konieczności, że wszystko w swoim istnieniu jest zależne. Wszystko, co się pojawia w doświadczeniu, pojawia się w zależności, czyli nie jest bytowo autonomiczne, nie znajdujemy w nim niczego, co istniałoby dzięki sobie. Zasada ta nie ma charakteru ontologicznego ${ }^{107}$ - jest wyrazem oglądu kształtowania sį̨ doświadczenia,

107 W tym zdecydowanie muszę przeciwstawić się opinii Kalupahany, który uważa, że zasada przyczynowości ma charakter metafizyczny, a jej obiektywność 
które standardowo jest zawsze egzemplifikowane jako uwarunkowane niewiedzą, a kończące się starością i śmiercią, czyli doświadczeniem nietrwałości, przemijalności, a zatem cierpienia. Owo przekonanie o zależności wszystkiego wyraża określenie idappaccayata (s. idam-pratyayatā), które przełożyć można jako „stan bycia tym uwarunkowanym". Jest to podstawowa cecha całego naszego sansarycznego doświadczenia, a zatem jest to cecha uniwersalna i w tym sensie można powiedzieć, że obiektywna.

Obiektywność zasady zależnego powstawania stwierdza sam Budda w SN II, 25, gdzie czytamy:

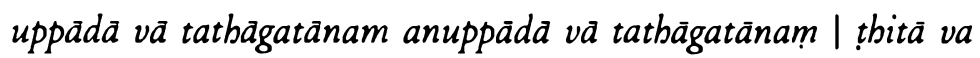
sā dhātu dhammațthitata dhamma-niyāmatā idappaccayatā

Czy tathagata się pojawia, czy się nie pojawia, ta zasada bezwzględnie obowiązuje: stałość dhammy (dhammațthitatā), niewzruszoność dhammy (dhamma-niyamata), fakt warunkowania (idappaccayatā).

I dalej myśl tę pogłębia w SN II, 26:

iti kho bbikkhave ya tatra tathata avitathatā anañnathatā idappaccayata | ayam vuccati bbikkbave pațicca-samuppādo ||

Tak więc, mnisi, co jest takością (tathata), realnością (avitathata), regularnością (anañnathatā), faktem warunkowania (idappaccayata), to zwie się, mnisi, zależnym powstawaniem.

dana jest w postrzeganiu pozazmystowym, zob. D. J. Kalupahana, Causality..., s. 104-107. Zgadzam się natomiast z opinią Hsueh-Li Chenga, który twierdzi, że Budda odwołuje się do zasady zależnego powstawania wyłącznie w celach soteriologicznych, a nie w celu opisu czy objaśnienia świata, zob. Hsueh-Li Cheng, Causality As Soteriology: An Analysis of the Central Pbilosophy of Buddhism, JChP 9 (1982), s. 423. 
Powód, dla którego badacze skłonni są widzieć w nauce o zależnym powstawaniu zasadę ontologiczną, tkwi w ogólnym, formalnym i abstrakcyjnym jej sformułowaniu. Nauka ta wyrażona w ten sposób wydaje się logicznie przejrzysta i budzi skojarzenia z klasycznymi próbami wysłowienia przyczynowości, zwłaszcza w ujęciu kontrfaktycznym.

Zasadniczym błędem $w$ analizie owej formalnej formuły jest rozpatrywanie jej wyłącznie $w$ aspekcie logicznym $w$ oderwaniu od jej egzemplifikacji, czyli od konkretnych powiązań przyczynowo-skutkowych, które ona uogólnia. Wszystkie egzemplifikacje tej ogólnej zasady przywołują struktury warunkowania przyczynowo-skutkowego bezpośrednio bądź pośrednio objaśniające powstawanie doświadczenia cierpienia, wśród których schemat $\mathbf{w}$ dwunastu ogniwach uchodzi za standardowy. Dobrym przykładem jest Kazanie o warunkacb (Paccaya-sutta; SN II, 25-27), w którym objaśniając powstawanie zjawisk, Budda przywołuje wyłącznie proces kształtowania się doświadczenia cierpienia. Nigdzie $w$ kazaniach nie znajdziemy aplikacji zasady zależnego powstawania do objaśnienia w kategoriach powiązań przyczynowych powstawania tzw. zewnętrznego świata. Innymi słowy, aplikacja zasady zależnego powstawania do kontekstu kosmologicznego jest Buddzie całkowicie obojętna ${ }^{108}$. Jeżeli w ogóle pojawiają się jakieś uwagi o warunkowaniu w zewnętrznym świecie (np. ziarno, snopki), mają stużyć jako ilustracje, których zadaniem jest ułatwienie zrozumienia warunkowania w obszarze ksztattowania się doświadczenia cierpienia. Ważne jest jednak to, że analiza nauki o zależnym powstawaniu w jej konkretnych wysłowieniach, w szczególności zaś tych powiązanych z kontekstem jej odkrycia, oraz uwzględnienie kontekstu

${ }^{108}$ Czy jest mu też całkowicie obca, to sprawa dyskusyjna, którą nie będę się tutaj zajmował. Joanna Jurewicz próbowała dowodzić, że w dwunastoczłonowej formule zależnego powstawania można doszukać się polemiki Buddy z wczesną zorientowaną kosmologicznie myślą wedyjską, zob. J. J u rewicz, Playing with Fire. The pratityasamutpada from the Perspective of Vedic Thought, JPTS 26 (2000), s. 77-103 [reprint w: Buddhism. Critical Concepts in Religious Studies, vol. 1, ed. P. Williams, London-New York 2005, s. 169-187]. 
praktycznego, tj. spojrzenie na tę zasadę jako na narzędzie realizacji soteriologicznego celu, nie potwierdzają wniosków formułowanych wyłącznie w ramach analizy reguły formalnej. Mamy podstawy sądzić, że Buddę interesuje jedynie aspekt konieczności przyczyny, a nie jej wystarczalności ${ }^{109}$.

Wraz z dojściem do głosu abhidharmicznej wykładni myśli Buddy interpretacja zasady zależnego powstawania została rozszerzona w kierunku rozumienia ontologicznego, w ramach którego koncepcję konieczności przyczyny zrównoważono położeniem nacisku na jej cechę wystarczalności. Wiązało się to z rozwojem pojęcia przyczyny jako stanu złożonego $z$ różnego rodzaju przyczyn i warunków, czego najlepszym przykładem są teorie sarwastiwady i therawady ${ }^{110}$, oraz z refleksją nad sprawczością przyczyny pojętą jako zdolność do wywoływania skutku (artba-kriya-kāritva), która to zdolność została uznana za charakterystykę istnienia ${ }^{111}$. Zgodnie z tym wyobrażeniem istnienie można przypisać tylko temu, co wywołuje skutki, czyli temu, co jest ontycznie aktywne czy też wręcz kreatywne. Jednocześnie nie wszyscy późniejsi buddyjscy myśliciele akceptowali abhidharmiczne pomysły. Tymi, którzy zdecydowanie im się przeciwstawiali jako wypaczającym idę̨ Buddy, byli zwłaszcza madhjamikowie z Nagardżuną na czele. Im się niebawem przyjrzymy.

Jak wspomniałem wcześniej, Assadżi uznał naukę o zależnym powstawaniu za podstawowy przekaz nauczania Buddy. Nie był w swoim

109 Odnośnie do dyskusji na temat konieczności i wystarczalności w rozumieniu przyczynowości w buddyzmie zob. J. D. Watts, Necessity and Sufficiency in the Buddhist Causal Schema, PEW 32/4 (1982), s. 407-423; zob. także N. Ronkin, op. cit., s. 204-207; S. Hamilton, Early Buddhism..., s. 214.

$110 \mathrm{Na}$ ten temat zob. A. Hirakawa, A History of Indian Buddbism. From Sakyamuni to Early Mabayana, Honolulu 1990, s. 179-184; zob. także D. J. Kalupahana, The Philosopby of Relations in Buddhism (1), „University of Ceylon Review" 20 (1962), s. 19-54.

111 Zob. D. J. Kalupahana, Causality..., s. 73, 75, 81; R. Gupta, The Buddhist Doctrine of Momentariness and Its Presuppositions, JIP 8 (1980), s. 47-48. 
przeświadczeniu odosobniony, a nawet można powiedzieć, że w dokonanym wyborze pozostawał wierny wskazówkom samego nauczyciela. Tradycja wkłada bowiem w usta Buddy wypowiedź, która to przekonanie artykułuje w sposób znacznie bardziej dobitny. W MN I, 190-191 czytamy:

yo paticca-samuppadam passati so dhammam passati, yo dhammam passati so pațicca-samuppādam passati

Kto widzi zależne powstawanie, widzi dhammę; kto widzi dhammę, widzi zależne powstawanie.

Nauka o zależnym powstawaniu jest kwintesencją dhammy. Wszystko, czego naucza Budda, jeżeli nie dotyczy zależnego powstawania bezpośrednio, wiąże się z nim pośrednio. Zrozumienie dhammy oznacza zrozumienie zależnego powstawania, a zrozumienie zależnego powstawania oznacza otworzenie drzwi do niezależności, czyli wyzwolenia. Poniższy cytat w sposób klarowny wyraża tę myśl (SN II, 43):

yato kbo bbikkbave ariya-sāvako evam paccayam pajānāti evam paccaya-nirodbam pajānati | evam paccaya-nirodba-gāminim pațipadam pajānāti | ayam vuccati bbikkbave ariya-sāvako ditți-sampanno iti pi I dassana-sampanno iti pi aggato imam sad-dhammam iti pi | passati imam sad-dhammam iti pi | sekkbena ñanena samannagato iti pi | sekkbajya vijjāya samannagato iti pi | dbamma-sotam samapanno iti pi | ariyo nibbedhika-pañño iti pi | amata-dvāram ābacca tiț̣hati iti pi ti

Zaprawdę mnisi, kiedy szlachetny uczeń w ten sposób pojmuje warunek, w ten sposób pojmuje zanik warunku, w ten sposób pojmuje drogę prowadzącą do zaniku warunku, nazywa się go, mnisi, szlachetnym uczniem obdarzonym poglądem, obdarzonym widzeniem, który doszedł do tej prawdziwej nauki (sad-dbamma), który widzi tę prawdziwą naukę, który posiada poznanie praktykującego, który posiada wiedzę praktykującego, który wstąpił w strumień nauki, szla- 
chetny $z$ przenikliwą mądrością, który stoi, pchając drzwi nieśmiertelności.

Zrozumienie nauki o zależnym powstawaniu zbliża szlachetnego ucznia do wyzwolenia, on już „pcha drzwi nieśmiertelności”. Ma ono też inne ważne konsekwencje, które powinniśmy uwypuklić. Określa je poniższa wypowiedź (SN II, 26-27):

yato kho bbikkbave ariya-sävakassa ayañca pațicca-samuppädo ime ca pațicca-samuppanna dhamma yatba-bbütam sammä- paññaya sudițțaa bonti | so vata pubbantam va pațidhāvissati | [...] I| aparantam va upadhavissati \| [...] || etarabi va paccuppannam addhānam ajjhattam kathamkathī bhavissati $\|$ [...] | netam thanam vijjati ll

Mnisi, gdy szlachetny uczeń jasno widzi $z$ właściwą mądrością, jakimi są to zależne powstawanie oraz te powstałe $\mathbf{w} z \mathrm{z}^{-}$ leżności zjawiska, niemożliwe jest, aby wracał do przeszłości [myśląc] [...], aby wybiegał w przyszłość [myśląc], [...], aby teraz wewnętrznie wątpił o teraźniejszości [myśląc] [...].

Ten, kto poznaje i widzi w ten sposób, nie zadaje już pytań o przeszłość (np. czy się istniało w przeszłości, czy się nie istniało; czym się było; jak się było; czym się było, zanim stało się czymś innym) ani o przyszłość (analogicznie jak do przeszłości), ani o teraźniejszość (czy jestem; czy nie jestem; kim jestem; jak jestem; skąd pochodzę; gdzie sį̨ udam). Pytania te nie mają dla niego już żadnego sensu, dosłownie wręcz, jak mówi tekst, sytuacja ich zadawania jest niemożliwa (netam thānam vijjati). Zrozumienie zależnego powstawania, czyli uchwycenie sensu nauki o środkowej drodze, ma swoje konsekwencje w wymiarze epistemologicznym - ten, którego jest ono udziałem, nie opowiada się już za żadną opinią, lecz puszcza wszystkie, nie lgnie do żadnych. Tą kwestią zajmę się jednak w części drugiej niniejszej pracy.

Kazanie do Katjajany kończy się w sposób optymistyczny, spotykany w wielu innych kazaniach, zapewnieniem, że nauka Buddy spełniła 
pokładaną w niej nadzieję i Katjajana osiągnął wyzwolenie. Czytamy zatem (NidSa 19.10):

asmin kbalu dharmaparyaye bhassyamāna āyușmatab sandbākāt yäanasyānupädāyāsravebhyaś cittạ̣ vimuktam

Gdy tylko ten wykład dharmy wybrzmiał, umysł szacownego Sandhakatjajany wyzwolił się ze skaz poprzez nielgnięcie. 


\section{Poza bytem i niebytem, czyli droga środka w madhjamace Nagardżuny}

\subsection{Znaczenie Kazania do Katjajany w myśli Nagardżuny}

Jak już kilkakrotnie wspomniałem, jedynym tekstem sutrowym, który Nagardżuna przywołuje z tytułu nie tylko w swoim głównym dziele Podstawowych strofach madbjamaki, ale we wszystkich swoich pracach, jest Kazanie do Katjajany. Już sam ten fakt jest niezwykle wymowny. Czandrakirti, komentując go, zaznacza, że kazanie to znane jest we wszystkich szkołach buddyjskich (PP 269-270), co stanowi sugestię, że ma w nich status nauki obowiązującej i zobowiązującej. Bez wątpienia świadczy on o tym, że twórca madhjamaki postrzegał swoje dzieło jako wykładnię najbardziej pierwotnych i tym samym konstytutywnych dla nauki buddyjskiej intuicji zawartych w Kazaniu do Katjajany. W niniejszym rozdziale określę relację między filozofią pustki (śūnyatā-vāda) Nagardżuny a treścią owego kazania.

Nagardżuna powołuje się na Kazanie do Katjajany w piętnastym rozdziale Podstawowych strof madbjamaki. Za sprawą komentarza Czandrakirtiego, jedynego zachowanego w sanskrycie, rozdziałowi temu standardowo nadaje się tytuł Badanie samobytu (Svabhāva-parīkșa). Jednak we wcześniejszych komentarzach, w Akutobbaji (Akutobbayā) przypisywanej samemu Nagardzunie, u Buddhapality (Buddhapālita) i Bhawawiweki (Bhāvaviveka), rozdział ten nosi tytuł 
Badanie bytu i niebytu (Bhāväbhāva-parīkșā) $)^{112}$. Chociaż oba tytuły znajdują uzasadnienie w treści rozdziału, to ten drugi, czyli chronologicznie wcześniejszy, sądzę, trafniej ją oddaje właśnie ze względu na dobitniej zaznaczony związek z Kazaniem do Katjajany, tj. z fundującą przesłanie tego tekstu opozycją istnienia i nieistnienia. Nagardżuna przywołuje to kazanie dokładnie z powodu owej opozycji, stanowiącej centralny punkt jego rozważań w piętnastym rozdziale MMK. Jego myśl, a tym samym też myśl madhjamaki będzie stale krążyła wokół zasadniczej kwestii tej sutry, tj. wokół poznawczej i deskryptywnej wartości kategorii istnienia i nieistnienia oraz konsekwencji związanych $\mathrm{z}$ ich kontestacją.

Zanim jednak podejmę się analizy recepcji przesłania Kazania do Katjajany dokonanej przez Nagardżunę, przyjrzymy się temu, jak idee tego kazania, w szczególności rozumienie istnienia oraz środkowej drogi, zostały przyswojone i rozwinięte w dwóch niezwykle ciekawych tekstach mahajanistycznych - w Księdze Kaśjapy (Kãsyapa-parivarta-sūtra) i w Sutrze doskonatości mądrości $w$ ośmiu tysiacach strof (Asța-sābasrikāa-prajñā-pāramita-sūtra, dalej będę często dla wygody posługiwał się skróconym tytułem AsțalAszta). Zgodnie z powszechnie utrzymywaną opinią badaczy teksty te należą do grupy najwcześniejszych sutr mahajanistycznych i z całą pewnością wyprzedzały moment pojawienia się filozofii madhjamaki, dlatego mogą być, a nawet ze względu na swoją treść powinny być traktowane jako pomost między wczesną myślą Buddy a wykładnią Nagardżuny.

112 Zob. M. Siderits, Sh. Katsura, Nagarjuna's Middle Way. Mülamadhyamakakarika, Boston 2013, s. 153. 


\subsection{Istnienie i nieistnienie we wczesnej literaturze mahajany}

Najwcześniejszym wiarygodnym świadectwem pozwalającym datować Kaśjapapariwartasutrę oraz Aszt̨̧ są tłumaczenia obu tekstów na chiński dokonane przez indo-scytyjskiego mnicha Lokakszemę (Lokakșema) około 179 r., czyli w domniemanym okresie życia Nagardzuny, jak się zwykle uznaje. Na tej podstawie tekst pierwszy bywa lokowany w I-II w. n.e. ${ }^{113}$ Jeśli chodzi o Aszte, to od ponad dekady dysponujemy dodatkowym niezwykle interesującym świadectwem, jakim są zachowane $w$ języku gandharyjskim $w$ piśmie kharoszthi fragmenty jej pierwszej i piątej księgi datowane przy pomocy węgla $C_{14}$ na okres między drugą połową I w. n.e. a pierwszą połową II w. ${ }^{114}$ Treść zachowanego kolofonu, jak stwierdza Harry Falk, pozwala wyciągnąć wniosek, że jest to tylko kopia starszego manuskryptu ${ }^{115}$. Wydaje się

113 Ogólnie na temat tego tekstu i jego datowania zob. R. E. B uswell, D. S. Lopez, The Princeton Dictionary of Buddhism, Princeton 2014, s. 426; Bhikkhu Pāsādika, The Kāśyapaparivarta (Od-srung-gi le'u) - Prolegomena, TJ 5/4 (1980), s. 48-58 oraz A. Hirakawa, op. cit., s. 247-252; wartościowe uwagi o strukturze tego tekstu oraz jego rozwoju podaje: J. A. Silk, The $\mathrm{Na}$ ture of the Verses of the Kàsyapaparivarta, "Bulletin of the Asia Institute” 23 (2009), s. 181-190. Przez długi okres czasu (co najmniej siedem wieków) tekst ten funkcjonował pod tytułem [Wielki] stos klejnotów ([Maba]-ratna-kūṭa), mianem tym bowiem sam siebie kilkakrotnie określa (KP 52, 150, 157, 159 i 160). Pod tym tytułem był też przywoływany w tekstach sanskryckich, chińskich i tybetańskich do IX w. Na podstawie źródeł tybetańskich James B. Apple stwierdza, że zmiana tytułu na Kasyapaparivarta nastąpiła między VIII a XI w., zob. J. B. A pple, The Old Tibetan Version of the Kāśyapaparivarta preserved in Fragments from Dunbuang (1), ARIRIAB 20 (2017), s. 208-209. $\mathrm{Z}$ czasem tytuł Ratna-kūṭa został przeniesiony na cały zbiór, do którego ten tekst został włączony jako czterdziesty trzeci.

114 H. Falk, The "Split" Collection of Kharoșthi Texts, ARIRIAB 14 (2011), s. 20.

115 Ibidem, s. 23. Streszczenia wyników badawczych doryczących zachowanych gandharyjskich fragmentów Aszty dostarcza praca: H. Falk, S. Karashima, A First-century Prajn̄āpāramitā Manuscript from Gandbara - parivarta 1 (Texts from the Split Collection 1), ARIRIAB 15 (2012), s. 19-20. Najpełniej- 
więc całkiem prawdopodobne, że Așta w swojej najstarszej partii, za którą Edward Conze uznał dwa pierwsze rozdziały, może sięgać I w. p.n.e. ${ }^{116}$ Przy czym obok wersji prozaicznej należy uwzględnić również syntetyczną wersję wierszowaną znaną pod tytułem Strofy o gromadzeniu drogocennych jakości doskonatości mądrości (Prajña-paramitā-ratna-guna-samcaya-gātbā, dalej też w formie skróconej jako Rat$n a)^{117}$. W dalszej części przyjrzymy się obu wersjom tego tekstu, przy czym uwage skupimy na dwóch pierwszych najstarszych rozdziałach Aszty, do materiału zawartego w Ratnie będę odwoływał się głównie w celu ilustracji treści wyrażonych w tej pierwszej, przy czym sięgnę także sporadycznie do kolejnych rozdziałów.

Jeśli chodzi o Kaśjapapariwartasutrę, dla celu, jaki sobie tutaj stawiam, szczególnie ciekawą partią tekstu są paragrafy od 52 do 71 .

szym opracowaniem wszystkich odkrytych w ciągu ostatnich dekad gandharyjskich manuskryptów obejmującym również fragmenty Aszty i, dodajmy, stanowiącym fascynującą lekturę jest praca: R. Salo mon, Buddhist Literature of Ancient Gandbara. An Introduction with Selected Translations, Somerville 2018. Autorzy tych dwóch prac są zgodni, że najstarszą wersję tekstu Aszty prezentują manuskrypty gandharyjskie. Chiński przekład Lokakszemy zbliżony jest do wersji gandharyjskiej, aczkolwiek daje świadectwo pewnego narracyjnego rozwoju. Najbogatszą narracyjnie wersją jest wersja sanskrycka. Przy czym, jak podkreśla Salomon, rozbieżności dotyczą wysłowienia i literackiego opracowania, różnice doktrynalne są znikome, zob. R. Salomon, op. cit., s. 346.

116 Ściśle rzecz biorąc, Edward Conze uznał, że początki Aszty mogą sięgać 100 r. p.n.e. i że jest to najstarszy tekst z grupy literatury doskonałości mądrości. Przekonanie swoje sformułował na podstawie analizy treści Aszty. Jego opinia w tej kwestii ciągle cieszy sį̧ statusem opinii standardowej, a odkrycia $z$ ostatnich lat $\mathbf{w}$ obszarze świadectw materialnych tylko ją uwiarygadniają, zob. E. Conze, Preface, [w:] The Perfection of Wisdom in Eight Thousand Lines and Its Verse Summary, trans. E. Conze, Bolinas 1975, s. X; idem, The Prajñaparamitā Literature, Tokyo 1978, s. 1-10.

$117 \mathrm{Na}$ temat relacji między wersją prozaiczną a wierszowaną zob. idem, The Prajñaparamita..., s. 9-10, a takie id e m, The Composition of the Astasabasrika Prajñaparamita, [w:] ide m, Thirty Years of Buddhist Studies. Selected Essays, Oxford 1967, s. 175-182. 
Partię tę należy podzielić na dwie części: pierwsza to paragrafy od 52 do 63 , druga - od 64 do 71 . W części pierwszej wszystkie paragrafy z wyjątkiem paragrafu 61 będącego kontynuacją paragrafu wcześniejszego kończą się frazą: "to nazywa się, Kaśjapo, środkową drogą - właściwym oglądem zjawisk" (iyam ucyate kãsyapa madhyamā pratipad dharmānām bbūta-pratyavekșā). Część ta poświęcona jest, jak widzimy na podstawie cytatu, ekspozycji idei środkowej drogi (madhyamā pratipad). Część druga natomiast rozwija problematykę części pierwszej, eksplikując wagę idei pustki (śúnyatā), przy czym w ostatnich siedmiu paragrafach treści nie zostały wyrażone w sposób abstrakcyjny, lecz przy użyciu siedmiu różnych metafor mających pobudzać wyobraźnię i tym sposobem ilustrować koncepcję pustej rzeczywistości.

Käśyapa-parivarta idę̨ środkowej drogi przybliża poprzez zestawienie pięciu opozycji: trwałość - nietrwałość (§§ 53-56), jaźń - niejaźniowość (§ 57), prawdziwy umysł - nieprawdziwy umysł (§ 58), skalanie - oczyszczenie ( $(59)$ oraz istnienie - nieistnienie ( $\$ 60$ ). $\mathrm{Z}$ oczywistych powodów zacznę od przyjrzenia się opozycji ostatniej. W KP 60 czytamy zatem:

astīti käśyapa ayam eko 'ntạ nāstīty ayam dvitīìo 'ntạ yad etayor dvayor antayor madhyam iyam ucyate kāśsapa madhyamā pratipad dharmānām bbūta-pratyavekșā

"Istnieje”, Kaśjapo, to jeden kraniec; „nie istnieje” to drugi kraniec. Co jest pomiędzy tymi dwoma krańcami, to nazywa się, Kaśjapo, środkową drogą - właściwym oglądem zjawisk.

Następnie w $\S \S 61-62$ prezentowana jest standardowa formuła zależnego powstawania w dwunastu ogniwach - w $\S 61 \mathrm{w}$ pozytywnej wersji w przód (anuloma), w $§ 62 \mathrm{w}$ negatywnej wersji w przód.

Struktura tych trzech paragrafów oraz ich treść ewidentnie pozostaje w związku z Kazaniem do Katjajany. We wczesnej literaturze mahajany jest to najbardziej wyraziste i uderzające nawiązanie. Zwięzły $\S 60$ (bodaj najkrótszy w całym tekście) w dobitny sposób streszcza 
podstawowy problem Kazania do Katjajany - całe nasze doświadczenie tzw. rzeczywistości uwikłane jest $\mathrm{w}$ opozycję istnienia i nieistnienia. Paragraf ten mógtby zostać włączony do starszego kazania jako jego podsumowanie i nie wzbudziłoby naszych podejrzeń, że jest w nim ciałem obcym. Remedium na tkwienie w opozycji istnienia i nieistnienia ma być nauka o środkowej drodze, której treścią jest zasada zależnego powstawania przywołana $\mathrm{w}$ dwóch kolejnych paragrafach. Mamy więc tutaj do czynienia $\mathrm{z}$ dosłownym powtórzeniem myśli zawartej w Kazaniu do Katjajany, acz w syntetycznej formie. Co więcej, należy wyraźnie uwypuklić, że Käśyapa-parivarta koresponduje z sanskrycką, a nie palijską, wersją Kazania do Katjajany. Mowa jest tutaj bowiem o opozycji zbudowanej na przeciwstawieniu ogólnych idei istnienia i nieistnienia, a nie ogólnych sądów: „Wszystko istnieje” i „Nic nie istnieje". W tekście tym znajduje zatem kontynuację przekonanie, że problem naszego doświadczenia należy rozpatrywać w kategoriach kolektywnych, a nie dystrybutywnych. Innymi słowy, tkwi on w samym sposobie konstytuowania się naszego doświadczenia, a nie w tym, jak w obszarze naszego doświadczenia zdarzają się pomyłki. Wyraża się on na poziomie przeciwstawienia najbardziej ogólnych pojęć i dotyczy idei, czyli przeciwstawnych umysłowych postaw, nie zaś na poziomie zdroworozsądkowej idei istnienia. Opozycja dotyczy konstytuowania się i możliwości wyrażenia samej intuicji istnienia, a nie rozstrzygania, co istnieje, a co nie. Pamiętając o tym, powinniśmy wszelkie próby reinterpretowania owej opozycji w kategoriach dystrybutywnych uznać za nieuzasadnione. $Z$ sytuacją taką mamy do czynienia np. w badaniach Davida J. Kalupahany, który przywołując opozycję istnienia i nieistnienia z Kaśjapapariwartasutry, referuje ją jako opozycje między orzekaniem: [Everything] exists i [Everything] does not exist, sugerując tym samym całkowitą zgodność sensu między różnymi wysłowieniami tej kluczowej opozycji w różnych tekstach ${ }^{118}$.

118 Zob. D. J. Kalupahana, The Early Buddhist Notion of the Middle Path, JChP 7/1 (1980), s. 80. 
Prowadzi go to do uznania, że zawarte w tej partii tekstu inne wspomniane wyżej opozycje, poprzez które zostaje przedstawiona środkowa droga, stanowią mahajanistyczną innowację wykraczającą poza wczesne teksty. Ta wersja środkowej drogi, stwierdza Kalupahana, nie ma zakotwiczenia w nikajach i agamach, gdzie o owych opozycjach się w ogóle nie wspomina ${ }^{119}$. Za trafnością tego przekonania przemawiać ma ponadto fakt pojawienia się szeregu negatywnych określeń do opisu środkowej drogi.

Przyjrzyjmy się zatem owemu "nowatorskiemu” sposobowi prezentacji środkowej drogi, zadając sobie pytanie, na czym owo nowatorstwo faktycznie miałoby polegać. Najciekawszy przykład dotyczy orzekania jaźni. W KP 57 stwierdza się:

àtmeti kásyapa ayam eko 'ntạ nairatmyam ity ayam dvitīyo 'ntab yad àtma-nairätmyayor madbyam tad arüpy anidarsanam anabbasam avijñaptikam apratiștham aniketam iyam ucyate kaśsyapa madhyama pratipad dharmānām bbūta-pratyavekșā $\mid$

"Jaźń", Kaśjapo, to jeden kraniec; „niejaźniowość” to drugi kraniec. Co jest pomiędzy jaźnią i niejaźniowością, to jest bezforemne, nie dające sį̨ wskazać, niewyobrażalne, nieprzedstawialne, nieugruntowane, nieoznaczone, to nazywa się, Kaśjapo, środkową drogą - właściwym oglądem zjawisk.

Kalupahana uznaje, że w sformułowaniu tym nowością jest zarówno wyznaczenie krańców, których należy unikać, na bazie opozycji jaźni i niejaźniowości, jak i opis przy użyciu negatywnej terminologii środkowej drogi krańców tych unikającej. Zwłaszcza pojawienie się negatywnej terminologii pozwala mu stwierdzić, że w tym wypadku środkowa droga nie jest rozumiana fenomenalnie, lecz transcendentalnie ${ }^{120}$. Ewidentnie użycie negatywnej terminologii kojarzy się badaczowi z praktykami typowymi dla apofatycznych tradycji mistycznych

\footnotetext{
119 Ibidem.

120 Ibidem, s. 80-81.
} 
i nie przewiduje on możliwości innej interpretacji tej sytuacji. Nie mogę zgodzić się z tak jednoznacznym rozstrzygnięciem. Oczywiście należy przyznać Kalupahanie rację, że samo wysłowienie idei środkowej drogi przy pomocy owych opozycji, w tym także opozycji jaźni i niejaźniowości, ma walor nowości. Nie oznacza to jednak, że wyrażona $\mathrm{w}$ ten sposób idea nie ma zakorzenienia $\mathrm{w}$ praktyce samego Buddy. Szczególnie idea krańców opartych na przeciwstawieniu jaźni i niejaźniowości zdaje się nawiązywać do sposobu postępowania Buddy wobec Waczczhagotty i jego pytań o jaźń, a konkretnie do jego milczenia względem obu przeciwstawnych możliwości. Sądzę, że tę wykładnię środkowej drogi można traktować jako ekspresję i podsumowanie postawy Buddy ujawnionej w kontekście owych pytań. Większym walorem nowości odznaczałyby się pozostałe sformułowania idei środkowej drogi. Niemniej również one nie są pozbawione doktrynalnych podstaw, aczkolwiek ich dostrzeżenie wymaga pewnego wysiłku. Za taką podstawę należy uznać pierwotną idę̨ wyrażoną w Kazaniu do Katjajany i powtórzoną w Kaśjapapariwarcie, ujętą w opozycje istnienia i nieistnienia. Jest to najbardziej fundamentalna opozycja, jaką możemy sformułować w naszym myśleniu o rzeczywistości. Wszelkie inne opozycje, np. trwałości i nietrwałości, możemy sformułować wyłącznie $w$ relacji do pojęcia istnienia, ich deskryptywna wartość nabudowuje się na idei istnienia. Orzekanie trwałości i nietrwałości nie ma sensu bez założenia deskryptywnej wartości idei istnienia, to znaczy bez założenia, że możemy o czymś trafnie istnienie orzec. Kwestionując wartość opozycji istnienia i nieistnienia, kwestionujemy poznawczą wartość orzekania o rzeczywistości w ramach każdej innej opozycji. Nowatorstwo Kaśjapapariwartasutry polega więc na tym, że wyciąga ona oczywiste konsekwencje z kontestowania pierwotnej opozycji istnienia i nieistnienia, przy czym robi to $\mathrm{z}$ zastosowaniem kategorii ważnych dla buddyjskiej myśli. Zatem orzekanie przeciwstawnych jakości należy traktować jako wyraz błędu poznawczego ujawniającego się w pierwotnej intuicji istnienia, która każe nam wierzyć, że „być” musi znaczyć „być czymś”. 
Dlatego, przeciwstawiając się tej intuicji, sutra przechodzi w kolejnych paragrafach do idei pustki. Sposób narracji w tym momencie wyraźnie wskazuje, że dla autorów tekstu równoważność zależnego powstawania i pustki jest oczywista. Co więcej, wyraźnie daje się też wyczuć kontekst sporów, jakie musiały się toczyć wokół idei pustki w czasie powstawania tej sutry, gdyż tekst wprowadza tę ideę, uprzedzając od razu możliwość jej niewłaściwego zrozumienia. W KP 63 mamy więc:

punar aparam kāśsapa dharmānām bhūta-pratyavekșa yan

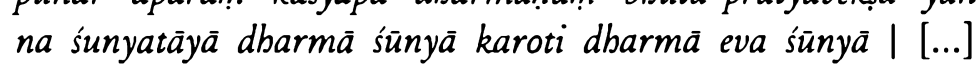
evam yo na 'svabbāvena dharmän asvabbāuī karoti dharmā caivāsuabhāvāa $\mid$

Ponadto, Kaśjapo, właściwy ogląd zjawisk nie robi zjawisk pustymi z powodu pustki, zjawiska po prostu sa puste. [...] Doprawdy [właściwy ogląd zjawisk] nie robi zjawisk niesubstancjalnymi z powodu niesubstancjalności, zjawiska po prostu są niesubstancjalne.

Chociaż wysłowienie myśli, zwłaszcza w przekładzie, może wydawać się nieco karkołomne, to zrozumienie jej sensu nie nastręcza problemów. Tekst przestrzega przed traktowaniem pustki wyłącznie jako soteriologicznego narzędzia, tzn. jako swoistego sposobu postrzegania rzeczywistości, który z samą rzeczywistością, co by to słowo nie miało tu oznaczać, ma niewiele wspólnego. W nauce o zależnym powstawaniu, a tym samym o pustce, nie chodzi o to, aby kształtować intencjonalnie sposób postrzegania rzeczywistości jako pustej. Ujmując to kolokwialnie, nie chodzi o to, aby wmówić sobie, że rzeczywistość jest pusta w nadziei, że da nam to wyzwolenie. Właściwy ogląd zjawisk nie polega na tym, żeby, kierując się pojęciem pustki, „robić rzeczy/ zjawiska pustymi", czyli żeby przedstawiać sobie rzeczy pustymi przy użyciu pojęć, abstrakcyjnie. Tego typu działanie jest nie tylko bezproduktywne, ale wręcz szkodliwe, jak zostanie stwierdzone w KP 64. 
Właściwy ogląd zjawisk polega na tym, aby widzieć faktyczny stan rzeczy, czyli ich pustkę.

$\mathrm{Na}$ podstawie powyższego fragmentu, jego treści oraz ulokowania w narracyjnej strukturze tekstu możemy sformułować dwa ważne wnioski. Pierwszy już wzmiankowałem, idea pustki jest tutaj skojarzona $\mathrm{z}$ ideą zależnego powstawania. Są to dwie równoważne idee wszystko, co zależnie powstaje, jest puste. Puste, czyli jakie? Odpowiedź na to pytanie jest drugim wnioskiem - być pustym oznacza literalnie być niesamobytem (asvabāva). Termin „samobyt” jest dosłownym przekładem słowa svabhāva. W tym miejscu nie będę się na jego temat rozwodzit. Wróç̨ do niego niebawem, gdy zajmę się myślą Nagardżuny. Tutaj wystarczy tylko, że powiem, iż rozumienie tego terminu zależne jest od kontekstu jego pojawienia się i zwykle w przekładzie wymusza dokonanie jakiejś zawężającej jego interpretacji. Dlatego w powyższym fragmencie zdecydowatem się na "niesubstancjalność", chociaż powinienem mówić po prostu o niesamobytności. Istotne jest jednak to, że Kâśyapa-parivarta rozwija idę pustki jako braku samobytu. Jest to istotne w związku ze zróżnicowanym sposobem rozumienia pustki w różnych buddyjskich tradycjach. Tekst ten ze swoim pojmowaniem tego pojęcia stanowi ważny krok w kierunku filozofii madhjamaki. Pustka jest tym, co ostatecznie o rzeczach możemy powiedzieć, gdyż jest tym, co ostatecznie możemy o nich odkryć. Potwierdza to KP 64, gdzie stoi:

na kbalu punab kásyapa pudgala-bbava-vinaśáa śūnyata pudgalaś caiva súnyata suunyata caiva śūnyata | atyanta-śunyata | pūrvānta-śnnyata $\mid$ aparānta-śunyatā | pratyutpanna-śnyatā | sunyata kásyapa pratisaratba ma pudgalam ye khalu puna kāsyapa sunyatopalambbena sunyata pratisaranti | tān abam kaśyapa nașta-pranaștan iti vadami ito pravacanat varam kbalu puna kásyapa sumeru-matra pudgala-drșțir äśrita na tv evadbimanikasya sunyata-drștim alinna $\mid$ tat kasmād dheto pudgala-drști-gatanàm kaśsapa sunyata nibsaranam sunyata-drsțti puna kaśyapa kena nibsarisyati ll 
Nadto, Kaśjapo, pustka nie jest unicestwieniem istnienia osoby, osoba po prostu jest pustka, jak i pustka po prostu jest pustką. Bezkresna pustka, pustka przeszłości, pustka przyszłości, pustka terá́niejszości. Podążaj za pustką, Kaśjapo, nie za osobą. Tych, Kaśjapo, którzy podązają za pustką, chwytając sį̨ pustki, nazywam całkowicie zgubionymi. To należy stwierdzić: zaprawdę, Kaśjapo, lepiej już lgnąć do poglądu o [realnej] osobie wielkiego jak góra Sumeru [tj. naznaczonego ogromnym błędem] niż trwać przy poglądzie o pustce jako arogant. A to dlatego, że środkiem zaradczym na przekonania o [realnej] osobie jest pustka, czym jednak usunąć pogląd o pustce?

Drugim zagrożeniem dla rozumienia idei pustki jest traktowanie tej ostatniej jako nicości, czyli ujmowanie jej w przeciwstawieniu do domniemanego bytu. W powyżsym fragmencie tym domniemanym bytem jest osoba (pudgala). Mamy tutaj do czynienia z zapowiedzią klasycznego zarzutu, jaki będzie stawiany zwolennikom koncepcji pustki rozumianej jako brak samobytu - idea pustki jest niczym innym jak ideą nicości. Tekst poprzestaje tylko na przestrodze, aby w ten sposób pustki nie pojmować. Ta nie przeciwstawia się bytowi osoby. Stwierdzenie, iż "osoba po prostu jest pustką" (pudgalaś caiva súnyatā) sugeruje, że pustka, czyli brak samobytu, jest tym, co w rzeczy ostateczne, jest jej faktycznym sposobem istnienia. W powyższym fragmencie mamy zapowiedź jeszcze jednego ważnego momentu, który będzie eksponowany w rozumieniu pustki. Tekst stwierdza, iż sama "pustka po prostu jest pustką" (śūnyatā caiva súnyată). Nie jest to banalna tautologia, jak mogłoby się na pierwszy rzut oka wydawać. Stwierdzenie to znaczy tyle, że pustki nie należy reifikować, nie należy jej ujmować jako czegoś w sobie, a tym samym czynić z niej przedmiotu lgnięcia. Pustka jest zawsze pustką rzeczy, czyli tego, co jako rzeczy nam się jawi. Poza tymi rzeczami mówienie o pustce nie ma najmniejszego sensu. W kolejnych tekstach myśl ta zostanie ujęta w określenie „pustka pustki" (śūnyatā-śūnyatā) ${ }^{121}$. W Kaśjapapariwarcie

121 Zob. np. PVS 24, gdzie wymienia się osiemnaście kategorii pustki w tym właśnie na pozycji czwartej pustkę pustki. 
mamy jej wyraźną antycypację. Wyobrażanie sobie pustki jako czegoś w sobie, a to robimy, gdy do niej lgniemy - stwierdza tekst - jest gorsze od tkwienia w błędnym przekonaniu o realności osoby. Nie ma nic gorszego, sugeruje tekst, niż czynienie narzędzia zniewolenia $\mathrm{z}$ instrumentu służącego wyzwoleniu.

Ponieważ pustka jest sposobem istnienia wszystkiego, co jest nam dane, to ostatecznie nie jesteśmy w stanie ustalić żadnych realnych różnic między rzeczami, czyli różnic ugruntowanych w ich wewnętrznej naturze. Dotyczy do równiez tak przeciwstawnych stanów jak cierpienie (zniewolenie) i wyzwolenie, jak wiedza i niewiedza. Dlatego KP 62 oznajmia:

zhes bstan pa de la 'od srung rig pa dang ma rig pa de dag gnyis ma yin zhing rnam pa gnyis su dbyer med de $\|^{122}$

Odnośnie tej nauki, Kaśjapo, wiedza i niewiedza, nie będąc dwiema, jawią się jako dwie, [chociaż] nie są oddzielone.

Wszelkie różnice są tylko różnicami w jawieniu się. To jednak nie umniejsza ich znaczenia. Naszym problemem bowiem jest, jak to wykazywałem we wcześniejszej części, właśnie to, jak nam się rzeczy jawią.

$\mathrm{O}$ ile w wypadku Kaśjapapariwartasutry stosunkowo łatwo jest wykazać istnienie ideowego związku tego tekstu z Kazaniem do $\mathrm{Ka}$ tjajany przynajmniej w partii dyskutującej idę środkowej drogi, to w wypadku Aszty zadanie takie wydaje się, przynajmniej na pierwszy rzut oka, trudniejsze. Nie jest mi znany żaden tekst o charakterze naukowym, w którym kwestia takiego związku byłaby dyskutowana, co można by odczytać jako wyraz przeświadczenia, że jest to zadanie wręcz karkołomne. Za tę sytuację, jak sądzę, odpowiada fakt, iż ani

122 Fragment ten nie zachował się $\mathrm{w}$ oryginale sanskryckim. Dlatego korzystam z tybetańskiego przekładu. Za lingwistyczną konsultację dziękuje Joannie Greli. 
w Aszcie, ani w Ratnie zagadnienie środkowej drogi nie jest dyskutowane wprost. Co więcej, nawet samo wyrażenie „środkowa droga”, tak przecież ważne dla buddyjskiej samoidentyfikacji, nie pojawia się w tych tekstach. W Aszcie dominuje kilka zagadnień, w obszarze praktyki będą to: idea doskonałości mądrości, postawa nielgnięcia oraz ideał bodhisattwy, natomiast w obszarze filozofii na plan pierwszy wysuwa się idea pustki. Niemniej sądzę, że Aszta rozwija te idee w ścisłym związku z przesłaniem sformułowanym w Kazaniu do Katjajany. Poniżej postaram się to unaocznić, wypełniając w ten sposób, przynajmniej do pewnego stopnia, wspomnianą lukę. Pokażę, że chociaż Aszta nie stawia zagadnienia środkowej drogi wprost, to kwestia ta jest w niej stale obecna jako tło ze względu na kluczowe negatywne odniesienie do ujmowania doświadczenia w kategoriach istnienia i nieistnienia.

Sutra zaczyna się od polecenia skierowanego przez Buddę do Subhutiego (s. Subhūti), aby ten objaśnił bodhisattwom, jak bodhisattwowie, mahasattwowie zmierzają do doskonałości mądrości. Bezpośrednim adresatem tej nauki będzie Siariputra (s. Śāriputra), a z czasem czynnymi uczestnikami konwersacji staną się też bogowie. Subhuti na wstępie oznajmia, że nie widzi (na samunupaśyãmi) dharmy zwanej „bodhisattwą” ani "doskonałością mądrości”, stąd też wyraża wątpliwość odnośnie do tego, kogo i czego ma nauczać ${ }^{123}$. Zaraz jednak dodaje, że jeżeli adresaci owej nauki po usłyszeniu informacji zdradzającej, iż żadna realna jakość bodhisattwy ani doskonałości mądrości nie jest postrzegana (co faktycznie oznacza jej nieistnienie), nie popadają w zniechęcenie i przygnębienie, to to są właśnie ci bodhisattwowie, których należy nauczać doskonałości mądrości. Następnie przystępuje do określenia właściwego sposobu ćwiczenia się w do-

123 Kwestia odnoszenia się do przedmiotów owych kluczowych dla nauczania $A s z-$ ty terminów powróci jeszcze $\mathrm{w}$ tym rozdziale trzykrotnie. Za każdym razem będzie ona pretekstem dla wprowadzenia nowych wątków, które będą uzupełniać przesłanie Aszty. Kwestia ta w pierwszym rozdziale buduje strukturę narracyjną tekstu. 
skonałości mądrości i od tej uwagi właśnie rozpocznę swoją analizę. W AS $3^{124}$ Subhuti oznajmia:

punar aparam bhagavan bodhi-sattvena maba-sattvena prajñ̄a-

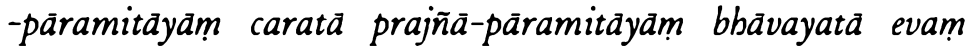
śikșitavyam yathā asau śiksyamannas tenäpi bodbi-cittena na manyeta | tat kasya betob? tatba bi - tac cittam acittam | prakrtiś cittasya prabhasvara $\|$

Ponadto, Czcigodny, gdy bodhisattwa mahasattwa ćwiczy się i wprawia $\mathbf{w}$ doskonałości mądrości, powinien $w$ taki sposób praktykować, aby nie popaść w pychę z powodu myśli o przebudzeniu. Dlaczego? Ponieważ, ta myśl jest niemyślą, a pierwotna natura myśli jest przejrzysta.

Subhuti przestrzega przed niewłaściwym sposobem praktykowania doskonałości mądrości - właściwie praktykujący powinien unikać popadania w pychę ze względu na kierowanie się myślą o przebudzeniu (bodbi-citta). Przestroga ta jest o tyle uzasadniona, że standardowo myśl o przebudzeniu przedstawiana jest w Aszcie jako doskonalsza od innych postać intencji motywującej do praktyki duchowej. Jest tak dlatego, gdyż jest to myśl ukierunkowana na przebudzenie nie własne, a wszystkich czujących istot. Stąd łatwo o poczucie wyższości względem tych, których intencję ocenia się jako naznaczoną swoistym duchowym egoizmem, a tym samym będącą niższego rodzaju. Niezwykle ciekawy jest jednak sposób, w jaki Subhuti uzasadnia swoją przestrogę. Tym, co ma chronić praktyka przed pychą, jest świadomość, że myśl o przebudzeniu jest niemyślą (tac cittam acittam) oraz że jej pierwotna natura jest przejrzysta (prabbāsvara). Oba te określenia będą w późniejszej tradycji mahajanistycznej szeroko dys-

${ }^{24}$ Tekst ten przywołuje w paginacji z pierwszej redakcji R. Mitry z 1888 r., którą przyjął $i$ upowszechnił w swoim tumaczeniu Conze, chociaż ze względu na wygodę użycia zwykle korzystam z redakcji P. L. Vaidyi z 1960 r. 
kutowane i refleksja nad nimi odegra ogromną rolę w rozwoju jej filozofii. W samej Aszcie jednak określenie drugie przechodzi bez echa ${ }^{125}$. Uwag̨ Siariputry przykuwa określenie pierwsze, które w literalnym wysłowieniu zdaje się wewnętrznie sprzeczne, bowiem o myśli, którą zaleca się w sobie pielęgnować, orzeka się, że jest niemyślą. Siariputra podejrzewa, że określenie to może stawiać pod znakiem zapytania samo istnienie takiej myśli, w związku z czym zadaje pytanie:

kim punar äyușman subbüte asti tac cittam yac cittam acittam?

Myśl, która jest niemyślą, czy ta myśl, dostojny Subhuti, istnieje [jako coś]?

125 Zważywszy na rolę, jaką to określenie odgrywało w późniejszej myśli mahajanistycznej, może zaskakiwać fakt, iż nie wzbudziło ono żadnego zainteresowania u Siariputry. Zaskoczenie będzie mniejsze, gdy uświadomimy sobie, że w pierwszym chińskim przekładzie Aszty dokonanym przez Lokakszemę oraz w zachowanych gandharyjskich fragmentach tego określenia nie ma, zob. na ten temat M. B. Orsborn, Chiasmus in the Early Prajn̄āpāramitā. Literary Parallelism Connecting Criticism and Hermeneutics in an Early Mahāyāna Sūtra, [rozpr. dokt.], The University of Hong Kong, Hong Kong 2012, s. 141. Nie znajdziemy tego określenia również w Ratnie, a w samej Aszcie pojawi się ono jeszcze tylko raz w AS 127 i to też raczej na marginesie rozważań. Wszystko to zdaje się uzasadniać przypuszczenie, że określenie to znalazło się tutaj w związku z późniejszym dopiskiem. Inną sprawą jest natomiast kwestia jego faktycznego znaczenia. Edward Conze uważał, że mamy tutaj do czynienia z „ideą absolutnej Myśli, która jest doskonale czysta i przejrzysta (prabbāsvara) w swojej naturze, w swoim bycie, w swojej substancji i która taką pozostanie na zawsze" (the idea of an absolute Thought which is perfectly pure and translucent [prabhāsvara] in its own nature, its own being, its own substance, and which remains so for ever), E. Conze, Buddhist Thought in India, London 1962, s. 196. Nie zgadzając się z wybitnym badaczem tekstów doskonałości mądrości, stwierdzę tylko krótko i ze względu na dygresyjny charakter tej uwagi nie będę jej rozwijał, iż uważam, że w tekstach doskonałości mądrości określenie przejrzystości myśli należy ściśle wiązać z jej pustką - myśl jest z natury przejrzysta, gdyż jest pusta, sama w sobie nie jest czymś określonym w swej naturze, nie jest więc ze swej natury skalana. Takie rozumienie przejrzystości myśli nie ma nic wspólnego z jej domniemanym absolutyzmem. 
Pytanie to wyznacza moment, w którym w Aszcie pojawia się zasadniczy problem Kazania do Katjajany. Warto zdać sobie sprawę, że ma to miejsce już na początku pierwszego, otwierającego cały tekst dialogu. Pytanie to będzie pobrzmiewało, jak za chwilę to wykażę, do końca drugiego rozdziału.

Na wątpliwość Siariputry Subhuti odpowiedział pytaniem jednoznacznie nawiązującym do Katjajanasutry:

kim punar āyușman śáriputra yã acittată, tatrācittatâām astita va nāstitā vā vidyate vopalabhyate vā?

Czy [realnie] istnieje, dostojny Siariputro, stan istnienia (astitä) lub stan nieistnienia (nästitā), bądź też czy ten, kto jest bez myśli, może w tym stanie niemyśli pojąć/uchwycić stan istnienia lub stan nieistnienia?

Siariputra tylko dobitnie zaprzeczył: „Za nic, dostojny Subhuti" ( $n a$ by etad àyuṣman subbūte). W zawiązku z czym Subhuti dalej indagowat:

api nu te yukta eșa paryanuyogo bbavati yadāyusmān śariputra evam aba - asti tac cittam yac cittam acittam iti?

Czy zatem to było właściwe pytanie, kiedy dostojny Siariputra spytał, czy „myśl, która jest niemyślą, czy ta myśl, dostojny Subhuti, istnieje"?

Nad tą konwersacją można by się zatrzymać znacznie dłużej, niż zamierzam to uczynić, szczególnie można by się pochylić nad strukturą pierwszego pytania Subhutiego, aby zastanowić się nad niuansami użycia formy vidyate. W istocie pytanie to można by oddać prościej, niż to uczyniłem, podążając w swojej interpretacji za przekładem Conzego ${ }^{126}$, a mianowicie: „Dostojny Siariputro, czy będąc bez myśli,

126 Zob. The Perfection of Wisdom in Eight Thousand Lines..., s. 84. 
w stanie niemyśli istnienie i nieistnienie może być stwierdzone bądź czy może być uchwycone?". Przejdę jednak od razu do tego, co w tym dialogu uważam za właściwą intencję Subhutiego. Otóż sądzę, iż pytaniami swoimi sugeruje on, że odrzucenie wartości orzekania istnienia i nieistnienia, które dokonało się w Kazaniu do Katjajany, stosuje się też do ontycznego statusu aktu umysłowego, który miałby ten stan rzeczy pojąć. Siariputra, pytając o realność myśli, pyta z obiektywistycznego punktu widzenia, tak jakby rozstrzygnięcie z Katjajanasutry nie stosowało się do myśli uchwytującej istnienie i nieistnienie. Subhuti sugeruje mu wniosek, że tak akt refleksji, jak też i akt metarefleksji nie wyprowadzają poza obszar orzekalności istnienia i nieistnienia. Zatem myśl, która uchwytuje istnienie lub nieistnienie, nie jest przez sam ten fakt bardziej realna i to samo należy powiedzieć o myśli uchwytującej myśl odnoszącą się do istnienia i nieistnienia. Siariputra po chwili zapytał ponownie: „Czym jest, dostojny Subhuti, ten stan niemyśli??" (kã punar eșā àyuṣman subbūte acittatā). Na co pytany odrzekł: „Stan niemyśli, dostojny Siariputro, jest stanem niezmiennym i nierozróżniającym (avikārā āyușman śāriputrāvikalpā acittatā).

Po tych wstępnych uwagach dotyczących praktykowania doskonałości mądrości Subhuti powraca do punktu wyjścia i ponownie oznajmia, że nie znajduje, nie dostrzega niczego, do czego odnosiłyby się słowa „bodhisattwa” czy „doskonałość mądrości” ${ }^{127}$. Nie znajduje niczego, gdyż to, co tymi słowami się nazywa, "nie jest stałe, nie jest niestałe, nie jest ani niestałe, ani nie niestałe" (na stbitam nāstbitam na vișţitam nāvișthitam). Określenia te, nie stosują się do tego, co nazywane, ze względu na "[realne] nieistnienie tego, do czego odnoszą się nazwy" (avidyamānatvena tasya nāmadbeyasya). Bodhisattwa ze spokojem przyjmujący tę wiedzę, podkreśla Subhuti (AS 4):

stbito 'vinivartanīyāyām bodbi-sattva-bbūmau, sustbito 'sthāna-yogena

127 AS 4: abam bhagavan etadeva bodhi-sattva-näma-dheyam na vedmi nopalabbe na samanupaśyàmi, prajñā-pāramitām api na vedmi nopalabbe na samanupaśyāmi. 
znajduje oparcie w nieodwracalnym stanie bodhisattwy, czyli znajduje stabilne oparcie poprzez nieznajdywanie oparcia nigdzie.

Zatem ćwicząc się i wprawiając w doskonałości mądrości, bodhisattwa nie znajduje oparcia w formie ani w pozostałych zespołach ${ }^{128}$. Oczywiście jest to myśl sięgająca nauczania samego Buddy, którą już w tej pracy przywoływałem. Kontynuując tę myśl Subhuti dodaje (AS 5): „W stanie doskonałej mądrości forma nie jest chwytana” (rūpam bi aparigrbìtam prajñāparamitāyām) i to samo należy powiedzieć odnośnie do pozostałych zespołów - zaden nie jest uchwytywany. Również doskonałości mądrości nie można uchwycić (sāpi prajñāpäramitā aparigrbìtā). Ostatecznie Subhuti określa stan umysłu będącego nieumysłem/niemyślą jako szczególną postać skupienia. Mówi bowiem (AS 5):

ayam ca bodbi-sattvasya mabä-sattvasya sarva-dharmaparigrbīto näma samadhir

To skupienie bodhisattwy, mahasattwy nazywa się „niechwytaniem zadnych dharm"129.

Bodhisattwa przebywający w tym skupieniu nie chwyta żadnych dharm, gdyż one nie istnieją. Dopóki nie uświadomi on sobie tego faktu, nie osiągnie doskonałości mądrości. Dlatego Subhuti precyzuje, na czym polega praktyka bodhisattwy. Oznajmia, że (AS 5):

${ }^{128}$ AS 4: bodhi-sattvena mabā-sattvena prajñā-pāramitayam caratā prajn̄ā- paramitạm bbavayata na rüpe stbätavyam na vedanäyām na samjñāyàm na samskareșu, na vijñane stbātavyam. Por. także RGS I, 6: na ca rupa vedana na samjña na cetand ca vijñana stbanu anumatra na bbonti tasya | so sarvadbarma-asthito aniketacari aparirigrbita labbate sugatana bodbim \|

129 Zwracam uwage na to określenie „niechwytanie żadnych dharm” (sarva-dharmaparigrhita), gdyż w drugiej części niniejszej pracy jeszcze do niego powrócę w kontekście rozważań nad epistemologią Nagardżuny. 
bodhi-sattvena maba-sattvena prajñā-päramitāyäm caratā prajña-pāramitām bhāvayatã evam upaparīksitavyam evam upanidhyātavyam - katamaișa prajn̄ā-päramitā? kasya caișā prajñā-päramitā? kim yo dharmo na vidyate nopalabhyate, sā prajña-paramiteti?

Bodhisattwa, mahasattwa dąząacy do doskonałości mądrości, doskonalący doskonatość mądrości, powinien badać i rozważać w ten sposób - czym jest ta doskonałość mądrości? czyja jest ta doskonałość mądrości? jak istnieje ta doskonałość mądrości będąca dharmą, która nie istnieje, której nie można uchwycić?

Ratna, powtarzając te pytania, oświadcza, że ten, który tak pyta, ostatecznie odkrywa, iż „wszystkie te dharmy są puste” (imi súnyaka sarva dharmaḅ) $)^{130}$. Wypowiedź ta jest niezwykle ważna, gdyż z jednej strony ukazuje, jaki jest ostateczny sens wszelkich i licznych twierdzeń oznajmiających nieistnienie różnych przedmiotów, w tym zwłaszcza dharm, z drugiej natomiast daje klucz do zrozumienia licznych paradoksów skonstruowanych na zasadzie zestawienia wypowiedzi sugerujących jednoczesne istnienie i nieistnienie konkretnego przedmiotu. Gdy w tekście oznajmia się, że coś nie istnieje, to należy domniemywać, że to coś nie istnieje jako przedmiot obdarzony samobytem, zatem nie jest czymś w sobie określonym, nie niesie w sobie własnej natury i w tym sensie nie jest czymś realnym. Być realnym w tym kontekście, znaczy po prostu posiadać własną naturę. Samoistność zdaje się być w Aszcie warunkiem minimalnym realności, czy jest jednak warunkiem wystarczającym, pozostaje sprawą wątpliwą. Nagardżuna, rozwijając myśl Aszty, będzie wykazywał, że spełnienie owego warunku minimalnego wymaga spełnienia warunku maksymalnego, którym jest bytowa pierwotność, tzn. niebycie wytworzonym przez

${ }^{130}$ RGS I, 8ab: vyuparikșate punarayam katareșu prajñā kasmätkuto va imi śünyaka sarva dharmāh. 
inny przedmiot ${ }^{131}$. Gdy z kolei w tekście natykamy się na paradoks, jak choćby związany z zaleceniem dążenia do doskonałości mądrości, która nie istnieje, to należy sądzić, że mamy tutaj do czynienia z paradoksem pozornym, w którym sprzeczność bierze się z zestawienia wypowiedzi na dwóch różnych poziomach - na poziomie codziennego doświadczenia i na poziomie ostatecznej prawdy o rzeczy (w kontekście buddyjskim są to poziomy niewiedzy i wiedzy).

Stwierdzenie pustki wszystkich dharm ma swoje konsekwencje dla praktyki. Subhuti wyraźnie rozróżnia dwie formy praktyki, z których jedna przybliża do doskonałości mądrości, druga nie (AS 6). Praktyka, która polega na ukierunkowaniu na zespoły (skandha) bądź która wyraża się $\mathrm{w}$ postawie przedstawiania sobie owych zespołów w różnych stanach rzeczy, jak np. w stanie powstawania (utpāda) lub unicestwienia (nirodba), praktyka, w której praktykujący przedstawia sobie siebie jako ,ja dążę do" (abam carāmìti) lub ,ja jestem bodhisattwą" (abam bodhisattva iti), a nawet praktyka, której przyświeca myśl „forma jest pusta" (rūpam śūnyam iti), jest niewłaściwą formą praktyki. Jest ona ukierunkowana na znak (nimitta), czyli na umysłową reprezentację przedmiotu ${ }^{132}$. Warto w tym miejscu wspomnieć, że wśród różnych form niewłaściwej praktyki Aszta wskazuje również na takie, które ukierunkowane są na umystowe reprezentacje ujęte w logiczną formę zwaną później tetralematem (catuṣoti). Nie należy zatem przedstawiać sobie: „ja dążę” (carami), „ja nie dążę” (na carāmi), „ja dążę i nie dążę" (carämi ca na carāmi ca), ,ja ani dążę, ani nie dążę" (naiva carāmi na na carāmi). W podążaniu ścieżką bodhi-

131 Określeń „samoistność" i „pierwotność bytowa" używam w rozumieniu zaproponowanym przez Romana Ingardena, zob. R. In garden, Spór o istnienie świata, t. 1, Warszawa 1987, s. 84-116. Od wielu lat uważam, że kategorie wypracowane przez Ingardena stanowią bardzo wygodne pojęciowe narzędzie do opisu problematyki ontologicznej rozważanej w filozofii buddyjskiej.

132 Korespondująca $z$ tym fragmentem RGS I, 9 podkreśla, że dążenie do skandh, jak też przedstawianie sobie skandh jako pustych oznacza dążenie do znaku (imi skandha śūnya parikalpayi bodhisattvo caratī nimitta). 
sattwy nie ma żadnego znaczenia, jaka jest logiczna struktura umysłowej reprezentacji. Należy bowiem wyzbyć się postawy odnoszenia do doświadczenia poprzez jakiekolwiek umysłowe reprezentacje. Zatem właściwą formą praktyki, powtarza Subhuti, jest ta, w której ma miejsce "skupienie bodhisattwy, mahasattwy zwane «nielgnięciem do żadnych dharm»" (sarva-dharmanupādāno nāma samadbir bodbi-sattvasya maba-sattvasya).

Powtórzone po raz drugi, stwierdzenie to pobudza Siariputrę do pytania (AS 7): „Czy można to skupienie okazać?” (śakyaḅ sa samadbir darśayitum). Subhuti zaprzeczył, a następnie dodał, dlaczego to nie jest możliwe: „Dlatego, że ten syn dobrego rodu nie poznaje i nie postrzega skupienia" (tam api bi sa kula-putrab samādbim na jānāti, na samjānīte). Siariputra jest wyraźnie zdziwiony, gdyż dopytuje się, cytując odpowiedź Subhutiego: „Dostojny Subhuti powiedział «nie poznaje i nie postrzega?”" (na janati na samjānīte ity àyuṣman subbūte vadasi). Subhuti potwierdza:

na jānāti na samjānite ity ayuṣman śāiputra vadami | tat kasya betor na janāti na samjanīte? avidyamānatvena tasya samädhes tam samädbị na janati na samjānīte |

Tak mówię, dostojny Siariputro, nie poznaje i nie postrzega. Dlaczego nie poznaje i nie postrzega? $\mathrm{Z}$ powodu nieistnienia tego skupienia nie poznaje i nie postrzega tego skupienia.

Uwaga Subhutiego spotyka się z aprobatą Buddy, który oznajmia (AS 8): „Szkoląc się w ten sposób, Siariputro, bodhisattwa, mahasattwa szkoli się w doskonałości mądrości" (evam śikșamānab sāriputra bodhi-sattvo mabā-sattvaḅ prajñā-päramitāyām sìșate). To z kolei prowokuje Siariputrę do pytania: „Szkoląc się w ten sposób, Czcigodny, w jakiej dharmie bodhisattwa, mahasattwa się szkoli?" (evam siksamāno bhagavan bodhi-sattvo mabā-sattvaḅ katamasmin dharme siksate). Budda udzielił znamiennej odpowiedzi, którą warto przywotać w całości: 
evam sìksamānạ̣ sáriputra bodbi-sattvo mabā-sattvo na kasmimścid dharme śikșate | tat kasya betob? na bi te śariputra dharmas tatba samvidyante yatba bala-prtbag-janā aśruta-vanto 'bbiniviștab | ayuṣmān śariputra aba - katbam tarbi te bhagavan samvidyante? bhagavan aba - yatba sariputra na samvidyante, tatba samvidyante evam avidyamanāb | tenocyante avidyeti | tan bala-prthag-jand aśrutavanto 'bbinivistab | tair asamvidyamanăb sarva-dbarmạb kalpitạ | te tän kalpayitva dvayor antayob saktạ tan dbarmanna jananti na paśyanti | tasmat te 'samvidyamanan sarva-dbarmān kalpayanti I kalpayitva dvavantavabbiniviśante abbiniviśya tannidānam upalambham niśrityātītan dbarman kalpayanti, andgatan dbarman kalpayanti, pratyutpannan dbarman kalpayanti te kalpayitva namarūpe 'bbinivisțạ | tair asamvidyamanaḅ sarva-dbarmāb kalpitạ | te tän asamvidyamanan sarva-dbarman kalpayanto yatba-bbütam margam na jananti na paśyanti I yatba-bbūtam mägam ajananto 'pasyanto na niryanti trai-dbatukāt, na budbyante bbūta-koțim | tena te bala iti samjiñm gacchanti | te satyam dharmam na śraddbadbati | na kbalu punạ̣ sáriputra bodbi-sattvä mabā-sattvā kaṃcid dharmam abbiniviśante |

"Szkoląc się w ten sposób, Siariputro, bodhisattwa, mahasattwa nie szkoli się w żadnej dharmie. Dlaczego? Albowiem dharmy nie istnieją w taki sposób, w jaki głupi, zwykli, nieuczeni ludzie przypuszczają, [że istnieją $]^{n_{133}}$.

Dostojny Siariputra powiedział: "Jak zatem, Czcigodny, one istnieją?"

133 Wypowiedź ta doskonale pokazuje, na czym polega problem z tłumaczeniem terminu dharma w związku z jego niejednoznacznością. W tym wypadku słowo to może raz znaczyć 'nauka', drugi raz natomiast 'jakość / zbiór jakości' przez tę naukę opisywanych oraz wyznaczanych jako niezbędne do jej urzeczywistnienia. $Z$ jednej strony można szkolić się w jakiejś nauce, czyli przyswajać ją sobie, a z drugiej przyswajanie sobie jakiejś nauki oznacza urzeczywistnianie pewnego zestawu jakości. Te dwa momenty w tym słowie podlegaja utożsamieniu. 
Czcigodny odpowiedział: „One istnieją tak, Siariputro, jak gdyby nie istniały. Ponieważ one nie istnieją w ten sposób, mówi się o nich «niewiedza/nieistnienie» (avidyalavidya). Głupi, zwykli, nieuczeni ludzie są nimi pochłonį̨ci. Żadne dharmy, jakie sobie wyobrażają, nie istnieją. Wyobraziwszy sobie je, przywiązani do dwóch krańców nie poznają i nie widzą tych dharm. Dlatego nie istnieją żadne dharmy, jakie sobie wyobrażają. Wyobraziwszy sobie [dharmy], przywiązują się do dwóch krańców, przywiązani, polegają na postrzeżeniu przedmiotu jako na podstawie i wyobrazają sobie przeszłe zjawiska/dharmy, przyszłe oraz teraźniejsze. Wyobraziwszy sobie je, są pochłonięci nazwą i formą. Wyobrazili sobie wszystkie dharmy, które nie istnieją. Wyobrażając sobie te wszystkie nieistniejące dharmy, nie poznają i nie widzą ścieżki, jaką faktycznie jest. Nie poznając i nie widząc ścieżki, jaką faktycznie jest, nie opuszczają trojakiej sfery [bytowania], nie przebudzają się do kresu istnienia [tj. nie poznają nirwany]. Dlatego określa się ich mianem "głupców». Nie rozwijają zaufania do prawdziwej dharmy. Zatem, Siariputro, bodhisattwa, mahasattwa w ogóle nie daje się pochłonąć dharmom".

Zdecydowałem się przytoczyć ten fragment w obszernym przekładzie, gdyż w nim odniesienie do Katjajanasutry jest najbardziej uderzające. Znajdujemy tutaj konstytutywny dla Kazania do Katjajany motyw opozycji dwóch krańców istnienia i nieistnienia, w których zamknięci są niewiedzący, a także motyw niewidzenia ścieżki przez tych, którzy tkwią przywiązani do tych dwóch krańców. Chociaż nie pada określenie „środkowa droga”, to wspomniana ścieżka (märga) niewątpliwie stoi w pozycji, jaką w Kazania do Katjajany zajmowała środkowa droga, i można uznać, że faktycznie ją zastępuje. Niewidzenie tej ścieżki, tak jak niewidzenie środkowej drogi w Kazaniu do Katjajany, skutkuje pozostawaniem w sferze bytowania. Pewną nowością w stosunku do tego kazania, ale bardziej na zasadzie dopowiedzenia i uzupełnienia niż zmiany akcentów, jest zwrócenie uwagi na rolę wyobraźni jako instrumentu odpowiadającego za przedstawianie 
sobie owych krańców. W miejscu, w którym w Kazaniu do Katjajany pojawia się właściwy pogląd, Aszta stawia wyobraźnię jako instrument odpowiedzialny za popadanie w fałszywy pogląd. W tym sensie uwaga ta ujawnia, na czym polega owa fundacyjna rola istnienia i nieistnienia wspomniana w Katjajanasutrze.

Jest jednak w tym fragmencie moment, w którym pojawia się całkiem nowy motyw, niemający swojego odpowiednika w Kazaniu do Katjajany. Ewidentnie mamy w tym ustępie do czynienia z zamierzoną grą dwóch słów: avidyā i avidya, przez to, iż występującą w tekście formę zsandhizowaną avidyeti można by rozłożyć, używając obu - jako avidya iti lub avidya iti. Ta dwuznaczność wprowadza nowy wymiar do rozumienia buddyjskiego stanowiska. Pierwsze słowo standardowo thumaczy się jako 'niewiedza', drugie należałoby przełożyć jako 'nieistnienie', ale ich faktyczne znaczenie w pewnych kontekstach może ulegać wymianie, zwłaszcza gdy za ich zestawieniem obok siebie stoi intencja. Problem z wykładnią znaczenia owych słów, gdy występują razem, wynika z tego, że oba pochodzą od dwóch zanegowanych homonimicznych rdzeni czasownikowych $\checkmark$ vid, jednego w znaczeniu 'wiedzieć' (klasa 2), drugiego w znaczeniu 'znaleźć' (klasa 6), koniugowanych według różnych paradygmatów. Ten drugi w swoich dalszych znaczeniach ma też 'istnieć, byc' ${ }^{\prime 134}$. Badacze uważają jednak, że oba wywodzą się od wspólnego rdzenia ${ }^{135}$. Byłyby to więc faktycznie polisemy. Urobione od nich rzeczowniki tę cechę przejęły. Jednak to nie kwestie etymologiczne są tutaj najważniejsze. Znacznie istotniej-

134 Warto zwrócić uwagę, ze w języku polskim również słowo „znaleźć” w pewnych kontekstach nabierało znaczenia 'istnieć', chociaż dzisiaj te formy brzmią już raczej archaicznie, jak np. w zdaniu „Znajduje cię w dobrym zdrowiu”, które znaczy mniej więcej tyle, co „Widzę, że jesteś zdrowy”. W sanskrycie klasycznym formy od $\downarrow$ vid $\mathrm{w}$ znaczeniu 'istniec' były powszechnie stosowane, dlatego w przywołanym wyżej pytaniu Subhutiego vidyate tłumaczyłem jako "istnieje".

135 Zob. W. D. Whitney, The Roots, Verb-Forms, and Primary Derivatives of the Sanskrit Language, Leipzig 1885, s. 159-160. 
sze jest to, że owa dwuznaczność jest w pełni zamierzona i co więcej, płynie z niej doniosły wniosek. Tekst wyraźnie poprzez tę grę słów sugeruje, że w uchwytywaniu istnienia, w wyobrażaniu sobie istnienia, w przedstawianiu sobie istnienia, w konceptualizacji istnienia, wreszcie w orzekaniu istnienia wyraża się niewiedza. Niewiedza i istnienie to dwa aspekty tego samego stanu rzeczy. Znaczy to tyle, że nie mamy żadnego dostępu do istnienia, które poprzedzałoby niewiedzę, nie sposób więc mówić o żadnym istnieniu w sensie obiektywnym, czyli niezależnym od procesu poznawczego. Innymi słowy, niewiedza nie polega na błędnym rozpoznaniu sytuacji w obszarze uprzednio i wiarygodnie nam danego istnienia. Samo doświadczenie tego ostatniego konstytuuje się jako ekspresja niewiedzy. Tłem dla owej gry słów jest bez wątpienia abhidharmiczny sposób rozumienia istnienia, który, jak wcześniej stwierdziłem, wpłynął na pojawienie się rozbieżności między palijską wersją Kazania do Katjajany a wersją sanskrycką. W zwięzły, a przez to jeszcze bardziej dobitny sposób myśl tę formułuje Ratna. W RGS I, 13 czytamy:

yo 'sau na vidyati sa eșa avidyamāno tām bālu kalpayi avidya karoti vidyam | vidya avidya ubbi eti asanta dharmā niryati yo iti prajanati bodbi-sattvo \|

Co nie istnieje, to głupiec, przedstawiając sobie jako nieistniejące, robi nieistniejącym i istniejącym. Istnienie, jak i nieistnienie są nierealne (vidya avidya ubbi eti asanta dharmā). Gdy to rozpoznaje, bodhisattwa odchodzi.

Chociaż strofa ta jest paralelna wobec przywołanego fragmentu Aszty, również w tym, że gra na tej samej dwuznaczności, to wprowadza nowy wątek czy też może raczej uwyraźnia moment, który w przywołanym fragmencie Aszty nie byt tak czytelny. W pierwszym zdaniu w jego drugiej padzie mamy klarowne nawiązanie do Kazania do Katjajany - tkwimy w opozycji istnienia i nieistnienia, którą sami kreujemy. Tajemnicza zdaje sį̨ część pierwsza tego zdania. Dlaczego 
przedstawianie sobie tego, co nie istnieje, jako nieistniejącego, ma być problemem? Otóż stanowi ono problem właśnie dlatego, że jest przedstawianiem - głupiec przedstawia sobie, czyli formuje, ksztattuje, konstruuje w myśli (kalpayı) nieistnienie, a w myśli nieistnienie można formować tylko w opozycji do równie przedstawianego istnienia. Głupiec nie widzi bezpośrednio, jak jest faktycznie, tylko sobie wyobraża, a tym samym wyraża istnienie/niewiedzę. Dlatego w zdaniu drugim stwierdza się, że „istnienie, jak i nieistnienie są nierealne” (vidyā avidya ubbi eti asanta dharmā), są to bowiem tylko umysłowe przedstawienia. $Z$ drugiej strony, mając $w$ pamięci wspomnianą grę dwuznaczności, stwierdzenie to moglibyśmy także przełożyć jako: „wiedza i niewiedza są nierealne”. To jest ten nowy moment, o którym przed chwilą wspomniałem. Mamy tutaj wyraźną sugestię, że stan wiedzy w sensie ontycznym niczym nie różni się od stanu niewiedzy, oba są w ten sam sposób nierealne, czyli puste, pozbawione własnej natury. Dlatego bodhisattwa, szkoląc się w doskonałości mądrości, nie szkoli się w żadnej dharmie ${ }^{136}$, gdyż nie postrzega doskonałości mądrości jako zestawu korzystnych realnych i obiektywnych jakości/dharm, z którymi miałby wejść w realną relację przyswojenia ich sobie, w przekonaniu, że to zmieni i wzbogaci jego realne istnienie, czyli ugruntowane w trwałej, ontycznej podmiotowości. Tak jak bodhisattwa nie dostrzega w sobie żadnej realnej podmiotowości ${ }^{137}$, czyli

136 Por. RGS XXII, 4:

yatha prajña-pāramita súnyata lakșanena tatba-laksanāa ya imi jānati sarva-dharmān |

súnyānalakșana prajānaya-māna dbarmān evam carantu caratì sugatāna prajñam $\|$

Jak poznaje doskonałość mądrości poprzez cechę pustki, tak poznaje wszystkie te dharmy poprzez tę samą cechę. Poznając dharmy jako puste i bez cech, w ten sposób dążąc, dąży do mądrości Sugaty.

137 Por. RGS XXII, 7:

yatha udgrabo tatha prakaśitu samkileśo vyodāna ukta abu mabya anopalabdbi na bi atra kaści yo klísyati sudbyate va prajñāya paramita budbyati bodhisattve \| 
przedstawianie sobie tego, co nie istnieje, jako nieistniejącego, ma być problemem? Otóż stanowi ono problem właśnie dlatego, że jest przedstawianiem - głupiec przedstawia sobie, czyli formuje, ksztattuje, konstruuje w myśli (kalpayı) nieistnienie, a w myśli nieistnienie można formować tylko w opozycji do równie przedstawianego istnienia. Głupiec nie widzi bezpośrednio, jak jest faktycznie, tylko sobie wyobraża, a tym samym wyraża istnienie/niewiedzę. Dlatego w zdaniu drugim stwierdza się, że ,istnienie, jak i nieistnienie są nierealne” (vidyã avidya ubbi eti asanta dharmā), są to bowiem tylko umysłowe przedstawienia. $\mathrm{Z}$ drugiej strony, mając $\mathrm{w}$ pamięci wspomnianą grę dwuznaczności, stwierdzenie to moglibyśmy także przełożyć jako: „wiedza i niewiedza są nierealne”. To jest ten nowy moment, o którym przed chwilą wspomniałem. Mamy tutaj wyraźną sugestię, że stan wiedzy w sensie ontycznym niczym nie różni się od stanu niewiedzy, oba są w ten sam sposób nierealne, czyli puste, pozbawione własnej natury. Dlatego bodhisattwa, szkoląc się w doskonałości mądrości, nie szkoli się w żadnej dharmie ${ }^{136}$, gdyż nie postrzega doskonałości mądrości jako zestawu korzystnych realnych i obiektywnych jakości/dharm, z którymi miałby wejść w realną relację przyswojenia ich sobie, w przekonaniu, że to zmieni i wzbogaci jego realne istnienie, czyli ugruntowane $w$ trwałej, ontycznej podmiotowości. Tak jak bodhisattwa nie dostrzega w sobie żadnej realnej podmiotowości ${ }^{137}$, czyli

136 Por. RGS XXII, 4:

yatha prajña-pāramita súnyata lakșaṇena tatba-laksanāa ya imi jānati sarva-dharmān |

súnyānalaksaṇa prajanaya-mana dharmān evam carantu caratī sugatana prajñam $\|$

Jak poznaje doskonałość mądrości poprzez cechę pustki, tak poznaje wszystkie te dharmy poprzez tę samą cechę. Poznając dharmy jako puste i bez cech, w ten sposób dạżąc, dạży do mądrości Sugaty.

137 Por. RGS XXII, 7:

yatha udgrabo tatha prakaśitu samkileśs vyodāna ukta abu mabya anopalabdbi na bi atra kaści yo kliśyati śudhyate va prajñāya paramita budbyati bodhisattve II 
jaźni, tak też nie dostrzega takiej podmiotowości (resp. tożsamości) w niczym innym. Dla niego nie istnieją realnie, czyli jako obdarzone własną naturą, żadne dharmy, odnośnie do których zwykli ludzie wyobrażają sobie, że taką własną naturę w sobie niosą.

Zatem uzyskanie wiedzy nie oznacza porzucenia sfery iluzji w sensie przejścia do obszaru autentycznego bytu, żadnego bowiem autentycznego bytu nie ma. Iluzja (majȳa) w rozumieniu Aszty nie jest fenomenalną zasłoną, za którą kryje się realny byt w sobie. Aszcie dystynkcja na sferę zjawisk i sferę bytu w sobie jest obca tak samo, jak obca ona była Buddzie, co starałem się pokazać we wcześniejszym rozdziale.

Idąc tym tropem, Subhuti oświadcza (AS 8): „Doprawdy, Czcigodny, forma jest iluzją, iluzja jest formą" (rūpam eva bhagavan māyā, māyaiva rüpam) i to samo mówi o pozostałych zespołach. Forma nie istnieje tak, jak jawi się przysłowiowym zwykłym ludziom, czyli jako przedmiot godny pożądania ze względu na jego domniemaną wartościową dla nas naturę. Jest więc iluzją, tak jak iluzją w tym znaczeniu są pozostałe zespoły. Jednocześnie, oznajmia Subhuti, iluzja jest formą, czyli jest wszystkim, co jest nam dane zmysłowo. To samo należy powiedzieć o pozostałych zespołach, z tym że są one oczywiście ujmowane nie zmysłowo, a introspekcyjnie. W rozumieniu Aszty iluzja nie polega na projektowaniu zjawisk przysłaniających byt, jak tę kwestię rozumieją tradycje idealistyczne, lecz na projektowaniu wyobrażenia o własnej naturze owych zjawisk i na podejmowaniu adekwatnego działania w związku z tym wyobrażeniem. W sformułowaniu tym mamy jaskrawą zapowiedź motywu, który stanie się dominujący w Sutrze serca (Prajñā-pãramitā-brdaya-sūtra), a który wyrażany jest w formule: „Forma jest pustką, a pustka jest formą" (rūpam śūnyatā

Gdy zwraca się uwagę [tj. gdy się chwyta], wówczas ujawnia się splamienie. Niepostrzeganie [tj. niechwytanie się] "Ja" $\mathrm{i}$ "moje” zwie się oczyszczeniem. Doprawdy nie ma tutaj nikogo, kto podlegatby splamieniu lub oczyszczeniu. Doskonałość mądrości budzi się w bodhisattwie, [gdy to pojmuje]. 
súnyataiva rüpam), obowiązującej także w odniesieniu do pozostałych zespołów ${ }^{138}$.

Motyw iluzji powrócił w AS 20 w rozmowie Subhutiego z bogami, w której wszystko zostało przyrównane do iluzji (māyā). Wszystko, oznajmia Subhuti, czyli wszystkie byty (sattva), wszystkie zjawiska (dharma) są jak iluzja (māyopamā), są jak sen (svapnopamā), nawet Budda i nirwana. Jednocześnie Subhuti podkreśla, że iluzja i sen nie są czymś różnym od bytów ${ }^{139}$. Chce przez to powiedzieć, że iluzji nie należy rozumieć jako zasłony skrywającej głębszą, prawdziwą rzeczywistość, różną od tej, która się jawi. Nie ma żadnej innej rzeczywistości poza tą, która się jawi ${ }^{140}$.

Po refleksji na temat iluzji Subhuti po raz kolejny powraca do otwierającej tekst kwestii i zadaje Buddzie pytanie (AS 9): „Co, Czcigodny, oznacza "bodhisattwa»"? (bodhi-sattva iti bhagavan kạ padartha). W odpowiedzi Budda stwierdzit:

apadärthạ subbūte bodhisattva-padārtbạ̣ | tat kasya hetọ̣? sarva-dharmānām bi subbūte bodhisattvo mabäsattvo 'saktatâyām sỉksate |

Subhuti, „bodhisattwa” nic nie oznacza. Dlaczego? Albowiem, Subhuti, bodhisattwa, mahasatwa szkoli się w nieIgnięciu/nieprzywiązaniu do żadnych dharm.

138 Zob. E. Conze, The Prajñaparamita-brdaya Sūtra, [w:] ide m, Thirty Years of Buddhist Studies. Selected Essays, Oxford 1967, s. 150.

139 AS 20: iti bi maya ca sattvaś cadvayam etad advaidbikāram, iti bi svapnaś ca sattvas cadvayam etad advaidbikaram.

140 W tym miejscu wyraźnie widać, że słowo sattva jest w Aszcie używane szeroko, na oznaczenie wszelkiego tzw. obiektywnego bytu, w sensie konkretnych, jednostkowych rzeczy, a nie tylko istot żywych, jak się to słowo thumaczy, gdy występuje w kontekście terminów określających różne idee osobowego bytu (dusza, jaźń, osoba, duch). Widać to po tym, jak w jednym zdaniu pojawia się sattva, a w kolejnym słowo to zostaje zastąpione terminem dharma, oba są w liczbie mnogiej (sarva-dharma api deva-putrā mayopamạ̣ svapnopamăb; AS 20). 
W pierwszym momencie słowa te mogą zaskakiwać, jako że odnosi się wrażenie, iż nie są odpowiedzią na zadane pytanie. Wszak dlaczego nielgnięcie do żadnych dharm ma tłumaczyć stwierdzenie, że „bodhisattwa" nic nie oznacza? Na tę odpowiedź jednak należy spojrzeć przez pryzmat i w nawiązaniu do uwag oraz odpowiedzi wcześniejszych, które padały w związku z tą kwestią. Wcześniej już zostało ustalone, że słowo to nic nie oznacza, gdyż realnie nie istnieje żaden przedmiot (dharma) będący bodhisattwą. Skoro realnie żaden taki przedmiot nie istnieje, to na czym faktycznie polega bycie bodhisattwą, bo przeciez nie na przyswojeniu sobie realnych jakości. Dlatego Budda stwierdza, że „bodhisattwa” oznacza nie jakąś realną jakość, ze względu na którą używa się tej nazwy, lecz polegający na nielgnięciu sposób bycia urzeczywistniany $\mathbf{w}$ obliczu braku realności, czyli w obliczu pustki wszystkiego. Aszta jak żaden wcześniejszy tekst buddyjski ugruntowuje postawę nielgnięcia $w$ fakcie pustki. Zaprzestanie lgnięcia było postawą promowaną już w Kazaniu do Katjajany, ale dopiero Aszta wyraźnie i jednoznacznie powiązała idę̧ pustki z postawą nielgnięcia. Sutra ta stwierdza, iż zaprzestać lgnięcia można tylko, uświadomiwszy sobie pustkę wszystkiego, w tym również dharm. Dopóki kierujemy się abhidharmicznym przekonaniem o realności dharm, czyli de facto jakości, dopóty nie jesteśmy w stanie tej postawy urzeczywistnicín ${ }^{141}$.

W identycznym tonie Subhuti wypowiedział się o mahasattwie wielką istotą nazywa się tego, kto nie lgnie (dosł. jest nielgnący; asakta) do myśli o przebudzeniu (bodbi-citta) i jest w nią niezaangażowany (aparyapanna) oraz nie lgnie do innych myśli/wyobrażeń o chwalebnym celu (AS 9-10). Również w tym miejscu nielgnięcie do myśli o przebudzeniu tłumaczy się przez odwołanie do faktu, że jest to niemyśl (acitta). Myśl, która nie jest myślą, to myśl do niczego nielgnąca - ani do myśli o przebudzeniu, ani do myśli o wszechwiedzy. Kogoś takiego nazywa się mahasattwą. W stanie braku myśli,

141 W RGS I, 16 podkreśla się, że bodhisattwa „pragnie uciszyć wszelkie przywiązanie" (sarvatra sarigakriya icchati). 
czyli nielgnięcia nawet do myśli o przebudzeniu, w stanie doskonałej równowagi umystu (upekșa) nie istnieje nawet myśl „istnieje” ani „nie istnieje”. Jak widać, Aszta nieustannie nawiązuje do Kazania do Katjajany, rozwijając zawarte w niej intuicje.

W AS 13 kwestia odniesienia terminu „bodhisattwa” powraca po raz ostatni. Oznajmiwszy kolejny raz: „Nie widzę tej dharmy, którą nazwa "bodhisattwa» oznacza. Doskonałości mądrości też nie widze i nie dostrzegam" (nāham bhagavan tam dharmam samanupaśyāmi yasyaitan nama-dheyam yad uta bodbi-sattva iti | prajñā-pāramitām api na samanupaśyāmi nopalabbe), Subhuti dodaje, że „Budda”, "bodhisattwa", "doskonałość mądrości” to tylko nazwy (nāma-dheya-mātra), które tak jak słowo njaźñ" (ätman), chociaż są używane, oznaczają coś niepowstałego (anabbinirvrtta), czyli realnie nieistniejącego ${ }^{142}$. Stwierdzenie, że dharmy realnie nie powstały, jest dla Subhutiego równoważne ze stwierdzeniem, że nie posiadają własnej natury, czyli są wewnętrznie bezistotowe ( $y \bar{a}$ asvabhāvatā, sā anabbinirurttiḅ).

Powinniśmy w tym miejscu poczynić drobną uwagę, aby zapobiec nietrafionym pod adresem Aszty oskarżeniom. Można by przecież pomyśleć, że to, co istnieje ze swej natury, realnie nie powstało, a przecież nie jest puste, wręcz przeciwnie, jest, jeśli trzymać się metafory pustki, pełne siebie, czyli realne $w$ najpełniejszy $z$ możliwych do po-

142 RGS I, 27 dodaje: „Należy wyjść poza wszystkie określenia rzeczy” (dharma-nama sarveșu pada-samatikramu). Wcześniej w RGS I, 14 pojawiła sį̨ juz uwaga, że bodhisattwa jest "wolny od pojęcia wielości reeczy" (nānatva-samjña-vigato). Podobnie w RGS XVIII, 7 pada stwierdzenie, ze bodhisattwa „wszystkie te dharmy [tj. rzeczy/nauki], które Budda ukazał, wypowiedział i ujawnił, rozpoznaje jako tylko mowę (abbilapa-matra ima jānati sarva-dharmam buddhena deśita prayukta prakaśitamś ca). A RGS XVIII, 8 dodaje, ze "podobnie owych pięć doskonałości Zwycięzców, one również zostały uznane tylko za nazwy/słowa" (ye capi pañca imi paramita jinanam ete 'pi dharma parikirtita nama-matraḅ). Stwierdzenia te znaczą tyle, iż to, do czego odnoszą się słowa, nie istnieje jako $w$ sobie określone. Słowa nie oznaczają niczego realnego, czyli niczego, co byłoby czymś samo w sobie, co w sobie zawierałoby swoją naturę. 
myślenia sposobów. W związku z tym równoważność między pustką a realnym niepowstawaniem jest nie do utrzymania. Zarzut ten jest nietrafny o tyle, że nie uwzględnia właściwie kontekstu, w jakim Aszta mówi o niepowstawaniu. Sutra ta mówi o powstawaniu z perspektywy doświadczenia. Podstawową cechą naszego doświadczenia jest zmienność, nietrwałość (anityatā), pojawianie się i znikanie „rzeczy”. W naturalnym nastawieniu, w którym usposobieni jesteśmy realistycznie, przedstawiamy sobie tę zmianę jako realną zmianę rzeczy, jako ich realne powstawanie i zanik, czyli jako wchodzenie w byt, co oznacza wchodzenie w stan posiadania samobytu, i wychodzenie z niego, czyli faktyczne unicestwienie. Aszta unieważnia, a za nią będzie to robiła tradycja madhjamaki, ten realistyczny sposób patrzenia na zmianę ${ }^{143}$. Rzeczy są puste, a o tym, co jest puste, nie można orzekać realnego powstawania i niepowstawania. Dlatego Subhuti w AS 15 ostatecznie przyznaje, że: "niepowstawanie jest [jedynie] powiedzeniem” (anutpāda evāyusman śáriputra jalpaḅ), czyli sposobem wyrażania się, który odzwierciedla nasze doświadczenie, ale nie ugruntowaną w sobie rzeczywistość rzeczy.

Nauka o pustce rzeczy pociąga za sobą konsekwencje nie tylko o charakterze semantycznym, czyli związane z referencją słów, ale także etycznym, związanym z budowaniem motywacji do działania, $\mathrm{z}$ wyborem właściwego celu i dążeniem do niego. Celem promowanym przez Asztę jest doskonałość mądrości właściwa dla bodhisattwy. Pojawia się jednak pytanie, jak można stawiać sobie za cel to, co jest puste, czyli realnie nie istnieje, i do tego dążyć. Wątpliwość ta ogarnęła przysłuchujących się konwersacji bogów, którzy nie omieszkali jej zakomunikować. Uczynił to w ich imieniu Siakra (s. Śakra) zwany też Kausiką (s. Kauśika), król owej grupy bogów. Odpowiedział mu Subhuti (AS 17):

${ }^{143}$ Przeciwko realistycznej idei bytu koniecznego madhjamaka wytacza odmienne argumenty. 
śünyatayạm kausíka tișthata bodbi-sattvena maba-sattvena prajña-paramitayam stbatavyam |

Poprzez znajdywanie oparcia w pustce, Kausiko, bodhisattwa powinien znajdować oparcie $w$ doskonałości mądrości ${ }^{144}$.

Następnie Subhuti wymienia długą listę tego, w czym bodhisattwa nie powinien znajdować oparcia (AS 18), począwszy od formy (na rūpe sthātavyam) i pozostałych zespołów, przez zmysły, kontakt i świadomość zmysłową, różne przeciwstawne wyobrażenia o zespołach, np. że forma jest trwała lub nietrwała (rüpam nityam anityam iti na stbātavyam), że jest błoga lub bolesna (rüpam sukbam dubkbam iti na sthātavyam), że jest pusta lub niepusta (rūpam śūnyam aśūnyam iti na sthātavyam), jak też, co należy mocno podkreślić, że jest jaźnią bądź nie jest jaźnią (rūpam ātmānātmeti na sthātavyam), a skończywszy ostatecznie na naturze buddy (na buddhatve sthätavyam). Ta tyrada wzbudziła w Siariputrze wątpliwości dotyczące tego, jak bodhisattwa powinien w ogóle postępować i praktykować, skoro w niczym nie powinien znajdować oparcia. Wątpliwość te rozwiał jednak po chwili sam, uznając, że bodhisattwa powinien naśladować Tathagatę, który „nigdzie nie znajduje oparcia, ponieważ jego umysł nie znalazt podpory" (na kvacid āyusman subbüte tathägato 'rhan samyak-sambuddhab sthitaḅ | tat kasya hetor? apratișthita-mānaso bi tathāgato 'rhan samyak-sambuddhab) $)^{145}$.

144 Ratna, podsumowując ten fragment, nazywa pustkę naturą rzeczy (dharmata), zob. RGS II, 1:

rupasmi yo na sthibate na ca vedanäyạm samjñãya yo na sthibate na ca cetanāyām | vijñani yo na sthibate sthitu dharmatāyām eșā sa prajña-vara-paramitaya carya $\|$

Kto nie znajduje oparcia $w$ formie, w uczuciu, w postrzeżeniu, w woli, w świadomości, znajduje oparcie w naturze rzeczy. Oto praktyka najwyższej doskonałości mądrości.

145 Por. RGS II, 2:

nityam anitya-sukba-duḅkb-aśubbä-śubbam ti atmany anatmi tathata tatha śūnyatāyàm | 
Bogowie jednak czują się tą nauką przytłoczeni i zastanawiają się, czy w ogóle ją rozumieją. Subhuti reaguje na ich niepewność i oznajmia w typowy dla siebie, czyli paradoksalny, sposób (AS 19):

na vijñayate na vijñayate idam devaputrāb | tatha bi nătra kimcit sūcyate, nātra kimcit śrūyate \|

Nie ma tu, bogowie, niczego do zrozumienia, zupełnie niczego. Albowiem nic nie zostało tu wskazane, nic nie zostało tu stwierdzone.

Paradoksalność tej wypowiedzi, tak jak i wcześniejszych stwierdzeń, jest oczywiście pozorna. Wyrasta ona ze zderzenia naiwno-realistycznych oczekiwań, które każą wierzyć w rzeczy obdarzone samobytem z faktycznym, w rozumieniu Aszty, stanem rzeczy, czyli z ich pustką. Niczego nie ma do zrozumienia, gdyż w sensie realistycznym po prostu niczego nie ma, czyli nie istnieją żadne rzeczy określone w sobie, noszące w sobie swoją własną naturę, którą należy uchwycić w zrozumieniu $^{146}$. W tym sensie Aszta niczego nie wskazuje, nie stwierdza istnienia niczego realnego. Subhuti wraca do tej uwagi, rozwijając ją, pod koniec konwersacji z bogami. Należy podkreślić, iż w tym powrocie można ponownie dopatrzyć się nawiązania do Katjajanasutry. Oznajmia zatem (AS 24):

sthavirab subbūtir aba - tat kam manyase kauśika katamasyaitad dharmasyaddhivacanam yad uta sattvab sattva iti? 'sakra aba - naitad arya subhüte dharmasyadbivacanam

phala-präptitāya athito arabanta-bbūmau pratyeka-bbümistbito tatba buddha-bbümau \|

Trwały, nietrwały; przyjemny, nieprzyjemny; czysty, nieczysty; jaźń, niejaźn $-w$ ten sposób takość jest w pustce. Nie znajduje oparcia w osiągniętym celu - w stanie arhata, pratjeka[buddy] i buddy.

${ }_{146}$ Por. RGS II, 3d: asthanu stbanu ayu stbannu jinena ukto („Stanowisko bez stanowiska Zwycięzca nazwał stanowiskiem"). 
nädharmadhivacanam yad uta sattvab sattva iti | agantukam etan näma-dheyam prakșiptam | avastukam etan nama-dheyam prakșiptam | anātmīyam etan nama-dheyam praksiptam I anarambanam etan nama-dheyam praksiptam yad uta sattvah sattva iti | sthaviraḅ subbūtir äba - tat kim manyase kausika kācid atra sattva-paridīpanā krta? śakra aba no bïdam ärya subbūte | subbütir äba - yatra kausika na kacit sattva-paridīpanā krtä, tatra kā sattvänantatā? sacet kausika tathdgato 'rhan samyak-sambuddho 'nanta-vijñapti-ghosena gambbira-nirghosena svarena gangāa-nadī-valukopamān kalpān api vitișthamānaḅ sattvah sattva iti vācam bhäseta, api nu tatra kaścit sattva utpanno va utpatsyate votpadyate vā, niruddho vā nirotsyate vā nirudbyate vã? 'sakra äba - no bìdam ärya subbūte | tat kasya betọ?? adi-suddhatvad adi-pari-śuddhatvät sattvasya |

Starszy Subhuti powiedział: „Co myślisz, Kausiko, to określenie "byt» oznacza realne istnienie jakiej dharmy?".

Siakra odpart: „Szlachetny Subhuti, to określenie «byt» nie oznacza żadnej realnej dharmy ani niedharmy. Nazwa ta jest podana jako coś przygodnego, bezprzedmiotowego, nieistotnego, bezpodstawnego".

Starszy Subhuti odrzekł: „Co sądzisz, Kausiko, czy jakiś byt został tutaj ukazany/objaśniony?”.

Siakra odpart: "Żaden, szlachetny Subhuti".

Subhuti rzekł: „Skoro, Kausiko, nie ukazano żadnego bytu, to jakże niezliczoność bytów [można ukazać]? Gdyby, Kausiko, Tathagata, godny, w pełni doskonale przebudzony, głosem o nieograniczonym zasięgu, głęboko bezdźwięcznym głosem, przez eony niezliczone jak ziarna piasku w Gangesie, wypowiadat słowo "byt", «byt», to czy jakikolwiek byt stworzytby lub unicestwił kiedykolwiek [tzn. w trzech czasach przeszłości, teraźniejszości i przyszłości]?”.

Siakra odpart: „Żaden doprawdy, szlachetny Subhuti. Dlatego, że byt od początku jest czysty, całkowicie czysty".

Stwierdzenie, że rzeczy są od początku całkowicie czyste (ädi-pari-śuddhatva, dosł. od początku są w stanie całkowitej czystości) 
nie jest sugestią jakiegoś ich zakotwiczenia w doskonałym, pierwotnym bycie, który byłby gwarancją ich czystości. Z sytuacją, którą się tutaj neguje, mamy do czynienia $w$ monistycznych wizjach wedantycznych, dla których błąd poznawczy polega na myleniu skutku, to znaczy rzeczy, z doskonałą, czyli czystą przyczyną. Z sytuacją taką mamy też do czynienia np. w wizji chrześcijańskiej. Doskonały bóg nie może stwarzać rzeczy złych, czyli nieczystych. Jeżeli więc świat jest bożą kreacją, to musi być w sobie dobry, czysty. Gwarantem tej czystości ma być doskonałość jego kreatora. Na podstawie kontekstu, jaki w drugim rozdziale Aszty stwarza idea pustki, możemy uznać, że stwierdzenie czystości rzeczy oznacza, iż są one po prostu puste. Sądzę, że czystość rzeczy należy rozumieć tak samo, jak wspomnianą wcześniej przejrzystość umysłu, czyli jako pustkę. Wszystko jest puste, czyli pozbawione realności rozumianej jako istnienie $w$ oparciu o swoją własną dyspozycję. Nic nie jest więc skażone ze swej natury ${ }^{147}$. Nawet Budda, określający w buddyjskiej wizji najwyższą wyobrażalną doskonałość, nie potrafi tego stanu zmienić148. Kwestia możliwości

147 Ta wykładnia czystości rzeczy znajduje potwierdzenie w XII rozdziale, tj. w AS 137, gdzie Budda mówi o doskonałości mądrości, że „ukazuje ona świat jako oczyszczony ze świata" (loka-viśuddbya lokam sūcayati). Innymi słowy, ukazuje ona świat jako oczyszczony z samego siebie, czyli z wewnętrznej natury bycia światem. Swiat jest czysty, czyli pusty (śūnya). Tak rozumianą czystość należy odróżnić od czystości w sensie realistycznym. W tym drugim sensie czystość rozumiana jest jako posiadanie realnych jakości ujmowanych w opozycji do realnych jakości nieczystych. W rozumieniu Aszty, a za nią madhjamaki, czystość jest niebyciem określonym ze swej własnej natury, czyli, mówiąc prościej, brakiem własnej natury rzeczy, brakiem własnej istoty.

148 Por. RGS II, 12:

sacigangga-valuka-samani sthibitva kalpam sattveti śabda parikìrtayi nāyako 'yam | sattvasy' upadu kutu bhesyati adiśuddho eșã sa prajña-vara-paramitaya caryä I|

Gdyby przez eony liczne jak ziarna piasku w Gangesie sam Mistrz (näyaka) stale wypowiadał słowo „byt” (sattva), mówieniem bytu nie powoła do istnienia [dost. jak wypowie powstanie bytu?], choć byłby czysty od początku. To jest praktyka najwyższej doskonałości mądrości. 
takiej zmiany stanie się zasadniczym problemem w refleksji Nagardżuny. Jestem przekonany, że myśl ta ma swój początek w rozważaniach Buddy dotyczących jaźni. W jednym $z$ dwóch podstawowych argumentów przeciwko możliwości uznania zespołów za jaźń Budda pytał, czy mamy zdolność decydowania o jakości owych zespołów, czy jesteśmy $w$ stanie je tworzyć zgodnie $z$ własną wolą. Jeżeli nie, to na jakiej zasadzie możemy uznawać je za jaźń, tj. za coś istotnie wsobnego, czyli za coś, co z natury samo sobie w pełni jest dostępne zarówno poznawczo, jak i ontycznie, co pozostaje całkowicie w swoim zasięgu, we własnej i tylko własnej dyspozycji ${ }^{149}$.

Powtórzmy to raz jeszcze - czystość bytu oznacza jego pustkę, czyli niesamobytność. Stwierdzenie, iż nawet Budda nie jest w stanie sprawić powstania bytu, oznacza, że nawet Budda nie dysponuje mocą, aby powołać do istnienia byt obdarzony samobytem. Podobnie też nie byłby on $\mathrm{w}$ stanie takiego bytu unicestwić $\mathrm{i}$ to $\mathrm{z}$ dwóch powodów, o których tekst jednak nie mówi. Pierwszy jest taki, że gdyby istniał byt obdarzony samobytem, to nikt nie byłby w stanie zmienić jego stanu, gdyż istniałby z konieczności. Drugi jest taki, że skoro nie ma bytów obdarzonych samobytem, to zniszczenie bytu nie jest w sensie realistycznym faktycznie jego zniszczeniem, czyli nie jest przeprowadzeniem samobytującego bytu w stan nieistnienia. Stwierdzenie to podważa realistyczny sposób rozumienia zmiany.

Pustka jest tym, co ostatecznie o rzeczach możemy stwierdzić. Przy czym nie jest to kwestia naszych zdolności poznawczych, tylko ostatecznej prawdy samych rzeczy, tego, co w tekstach doskonałości mądrości nazywa się ich takością (tatbatā). Ratna bardzo dobitnie eksponuje ten fakt. W RGS XII, 4 czytamy:

tișthantu loka-vidunām parinirurtānam sthita eșa dharmata-niyāma śünya-dharmā l

tām bodhi-sattva tathatam anubuddhayanti tasma bu buddha krta nama tathagatebhib $\|$ 
Czy znawcy świata przebywają [w świecie], czy też ostatecznie wygaśli, porządek rzeczy pozostaje ustalony: dharmy są puste. Tę takość bodhisattwa pojmuje [dost. przebudza się na nią / do niej]. Dlatego właśnie buddów zwie się „tathagatami”.

Porządek rzeczy (dharmata-niyama) ${ }^{150}$, jak oznajmia powyższa strofa, nie jest funkcją nauczania buddów, w żaden sposób od nich nie zależy. Wręcz przeciwnie, to ich ze względu na to, że ten porządek rozpoznają, nazywa się tathagatami ${ }^{151}$. Na podstawie RGS XII, 3c stwierdzić możemy, że takość ta poprzedza byt i niebyt, nie możemy więc o jej istnieniu i nieistnieniu orzekać, czytamy tam bowiem: „takość jest jedna, wolna od bytu/istnienia, niezmienna” (ekaiva bhāva-vigatā tathatā ananyā). Chociaż możemy mówić o takości: przeszłości, przyszłości, arhatów itd., to z owej formy wypowiedzi nie należy wnosić, że istnieją jakieś różne takości czy też że takość jest w sobie jakoś zróżnicowana. RGS XVI, 2d wyklucza jednoznacznie takie domniemanie, oznajmiając: „wszystko jest takością dharm, niezróżnicowaną" (sarveșa dharma-tathata na viśeșa-präptā). Rozpoznanie takości oznacza rozpoznanie natury wszystkich rzeczy. Mówi o tym wprost RGS XIII, la: „Kto tak widzi, widzi wszystkie dharmy” (yo eva paśyati sa paśyati sarva-dharmān), a RGS XIV, 4b dodaje, że ci, którzy to rozpoznają, są „zręczni w [widzeniu] własnej natury istnienia” (bhāva-svabhāva-kuśalā) oraz są tymi, którzy widzą to, co ostateczne (paramārtba-darsīi).

Aszta roztacza wizję rzeczywistości, która od początku budziła kontrowersje. Opór ten jest zrozumiały o tyle, że wizja ta narusza podstawowe nawyki, kierujące naszym codziennym życiem, a wyrastające z naturalnego doświadczenia. Z sytuacją tą autorzy Aszty nieustannie

150 Zapis owego wyrażenia nie jest błędem. Ratna nie jest bowiem pisana klasycznym sanskrytem, stąd kształt tego wyrażenia różni sį̧ od klasycznej formy, która powinna wyglądać raczej następująco: dharmata-niyama.

15ı Oczywiście mamy tutaj do czynienia z często spotykaną w tekstach buddyjskich etymologią ludową, opartą o skojarzenia fonetyczne, a nie naukową. 
się konfrontowali. Analizę tego tekstu zakończ̨̧ uwagami, jakie wypowiedział Subhuti o tych, którzy w promowanym przez Asztę modelu praktyki dostrzegają piętrzące się trudności (AS 14). Tych w opinii Subhutiego nie można uznać za bodhisattwów. Bodhisattwa powinien rozwijać $\mathbf{w}$ sobie współczucie wolne od pojęcia bytu ${ }^{152}$, ćwicząc się w utożsamianiu wszystkich istot ze swoimi rodzicami i dziećmi. Bodhisattwa powinien pielęgnować w sobie myśl, że „tak jak żadna jaźn w żaden sposób i pod żadnym względem nie istnieje, i nie jest ujmowana/postrzegana, tak też żadne dharmy w żaden sposób i pod żadnym względem nie istnieją, i nie są ujmowane" (yatha sarvena sarvam sarvathā sarvam àtmā na vidyate nopalabhyate, evam sarvena sarvam sarvathā sarvam sarvadharmā na samvidyante nopalabbyante), dalej zaś dodaje: „w ten sam sposób idę̨ tę powinien stosować do wszystkich dharm, wewnętrznych i zewnętrznych" (evam ādbyātmika-bābyeșu sarva-dharmeșu samjñotpādayitavyā). Wypowiedź ta potwierdza przekonanie, jakie zgłaszałem we wcześniejszym rozdziale, że kwestia jaźni w buddyzmie nie sprowadza się po prostu do problemu jej istnienia bądź nieistnienia. W idei jaźni (ätman), w poczuciu indywidualnego istnienia (sat-kāya-drsstı) wyraża się najbardziej pierwotna intuicja istnienia, którą Budda, a za nim autorzy wczesnych tekstów mahajanistycznych, takich jak Käśyapa-parivarta-sūtra i zwłaszcza Aszta, zakwestionowali jako sposób manifestowania się pierwotnej niewiedzy (avidyā).

\section{3. Środkowa droga jako pustka}

W filozoficznych tekstach Nagardżuny nie znajdziemy żadnych otwartych deklaracji świadczących o inspirowaniu się Asztą i Kaśjapapariwartasutrq. Nie oznacza to jednak, iż teksty te były mu obce. Wręcz

152 Por. RGS I, 24c: mabatìm janeti karunām na ca sattva-samjña („Rozwija w sobie wielkie współczucie wolne od pojęcia bytu/istoty"). 
przeciwnie, sądzę, że jego twórczość pozostaje z nimi w bezpośrednim związku, czego jednak buddyjski filozof nie eksponuje. Za tym postępowaniem kryje się świadoma decyzja. Do tej kwestii powrócę w dalszym toku rozważań. Bazą dla filozoficznej twórczości Nagardzuny jest Kazanie do Katjajany i od określenia jego rangi dla tej twórczości zacznę niniejszy podrozdział.

Analizę filozofii Nagardżuny można prowadzić, wychodząc z kilku różnych punktów. Tutaj zaczniemy od XV rozdziału Podstawowych strof madbjamaki, czyli od tego, w którym twórca madhjamaki przywołał Kazanie do Katjajany. Rozdział ten inicjuje uwaga wiążąca samobyt (svabhāva) z zależnym powstawaniem. W MMK XV, 1 autor stwierdza ${ }^{153}$ :

na sambbavab svabbavasya yuktab pratyaya-betubbib | betu-pratyaya-sambbūtab svabbavab krtako bbavet \|

Powstawanie samobytu (svabbava) za sprawą warunków i przyczyn jest niezrozumiałe. [Bowiem] samobyt powstały dzięki przyczynom i warunkom byłby czymś wytworzonym (krtaka).

W terminie „samobyt” (svabbãva) można wyróżnić dwa momenty znaczeniowe, które Nagardżuna ściśle ze sobą wiąże. $Z$ jednej strony słowo to znaczy 'własna natura, istota', z drugiej zaś 'istnienie dzięki sobie samemu, istnienie $z$ siebie ${ }^{154}$. W znaczeniu pierwszym wydobyty jest moment esencjalny, w znaczeniu drugim egzystencjalny. Moment pierwszy wiąze się z naturalnym i powszechnym przekonaniem, że doświadczane rzeczy w sobie niosą fundament własnej tożsamości, w sobie są określone pod względem tego, co stanowi ich własną charakterystykę. Dlatego doświadczając rzeczy, mamy je odkrywać, a nie

153 Pełny przekład tego rozdziału zob. w: K. Jakubczak, Madbjamaka Nagardżuny. Filozofia czy terapia?, Kraków 2010, s. 203-205.

154 Dokładniej na temat owych dwóch momentów znaczeniowych w słowie svabbāva zob. ibidem, s. 175-176. 
tworzyć. Twórca madhjamaki będzie dowodził, że momentu esencjalnego nie da się odseparować od momentu egzystencjalnego. Absurdem jest twierdzić, że rzeczy mogą zawdzięczać swoje istnienie czemuś od nich różnemu i jednocześnie utrzymywać, że swoją tożsamość zawdzięczają sobie samym, czyli że mogą być zależne pod względem egzystencjalnym i niezależne pod względem esencjalnym. $\mathrm{Na}$ to właśnie wskazuje powyższa strofa. Nie da się pogodzić twierdzenia o zależnym powstawaniu rzeczy z przekonaniem, że rzeczy są obdarzone własną naturą. Jeśli więc utrzymujemy, że przesłaniem nauki Buddy jest powstanie w zależności, to musimy zaakceptować brak samobytu rzeczy. Pociąga to jednak dalsze konsekwencje, związane z możliwością określenia różnicy. Na tę okoliczność Nagardżuna zwraca uwagę w MMK $\mathrm{XV}, 3$, oznajmiając:

kutạ̣ svabhāvasyäbhāve parabhāvo bhavisyati | svabbävab parabbāvasya parabhāvo bi kathyate \|

Jeśli samobyt nie istnieje, to w jaki sposób może istnieć innobyt (parabbava)? Wszak samobyt innobytu zwany jest innobytem.

Wykładnia tej strofy nastręcza pewnych trudności ze względu na dwuznaczność terminu „innobyt” (parabhāva). W nim także można wyróżnić dwa pola semantyczne. $Z$ jednej strony może on znaczyć 'inny byt', z drugiej zaś 'byt istniejący dzięki czemuś innemu'. Przy pierwszym znaczeniu powyższa strofa wskazywałaby na zasadniczą trudność w objaśnieniu różnicy, odmienności. Jeżeli nie istnieje samobyt, czyli rzeczy nie niosą w sobie swej tożsamości, to nie sposób orzec realnej różnicy między nimi. Odmienność bowiem stwierdzana jest w oparciu o odniesienie do siebie dwóch różnych natur. Być różnym, to mieć inną własną naturę względem tego, do czego się odnosimy. Zatem realna różnica wymaga istnienia różnych samobytów. Jeżeli samobyt nie jest możliwy, to nie jest możliwe określenie realnej różnicy. Tak rozumiem przesłanie tej strofy, w którym uwypukla sį̨ 
pierwszy moment znaczeniowy. Jednak Mark Siderits i Shōryū Katsura proponują interpretować tę strofę w sposób odmienny, który koresponduje $z$ drugim momentem znaczeniowym. Według tych badaczy innobytem jest to w rzeczy, co jest różne od jej samobytu, czyli własnej natury, a co zawdzięcza ona temu, iż powstała w zależności od czegoś innego. Dla wody takim innobytem byłaby jej jakość ciepła, nienależąca do własnej natury wody, a tym samym przysługująca tejże ze względu na przyczynowe oddziaływanie ognia, w naturze którego, zgodnie $z$ indo-buddyjską tradycją, znajduje się ciepło. Innymi słowy, innobytem byłoby to jakościowe uposażenie rzeczy, które nie przynależy jej z własnej natury, a tym samym musi być ostatecznie zapożyczone od własnej natury innej rzeczy. Ponieważ jednak samobyt nie istnieje, nie sposób określić w rzeczy tego, co jest w niej inne od jej własnej natury. Ostatecznie więc orzekanie innobytu w drugim znaczeniu odsyła do możliwości orzeczenia innobytu w znaczeniu pierwszym $^{155}$.

Nie twierdzę, że wykładnia ta pozbawiona jest podstaw. Siderits formułuje ją na bazie komentarzy Bhawawiweki i Czandrakirtiego ${ }^{156}$. Mam jednak wątpliwości, czy obaj komentatorzy mówią to samo. $\mathrm{O}$ ile wypowiedź pierwszego zdaje się stanowić wsparcie dla wykładni Sideritsa, o tyle w słowach drugiego znajduje potwierdzenie mojego rozumienia powyższej strofy. Czandrakirti oznajmia bowiem (PP 266):

iha svabbava eva bi loke kaścit-svabbāvāntarāpeksayā para iti vyapadiśyate | yadi bi agnerausnyam svabhävab syãt, drava-svabbava-salila-sapeksaya parabhāva iti vyapadiśyeta |

$155 \mathrm{~W}$ ten sposób badacze ci objaśniają trzecią strofę piętnastego rozdziału MMK w: M. Siderits, Sh. Katsura, op. cit., s. 157-158. Wykładnia ta jest bez wątpienia działem pierwszego z tych badaczy, gdyż przedstawił on ją już wcześniej, zob. M. Siderits, op. cit., s. 201.

156 Zob. M. Siderits, op. cit., s. 201. 
Tutaj w tym świecie samobyt określa się jako „inny/odmienny" w odniesieniu od jakiegoś innego samobytu. Gdyby ciepło faktycznie było samobytem ognia, to określane byłoby jako „innobyt" w odniesieniu do płynności jako samobytu wody.

Siderits, tłumacząc ten fragment, pomija w drugim zdaniu słowo "płynność" (drava), co istotnie zmienia wymowę tekstu. Mamy zatem u niego:

Here is indicated that for the world, intrinsic nature is designated as "other" in dependence on some other intrinsic nature. If indeed beat were the intrinsic nature of fire, then extrinsic nature would be designated in dependence on water as a substantial intrinsic nature ${ }^{157}$.

W zdaniu pierwszym Czandrakirti wyraźnie oznajmia, że odmienność orzeka się na podstawie zestawienia ze sobą dwóch różnych samobytów. Zdanie drugie dostarcza ilustracji dla tego stwierdzenia. W thumaczeniu Sideritsa jednak związek między tymi dwoma zdaniami zostaje w najlepszym wypadku rozluźniony, a moim zdaniem wręcz zerwany. Badacz sugeruje w ten sposób, że orzekanie innobytu dokonuje się w obszarze wody poprzez rozróżnienie tego, co stanowi jej własną i nabytą (tj. zewnętrzną wobec własnej) naturę.

Nie twierdzę, jeszcze raz to podkreślę, że propozycja Sideritsa (a za nim też Katsury) jest zawieszona w próżni. Uważam tylko, iż sami buddyjscy komentatorzy wskazują w tym momencie na różne możliwości interpretacyjne. Wypowiedź Nagardżuny jest na tyle enigmatyczna, że pozostawia pole dla różnych sposobów jej rozumienia. Aczkolwiek sądzę, że sformułowanie "samobyt innobytu zwany jest innobytem" (MMK XV, 7 cd) sprzyja raczej wykładni Czandrakirtiego niż Bhawawiweki, za którym podąża Siderits. Z drugiej strony interpretacja ta ma pewną swoją wartość, gdyż narusza zdroworozsądkowe 
przekonanie, że rozróżnienie w rzeczy cech istotnych, czyli koniecznych i akcydentalnych (przypadkowych), znajduje podstawę w samej rzeczy. Sądzę jednak, iż egzegeza Czandrakirtiego, tak przynajmniej jak ją rozumiem, jako ogólniejsza daje wystarczające przesłanki, aby tę dystynkcję w równym stopniu unieważnić ${ }^{158}$.

Jeżeli usuwamy metafizyczne podstawy dla określenia tożsamości i zróżnicowania rzeczy, to ustalenie pojęć bytu (bhāva) i niebytu (abbāva) staje się niemożliwe. Nagardżuna stwierdza to w kolejnych dwóch strofach (MMK XV, 4-5) ${ }^{159}$. Ludzie jednak nieustannie starają się pojmować naukę Buddy poprzez użycie tych czterech pojęć. $\mathrm{Ci}, \mathrm{którzy}$ to czynią, ogtasza Nagardżuna, jej nie rozumieją (MMK $\mathrm{XV}, 6)$. W tym kontekście twórca madhjamaki przywołuje Kazanie do Katjajany. W MMK XV, 7 oznajmia:

kātyāyanävavāde cāstîti nāstīti cobhayam | pratișiddham bhagavata bhāväbhãva-vibhāvinā $\|$

W Pouczeniu Katjajany Czcigodny, który zna byt i niebyt, zanegował zarówno ,jest”, jak i „nie jest”.

Nie powinien zrażać nas fakt, iż Nagardżuna przytacza interesujące nas kazanie pod tytułem Pouczenie Katjajany (Kätyayanávavada). Zarówno bowiem wskazany adresat, jak i zwłaszcza przywołana treść pozwalają jednoznacznie zidentyfikować tę mowę. Co więcej, na podstawie treści możemy stwierdzić, że Nagardżunie bliższe jest kazanie w wersji sanskryckiej niż palijskiej. Chociaż wypowiada się o istnieniu zarówno poprzez formy czasownikowe (asti - 'istnieje'), jak i rzeczownikowe (astita, astitva - 'istnienie'), nigdy nie mówi o nim, korzystając $\mathrm{z}$ dużego kwantyfikatora ${ }^{160}$. Identycznie postępuje Czandrakirti, który komentując MMK XV, 7, oznajmia (PP 270):

${ }_{158}$ Do kwestii rozumienia innobytu (parabbava) wróç jeszcze za chwilę przy okazji krytyki przyczynowości w MMK I.

159 Por. także RĀ I, 71d: nastitvam api castitam („nieistnienia nie ma bez istnienia”).

160 Nie zgadzam się tutaj z opinią Kalupahany, który twierdził, że nie istnieją świadectwa pozwalające uznać, iż Nagardżuna korzystał z wersji kazania znacz- 
tena bhagavatā bhāväbbava-vibhävinā yasmād astitvam ca nastitvam cobhayam etat pratișiddham, tasmänna yuktam bhāvābhàva-darśanam tattvam ityāsthātum \|

Ponieważ Czcigodny, znawca bytu i niebytu, zanegował zarówno istnienie, jak i nieistnienie, dlatego nie jest właściwe twierdzić, że rzeczywistość/prawda jest widzeniem bytu i niebytu.

Zaraz po tych słowach komentator przytacza cytat z Kaśjapapariwartasutry. Odwołuje się do $\S 60$, o którym powiedziałem wcześniej, że stanowi najjaskrawsze nawiązanie do Kazania do Katjajany we wczesnych sutrach mahajany. Przy czym Czandrakirti przytacza ten fragment w poszerzonej wersji uzupełnionej o treść, która pojawia sį̨ w $\S 56$ i 57. Mamy więc (PP 270):

astīti kāsyapa ayameko ńtậ | nāstīti kásyapa ayameko 'ntạ I yad enayor antayor madhyam, tad arüpyam anidarśanam apratiștham anäbbäsam aniketam avijñaptikam | iyam ucyate kásyapa madhyamām pratipad bhüta-pratyavekșā iti $\|$

"Istnieje”, Kaśjapo, to jeden kraniec; „nie istnieje” to drugi kraniec. Co jest pomiędzy tymi krańcami, to jest bezforemne, niedające się wskazać, nieugruntowane, niewyobrażalne, nieoznaczone, nieprzedstawialne, to nazywa się, Kaśjapo, środkową drogą - właściwym oglądem zjawisk.

Dążąc do zakotwiczenia myśli Nagardżuny w tekstach sutrowych i tym samym jej uprawomocnienia jako wykładni ortodoksyjnej, wybitny komentator przywołuje jeszcze jeden niezwykle wymow-

nie różniącej sį̧ od palijskiej Kaczczajanagottasutty zachowanej też w wersji chińskiej, zob. D. J. Kalu pahana, Nagarijuna. The Philosophy pf the Middle Way, Albany 1986, s. 7. Wersja chińska oraz zachowana wersja sanskrycka, istnienie której umknęło uwadze tego autora, różnią się od wersji palijskiej brakiem dużego kwantyfikatora. Jak wskazywałem wcześniej, wbrew pozorom jest to różnica, która wpływa radykalnie na filozoficzną wymowę obu wersji. 
ny fragment z Samadbiradżasutry (Samādbi-räja-sūtra) ${ }^{161}$ LX, 34-35 (PP 270):

astīti nāstìti ubbe , pi antā śuddhì aśuddhìti ime, pi antā | tasmäd ubbe anta vivarjayitva madbye, pi sthanam na karoti panditab $\|$

astìti nāstīti vivāda eșab śuddhì aśuddbīti ayam vivādạ | vivādapraptyā na duḅkbam praśámyati avivādapräptya ca dubkbam nirudhyate $\|$

„Istnieje” i „nieistnieje” to dwa krańce. „Czystość” i „nieczystośćn to także dwa krańce. Dlatego, porzuciwszy oba krańce, mędrzec nie zajmuje stanowiska pośrodku.

„Istnienie” i „nieistnienie” tworzą spór. „Czystość” i „nieczystość" tworzą spór. Gdy sį̧ tkwi w sporze, cierpienie nie może zostać wyciszone. Gdy się nie tkwi w sporze, cierpienie zostaje usunięte ${ }^{162}$.

Pierwsza strofa tego fragmentu powtarza myśli znane nam już z Kaśjapapariwartasutry. W strofie drugiej pojawia się motyw nowy. Warto zwrócić na niego uwage jako zapowiedź rozważań, które pojawią się w drugiej części niniejszej pracy. Tekst podkreśla, że ujmowanie doświadczenia $w$ kategoriach opozycji tworzy wyrażające się $\mathbf{w}$ gotowości do sporów napięcie, które uniemożliwia osiągnięcie wyzwolenia.

${ }^{161}$ Samädhi-raja-sütra uważana jest za stosunkowo wczesny tekst mahajanistyczny, którego początki sięgają II w., zob. Studies in the Literature of the Great Vebicle. Three Mabayana Buddhist Texts, ed. L. O. Gomez, J. A. Silk, Ann Arbor 1989, s. 11. Zob. takze A. Skilton, Dating the Samadhiraja Sütra, JIP 7 (1999), s. 648. Tekst ten szczególnym uznaniem cieszył się w późnej tradycji madhjamaki. Cytowali go: Czandrakirti, Siantidewa (s. Śāntideva, koniec VII - poł. VIII w.) oraz Kamalasila (s. Kamalaśila, VIII w.), zob. na ten temat Studies in the Literature of the Great Vebicle..., s. 32-38.

162 Ten sam cytat Czandrakirti przywołał także w komentarzu do MMK V, 8 (PP 135). 
Strofa MMK XV, 7 nie jest jedynym miejscem, w którym Nagardżuna wspomina o szkodliwości opozycji istnienia i nieistnienia oraz potrzebie jej zaniechania. Ten akurat fragment jest ciekawy ze względu na jednoznaczne nawiązanie do wczesnej literatury buddyjskiej. Twórca madhjamaki do przeciwstawienia istnienia i nieistnienia $\mathrm{w}$ swoich tekstach $\mathrm{w}$ różnych kontekstach wracał wielokrotnie. Dziełem, w którym motyw ten pojawia się szczególnie często, jest Ratnawali (Ratnāvalī). Dla ilustracji tego stwierdzenia warto tutaj przytoczyć choćby tylko kilka przykładów.

W RĀ I, 62 Nagardżuna przyznaje wprost, podążając za Kazaniem do Katjajany, że istotą nauki Buddy jest wyjście poza kategorie istnienia i nieistnienia. Czytamy tam:

dharma-yautakam ity asmān nāstyastitva-vyatikramam | viddhi gambhìram ity uktam buddhānam śäsanämrtam ||

Dlatego powinieneś poznać dar dharmy przekraczającej istnienie i nieistnienie określanej głęboką, będącą nektarem nauki buddów.

Wyrazistość i kategoryczność tej deklaracji skłoniła Czandrakirtiego do przywołania jej w swoim komentarzu do MMK (PP 275). Idąc za Nagardżuną, podkreśla, że przekraczanie istnienia i nieistnienia wyróżnia madhjamakę na tle innych indyjskich i buddyjskich tradycji filozoficznych.

Jeszcze dobitniej Nagardżuna wypowiada się w RĀ II, 5, gdzie stwierdza:

iti satyanrtatito loko 'yam paramarthatab | asmad eva ca tattvena nopaity asti ca nasti ca \|

Ostatecznie ten świat jest poza prawdą i fałszem i dlatego nie [twierdzi się, że] realnie istnieje bądź nie istnieje. 
Z kolei w RĀ I, 45 Nagardżuna oznajmia, że wyjście poza istnienie i nieistnienia jest jednocześnie wyjściem poza opozycję występku i cnoty. Mamy więc:

jñānān nästyastitäśānteḅ papa-punya-vyatikramạ | durgateḅ sugateś casmāt sa mokșab sadbbir ucyate \|

Gdy dzięki poznaniu wyciszyło się istnienie i nieistnienie, przekracza się występek i cnotę. Dlatego święci mówią, że to jest wyzwolenie od nieszczęścia i pomyślności.

Zaniechanie opozycji istnienia i nieistnienia pociąga ważne konsekwencje nie tylko dla sposobu waloryzowania codziennego doświadczenia, ale także dla rozumienia nirwany. Jej osiągnięcie nie może oznaczać zanegowania doczesnego istnienia. Nie można na nią patrzeć jako na unicestwienie istnienia naznaczonego cierpieniem, gdyz to by oznaczało ujmowanie jej w opozycji do istnienia. Tak pojmowana nirwana byłaby przekreśleniem istnienia, unieważnieniem istnienia, negacją istnienia. W związku z tym Nagardżuna w RA I, 73 oznajmił:

nirurtes tena lokasya nopaity ünatvam arthatạ̧ |

antavän iti lokaś ca prștas tūṣnīm jino 'bhavat \|

W rzeczywistości wygaśnięcie [tj. nirwana] nie oznacza zaniku świata. Dlatego Zwycięzca pytany, czy świat ma koniec, zachowat milczenie.

Standardowy zarzut stawiany madhjamace zrównuje pustkę rzeczy z ich nieistnieniem. Nagardżuna zarzut ten odpierał, wskazując, iż koncepcja pustki nie jest koncepcją unicestwienia rzeczy, tylko koncepcją odmiennego spojrzenia na rzeczy, spojrzenia wykraczającego poza perspektywę istnienia i nieistnienia. $Z$ jednej strony zarzut nihilizmu ma sens tylko w obszarze istnienia zreifikowanego, zamkniętego w wewnętrznej naturze bytu. Jeżeli istnienie przysługiwać ma bytowi w sobie określonemu, to żadna zmiana nie jest możliwa. Zostajemy w ten sposób uwięzieni w bycie Parmenidesa. Z drugiej strony 
wszelkie orzekanie nieistnienia o bycie, który w sobie miał nieść swoją tożsamość, musi ostatecznie oznaczać jego całkowite przekreślenie. W wypadku pierwszym istnienie zostaje spetryfikowane. W wypadku drugim wszelka zmiana zostaje sprowadzona do nicestwienia. Tę myśl Nagardżuna formułuje w ostatniej strofie rozdziału (MMK XV, 11):

asti yad dhi svabhāvena na tan nāstīti śáśvatam | nastìdānim abbūt pürvam ity ucchedạ̣ prasajyate $\|$

[Twierdzenie, że] "to, co istnieje za sprawą samobytu (svabhāvena), nie może nie istniećn, implikuje wieczne trwanie (śäsvata). [Twierdzenie, że] „to, co teraz nie istnieje, istniało wcześniej", implikuje unicestwienie (uccheda).

Idea pustki jest wyrazem niezgody na istnienie, które petryfikuje. W związku z tym, gdy madhjamik mówi, że doświadczane rzeczy realnie nie istnieją, to obnaża w ten sposób iluzyjność naszej ufundowanej na niewiedzy intuicji istnienia. W ostatnim zdaniu zamykającym komentarz do tego rozdziału Czandrakirti wskazuje na faktyczną intencje madhjamaki kryjącą się za negacją bytu. Oznajmia: „orzec nieistnienie rzeczy to tyle, co orzec nieistnienie samobytu" (bhāvābhāvārtha eva svabhāvābhāvārtbaḅ; PP 279). Madhjamik, negując byt, nie opowiada się za nicością, tylko odmawia uznania kategorii istnienia skonstruowanej na wyobrażeniu wewnętrznej tożsamości rzeczy. W innym miejscu Czandrakirti dodaje (PP 495):

samurti-satyam bi ajñana-mātra-samutthapitam niḅsvabbavam buddhā tasya paramartha-lakșañạm suunnatām pratipadyamāno yogi nantadvaye patati $\mid$

Jogin, który rozpoznał, że konwencjonalna prawda pojawia się jedynie za sprawą niewiedzy i jest pozbawiona samobytu, który odkrył, że cechą tego, co ostateczne, jest pustka, nie popada w żaden $\mathrm{z}$ dwóch krańców. 
W Kazaniu do Katjajany odpowiedzią Buddy na błędne przeświadczenie o realności istnienia i nieistnienia była nauka o zależnym powstawaniu, która unieważniając obie kategorie, wyznaczała środkową drogę. Nagardżuna, podążając ową środkową drogą, dowodzi, iż konsekwencją nauki o zależnym powstawaniu jest idea pustki rzeczy, której status jest równie konwencjonalny jak każdego innego określenia sugerującego domniemane realne istnienie desygnatu. Mówi o tym wprost w MMK XXIV, 18:

yạ pratītya-samutpādạ śünyatațam pracakșmahe | sā prajñaptir upādāya pratipat saiva madhyamā $\|$

Twierdzimy, że co jest zależnym powstawaniem, to jest pustką. Ona jest względną nazwą. Ona jest środkową drogą.

Strofa ta określa równoważność czterech kategorii: zależnego powstawania, pustki, względnej nazwy, tj. konwencjonalnego określenia, i środkowej drogi.

Nagardżuna rozpoczyna MMK od określenia sensu nauki o zależnym powstawaniu. Temu zagadnieniu poświęcony jest rozdział I. Nie tylko on jest jednak poświęcony zależnemu powstawaniu. Kwestia ta stanowi przewodni temat jeszcze w rozdziałach VII, XX, XXVI oraz wraca w wielu obszernych fragmentach (jak np. w rozdziale $X$ ) i pojedynczych wypowiedziach. Niemniej rozdział I jest najważniejszy. W nim zostaje postawiona teza o niezgodności idei zależnego powstawania i samobytu poprzez wykazanie, że idei zależnego powstawania, o ile ma być rozumiana jako powstawanie rzeczy obdarzonych samobytem na podstawie oddziaływania rzeczy obdarzonych samobytem, nie da się utrzymać. W pozostałych rozdziałach owa równoważność jest już do pewnego stopnia założona i Nagardżuna więcej uwagi poświęca na odparcie zarzutów sformułowanych na bazie tego założenia.

Fakt, iż Nagardżuna rozpoczął swoje gtówne dzieło od kwestii zależnego powstawania, przyciągał uwage badaczy. Jay Garfield za powód takiego postępowania uznat to, iż $\mathbf{w}$ analizie przyczynowości 
w zarodkowej postaci zawarta jest główna koncepcja wyrażona w MMK XXIV, 18 o równoważności czterech kategorii ${ }^{163}$. Nie przecząc temu, iż $\mathrm{w}$ analizie tej obecna jest już zapowiedź podstawowego przesłania madhjamaki, sądzę, że za decyzją Nagardżuny stał poważniejszy powód. Nauka o zależnym powstawaniu stanowi kwintesencje dharmy Buddy. Kazanie do Katjajany jest tego najbardziej dobitnym świadectwem. Mowę tę, przypomnijmy, wieńczy twierdzenie głoszące, że widzenie zależnego powstawania oznacza widzenie nauki Buddy jako środkowej drogi. Owa środkowa droga została w kazaniu tym określona jako sposób wyjścia poza ujmowanie doświadczenia w kategoriach istnienia i nieistnienia. Jak już kilkakrotnie zauważyłem, mowa ta jest dla Nagardżuny kluczowa. Dlatego podążając środkową drogą, zaczyna on swoje najważniejsze dzieło właśnie od określenia sensu nauki o zależnym powstawaniu, zwłaszcza że w intensywnie rozwijającej się $w$ jego czasach tradycji abhidharmicznej idea ta znajdowała wykładnię, która w jego przekonaniu kłóciła się z nauką o porzuceniu istnienia i nieistnienia. Potwierdzenie tej opinii znajdziemy w pismach samego Nagardżuny. W słynnym hymnie Acintya-stava myśliciel ten oznajmił (CS III, 22):

astīti śáśvatì drștir nāstīty uccheda-darśanam | tenanta-dvaya-nirmukto dharmo 'yam desitas tvaya $\|$

"Istnieje" to pogląd o wieczności [tj. eternalizmu]. „Nie istnieje" to opinia o unicestwieniu [tj. anihilacjonizmu]. Dlatego przedstawiłeś tę naukę [o zależnym powstawaniu], wolną od dwóch krańców ${ }^{164}$.

163 J. Garfield, Dependent Arising and the Emptiness of Emptiness. Why Did Nagariuna Start with Causation?, PEW 44/2 (1994), s. 234.

164 Dwie pierwsze pady tej strofy to niemal dosłowny cytat z MMK XV, 10, czyli z rozdziału, w którym Nagardżuna powołuje się na Kazanie do Katjajany. Czytamy tam:

astiti śásvata-grabo nastīti uccheda-darśanam | tasmad astitva-nastitve naśriyeta vicakșanaḅ \| 
Nagardżuna sformułował złożoną i rozbudowaną krytykę idei zależnego powstawania. Przeprowadził ją na dwóch poziomach - uniwersalnym i lokalnym. Na poziomie pierwszym dążył do zakwestionowania relacji przyczynowej w ramach ogólnego modelu ujmującego w sposób wyczerpujący możliwe logiczne relacje między przyczyną i skutkiem. Tym samym chciał w ten sposób podważyć wszelkie możliwe teorie przyczynowości. $\mathrm{Na}$ poziomie drugim przedmiotem jego krytyki była przedstawiona w szkole sarwastiwady koncepcja przyczynowości, którą, jak się wydaje, traktował jako reprezentatywną dla sposobu myślenia abhidharmy ${ }^{165}$. Dla celu, jaki sobie stawiam w tej pracy, szczegółowa analiza owej krytyki jest zbędna. Poprzestanę tylko na poziomie uniwersalnym, co wystarcza do zilustrowania toku myślenia madhjamików kulminującego w przekonaniu o niemożliwości pogodzenia idei zależnego powstawania $z$ ideą samobytu. Ogólny plan swojej krytyki buddyjski myśliciel zaprezentowat już w pierwszej strofie rozdziału I (MMK I, 1), gdzie oznajmia:

na svato nāpi parato na dväbbyām nāpy abetutạ | utpanna jätu vidyante bhävạb kva cana ke cana \|

Nigdzie nie istnieją żadne rzeczy powstałe dzięki sobie samym, dzięki czemuś innemu, dzięki obu bądź bez przyczyny.

Chociaż wyróżnione zostały cztery możliwości, traktowane jako komplementarne i wyczerpujące domniemane relacje przyczynowo-skutkowe, uwage Nagardżuny i późniejszych komentatorów zaprzątają dwie pierwsze. Możliwość trzecia bowiem, jako uzyskana na drodze koniunkcji dwóch pierwszych, podziela $z$ nimi ich wady. Nie stanowi więc poważnej propozycji, jeżeli choćby jedna $\mathrm{z}$ nich jest nie

"Istnieje” to pojęcie eternalizmu. „Nie istnieje” to opinia anihilacjonizmu. Dlatego mędrzec nie powinien obstawać przy istnieniu i nieistnieniu.

${ }_{165} \mathrm{Na}$ temat koncepcji przyczynowości w szkole sarwastiwady zob. K. L. D ha mmajoti, Sarvāstivaada Abbidbarma, Hong Kong 2007, s. 181-189, 217-229. 
do utrzymania. Przeciwko możliwości czwartej natomiast, dopuszczającej powstawanie skutku w sposób całkowicie nieuwarunkowany, której wyrazem byłby czysty chaos, przemawiać ma codzienna praktyka i autorytet nauczania Buddy ${ }^{166}$. Dlatego w MMK I, 2 Nagardżuna zauważa ${ }^{167}$ :

na bi suabhãvo bhavaanäm pratyayadișu vidyate $\mid$

avidyamane svabbave parabhāuo na vidyate $\|$

Samobyt rzeczy nie istnieje w warunkach itd. Gdy nie istnieje samobyt, nie można znaleźć innobytu.

Stwierdzenie, że rzeczy powstają same z siebie, oznacza, że skutek obecny jest już w przyczynie. Klasycznym rzecznikiem takiej koncepcji w tradycji indyjskiej jest filozofia sankhji (sāmkbya). Madhjamaka podkreśla problematyczność rozumienia tej obecności. Jeżeli skutek jest rzeczą posiadającą własną naturę, to bycie obecnym w przyczynie sprowadza się do tego, że natura skutku jest tożsama z naturą przyczyny. Zatem obecność skutku w przyczynie musi oznaczać, że natura owego skutku daje się w przyczynie dostrzec przed pojawieniem sį̨ skutku. Jeżeli jednak natura skutku byłaby obserwowalna w przyczynie, to na czym faktycznie miałoby polegać zaistnienie skutku? Zatem

${ }_{166}$ Dokładniejszą analizę owych czterech możliwości znaleźć można w: J. Westerhoff, Nagarjuna's Madhyamaka. A Philosophical Introduction, OxfordNew York 2009, s. 94-112.

${ }^{167}$ W standardowej redakcji MMK de la Vallée Poussina podążającej za komentarzem Czandrakirtiego strofa ta pojawia się jako MMK I, 3. Wcześniejsze komentarze dostarczają jednak podstaw, aby sądzić, iż porządek strof drugiej i trzeciej w wersji pierwotnej mógt być odwrotny. Wydaje się też, że zmiana kolejności pozwala zbudować spójniejszą narracje. W swojej opinii podạżam za Sideritsem i Katsurą, którzy z kolei poszli za najnowszą redakcją MMK Shaoyonga Ye z 2011 r., zob. M. Siderits, Sh. Katsura, op. cit., s. 18. Niestety nie miatem możliwości skonsultować tej kwestii $z$ redakcją Shaoyonga Ye. 
mówienie o powstawaniu skutku tożsamego z przyczyną, przez co rozumie się realne jego zaistnienie, nie ma najmniejszego sensu, byłoby to bowiem powoływanie do istnienia tego, co już istnieje. $Z$ drugiej strony, jeżeli natura skutku jest już zawarta w naturze przyczyny, czyli w jej samobycie, to żadna zmiana nie jest możliwa, a to, co tutaj jest umownie nazywane przyczyną, będzie trwać niezmiennie ${ }^{168}$. Jeśli jednak skutek powstaje, nie może mieć własnej natury, gdyż jako obdarzony własną naturą, czyli samobytem, powstać by nie mógt.

Czy zatem rzeczy mogą istnieć dzięki czemuś innemu? Ta droga zamknięta jest ze względu na problem z ustaleniem owej inności. Czandrakirti stwierdza, że „inność to wzajemna relacja” (parasparäpeksam paratvam; PP 78.11-12) i podaje przykład wzajemnej relacji między dwoma współistniejącymi osobami. W wypadku skutku i przyczyny nie jest ona możliwa do ustalenia. Żeby ją bowiem ustalić, skutek musiałby współistnieć z przyczyną. Albo więc skutek współistnieje z przyczyną, wówczas jednak musi posiadać samobyt, a tym samym nie może być skutkiem danej przyczyny, albo nie współistnieje z przyczyną, wówczas jednak nie można określić inności, a tym samym nie można stwierdzić powstawania z czegoś innego.

Wniosek z powyższych rozważań płynie taki, iż nie sposób pogodzić idei zależnego powstawania $z$ ideą samobytu rzeczy, tzn. nie da się uzgodnić formuły zależnego powstawania z przekonaniem, że formuła ta opisuje relację między członami obdarzonymi samobytem. Dlatego w MMK I, 10 Nagardżuna zauważył:

bhāvānàm nịssuabhāvānām na satta vidyate yatạ | satidam asmin bhavatity etan naivopapadyate $\|$

Gdy nie zachodzi istnienie rzeczy pozbawionych samobytu, to formuła: "Jeśli to istnieje, to to powstaje" nie obowiązuje.

${ }^{168}$ Por. np. MMK XXIV, 38, gdzie Nagardziuna oznajmia, że gdyby rzeczy nie były puste, świat bytby statyczny. 
Jedynym zatem sposobem na uratowanie wartości owej formuły jest uznanie, że nie opisuje ona relacji między osadzonymi w sobie bytami, a nasze doświadczenie, czyli to, jak rzeczy nam się jawią, a jawią nam się jako zależne. Jej wartość jest zatem konwencjonalna (samvrtı). Podążając za tą myślą, Czandrakirti określił naturę konwencjonalnej praktyki, stwierdzając (PP 54.11):

kim samurter vyavastbanam vaktavyam | idam-pratyayatā-matrena samurteb siddbir abbyupagamyate |

Jak określa się stan konwencji? Uznaje się, że konwencjonalna praktyka określona jest jako całkowita zależność.

Według madhjamaki doniosłość nauki o zależnym powstawaniu polega na tym, iż nauka ta nie pozostawia miejsca na wyobrażenie samobytu, czyli na przekonanie, że istnieją byty, które w swoim istnieniu i w swojej tożsamości są autonomiczne i jako takie nie podlegają warunkowaniu. Pozostaje więc uznać, że najwłaściwszym sposobem opisu rzeczy, jest ujmowanie ich jako całkowicie zależnych (idam-pratyayatā-mātra). Całkowita zależność rzeczy wyklucza się z ideą samobytu. Prowadzi to do paradoksalnych wypowiedzi, które w warstwie literalnej przeczą przekonaniu o zależnym powstawaniu, przypisując rzeczom np. jakość niepowstania (anutpāda). Często pojawiają się one w tekstach madhjamików, sprawiając badaczom spore trudności interpretacyjne ${ }^{169}$. Czandrakirti w Jasnych stowach (Prasanna-padā) trzykrotnie wracał do tej kwestii, przywołując szerzej nie znaną su-

169 Ustępem najbardziej bodaj znanym $\mathrm{z}$ nagromadzenia takich paradoksalnych określeń jest tzw. mangala-śloka $\mathrm{MMK}$, czyli strofy otwierające traktat, w których Nagardżuna wskazuje na powód swojego szacunku dla Buddy. Oświadcza on tam: anirodham anutpadam anucchedam asásuatam | anekartham anänartham andgamam anirgamam \| yab pratitya-samutpadam prapañcopaśamam śivam 1 deśayāmäsa sambuddhas tam vande vadatām varam || 
trę Anavatapta-bradāpa-samkramana, dookreślając kontekst, w jakim owe paradoksy należy odczytywać. Stwierdza on (PP 239.10-13 oraz 500.7-10, 504.1-4):

yab pratyayair jayati sa by ajäto, no tasya utpadu sabbavato 'sti | yạ pratyayadbīnu sa śunya ukto yạ śūnyatạm jānati so 'pramattab ||

Co rodzi się dzięki warunkom, to jest niezrodzone, albowiem nie powstaje dzięki samobytowi. Co zależy od warunków, to określa się jako puste. Kto poznaje pustkę, jest uważny.

Zależne powstawanie rzeczy jest powstawaniem w obszarze doświadczenia. Doświadczamy pojawiania się i zaniku rzeczy. $\mathrm{Na}$ to doświadczenie rzutujemy przeświadczenie, o tym, iż owe rzeczy są w sobie określone, niosą w sobie swoją tożsamość. Żywimy więc przekonanie, iż powstawanie polega na wchodzeniu w byt realnych, $\mathrm{tj}$. obdarzonych samobytem, rzeczy, a ustawanie na ich z bytu wychodzeniu. $Z$ perspektywy pustki rzeczy sytuacja wygląda jednak inaczej. O tym, co jawi się jako realnie powstające, jako o faktycznie pustym, nie można ostatecznie orzec, iż realnie powstaje. Nie można o nim też orzec, że realnie zanika. Nie można o tym orzekać realnej trwałości, nie można też orzekać realnego unicestwienia itd. Jeżeli więc orzekamy powstawanie i ustawanie, to robimy to tylko w ramach codziennej, konwencjonalnej praktyki. Praktyka ta byłaby niemożliwa, gdyby rzeczy nie były pustymi. Dlatego Nagardżuna mógł powiedzieć w MMK XXIV, 36:

sarva-samvyvabarāmśs ca laukikan pratibadhase | yat pratìtya-samutpada-sūnyatạm pratibadbase \|

Składam hołd temu doskonale przebudzonemu, najlepszemu z nauczycieli, który nauczał o zależnym powstawaniu, dobroczynnym uciszeniu rozplenienia, niezanikaniu, niepowstawaniu, nieunicestwieniu, nietrwałości, nietożsamości, niezróżnicowaniu, nieprzychodzeniu, nieodchodzeniu. 
Kto odrzuca pustkę zależnego powstawania, ten odrzuca wszystkie światowe konwencje.

Obstawanie przy samobycie unieważnia codzienną praktykę, w tym również, a może zwłaszcza tę, która wyraża się w utrwalonym przez doświadczenie przekonaniu o powstawaniu i ustawaniu w zależności. Bez tej konwencji, bez tej wiary wszelkie podejmowanie wysiłku w ramach duchowej praktyki traci sens.

Często można spotkać się z twierdzeniem opartym na starszych badaniach, że idea pustki stanowi innowację Nagardżuny ${ }^{170}$. Przekonanie to wyrastało z jednej strony ze sposobu badania jego myśli, który polegał na kontrastowaniu jej z filozofią abhidharmy. Podstawowe strofy madbjamaki dostarczają wielu argumentów za tym, że rozwijająca się abhidharma była dla tego myśliciela ważnym negatywnym punktem odniesienia. Wystarczy tutaj wspomnieć ponownie choćby krytykę koncepcji przyczynowości w wydaniu sarwastiwady. Zatem takie podejście samo w sobie nie byłoby problematyczne, gdyby nie charakteryzująca postawę badaczy tendencja do tego, aby w poszukiwaniu reprezentatywnej wykładni abhidharmy odwoływać sį̨ do dzieł o dwa, a nawet trzy wieki późniejszych - do Abbidbarmakosi Wasubandhu (IV-V w.) i Wisuddbimaggi (Visuddbi-magga) Buddhaghosy (V w.) ${ }^{171}$. Chociaż same w sobie prace te są niezwykle wartościowe i interesujące, to reprezentują one dojrzałą fazę rozwoju abhidharmicznej tradycji,

170 Przez starsze badania rozumiem prace takich uczonych jak: T. Stcherbatsky, The Conception of Buddhist Nirvāna, Leningrad 1927; S. Schayer, Ausgewablte Kapitel aus der Prasannapada, Kraków 1931; T. R. V. Murti, The Central Pbilosopby of Buddhism, London 1955. Pierwszy uwaziat, ze Nagardżuna podważa całą wcześniejszą myśl buddyjską, zob. T. Stcherbatsky, op. cit., s. 54. Trzeci zaś mówił o Kopernikańskiej rewolucji dokonanej przez Nagardżunę w myśli buddyjskiej, zob. T. R. V. Murti, op. cit., s. 123.

171 Zob. S. Huifeng, "Dependent Origination = Emptiness" - Nagāriuna's Innovation? An Examination of the Early and Mainstream Sectarian Textual Sources, JCBSSL 11 (2013), s. 175-228. 
choćby w tym, iż ujednoznaczniają wykładnię abhidharmy. Usuwając wieloznaczności istniejące we wczesnej fazie rozwoju przez pomijanie potencjału interpretacyjnego, jaki tkwił w używanej w tym okresie terminologii, zamykają badaczom drogę do prześledzenia historii i dynamiki rozwoju myśli madhjamaki wyrastającej z podzielanego z wczesną abhidharmą słownika. Kategoria pustki, jak sądzę, stanowi dobrą ilustrację tej sytuacji. Kontekst pojawiania się tej kategorii w Sanjuktagamie szkoły sarwastiwady mógł dawać podstawy dla rozwoju wykładni jej znaczenia w madhjamace, chociaż w samej sarwastiwadzie rozwój poszedł $w$ innym kierunku ${ }^{172}$. Owych wczesnych badaczy można do pewnego stopnia usprawiedliwić. Madhjamaka bowiem pozostawała $\mathrm{w}$ dyskursie $\mathrm{z}$ abhidharmą przez wiele wieków i dla autorów późniejszych komentarzy do MMK z pewnością ważniejszym punktem odniesienia w polemice $\mathrm{z}$ abhidharmą były dojrzałe prace tej tradycji im współczesne, a nie teksty wczesne.

Jednocześnie niewątpliwy wpływ na utrwalanie się przekonania o rewolucyjnym charakterze myśli Nagardżuny miała narracja, jaką myśliciel ten stosowat w swoich pracach. Dbał on bowiem o to, aby przywoływać metaforykę dobrze ugruntowaną we wczesnych powszechnie akceptowanych tekstach. W pracach o charakterze stricte filozoficznym brak jest jakichkolwiek odniesień do wczesnej sutrowej literatury mahajany ${ }^{173}$, w tym zwłaszcza do koncepcji bodhisattwy. Chociaż w późniejszej mahajanie Nagardżuna będzie ściśle

172 Zob. wybór kazań z Sanjuktagamy, w których orzeka sį̨ pustkę w: M.-k. Choong, Annotated Translation of Sütras from the Chinese Samyuktagama relevant to the Early Buddhist Teachings on Emptiness and the Middle Way, Songkhla 2010. Zob. także É. Lamotte, Three Sūtras from the Samyuktagama concerning Emptiness, trans. S. Boin-Webb, BSR 10/1 (1993), s. 1-23.

173 Stąd Anthony K. Warder postawił wręcz pytanie, czy Nagardiuna był myślicielem mahajany, zob. A. K. Warder, Is Nagarjuna a Mabayanist?, [w:] The Problem of Two Trutbs in Buddhism and Vedanta, ed. M. Sprung, Dordrecht-Boston 1973, s. 78-88. Zob. także idem, A Course in Indian Pbilosophy, Delhi 1998, s. 138. 
wiązany $\mathrm{z}$ literaturą doskonałości mądrości ${ }^{174}$, można odnieść wrażenie, że jest mu ona całkowicie obca. Stąd zgłaszana przez niego koncepcja pustki może jawić się jako jego osobista innowacja.

Sprawa znacznie się komplikuje, gdy pod uwag̨ weźmiemy Ratnãvalī. W tym obszernym dziele, mającym status duchowego pouczenia (parikathā), a nie traktatu filozoficznego (śästra), nie tylko pojawia się typowa dla mahajany nomenklatura (bodhisattwa, stopnie bodhisattwy, sześć doskonałości, związek między współczuciem a mądrością), ale też wyraźnie zarysowana jest opozycja między wielkim pojazdem (mabā-yanā) a pojazdem stuchaczy (śrāvaka-yāna). Cechy te pozwalają w sposób jednoznaczny wiązać Ratnāvalī z sutrą Așta-sābasrika-prajñā-päramitā, która w swojej najstarszej postaci, jak zaznaczałem wcześniej, zdecydowanie wyprzedza okres życia Nagardżuny. Dlatego też niektórzy badacze skłonni są poddawać w wątpliwość autorstwo Nagardżuny i uznawać to dzieło za apokryf ${ }^{75}$. Postępowanie takie uważam za przejaw literaturoznawczej nadwrażliwości, gotowej w imię jakiejś wydumanej idei naukowej obiektywności, catkowicie ignorować świadectwa pochodzące $\mathrm{z}$ najbliższego otoczenia Nagardżuny, a zwłaszcza dostarczane przez dzieło jego bezpośredniego ucznia Arjadewy (Āryadeva; kon. II w. - pocz. III w.), zatytułowane Catub-śataka. Wydaje się bowiem czymś niezwykle mało prawdopo-

174 Postać Nagardżuny owiana jest legendą do tego stopnia, iż niewiele faktów $\mathrm{z}$ jego życia jesteśmy w stanie stwierdzić $\mathbf{w}$ sposób niebudzący wątpliwości. $\mathrm{Na}$ temat jego życia i legendy zob. m.in. M. Walleser, The Life of Nägarjuna from Tibetan and Chinese Sources, trans. A. A. Probsthain, AM 1 (1923), s. 421-455; V. W. Karambelkar, The Problem of Nagariuna, JIH 30/1 (1952), s. 21-33; S. K. Path ak, Life of Nagarjuna, IHQ 30/1 (1954), s. 93-95; K. S. Murty, Nagarjuna, New Delhi 1983 (rep.); J. Yün-hua, Nagarjuna, One or More?'A New Interpretation of Buddhist Hagiography, HR 10/2 (1970), s. 139-155; I. Mabbett, The Problem of the Historical Nagarjuna Revisited, JAOS 118/3 (1998), s. 332-346. Ogólnie na temat Nagardżuny i jego twórczości zob. D. S. Ruegg, The Literature of the Madhyamaka School of Philosophy in India, Wiesbaden 1981, s. 4-9.

175 Zob. A. K. Warder, A Course..., s. 138-139. 
dobnym, aby Nagardżuna wykazywał wobec idei wczesnej mahajany tak daleko idącą rezerwę, podczas gdy jego wierny uczeń tak zdecydowanie owe idee, zwłaszcza koncepcję bodhisattwy, promował. Jeżeli więc Nagardżuna w swoich siastrach milczy na temat mahajany, to należy w tym widzieć świadomy zamysł dążenia do oparcia głoszonej nauki wyłącznie na podzielanych przez wszystkich tekstach i nadania jej w ten sposób $\mathrm{z}$ jednej strony uniwersalnego wymiaru, z drugiej zaś ortodoksyjnego charakteru.

Zakorzenienie madhjamaki we wczesnych tekstach nie realizuje się jednak poprzez odwołania do obecnych w nich sformułowań idei pustki. Polega ono na podążaniu za wyrażaną w nich najbardziej fundamentalną intuicją istnienia i nieistnienia, a zwłaszcza za przestrogą, aby obu tych kategorii unikać. Zarówno w siastrach, jak i w Ratnāvali przestroga ta jest wyraźnie wyeksponowana, a w tym ostatnim dziele liczba odniesień do niej znacznie przewyższa liczbę odniesień do idei pustki. $\mathrm{Na}$ tę ostatnią należy zaś patrzeć nie tylko i nie tyle poprzez pryzmat jej związku z ideą zależnego powstawania, co poprzez pryzmat związku idei zależnego powstawania $z$ ideą środkowej drogi, czyli z zaleceniem zaniechania kategorii istnienia i nieistnienia. Idea pustki jako ściśle powiązana $\mathrm{z}$ ideą zależnego powstawania stanowi odpowiedź madhjamaki na ujmowanie doświadczenia w przeciwstawne kategorie bytu i niebytu.

Uważam zatem, iż koncepcja pustki madhjamaki nie stanowi myśli rewolucyjnej ${ }^{176}$. Sam termin „pusty/pustka” (p. suñña/suññatā, s. súunya/śúnyatā) pojawia się w nikajach i agamach na tyle często,

176 Nie jestem w tym przekonaniu odosobniony. Ostatnie dwie dekady przyniosły pewną grupe prac, których autorzy starają się przedstawić idee wczesnej madhjamaki jako $z$ jednej strony zakorzenione we wczesnych kazaniach Buddy, a $z$ drugiej jako efekt naturalnego i dość oczywistego w swojej dynamice rozwoju myśli w tych kazaniach wyrażonej, zob. A. Vélez de Cea, Emptiness in the Pali Suttas and the Question of Nagarjuna's Ortbodoxy, PEW 55/4 (2005), s. 507-528; A. Wynne, Early Buddbist Teachings...; Sh. Huifeng, op. cit.; M.-k. Choong, The Notion of Emptiness in Early Buddbism, Delhi 1999. 
dobnym, aby Nagardżuna wykazywał wobec idei wczesnej mahajany tak daleko idącą rezerwę, podczas gdy jego wierny uczeń tak zdecydowanie owe idee, zwłaszcza koncepcję bodhisattwy, promowat. Jeżeli więc Nagardżuna w swoich siastrach milczy na temat mahajany, to należy w tym widzieć świadomy zamysł dążenia do oparcia głoszonej nauki wyłącznie na podzielanych przez wszystkich tekstach i nadania jej w ten sposób $\mathrm{z}$ jednej strony uniwersalnego wymiaru, $\mathrm{z}$ drugiej zaś ortodoksyjnego charakteru.

Zakorzenienie madhjamaki we wczesnych tekstach nie realizuje się jednak poprzez odwołania do obecnych w nich sformułowań idei pustki. Polega ono na podążaniu za wyrażaną w nich najbardziej fundamentalną intuicją istnienia i nieistnienia, a zwłaszcza za przestrogą, aby obu tych kategorii unikać. Zarówno w siastrach, jak i w Ratnāvalī przestroga ta jest wyraźnie wyeksponowana, a w tym ostatnim dziele liczba odniesień do niej znacznie przewyższa liczbę odniesień do idei pustki. $\mathrm{Na}$ tę ostatnią należy zaś patrzeć nie tylko i nie tyle poprzez pryzmat jej związku $z$ ideą zależnego powstawania, co poprzez pryzmat związku idei zależnego powstawania $\mathrm{z}$ ideą środkowej drogi, czyli z zaleceniem zaniechania kategorii istnienia i nieistnienia. Idea pustki jako ściśle powiązana $\mathrm{z}$ ideą zależnego powstawania stanowi odpowiedź madhjamaki na ujmowanie doświadczenia w przeciwstawne kategorie bytu i niebytu.

Uważam zatem, iż koncepcja pustki madhjamaki nie stanowi myśli rewolucyjnej ${ }^{176}$. Sam termin „pusty/pustka” (p. suñ̃a/suñnatā, s. śūnya/śūnyatā) pojawia się $\mathrm{w}$ nikajach i agamach na tyle często,

176 Nie jestem w tym przekonaniu odosobniony. Ostatnie dwie dekady przyniosły pewną grupe prac, których autorzy starają się przedstawić idee wczesnej madhjamaki jako $z$ jednej strony zakorzenione we wczesnych kazaniach Buddy, a $z$ drugiej jako efekt naturalnego i dość oczywistego w swojej dynamice rozwoju myśli w tych kazaniach wyrażonej, zob. A. Vélez de Cea, Emptiness in the Pali Suttas and the Question of Nagarjuna's Ortbodoxy, PEW 55/4 (2005), s. 507-528; A. Wynne, Early Buddhist Teachings...; Sh. Huifeng, op. cit.; M.-k. Choong, The Notion of Emptiness in Early Buddbism, Delhi 1999. 
przekonania o konieczności całkowitego zarzucenia kategorii istnienia i nieistnienia do opisu naszego doświadczenia. To z kolei będzie oznaczało rozszerzenie zastosowania idei niejaźniowości na wszelkie możliwe przedmioty, w tym również na dharmy. Celem ugruntowania powyższych spostrzeżeń $w$ materiale źródłowym warto przyjrzeć się przynajmniej kilku miejscom $\mathrm{z}$ wielu, w których pojawia się odwołanie do pustki.

W MN III, 293-297 zrelacjonowana została rozmowa Buddy z Sariputtą. Budda spytał swojego wybitnego ucznia: „W jakim stanie często teraz przebywasz, Sariputto?" (katamena tvam, sāriputta, vibärena etarabi babulam vibarasitit), na co ten odpowiedział: „Teraz, Dostojny, często przebywam w pustce" (suññatā-vihārena kbo abam, bhante, etarabi babulam vibarāmīti). $\mathrm{Na}$ tę informację Budda zareagowat w sposób niezwykle pozytywny, stwierdzając: „Dobrze, dobrze, Sariputto! Teraz doprawdy często przebywasz w stanie wielkiego człowieka. Albowiem to jest siedziba wielkiego człowieka, mianowicie, pustka" (sādbu sādbu, sāriputta. mabā-purisa-vibārena kira tvam, sāriputta, etarabi babulam vibarasi. mabā-purisa-vihāro b' esa, sāriputta, yadidam suññatā). Następnie Budda daje opis praktyki uważności, polegającej na śledzeniu własnych afektywnych postaw zajmowanych wobec tego, czego się doświadczało poszczególnymi zmysłami podczas zbierania jałmużny. W wypadku rozpoznania stanów szkodliwych zaleca dążenie do ich usunięcia. W wypadku doświadczeń korzystnych zaleca utrwalanie postawy. Określenie suñnatā-vihāra zdaje się tu występować $\mathbf{w}$ dwóch rolach - jako określenie swoistej praktyki uważności polegającej na opróżnianiu doświadczającego umysłu ze szkodliwych reakcji oraz jako określenie stanu umystu oczyszczonego $z$ owych szkodliwych postaw, który to stan wieńczy ową praktykę uważności, a który charakteryzuje wielkich ludzi (mabã-purisa), czyli istoty przebudzone.

Z kolei w SN IV, 360 pustka pojawia się jako określenie jednego $\mathrm{z}$ wyżsych stanów skupienia, zwanego skupieniem na pustce (suñ̃ato samādbi), którego praktykowanie zbliża do osiągnięcia stanu 
nieuwarunkowanego (asankbata), czyli nirwany. Niezwykle ciekawe miejsce znajdziemy w MN I, 297-298. Sariputta poucza Mahakotthitę (p. Mahākoțthita), jak ten powinien rozumieć określenie „wyzwolenie umysłu poprzez pustkę" (suñ̃atāa-cetovimutti). Stwierdza, co następuje:

katamã c' āvuso suññatā cetovimutti | idh' àvuso bbikkbu arañña-gato vā rukkba-mūla-gato vā suñña-gāra-gato vā iti pațisañcikkbati | suñ̃am idam attena vā attaniyena vã ti | ayam vuccat' àvuso suñ̃̃ātã cetovimutti $\|$

Czym, przyjacielu, jest wyzwolenie umyshu poprzez pustkę? Przyjacielu, oto w tym świecie mnich, który odszedł do lasu lub udał się pod drzewo, lub do pustej chaty, tak rozważa: „to jest puste pod względem jaźni lub tego, co należy do jaźni”. To zwie się wyzwoleniem umysłu poprzez pustkę ${ }^{180}$.

$\mathrm{Z}$ wypowiedzi tej dowiadujemy się, że wyzwolenie umysłu poprzez pustkę określa taki jego stan, w którym całkowicie uwolnił się od pojęcia jaźni, czyli osiągną̧ nirwanę.

Analizując takie przypadki, Nancy McCagney postawiła swego czasu tezę, że w najwcześniejszym okresie myśli buddyjskiej terminem „pustka” określano szczególne stany medytacyjne, a zwłaszcza takie, które równały się osiągnięciu wyzwolenia ${ }^{181}$. Określenie pustki miało stosować się do nirwany, nie do sansary. Opinia ta jednak sformułowana została zbyt pochopnie i w oparciu o zawężoną lekturę tekstów źródłowych ${ }^{182}$. Niemniej posłużłła badaczce do tego, aby uprawomocnić przekonanie o heterodoksyjności wykładni Nagardżuny ${ }^{183}$, która

180 Analogiczne pouczenie pojawia się w SN IV, 296-297 w rozmowie czcigodnego Godatty (p. Godatta) z pewnym Czittą (p. Citta).

181 Zob. N. McCagney, Nagarjuna and the Philosophy of Openness, Lanham 1997, s. 57.

182 Zob. A. Vélez de Cea, op. cit., s. 508-509.

${ }^{183}$ N. McCagney, op. cit., s. XIX. 
to cecha miała być szczególnie wyraźnie widoczna w twierdzeniu filozofa o braku rozróżnienia między sansarą a nirwaną (MMK XXV, 19).

Liczne przykłady $z$ wczesnych tekstów przemawiają przeciwko temu przekonaniu. Jeden $\mathrm{z}$ bardziej znamienitych pochodzi z krótkiego Kazania o pustce (Suñna-sutta) zamieszczonego w SN IV, 54. Budda odpowiada w nim na pytanie zadane przez swojego ucznia Anandę:

suñ̃̃o loko suñño loko ti bhante vuccati | kittavatã nu kbo bhante suñño loko ti vuccati $\|$ yasmā ca kbo änanda suññam attena vã attaniyena vã | tasmã suñño loko ti vuccati ||

Mówi się, Dostojny, „świat jest pusty, świat jest pusty”. W jakim sensie, Dostojny, mówi się „świat jest pusty"?

Ponieważ, Anando, pusty jest pod względem jaźni i tego, co należy do jaźni, dlatego mówi się „świat jest pusty”.

Następnie Budda wskazuje na oko (tj. zmysł wzroku) jako na puste, na formę materialną jako na pustą, na świadomość wzrokową, na kontakt wzrokowy, na uczucia, a w domyśle na wszystkie władze ujmowania i na pięć zespołów jako na puste.

Podczas wstępnej lektury można by odnieść wrażenie, że stwierdza się tutaj tylko tyle, iż w świecie nie ma żadnych jaźni i żadne zjawisko, które określa ludzkie doświadczenie, nie ma związku z żadną jaźnią. Takie odczytanie tego tekstu, choć możliwe, zatrzymuje się na jego powierzchni.

Pierwszą rzeczą, na którą powinniśmy zwrócić uwagę, jest pozorna rozbieżność pomiędzy przedmiotem zapytania, a uszczegółowioną odpowiedzią Buddy. Ananda pyta o pustkę świata. Budda zaś po stwierdzeniu, iż ta oznacza pustkę pod względem jaźni i tego, co należy do jaźni, daje opis świata, sprowadzając go do doświadczenia świata. Rozbieżność jest pozorna, gdyż bazuje na zdroworozsądkowym rozumieniu świata jako tego, co realnie istnieje na zewnątrz. We wcześniejszym rozdziale wykazywałem, że nowatorstwo idei Buddy polegało na tym, iż odrzucił takie rozumienie świata, uznając je za sposób 
wyrażania się niewiedzy. Światem dla twórcy buddyzmu jest nasze doświadczenie świata. Zatem sposób udzielania odpowiedzi przez Buddę jest zgodny $z$ jego odkryciem i stanowi kolejny dowód na stuszność postawionej we wcześniejszym rozdziale tezy.

W związku z tym, i to jest druga rzecz, którą należy podkreślić, gdy Budda mówi o niejaźniowości świata, mówi znacznie więcej, niż sugeruje to powierzchniowe odczytanie tekstu. Oznajmia mianowicie, że nie dysponujemy żadnym innym pojęciem istnienia, w szczególności żadnym obiektywnym pojęciem istnienia od tego, które wyraża sį̨ w naszym doświadczeniu świata ujmowanym w opozycję bytu i niebytu. Odpowiedzią na takie doświadczenie świata była nauka o zależnym powstawaniu. Mówi ona o kształtowaniu się naszego doświadczenia. Ale nie o kształtowaniu się naszego fałszywego przekonania o istnieniu jaźni w różnym od niej obiektywnym świecie, jak sugeruje abhidharma, lecz o kształtowaniu się naszego doświadczenia świata, czyli po prostu o kształtowaniu się świata. Wszystko w naszym doświadczeniu jest uwarunkowane, nie ma niczego, co byłoby w sobie określone niezależnie od wszystkiego innego. Stwierdzenie, że świat jest pusty oznacza zatem, że kategorie bytu i niebytu się do niego nie odnoszą. Jeżeli wszystko w naszym doświadczeniu jest uwarunkowane, to wszystko uwarunkowane jest w świecie. Nie ma żadnego dharmy, żadnego zjawiska, które niosłoby w sobie swoją tożsamość. To jest powód, dla którego Kazanie do Katjajany jest tak ważne dla Nagardżuny. Jeżeli myśl twórcy madhjamaki jest rewolucyjna, to dlatego, że rewolucyjna jest myśl Buddy, a jej manifestem jest Kātyāyana-sūtra. Nagardżuna w związku z tym jest rewolucjonistą ortodoksyjnym czy też może lepiej byłoby powiedzieć - rewolucyjnym ortodoksem.

Patrzeć na świat jako na bezjaźniowy oznacza zatem wyzwolić się $\mathrm{z}$ opisu świata poprzez kategorie istnienia i nieistnienia, a to równoznaczne jest $\mathrm{z}$ wyzwoleniem jako takim. Myśl tę Budda wypowiedział w Sn. 1118-1119. Mogharadża (p. Mogharāja) spytał tam go: ,jak na świat patrzącego pan śmierci nie widzi?" (katbam lokam avekkbantam maccu-rājā na passati), czyli jak trzeba patrzeć na świat, żeby nie pod-| 
legać więzom sansary, tj. być wyzwolonym (nie być widocznym dla pana śmierci). Budda odpowiedział:

suñnato lokam avekkhassu mogharäja sadā sato attannu-dițthim übacca, evam maccu-taro siya, evam lokam avekkbantam maccu-raja na passati

Mogharadżo, pozostając uważnym, patrz na świat jako na pusty, usunąwszy pogląd o jaźni, w ten sposób przekroczy się śmierć, tak na świat patrzącego pan śmierci nie widzi.

Pamiętając o tym, Nagardżuna mógt oznajmić w RĀ II, 2:

sarvadbarma anätmäna ity ato bhasitam jinaib |

dhātusatkam ca taị sarvam nimititam tac ca nārthatạ $\|$

Dlatego zwycięzcy powiedzieli, że wszystkie zjawiska są niejaźnią. Stwierdzili, że sześć elementów [tutaj: sześć władz ujmowania] tak jak to wszystko jest nierealne.

Dla Nagardżuny, jak widzimy, zgodnie z tym, co powiedziałem powyżej, kategoria „niejaźni” (anatman) ma nie tylko ten sam zakres co kategoria „pustki” (śūnyatā), czyli stosuje się do wszystkich zjawisk, ale wręcz znaczy to samo - niesamobytność (nibssvabhāva), czyli brak obiektywnej realności (närthataḅ). W RĀ II, 3 filozof potwierdza, że podstawę dla takiej wykładni myśli Buddy znajduje w postawie, jaką ten drugi zajmował wobec kwestii jaźni. Czytamy tam:

naivam atma na canātmā yätba-bbütyena labbyate | atmänatma-krte drșți vavärasman mabā-muniḅ $\|$

Z ostatecznej perspektywy [tj. z perspektywy faktycznego sposobu istnienia rzeczy] ani jaźni, ani niejaźni nie można pojąć. Dlatego Wielki Asceta wykluczył oba poglądy odnoszące się do jaźni i niejaźni. 
Nauka o niejaźniowości jest nauką o pustce, czyli o tym, że nic w sobie nie niesie swojej realności. Gdy patrzymy jednak na negacje jaźni z tzw. obiektywnej perspektywy, to tkwimy w tym samym błędzie, co ci, którzy afirmują istnienie jaźni. Dlatego w ramach owej obiektywizującej perspektywy obie możliwości zostały wykluczone, gdyż obie są wyrazem tego samego błędu.

Przykładem orzekania pustki we wczesnych tekstach, na który warto wskazać w kontekście omawiania postawy madhjamaki, jest wypowiedź Buddy przytoczona w SN II, 267. Wartość tego przykładu polega na tym, że mamy tutaj do czynienia z wyraźną sugestią istnienia związku między pustką a zależnym powstawaniem. Jest to sugestia $\mathrm{w}$ tym sensie, że nie wspomina się o zależnym powstawaniu wprost, tylko przywołuje się je, mówiąc o nauce głębokiej (gambbirā) i zasobnej w znaczenie (gambbiratthā). Tymi bądź synonimicznymi do nich określeniami Budda standardowo, jak to już wcześniej mogliśmy zobaczyć, nazywał naukę o zależnym powstawaniu (DN II, 55; SN II, 36; SN II, 92). Budda zaleca zatem, aby uczniowie studiowali „te kazania wygłoszone przez Tathagatę, które są głębokie, zasobne w znaczenie, pozaświatowe i związane z pustką" (ye te suttantā tathagata-bbāsitã gambhīra gambhīratthā lokuttarā suññata-pațisamyutta) $)^{184}$.

Deklaracje o związku między środkową drogą, zależnym powstawaniem a pustką bez problemu znajdziemy także w Sanjuktagamie. Wspomnę tutaj tylko o dwóch. W SĀ $293^{185}$ Budda oświadcza, że

184 Zob. także AN I, 72, gdzie mowa jest o dwóch rodzajach zgromadzenia (parisā). Pierwsze tworzą ci, którzy są wyszkoleni w ozdobnej mowie (ukkācita-vinìta), drugie ci, którzy są wyszkoleni w badaniu (pațipucchā-vinītā). Pierwsi nie wnikają w głęboką naukę Buddy, zadowalając się zgrabnymi słowami. Drudzy natomiast ją studiują, nie przykładając wagi do ładnych sformułowań. Do opisu tej nauki użyta została ta sama fraza. Zob. też SN V, 407, gdzie Budda poucza świeckiego wyznawcę o wartości studiowania głębokiej nauki. Tutaj również przytoczona została ta sama fraza.

185 Nie jest znana palijska wersja tej sutry. Zachowała się natomiast wersja sanskrycka NidSa 11. Przekład tej sutry z języka chińskiego znaleźć można w: M.-k. Choong, Annotated Translation..., s. 10-15. 
naucza dharmy, która jest pozaświatowa (lokottara), związana z pustką (śūnyatā-pratisamyukta) oraz zgodna z zależnym powstawaniem (pratītya-samutpādānulomatā) $)^{186}$. Natomiast w SĀ $297^{187}$ naukę o zależnym powstawaniu określa jako „mowa dharmy zwana wielką pustką" (mabā-śūnyatā-nāma dharma-paryāya; NidSa 15.3). Chociaż w NidSa 15.4 pojawia się także określenie mabā-śūnyatā-dharma-paryāya, co pozwala tę nazwę przełożyć jako „wielka mowa dharmy o pustce"188.

Wskazywatem powyżej, że powiązanie we wczesnych tekstach pustki z niejaźniowością stanowi wystarczająca podstawę dla wsparcia koncepcji pustki głoszonej przez madhjamików. Niemniej można w nikajach znaleźć miejsce, w którym odniesienie do pustki jako niesubstancjalności zostało dobitniej zaznaczone, chociaż zamiast terminu suñ̃a/suñnatā pojawiły się jego synonimy. W Kazaniu o pianie (Phena-sutta; SN III, 140-143) Budda opowiedziat historię o człowieku obdarzonym dobrym wzrokiem, który dostrzegłszy wielki bałwan piany na rzece, poddał go badaniu. Przekonał się wówczas, że owa piana jest pusta (rittaka), próżna (tucchaka) oraz niesolidna (asāraka), tj. pozbawiona substancji, istoty, wartości. W ten sam sposób, oznajmia Budda, mnich, który poddał gruntownemu i wnikliwemu badaniu formę materialną ( $r u \bar{p} a$ ), odkrywa, że ona ,jest pusta i próżna" (rittakam tucchakam boti; SN III, 142) oraz, że „żadnej substancji [ew. solidności, istoty] tutaj nie można znaleźć" (säro ettha na vijjati; SN III, 143). Kontynuując swoją opowieść, Budda po kolei przyrównuje uczucia do bąbli na wodzie powstałych podczas deszczu, postrzeżenia do nocnego mirażu, formacje wolicjonalne do pustego w środku pnia bananowca, a świadomość do iluzji. Na temat wszystkich

186 Dwa ostatnie określenia znajdują się tylko w chińskiej wersji sutry. W zachowanej sanskryckiej ich nie ma, chociaż drugie pojawia się w NidSa 14.6.

187 Palijska wersja tego kazania w SN II, 60-63. Zachowała się wersja sanskrycka - NidSa 15. Przekład tego kazania zob. M.-k. Choong, Annotated Translation..., s. 33-38. Zob. także É. Lamotte, op. cit., s. 9-15.

${ }_{188}$ Określenia te nie pojawiają się w wersji palijskiej. 
zespołów powtarza, że są puste, próżne i niesolidne. Postrzegając je w ten sposób, Budda kończy swoją opowieść, mnich doświadcza znużenia (nibbindatı) nimi, a to prowadzi do bezpragnieniowości (viräga) i w konsekwencji do wyzwolenia (vimutta). Nie sposób nie dopatrzeć się $\mathbf{w}$ tych określeniach zapowiedzi nauki o pustce jako niesamobytności (resp. braku realności) wszystkich zjawisk. Tak na tę opowieść patrzył Czandrakirti, który przywołał wszystkie powyższe metafory jako argument świadczący na rzecz idei pustki - rzeczy ostatecznie nie są takie, jakimi wydają się konwencjonalnie (PP 41).

Zamykając wątek pustki we wczesnych tekstach, przywołam jeszcze jedno kazanie, które pojawia się zarówno w palijskiej Sanjuttanikaji (SN III, 132-135), jak i w chińskiej (sanskryckiej) Sanjuktagamie (SĀ 262) ${ }^{189}$. Obie wersje są do siebie bardzo zbliżone pod względem strukturalnym, narracyjnym oraz zawartego w nich sensu. Niemniej w jednym momencie różnią się od siebie. W SĀ 262 pojawia się istotne dopowiedzenie, którego nie ma w wersji palijskiej. Bohaterem opowieści jest mnich Czhanda/Czhanna (s. Chanda, p. Channa), który zwrócił się do starszych mnichów, aby nauczyli go dharmy w taki sposób, żeby mógt ją widzieć. Mnisi pouczyli Czhandę o nietrwałości i niejaźniowości wszystkich zespołów. Ten jednak oznajmił, że wie o nietrwałości i niejaźniowości. W tym miejscu obie opowieści na moment się rozchodzą. W wersji palijskiej Czhanna przyznaje, że chociaż to wszystko wie, to jego umysł nie znajduje spokoju, nie potrafi zaprzestać pragnienia, lgnięcia, nie potrafi się wyzwolić. W wersji chińskiej (sanskryckiej) ton wypowiedzi Czhandy zostaje zachowany, ale sformułowanie jest odmienne. Czhanda bowiem przyznaje się, że nie raduje go, gdy słyszy o pustce (vivikta) wszystkich działań, o tym, że nie należy lgnąć, oraz o tym, że nirwanę osiąga się zniszczeniem pragnienia $\mathrm{i}$ wygaszeniem pożądania ${ }^{190}$. W wyniku tego wyznania,

189 Zob. przekład tej sutry z chińskiego w: M.-k. Choong, Annotated Translation..., s. 16-28.

${ }^{190}$ Zob. ibidem, s. 18. 
obie wersje się w tym zgadzają, Czhanda został odesłany do Anandy, który powtórzył mu w całości Kazanie do Katjajany. W obu wypadkach efekt tego zabiegu był ten sam. W wersji palijskiej Czhanna urzeczywistnił naukę (dhammo abbisameto), w wersji chińskiej osiągnął oko mądrości (prajña-cakșu), czyli wgląd i wyzwolenie (vimukti). Z tym, że w drugiej wersji dzięki urzeczywistnieniu, mógł wreszcie ze spokojem znieść słowa o pustce i wyciszeniu wszystkiego. Taka siła przekazu tkwi według opinii tradycji w Kazaniu do Katjajany.

Nagardżuna kazanie to przywołał tylko raz, ale w swoich dziełach wielokrotnie odwoływał się do jego przesłania, czyli do zaniechania ujmowania doświadczenia w kategoriach istnienia i nieistnienia. Zwracałem już na to uwagę i wskazywałem kilka przykładów. W MMK IX, 12 twórca madhjamaki daje wyraz klasycznemu buddyjskiemu przekonaniu, że instrumentem do osiągnięcia tego celu jest wykazanie sprzeczności tkwiących w przekonaniu o istnieniu jaźni. Konkludując rozważania na ten temat, stwierdził:

prāk ca yo darśanädibhyab sạmpratam cordhvam eva ca | na vidyate 'sti nāstīti nivrttās tatra kalpanāb $\|$

Doprawdy nie istnieje nic przed postrzeżeniem itd., równocześnie oraz po nim. W tych okolicznościach pojęcia „istnienia" $\mathrm{i}$ „nieistnienia” zanikły.

Gdy zobaczymy, że ugruntowane w poczuciu sobości przekonanie o istnieniu jaźni jako podmiotu widzenia, słyszenia i pozostałych aktywności ujmowania nie daje się obronić ani przy założeniu, że wyprzedza ona $w$ swoim istnieniu postrzeganie, ani że istnieje $z$ nim równoczesne, ani tym bardziej że istnieje dopiero po zajściu postrzeżenia, to ogólne pojęcia/wyobrażenia (kalpana) istnienia i nieistnienia przestają nas zniewalać (nivrtta) i zostają wyciszone. Osiągnięcie tego celu wymaga jednak samozaparcia i ufności, czego świadectwo dat wspomniany przed chwilą Czhanda. Mając na względzie ten fakt, $\mathrm{Na}-$ gardżuna podkreśla w MMK V, 8: 
astitvam ye tu paśyanti nastitvam cālpabuddbayaḅ | bbāvanam te na paśyanti draștavyopaśamam śivam \|

Ci małego umysłu, którzy postrzegają istnienie i nieistnienie bytów, nie dostrzegają dobroczynnego uciszenia tego, co sį̨ jawi.

Tkwiąc w opozycji bytu i niebytu, również na nirwanę patrzy się przez pryzmat tych dwóch kategorii. Ci, którzy postrzegają stan aktualny jako istnienie, będą widzieć w niej całkowite ustanie czy wręcz unicestwienie istnienia. Inni, którzy odbierają wartość stanowi aktualnemu, wykazując jego bytową ułomność, będą w nirwanie widzieli przejście do autentycznego bytu. Nagardżuna odrzuca obie opcje jako będące konsekwencją tego samego błędu. Dlatego w MMK XXV, 10 filozof zauważa:

prabānam cabravīc chasta bbavasya vibbavasya ca |

tasmān na bbavo näbbavo nirvanam iti yujyate II

Nauczyciel mówił o zaniechaniu istnienia i nieistnienia [ew. powstawania i ustawania]. Dlatego właściwe jest mówić, że nirwana nie jest ani bytem, ani niebytem.

Natomiast w RĀ I, 42 uzupełnia tę myśl o pozytywny opis nirwany. Czytamy tam:

na cābbavo 'pi nirvānam kuta evàsya bbāvatā | bhāvabbava-paramarśa-ksayo nirvānam ucyate \|

Nirwana nie jest nawet niebytem, jakże może być bytem? Nirwaną określa się zanik przywiązania do bytu i niebytu.

Na przykładzie powyższego cytatu możemy się przekonać, jak poważnie Nagardżuna potraktował Kazanie do Katjajany. Bez większego ryzyka można by stwierdzić, że cała jego filozofia, to wyciąganie konsekwencji z dokonanego przez Buddę odkrycia dotyczącego roli, jaką w konstytuowaniu się sansarycznego doświadczenia cierpienia odgry- 
wają kategorie istnienia i nieistnienia. Dlatego nirwanę, podkreśla Nagardżuna $z$ emfazą, należy rozumieć jako przemianę postawy na taką, w której kategorie te przestają odgrywać jakiekolwiek znaczenie. Nirwana, jeżeli można tak powiedzieć, jest stanem epistemicznym, a nie ontycznym. Wszelkie zatem pytania o to, czym jest nirwana z perspektywy ontologii, nie mają najmniejszego sensu, tak samo jak nie mają sensu pytania o pośmiertny stan tego, który nirwanę osiągnął. Można by powiedzieć, że ich sens zamknięty jest w perspektywie światowej (s. laukika, p. lokiya). Ci, którzy w niej tkwią, dają świadectwo niezrozumienia transcendentalnego (s. lokottara, p. lokuttara) przesłania nauki Buddy. Aby przyblizyć ich do zrozumienia tego przesłania, oznajmia Nagardżuna w MMK XVIII, 6, Budda stosował szczególne narzędzia pedagogiczne. Czytamy tam:

ätmety api prajñapitam anätmety api deśitam 1 buddhair nätmã na cānātmā kaścid ity api desitam ||

Buddowie powiadali „jaźń” oraz nauczali „niejaźñ”. Nauczali także „ani jaźń, ani niejaźñ".

Nauka Buddy w Kazaniu do Katjajany sformułowana została z ostatecznej tzn. transcendentalnej perspektywy. Jest ona ekspresją bezpośredniego widzenia faktycznego stanu rzeczy. Perspektywa ta nie pozostawia miejsca na „jest” $i$ „nie jest”. Dla tego, kto tkwi w perspektywie sansarycznej ufundowanej na poczuciu sobości wyrażającym się poprzez "doświadczanie" istnienia i nieistnienia, perspektywa ta może się jawić jako nie tyle niezrozumiała, co wręcz absurdalna i groźna. Przy czym nie jest to efekt wyłącznie ograniczenia poznawczego, lecz w równym stopniu też afektywnego. Ściśle rzecz ujmując, oba te ograniczenia są jednym. Niewiedza bowiem nie jest zwykłym brakiem wiedzy, lecz nacechowaną afektywnie afirmacją błędu poznawczego. Aby ten stan zmienić, należy ów fakt uwzględnić. Sposobem na to jest stopniowe kruszenie kognitywnych zahamowań, do czego używane są różne sposoby orzekania o jaźni i bycie. Mając to na względzie, twórca madhjamaki oświadcza (YṢ 30): 
sarvam astīti vaktavyam ädau tattva-gaveșinab | paścad avagatārthasya nibssangasya viviktata $\|$

$\mathrm{Na}$ początku należy mówić poszukiwaczowi prawdy, że „wszystko istnieje”. Później, gdy zrozumiał znaczenie [tych słów] i nie lgnie [do świata, osiąga] oderwanie (viviktata).

Oczywiście wypowiedź ta ujmuje tylko punkt wyjścia i punkt dojścia. W poniższej relacji Nagardżuna zwraca uwagę na etapy pośrednie (ŚS 44):

yod ces pa dang yod med ces yod dang med ces de yang yod 1 sangs rgyas rnams kyis dgongs pa yis gsungs pa rtogs par sla ma yin $\|$

Buddowie mówili „istnieje”, "nie istnieje” oraz „istnieje i nie istnieje" z pewną intencją. Niełatwo to zrozumieć.

Ostatecznie tych etapów może być cztery, jak dowiadujemy się z traktatu Arjadewy. Wybitny uczeń Nagardżuny wyartykułował to przekonanie następująco (CŚ VIII, 20):

sad asad sad-asac ceti nobbaym ceti kathyate |

nanu vyādhi-vaśát sarvam ausadham nạma jayate \|

Mówi się „istnieje”, "nie istnieje”, „istnieje i nieistnieje” oraz żadne [tzn. ani istnieje, ani nie istnieje]. Czyż nie jest tak, że ze względu na chorobę wszystko staje się tym, co zwie się lekarstwem?

Nagardżuna i Arjadewa potwierdzają, że na naukę Buddy należy patrzeć wyłącznie pod kątem jej funkcji, jaką jest niesienie pomocy innym w ich dążeniu do przebudzenia. Wszystko, co mówi Budda, mówi z pewną intencją. Przenika ona całą jego naukę. Podkreślając ten fakt, Budda posłużył się słynną metaforą przyrównującą rolę, jaką pełni ona w jego nauce, do roli soli w morzu. Tak jak woda morska ma tylko jeden smak - smak soli, tak jego nauka ma jeden smak - 
smak wyzwolenia ${ }^{191}$. Intencją nauki Buddy jest pomoc w zmianie sytuacji poznawczej cierpiącej istoty. Nie jest nią wyprowadzenie cierpiącej istoty ze sfery ułomnego istnienia i wprowadzenie jej do sfery istnienia autentycznego. Dążąc do zrozumienia nauki Przebudzonego, należy wyzbyć się owego Platońskiego schematu. Nagardżuna dał temu wyraz w MMK XXV, 24, gdzie oznajmił:

sarvopalambhopaśamab prapañcopaśamạ śivab | na kva cit kasyacit kaścid dharmo buddhena desitab \|

Uciszenie poznawania wszystkiego, uciszenie [pojęciowego] rozplenienia jest dobroczynne. Budda nikogo i nigdzie nie nauczał żadnej dharmy.

Uciszenie poznawania wszystkiego (sarvopalambhopaśama) nie jest świadectwem nihilizmu poznawczego, nie jest przejawem przekonania o przyrodzonej słabości naszych władz poznawczych. Chodzi tu bowiem o uciszenie poznania rozumianego jako aktywność w obszarze świata ufundowanego na istnieniu i nieistnieniu, czyli w obszarze świata, w którym za stosowne uważamy rozstrzygnąć, co istnieje i co nie istnieje. Innymi słowy, jest to poznawanie w obszarze błędu poznawczego. Intencją nauki Buddy jest pokazanie, jak ten błąd zniwelować. Dlatego Nagardżuna może oświadczyć, że „Budda nikogo i nigdzie nie nauczał żadnej dharmy". Jego nauka bowiem nie jest opisem niczego, co istniałoby w sensie realistycznym, czyli jako w sobie ufundowane. W stwierdzeniu tym filozof pozostaje wierny Aszcie, ale też najstarszym tekstom buddyjskim. To jednak wykażę w części drugiej niniejszej pracy.

Upowszechniana przez Nagardżunę nauka o pustce wszystkich rzeczy ma swoją podstawę w Kazaniu do Katjajany. Jednak w oczach

191 AN IV, 203: „Tak, Paharado, jak wielki ocean ma tylko jeden smak - smak soli, tak też, Paharado, ta nauka i dyscyplina ma jeden smak - smak wyzwolenia" (seyyathā pi pabāräda maba-samuddo eka-raso lona-raso, evam eva kho pabāräda ayam dhamma-vinayo ekaraso vimutti-raso). 
oponentów, wierzących w deskryptywną, a tym samym też poznawczą wartość kategorii istnienia, nauką tą twórca madhjamaki sprzeniewierza się buddyjskiemu przesłaniu. Usuwając ontyczny fundament, usuwa fundament poznawczy, czyli czyni poznanie niemożliwym z powodu braku przedmiotu, którego poznać należy w jego istnieniu i w jego jakościowym uposażeniu. Pozbywa się w ten sposób również fundamentu aksjologicznego, gdyz wszelkie wartościowanie zostaje zawieszone w pustce, a nie w bycie. Ma tym samym odbierać nadzieje na wyzwolenie. W świetle nauki o pustce staje się ono niemożliwe, gdyż nie istnieje nic, do czego warto by dążyć

Odpowiedź Nagardżuny jest jednoznaczna i bezkompromisowa. To ci, którzy nie potrafią wyzbyć się istnienia i nieistnienia, czyli nie potrafią wyzbyć się lgnięcia do wyobrażenia istnienia, występują przeciwko nauce Buddy. Przywiązanie do istnienia musi bowiem ostatecznie skutkować albo spetryfikowaniem bytu, albo pojęciem nicości jako owego bytu całkowitym przekreśleniem. W obu wypadkach konsekwencje są fatalne. Dopiero nauka o pustce otwiera przestrzeń dla nadziei na wyzwolenie. Taki jest sens poniższej wypowiedzi Nagardżuny z MMK XXIV, 14:

sarvạ̣ ca yujyate tasya śūnyatã yasya yujyate | sarvam na yujyate tasya śūnyam yasya na yujyate \|

Wszystko jest możliwe dla tego, dla kogo pustka jest możliwa. Nic nie jest możliwe dla tego, dla kogo pustka nie jest możliwa.

Pustka otwiera przestrzeń dla nadziei na wyzwolenie, gdyż pozwala we właściwy sposób spojrzeć na codzienne doświadczenie ${ }^{192}$. Dopiero w obliczu pustki jesteśmy w stanie zrozumieć, co to znaczy, że wszystko podlega warunkowaniu. A skoro wszystko podlega warunkowaniu,

192 Zob. PP 368-369. Zob. także K. Lang, Candrakirti on the Limits of Language and Logic, [w:] A Companion to Buddhist Pbilosopby, ed. S. M. Emmanuel, Chichester 2013, s. 335. 
to nic nie stoi na przeszkodzie, abyśmy mogli wziąć $\mathrm{w}$ tym procesie czynny udział. Nadziei tej nie mogą żywić ci, którzy trzymają się istnienia. Doświadczenie oceniane poprzez idę̧ istnienia staje się ostatecznie jakąś niezrozumiałą aberracją doskonałego bytu, co stwierdził już pozostający u źródeł greckiej filozofii Parmenides. W nie lepszej sytuacji są ci, którzy trzymają się idei nieistnienia. Wierzą oni bowiem ostatecznie, że orzekanie realnego istnienia ma sens wyłącznie wobec tego, czego doświadczają, a ponieważ doświadczają też zmiany, sądzą, iż oznacza ona realne nicestwienie bytu. Skoro wszystko podlega nicestwieniu, to nie sposób żywić nadziei na trwały sukces. Dlatego Nagardżuna oznajmił w MMK XXIV, 36:

sarva-samvyvabaramís ca laukikan pratibādhase | yat pratītya-samutpada-sūunyatam pratibädhase \|

Negujesz wszystkie powszechne praktyki, jeśli negujesz pustkę zależnego powstawania.

Tylko perspektywa pustki zgodna jest $z$ intencją przyświecającą nauce Buddy. Zrozumieć pustkę, to zrozumieć zależne powstawanie; zrozumieć zależne powstawanie, to zrozumieć cztery szlachetne prawdy - ogłasza Nagardżuna w MMK XXIV, 40:

yạ pratītya-samutpādam paśyatĩdam sa paśyati $\mid$ dubkham samudayam caiva nirodham märgam eva ca $\|$

Kto widzi zależne powstawanie, ten widzi to: cierpienie, powstawanie, ustanie i ścieżkę. 



$$
\begin{aligned}
& \text { Część druga } \\
& \text { PRAWDA } \\
& \text { JAKO PRZEDMIOT LGNIECCIA } \\
& \text { POZA ABSOLUTYZMEM I NIHILIZMEM } \\
& \text { EPISTEMOLOGICZNYM }
\end{aligned}
$$





\section{Nauka Buddy jako sceptycyzm}

\subsection{Poznanie, widzenie, mądrość}

Jest czymś zadziwiającym, jak uporczywe okazuje się przeświadczenie wiążące myśl buddyjską ze sceptycyzmem. W 1908 r. wyraził je John Burnet, komentując doniesienie Antygonosa z Karystos o sposobie życia Pirrona (ok. 360-270 r. p.n.e.). Stwierdzit: „Widzimy, że ci, którzy znali dobrze Pirrona, przedstawiali go jako kogoś w rodzaju buddyjskiego arhata, a to nie pozostawia wątpliwości co do tego, jak

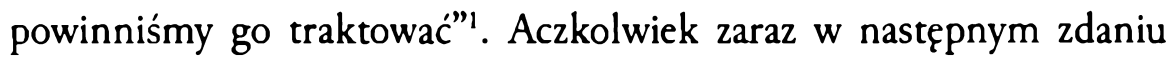
zastrzegł, że powiązanie Pirrona $z$ buddyzmem w mniejszym stopniu wskazuje na sceptycyzm tego pierwszego, bardziej zaś na jego ascetyczne i kwietystyczne usposobienie. Burnet zdecydowanie podążał za sugestią Friedricha Nietzschego, któremu postawa starożytnego filozofa, zarówno pod względem epistemologicznym, jak i etycznym, kojarzyła się z buddyzmem do tego stopnia, iż nazwał go „buddystą dla Grecji"2.

Przekonanie o istnieniu ideowych, bo nie historycznych, związków między sceptycyzmem a buddyzmem wyraził także inny badacz -

1 J. Burnet, Sceptics, [w:] Encyclopaedia of Religion and Ethics, ed. J. Hastings, vol. 11, New York 1908, s. 229: We see that those who knew Pyrrho well described him as a sort of Buddhist arhat, and that is doubtless bow we should regard bim.

2 F. Nietzsche, Wola mocy, thum. S. Frycz, K. Drzewiecki, Warszawa 1910-1911, s. 268. 
Louis de la Vallée Poussin, który w encyklopedycznym haśle Scepticism (Buddhist) orzekł, iż takiego podobieństwa można dopatrzyć się w odniesieniu do szkoły madhjamaki, znanej ze swojej negatywnej postawy. Według niego buddyści (tj. madhjamikowie) „są sceptykami jeśli chodzi o ostateczną rzeczywistość, a nie w odniesieniu do zwykłego istnienia"'. Sceptycyzm madhjamaki byłby zatem sceptycyzmem lokalnym związanym z niemożliwością rozstrzygnięcia prawdziwości żadnego sądu odnoszącego się do ostatecznej rzeczywistości, tj. do jakiegoś ostatecznego bytu fundującego empiryczną fenomenalną rzeczywistość.

$\mathrm{O}$ ile przekonanie drugie wiążące madhjamakę ze sceptycyzmem znalazło w kolejnych dekadach sporą grupę zagorzałych obrońców i było powtarzane wielokrotnie ${ }^{4}$, o tyle przekonanie pierwsze długo pozostawało raczej ewenementem ${ }^{5}$. W $1980 \mathrm{r}$. podjął się jego obrony Everard Flintoff . W 1988 r. bardzo ogólnie, acz dobitnie, tezę te wspart Richard P. Hayes, który stwierdził: „Jednak podejście Buddy wykazuje podobieństwo pod względem pewnych cech do słabszej metodycznie postaci sceptycyzmu przypisywanej domniemanemu założycielowi sceptycznej szkoły, Pirronowi z Elidy" ${ }^{\prime}$. Dalej zaś czytamy:

3 L. de la Vallée Poussin, Scepticism (Buddhist), [w:] Encyclopaedia of Religion and Etbics, ed. J. Hastings, vol. 11, New York 1908, s. 232: [Buddhists] are sceptics as concerns ultimate reality, not as concerns mere existence.

4 Zob. np. B. K. Matilal, Perception. An Essay on Classical Indian Theories of Knowledge, Oxford 1986; A. Kuzminski, Pyrrbonism. How the Ancient Greeks Reinvented Buddhism, Lanham 2008; J. L. Garfield, Epoche and Sünyatd. Skepticism East and West, PEW 40/3 (1990), s. 285-307.

5 Wyjątkiem jest niemieckojęzyczny artykuł rumuńskiego badacza Arama M. Frenkiana z 1958 r., w którym streszcza tezy swojego doktoratu z 1957 r. Formułuje w nim opinię o indyjskich korzeniach myśli Pirrona, zob. A. M. Frenkian, Der griechische Skeptizismus und die indische Philosopbie, „Bibliotheca Classica Orientalis” 4 (1958), s. 211-250.

6 E. Flint off, Pyrrbo and India, ${ }_{n}$ Phronesis" 25/1 (1980), s. 88-108.

7 R. P. Hayes, Dignaga on the Interpretation of Signs, Dordrecht-Boston-London 1988, s. 51: But the outlook of the Buddha does show a resemblance to some features of the less methodical form of skepticism that is attributed to the putative 
„Przynajmniej w dążeniu do obrony doksastycznego minimalizmu, tj. w ograniczaniu opinii do minimum, pirronizm i buddyzm, jak się wydaje, mają wystarczająco wiele wspólnych cech, aby uzasadnić nazywanie pewnej wczesnej tendencji w ramach kanonicznego buddyzmu nierozwiniętym sceptycyzmem".

Dopiero jednak Christopher I. Beckwith, wzmacniając sugestie wyrażone niewiele wcześniej przez Georgiosa T. Halkiasa ${ }^{9}$, przekonanie to uczynił główną tezą swojej książki zatytułowanej Greek Buddba (2015). Twierdzi w niej, że myśl Pirrona zarówno co do swej treści, jak i struktury odzwierciedla myśl wczesnego, prenormatywnego buddyzmu ${ }^{10}$. Według Beckwitha zasadnicza intencja nauk starożytnego filozofa - uzyskanie spokoju umystu (ataraxia) poprzez wyzbycie się wszelkich poglądów - „stanowi dobrze znaną idę̧ wczesnego buddyzmu"11. Autor gtosi, że Pirron nie tylko dokonał zapożyczeń z myśli buddyjskiej, lecz wręcz ją skopiował i przetransponował na grunt grecki ${ }^{12}$. Tym samym Beckwith uważa, że stanowi ona pierwsze historycznie wiarygodne świadectwo buddyjskich przekonań ${ }^{13}$, tym bardziej interesujące, że zachowane w Grecji ${ }^{14}$.

founder of the skeptical school, Pyrrbo of Elis. Zob. takzie ibidem, s. 52, gdzie Hayes stwierdzit, ze Nagardżuna dał pierwszą apologię buddyjskiego sceptycyzmu w postaci rozwiniętego systemu.

8 Ibidem, s. 52: At least in their advocacy of doxastic minimalism, that is, keeping one's opinions as few as possible, Pyrrhonism and Buddhism appear to have enough of a characteristic in common to warrant our calling one early strain within $\mathrm{Ca}$ nonical Buddhism an inchoate skepticism.

9 Zob. G. T. Halkias, When the Greeks Converted the Buddha. Asymmetrical Transfers of Knowledge in Indo-Greek Cultures, [w:] Religions and Trade, ed. P. Wick, V. Rabens, Leiden-Boston 2014, s. 65-115.

10 Ch. I. Beckwith, Greek Buddha. Pyrrho's Encounter with Early Buddhism in Central Asia, Princeton-Oxford 2015, s. 21.

11 Ibidem, s. 18.

12 Ibidem, s. 21, 32.

13 Ibidem, s. 61.

14 Warto $\mathrm{w}$ tym momencie wspomnieć, że w pewnym sensie przeciwstawnej opinii broni Thomas McEvilley. Uważał on, że wszystkie te momenty 
W dalszej części skonfrontuję się z twierdzeniem Beckwitha o istnieniu analogii $\mathrm{w}$ obszarze pojęciowych relacji między wczesnym buddyzmem a filozofią Pirrona. Mimo istnienia pewnych analogii, które obejmują nawet poziom pojęciowej struktury, nie wykluczając możliwości faktycznych zapożyczeń, będę wykazywat, że istnieje zasadnicza różnica między myślą buddyjską a sceptycyzmem greckiego filozofa oraz neopirronizmu, która polega na ukierunkowaniu logicznych relacji między pojęciami tworzącymi semantyczne struktury obu koncepcji. Wykażę, że owo ukierunkowanie logicznych relacji między pojęciami sprawia, że myśli buddyjskiej w najmniejszym nawet stopniu nie można przypisać sceptycznych intuicji ${ }^{15}$.

Oczywiście przypisanie buddyzmowi sceptycyzmu wobec powszechnie uznawanego przeświadczenia o tym, iż ten pierwszy kładzie ogromny nacisk na poznanie prawdziwe, może dokonać się tylko w oparciu o starannie pod względem historycznym i merytorycznym wyselekcjonowany zestaw materiału źródłowego. W konsekwencji

w myśli Pirrona, wobec których formułuje się podejrzenie, że zostały zapożyczone z Indii, ukształowały się w Grecji w okresie wcześniejszym, zob. Th. McEvilley, The Shape of Ancient Thought. Comparative Studies in Greek and Indian Pbilosopbies, New York 2002, s. 493-499. Z drugiej strony stawiał on hipotezę, że to filozofia madhjamaki (zwłaszcza u jej źródeł, czyli w twórczości Nagardżuny) wykazuje wyraźne wpływy sceptycyzmu oraz przede wszystkim greckiej dialektyki i logiki, co z kolei mogło być ważnym źródłem stawianego jej zarzutu nihilizmu, zob. ibidem, s. 501-505.

15 Należy mocno podkreślić, iż termin nsceptycyzm ${ }^{n}$ bywa $\mathrm{w}$ odniesieniu do buddyzmu nadużywany. Mianem tym badacze skłonni są określać charakterystyczne dla myśli buddyjskiej postawy, które są wyrazem jej krytycyzmu. Buddyzm z jednej strony nacechowany jest szczególnym dystansem poznawczym, który wyraża sį̨ odmową wchodzenia w dyskusję na pewne tematy, z drugiej strony natomiast przeprowadza liczne krytyki charakterystycznych dla filozofii niebuddyjskiej idei. Owego krytycyzmu nie należy jednak mylić ze sceptycyzmem we właściwym tego słowa znaczeniu, czyli ze świadomie wyrażaną negatywną postawą wobec możliwości zdobycia wiedzy. W niniejszej pracy terminu ${ }_{n}$ sceptycyzm" używam tylko w tym wąskim, technicznym, znaczeniu. 
W dalszej części skonfrontuję się z twierdzeniem Beckwitha o istnieniu analogii $w$ obszarze pojęciowych relacji między wczesnym buddyzmem a filozofią Pirrona. Mimo istnienia pewnych analogii, które obejmują nawet poziom pojęciowej struktury, nie wykluczając możliwości faktycznych zapożyczeń, będę wykazywał, że istnieje zasadnicza różnica między myślą buddyjską a sceptycyzmem greckiego filozofa oraz neopirronizmu, która polega na ukierunkowaniu logicznych relacji między pojęciami tworzącymi semantyczne struktury obu koncepcji. Wykażę, że owo ukierunkowanie logicznych relacji między pojęciami sprawia, że myśli buddyjskiej $w$ najmniejszym nawet stopniu nie można przypisać sceptycznych intuicji ${ }^{15}$.

Oczywiście przypisanie buddyzmowi sceptycyzmu wobec powszechnie uznawanego przeświadczenia o tym, iż ten pierwszy kładzie ogromny nacisk na poznanie prawdziwe, może dokonać się tylko w oparciu o starannie pod względem historycznym i merytorycznym wyselekcjonowany zestaw materiału źródłowego. W konsekwencji

w myśli Pirrona, wobec których formułuje się podejrzenie, że zostały zapożyczone z Indii, ukształtowały się w Grecji w okresie wcześniejszym, zob. Th. McEvilley, The Shape of Ancient Thought. Comparative Studies in Greek and Indian Pbilosophies, New York 2002, s. 493-499. Z drugiej strony stawiał on hipoteze, że to filozofia madhjamaki (zwłaszcza u jej źródeł, czyli w twórczości Nagardżuny) wykazuje wyraźne wpływy sceptycyzmu oraz przede wszystkim greckiej dialektyki i logiki, co z kolei mogło być ważnym źródłem stawianego jej zarzutu nihilizmu, zob. ibidem, s. 501-505.

is Należy mocno podkreślić, iż termin „sceptycyzm” bywa $\mathbf{w}$ odniesieniu do buddyzmu nadużywany. Mianem tym badacze skłonni są określać charakterystyczne dla myśli buddyjskiej postawy, które są wyrazem jej krytycyzmu. Buddyzm z jednej strony nacechowany jest szczególnym dystansem poznawczym, który wyraża się odmową wchodzenia w dyskusję na pewne tematy, z drugiej strony natomiast przeprowadza liczne krytyki charakterystycznych dla filozofii niebuddyjskiej idei. Owego krytycyzmu nie należy jednak mylić ze sceptycyzmem we właściwym tego słowa znaczeniu, czyli ze świadomie wyrażaną negatywną postawą wobec możliwości zdobycia wiedzy. W niniejszej pracy terminu "sceptycyzm" używam tylko w tym wąskim, technicznym, znaczeniu. 
samo owo przeświadczenie musi spotkać się z kontestacją i ostatecznie musi zostać uznane za historycznie nieuprawnioną ekstrapolację buddyjskich przekonań z okresu późniejszego na naturę myśli buddyjskiej z okresu najwcześniejszego.

Zgodnie $\mathrm{z}$ owym powszechnie uznawanym przeświadczeniem buddyzm od samego początku miał kłaść nacisk na poznanie prawdziwe jako na drogę do przebudzenia, a tym samym do wyzwolenia. Wypowiedzi na różne sposoby odmieniające sformułowanie "Ja to poznaje i widzę" (tam abam jānāmi passāmi; MN I, 329) pojawiają się w Trójkoszu niezliczoną liczbę razy. Za klasyczną wypowiedź to poświadczającą uznać można następujące słowa z MN I, 7:

janato abam bbikkhave passato asavānam kbayam vadāmi no ajānato no apassato

Nauczam, mnisi, że dzięki poznaniu i widzeniu (jānato passato) następuje zniszczenie/wygaszenie wycieków/skaz (äsava), a nie dzięki niepoznaniu i niewidzeniu ${ }^{16}$.

Wycieki (āsava), które mają być w ten sposób wygaszone, to karmicznie ukształtowane siły, same wpływające na kształtowanie się dalszego karmana, ukierunkowując ludzkie działanie. Ich wygaszenie równoważne jest $\mathrm{z}$ osiągnięciem stanu arhata, a zatem stanu wyzwolenia $z$ sansary ${ }^{17}$. Tym, co należy $w$ ten sposób poznawać i widzieć, jest natura pięciu skandh, czyli zespołów, ich powstawanie i ustawanie

16 Identyczne sformułowanie pojawia się taki̇e w SN II, 29 oraz SN III, 152. Zob. takize. M.-k. Choong, The Fundamental Teachings of Early Buddhism, Wiesbaden 2000, s. 34.

17 Standardowa lista podaje cztery takie wycieki/skazy: skaza [skłaniania się ku] pragnieniu zmysłowemu (kämäsava), skaza [skłaniania się ku] istnieniu (bhavasava), skaza [skłaniania się ku] poglądowi/spekulacji (dițthasava) i skaza [skłaniania się ku] niewiedzy (avijjasava). Czasami w wyliczeniu pomija się skazę [skłaniania się ku] poglądowi, czasami zaś w wyliczeniu pojawia się skaza [skłania się ku] nieistnieniu (abhavasava). Do tego zagadnienia, zwłaszcza w związku z wyciekiem trzecim, niebawem powrócę. 
(SN II, 29; SN III, 152-153). Jeżeli osiągamy tę formę naoczności, w pełni poznajemy (pajānäti) rzeczy, jakimi są (yatbā-bbüta), a tę formę naoczności osiągamy dzięki medytacyjnemu doskonaleniu umystu (bbavanä; SN III, 153-154) polegającemu na praktyce skupienia (samāabi; SN III, 13) ${ }^{18}$, która dokonuje się w samotności (pațisallana; SN III, 15), tzn. osiągana jest własnym wysiłkiem. Zaniedbując ową praktykę, nie osiągniemy żadnego poznania. W szczególności sama wola, samo postanowienie usunięcia lgnięcia, podkreśla Budda, nie jest czynnikiem wystarczającym do tego, aby faktycznie zaprzestać owego lgnięcia, co równoważne jest $z$ usunięciem wycieków (SN III, 153) ${ }^{19}$.

Jeszcze bodaj mocniej na rolę poznania $w$ realizacji ostatecznego celu nauki buddyjskiej zwracają uwagę teksty buddyjskie, dookreślając sens mądrości. W suttcie Mahā-vedalla na pytanie o to „dzięki czemu rozpoznaje się stan, który poznać można?”, pada odpowiedź: „stan, który można poznać, poznaje się okiem mądrości (pañ̄na-cakkbu)", a następnie dodaje się: „celem mądrości jest bezpośrednie poznanie (abbiñna), pełne poznanie (pariñ̃a), porzucenie (pabāna)"20. Innymi słowy, celem mądrości jest widzenie rzeczy, jakimi one są, oraz ich porzucenie, czyli zaniechanie lgnięcia do nich. To poznanie oraz porzucenie równoważne są z osiągnięciem wyzwolenia (nibbāna), gdyż mądrość odcina wszelkie podstawy istnienia (upadbi; MN III, 245), czyli zgodnie z komentatorską tradycją pięć zespołów (kbandha), skalania (kilesa), dyspozycje wolicjonalne (abbisankhära) oraz pragnienie $(\text { käma })^{21}$. Dlatego Dhätu-vibbañga-sutta kilkakrotnie z determinacja podkreśla, że (MN III, 239):

18 SN III, 13: samadhim bhikkbave bhavetha. samäbito bhikkbave bbikkbu yathä-bbūtam pajānāti.

19 Por. także AN IV, 125-127, gdzie myśl ta w skróconej formie została powtórzona przy uzyciu tych samych metafor.

20 MN I, 293: neyyam pan' avuso, dhammam kena pajandtīti. neyyam kho avuso dhammam pañna-cakkbunā pajānätîti. pañña pan' avuso kimatthiyã ti. paññā kho avuso abbiñnattha pariñnattha pabanattba ti.

21 Zob. The Middle Length Discourses of the Buddha, trans. Bhikkhu Ñà na mol i, ed. Bikkhu Bodhi, Boston 1995, s. 1268, przyp. 674. 
paññam nappamajjeyya saccam anurakkbeyya cagam anubrūbeyya santim eva so sikkbeyyati

Nie należy zaniedbywać mądrości (pañna), należy strzec prawdy (sacca), należy kultywować wyrzeczenie (caga) i ćwiczyć się w spokoju (santi) ${ }^{22}$.

Prezentując buddyjski ideał poznawczy, obok wypowiedzi, które w sposób pozytywny wskazują na rangę poznania w tradycji buddyjskiej, należy zwrócić uwagę również na te, które uwypuklają rangę poznania w sposób negatywny, tzn. piętnują te umysłowe postawy, które stoją w opozycji do poznania, stanowiąc przeszkody na drodze do niego. Szczególnym rodzajem takiej przeszkody jest totalne, często w przekładach dodaje się "sceptyczne”, wątpienie (vicikicchā). Nie chodzi tutaj oczywiście o gloryfikowanie postawy bezkrytycznej akceptacji przekonań wzmocnionych siłą stojącego za nimi autorytetu. Tego typu postawa w filozoficznej tradycji buddyjskiej od początku jej istnienia spotykała się z odrzuceniem, czego dobitny przykład znajdziemy w słynnej sutcie wygłoszonej przez Buddę do Kalamów (Käläma-sutta; AN I, 188-193). Z jednej strony tekst ten stanowi buddyjską apoteozę radykalnej postawy krytycznej wyrażającej się w kultywowaniu poznawczego dystansu, metodycznego wątpienia i krytycyzmu zarówno wobec potencjalnych autorytetów zewnętrznych (indywidualnych oraz zbiorowych, tj. różnych form tradycji), jak i osobistych rozstrzygnięć opartych o własne emocjonalne predylekcje i zaufanie do własnych zdolności intelektualnych oraz spekulatywnych. $Z$ drugiej strony jednak uznać go można za apoteozę buddyjskiego ideału poznawczego, który wyraża się w osobistym wysiłku ukierunkowanym na pozyskanie poznania będącego widzeniem rzeczy, jakimi one są, a zatem oczyszczonego z wszelkich subiektywnych, tj. naznaczonych egotyzmem, postaw i przeświadczeń. Wątpienie, o którym tutaj mowa, jest formą umysłowej postawy, co do

22 Zob. też MN III, 240, 246. 
której żywi się przekonanie, że w kontekście możliwości poznawczych człowieka jest najwłaściwszą i taką, której pielęgnowanie gwarantuje emocjonalny, a tym samym egzystencjalny komfort. $Z$ perspektywy buddyjskiej szkodliwość tej postawy wyraża się w tym, iż osłabia ona czy też wręcz odbiera motywacje do poznawczych oraz duchowych poszukiwań, rozstrzygając w punkcie wyjścia o ich nieefektywności, a tym samym wpływa negatywnie na wolę wydatkowania energii celem osiągnięcia sukcesu poznawczego. Kultywowanie tej postawy sprawia, że osiągnięcie tego ostatniego, a tym samym osiągnięcie wyzwolenia, właśnie ze względu na ogromną energię (p. virya, s. vīrya), którą w tym celu należy wydatkować, staje się niemożliwe. Jest to powód, dla którego totalne wątpienie w tradycji buddyjskiej traktowane jest jako jeden $\mathrm{z}$ dziesięciu więzów (samyojana) łączących istotę $z$ istnieniem $w$ sansarze.

\subsection{Czym jest sceptycyzm?}

Miano sceptycyzmu nadaje się zjawisku niejednorodnemu ${ }^{23}$. Istnieją różne, acz w pewnym stopniu pokrewne, filozoficzne postawy, które określa się tym terminem, mimo iż one same w oparciu o własne założenia takiego miana gotowe byłyby sobie wzajemnie odmówić i zdarzało się, że odmawiały. Klasycznym przykładem byłby tutaj starożytny neopirroński sceptycyzm, który w osobie odnowiciela pirronizmu Ainezydema (I w. p.n.e.) odmawiat tej nazwy tzw. sceptycyzmowi akademickiemu, zaś w osobie Sekstusa Empiryka (II-III w. n.e.) - zarówno sceptycyzmowi akademickiemu, jak też i samemu Ainezydemowi $^{24}$. Dla Sekstusa forma sceptycyzmu, wyrażająca się $\mathbf{w}$ tezie o braku

23 Obszernie na temat różnych form sceptycyzmu pisze: R. Ziemińska, Historia sceptycyzmu. W poszukiwaniu spójności, Torun 2013.

24 Eadem, Czy Pirron byt sceptykiem? Nowe interpretacje starożytnego sceptycyzmu, ${ }_{n}$ Studia Philosophica Wratislaviensia" 6/1 (2011), s. 172; Sekstus Empiryk, PH I, 3-4; I, 210-212 oraz I, 220-235. 
wiedzy ${ }^{25}$, była niczym innym jak postacią negatywnego dogmatyzmu. Zresztą z perspektywy tradycji neopirrońskiej, której ze względu na cel, jaki sobie w niniejszej pracy stawiam, poświęcimy najwięcej uwagi, każda inna forma późniejszego sceptycyzmu sprowadzająca go do tezy głoszącej, że wiedza nie istnieje, zasługuje na takie określenie. Sceptycyzm neopirroński bowiem, stojąc $\mathrm{w}$ obliczu nierozstrzygalności poznawczej wartości sądów związanej z faktem równej siły ich uzasadnień (isostenia), postuluje niewyrokowanie (aphasia), tj. powstrzymanie sį od ich formułowania, oraz zaleca zawieszenie wszelkich sądów (epochē) i pozostawanie w postawie badawczej. Neopirroński sceptyk to badacz (skeptikos) prawdy, to jej poszukiwacz (zetetikoi), który nie wyklucza w punkcie wyjścia, że uda mu się kwestię prawdy i fałszu ostatecznie rozstrzygnąc ${ }^{26}$, aczkolwiek podkreśla, że dotychczas mu się to nie powiodło i dlatego nieustannie poszukuje. Pozostaje jednak wątpliwość, czy argumenty, które przedstawia, a które w przeważającej mierze podają w wątpliwość wartość dotychczas zgłoszonych i pozostających w obiegu narzędzi poznawczych, pozwalają żywić jakąkolwiek nadzieję na to, że uda się je ostatecznie przekroczyć i unieważnić. Wydaje się, że jedynym potencjalnym sposobem na ich przekroczenie mogtoby być odkrycie czy akceptacja innych, niepoddających się owym krytycznym argumentom narzędzi poznawczych, gdyż raczej nie unieważnienie sformułowanych argumentów krytycznych. Czy sceptycyzm neopirroński taką możliwość dopuszcza, pozostaje kwestią wątpliwą. Zrealizowała sį̨ ona jednak w czasach średniowiecza w postaci sceptycyzmu chrześcijańskiego, który krytyką poznawczą obejmował wyłącznie przyrodzone narzędzia poznawcze,

25 Według dominującej opinii badaczy tezę taką utrzymywał już twórca akademickiego sceptycyzmu - Arkezylaos, zob. R. Zie m i ń ska, Historia..., s. 67-68.

26 W PH I, 226, przeciwstawiając się negatywnej tezie akademików „wszystko jest nieuchwytne”, Sekstus stwierdza, że "sceptyk dopuszcza myśl, że pewne rzeczy może i dają się uchwycić". Wszystkie cytaty z Zarysów pirrońskich podaje w przekładzie Adama Krokiewicza. 
akceptując ponadnaturalne ${ }^{27}$. Innymi słowy, nawet jeżeli neopirroński sceptyk na poziomie deklaratywnym zgłasza niesłabnącą gotowość do poszukiwania prawdy, to czy nie jest to deklaracja pusta, która maskuje nieuchronną płynącą z przekonania o równosilności sądów konsekwencje, że żadne poznawcze pozytywne rozstrzygnięcie, a tym samym żadna wiedza nie są możliwe? Sceptycyzm akademicki, jak też i sceptycyzm późniejszych epok ową konsekwencję świadomie zaakceptowały i dlatego dokonały negatywnego rozstrzygnięcia, zgłaszając tezę o nieistnieniu wiedzy.

Pytanie o możliwość powrotu do postawy wyrokowania jest szczególnie intrygujące $w$ kontekście etycznego wymiaru myśli Pirrona i neopirronizmu. To właśnie ze względu na ten wymiar, który uzupełnia postawę powstrzymania sį̨ od wyrokowania, myśl ta niektórym badaczom jawi się jako atrakcyjny i wielce obiecujący punkt odniesienia dla analizy porównawczej z myślą buddyjską. Jeżeli zawieszenie wszelkich sądów miałoby charakter czasowy i wiązałoby się z dopuszczeniem możliwości ich odwieszenia, to pod znakiem zapytania stawałby etyczny wymiar sceptycyzmu jako dążenia do szczęścia realizowanego poprzez uspokojenie umystu (ataraxia) i beznamiętność (apatheia), a osiąganego dzięki ustaleniu się w postawie niewyrokowania. Zanim jednak skonfrontuję się $\mathrm{z}$ tą kwestią, wypada pokrótce zrekonstruować myśl Pirrona, wskazując na kontekst, w jakim ów etyczny wymiar się ujawnił.

Zasadniczym źródłem wiedzy o myśli Pirrona jest niewielki fragment pochodzący z pisma perypatetyka - Arystoklesa z Messyny (przełom I w. p.n.e. i I w. n.e. lub druga poł. II w.) - przywołującego

27 Owym ponadnaturalnym narzędziem poznawczym była Boża iluminacja, zob. na ten temat R. Ziem ińska, Historia..., s. 162-165. Podobną postawę, którą uważa za obcą sceptycyzmowi, Sekstus przypisywat twórcy średniej Akademii Arkezylaosowi (koniec IV w. p.n.e. - III w. p.n.e.), korzystającemu ze sceptycyzmu w sposób instrumentalny jako wstępu do nauki o transcendentnych ideach poprzez wykazanie niemożliwości wyrokowania o tym, co zmienne, zob. Sekstus Empiryk, PH I, 234. 
w nim opinię Tymona z Fliuntu (IV-III w. p.n.e.) na temat stanowiska swojego nauczyciela Pirrona, przekazany przez biskupa Cezarei Euzebiusza (IV w.) ${ }^{28}$. Jeśli wierzyć Tymonowi, Pirron miał stawiać trzy pytania, od rozstrzygnięcia których uzależniał możliwość osiągnięcia szczęścia (eudaimonia), czy też bardziej wybór prowadzącej do niego drogi. W pierwszym, według najpowszechniejszej wykładni badaczy, pytał o naturę rzeczy (ta pragmata). W drugim dociekał, jaką powinniśmy wobec nich przyjąć postawę. W trzecim zaś dochodził korzyści, jakie pojawią się w związku z przyjętą postawą. Udzielając odpowiedzi na pytanie pierwsze, Pirron miał podawać trojaką charakterystykę. Rzeczy są mianowicie adiaphora, astatbmēta i anepikrita. Ze względu na to nie można ani wrażeniom, ani sądom przypisywać wartości prawdy i fałszu.

Przywołuję te określenia w wersji oryginalnej, gdyż wokół ich wykładni toczy się podstawowy spór o charakter stanowiska Pirrona. Można je rozumieć na dwa sposoby - metafizycznie i epistemologicznie $^{29}$. Według pierwszej wykładni terminy te odnoszą się do natury rzeczy. Pirron ma twierdzić, że rzeczy w swej naturze są odpowiednio niezróżnicowane, nieustalone i nieokreślone. Według drugiej epistemologicznej i równie popularnej wykładni określają one poznawczą dostępność rzeczy uwarunkowaną nie ich naturą, a możliwościami poznawczymi poznających podmiotów. Przy tej wykładni Pirron ma utrzymywać, że rzeczy są nie do rozróżnienia, nie do ustalenia i nie do określenia. Za interpretacją drugą przemawiać ma fakt, iż zdaje się lepiej korespondować z postawą późniejszej neopirrońskiej tradycji, co uwydatnia i potwierdza założycielską rolę Pirrona dla sceptycznej tradycji. Według pierwszej wykładni, metafizycznej, rola ta sprowadzałaby się do swobodnej inspiracji w warstwie etycznej, gdyz Pirron jawi

28 Polski przekład owego fragmentu daje: A. Krokiewicz, Sceptycyzm grecki (od Pirrona do Karneadesa), Warszawa 1984, s. 104-105.

29 Szerzej na ten temat zob. R. Bett, Pyrrbo, His Antecedents, and His Legacy, Oxford 2000, s. 18-29. 
się w niej jako dogmatyczny metafizyk wychodzący w swej refleksji od rozpoznania natury rzeczy, tzn. od rozpoznania, że rzeczy w swej naturze są nieokreślone.

Pewną popularnością cieszy się także trzecia wykładnia myśli Pirrona - etyczna. Bazuje ona jednak nie na egzegezie przywołanych trzech określeń, a na odmiennej propozycji rozumienia owych „rzeczy" (ta pragmata), o które Pirron zapytuje. W interpretacji tej wyraża się przekonanie, że należy je rozumieć nie jako przedmioty otaczającego nas świata, konkretne jednostkowe byty, lecz jako rzeczy, które są ważne dla życia człowieka, dla jego postępowania, takie jak sprawiedliwość, niesprawiedliwość, odwaga itd. ${ }^{30}$ Propozycja ta kładzie nacisk na zbieżność postawy Pirrona i Sokratesa. Zgodnie z nią Pirron nie jest w ogóle zainteresowany fizyką, jego domeną ma być wyłącznie problematyka etyczna i podstawowe dla niej w owym czasie pytanie o dostępność szczęścia. Za taką interpretacją myśli Pirrona opowiedział się Christopher I. Beckwith ${ }^{31}$, który twierdzi, że w swojej postawie grecki filozof pozostaje $w$ zgodzie $z$ nauką prenormatywnego buddyzmu. Nie jest to jedyna zbieżność myśli filozofa $z$ Elidy z filozofią wczesnobuddyjską. Beckwith idzie znacznie dalej, twierdząc, że owe trzy określenia pojawiające się w odpowiedzi na pierwsze pytanie Pirron sformułowat, kopiując naukę Buddy o trzech ogólnych znakach egzystencji (tri-lakṣana): nietrwałości (anityatā), cierpieniu (duḅba) i bezjaźniowości (anätman). Ponieważ jednak w charakterystyce Pirrona nie sposób znaleźć określenie, które łatwo poddawałoby się skojarzeniu z buddyjskim rozumieniem cierpienia jako powszechnej cechy egzystencji, Beckwith zgłasza hipotezę, iż terminem „cierpienie” (dukkba/duḅkba) późniejsza normatywna buddyjska tradycja zastąpiła wcześniejszy, używany przez Buddę i obowiązujący w najwcześniejszym prenormatywnym okresie termin dubstha, znaczący właśnie

30 Taką wykładnic daje m.in. H. W. Ausland, On the Moral Origin of the Pyrrbonian Pbilosopby, „Elenchos” 10 (1989), s. 359-434; zob. takie J. Brunschwig, Papers in Hellenistic Pbilosopby, Cambridge 1994, s. 197-200.

31 Zob. Ch. I. Beckwith, op. cit., s. 24-25, 189-192. 
'nieustalony' (astatbmēta). Owo czysto hipotetyczne rozstrzygnięcie, nieznajdujące w tekstach buddyjskich żadnego wsparcia, pozwala mu jednak stwierdzić w konkluzji: „To zdecydowanie sugeruje, że środkowy termin Pirrona jest u swej podstawy prostą kalką"32.

Ze względu na nikłą dostępność zachowanych na temat greckiego filozofa źródłowych materiałów, jak też i z powodu utrwalonego oraz powtarzanego w starożytności przekonania o roli, jaką w rozwoju myśli Pirrona odegrał jego pobyt w Indiach ${ }^{33}$, nie można $z$ absolutną pewnością wykluczyć, że mamy w wypadku owej charakterystyki do czynienia z jakimś zapożyczeniem. Aczkolwiek argumentacja Beckwitha na rzecz tej tezy jest niezwykle spekulatywna ${ }^{34}$. Faktycznie jednak to nie owe potencjalne zapożyczenia w obszarze charakterystyki rzeczy są czynnikiem decydującym o zbieżności bądź rozbieżności myśli Pirrona i wczesnego buddyzmu. Ten decydujący moment umiejscowiony jest w odpowiedzi, jakiej Grek udziela na pytanie drugie oraz, wtórnie, w pozostającej od niej w zależności odpowiedzi na pytanie trzecie.

Ponieważ nasze wrażenia i sądy pozostają nieokreślone pod względem prawdy i fatszu, Pirron zaleca zachowanie wobec nich dalece idącej powściągliwości zarówno w wydawaniu opinii na ich temat, jak i emocjonalnym w nie zaangażowaniu - należy nie mniemać (adoxastoi), czyli nie wydawać na ich temat żadnej opinii, nie przychylać sį̨ do żadnej strony (aklineis), czyli nie żywić w ich kierunku żadnych pragnień, i ostatecznie nie ulegać żadnym wzruszeniom (akradantoi), czyli powstrzymać w związku z nimi wszelkie emocje. Ci, którzy potrafią kultywować taką postawę, pozostają w stanie niewyrokowania (aphasia) i osiągają spokój umysłu (ataraxia).

32 Ibidem, s. 30. Oczywiście przekonanie to pociąga drastyczne konsekwencje dla oceny późniejszego buddyzmu. Wynika bowiem z niego, że cała późniejsza narracja, tak charakterystyczna dla buddyzmu, która w centrum stawia doświadczenie cierpienia, jest banalną mistyfikacją.

33 Diogenes Laertios, Żyoty i poglądy stynnych filozofów, thum. I. Krońska, W. Olszewski, B. Kupis, Warszawa 1988, s. 553 (IX, 61), 554 (IX, 63).

34 Ch. I. Beckwith, op. cit., s. 28-33. 
Należy tutaj zwrócić uwagę na trzy momenty, ważne ze względu na dalsze rozważania o domniemanym sceptycyzmie wczesnego buddyzmu. Po pierwsze, wypada podkreślić, że powściągnięcie poglądów, pragnień i emocji następuje w związku z poznawczą nierozstrzygalnością (niedostępnością prawdy i fałszu). Po drugie, uspokojenie umystu następować ma po osiągnięciu stanu niewyrokowania, a tym samym, jak można domniemywać, ugruntowane jest ostatecznie w poznawczej nierozstrzygalności. Po trzecie, problematyczne jest rozumienie owego ostatecznego dobrostanu, jakim jest uspokojenie umystu (ataraxia). Pojawia się pytanie, czy można je traktować jako przeprowadzenie stanu powściągnięcia na poziom trwały, czy też jest to stan jakościowo nowy, wykraczający dalece poza samo powściągnięcie wyrokowania.

W związku z punktem pierwszym trzeba zaznaczyć z naciskiem, że Pirron wyraźnie określa kierunek zależności między postulowaną w odpowiedzi na drugie pytanie postawą, a konstatowanym w odpowiedzi na pierwsze pytanie stanem rzeczy. Podstawą dla postulowanej wstrzemięźliwości w zakresie orzekania oraz w obszarze emocji jest ustalenie poznawczej nierozstrzygalności w odniesieniu do rzeczy, czyli utrata nadziei na poznawczy sukces. Utrata owej nadziei nadaje sens dalszemu postępowaniu. Można przypuszczać, że dopóki żywimy nadzieję na rozstrzygnięcie poznawczego dylematu, dopóty postulowana wstrzemięźliwość będzie miała charakter przejściowy i co najwyżej czysto instrumentalny. Jako wyraz poznawczej ostrożności będzie określała procedurę postępowania w dochodzeniu do prawdy. Trudno oczekiwać, żeby tego typu postawa przyniosła radykalne przemiany umysłowej charakterystyki. Pirron jednak zdaje się formułować postulat znacznie bardziej radykalny. Nie chodzi mu wyłącznie o zachowanie poznawczej ostrożności, a o gruntowną przemianę naszego sposobu bycia - gruntowną, gdyż sięgającą nie tylko żywionych przekonań, ale także fundujących je pragnień i emocji. Należy zrezygnować z teoretycznych rozważań, ale jeszcze bardziej z motywacji, które je napędzają. Pirron zdaje się uważać, że ze względu na nierozstrzygalność wszelkich opinii o rzeczach, kierowanie się wobec nich 
pragnieniami i emocjami nie może przynieść żadnego pozytywnego rezultatu i w związku z tym jest, jak można domniemywać, działaniem nierozsądnym.

Chociaż kierunek zależności między odpowiedziami na pytanie pierwsze i drugie jest wyraźnie określony, to już jej charakter wydaje się niejednoznaczny. Referując Pirrona, sugerowałem, że jest to charakter nadawania sensu. Pirron pyta bowiem o powinność określającą nasze działanie w związku $\mathrm{z}$ treścią odpowiedzi na pytanie pierwsze. Chociaż postawa taka wydaje się zgodna z ogólnym dogmatycznym ukierunkowaniem samego Pirrona ujawniającym się w owej odpowiedzi, to budziła zastrzeżenia w późniejszym neopirrońskim sceptycyzmie, który gorliwie dążył do niwelacji wszelkich tkwiących w nim dogmatycznych tendencji, a w najgorszym wypadku starannie je maskował. Sekstus Empiryk będzie sugerował, że owa zależność jest raczej natury przyczynowej i polega na psychologicznej reakcji pojawiającej się w obliczu konfrontacji z sytuacją nierozstrzygalności sądów ${ }^{35}$. Czy jest to jednak reakcja nieuchronna, czyli konieczna, powinno pozostać kwestią otwartą. Wszelka próba uogólnienia będzie wiązała się $\mathrm{z}$ rozpoznaniem powszechnie obowiązujących $w$ naturze mechanizmów, a to musi pociągnąć za sobą zarzut dogmatyzmu. Jedyne, co pozostaje konsekwentnemu sceptykowi w tej sytuacji, to przyznanie się, że w jego przypadku czy też w przypadku niektórych taka reakcja miała miejsce. Analogicznie też, do czego za chwilę powrócę, aby uniknąć dogmatycznego uogólnienia, Sekstus twierdził, że tym, którym udało się powściągnąć skłonność sądzenia, przydarzył się spokój umystu (PH I, 26 i 29). Nie ma jednak żadnej gwarancji, że w obliczu nierozstrzygalności sądów musi wydarzyć się reakcja w postaci zawieszenia wszelkich opinii, pragnień i emocji. Do pomyślenia jest zachowanie odmienne - równoczesnej afirmacji obu wykluczających

35 Zob. na ten temat R. Bett, How Ethical Can an Ancient Skeptic Be?, [w:] Pyrrhonism in Ancient, Modern, and Contemporary Pbilosophy, ed. D. Machuca, Dordrecht 2011, s. 4. 
się opinii w przekonaniu, że rzeczywistość w swojej naturze jest wewnętrznie sprzeczna - co nie jest znowu tak niespotykane w historii filozofii. Orientacja taka wielokrotnie ujawniała się zarówno w najwcześniejszej filozofii greckiej, jak i w późniejszych koncepcjach mistycyzujących, które świadomie odrzucały zasadę niesprzeczności. Aby odmówić takiej postawie sensu, neopirronizm powinien odwołać się do kryteriów racjonalności, czyli zachować się w sposób dogmatyczny na poziomie metafilozofii, ale nie może tego zrobić na żadnym poziomie. Pozostaje zatem tylko ufać, że w naszym wypadku, gdy skonfrontujemy się $\mathrm{z}$ równosilnymi uzasadnieniami przeciwstawnych opinii, zrealizuje się sceptyczna wersja wydarzeń.

Drugą kwestią, na którą należy zwrócić uwagę, jest powiązanie stanu uspokojenia umystu ze stanem niewyrokowania. Tymon w swojej relacji zdaje się stwierdzać, że kierunek zależności między tymi dwoma stanami jest wyraźnie określony, a ich początkiem jest konstatacja poznawczej nierozstrzygalności wszelkich sądów i wrażeń. Pirron miał uzyskać spokój, sugeruje jego uczeń, gdyż nie angażował się w teoretyczne rozważania. Mamy tutaj do czynienia z sekwencją trzech stanów, które przynajmniej w relacji Tymona, wydają się pozostawać ze sobą w pewnej genetycznej zależności. Na etapie pierwszym ma miejsce konstatacja nieokreśloności wrażeń i sądów pod względem prawdy i fałszu, co późniejsza tradycja neopirrońska ubrała w nomenklaturę równosilności uzasadnień przeciwstawnych opinii (isostenia). Najwłaściwszą, żeby nie powiedzieć najsensowniejszą, postawą wobec tej konstatacji jest, jak to wyrazi tradycja neopirrońska, zawieszenie wszelkich opinii (epochē). Doskonałą formą realizacji postawy zawieszenia opinii jest stan niewyrokowania (apbasia) - to etap drugi ${ }^{36}$.

36 Standardowo afazja bywa traktowana łącznie $\mathbf{z}$ ataraksją jako trzeci etap praktyki sceptycznej, sądzę jednak, czego nie będę tu rozwijał, że sensowniejsze jest traktowanie jej jako przynależnej do etapu drugiego. Przy tym rozumieniu afazja stanowi zwieńczenie drugiego etapu i określa stan doskonałego zawieszenia sądzenia. 
$\mathrm{Ci}$, którzy zrealizują ten stan, mówi Tymon, zyskają spokój umysłu (ataraxia) i to jest etap trzeci.

W tym miejscu po raz drugi dochodzi do poważnego rozdźwięku między przekazem Tymona, a sposobem, w jaki kwestię tę będzie później objaśniał Sekstus Empiryk. Tymon, relacjonując sekwencje tych trzech etapów, składa nam obietnicę - zyskamy coś, czyli spokój umysłu, jeśli będziemy potrafili wytrwać w postawie zawieszenia opinii i niewyrokowania. Warunkiem złożenia tej obietnicy jest uznanie, że między stanem niewyrokowania a stanem spokoju umysłu zachodzi jakiś rodzaj genetycznego wręcz powiązania. Żeby obietnica ta miała jakąkolwiek wartość motywacyjną, Tymon musi uznać, że pojawienie się stanu doskonałości niewyrokowania musi z konieczności pociągnąć pojawienie się stanu uspokojenia umysłu. Filozof nie wyklucza możliwości osiągnięcia spokoju umysłu drogą postulowaną przez dogmatyków. Obiecuje tylko, że ta wskazana przez Pirrona, wiodąca poprzez niewyrokowanie, prowadzi do spokoju umystu. Kwestię, czy to jest jedyna droga do spokoju umysłu, czy też jest to droga względem drogi dogmatyków alternatywna, Tymon pozostawia bez rozstrzygnięcia.

Podobnie kwestię tę traktuje Sekstus. On również nie podejmuje próby rozstrzygnięcia zagadnienia unikatowości drogi prowadzącej do spokoju ${ }^{37}$. Kierując się swoim antydogmatycznym zapałem, czuje się jednak zobowiązany, aby problem relacji między niewyrokowaniem a spokojem umystu objaśnić w sposób całkowicie odmienny. Postawa Tymona, a zatem i Pirrona jest postawą dogmatyczną, zasadzającą się na uzyskaniu poznawczej pewności w kwestii przyczynowego powiązania dwóch stanów umysłu. Nie zgadzając się na taki sposób objaśniania, Sekstus radykalnie zmieni styl narracji. Tymon za Pirronem obiecuje, Sekstus, jak pokazują poniższe cytaty, tylko relacjonuje:

37 Ściśle rzecz biorąc, nie robi tego w sposób jednoznaczny. Różne jego wypowiedzi, zarówno z Zarysów pirrońskich, jak i z Przeciw matematykom, moga jednak sugerować, że Sekstus tę kwestię rozstrzygał na niekorzyść dogmatyków. Do tego zagadnienia jeszcze powrócę. 
Zacząwszy bowiem filozofować, by osądzić wyobrażenia i uchwycić, które są prawdziwe, a które fałszywe, i tak zyskać spokój, utknął na równowadze sprzeczności, nie mogąc zaś jej rozsądzić, powstrzymał się od wyrokowania, a kiedy się powstrzymał, uzyskał zrządzeniem losu (tuchikōs) niezakłócony spokój wobec przypuszczeń (PH I, 26).

Otóż i sceptycy myśleli, że zdobędą niezakłócony spokój, jeżeli rozsądzą sprzeczności rzeczy jawnych i rzeczy umysłowych, nie mogąc zaś tego dokonać, wstrzymali się od wyrokowania, kiedy się zaś wstrzymali, wydarzył się im niejako (tuchikōs) niezakłócony spokój, towarzyszący powściągliwości niby cień ciału (PH I, 29).

Sekstus składa relację z tego, co - jak oznajmia - dawnym sceptykom miało się przydarzyć. Kiedy osiągnęli stan niewyrokowania, zaskakującym zrządzeniem losu, całkowicie przypadkowo zdarzyło im się doświadczyć spokoju umysłu. Aby zilustrować owo cudowne zrządzenie losu, Sekstus przytacza słynną przypowieść o malarzu Apellesie. Tak jak owemu malarzowi zdarzyło się osiągnąć sukces w postaci przedstawienia piany na pysku konia, gdy po wielu nieudanych podejściach zdesperowany zaniechał prób jej oddania, korzystając ze swojego malarskiego kunsztu, i w złości rzucił w obraz gąbką, tak sceptykom, którzy w desperacji zarzucili wyrokowanie o prawdzie i fałszu, miał się zrządzeniem losu, niejako przez przypadek (tuchikōs), przydarzyć sukces $\mathrm{w}$ postaci spokoju umysłu (PH I, 28-29).

Podkreślić należy, iż użycie w tym miejscu przysłówka tucbikōs budzi wśród badaczy zróżnicowane opinie. Niektórzy, idąc za dogmatyczną tendencją Pirrona/Tymona, sugerują, iż nie należy go rozumieć dosłownie jako „przypadkowo, przez przypadek”, tylko jako „nieoczekiwanie”, bowiem pojawienie się spokoju w sytuacji niewyrokowania jest czymś zaskakującym, niespodziewanym w kontekście wcześniejszych wyrastających $z$ dogmatycznej postawy domniemywań 
i oczekiwań ${ }^{38}$. Ponieważ Sekstus, opisując następstwo spokoju umysłu po osiągnięciu niewyrokowania, wyraźnie wystrzega się dogmatycznych generalizacji, badacze ci ową relację będą przedstawiali równie niejednoznacznie, jak sam Sekstus. Podkreślając, że Sekstus zdaje tylko relację, z tego, co się przydarzyło niektórym sceptykom, a może także i jemu samemu, będą zaznaczali, że w istocie ani nie stwierdza istnienia przyczynowej zależności między obydwoma stanami umysłu, ani jej nie zaprzecza ${ }^{39}$. Są jednak też tacy badacze, którzy postulują dosłowne rozumienie owego przysłówka, odrzucając jednoznacznie wszelką możliwość dogmatycznej wykładni ${ }^{40}$.

Problematyczność postawy Sekstusa polega na tym, że nie daje on żadnej gwarancji, iż to, co się przydarzało wcześniej (czy wszystkim sceptykom?), przydarzy się też każdemu, kto zrealizuje stan niewyrokowania. $\mathrm{Z}$ drugiej strony powinniśmy zauważyć, że chociaż Sekstus

38 Zob. np. L. Castagnoli, Aporia and Enquiry in Ancient Pyrrbonism, [w:] The Aporetic Tradition in Ancient Philosophy, ed. G. Karamanolis, V. Politis, Cambridge 2018, s. 218, przyp. 60; S. H. Svavarsson, The Pyrrbonian Idea of a Good Life, [w:] The Quest for the Good Life. Ancient Philosophers on Happiness, ed. Ø. Rabbås et al., Oxford 2015, s. 209-210.

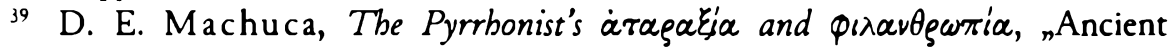
Philosophy" 26 (2006), s. 116-117. Znakomitym przykładem zakłopotania i niepewności, jakie uwidaczniają sį̨ w związku $z$ interpretacją tej kwestii, sq̨ następujące słowa jednego $\mathrm{z}$ badaczy, które pojawiły się po wypowiedzi odrzucającej dosłowne rozumienie omawianego tu przysłówka: "Jest to zgodne $\mathrm{z}$ ideą głoszącą, że zachodzi trwały związek pomiędzy powściągnięciem sądzenia a spokojem [...], chociaż istnienie i natura owego zwiazku nie może być dla sceptyka przedmiotem dogmatycznego przekonania" (This is compatible with the idea that there is a constant connection between suspension of judgement and tranquillity [...], although of course the existence and nature of the connection cannot be an object of dogmatic belieffor the Sceptic), zob. L. Castagnoli, op. cit., s. 218, przyp. 60. Jeżeli autor ma racje, to wychodzi na to, że wszyscy sceptycy wiedzą o istnieniu powiązania, o którym nikt nie chce niczego powiedzieć $\mathbf{w}$ związku z groźbą oskarżenia o dogmatyzowanie.

11 Zob. P. Massie, Philosopby and Ataraxia in Sextus Empiricus, „Peitho / Examina Antiqua" 1/4 (2013), s. 228. 
zmienił styl narracji z obietnicy na relację, to utrzymał porządek owej sekwencji zdarzeń. Jeżeli sceptycyzm ma być formą terapii, jak oznajmia filozof, to ów porządek nie jest bez znaczenia. Jeżeli dzieło Sekstusa ma zachęcać nas do podjęcia trudów tej terapii, to utrzymaną w sprawozdawczym stylu relację należy potraktować jak prezentacje mapy, która przedstawia drogę, jaką przemierzyli poprzednicy: wyszli od dogmatycznej nadziei na poznawczy sukces, skonstatowali równosilność wszelkich przeciwstawnych opinii, przeszli przez zawieszenie sądzenia i niewyrokowanie, aby ostatecznie dojść do spokoju umysłu. Wydaje się więc, że mimo zmiany stylu narracji Sekstus nie przestaje obiecywać, robi to tylko w mniej nachalny sposób. Ostatecznie bowiem, jeżeli owa mapa nie dawałaby żadnej nadziei na sukces, to przypisywanie sceptycyzmowi terapeutycznej funkcji nie miałoby najmniejszego sensu'1 . Uznać zatem możemy, że każdy moment owej sekwencji, jak też jej kolejność mają znaczenie. W związku z tym powinniśmy stwierdzić, że dla osiągnięcia spokoju umysłu konstytutywnym momentem dla całego procesu jest konfrontacja $\mathrm{z}$ równosilnością opinii, czyli uświadomienie sobie niemożliwości dokonania prawomocnego rozstrzygnięcia na rzecz prawdy bądź fałszu jakiejkolwiek opinii.

Co to jednak znaczy konfrontacja $\mathrm{z}$ równosilnością opinii? Zasadnicze pytanie jest takie, czy sceptyk odkrywa i uświadamia sobie pewien obiektywny fakt na temat opinii, czy też go intencjonalnie konstytuuje. Żeby na nie odpowiedzieć, powinniśmy się przyjrzeć znamiennej wypowiedzi Sekstusa. W PH I, 34 oznajmia on, co następuje:

jak, zanim powstał twórca twojego obecnego wyznania, uwarunkowany w nim wywód nie był jasny chociaż w rzeczywistości istniał, tak może i wywód przeciwny twojemu obecnemu wywodowi istnieje w rzeczywistości, ale my go jeszcze nie znamy; nie musimy więc zgoła przytwierdzać twojemu wywodowi, który się na razie wydaje bardzo silnym!

41 Skłonny jestem uznać, że chociaż sam Sekstus relacjonuje zdarzenie, to żeby relacja ta miała wartość motywacyjną, adresat musi odczytać ją w pewnym sensie w sposób dogmatyczny, tzn. musi nadać jej uniwersalny wymiar. 
Na podstawie powyższej wypowiedzi możemy zaryzykować stwierdzenie, że sceptyk szuka prawdy, zakładając z góry niemożliwość jej poznania. Silnemu argumentowi, któremu nie potrafi się jawnie sprzeciwić, przeciwstawia możliwość wytoczenia kontrargumentu w przyszłości. Zatem postulat równosilności sądów nie wydaje się przygodną konstatacją aktualnego stanu dostępności do prawdy sformułowaną w trakcie badania przedłożonych dotychczas argumentów na rzecz posiadania jakiejś prawdy, lecz wyrasta z konstatacji nieuchronnej konieczności, w jakiej musi się znaleźć każdy potencjalny argument sformułowany w przyszłości. Jeżeli jednak mamy faktycznie do czynienia z koniecznością, to musi być ona ugruntowana w jakiejś naturze, czy to podmiotu poznającego, czy też poznawanych rzeczy; tym samym uznać należy, że postulat równosilności sądów wyrasta $z$ rozpoznania owej natury. Mamy więc tutaj do czynienia z podwójnym złamaniem neopirrońskich oświadczeń: z jednej strony deklaracji o nieustannej gotowości do poszukiwania prawdy, która okazuje się pusta, z drugiej zaś postulatu nieorzekania niczego, który maskuje tylko fakt rozpoznania wspomnianej natury. Co więcej, wyrażając takie przekonanie, sceptyk postępuje w sposób dogmatyczny, gdyż żadne dotychczasowe doświadczenie, w związku z własnymi kryteriami stosowanymi do oceny jego poznawczej wartości, nie upoważnia go do sformułowania takiej konstatacji.

Aby wybrnąć z podejrzenia o dogmatyzm, sceptykowi pozostaje jeszcze inne rozwiązanie, zgodnie z którym konstatacja równowagi sądów nie wiąże się $z$ rozpoznaniem obiektywnego faktu na temat sądów, lecz jest pewnego rodzaju ukierunkowaniem poznawczej uwagi. W tym kontekście cała krytyczna aparatura sceptycyzmu okazuje się swoistą zasłoną dymną. Gdy sceptyk mówi o równosilności sądów, jeżeli chce być konsekwentny, nie może mieć na myśli zjawiska z obszaru semantyki, lecz psychologii. Chodzi mu bardziej o utrzymywanie pewnej wewnętrznej postawy umysłu, która jest niezależna od logicznej, dowodowej wartości wytaczanych argumentów, od czegoś, co można by nazwać ich mocą uzasadniania. Wszak nawet w obliczu 
braku argumentu, czyli w obliczu faktycznej nierównowagi opinii, sceptyk ma wzbudzać w sobie postawę zawieszenia sądów, tak jakby miał do czynienia $\mathrm{z}$ faktyczną równosilnością, $\mathrm{w}$ istocie motywowany samą tylko domniemaną możliwością wytoczenia w przyszłości stosownego kontrargumentu. W związku z tym cała narracja o poszukiwaniu prawdy jawi się jako zabieg czysto retoryczny. Można w niej ewentualnie widzieć narzędzie terapeutyczne, które ma pobudzać w potencjalnym sceptyku motywację do przyjęcia określonej postawy. Równie dobrze Sekstus mógtby jednak powiedzieć: przestań w końcu ględzić o prawdzie i fałszu tylko od razu wzbudź w sobie postawę zawieszenia sądów. Pozostaje jednak pytanie: po co? Czemu to ma służyć? Można oczywiście odwołać się do celu, do ataraksji i stwierdzić, że jest to alternatywna, może lepsza, a może nawet jedyna droga do uspokojenia umysłu. Żeby jednak tak stwierdzić, sceptyk musi zaakceptować możliwość rozpoznania zachodzącej między epoche, afazją i ataraksją przyczynowej zależności, czyli konieczności. To jednak oznacza akceptacje postawy dogmatycznej, czego sceptyk znowu zrobić nie może.

Trzecim zagadnieniem, jakie powinniśmy rozważyć w związku z podejrzeniem o pokrewieństwo sceptycyzmu z buddyzmem, jest rozumienie ostatecznego sceptyckiego dobrostanu, jakim jest spokój umysłu (ataraxia). W tym kontekście należy odpowiedzieć sobie na kilka powiązanych pytań. Jakiego rodzaju stanem jest ataraksja? Czy jest to stan mądrościowy, czyli czy osiągnięcie ataraksji wiąże się $\mathrm{z}$ jakiegoś rodzaju wglądem poznawczym? Czy ataraksje w wydaniu sceptycznym można traktować jako swoisty rodzaj oświecenia? Czy w zgodzie z postawą sceptycyzmu ataraksja może w ogóle być stanem poznawczym? Czy jest to stan umysłu doskonale poznającego, czy też jest to tylko nieobecność niepokoju (tarachē) - innymi słowy, czy jest to stan epistemiczny, czy wyłącznie psychiczny?

Dla dogmatyków osiągnięcie ostatecznego dobrostanu w postaci spokoju umystu (ataraxia u epikurejczyków, apatheia u stoików 
i neoplatoników $)^{42}$ wiązało się z uzyskaniem pewności poznawczej. W przypadku sceptycyzmu jednak mamy do czynienia z odmienną sytuacją. Wszak, jak można wnosić na podstawie zestawienia sceptycyzmu w konfrontacji z dogmatyzmem i akademizmem, Sekstus postuluje konieczność kontynuowania poszukiwań prawdy po osiągnięciu ataraksji. Sceptycy bowiem to ci, którzy „wciąż szukają” (PH I, 2). W przeciwieństwie do dogmatyków, w wypadku sceptyków osiągnięcie spokoju umysłu nie wiąze się z uzyskaniem pewności poznawczej, lecz z ustaleniem się w postawie zawieszenia sądów i niewyrokowania $^{43}$. Czy sceptycy nie proponują zatem - musimy zapytać - całkiem odmiennego pojęcia ataraksji niż dogmatycy?

Teoretycznie moglibyśmy podjąć próbę zbliżenia się do odpowiedzi na powyższe pytanie na drodze analizy doniesień o życiu neopirrońskich sceptyków, a w szczególności o tym, jak w praktyce wyrażali ową ataraksję. Praktycznie jednak postępowanie takie wydaje się mało obiecujące ze względu na szczupłość materiału, jakim dysponujemy. Zachowało się tylko kilka anegdot na temat postawy samego Pirrona, a i te wydają się mało wiarygodne, gdyz obraz filozofa z Elidy, jaki się z nich wyłania, zdaje się mocno przerysowany i w niewielkim tylko stopniu koresponduje z modelem życia sceptyka przedstawionym przez Sekstusa Empiryka. Pirronowi przypisuje się w owych anegdo-

42 Na temat różnych synonimicznych kategorii opisujących stan wyciszenia umysłu w różnych hellenistycznych szkołach zob. G. Striker, Ataraxia. Happiness as Tranquillity, [w:] eadem, Essays on Hellenistic Epistemology and Ethics, Cambridge 1996, s. 183-195; P. Massie, Ataraxia: Tranquility at the End, [w:] A Companion to Ancient Philosophy, ed. S. D. Kirkland, E. Sanday, Evanston 2018, s. 245-262.

43 Wydaje się, że w tej kwestii postawa Sekstusa różni się zasadniczo od postawy Pirrona. Pierwszy postuluje konieczność podtrzymania poszukiwań prawdy mimo uzyskania spokoju umysłu, podczas gdy Pirron porzuca poszukiwania po skonkludowaniu niemożności ostatecznego wyrokowania, zob. na ten temat R. Bett, Pyrrbo, [w:] The Stanford Encyclopedia of Philosophy, ed. E. N. Zalta, https://plato.stanford.edu/archives/win2014/entries/pyrrho/ (dostep: 2.08.2018). 
tach obojętność nie tylko względem opinii, ale też, co należy szczególnie mocno podkreślić, względem wrażeń zmysłowych. Według relacji Diogenesa Laertiosa Pirron z pełną obojętnością podchodził do społecznych konwencji, wykonując czynności jemu nieprzystojne, jak sprzątanie domostwa, mycie prosiaków i handel nimi (Diogenes Laertios IX, 66). Z równą obojętnością miał też podchodzić do świadectwa zmysłów. Do tego stopnia je ignorował, że tylko towarzyszącym uczniom miał zawdzięczać unikanie różnych niebezpieczeństw na drodze (Diogenes Laertios IX, 62). Jak wskażę za chwilę w dyskusji nad zarzutem bezczynności, oba te zachowania - ignorowanie konwencji oraz zjawisk - nawet jeżeli relacje o nich uznamy za mocno przejaskrawione, chociaż świadczą o obojętności Pirrona, co przyniosło mu pewien rozgłos, kłócą się z modelem postępowania neopirrońskiego sceptyka określonym przez Sekstusa ceniącego sobie zarówno konwencje, jak i świadectwo zmysłów.

Gdy Sekstus określa ataraksje jako „wolność od utrapień i pogodę ducha" (PH I, 10), to powinniśmy jego słowa czytać literalnie. Sceptykowi o nic innego nie chodzi, jak o całkowity brak zaangażowania we wrażenia i opinie. Dąży on do zachowania wewnętrznego dystansu wobec doświadczenia. Musimy jednak zdać sobie dokładnie sprawę, na czym polega ów wewnętrzny dystans, o który zabiega neopirroński sceptyk. Sekstus próbuje tę kwestię dookreślić. W PH I, 25 czytamy:

Powiadamy na razie, że celem sceptyka jest niezakłócony spokój wobec przypuszczeń, a wobec rzeczy mu narzuconych umiarkowane ich doznawanie.

W wypowiedzi tej pojawia się niezwykle ważne rozróżnienie. Sekstus wskazuje w celu dążenia sceptyka na dwa odmienne momenty - na stosunek do przypuszczeń oraz stosunek do rzeczy mu narzuconych. Rozumienie przypuszczeń nie nastręcza wielkich problemów, to nic innego, jak - zdaniem sceptyka - nieuprawnione opinie, jakie żywimy na temat rzeczy na podstawie tego, co nam się jawi. Doświadczamy słodkości miodu i w związku z tym wnosimy, że słodkość 
jest wewnętrzną cechą miodu, że przynależy mu z natury. Ataraksja, czyli niezakłócony spokój umystu, to całkowite wyzbycie się tego rodzaju opinii. Jeżeli sceptyk osiągnie taki spokój umysłu, to będzie w stanie umiarkowanie doznawać rzeczy mu narzuconych, czyli zjawisk. Ze względu na zadanie, jakie sobie tutaj stawiam, a mianowicie krytyczną analizę tezy głoszącej głębokie pokrewieństwo sceptycyzmu z buddyzmem, powinniśmy szczególnie uważnie przyjrzeć się temu, jak sceptyk pojmuje owe zjawiska. Pomocny będzie tutaj następujący fragment PH I, 22:

Powiadamy zaś, że kryterium sceptycyzmu jest to, co się jawi, nazywając tak zasadniczo wyobrażenie. Jakoż nie nastręcza ono wątpliwości i nie wymaga poszukiwań, albowiem polega na biernym doznaniu bez udziału woli.

Zjawisko jest, zdaniem Sekstusa, tym, co nam się narzuca w sposób całkowicie od nas niezależny. Zjawiska konstytuują to, co dla sceptyka jest naturalne - naturalne jest to, co nam się narzuca, z czym się po prostu konfrontujemy jako z czymś nieuniknionym, koniecznym. Koniecznym nie ze względu na jakieś fatum, tylko z powodu całkowitej tego niezależności. Fenomenalny świat jest naturalny w tym sensie, że go po prostu zastajemy. Na zjawiska, czyli na to, czego doznajemy i jak tego doznajemy (czyli np. wspomniana słodkość miodu), z jednej strony nie mamy żadnego wpływu, z drugiej zaś, jak można sądzić po słowach Sekstusa, są one dla nas poznawczo całkowicie przejrzyste. W doznawanych zjawiskach nie ma nic wątpliwego, nic, co domagałoby się jakiegoś odkrycia, jakiegoś rozjaśnienia, a zatem nic, co mogłoby być przedmiotem mniemania, domysłu, przekonań ${ }^{44}$. Jedyne, co nam pozostaje - głoszą neopirroniści - to umiarkowane ich doznawanie, czyli bez owego naddatku w postaci opinii.

${ }^{44} \mathrm{Na}$ kwestię tę zwraca uwagę Andrew D. Wong, zob. A. D. Wong, Unmitigated Skepticism. The Nature and Scope of Pyrrhonism, [rozpr. dokt.], University of California, San Diego 2017, s. 31. 
Dogmatyk, doznając przykrości, cierpi podwójnie - w związku z samym przykrym zjawiskiem i w związku z mniemaniem, zgodnie z którym źródło tej przykrości tkwi w doświadczanej rzeczy, co z kolei skutkuje niespełnialnym, jako że na zjawiska wpływu nie mamy, pragnieniem unikania takich przykrych rzeczy. Neopirronista ma żyć spokojniej, gdyż całkowicie godząc się na to, czego doznaje, nie żywi żadnej opinii o źródle owego doznania, a tym samym tego, czego doznaje, doznaje w sposób umiarkowany. Sekstus pisze lapidarnie (PH I, 30):

Sceptyk natomiast, wystrzegając się mniemania, jakoby każda $\mathrm{z}$ owych rzeczy była istotnie zła, cierpi od nich umiarkowaniej.

W dogmatycznym rozumieniu spokoju umysłu można wskazać dwa aspekty - negatywny i pozytywny. Pierwszy wyraża się w emocjonalnym wyciszeniu, drugi jednak w adekwatnym działaniu względem poznawanych rzeczy; adekwatnym, czyli odpowiednim do rozpoznawanej natury rzeczy. W sceptycznym pojęciu ataraksji występuje tylko jeden aspekt - negatywny. Nie sposób bowiem uznać, że zachowanie równego dystansu wobec wszelkich wrażeń i opinii stanowi adekwatną odpowiedź na to, co doświadczane. Ściśle rzecz ujmując, nie sposób tego uznać w wypadku neopirronistów, jakimi przedstawia ich Sekstus. Spokój umysłu nie może wyrażać się w adekwatnym działaniu, gdyż jego uzyskanie nie wiąże się ani z rozpoznaniem natury rzeczy jako niepoznawalnej, ani z rozpoznaniem natury podmiotu poznającego jako niezdolnego do uzyskania poznania. Sceptyczny spokój umysłu jest czymś niespodziewanym, co przydarzyło się sceptykowi w związu z doświadczeniem jego aktualnej, przygodnej niezdolności poznawczej. Sceptyk utknąt w przeciwstawieniu opinii i nie mogąc się z tego klinczu wyrwać, zareagował jej zawieszeniem. Neopirroński sceptyk dopuszcza jednak, że ta niezdolność może być tymczasowa. Możliwe jednak, że zasada ta nie stosuje się do samego Pirrona, który z dogmatyzmu się nie wyzwolił i dla którego zawieszenie opinii oraz 
spokój mogą w związku z tym być jedynymi właściwymi czy też „adekwatnymi" działaniami.

Jeśli wyrażone tu przekonanie trafnie ujmuje umiejscowienie ataraksji w strukturze myśli sceptycznej, to sugestia Sekstusa, że sceptykom przydarzyło się osiągnąć to, do czego dążą dogmatycy, zawieszając sądzenie, wydaje się myląca - ataraksja sceptyków jest stanem jakościowo odmiennym od ataraksji dogmatyków w tym sensie, że pozbawiona jest komponentu poznawczego - ataraksja dogmatyków jest spokojem pewności, ataraksja neopirronistów jest spokojem rezygnacji. Innymi słowy, to, co osiągają sceptycy, nie jest tym, do czego dążą dogmatycy, nie jest nawet tym, do czego dążyli oni sami w fazie presceptycznej, w której przystępowali do badań z nadzieją odnalezienia prawdy.

Kolejnym ważnym zagadnieniem związanym $z$ ataraksją, na które musimy zwrócić uwagę, jest praktyczny aspekt tej kategorii. Innymi słowy, zastanowimy się nad tym, jak neopirroniści proponują rozwiązywać kwestie moralne. W szczególności zapytamy, czy uspokojenie umysłu oznacza całkowite zawieszenie moralnego kwalifikowania czynów. $\mathrm{Na}$ temat działania w kontekście moralnym oraz przede wszystkim na temat kierowania sį̨ decyzjami odnoście do tego, co dobre, a co złe z natury, Sekstus wypowiedział się kilkakrotnie. W początkowej partii Zarysów pirrońskich odniósł się do wyrokowania o rzeczach dobrych i złych w nawiązaniu do ogólnego zagadnienia powstrzymania się od wyrokowania o prawdzie i fałszu. Czytamy tam (PH I, 28):

Kto natomiast nie wyrokuje o rzeczach istotnie pięknych [resp. dobrych - przyp. K. J.], albo złych, ten ani nie ucieka, ani nie ściga bez wytchnienia, a zatem zażywa spokoju.

Obszerniej do zagadnienia wyrokowania w kwestiach dobra i zła Sekstus powrócił w trzeciej księdze Zarysów oraz przede wszystkim w księdze Przeciw etykom ${ }^{45}$. W Zarysach, wykazując brak kryterium

45 Przeciw etykom funkcjonuje jako jedenasta księga Przeciw matematykom, które to dzieło od czasów średniowiecza ujmuje łącznie pod wspólnym tytułem 
oraz dowodu, przeczy istnieniu dobra i zła z natury (PH III, 182, 190, 235). Bardziej znamienna jest postawa Sekstusa w Przeciw etykom. W tekście tym nie tylko powtarza opinię wyrażoną w Zarysach, ale znacznie silniej wiąże powstrzymanie się od sądzenia w kwestiach dobra i zła z osiągnięciem spokoju umysłu. Stwierdza (AM XI, 30):

Skoro zaś rozumowanie dowiodło, że nic nie jest z natury dobre ani $z$ natury złe, nastąpi uwolnienie od udręki i będzie oczekiwało nas życie pełne spokoju.

Sekstus na tym nie poprzestaje, dalej rozwija swoją apologię ataraksji i, czego nie zrobił wprost w Zarysach, utożsamia ją ze szczęściem (AM XI, 111-114, 118, 144, 160).

Badacze podkreślają, iż $w$ tych fragmentach rzuca się w oczy nieobecność problematyki prawdy ${ }^{46}$. Ponieważ kwestia prawdy w ogóle się tutaj nie pojawia, można wręcz odnieść wrażenie, iż Sekstus skłonny jest twierdzić, że spokój umysłu osiąga się nie poprzez powstrzymanie sądzenia o wszelkich rzeczach, lecz właśnie poprzez powstrzymanie sądzenia o dobru i złu ${ }^{47}$. Temu zagadnieniu jednak nie będziemy poświęcać uwagi. Skupimy się natomiast na pytaniu: czym kieruje się sceptyk w praktycznym działaniu?

Kompleksowej odpowiedzi na to pytanie udzielił Sekstus w początkowej partii Zarysów pirrońskich, a później wielokrotnie do niej powracał. Powodem, dla którego czuł się zobowiązany, aby tak szybko uporać się z kwestią praktycznego działania, była powszechność

pozostałe zachowane teksty Sekstusa Empiryka. Wszystkie cytaty z tej księgi podaje w przekładzie Zbigniewa Nerczuka.

46 Zob. R. Bett, How Etbical..., s. 7-9.

47 Svavar H. Svavarsson twierdzi wręcz, że w pirrońskiej tradycji mamy do czynienia $z$ dwoma powiązanymi objaśnieniami drogi prowadzącej do spokoju umysłu - pierwsza poprzez wyzbycie się wszystkich przekonań, druga zaś poprzez wyzbycie się pozytywnych przekonań o dobru i złu, zob. S. H. Svavarsson, Two Kinds of Tranquility. Sextus Empiricus on Ataraxia, [w:] Pyrrhonism in Ancient..., s. 19-31; ide m, The Pyrrbonian Idea..., s. 198, 208. 
stawianego sceptycyzmowi zarzutu tzw. apraksji, czyli bezczynności. Głosi on, że sceptyk, jeżeli miałby postępować zgodnie z przyjętą perspektywą, ze względu na całkowity brak przekonań nie byłby w stanie wykonać żadnego działania. Stanowiłby szczególny przypadek osła Buridana, który nie może podjąć żadnego działania nie dlatego, że jedno kusi i drugie nęci, tylko dlatego, że absolutnie nic go nie kusi i nie nęci.

Odpierając zarzut bezczynności, autor Zarysów stwierdza, iż sceptyk, niczego nie przesądzając, zważając tylko na zjawiska, w swoim postępowaniu kieruje się własnym doświadczeniem życiowym, które konstytuowane jest przez cztery czynniki: wskazówki natury, przymus doznań, przekaz praw i obyczajów oraz nauczanie kunsztów (PH I, 2324). Dwa pierwsze aspekty określają nasz wymiar cielesny (wrażenia zmysłowe i potrzeby), dwa drugie wiążą się z wymiarem społecznym, tj. z faktem przynależenia do określonego społeczeństwa i kultury. Sceptyk zatem nie pozostaje bierny, tylko kieruje się w swoim postępowaniu zarówno tradycjami, prawami i obyczajami społeczeństwa, które inkulturował w procesie socjalizacji, jak też i "naturalnymi”, tj. odczuwanymi jako narzucające się, potrzebami i wrażeniami.

Pewnego wyobrażenia o tym, na czym miałoby polegać owo kierowanie się tak rozumianym doświadczeniem życiowym, dostarcza wzmianka o tyranie zmuszającym sceptyka do popełnienia niegodziwego czynu (AM XI, 164-165). Według dogmatyka sceptyk musiałby coś wybrać: albo odmowę i w konsekwencji śmierć, albo spełnienie polecenia celem uniknięcia tortur, a w konsekwencji śmierci. $\mathrm{Za}-$ tem - stwierdza oponent - musiałby dokonać wyboru, a to go spycha na pozycje dogmatyczne. Innymi słowy, każde działanie wymaga dokonania wyboru, a ten zawsze wiąże się rozstrzygnięciem dotyczącym jakiegoś dobra, a zatem musi mieć charakter dogmatyczny. Odpowiedź sceptyka jest znamienna. Oznajmia, że wskazana dystynkcja jego nie dotyczy, gdyż poczyniona jest „zgodnie z teorią filozoficzną”, czyli zgodnie z postawą polegającą na zabieganiu o rozstrzygnięcie, co jest faktycznie z natury dobre, a co złe. Sceptyk nie stawia sobie tego 
pytania, gdyż kieruje się tylko obserwacją, tj. zjawiskami. Oznacza to, że podejmuje on działanie, bądź to ulegając utrwalonym w jego kulturze tradycjom i zwyczajom, bądź też zgodnie z narzucającymi mu się potrzebami i wrażeniami. Dla bycia sceptykiem, nie jest ważne, co sceptyk w tej sytuacji zrobi, lecz jak to zrobi. Dogmatyk działa w sposób refleksyjny, próbując dostosować życie do uzyskanych na drodze refleksji przekonań o dobru i złu, natomiast refleksyjność sceptyka polega na tym, żeby być świadomie bezrefleksyjnym. Sceptyk pozwala na to, aby kierowaty nim przedrefleksyjne, narzucające mu się impul$\mathrm{sy}^{48}$. Ma to mu zapewnić spokój umysłu, dzięki któremu „cieszy się najdoskonalszą szczęśliwością" (AM XI, 161).

48 Pascal Massie twierdzi, że sposób działania sceptyka to trzecia droga poza bezrefleksyjną drogą prefilozoficznej osoby i refleksyjną drogą dogmatycznego filozofa. Tym, co ją określa, jest podtrzymywanie postawy badawczej mimo powstrzymania się od sądzenia i uzyskania spokoju umysłu. Pozwala to sceptykowi zachować dystans do własnych myśli, czyni to z niego widza i sędziego własnych myśli, które bada, ale którym nie daje pełnej akceptacji; zob. P. Massie, Ataraxia..., s. 204-205. Abstrahując od trudności, jaką sprawia deklaracja podtrzymywania postawy badawczej w kontekście idei równosilności sądów, uważam, że Massie myli się w swojej analizie. Sceptyk bowiem w pełni akceptuje to, co mu się jawi, „albowiem [to, co sį̨ jawi - K. J.] polega na biernym doznaniu bez udziału naszej woli" (PH I, 22). Jedyne, wobec czego sceptyk się dystansuje, to dogmatyczne przekonanie głoszące, że to, co sį̨ jawi, jest faktycznie takie, jakim się jawi, przekonanie, które może być udziałem zarówno filozofa, jak też i osoby prefilozoficznej. W praktycznym działaniu jednak sceptyk wraca do postawy przedrefleksyjnej, a ponieważ robi to świadomie, uchroni go to - jak sądzi - przed poczuciem winy za swoje czyny i wyrzutami sumienia. Ze względu na ową postawę świadomej bezrefleksyjności całkowicie nie zgadzam się także z interpretacją sceptycyzmu Sekstusa Empiryka zaproponowaną przez Tada Brennana, zob. T. Brennan, Etbics and Epistemology in Sextus Empiricus, New York-London 1999, s. 5-6. Autor ten postawę sceptyczną zrównuje z postawą zwykłego człowieka niefilozofującego, przeciwstawiając obie postawy postawie dogmatycznego filozofa. Uważam, że człowiek świadomie niefilozofujący dogmatyzuje w nie mniejszym stopniu od dogmatycznego filozofa, a może nawet robi to znacznie intensywniej, gdyz ten drugi obudowuje swoją skłonność do dogmatyzowania krytyczną aparaturą, 
Sądzę, że na podstawie tej odpowiedzi, można zaryzykować wniosek, że spokój, jakim chce się cieszyć sceptyk, jest spokojem indyferentyzmu. Taki spokój był udziałem żon obozowych oprawców, które codziennie $z$ uśmiechem na twarzy wyprawiały męzów do pracy w obozie koncentracyjnym. Nie chciały one w żaden sposób reflektować tego, co dzieje się za drutami obozu. Wybiegając do przodu, moglibyśmy stwierdzić, że przypowieść o tyranie pokazuje, jak bardzo podejście sceptyczne różni się od postawy buddyjskiej. Sceptyk chce wyłączyć wszelką decyzyjność, dąży do wyłączenia świadomości podczas dokonywania wyboru. Nie robi tego jednak, aby uzyskać zdolność spontanicznego, przedrefleksyjnego działania, w którym wyrażałaby się jakaś moralna intuicja dokonująca adekwatnej oceny stanu rzeczy pod względem dobra i zła. Spontaniczność, jeżeli możemy tutaj użyć tego słowa, o którą chodzi sceptykowi, jest całkowicie odmiennego rodzaju. Sceptyk chce wyłączyć wszelkie impulsy, które byłyby powodowane jakimiś świadomymi opiniami na temat tego, co dobre i złe $z$ natury, ale nie po to, żeby zrobić miejsce dla moralnej intuicji, lecz po to, żeby postąpić zgodnie $z$ utrwalonymi w nim na drodze inkulturacji i społecznego oddziaływania dyspozycjami. Godzi się on na postępowanie zgodnie $z$ utrwalonymi $w$ jego kulturze zwyczajami i modelami postępowania. Ostatecznie jednak nawet te mogą okazać się za słabe $\mathrm{w}$ swoim oddziaływaniu wobec zakodowanych $\mathrm{w}$ nas odruchów biologicznych. Analizowany z tej perspektywy sceptyk jawi się jako konformista ulegający ostatecznie spokojnemu, zatem szczęśliwemu oportuniście ${ }^{49}$.

zatem robi to w sposób ostrożniejszy. Dlatego też nie zgadzam się z opinią Brennana głoszącą, że sceptyczny spokój umysłu jest wyłącznie spokojem wobec przekonań filozoficznych, który nie dotyczy przekonań żywionych przez człowieka nieoddającego się świadomie filozofii, zob. ibidem, s. 76. Por. też przyp. 56 poniżej.

49 Przedstawiona tu surowa ocena sceptycyzmu wyrasta z prowadzonej na poziomie abstrakcyjnym analizy jego pojęciowej struktury i postawy. Broniąc sceptycyzm przed tak drastyczną oceną, można wskazywać na faktyczne, 
Warto zwrócić uwag̨ na jeszcze jeden związany $z$ ataraksją problem, aczkolwiek nie dotyczy on samej charakterystyki tego stanu, lecz perspektywy, z jakiej Sekstus wypowiada swoją opinię. Wskazując w Zarysach pirrońskich na spokój umysłu jako na cel sceptycyzmu (PH I, 25-26), Sekstus dokonuje przeciwstawienia sceptycznej drogi do ataraksji drodze dogmatycznej oraz wartościuje obie. Czyniąc to, sprzeniewierza się neopirrońskiej dewizie zdawania relacji z wrażeń, bowiem dokonuje nieuprawnionego uogólnienia. Dla zilustrowania tej opinii przytoczę tylko jedno zdanie (PH I, 27):

Kto przypuszcza na przykład, że coś jest istotnie piękne, albo złe, ten się skazuje na ustawiczny zamęt.

Otóż stwierdzenie to ma charakter ogólny i dotyczy pewnego obiektywnego stanu rzeczy, jakim jest stan umysłu dogmatyków. Sekstus nie relacjonuje tutaj swoich wrażen, nie zdradza swoich przypuszczeń, tylko wyraża ogólną opinię o stanie umysłu tych, którzy sądzą, że istnieją rzeczy z natury dobre bądź złe. Należy zapytać, na jakiej podstawie filozof tę opinię sformułowat, jakim wglądem poznawczym posłużył się, żeby zajrzeć w umysły dogmatyków i stwierdzić, ze jest to sytuacja nie tylko powszechna, ale uniwersalna. Możemy oczywiście podejść do tej wypowiedzi z wyrozumiałością i uznać, że mimo wszystko mamy tutaj do czynienia $\mathrm{z}$ relacją $\mathrm{z}$ własnych subiektywnych wrażeń i podejrzeñ ${ }^{50}$. W tym wypadku jednak wypowiedź ta

utrwalone w historycznym przekazie, postawy sceptyków, które nie tylko nie przyniosty im opinii oportunistów, ale wzbudzały ogólny podziw i szacunek. Dobitnym przykładem jest postawa samego Pirrona. W odpowiedzi na tak prowadzoną obronę należałoby podkreślić, pozostając $\mathbf{w}$ zgodzie $z$ postawą sceptyczną, ze to, jak faktycznie postępują sceptycy, zależy od przyrodzonej im, niejako naturalnej, moralnej wrażliwości. Jest to jednak kwestia indywidualna. Sceptyk zawsze powinien postępować w zgodzie z tym, co narzuca mu się jako naturalne. Można oczekiwać, że sceptykom obdarzonym ową moralną wrażliwością i jej pozbawionym będą narzucaty się różne wybory.

so W PH I, 197-201 Sekstus objaśnia znaczenie dużego kwantyfikatora, jaki pojawia się w zwrotach "niczego nie określam", „wszystko jest nieokreślone", 
straci swoje walory perswazyjne i będzie przekonująca tylko dla tych, którzy są już przekonani, tzn. dla tych, którzy podzielają z Sekstusem te same wrażenia i którzy skłonni są odpowiedzieć na nie zawieszeniem sądzenia ${ }^{51}$. Innymi słowy, problem, przed jakim staje sceptyk, polega na tym, że chcąc być wiernym swoim deklaracjom, może on mówić tylko o swoich subiektywnych stanach - wrażeniach i przekonaniach, i nie ma żadnego sposobu, żeby poza sferę subiektywności wyjść. Na przykładzie powyższej wypowiedzi widać jednak, że nawet tak samoświadomemu sceptykowi, jakim był Sekstus, trudno było zachować deklarowaną powściągliwość i przeciwstawić się pokusie formułowania sądów uniwersalnych.

Oświadczenie sceptyka, że zawiesza wszelkie opinie na temat rzeczy dobrych i złych z natury, stawia nas przed jeszcze jednym dylematem. W świetle tego oświadczenia pod znakiem zapytania staje wartość deklaracji leczenia dogmatyków. Dla prawomyślnego sceptyka spokój umysłu nie może być z natury lepszy od szaleństwa, w jakim tkwią dogmatycy. Spokój umysłu przydarzył się sceptykowi niejako mimochodem. Co prawda w swoim punkcie wyjścia ten poszukiwał spokoju, ale poszukiwał go jako dogmatyk, zanim zdał sobie sprawę z równosilności sądów. Gdy powściągnął sądy, ku swojemu zaskoczeniu uzyskał spokój umysłu. W zgodzie z postawą sceptyczną pozostaje mu tylko zdać z tego wydarzenia relację. Jeżeli jednak sceptyk przedkłada wyższość spokoju umysłu nad szaleństwo dogmatyków, to dokonuje wartościowania, poniekąd wraca do swojego dogmatycznego punktu wyjścia, tym samym zmienia postawę deskryptywną na preskryptywną. Zmiana taka oznacza jednak przejście na pozycje dogmatyzmu, czyli sprzeniewierzenie się sceptycznym postulatom.

czy "wszystko jest nieuchwytne”. Stwierdza, iż w rzeczywistości zwroty te określają tylko subiektywne, „osobiste poczucie”, to, jakimi rzeczy wydają sį̧ dla niego i nie powinny być rozumiane dogmatycznie.

$\therefore$ Kwestiç tę w przekonujący sposób omawia: R. J. Hankinson, The Sceptics, London-New York 1995, s. 273-276, zwł. s. 275. 
$\mathrm{Na}$ podstawie dotychczasowych rozważań mamy prawo zapytać, czy spokój umysłu jest konstytutywnym czynnikiem określającym postawę sceptyka. Czy ataraksja jako cel jest czymś niezbywalnym dla postawy sceptycznej, czy też jest celem, który został wskazany przygodnie, w związku z tym, że ataraksja jako cel funkcjonowała w kulturowym środowisku, w którym sceptycyzm się rozwijał - i stąd na drodze asymilacji trafiła do sceptycyzmu? ${ }^{52}$ Sprawa nie jest jednoznaczna. Musimy bowiem zauważyć, że sceptyk stawiał przed sobą cel ataraksji w fazie, w której sceptykiem jeszcze nie był, i wiązał jej osiągnięcie z nadzieją osiągnięcia prawdy. Gdy zatrzymał się $\mathbf{w}$ poszukiwaniu prawdy, jednocześnie też zaniechał dążenia do ataraksji i wtedy, nieoczekiwanie, ataraksja mu sį̨ przydarzyła. Czy taki rozwój wypadków uprawnia nas jednak do uznania, że w jakimś sensie sceptyk mimo zawieszenia sądów dalej żywił na nią nadzieję? Wielu badaczy sądzi, że dążenie sceptyka do spokoju umystu broni się przed zarzutem dogmatyzmu z tego względu, iż sceptyk traktuje je jako naturalny impuls porównywalny do innych naturalnych impulsów, jak np. dążenie do zaspokojenia pragnienia czy wyzbycia się bólu ${ }^{53}$. Codzienna obserwacja tego jednak nie potwierdza, utożsamianie szczęścia ze spokojem umysłu wydaje się praktyką typową raczej dla pogłębionej refleksji filozoficznej niż powszechnie spotykanym dążeniem. Stąd też niektórzy badacze kontestują to przekonanie, utrzymując, że idea spokoju umysłu nie konstytuuje postawy sceptycznej i jest dla niej czymś

52 Rzecznikiem drugiej opcji jest Mark L. McPherran, zob. M. L. McPherran, Ataraxia and Eudaimonia in Ancient Pyrrbonism. Is the Skeptic Really Happy?, "Proceedings of the Boston Area Colloquium in Ancient Philosophy" 5 (1989), s. 136-137.

53 Zob. na ten temat ide m, Skeptical Homeopathy and Self-refutation, "Phronesis” 32 (1987), s. 325; ide m, Ataraxia and Eudaimonia..., s. 165-167; J. A n nas, The Morality of Happiness, New York-Oxford, s. 209-210; M. Nussbaum, The Therapy of Desire. Theory and Practice in Hellenistic Ethics, Princeton 1994 , s. 305. 
przygodnym $^{54}$. Jeśli tak, to można wyobrazić sobie praktykę sceptyczną bez tej idei, jak też i praktykę sceptyczną ukierunkowaną na osiągnięcie całkiem innej idei.

Pytanie, jakie tutaj rozważamy, można by jednak sformułować w sposób znacznie ogólniejszy, mianowicie: czy w ramach sceptycznego dyskursu, który ma być tylko sprawozdaniem, możliwe jest formułowanie jakichkolwiek celów, które nie mają zakorzenienia w naszym naturalnym zestawie impulsów? W szczególności można postawić pytanie: czy takim celem może być dążenie do odkrycia prawdy? Sekstus, jak pamiętamy, wskazuje na poszukiwanie i badanie prawdy jako na postawę właściwą dla sceptyka nawet po osiągnięciu przez niego spokoju umysłu. Trudność stwarza jednak nie tyle spokój umysłu, co zawieszenie wszelkiego sądzenia. Mamy tutaj do czynienia $z$ dwoma dylematami. Po pierwsze: czy możliwe jest praktykowanie poszukiwania prawdy w stanie całkowitego zawieszenia sądzenia? Po drugie natomiast: czy warto poszukiwać prawdy? Innymi słowy, skoro jej poszukiwanie jest konstytutywne dla postawy dogmatyka, to w oparciu o jakie rozpoznanie sceptyk, po zawieszeniu sądzenia, uznaje prawdę za wartość, której należy poszukiwać?s5

¿4 Taką tezę postawił Diego E. Machuca, zob. D. E. Machuca, The Pyrrho-

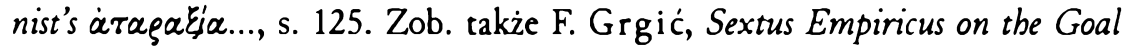
of Skepticism, „Ancient Philosophy” 26 (2006), s. 141-160.

is Niektórzy badacze skłonni są wręcz wyrażać wątpliwość w to, że Sekstus powaznie traktuje deklaracje o poszukiwaniu przez sceptyka prawdy, zob. J. Barnes, Introduction, [w:] Sextus Empiricus, Outlines of Scepticism, ed. J. A nnas, J. Barnes, Cambridge 2000, s. XXX: it is difficult to believe that Sextus ever seriously searched for the truth („trudno uwierzyć, że Sekstus kiedykolwiek na poważnie poszukiwał prawdy"). Z drugiej strony należy zauważyć, że sceptyk dążenie do prawdy może traktować jako naturalny impuls każdego człowieka. Sekstus dat temu wyraz w AM VII, 27, gdzie stwierdził: „człowiek jest z natury istotą miłującą prawdę" (w przekładzie Izydory Dąmbskiej); zob. także L. Joach i mowicz, Sceptycyzm grecki, Warszawa 1972, s. 113. Oczywiście wartość tego twierdzenia w świetle ogólnej metodycznej postawy sceptyka jest co najmniej dyskusyjna. 
Rekonstruując sceptycyzm, często formułowałem pytania, które rodzą się podczas uważnej lektury tekstów Sekstusa Empiryka. Odnosz̨̧ wrażenie, że udzielenie klarownej na nie odpowiedzi wiąże sį̨ zawsze $\mathrm{z}$ marginalizacją pewnych niewygodnych twierdzeń. Gdy tego nie uczynimy, pozostaje nam zwykle poprzestać na konstatacji gł̨bokiego rozdarcia $\mathrm{w}$ myśli neopirrońskiej, które wyraża się $\mathrm{w}$ wielu momentach poprzez sprzeczności. Sądzę, że w ramach podsumowania warto jeszcze raz postawić tutaj te pytania. Czy sceptycyzm neopirroński jest postawą epistemologiczną czy etyczną? Co właściwie jest celem filozoficznych poszukiwań podejmowanych przez neopirrońskiego sceptyka - osiągnięcie prawdy czy osiągnięcie szczęścia? Inaczej mówiąc: czy cel, jaki stawia przed sobą neopirroński sceptyk, jest tym samym celem, do którego dążył Pirron? Czy przystępując do poszukiwania prawdy, sceptyk żywi nadzieję na osiągnięcie tą drogą szczęścia? Czy sceptyk, w zgodzie z zasadami określającymi jego postawę, ma $\mathrm{w}$ ogóle prawo stawiać przed sobą jakiś cel? Czy równosilność sądów jest obiektywnym faktem odkrywanym przez sceptyka, czy też jest to tylko subiektywna umystowa postawa indukowana intencjonalnie? W jakim stopniu osiągnięcie szczęścia zależy od powstrzymania się od wydawania sądów oraz realizacji postawy beznamiętności? Czy sceptyczny projekt etyczny dopuszcza możliwość rezygnacji z postulatu zawieszenia sądów jako sposobu osiągania ataraksji? Czy sceptyczna droga do szczęścia jest jedynie alternatywna wobec innych dróg, w tym w szczególności wobec drogi stoików, czy jest jedyną możliwą drogą? Czy droga poznania, nawet jeżeli ostateczne odwieszenie sądów jest potencjalnie dopuszczalne, może w ogóle być drogą szczęścia, czyli czy nadzieja osiągnięcia szczęścia poprzez poznanie prawdy, z jaką przystępowaliśmy do filozoficznych poszukiwań, jest w ogóle spełnialna? Jeżeli sceptyczna droga do szczęścia jest drogą realizowalną, czyli gwarantującą, a przynajmniej dającą nadzieję na jego osiągnięcie, to jaki sens ma postulat poszukiwania prawdy, jeżeli osiągnięcie szczęścia w żaden sposób od poznania prawdy nie jest zależne? Jak spokój umysłu wiąże się $\mathrm{z}$ intencją poszukiwania prawdy? 
Czy osiągnąwszy spokój umysłu (ataraxia), sceptyk może faktycznie kontynuować poszukiwanie prawdy?

Przynajmniej nad jednym $z$ tych pytań warto się jeszcze na chwilę zatrzymać. Sugerowałem wcześniej, przy okazji omawiania relacji zachodzącej między spokojem umystu a zawieszeniem opinii (epochē) i niewyrokowaniem (aphasia), że Sekstus, tak jak Tymon, pozostawia otwartą kwestię tego, czy istnieją alternatywne drogi do osiągnięcia spokoju, w szczególności zaś, czy może doprowadzić do niego również droga dogmatyczna. Sprawa jednak nie jest tak oczywista, jak może się wydawać po lekturze wstępnej partii Zarysów pirrońskich, na podstawie której zwykle formułuje się przytoczoną tu opinię. Kończąc swoje dzieło, jak wspominałem, Sekstus przedstawia wartość krytycznej aktywności sceptyka w kategoriach terapii, która za pomocą argumentów wyrażanych w języku ma „leczyć w miarę możności karkołomny szał dogmatyków" (PH III, 280). Czy nazwanie postawy dogmatyków szałem jest tylko retorycznym zabiegiem propagandowym na rzecz sceptycyzmu, czy też kryje się za tym jakieś donioślejsze przekonanie? Sądzę, że należy się opowiedzieć za drugą sugestią. We wstępnych partiach swojego dzieła autor bardzo dbał o to, żeby określić różniç postaw między dogmatykami a sceptykami i żeby uchronić się przed zarzutem dogmatyzowania. W ostatnich jednak słowach pozwala sobie na znacznie większą dosadność i bezpośredniość. Czy do przyjęcia jest, że ci, którzy w opinii Sekstusa ogarnięci są umysłowym szałem $^{56}$, zdolni są na tej drodze uzyskać spokój umysłu? Jeżeli sceptycyzm jest terapią, to postawa niesceptyków jest chorobą, a trudno sobie wyobrazić, żeby filozof ten zaakceptował przekonanie, że droga do zdrowia może wieść poprzez jeszcze większe pogrążanie się w cho-

i6 Do tej grupy zaliczam zarówno dogmatycznych filozofów, czyli osoby świadomie oddające się refleksji filozoficznej i utrzymujące jednoznaczną pozytywną bądź negatywną opinię na temat możliwości uzyskania prawdy w poznaniu, jak też $\mathrm{i}$ osoby pozostające $\mathrm{w}$ naturalnej przedflozoficznej postawie, które dogmatyzują w sposób nieuświadomiony. Obie grupy cierpią na tę samą chorobę, lecz pierwsi w stosunku do drugich doświadczają jej ostrego stadium. 
robie. Oceniając sceptyczną postawę z tej perspektywy, wydaje się, że Sekstus nie może zaakceptować żadnej alternatywnej drogi do spokoju umystu z tego prostego powodu, że każda inna droga musi być droga dogmatyczną, a ci, którzy nią kroczą, muszą pogrążać się w szale, czyli chorobie $^{57}$. Jeżeli odnalezienie prawdy wiąże się $z$ aktem uznania, a ten wyklucza się z powstrzymywaniem sądzenia, warunkiem odnalezienia prawdy jest rezygnacja $z$ postawy powstrzymywania sądzenia, to z kolei oznacza utratę spokoju umysłu, który to spokój zrealizowat się w związku z powstrzymaniem się od wydawania sądów, a zatem utratę zdrowia. Tak więc poszukiwanie prawdy w sceptycznym punkcie wyjścia musi być skazane na porażkę. Sekstus bowiem nigdzie nie obiecuje, ani że spokój umysłu jest trwały, czyli że raz osiągnięty nie może zostać utracony, ani że sceptyczny spokój umystu jest instrumentem pozyskiwania prawdy, który działa w ten sposób, iż chroni przed popadaniem $w$ szał, $w$ jaki popadają ci, którzy $w$ ten instrument wyposażeni nie są. Można wręcz domniemywać, że pozostawanie w stanie spokoju umystu jest nietrwałe o tyle, o ile zależy od utrzymywania postawy zawieszenia sądzenia. To z kolei oznacza, że faktycznym celem sceptycyzmu jest nie prawda ${ }^{58}$, a spokój umystu, chyba że inspirowani dwudziestowieczną hermeneutyką zgodzimy się uznać, że samo poszukiwanie tego, czego ostatecznie odnaleźć nie sposób, jest dla sceptyka wartością samą w sobie ${ }^{59}$. W świetle powyższych uwag scep-

57 W Przeciw etykom Sekstus jednoznacznie opowiada się za nieistnieniem alternatywnych dróg do spokoju, np. w AM XI, 118 stwierdza wyraźnie: „Nie można zatem żyć szczęśliwie, przyjmując pewne rzeczy za dobre albo złe z natury", por. teì AM XI, 111, 113.

58 Niektórzy badacze twierdzą jednak, że sceptyk szuka prawdy niezależnie od poszukiwania ataraksji, zob. C. Perin, Pyrrbonian Scepticism and the Search for Truth, "Oxford Studies in Ancient Philosophy" 30 (2006), s. 344; a także D. E. Machuca, Ancient Skepticism. Pyrrhonism, „Philosophy Compass” 6/4 (2011), s. 253. Obszerną analizę tego, co jest celem sceptycznego poszukiwania, przedstawia Katja M. Vogt, zob. K. M. Vogt, The Aims of Skeptical Investigation, [w:] Pyrrhonism in Ancient..., s. 33-49.

59 Musimy jednak zauważyć, że jeżeli pójdziemy za inspiracją hermeneuryczną, to postąpimy niezgodnie z przekonaniem Sekstusa. W PH III, 183 kwestionuje on bowiem wartość dązenia dla samego dążenia. 
tyk jawi się jako nauczyciel, który utrzymuje przed swoimi studentami, że najlepszym sposobem zabezpieczenia się przed traumą związaną z oblaniem egzaminu, jest w ogóle do niego nie przystępować. Jednoznaczna wykładnia przesłania głoszonego przez neopirroński sceptycyzm jest zadaniem niezwykle trudnym, a wnosząc po liczbie odmiennych i przeciwstawnych interpretacji, można by wręcz zaryzykować hipotezę, że może i niewykonalnym. Pod pewnym względem jednak to bogactwo wykładni myśli neopirrońskiej wydaje się pozorne. Sądzę, że wszystkie one mieszczą się w jednym $z$ dwóch ogólnych modeli interpretacyjnych. Albo uznamy, że przesłanie sceptyczne ma walory uniwersalne i obiektywne, albo że jest ono partykularne i subiektywne. Za swoiste kryterium różnicujące oba modele uznać można sposób rozumienia równosilności sądów. Pierwszy model wyrasta z pojmowania równosilności jako faktu obiektywnego, który sceptyk napotyka w rzeczywistości, odkrywa i czuje się w obowiązku z nim skonfrontować. W ramach tego modelu sceptycyzm będzie się jawił jako uniwersalna krytyka możliwości poznania, będzie więc pewnym szczególnym stanowiskiem epistemologicznym i ostatecznie okaże sį̨ formą negatywnego dogmatyzmu, aczkolwiek ze względu na ogromny wysiłek wkładany przez Sekstusa, żeby temu zaprzeczyć, formą bardzo dobrze zakamuflowaną ${ }^{60}$. Drugi model ugruntowany jest w pojmowaniu równosilności jako zadania do wykonania - nie jest ona tym, co sceptyk odkrywa, lecz tym, co ustanawia. Zgodnie z tym modelem sceptycyzm jest umysłową praktyką, formą ćwiczenia duchowego wyrastającą z przygodnego i subiektywnego doświadczenia „utknięcia w równowadze sprzeczności" (PH I, 26) ${ }^{61}$. Tak rozumiany sceptycyzm bardziej zachęca i wzywa do podjęcia wysiłku praktykowania, wskazując na jego potencjalne duchowe korzyści w postaci ataraksji,

60 Przyznać należy, że ten model interpretacyjny w podejściu do sceptycyzmu dominuje. Neopirronizm standardowo przedstawiany jest jako wyrażaąca pretensje do uniwersalności epistemologiczna krytyka możliwości poznania.

${ }_{61}$ Rzecznikiem tego modelu jest np. Pascal Massie, zob. P. Massie, Pbilosopby and Ataraxia..., s. 211-234. 
niż jedynym sensownym wyborem $w$ dążeniu do niej ustanawia praktykę. Droga sceptyczna będzie drogą alternatywną dla innych potencjalnych dróg, drogą dla tych, których dotknęła swoista umysłowa przypadłość. W dalszej części pracy, próbując odnieść przesłanie neopirronizmu do myśli buddyjskiej, będę konfrontował się z obydwoma modelami interpretacyjnymi sceptycyzmu.

\subsection{Sceptyczne tendencje we wczesnym buddyzmie}

Sugestia, że nauka Buddy ma charakter sceptyczny, nie jest domeną wyłącznie współczesnych badaczy. Pojawiła się już w najwcześniejszym okresie obok zarzutu metafizycznego nihilizmu, a do pewnego stopnia też i w związku z nim. Pierwszym przykładem, który warto tutaj przywołać jest Kazanie o Wadżdżijamabicie (Vajjiyamābita-sutta; AN V, 189-192). W kazaniu tym świecki wyznawca Buddy staje w obronie swojego nauczyciela, któremu niebuddyjscy asceci zarzucają, że jest „sofistą, który niczego [wyraźnie] nie określa” (venayiko appaññattiko; AN V, 190). Słowo venayika w zgodzie z propozycją słownika ${ }^{62}$ często oddawane jest jako „nihilista”, chociaż określenie to wiąże się już z pewną uwzględniającą szerszy kontekst interpretacją. Dosłownie wenajiką jest ten, który nie (vi-) prowadzi (nayatı) myśli bądź wypowiedzi w sposób metodyczny, planowy (naya), a czyni tak, gdyż niczego wyraźnie nie ujmuje w pojęcia i nie nazywa (appaññatti), stąd lepiej pozostać przy określeniu „sofista”, żeby uniknąć terminu bardziej kolokwialnego, czyli "krętacz”. W opinii owych ascetów Budda jawi się właśnie jako taki sofista, który unika jasnych deklaracji, gdyż nie opowiada się po żadnej stronie.

Określenie venayika pojawia się też w słynnym i niezwykle ważnym Kazaniu o węzu (Alagaddūpama-sutta; MN I, 130-142), do którego jeszcze będziemy powracać. Tutaj poprzestaniemy tylko na samym

62 Pali-English Dictionary, ed. T. W. Rhys Davids, W. Stede, Delhi 1993, s. 648. 
oskarżeniu sformułowanym pod adresem Buddy, które brzmi: „Asceta Gotama jest sofistą, który naucza o unicestwieniu, zniszczeniu i ustaniu istniejącego bytu" (venayiko samano gotamo, sato sattassa ucchedam vinasam vibhavam paññāpeti; MN I, 140). To właśnie $\mathrm{z}$ tego powodu, czyli ze względu na skojarzenie z nauką o unicestwieniu jaźni, termin ten bywa przekładany jako „nihilista”. Nie jest jednak wcale pewne, czy Budda uznawany jest tutaj za wenajikę dlatego, że naucza o unicestwieniu istniejącej jaźni, czy też dlatego, że kluczy i nie chce się do tego wprost przyznać. Mówiąc inaczej, nie ma pewności, czy określenie to należy wiązać $z$ oskarżeniem o nihilizm metafizyczny czy epistemologiczny.

Jest całkiem możliwe, że $\mathrm{w}$ tym wypadku $\mathrm{w}$ grę wchodzi raczej to drugie rozwiązanie. Znajdziemy bowiem przykłady takiej postawy Buddy, która w oczach jego krytyków mogła być interpretowana jako zwykłe unikanie wyciągania konsekwencji z prowadzonego rozumowania. Wskazać tu możemy choćby SN III, 66-68. Budda przeprowadza tam rozumowanie dotyczące potencjalnej jaźni, które już przywoływałem w pierwszej części niniejszej pracy. Wykazuje w nim z jednej strony, że to, nad czym nie mamy kontroli, nie może być uznane za jaźń, z drugiej zaś, że za jaźń nie można uznać tego, co jest nietrwałe, a niczego trwałego w naszym doświadczeniu znaleźć nie możemy. Wydaje się zatem, że konsekwencją tego rozumowania powinna być jasna deklaracja, że jaźń nie istnieje. Taka jednak nie pada. Zamiast tego Budda zaleca jako konsekwencję przeprowadzonej analizy mądre patrzenie na pięć zespołów zgodnie ze stanem faktycznym (yathā-bbūta). Takie zaś patrzenie wyraża się w sformułowaniu: „to nie jest moje, to nie jestem ja, to nie jest moja jaźń" (netam mama neso bam asmi na me so attā).

$\mathrm{Z}$ postawą tą koresponduje wypowiedź Buddy z Wielkiego kazania o podstawach zależności (Mabā-nidana-sutta; DN II, 55-71), w której Budda stwierdza, że nie należy spekulować na temat tego, czy jaźń jest materialna czy niematerialna, czy jest ograniczona czy nieograniczona (DN II, 65). Podobnie też należy się powstrzymać od stwierdzania, 
czy uczucie jest jaźnią, czy jaźń jest niedoznająca czy doznająca, czy też ma ona naturę uczucia (DN II, 66-68). W tym stanie zawieszenia opinii osoba w ten sposób rozważająca zaprzestaje lgnięcia do czegokolwiek, a to ostatecznie prowadzi do wyzwolenia (DN II, 68).

Powodu do stawiania mu zarzutu o bycie wenajiką mógł dostarczać Budda również sposobem postępowania wobec pewnych pytań zwykle kojarzonych z postacią Waczczhagotty. W krótkim kazaniu z SN IV, 400-401 Budda na pytania ascety Waczczhagotty o istnienie jaźni, ewentualnie o jej nieistnienie, zachowat milczenie i pozwolił ascecie odejść, nie udzielając mu żadnej odpowiedzi. Chociaż Budda indagowany przez ucznia Anandę o powód takiego postępowania ostatecznie je zracjonalizował, wskazując m.in. na niezdolność pytającego do zaakceptowania odpowiedzi zgodnie $z$ intencją Buddy, to faktem pozostaje, że Waczczhagotta jasnej odpowiedzi się nie doczekał, mimo iz z perspektywy czysto logicznej miał prawo oczekiwać wyboru jednej $\mathrm{z}$ dwóch przeciwstawnych opcji.

To samo oczekiwanie ten sam Waczczhagotta miał prawo żywić podczas innej rozmowy z Buddą utrwalonej w Kazaniu do Waczczbagotty o ogniu (Aggi-vacchagotta-sutta; MN I, 484-487), zwłaszcza że przedstawił tam bardziej rozbudowaną logicznie opcję dla spodziewanej odpowiedzi. Sześć pierwszych pytań dotyczyło trzech kwestii - wieczności bądź niewieczności świata, jego skończoności bądź nieskończoności oraz tożsamości ciała $\mathrm{z}$ duszą bądź ich rozdzielności. Kolejne cztery pytania dotyczyły jednej kwestii - istnienia Tathagaty po śmierci. Waczczha pytał, czy Tathagata istnieje, czy nie istnieje, czy istnieje i nie istnieje oraz czy ani istnieje, ani nie istnieje po śmierci. $\mathrm{Na}$ żadne z tych pytań odpowiedzi się nie doczekał. Skonfundowany zaczął dociekać powodu takiego postępowania. Usłyszał wówczas, że są to wszystko spekulatywne poglądy, które nie prowadzą do nirwany, a wręcz przeciwnie - wywołują tylko zamęt i cierpienie.

Analogiczna sytuacja została przedstawiona w kazaniu adresowanym do Malunkjaputty (p. Māluñkyaputta) (Cūla-māluñkya-sutta; MN I, 426-432). Od udzielenia przez Buddę odpowiedzi na te same 
dziesięć pytań Malunkjaputta uzależnił kontynuowanie praktyki pod jego kierunkiem. Budda jednak pozostat niewzruszony wobec groźby opuszczenia go przez ucznia, stwierdzając, że nigdy nie obiecywał mu udzielenia na te pytania odpowiedzi. Nie robił tego - dodał - dlatego, iż odpowiedzi te nie mają żadnego związku z praktyką zmierzającą do przebudzenia. Uzupełniając uzasadnienie swojej postawy, przywołał powszechnie znaną przypowieść o człowieku trafionym zatrutą strzałą. W sytuacji cierpienia pytania te mają taką samą wartość, oznajmia Budda, jak pytania człowieka trafionego zatrutą strzałą, który uzależnia swoją zgodę na wyjęcie strzały od uzyskania odpowiedzi na pytania o to, jakiego stanu społecznego był ten, który tę strzałę wystrzelił, jak się nazywał, jakiej był postury, gdzie mieszka itp. Budda takimi pytaniami się w ogóle nie zajmuje, pozostawiając je bez odpowiedzi (abyäkata $=$ avyäkata $)$.

W powyższych kazaniach Przebudzony jawi się jako ten, który unika jasnych rozstrzygnięć bądź odmawia odpowiedzi na pytania w jego czasach powszechnie zadawane. Można jednak znaleźć wypowiedzi Buddy, które sugerują sceptycyzm ze względu na odmawianie wartości wszelkiemu pojęciowemu myśleniu. W DN II, 277 Budda objaśnia bogu Sakce (p. Sakka), skąd wśród bogów biorą się zazdrość i chciwość. Wskazuje ostatecznie na skłonność do ideacji i rozpleniania myśli (papañca-sañña-sañkbā). Zaleca w związku $\mathrm{z}$ tym powściągnięcie owej skłonności, jest ona bowiem podstawą myślenia (vitakka), a to napędza pragnienie (chanda).

Z kolei w Kazaniu o kuli miodu (Madbu-pindika-sutta; MN I, 108-114) Budda wskazuje, iż zanik skłonności do rozpleniania myśli pociąga zanik negatywnych stanów umysłowych. Mahakaczczana, objaśniając tę naukę, będzie wykazywał, że do zaniku tej skłonności prowadzi powściągnięcie postrzegania (MN I, 112).

Można się spodziewać, że skoro Budda kwestionuje wartość pojęciowego myślenia ze względu na to, że zasila ono cierpienie, to ostatecznie gotów będzie zakwestionować także sens głoszenia jakichkolwiek poglądów. Nie sposób bowiem sformułować żadnego $z$ nich, 
zaprzestając myślenia. Faktycznie, w Trójkoszu znajdziemy wypowiedzi, które zdają się to przypuszczenie potwierdzać. Wystarczy przywołać tutaj tylko dwie, ale za to bardzo wymowne strofy z Suttanipaty. W Sn. 837 czytamy:

idam vadāmì ti na tassa boti

(magandiya ti bhagava)

dhammesu niccheyya samuggabitam

passañca dițthisu anuggabaya

ajjbatta-santim pacinam adassam $\|$

(Czcigodny powiedział do Magandiji): Pośród wielu nauk nie istnieje żadna, którą bym po zbadaniu uznat, [mówiąc] "to głoszę". Rozpatrując poglądy, nie chwytając żadnego, poszukując, dostrzegłem wewnętrzny spokój.

Czytana literalnie, strofa ta zdaje się afirmować postawę uderzająco podobną do postawy sceptyka. Budda przyznaje się, że nie utrzymuje żadnego poglądu, chociaż zadał sobie trud, żeby wszystkie rozważyć. Co więcej, owo intensywne badanie niezwieńczone wyborem żadnego z nich poprzedza osiągnięcie wewnętrznego spokoju.

W dalszej strofie Budda przyznaje, że chwytanie się postrzeżeń i poglądów nie zapewnia dobrostanu. Wręcz przeciwnie - prowadzi ono do napięcia związanego z konfliktem. Czytamy tam (Sn. 847):

sañña-virattassa na santi gantba pañ̃a-vimuttassa na santi mobã sañnañ ca dițthiñ ca ye aggabesum te ghațayanta vicaranti loke till

Nie istnieją więzy dla tego, który oderwał się od postrzeżeń. $\mathrm{Nie}$ istnieje omroczenie, dla tego, który wyzwolił się dzięki mądrości. Jednak ci, którzy uchwycili się postrzeżeń i poglądów, błąkają się w świecie, wzbudzając spory.

Mając przed oczami takie strofy, trudno nie ulec przekonaniu, że wczesny buddyzm wykazywał silną inklinację do postawy sceptycznej. Wielu badaczy temu wrażeniu się faktycznie poddało. 
Jednym $z$ takich badaczy młodszej generacji jest Ethan Mills, dostrzegający w przykładach takich jak powyższe podstawy do tego, aby mówić o przejawianiu się we wczesnym buddyzmie tendencji kwietystycznej. Za Stevenem Collinsem definiuje ją następująco: „postawa kładąca nacisk na pasywność w religijnej praktyce i dążąca do osiągnięcia "wewnętrznego spokoju" jako swojego ostatecznego celu"63. Wyróżnia przy tym cztery jej odmiany: postawę wrogą spekulacji, postawę ukierunkowaną na eliminowanie pojęciowego rozplenienia, co de facto oznacza eliminowanie myślenia pojęciowego, postawę ujawniającą się w wyciąganiu niedogmatycznych wniosków $z$ własnych argumentów oraz postawę, która za cel stawia sobie porzucenie wszystkich poglądów $^{64}$. Tendencję tę kontrastuje $z$ drugą, jego zdaniem dominującą, tendencją ukierunkowaną na analizę i wgląd. Przyznaje się jednocześnie, że w zakłopotanie wprawia go dążenie wielu uczonych do tego, aby tak zróżnicowane i wielopostaciowe teksty jak wczesnobuddyjskie sprowadzać do „jednej istotnej idei bądź monolitycznej filozoficznej orientacji”. Dążność taka w jego opinii jest wyrazem typowego dla praktyków pragnienia, aby zaprezentować ,jakieś pojęcie autentycznego buddyzmu” bądź typowego dla uczonych pragnienia, aby „zamknąć bogatą tradycję w łatwym podsumowaniu", wiąże się to jednak z brakiem uważności przy czytaniu tekstów ${ }^{65}$. Dalej Mills dowodzi, że na bazie tego wczesnego kwietyzmu rozwinął się dojrzały metafilozoficzny, czyli wrogi filozofii jako takiej, sceptycyzm Nagardżuny ${ }^{66}$.

63 S. Collins, Selfless Persons. Imagery and Thought in Theravada Buddhism, Cambridge 1982, s. 139: an attitude which emphasizes passivity in religious practice, and which seeks to attain as its final goal a state of beatific „inner quiet”.

${ }^{64}$ E. Mills, Three Pillars of Skepticism in Classical India. Nägärjuna, Jayaräsí, and Srī Harșa, Lanham 2018, s. 13-14.

65. Ibidem, s. 18-19.

${ }_{66}$ Zob. ibidem, rozdz. 2-3. Teze o metafilozoficznym sceprycyzmie Nagardżuny autor sformułowat juz w swoim doktoracie, zob. idem, The Dependent Origination of Skepticism in Classical India. An Experiment in Cross-Cultural Pbilosopby, [rozpr. dokt.], The University of New Mexico, Albuquerque 2013; zob. także idem, Skepticism and Religious Practice in Sextus and Nagarjuna, 
Pogrążając się w niestarannej lekturze tekstów buddyjskich i sięgając po argumenty $w$ tych tekstach zawarte, $w$ dalszej części pracy podejmę się rozpaczliwego zadania obnażenia miałkości tego typu postawy metodologicznej.

\subsection{Prawda a kwestia nastawienia poznawczego}

Punktem wyjścia dla dalszych rozważań w tej książce jest pytanie, na które nie udzielę wyczerpującej odpowiedzi, ale które w pewnym sensie będzie organizowało te rozważania i wokół którego one będą krążyły. Spróbuję przyblizyć się do odpowiedzi, ujmując to zagadnienie z pewnej strony i zwracając uwagę na jeden jego aspekt. Pytanie to brzmi: w jakim sensie prawda wyzwala? Oczywiście dla niektórych intelektualnych tradycji ma ono żywotną wartość, podczas gdy dla innych nie ma żadnej. Tutaj będziemy mieli na uwadze tradycję, dla której pytanie to jest kluczowe.

Banalna, zdroworozsądkowa odpowiedź, jakiej możemy udzielić na wstępie, będzie głosiła, że poznanie prawdy wyzwala z pozostawania w nieprawdzie, czyli w fałszywych przekonaniach na temat rzeczywistości. Wyzwolenie oznacza w tym wypadku rozbudzenie i zaspokojenie poznawczej ciekawości. Zatem w tym sensie każda zwieńczona sukcesem aktywność poznawcza wyzwala. Ponieważ z sukcesem poznawczym od czasów co najmniej Arystotelesa kojarzy się przekonanie o praktycznych korzyściach płynących z poznania, to wyzwolenie takie, zgodnie $z$ utrwaloną $w$ kulturze atlantyckiej narracją, będzie przedstawiane jako wyrażające się w poprawie jakości życia, przez co ogólnie można rozumieć przyrost możliwości oddziaływania na otaczającą rzeczywistość zarówno przyrodniczą, jak i społeczną. Chociaż $\mathrm{z}$ tak rozumianym poznaniem wiązano od czasów Oświecenia ogrom-

[w:] Ethics without Self, Dharma without Atman. Western and Buddhist Philosophical Traditions in Dialogue, ed. G. F. Davis, Cham 2018, s. 91-106. 
ne, czasami niemal eschatologiczne nadzieje, wydaje się, iż wpływa ono głównie na zmianę treści naszego myślenia, nie prowadzi jednak do zasadniczej zmiany życiowej perspektywy.

W związku z tym istnieje wyraźna tendencja, aby pytaniu temu nadawać głębsze czy też dobitniejsze znaczenie, które w tradycji europejskiej zainicjowane zostało przez szkołę pitagorejską, a ugruntowane i upowszechnione przez myśl platońską. Zgodnie z tym znaczeniem wyzwolenie pojmowane jest nie tylko czy też raczej nie tyle jako zmiana treści myślenia, co gruntowna przemiana formy myślenia, czyli przekroczenie własnej kondycji. Wyzwolenie w tym wypadku jest transcendowaniem doczesnych ograniczeń. Takie rozumienie pytania o wyzwalające oddziaływanie prawdy zakłada negatywną waloryzacje aktualnego stanu istnienia pytającego i to nie w kategoriach Kantowskiej przygodnej niedojrzałości, a istotnej ułomności. Stan ten traktowany jest jako naznaczony jakąś głęboką skazą, ze względu na którą będzie przedstawiany jako ułomny, czy to pod względem metafizycznym czy epistemologicznym, czy też obu łącznie. Przy czym deficytu poznawczego, który ma nas cechować, nie da się nadrobić zgodnie z tym modelem poprzez prostą oświeceniową afirmację rozumu i wiedzy naukowej. Aby go uzupetnić, wymagana jest zwykle przemiana na poziomie wolitywnym i afektywnym, czyli w obszarze motywacji, aspiracji oraz uczuć. Właśnie ze względu na charakter i zakres tej przemiany, której zajście uzależniane jest od oceny kreatywnego potencjału człowieka, postawy egzemplifikujące ten model myślenia będą przybieraty różne postaci - od afirmacji porzucenia i ucieczki z doczesnej kondycji poprzez dążenie do jej przekształcenia aż po jej pełną rezerwy akceptację.

W tradycji buddyjskiej prawda i jej rozpoznanie, tzn. poznanie faktycznego stanu rzeczy, jest warunkiem niezbędnym do tego, aby owo wyzwolenie osiągnąc ${ }^{67}$. Jest ona warunkiem koniecznym. Zapytać na-

07 W kontekście badań nad buddyzmem pytanie o wyzwalający charakter prawdy pojawia się $w$ ramach dyskusji nad kilkoma powiązanymi zagadnieniami, 
tomiast musimy, czy jest warunkiem wystarczającym. Czy nie muszą być spełnione inne wymogi, aby w ogóle prawda mogta wyzwolić. Tradycja buddyjska wiele uwagi poświęca tej kwestii, pytając, jakie warunki muszą być spełnione w znaczeniu stanu poznającego podmiotu, aby prawda mogła zadziałać w sposób wyzwalający, czy też aby w ogóle mogło dojść do wyzwalającego rozpoznania prawdy. Jestem przekonany, że to, co tradycja buddyjska w tej kwestii ma do powiedzenia, posiada walory uniwersalne, tj. nawet jeżeli pytanie o to, jak prawda wyzwala w tym drugim egzystencjalnie donioślejszym sensie, jest dla nas bezwartościowe, to odpowiedź na nie, przynajmniej w tym aspekcie, który spróbuję ukazać, ma pewną ogólną, uniwersalną doniosłość, którą warto wziąć pod rozwagę.

Należy podkreślić, że buddyzm, a przynajmniej wczesny buddyzm, nie lubi magii. W związku z tym sposób przedstawiania prawdy pozbawiony jest zwykle owych magicznych akcentów, ze względu na które prawda jawiłaby się jako coś, co zawiera w sobie szczególną nadnaturalną moc przekształcania, z czym kontakt sprawia, że bez

takimi jak różnica między doświadczeniem nirwany a wglądem poznawczym (co bywa czasami formułowane jako pytanie o znaczenie doświadczenia mistycznego i poznania intelektualnego), różnica między medytacją wyciszającą a medytacją wglądu, wartość intelektualnej (tj. pojęciowej) analizy itp. Zob. na ten temat m.in.: L. de La Vallée Poussin, Musīla et Närada. Le chemin du nirvana, „Mélanges chinois et bouddhiques” 5 (1936-1937), s. 189-222 [Musila and Narada. The Path of Nirvana, trans. into English G. M. Chödrön, G. L. Sangpo, http://www.gampoabbey.org/kosharesources.php (dostep: 10.03.2015)]; L. Schmithausen, On the Problem of the Relation of Spiritual Practice and Philosophical Theory in Buddbism, [w:] German Scholars on India II, ed. Cultural Department of the Embassy of the Federal Republic of Germany, Bombay 1976, s. 235-251; idem, On Some Aspects of Descriptions or Theories of "Liberating Insight" and "Enlightenment" in Early Buddhism, [w:] Studien zum Jainismus und Buddbismus. Gedenkschrift für Ludwig Alsdorf, hrsg. K. Bruhn, A. Wezler, Wiesbaden 1981, s. 199250; R. F. Gombrich, How Buddhism Began. The Conditioned Genesis of the Early Teachings, London-New York 2006, zwł. rozdz. IV; A. Wynne, The Origin of Buddhist Meditation, London-New York 2007, s. 102-108. 
własnego wysiłku ulegamy przekształceniu. Wręcz przeciwnie, tak rozumiana prawda traktowana jest jako coś ścieżce buddyjskiej obcego. "Tak rozumiana”, czyli jak? Prawdą, którą Budda pozbawia magicznej mocy przekształcania, jest prawda zamknięta w sądzie, czyli w ujętym językowo poglądzie ${ }^{68}$. Nie istnieją żadne święte, magiczne formuły prawdy, których poznanie i opanowanie miałoby wyzwalać. To właśnie stwierdzają dwie poniższe strofy z Suttanipaty (Sn. 788-789):

\section{passämi suddham paramam arogam \\ ditthena samsuddhi narassa boti \\ etäbbijanam paraman ti ñatva \\ suddbanupassĩ ti pacceti ñānam \|}

„Widzę to, co czyste, najwyższe, bez choroby. Oczyszczenie człowieka następuje dzięki poglądowi”. Tak rozumując, poznawszy "oto najwyższe", dochodzi do wiedzy, myśląc „jestem widzącym to, co czyste”.

ditthena ce suddbi narassa boti

ñänena vã so pajabati dukkham

añnena so sujjbati sopadhiko

dițthì hi nam pàva tatbā vadānam $\|$

Jeśli oczyszczenie człowieka następuje dzięki poglądowi bądź dzięki wiedzy porzuca cierpienie, to on, lgnący [do bytowania], staje się czysty dzięki czemuś innemu [niż szlachetne prawdy]. Gdy tak mówi, pogląd mu to podpowiada.

W istocie strofy te wyrażają dużo więcej niż tylko sprzeciw wobec magicznego rozumienia prawdy. Mówi się tu nie tylko o tym, że pogląd pozbawiony jest mocy przekształcania - człowiek nie zostaje oczyszczony przez pogląd. Sam pogląd staje się tutaj wręcz czymś podejrzanym. Podpowiada bowiem człowiekowi fałszywą perspektywę poznawczą. Fałszywość tej perspektywy nie musi polegać - jak

68 Na temat magicznego pojmowania wiedzy we wczesnej kulturze indyjskiej zob. D. Schlingloff, Buddyzm, thum. L. Żylicz, Warszawa 2004, s. 67-68. 
się za chwilę przekonamy - na prostym fakcie niezgodności poglądu/ sądu z faktycznym stanem rzeczy. Pogląd oszukuje człowieka w tym, że podsuwa mu wiarę $w$ niego samego, tzn. pozwala mu wierzyć, że opanowując pogląd - w tym pogląd o tym, co najwyższe - osiąga się to, co najwyższe. Co więcej, i to stanowi podstawowy problem, na który Budda będzie zwracał uwagę, żywienie przekonania, że poznało się to, co najwyższe, nie jest bezosobowe. Żywienie przekonania zawsze jest żywieniem przekonania przez kogoś. Jak mówi Sn. 788, gdy przedstawia sobie "oto najwyższe”, to przedstawia sobie jednocześnie ,jestem widzącym to, co czyste”. Innymi słowy, ujmowanie rzeczywistości poprzez pogląd zawsze jest ujmowaniem rzeczywistości poprzez przedstawienie jej sobie przez jakieś ,ja”. Wiara w magiczną moc formuł prawdy, tak charakterystyczna dla tradycji wedyjskiej, okazuje się wiarą we własne ,ja", jest zatem tylko kolejnym sposobem przejawiania się niewiedzy.

Dobrą ilustracje powyższych uwag znaleźć możemy w Kazaniu do Magandiji (Magandiya-sutta; MN I, 501-514). Budda poucza ascetę Magandiję (p. Māgandiya) o roli zmysłowego pragnienia w konstytuowaniu się cierpienia oraz o wyzbyciu się pragnienia jako sposobu na osiągnięcie nirwany. Pouczenie kończy formułą (MN I, 508):

arogya-paramā läbhā, nibbānam paramam sukbam, ațthangiko ca maggānam, khemam amata-gäminan'ti

Największym osiągnięciem jest zdrowie, nirwana jest największym szczęściem,

Ośmioraka ścieżka jest najlepszą ze ścieżek, gdyż prowadzi bezpiecznie do nieśmiertelności.

Po wystuchaniu tej formuły asceta Magandija powtórzył zachwycony jej dwie pierwsze pady, dodając, że słyszał już te słowa od nauczycieli tradycji, którą podąża. Budda zareagował na to oświadczenie pytaniem o to, co jest tym zdrowiem i tą nirwaną. Magandija dotknął swojego ciała, oznajmiając (MN I, 509): 
idantam bho gotama arogyam, idantam nibbanam. abam bi bho gotama etarabi arogo sukbī, na mam kiñci äbādhatīti.

To jest to zdrowie, przyjacielu Gotamo, to jest ta nirwana. Jestem teraz zdrowy i szczęśliwy, przyjacielu Gotamo, i nic mi nie dolega.

W odpowiedzi Budda przytoczył przypowieść, która miała uprzytomnić Magandiji, w jak wielkim jest błędzie. Wyobraźmy sobie, mówi Przebudzony, człowieka niewidomego od urodzenia. Nie widział on nigdy kolorów, światła ani ciemności. Pewnego razu usłyszał jednak od człowieka widzącego, że białe szaty są dobre, piękne i czyste. Zapragnął zatem je zdobyć. Ów widzący człowiek podarował niewidomemu szaty brudne, zapewniając, że daje mu szaty białe i czyste. Niewidomy je założyt i zadowolony rozpowiadał dookoła, powtarzając słowa, które sam usłyszał, że białe szaty są dobre, piękne i czyste. W związu z tym Budda zadał pytanie o to, czy on te słowa powtarzał, poznawszy i zobaczywszy (jananto passanto), czy też kierując się wiarą (saddhaya) w to, co usłyszał. Oczywiście Magandija przyznał, że kierowała nim wiara. W ten sam sposób, oznajmił Budda, postępują owi asceci, którzy powtarzają skądinąd prawdziwą formułę, ale nigdy jej prawdziwości nie potwierdzili, poznając ją i widząc. W równym stopniu, dodał Budda, dotyczy to także Magandiji, który powtarza tę formułę, ale nigdy nie doświadczył owej szlachetnej wizji (ariya cak$k b u$ ), dzięki której zweryfikowałby prawdziwość tejże formuły (MN I, 510). Wniosek z tego płynie taki, że powtarzanie prawdziwych poglądów nie ma w sobie żadnej mocy wyzwalającej. Nirwan̨̧ osiąga się, poznając $\mathrm{i}$ widząc, czyli w sposób w poglądzie niezapośredniczony.

Tak więc nauka Buddy wyrasta z postawy antymagicznej. Myśl buddyjska będzie w związku z tym przykładała ogromną wagę do odpowiedniego przygotowania podmiotu na to, aby prawda mogła zadziałać w sposób wyzwalający. Mówiąc inaczej, z perspektywy tradycji buddyjskiej interesująca będzie analiza tych czynników umysłowych, które nas ograniczają w uchwytywaniu prawdy, w jej rozumieniu. Kwestii 
tej tradycja buddyjska poświęca wiele uwagi, wskazując w różnych kontekstach na różne umysłowe czynniki, w których wyraża się nasza postawa niewiedzy i które z drugiej strony wpływają na trwanie w tej postawie, kształtując ją, tzn. determinując nasz potencjał poznawczy.

Jedna ze standardowych list takich czynników zwanych więzami (samyojana) podaje ich dziesięć (AN V, 17): przeświadczenie o indywidualnym istnieniu (sakkāya-dițthi), wątpienie (vicikiccbā), przywiązanie do praktyk i ślubów religijnych (sïlabbata-parāmāsa), pożądanie przyjemności zmysłowej (kāmacchanda), niechęć (vyāpāda), pragnienie [istnienia w sferze czystej] formy (rüpa-raga), pragnienie istnienia w sferze bezforemnej (arūpa-rāga), pycha (mana), zniecierpliwienie (uddbacca) oraz niewiedza (avijja). Ogólniejsza i bardziej podstawowa lista takich czynników zwanych skazami (dosł. napływy, nacieki, ale też wypływy) (äsava) wymienia ich trzy (MN I, 55): skaza przyjemności zmysłowej (kamasava), skaza bytowania (bhavāsava) i skaza niewiedzy (avijjasava). Często jednak w ogólnych opracowaniach wymienia się cztery skazy, gdyż taka poszerzona o skazę żywienia poglądów (dițthāsava) lista pojawiła się w Winajapitace (VP III, 5). Zestaw ten został następnie spopularyzowany przez abhidhammiczny traktat Dhamma-sangani (DhS 1096). Zaznaczmy od razu, że nie był to jakiś nowatorski pomysł. Podstawą dla niego były obecne w nikajach wykazy czterech negatywnych czynników, które faktycznie ujmowały owe skazy, tylko określały je odmiennymi (synonimicznymi) nazwami, takimi jak wylewy/rozlewiska (ogha) i związania/jarzma (yoga). Stąd też mamy odpowiednio kamogha, bhavogha, ditțhogha, avijjogha oraz kāma-yoga, bbava-yoga, dițthi-yoga i avijjā-yoga (DN III, 230 i 276; SN V, 59).

My jednak zwrócimy uwage na inny czynnik, a mianowicie na Ignięcie czy też chwytanie (upädāna). W procesie konstytuowania się doświadczenia czynnik ten odgrywa kluczową rolę. Definiowany jest następująco: „Ignięciem jest znajdowanie przyjemności w formie materialnej" (yā rūpe nandi tad upādānam) i w pozostałych zespołach (SN III, 14). 
Wyróżniona pozycja tego czynnika uwidacznia się w koncepcji zależnego powstawania opisującej formowanie się ludzkiego doświadczenia i bytowania. Lgnięcie jest czynnikiem dziewiątym, który bezpośrednio poprzedza pojawienie się kolejnego wcielenia. Jako siła ukształtowana w naszym dotychczasowym życiu decyduje o tym, że następuje kontynuacja, następuje przeniesienie istnienia w kolejny żywot. Nie będziemy tutaj rozwijać koncepcji w ogólnym zarysie znanej i wzmiankowanej już w pierwszej części. Wystarczy tylko, że zwrócimy uwagę na to, iż z perspektywy buddyjskiej w tym opisie sił, czynników kształtujących naszą transmigrację lgnięcie pojawia się jako bezpośrednio związane $\mathrm{z}$ kolejnym wcieleniem. Jest bezpośrednim warunkiem, na bazie którego nabudowuje się następne wcielenie. Przy czym, ściśle rzecz biorąc, gdy mówimy o kolejnym wcieleniu, posługujemy się tylko pewną konwencją opisującą bytowanie pod względem kolejnych czasowych faz wyróżnionych dla naszych potrzeb. Lgnięcie zatem jest czynnikiem, który nie tyle odpowiada za kolejne wcielenie, co po prostu za samo doświadczenie istnienia (bhava).

Budda podkreśla to w przywoływanym przed chwilą Kazaniu do Magandiji. Tak jak wspomniany w przypowieści niewidomy człowiek po odzyskaniu wzroku odrzuciłby brudne szaty, o których wcześniej sądził, że są czyste, tak też Magandija, gdy uzyska wgląd w faktyczny stan rzeczy, porzuci pożądanie i pragnienie do pięciu zespołów naznaczonych lgnięciem, gdyż uświadomi sobie, że cały czas lgnął tylko do owych zespołów. Magandija zrozumie wówczas, że (MN I, 511-512):

tassa me upadana-paccayā bbavo, bbava-paccayā jatti, jati- paccaya jarä-maranam soka-parideva-dukkba-domanassupayasa sambbavanti, evam etassa kevalassa dukkbakkbandhassa samudayo boti.

Uwarunkowane moim Ignięciem powstaje istnienie, uwarunkowane istnieniem powstają narodziny, uwarunkowane narodzinami powstają starość-i-śmierć, boleść, żałość, męka, udręka i niepokój. Tak powstaje ten cały zespół cierpienia. 
W pierwszej części niniejszej książki wskazywałem na rolę, jaką w konstytuowaniu się doświadczenia istnienia odgrywa poczucie ,ja" jako wzorca dla formowania się pojęcia istnienia. Wyróżniona pozycja lgnięcia polega na tym, że odgrywa ono w tym procesie kluczową rolę. Potwierdza to Ananda, przywołując słowa starszego mnicha Punny Mantaniputty (p. Puṇna Mantāniputta), jakie od niego usłyszał w czasach swojego nowicjatu (SN III, 105):

upädàa āvuso ānanda asmīti hoti no anupädäya \| kiñca upādàya asmìti boti no anupādāya \| rūpam upadāya asmìti hoti no anupadāya | vedanam | saññam | sankbare | viññanam upadaya asmìti boti no anupaadaya ||

To w związku z lgnięciem, przyjacielu Anando, pojawia się pojęcie ,ja jestem”, a nie niezależnie od lgnięcia. W związku $z$ lgnięciem do czego pojawia się pojęcie ,ja jestem", a nie niezależnie od lgnięcia? W związku z lgnięciem do formy pojawia się pojęcie ,ja jestem", a nie niezależnie od lgnięcia. W związku z lgnięciem do uczuć [...], do postrzeżeń [...], do formacji wolicjonalnych [...], do świadomości pojawia się pojęcie ja jestem", a nie niezależnie od lgnięcia.

Ujmując rzecz z perspektywy fenomenologicznej, można by powiedzieć, że lgnięcie jest stałym ukierunkowaniem umysłu na ujmowane treści, w którym dokonuje się uznanie w bycie zarówno owych treści jako ujmowanego przedmiotu, jak i umystu jako ujmującego podmiotu $^{69}$.

Tradycja buddyjska poddała owo lgnięcie refleksji, aczkolwiek w moim przekonaniu dalece niewystarczającej. Generalnie jednak wyróżniono cztery jego formy, którymi są lgnięcie: do przyjemności zmysłowej (käma), do poglądów (dițthi), do praktyk moralnych i ślu-

69 Na temat lgnięcia zob. Ch. K. Fink, Clinging to Notbing. The Phenomenology and Metaphysics of Upädana in Early Buddhism, APh 25/1 (2015), s. 15-33. Zob. także S. Hwang, Metaphor and Literalism in Buddhism. The Doctrinal History of Nirvana, London-New York 2006, s. 16-18. 
bów religijnych (silabbata) oraz do koncepcji jaźni (attavada) (DN III, 230; MN I, 50-51; SN II, 3; SN IV, 258; SN V, 59). Ze względu na cel niniejszego tekstu dla nas najciekawszą formą jest druga - lgnięcie do poglądów (dițthupādāna). Tak jak na temat zmysłowych władz ujmowania Budda oświadczył, że znajdują przyjemność w ujmowanych przedmiotach, tak też powtarza to o umyśle. W MN I, 503 czytamy: „umysł Magandijo znajduje przyjemność w przedmiotach umysłowych, raduje się przedmiotami umysłowymi, cieszy się przedmiotami umysłowymi" (mano kbo mägandiya dhammärämo dhamma-rato dhamma-sammudito), a jednym z tych przedmiotów są poglądy. Uwaga ta stanowi klucz do zrozumienia tych postaw afirmowanych przez Buddę oraz wczesną myśl buddyjską, które bywają podejrzewane o sceptycyzm.

\subsection{Lgnięcie do prawdy jako problem epistemologiczny}

Gdy przyjrzymy się, jak wyrażenie dițţhupādāna przekładano w różnych pracach, zarówno translatorskich, jak i monograficznych skądinąd wybitnych badaczy, łatwo możemy wyrobić sobie błędny pogląd na temat tego, jak tradycja buddyjska owo lgnięcie do poglądów rozumie. Poniższe przykłady można potraktować jako świadectwo standardowego sposobu ujmowania tego zagadnienia przez badaczy. Mamy więc: the grasping of error ${ }^{70}$, attachment to speculative ideas ${ }^{71}$, the grasping of beresy ${ }^{72}$, clinging to a metaphysical theory / to metaphysical beliefs ${ }^{73}$.

70 Zob. Dialogues of the Buddha, vol. 3, trans. T. W. Rhys Davids, C. A. F. Rhys Davids, London 1921, s. 222 (DN III, 230).

7 Zob. Further Dialogues of the Buddha, vol. 1, trans. R. Chalmers, London 1926, s. 37 (MN I, 51).

72 Zob. E. J. Thomas, The History of Buddhist Thought, London 1933, s. 98.

73 Zob. K. N. Jayatilleke, Early Buddhist Theory of Knowledge, London 1963, s. 430. Z kolei dittthasava Horner przetoziyła jako the canker of false views, zob. 
Takie odczytanie tego wyrażenia ma oczywiście w tekstach buddyjskich pewną podstawę. Szło ono za przykładami poglądów, do których możemy lgnąć, podawanymi w późniejszych komentarzach czerpiących inspirację z wyliczeń fałszywych poglądów zawartych w kanonie, np. w MN III, 71-72 (MN 117), jak też i w późniejszych tekstach abhidharmicznych ${ }^{74}$. Nie można zatem powiedzieć, że jest ono catkowicie wyrwane $z$ kontekstu, będąc inwencją badaczy. Podstawa ta jednak, ściśle rzecz ujmując, nie określa, jak w tekstach buddyjskich objaśniane jest samo pojęcie dițţhupādāna, czyli lgnięcie do poglądów, lecz wiąże się z tym, jak w tekstach buddyjskich przedstawiane są błędne poglądy. W tekstach buddyjskich mamy wiele uwag na temat tego, czym są błędne poglądy, czyli micchā-dițthi. W związku z tym badacze, którzy próbowali uporać się z wyrażeniem „lgnięcie do poglądów", wykorzystywali uwagi buddyjskich tekstów na temat błędnych poglądów. Tym samym od razu zawężali semantyczny obszar tego wyrażenia tylko i wyłącznie do obszaru błędu, nieprawdy ${ }^{75}$.

Standardowa opinia zatem sugeruje, że przez lgnięcie do poglądów rozumie się nie lgnięcie do poglądów jako takich, niezależnie od ich semantycznej wartości, lecz lgnięcie do fałszywych poglądów (miccbā-dițthi), np. do przekonania o nieobowiązywaniu prawa karmana (MN III, 71) ${ }^{76}$. Chodzi o lgnięcie do błędnych poglądów, a nie do poglądów w ogóle, w tym w szczególności nie do poglądów praw-

The Book of the Discipline (Vinaya-pitaka), vol. 1, trans. I. B. Horner, London 1938, s. 10 (VP III, 5).

74 DhS 1099 jako przykład skazy poglądu (ditţhāsava) wylicza np. dziesięć klasycznych pytań pozostawionych bez odpowiedzi. Buddhaghosa, mówiąc o lgnięciu do poglądów, wymienia sześćdziesiąt dwa błędne poglądy z Brabmadzalasutty (VM 569).

75 Można się w tej postawie dopatrzyć nawyków ukształtowanych pod wpływem tradycji chrześcijańskiej, kładącej nacisk na rozumienie wiary, kredo, ortodoksji itp.

76 Taką standardową opinię znaleźć można w: M. Sayādaw, $A$ Discourse on Dependent Origination, trans. U Aye Maung, ed. Bhikkhu Pesala, Middlesex 2013, s. 86-91. 
dziwych. Problem zatem jest nie w tym, że lgniemy, tylko w tym, do czego lgniemy. Jako argument na poparcie takiego przekonania przywołuje się fakt, iż w praktyce buddyjskiej właściwy pogląd (sammā-dițthi) jest punktem wyjścia dla tej praktyki, stanowiąc pierwsze ogniwo ośmiorakiej szlachetnej ścieżki, które ma warunkować pojawienie się innych właściwych jakości umysłu ćwiczonych w praktyce tejże (MN III, 71). Skoro właściwy pogląd jest punktem wyjścia i na jego bazie mają się kształtować inne aspekty rozwoju duchowego, to przylgnięcie do właściwego poglądu, czyli do poglądu prawdziwego, jest właściwą postawą, nie jest czymś negatywnym w sensie poznawczym, tzn. w sensie taktyki duchowej. Cóż może być bardziej właściwego, jak przylgnąć do właściwego poglądu.

Uważam, że jest to niezwykle wąskie i nietrafne odczytanie interesującego nas wyrażenia. Twierdzę, że istnieją solidne podstawy do tego, aby rozszerzyć rozumienie owego lgnięcia do poglądów i przenieść akcent na fakt lgnięcia, a nie na to, do czego lgniemy. W wyrażeniu tym chodzi nie tyle o kwestię semantycznej wartości poglądów, co o szczególny aspekt postawy względem poglądów, w tym w szczególności względem tych afirmowanych. Tym szczególnym aspektem jest egotyczna postawa względem poglądów. Oczywiście z perspektywy buddyjskiej jest czymś znacznie gorszym lgnąć do fałszywego poglądu niż lgnąć do poglądu prawdziwego. Ostatecznie jednak nawet lgnięcie do prawdziwego poglądu jest lgnięciem, czyli jest czynnikiem, który wiąże $z$ sansarą.

Punktem wyjścia dla niniejszej analizy będą dwie ważne dla tradycji buddyjskiej metafory, które później znajdą, moim zdaniem, eksplikację w myśli Nagardżuny. Pierwsza pojawia sį̨ w ważnym i popularnym tekście buddyjskim - Dbamma-pada ${ }^{77}$. W piątym rozdziale

77 Dhamma-pada to zbiór 423 strof przypisywanych przez tradycje samemu Buddzie. Tekst uważa się za wczesny, aczkolwiek nie sposób jednoznacznie określić daty jego powstania. Już w początkowym okresie swojego istnienia musiał cieszyć się niezwykłą popularnością, o czym świadczyć może fakt, 
tego tekstu przybliżającym buddyjskie rozumienie głupca (bäla), czyli osoby pogrążonej w niewiedzy, pojawia się jego charakterystyka podkreślająca egotyczny stosunek do rzeczy. Mówi się tam (DhP 62):

putta m'atthi dhanam m'atthi iti bālo vibañnati attä bi attano n'attbi kuto putta kuto dhanam

"Oto mam synów, mam bogactwa" tak się $\mathbf{w}$ udręce troszczy głupiec.

A przecież nawet siebie nie ma, skąd więc ma synów, skąd bogactwa? ${ }^{78}$

Głupiec zatem odnosi się do rzeczywistości przez pryzmat posiadania. W posiadaniu czegoś widzi pewną swoją wartość. Dąży do posiadania syna, bo bez niego ma poczucie, że nie jest spełnionym człowiekiem, dąży do posiadania bogactwa, pozycji społecznej, szacunku. Zabiega o te rzeczy jako o cel swojego życia. W drugiej części strofy wartość takiej postawy zostaje zdyskwalifikowana poprzez nawiązanie do fundamentalnej buddyjskiej nauki o niejaźni. Jak on to wszystko może osiągnąć, pyta tekst, skoro faktycznie nie ma niczego, co byłoby nim w sensie trwania, czyli nie ma niczego, co mogłoby być owym właścicielem $\mathrm{w}$ rozumieniu metafizycznym, do którego te rzeczy mogłyby przynależeć. Nie uświadamiając sobie swojego faktycznego sposobu istnienia, czyli swojej niejaźniowości, jest głupcem, gdyż postępuje tak, jakby owa domniemana jaźń mogła stać się właścicielem różnych jakości czy, mówiąc najogólniej, rzeczy.

Kolejna strofa jest nie mniej ciekawa. Czytamy tam (DhP 63):

yo balo mañnati bälyam pandito vä́pi tena so balo ca panditamāni sa ve bälo'ti vuccati

iż zachował sį̧ w kilku redakcjach (różnej długości) i językowych wersjach. Również dzisiaj jest to jeden z najpopularniejszych buddyjskich tekstów, zob. K. R. Norman, On Translating the Dhammapada, BSR 6/2 (1989), s. 153.

Dhammapade przywołuje w przekładzie Stanisława F. Michalskiego. 
Gdy głupiec pozna, że jest głupcem, przez to poznanie jest już mędrcem.

Głupiec, gdy mędrcem chce się wydać, zostanie zawsze głupcem tylko.

Analiza drugiej części tej strofy przynosi interesujące dla nas spostrzeżenia. Kiedy głupiec, powinniśmy zapytać, chce się wydać mędrcem? Otóż np. wtedy, gdy głosi poglądy prawdziwe. Kto przywołuje prawdziwe poglądy, afirmując siebie, zawsze pozostanie tylko głupcem. Nawet przekonanie o prawdziwości prawdziwego sądu może okazać się równie szkodliwe, jak przekonanie o prawdziwości sądu fałszywego.

Potwierdzenie przeświadczenia, że lgnięcie do prawdy z głupca mędrca nie czyni, znajdziemy w innej strofie tego samego rozdziału, która brzmi następująco (DhP 72):

yavad eva anatthaya ñattam balassa jayati

banti balassa sukkamsam muddham assa vipātayam

A kiedy wiedza w głowę głupca

na jego własną szkodę wejdzie,

zniszczy w nim jego lepszą cząstkę -

rozsadza wiedza głowę głupca.

Wydawałoby się, że wiedza, która wchodzi w głowę głupca, powinna uczynić $z$ niego mędrca. Co to bowiem znaczy być mędrcem? Być mędrcem znaczy przede wszystkim wiedzieć. Tutaj zaś wyraźnie się mówi, że jest coś w postawie głupca, co sprawia, że nawet wiedza, nie tylko nie czyni z niego mędrca, ale rozsadza jego głowę, czyli czyni z niego jeszcze większego głupca, a nawet idiotę. Wiedza zatem paradoksalnie pogrąża go w stanie głupoty. Wchodząc w jego głowę, szkodzi mu, spychając go w stan niewiedzy. W strofie tej wyraźnie zwraca się uwag̨̨ na to, że nie chodzi o fakt posiadania bądź nieposiadania wiedzy, tylko o fakt odniesienia się do niej. Innymi słowy, tym, co czyni z człowieka głupca, jest sposób, w jaki on tę wiedzę traktuje. 
Chodzi zatem o to, jaki jest jego stosunek do wiedzy, czy do niej lgnie, czy nie lgnie. W przypadku głupca możemy ten stosunek nazwać egotycznym. Głupiec staje się mędrcem wówczas, gdy ujmuje wiedzę w sposób nieegotyczny, czyli nie traktuje wiedzy jako czegoś, co nadaje mu wartość, którą może się chełpić i ze względu na którą może domagać się zaszczytów. Klasyczny przykład pochodzący z Dhammapady dopowiada, że to jest ktoś taki, kto będąc pustelnikiem, chce być królem pustelników, czyli chce mieć wśród nich wyróżnioną pozycję, zaś wśród ludzi świeckich zabiega o cześć i aplauz (DhP 73-74).

Przedstawioną tu opinię, że w owej szkodliwej umysłowej postawie chodzi o lgnięcie do poglądu nawet prawdziwego, a nie po prostu o lgnięcie do fałszu, jeszcze wyraźniej potwierdza niezwykle ważna metafora wczesnego buddyzmu wyrażona w słynnym kazaniu o chwytaniu węża (Alagaddūpama-sutta, MN I, 130 [MN 22]). Kazanie to mówi o głupcu, który studiuje naukę (dhamma) kierowany intencją niezgodną z tą, jaka stała za wygłoszeniem owej nauki. Głupiec to jest ten, który podejmuje dharmę, naukę prawdziwą, poświęca czas i wkłada wysiłek w jej przyswojenie w sposób kłócący się z przyświecającą tej nauce intencją. Celem nauki ujętej jako właściwy pogląd jest nirwana, głupiec zaś wykorzystuje naukę do osiągania doczesnych korzyści, takich jak krytykowanie innych i zwycięstwo w sporze. Nie chodzi tu o to, że krytyka jako taka jest niewłaściwa, lecz o to, że przystępuje się do nauki, nabiera się wiedzy z myślą o tym, aby górować nad innymi. W tym właśnie kontekście pojawia się metafora chwytania węża. Otóż potrzebuje węża. Mogę go jednak uchwycić na dwa sposoby - właściwie i niewłaściwie. Wąż uchwycony za ogon odwróci się i wyrządzi chwytającemu krzywdę. Złe uchwycenie węża skutkuje cierpieniem, gdyż gad się zwraca przeciwko temu, który go chwyta. Chwytając niewłaściwie prawdę czy też konkretniej prawdziwy pogląd, gdyż jego wąż tutaj symbolizuje, w gruncie rzeczy pogrążam się w niewiedzy i cierpieniu. Prawda działa w tej sytuacji na moją niekorzyść. Zatem moje ukierunkowanie się na nią, któremu towarzyszy lgnięcie, zwraca się przeciwko mnie. 
Przedstawioną tu sytuacje niewłaściwego stosunku do prawdy przywołuje także inna, pochodząca z tej samej sutty, nie mniej słynna metafora, która naukę buddyjską przyrównuje do tratwy (MN I, 134-135). Tratwa użyteczna jest dopóty, dopóki pozwala przepłynąć na drugi brzeg. Jednakże po dotarciu do celu powinna zostać porzucona. Nierozsądne jest jej dalsze dźwiganie. Prawdziwa nauka jest jak tratwa, której celem jest przedostanie się na drugi brzeg cierpienia. W tym wyczerpuje się jej walor prawdy. Jednak gdy do niej lgniemy, gdy czerpiemy z niej poczucie wartości, gdy szukamy prawdy dla satysfakcji jej posiadania, używamy jej niezgodnie z celem jej wygłoszenia. Przypowieść tę Budda kończy zaleceniem (MN I, 135): „Mnisi, poznawszy przypowieść o tratwie, powinniście porzucić nawet dhammy, tym bardziej niedhammy" (kullüpamam vo bbikkbave äjänantebi dhammā pi vo pabātabhä, pag-eva adhammä). Innymi słowy, mnisi powinni przestać lgnąć nie tylko do jakości negatywnych, co jest oczywiste, ale także do pozytywnych. Powinni przestać lgnąć nie tylko do nauk skutkujących pogłębianiem i utrwalaniem negatywnych jakości, ale także do nauk promujących rozwój jakości pozytywnych. Problemem bowiem jest samo lgnięcie, a nie jego przedmiot.

W godny uwagi sposób metafora tratwy została przywołana również $\mathrm{w}$ Wielkim kazaniu o zniszczeniu pragnienia (Mabā-tanhbā-sankkbaya-sutta; MN I, 256-271 [MN 38]). Budda indaguje mnichów o pojawianie się wątpienia (vicikicchā) odnośnie do powstawania czegoś. Ustala, że wątpienie pojawia się, gdy jest się niepewnym, czy coś powstało czy nie; gdy jest się niepewnym, czy to powstało, mając to i to za pożywienie (tj. warunek), czy nie; gdy jest się niepewnym, czy wraz z zanikiem tego pożywienia to, co powstało, zaniknie czy nie. Wątpienie zanika, gdy widzi się, jakim faktycznie jest, właściwą mądrością (yathā-bhūtam sammappaññaya passato), powstawanie czegoś, powstawanie tego czegoś $\mathrm{w}$ zależności od określonego pożywienia oraz zanik powstałego, gdy pożywienie zanika.

Następnie Budda pyta mnichów, czy są wolni od wątpienia w tych trzech kwestiach. Otrzymawszy pozytywną odpowiedź, pyta ponow- 
nie, czy widzieli dokładnie, właściwą mądrością, jak faktycznie ma się rzecz (yatbā-bbütam sammappañ̃naya sudițtha) w tych trzech kwestiach. Po otrzymaniu twierdzącej odpowiedzi zadaje kluczowe pytanie o właściwy stosunek do owego widzenia/poglądu (dițți) (MN I, 260):

imam ce tumbe bbikkbave dițthim evam parisuddham evam pariyodatam alliyetha kelayetha dhanäyetha mamāyetha, api nu tumbe bbikkbave kullūpamam dhammam desitam äjāneyyātha nittharanatthāya no gabanatthāyāti.

Mnisi, jaki by nie był ten pogląd czysty i przejrzysty, jeśli byście do niego lgnęli, hołubili go, cenili go, miłowali go, czy moglibyście zrozumieć dhammę przedstawianą jako podobną tratwie, której celem jest przekroczenie (nittbarana), a nie chwytanie (gabana)?

Mnisi odpowiedzieli przecząco. Lgnięcie nawet do najczystszej nauki świadczy o jej niezrozumieniu. Nauka nie stuży do tego, aby do niej lgnąć, aby czerpać z niej dumę i poczucie wartości, lecz aby dotrzeć na drugi brzeg i ją porzucić jak tratwę ${ }^{79}$. Podkreślmy to wyraźnie: zrozumienie, że nauka Buddy pełni wyłącznie rolę środka do osiągnięcia wyzwolenia, że nie została ona wypowiedziana po to, aby afirmować prawdę dla samej prawdy, że nie chodzi w niej o kontem-

79 Metafora tratwy pojawia się także w sutrach doskonałości mądrości, a konkretnie w Sutrze diamentowej (VC 6). Vajracchedika-prajña-päramitä-sūtra, czyli Sutra doskonatości madrości [będaca jak] diamentowe ostrze jest tekstem o niepewnym datowaniu. Obok klasycznej opinii Conzego, wyznaczającej powstanie tego tekstu na okres 350-400 n.e., popularnością cieszy się też przekonanie, że sutra ta należy do starszych tekstów literatury doskonałości mądrości i może być niewiele młodsza od Aszty; na ten temat zob. G. Schopen, The Pbrase "sa pṛthivipradeśas caityabhūto bhavet" in the Vajracchedikā. Notes on the Cult of the Book in Mabayana, IIJ 17 (1975), s. 153, przyp. 16-17; P. Williams, Mabayana Buddhism. The Doctrinal Foundations, New York 1989, s. 41-42. Dalej ten tekst przywołuje jako Sutra diamentowa - pod tym tytułem, chociaż nie oddającym dokładnie sensu oryginału, dzieło to się spopularyzowało i jest powszechnie znane. 
plowanie prawdy, o obronę prawdy, o strzeżenie prawdy, wyraża się poprzez zaprzestanie lgnięcia do owej nauki ${ }^{80}$. Warunkiem zrozumienia, czyli poznania, oznajmia Budda, jest wyzbycie się owego niewłaściwego nastawienia (MN I, 261).

Oczywiste jest, że skoro ostatecznie należy zarzucić nauki prowadzące do nirwany (dhamma), to tym bardziej te, które do niej nie prowadzą (adhamma). Pamiętać jednak musimy, że w lgnięciu do poglądów chodzi o szkodliwą postawę zajmowaną wobec wszelkich poglądów, a nie tylko wobec poglądów fałszywych.

Swoje rozważania rozpocząłem od Dhammapady w przekonaniu, że nawet $w$ tak popularnym tekście interesujący nas motyw znajdzie potwierdzenie. Jednak prawdziwą skarbnicę wartościowych dla nas wypowiedzi znajdziemy $w$ innym kanonicznym tekście - Suttanipacie. Uwage zwrócimy zwłaszcza na czwarty rozdział tego tekstu zatytułowany Ósemki (Atţbaka-vagga), w którym dominującym zagadnieniem jest kwestia poglądów, a ściśle mówiąc, właściwej postawy wobec poglądów. Warto przypomnieć, że rozdziat ten wraz z kolejnym należą do najstarszej warstwy literatury buddyjskiej. Kenneth $R$. Norman, który na początku lat dziewięćdziesiątych ubiegłego wieku dokonał przekładu Suttanipaty dla Pali Text Society, uznał za wielce prawdopodobne, iż $\mathrm{w}$ kształcie zbliżonym do obecnego rozdział ten funkcjonowat już w czasach Buddy, w czym zgadzał się $\mathrm{z}$ innym badaczem - Hajime Nakamurą ${ }^{81}$. Przyjąć zatem możemy, że zawarte

Bo Por. także Sutte o wymianie rydwanów (Rathāvinita-sutta; MN I, 147), w której osiąganie kolejnych czystości dzięki praktyce życia religijnego porównane zostaje do wymiany przez króla zaprzęów celem dotarcia do miasta - tak jak król pozostawia kolejne zaprzęgi, dążąc do miasta, tak praktyk pozostawia kolejne czystości, dążąc do nibbany bez lgnięcia.

81 K. R. Norman, Pali Literature. Including the Canonical Literature in Prakrit and Sanskrit of All the Hinayana Schools of Buddhism, Wiesbaden 1983, s. 6364, 67-69, 85-86. Zob. także H. Na ka mu ra, Indian Buddhism. A Survey with Bibliographical Notes, Delhi 1996, s. 45; K. R. Norman, The Atthakavagga and Early Buddhism, [w:] Jainism and Early Buddhism. Essays in Honour of Padmanabb S. Jaini, vol. 2, ed. O. Qvarnström, Fremont 2003, s. 511-522. 
w nim treści w dużym stopniu odzwierciedlają faktyczne nauczanie twórcy buddyzmu, chociaż niekoniecznie je wyczerpują.

Nim jednak przejdę do analizy tego rozdziału, warto wspomnieć w nawiązaniu do wcześniejszych uwag, że metafora tratwy została przywołana także w drugiej sutcie Suttanipaty. W Sn. 21 Budda zgodnie $\mathrm{z}$ wcześniej afirmowaną już postawą stwierdził, że po osiągnięciu drugiego brzegu nie potrzebuje więcej tratwy, chociaż była dobrze wykonana. Co ciekawe, również na początku czwartego rozdziału, którym się za chwilę zajmiemy, pojawia się analogiczna metafora. W Sn. 771 (Sn. IV.1.6) mówi się, iż po porzuceniu przedmiotów pragnienia przekracza się rozlewisko (ogha), osiąga drugi brzeg i opuszcza łódż ${ }^{82}$. Rozlewiskiem, które się w ten sposób przekracza, są skazy, a jedną z nich, jak wskazywałem powyżej, jest skaza żywienia poglądu (dițthogha; dițthāsava). Metafora tratwy jest ważna, ponieważ określa postawę przebudzonego wobec poglądów. Przebudzony nie traktuje ich jako własnych, gdyz niczego $w$ ten sposób nie traktuje. Użytą w tym miejscu metaforę tratwy/łodzi można zatem uważać za zapowiedź tematu, który będzie dominował w czwartym rozdziale Suttanipaty. Tematem tym jest zaniechanie wszelkich pragnień, ze szczególnym uwzględnieniem pragnień ukierunkowanych na poglądy. Innymi słowy, ważnym wątkiem czwartego rozdziału jest afirmacja

Zwięzty, choć wyczerpujący opis struktury Suttanipaty uwzględniający także jej chronologię ze wskazaniem na najstarsze jej warstwy znaleźć mozina w: Bhikkhu Bodhi, Introduction, [w:] The Suttanipata. An Ancient Collection of the Buddha's Discourses Together with Its Commentaires, trans. ide m, Somerville 2017, s. 27-32.

82 Prawde powiedziawszy, to motyw przemierzania rozlewiska jest częstą metaforą w Suttanipacie. Pojawia się w Sn. 173, 174, 178, 183, 184, 219, 273, 471, 495, 538. W czwartym rozdziale pojawia sį̧ też w drugiej sutcie Sn. 779 (Sn. IV.2.8), gdzie stwierdza się: „w pełni zrozumiawszy postrzeżenie, powinien przekroczyć rozlewisko" (sañnam pariññã vitareyya ogham). W czwartym rozdziale pojawia się jeszcze w Sn. 823 (Sn. IV.7.10). Motyw ten powraca też w piątym, uchodzącym za równie wczesny, rozdziale - w Sn. 1070 (Sn. V.7.2); 1081-1083 (Sn. V.8.5-7); 1096 (Sn. V.12.1); 1101 (Sn. V.13.1). 
nieposiadania żadnych poglądów czy też krytyka postawy afirmującej wartość ich posiadania. Właśnie ze względu na tę krytykę głosi się przekonanie, że w obrazie wczesnego buddyzmu naszkicowanym w tym tekście dominuje tendencja sceptyczna.

Na poparcie tego przekonania można przytoczyć kilka strof obok tych dwóch, które przywołałem już we wcześniejszym rozdziale. W Sn. 787 oznajmia się, że ten, który nie lgnie, nie posiada żadnych własnych poglądów, niczego nie twierdzi i nie neguje. Czytamy tam:

upayo bi dhammesu upeti vädam anüpayam kena katham vadeyya attam nirattam na bi tassa attbi adbosi so dițthi-m-idb' eva sabba ti $\|$

Doprawdy ten, który lgnie, angażuje się w spór między naukami. Ale jak i o co można spierać się z tym, który nie lgnie? On niczego nie uznaje i nie odrzuca. Otrząsnąt się w tym świecie $\mathbf{z}$ wszelkich poglądów.

Podobnie utrzymuje sį̨ w Sn. 851:

niräsatti anägate atītam nänusocati

viveka-dassi phassesu dițthisu ca na niyyati ll

Nie lgnąc do przyszłości, nie żałuje przeszłości. Doświadczając oderwania w sferze kontaktu, nie kierują nim poglądy.

Brak poglądów jeszcze dobitniej stwierdza się w Sn. 911. Doskonały nie tylko nie posiada własnych poglądów. Co więcej, oznajmia się tam, że nie posiada on w ogóle żadnej wiedzy, a wobec opinii zachowuje równy dystans, czyli żadnej nie akceptuje, ale też żadnej nie zwalcza. Strofa zatem głosi:

na bräbmano kappam upeti samkbam

na dițthisari na pi ñana-bandbu

ñatvā ca so sammutiyo putbujja

upekbati uggabananta-m-añne $\|$ 
Bramin [tj. doskonały], po oszacowaniu, nie angażuje sį̧ w umysłowe fikcje [kappa; tj. myśli, przedstawienia], nie kieruje się poglądami ani nie wiąze się z wiedzą. Poznawszy zwykłe opinie, zachowuje równowage [umystu], podczas gdy inni je chwytają.

Z kolei w Sn. 913 o takim mędrcu, który nie kieruje się pożądaniem, mówi się ze względu na budzone skojarzenia w sposób niezwykle znamienny, że nie jest dogmatykiem (nivissa-vadin), czyli nie jest tym, który głosi ustalenie się, ulokowanie się, osadzenie się (od nivisati - 'ustala się, lokuje się, osiedla się, zamieszkuje') w jakimś poglądzie. Strofa brzmi:

pubbāsave bitvã nave akubbam na chandagù no pi nivissa-vädo sa vippamutto dițthi-gatebi dhìro na lippati loke anatta-garabī $\|$

Porzuciwszy przeszłe skazy, nie tworząc nowych, nie podążając za pragnieniem, nie jest dogmatykiem (nivissa-vädin). Całkowicie wyzwolony z dążenia do poglądów (dițthi-gata), mędrzec (dhira), nie obwiniając siebie, pozostaje nieskalany światem.

Na zakończenie tego przeglądu przykładów przypomnieć możemy jeszcze przywoływaną już w pierwszej części tej pracy wypowiedź (Sn. 786ab [Sn. IV.3.7ab]) głoszącą, że:

dhonassa bi n' attbi kubiñci loke pakappitā dițthi bhavabbavesu

Nigdzie w świecie oczyszczony nie posiada wymyślonych poglądów na temat [rzeczy] istniejących i nieistniejących.

Wobec powyższych świadectw powinniśmy zapytać, czy podejrzenia o sceptycyzm kierowane pod adresem Buddy i wczesnej buddyj- 
skiej tradycji nie są faktycznie uzasadnione. Wszak podobieństwa ze starożytnym pirrońskim sceptycyzmem wydają się uderzające. Sądzę, iż odpowiedź na to pytanie znajdziemy w pierwszej strofie trzeciej sutty tego rozdziału (Sn. 780 [Sn. IV.3.1]), w której oświadcza się, co następuje:

vadanti ve duțtha-manā pi eke atho pi ve sacca-mana vadanti vädañ ca jatam muni no upeti tasmä munī nattbi kbilo kubiñci ll

Zaiste niektórzy ludzie o skażonych umysłach uczestniczą w dyskusji. Jednak również ci o umysłach wspartych o prawdę uczestniczą w dyskusji. Mędrzec (muni) nie angażuje się w powstałą dyskusję, dlatego nigdzie nie istnieje nieprzejednany/uparty mędrzec.

W strofie tej rozróżnione zostały trzy postawy, jakie ludzie moga zajmować względem dyskusji. Pierwsza postawa (1) charakterystyczna jest dla tych, którzy wchodzą w dyskusję, będąc skażeni, czyli podlegając niewiedzy; postawę drugą (2) wyznaczają ci, którzy wchodzą w dyskusję, mając umysły wsparte o prawdę; podczas gdy postawa trzecia (3) cechuje mędrców, którzy nie wchodzą w dyskusję i dlatego nie są zniewoleni. Trzecią postawę uznaje się za najdoskonalszą. Mędrcy ci, będąc oczyszczeni, nie wchodzą w dyskusję, gdyz - jak dodaje strofa siódma - nie posiadają poglądów na temat bytu i niebytu (Sn. IV.3.7ab).

Przywołany podział jest niezwykle ważny, gdyż jego analiza pozwala już na wstępie odciąć wszelkie spekulacje na temat domniemanego sceptycyzmu wspomnianych mędrców. Chociaż stwierdza się, że mędrcy nie posiadają poglądów, to na przykładzie drugiej postawy wyraźnie widać, iż prawda czy też możliwość prawdziwego orzekania nie została zanegowana. Powodem, dla którego mędrcy nie posiadają poglądów, nie jest rozpoznanie równosilności wszelkich sądów, czyli ostatecznej niemożliwości rozstrzygnięcia prawdy bądź fałszu żadnego 
sądu. Wartość trzeciej postawy wynika z zaprzestania lgnięcia do wszelkich poglądów. Mędrcy nie posiadają poglądów, gdyż wyzbyli się lgnięcia, przywiązania, pragnienia.

Warto przywołać dwie wymowne strofy z kolejnej sutty, które tę uwagę potwierdzą (Sn. 794-795 [Sn. IV.4.7-8]):

na kappayanti na purekkbaronti

accanta-suddhiti na te vadanti

ädana-gantham gathitam visajja

äsam na kubbanti kubiñci loke $\|$

[Brahmani, czyli doskonali] nie spekulują (na kappayanti), nie opowiadają się (na purekkbaronti), nie głoszą „oto najwyższa czystość" (accantasuddbìti na te vadanti). Rozerwawszy zapleciony węzeł pragnienia, niczego $\mathrm{w}$ świecie nie pragną.

simatigo brabmano tassa n' atthi

ñatvã ca disva ca samuggahitam

na räga-rägi na viräga-ratto

tassidba n'attbī param uggabītan till

Brahman [tj. doskonały], który przekroczył granice, który poznat i zobaczył, nie chwyta niczego. Nie znajduje upodobania w pragnieniu ani w braku pragnienia/bezpragnieniowości. Nie ma niczego w tym świecie, co uznaje za najwyższe [dosł. chwyta jako najwyższe].

Podkreślić musimy, że strofa 795 ukazuje postawę doskonałego jako radykalnie przeciwstawną postawie sceptyka. Ten drugi nie posiada poglądów w związku z przekonaniem, że nie sposób niczego poznać. Doskonały nie posiada poglądów, właśnie dlatego że poznat i zobaczył (ñatva ca disvã ca). W przeciwieństwie do sceptyka nie pozostaje on w poznawczej pustce owładnięty poznawczą niemocą. Poznanie doskonałego nie wyraża się jednak w sądzie o rzeczywistości, gdyż brahman niczego nie poznaje jako jakieś, tzn. nie odnosi się do poznawanego poprzez przedstawianie sobie jego pojęcia. Wspar- 
cie dla tej uwagi znajdziemy w Sn. 802 (Sn. IV.5.7), gdzie możemy przeczytać:

tassidha ditțe va sute mute va pakappita n' atthi añu pi sañna tam brabmanam dițthim anadiyanam kenidha lokasmim vikappayeyya \|

Nie tworzy nawet najskromniejszego pojęcia [ew. nie żywi najmniejszego przypuszczenia] (pakappita n' attbi aṇu $p i$ sañ̃āa) odnośnie tego, co widzi, styszy, myśli. Jak zatem w tym świecie zaklasyfikować tego brahmana, który nie przyjmuje żadnego poglądu?

Wyjdźmy na chwilę poza Suttanipatę. Analogiczną myśl odnajdziemy w Suttcie wygtoszonej w parku Kalaki zawartej w Anguttaranikaji (Kälakārāma-sutta; AN II, 25-26). Budda oznajmia tam (fragment ten parafrazuje), że:

Postrzegając, co jest do postrzeżenia, poznając, co jest do poznania, Tathagata nie konstruuje przedmiotu jako postrzeżonego/poznanego, jako niepostrzeżonego/niepoznanego, jako wymagającego postrzeżenia/poznania. Nie konstruuje też postrzegającego/poznającego. Widząc rzeczy, jakimi są, Tathagata nie twierdzi, że to, co inni widzą, co uznają za prawdziwe, jest prawdziwe ani nawet że nie jest prawdziwe. Dla Tathagaty nie ma niczego, na czym mógtby się oprzeć, czego mógtby się uchwycić.

Właściwe widzenie, możemy więc stwierdzić, polega na tym, żeby $\mathrm{w}$ odniesieniu do widzianego było tylko widziane, $\mathbf{w}$ odniesieniu do słyszanego - słyszane itd. Jeżeli doświadcza się w ten sposób, to w związku z tym, co widziane, nie pojawia się widzący itd., jak powtarza Mālunkyaputta-sutta z Sanjuktanikaji (SN IV, 73) oraz Babiya-sutta z Udany (Ud. 8). Natomiast Dbammapada stwierdza lakonicznie (DhP 273): „najlepszy człowiek - ten, co widzi” (setttho [...] dipadānañ ca cakkbumā). 
Utrzymywanie takiej postawy ma ciekawe konsekwencje, na które warto wskazać. W dwudziestym szóstym kazaniu Dighanikaji, tj. w Kazaniu beqdacym jak ryk lwa o obrocie kotem (Cakka-vatti-siba-nada-sutta), Budda dwukrotnie zaleca mnichom (DN III, 58 i 77), aby ci polegali tylko na sobie i na dhammie, żeby sami dla siebie byli wyspa, tylko w sobie i w dhammie znajdowali schronienie. Pojawia się jednak pytanie, jak mnisi mają polegać na sobie. Odpowiadając na nie sobie samemu, Budda oznajmia, że polegają oni na sobie, gdy obserwują ciało w ciele, uczucia w uczuciach, umysł w umyśle, przedmioty umysłu w przedmiotach umysłu, czyli, mówiąc krótko, zachowują czujność (sampajāna) i uważność (satimā) umysłu. Ten, który jest uważny, polega tylko na sobie, czyli widzi tylko to, co wi$\mathrm{dzi}$, niczego nie projektując, niczego nie nakładając, nie zdając się na nic innego, w tym również nie zdając się na wiarę (saddbā), będącą $\mathrm{w}$ istocie projekcją własnych oczekiwań i nadziei. Ktoś taki, mówi się w Sn. 853, „nie jest ani bezkrytyczny [tj. pełen ufności], ani nie niezainteresowany" (na saddho na virajjatı). Nie dziwi więc, że w samym tylko czwartym rozdziale Suttanipaty uważność wspomniana jest aż dziesięć razy ${ }^{83}$.

$\mathrm{Na}$ znaczenie uważności wskazuje Kazanie o wszystkich skazacb (Sabbasava-sutta; MN I, 6-12 [MN 2]). Stwierdza się tam, iż osoba prosta, zachowując nieodpowiednią uwagę (ayoniso manasikära), chwyta się różnych poglądów, których podstawą jest przedstawienie „ja”. Budda oznajmia (MN I, 8): „Owo żywienie/chwytanie się poglądów, mnisi, nazywa się gąszczem poglądów, pustynią poglądów, skrzywieniem poglądów, chwiejnością poglądów, kajdanami poglądów" (idam vuccati bbikkbave dițthi-gatam dițthi-gahanam dițthi-kantäram dițțhi-visūkam dițthi-vipphanditam dițți-samyojanam $)^{84}$. Ten natomiast, który zachowuje odpowiednią uwagę (yoniso manasikāra),

${ }_{83}$ Odniesienie do uważności pojawia się w: Sn. IV.1.3, 6; IV.10.8; IV.14.2, 19; IV.16.8, 10, 19, 20, 21.

84 Podobna uwaga pojawia się w MN I, 485. 
usuwa skazy (äsava) poprzez widzenie (dassana), a tym, co widzi, są cztery szlachetne prawdy, czyli cierpienie, powstawanie cierpienia, ustanie cierpienia oraz droga prowadząca do ustania cierpienia ${ }^{85}$.

Wróćmy jeszcze na chwilę do sutty Mabā-tanbä-sañkbaya (MN 38), wzmiankowanej powyżej przy okazji omawiania metafory tratwy. Kontynuując swoją naukę o widzeniu zależnego powstawania, Budda oznajmia, że ci, którzy poznają i widzą zależne powstawanie, nie mówią: „Nauczyciel cieszy się naszym szacunkiem. Mówimy, jak mówimy z szacunku do nauczyciela" (satthā no garu, sattbugāravena ca mayam vadema; MN I, 265). Oni też nie zajmują postawy zaprzeczania poglądom innych ascetów, chociaż nie akceptują poglądów innych nauczycieli. Nie wracają do praktyk, sporów ani pomyślnych znaków manifestowanych przez innych ascetów i braminów. Mówią tylko to, co sami poznali, zobaczyli i odkryli (yadeva tumbākam sāmam ñātam sāmam dițţham sāmam viditam, tadeva tumbe vadetha) ${ }^{86}$. Dlatego też, kiedy pewnego razu Sariputta dał wyraz swojej wierze w to, iż nigdy nie było i nie będzie nikogo o doskonalszym umyśle niż Budda, ten go upomniał, oznajmiając, że nie powinien wypowiadać się o stanie umysłów innych, jeżeli ich nie poznał (DN III, 99-100). Doskonały bowiem, jak zapewnia DhP 97, widzi, nie ma wierzeń.

Kwestia właściwego sposobu patrzenia powraca w nauczaniu Buddy wielokrotnie. Odniesiemy sį̨ do jeszcze jednego miejsca, w którym jest to zagadnienie centralne. W pierwszym kazaniu Madżdżimanikaji Budda poucza zaawansowanych uczniów (sekba), że należy unikać wyobrażania sobie każdego zjawiska i radowania się nim (MN I, 1-6). W szczególności przestrzega przed znajdowaniem upodobania w nirwanie. Tego rodzaju upodobanie jest związane z pojmowaniem owych

85 Więcej na ten temat zob. C. S. Anderson, Pain and Its Ending. The Four Noble Trutbs in the Theravada Buddhist Canon, London-New York 2013, s. 36.

${ }^{86}$ Zob. przywołana poniżej strofę Sn. 868, w której oznajmia się, że asceta wypowiada sį̧ o stanach umysłu, poznawszy je wprzódy. 
zjawisk i nirwany jako "moje”, czyli z egotycznym odniesieniem do nich. Ze względu na sposób odnoszenia się do zjawisk, stwierdza, można wyróżnić cztery kategorie istot. Pierwszą stanowi nieuczony zwykły człowiek (assutavā putbujjana). Odnosi się on do wszystkiego, przedstawiając sobie, wyobrażając sobie to, np. gdy taki człowiek postrzega ziemię jako ziemį̨ (pațhavim paṭhavito sañjānāti; MN I, 1), to postrzega ją na drodze przedstawiania sobie, postrzega za pośrednictwem przedstawienia (mañ̃anā), a przedstawianie sobie naznaczone jest egotyzmem, dlatego gdy postrzega, to to, co postrzega, pojmuje (mañnati) na różne sposoby, odnosząc siebie do tego, co postrzegane, jako tożsamego, jako zawartego w, jako odrębnego, jako będącego posiadaczem. Znajduje w tym upodobanie (abbinandati), ponieważ brak mu pełnego zrozumienia/poznania (apariññata). W ten sam egotyczny sposób odnosi się do nirwany.

Drugą kategorią jest zaawansowany uczeń (sekba; MN I, 4). Jako istota nieprzebudzona, która nie osiągnęła jeszcze celu, cierpi na tę samą przypadłość, co istota pierwszej kategorii. Różni się jednak od niej świadomie podejmowanym wysiłkiem ukierunkowanym na osiągnięcie pełnego zrozumienia (pariññeyya). On wie, że postrzegając ziemię jako ziemię, nie powinien pojmować (mā mañ̃̃) jej na różne sposoby, nie powinien znajdować w tym upodobania ( $m \bar{a}$ abbinandi).

Kategorię trzecią stanowi arahant (araba; arabant; MN I, 4), który zniszczył skazy (kbīnāsava), osiągnął cel (anuppatta-sadattba), zniszczył kajdany istnienia (parikkbina-bbava-samyojana), wyzwolił się dzięki właściwemu poznaniu (sammadaññā vimutta). Arahant niczego sobie nie przedstawia (na maññati), on poznaje bezpośrednio (abbijānātı). Nie znajduje w niczym upodobania (näbbinandatı), gdyż w pełni zrozumiał (pariñ̄āta), uwolnił się od pragnienia poprzez zniszczenie pragnienia (khayā rāgassa vītarāgattā), uwolnił się od awersji poprzez zniszczenie awersji (kbayā dosassa vìtadosattā) oraz uwolnił się z omroczenia poprzez zniszczenie omroczenia (kbayā mobassa vìtamobattā).

Kategorią czwartą jest Tathagata, który będąc w pełni doskonale przebudzonym (samma-sambudba; MN I, 5-6), zrozumiał, że upodo- 
banie, czyli znajdowanie w czymś radości, jest korzeniem cierpienia (nandī dukkbassa mūlan; MN I, 6).

Poniższą strofę z Suttanipaty można uznać za zwięzłe podsumowanie prezentacji Tathagaty, chociaż w pierwotnym kontekście określa ona cel dążeń mnicha. Czytamy w niej (Sn. 800 [Sn. IV.5.3]):

attam pabàa anupādiyāno

ñāne pi so nissayam no karoti

sã ve viyattesu na vaggasari

ditțim pi so na pacceti kiñci ll

Porzuciwszy to, co uznawat [tj. poglądy], i nie lgnąc do niczego nowego, nie znajduje oparcia (nissayam no karoti) nawet $\mathrm{w}$ wiedzy (ñana). Pośród uczonych (viyattesu) nie opowiada się po żadnej stronie (na vaggasari). Nie powraca do żadnego poglądu.

Ponownie widzimy, że problemem jest znajdywanie oparcia (nissaya), tj. lgnięcie. Nie należy lgnąć do poglądów, czyli do umysłowych przedstawień rzeczy, ale nie należy lgnąć też do wiedzy, czyli do przedstawiania sobie stanu poznania bez lgnięcia. Ściśle rzecz biorąc, to owo przedstawianie sobie poznania bez lgnięcia jest problemem tylko dla nieprzebudzonego. Być przebudzonym to po prostu widzieć, nie lgnąc. Taki jest sens stwierdzenia, że doskonały „nie znajduje oparcia nawet $w$ wiedzy". Strofa nie mówi, że nie powinien on tego robić, tylko orzeka, że tego nie robi. $Z$ jednej strony dlatego, iz doskonały nie traktuje poglądu jako właściwego sposobu wyrażania wiedzy. Nawet wiedza bowiem, czyli poznanie prawdziwe wyrażone w sądzie, może być czy też wręcz dla nieprzebudzonego zawsze jest przedmiotem lgnięcia. $Z$ drugiej strony nie odnosi się on do wiedzy jako tego, co dane jest jemu jako jakiemuś ,ja”, bowiem tylko widzi widziane, słyszy słyszane itd. Jego poznanie nie jest zapośredniczone w poglądzie, czyli w sądzie, tj. w umysłowej reprezentacji domniemanego stanu rzeczy. Suttanipata nie stwierdza zatem, że nie ma wiedzy, tylko że nawet wiedza nie jest właściwym przedmiotem lgnięcia. 
Tak jak wcześniej przywoływałem strofy sugerujące sceptycyzm, tak $\mathrm{w}$ równym stopniu można przytoczyć pochodzące $\mathrm{z}$ czwartego rozdziału wypowiedzi, które poznanie jednoznacznie afirmują. Gwoli przykładu przytoczę jeszcze tylko jedną. W Sn. 947 oznajmia się:

sa ve vidva sa veda-gũ ñatvã dhammam anissito sammã so loke iriyāno na pibetĩdha kassaci l|

Zaprawdę on jest wiedzącym, on osiągną̧ doskonałą wiedzę [tj. on jest prawdziwym znawcą Wedy], poznawszy dhammę, jest niezależny. Postępując $w$ życiu właściwie, niczego $w$ tym świecie nie pożąda.

Rola tej strofy nie polega tylko na tym, że w sposób niepozostawiający wątpliwości odnosi się do wiedzy $z$ uznaniem, używając aż trzech określeń wskazujących pozytywnie na poznanie i wiedzę. Mędrzec (muni), doskonaty (bräbmana), czyli faktycznie Budda, jest vidvā - wiedzącym, mądrym, veda-gū - tym, który osiągnął doskonałą, najwyższą wiedzę, oraz stał się niezależny (anissita), uprzednio poznawszy (ñatvā) dhammę. Strofa ta jest szczególnie interesująca ze względu na to, że poprzez określenie veda-gū w sposób ewidentny odnosi się krytycznie do bramińskiego ideału wiedzy. Prawdziwym brahmanem, prawdziwym znawcą Wedy, prawdziwym posiadaczem wiedzy, głosi ten wers, nie jest kapłan, znawca formułek i słów, tylko Budda. On posiadł bowiem jedyną wartościową, gdyż wyzwalającą, wiedzę, czyli, jak mówi cytowana dalej strofa Sn. 868, poznał funkcjonowanie umystu.

\subsubsection{Spór jako sposób wyrażania się lgnięcia}

$\mathrm{Ci}$, którzy wiedzy nie posiadają, czyli nie widzą bezpośrednio, pozostają $\mathbf{w}$ nieustannym sporze. Obok stwierdzenia, że doskonały nie posiada poglądów, drugim momentem, który może nasuwać podejrzenie, że $\mathbf{w}$ czwartym rozdziale mamy do czynienia z promowaniem 
postawy sceptycznej, jest stwierdzenie, że doskonały nie bierze udziału w sporach charakterystycznych dla tych, którzy bronią poglądów. Bez wątpienia Atțhaka-vagga nie wyraża się o sporze i w ogóle o filozoficznej dyskusji w sposób pozytywny. Dla zilustrowania tej negatywnej postawy warto przytoczyć kilka strof. W Sn. 796 (Sn. IV.5.1) oznajmia się:

paraman ti dițthisu paribbasano

yad uttarimkurute jantu loke,

bìnā ti aññe tato sabba-m-äba

tasmã vivadāni avîtivatto \|

Obstając przy poglądach uznanych za "najwyższe", człowiek ceni je najbardziej w świecie. Wszystkie inne nazywa "niższymi". Dlatego nie wyszedł poza spór.

Problem żywienia poglądów polega na tym, sugeruje tekst, że poglądy dla tego, kto je afirmuje, nie są emocjonalnie przejrzyste i neutralne. Dla Buddy asercja, czyli uznanie zdania za prawdziwe, oraz negacja, czyli odmówienie zdaniu prawdy, nie jest wyłącznie kwestią logiki, a nawet można by zaryzykować stwierdzenie, że kwestia logiczna jest tu najmniej istotna. Asercja, jak i negacja są ważne z perspektywy psychologii i poznawczej oraz soterycznej pragmatyki. Asercja bowiem nie jest czystą afirmacją prawdy jako takiej, tylko afirmacją prawdy dla tego i przez tego, który ją afirmuje. Mówiąc inaczej, asercja jest sposobem wyrażania sį̨ "ja" i dlatego musi, a nie tylko może, być nacechowana emocjonalnie. Stąd powszechna i w pewnym sensie naturalna obecność w kulturze narracji o strzeżeniu prawdy, o walce o prawdę, o obronie prawdy. Prawda zatem dla tego, kto jest jej rzecznikiem, staje się czymś najwyższym. Bronić jej bowiem to bronić własnego „ja", to bronić samego siebie. Atak na prawdę jest zawsze atakiem na ,ja" tego, dla którego to jest prawda. Tak więc jesteśmy skazani na spór, gdyż poglądy nas zniewalają, są dla nas kajdanami (gantha), jak stwierdza poniższa strofa (Sn. 798 [Sn. IV.5.3]). 
tạ̣ vāpi gantbam kusalā vadanti

yam nissito passati binam aññạ

tasma bi dițtham vā sutam mutam va

silabbatam bbikkbu na nissayeyya \|

Pogląd ten znawcy (kusala) nazywają kajdanami (gantba). W relacji do niego inne postrzega się jako niższe. Dlatego mnich (bbikkbu) nie powinien zależeć od tego, co widziane, słyszane, myślane, ani od cnotliwych czynów i rytualnych nakazów.

Jedynym rozwiązaniem jest dążenie do zaprzestania Ignięcia do tego, czego w najszerszym tego słowa znaczeniu doświadczamy, a zatem również do tego, co myślimy. Nie jest to jednak zadanie, któremu łatwo można podołać, a już z pewnością nie jest to kwestia samej decyzji. Potwierdza to kolejna strofa (Sn. 785 [Sn. IV.3.6]):

diț̣ininivesà na bi svātivattā dhammesu niccheyya samuggabìtam tasmā naro tesu nivesanesu nirassati adiyati-cca dbammam \|

Niełatwo przekroczyć przywiązanie do poglądów, gdy spośód wielu nauk po namyśle jakąśs się uznało. Dlatego człowiek odrzuca i przyjmuje naukę spośród owych upodobań.

Spór w nauczaniu Buddy przedstawiany jest zawsze jako forma konfliktu. Narzędzia konfliktu mogą się różnić, ale jego natura pozostaje stała. Spór ma źródło w lgnięciu. Ta kwestia jest tematem nieustannie przewijającym się w tekstach kanonu. W AN I, 66-67 Mahakaczczana został spytany o przyczynę konfliktów między świeckimi i między ascetami. W odpowiedzi wskazał na różnicę w przedmiocie lgnięcia obu tych grup. Świeccy i asceci spierają się z powodu przywiązania (vinivesa = abbinivesa), zniewolenia (vinibandba), taknienia (paligedba), obsesji (pariyuțţāna) i przylgnięcia (ajjhosāna), z tym ze w wypadku pierwszych przedmiotem tych umysłowych postaw jest zmystowe pragnienie (kāma-räga), w wypadku drugich pragnienie posiadania poglądów (dițthi-rāga). Nie należy tej uwagi rozumieć 
w ten sposób, że świeckim spory o poglądy są obce. Chodzi raczej o to, że w wypadku ascetów, przy założeniu, że są to faktycznie asceci, czyli ci, którzy z definicji zapanowali czy też dążą do zapanowania nad zmysłowym pożądaniem, ich egotyczna pożądliwość ciągle znajduje ujście w ukierunkowaniu na sposób, w jaki przedstawiają sobie stan rzeczy. Tylko Budda, przyznaje Mahakaczczana, przekroczył przywiązanie do zmysłowości i do poglądów.

Z kolei w Kazaniu do Kosambijczyków (Kosambiya-sutta; MN I, 320-325) Budda zareagował na fakt zaangażowania mnichów w intensywne spory filozoficzne. Wezwawszy ich przed swoje oblicze, zwrócił im uwagę na to, jak należy właściwie praktykować pogląd, który jest szlachetny i wyzwalający (dițthi ariya niyyānikā), i który prowadzi do całkowitego zniszczenia cierpienia (sammā-dukkbakkbaya). Otóż, oznajmia Budda, mnich, który taki pogląd praktykuje, powinien udać się na ubocze i badać siebie pod kątem tego, czy jego umysł nie ulega obsesji (pariyutțhāna), która uniemożliwiałaby mu poznanie i zobaczenie rzeczy, jakimi są (yathā-bbütam na jāneyyam na passeyyam). Badanie to powinno polegać m.in. na sprawdzaniu, czy nie jest się zaangażowanym $\mathbf{w}$ spekulacje na temat rzeczywistości oraz $\mathbf{w}$ filozoficzne spory. Umysł mnicha, który uczestniczy w sporach i pogrążony jest $\mathrm{w}$ dyskusjach, dźgając innych słowami, ogarnięty jest obsesją (MN I, 323). Jak widzimy, praktykowanie właściwego poglądu (sammā-dițthi) nie polega na trzymaniu się treści poglądu, na obronie prawdziwości tego poglądu, tylko na opróżnianiu umysłu z lgnięcia do wszelkiego poglądu. Tylko takie działanie jest zgodne $z$ intencją, która stała za wygłoszeniem przez Buddę tego, co tradycja nazywa właściwym poglądem.

Atṭhaka-vagga będzie ten obsesyjny aspekt sporów uwypuklać. Możemy się o tym przekonać na przykładzie poniższej strofy (Sn. 882 [Sn. IV.12.5]). 
sakam sakam dițthim akamsu saccam, tasmä bi bälo ti param dabanti $\|$

Nie mówię "to jest prawda", jak to mówią głupcy do siebie wzajemnie, którzy tylko własne poglądy uznają za prawdziwe. Dlatego oni uważają innych [tj. oponentów] za głupców.

Budda nie traktuje swojej wypowiedzi jako równorzędnej wypowiedziom innych nauczycieli. Nie traktuje jej też jako wyższej ani niższej. Jest ona względem innych niewspółmierna, gdyz Buddą w jego wypowiadaniu się kieruje intencja niesienia pomocy innym, a nie prawda $\mathbf{w}$ znaczeniu potrzeby pojęciowego przedstawienia innym, jakie rzeczy są. Każde pojęciowe przedstawienie rzeczy jest bowiem zapośredniczone w błędzie poznawczym, a tym samym prowadzi do konfliktu. W wypadku Przebudzonego niesienie pomocy innym polega na takim na nich oddziaływaniu, aby oni mogli sami powtórzyć jego wyzwalające doświadczenie. Chociaż Buddą nie kieruje prawda, to nie oznacza to jednak, iż z perspektywy buddyjskiej nie ma znaczenia, co jest głoszone, czyli postawa Przebudzonego nie prowadzi do poznawczego relatywizmu. Wręcz przeciwnie, w Suttanipacie pojawia się jednoznaczne zapewnienie o istnieniu tylko jednej prawdy. W Sn. 884 (Sn. IV.12.7), czytamy:

ekam bi saccam na dutīyam attbi yasmim paja no vivade pajanam nānā te saccāni sayam thunanti tasma na ekam samanā vadanti $\|$

Faktycznie istnieje tylko jedna prawda, drugiej nie ma, o którą człowiek, który to poznat, nie spiera się ${ }^{87}$. Oni gło-

${ }^{87}$ Fragment ten jest ekstremalnie niejednoznaczny. Podązam tutaj za rozstrzygnięciami Bhikkhu Bodhiego, który z kolei trzymał się wykładni sugerowanej w komentarzu, zob. The Suttanipata. An Ancient Collection..., s. 308; s. 1357, przyp. 207; s. 1157. 
szą jednak własne różne prawdy, dlatego asceci nie mówią jednego.

Prawda jest tym, co ostatecznie widziane, i jako taka jest tylko jedna, tzn. to, co ostatecznie widziane, może być widziane tylko w jeden sposób, żeby taka prawda wyzwalała. Ci, którzy widzą faktyczny stan rzeczy, nie spierają się. Innymi słowy, wyzwolenie polega na pozostawaniu umystu w stanie widzenia prawdy, a nie w stanie przedstawiania sobie prawdy, który to stan jest zawsze stanem jej domniemywania. Dlatego Budda nie musi mówić: „to jest prawdą”, nie musi nikogo o prawdzie zapewniać, nie musi do niej nikogo przekonywać, gdyż on ją widzi. Strofa Sn. 886 (Sn. IV.12.9) również zapewnia o jednej prawdzie.

na b’ eva saccāni babūni nānà

añnatra saññaya niccāni loke

takkañ ca ditthisu pakappayitva

saccam musa ti dvaya-dbammam abu \|

Nie ma jednak wielu różnych prawd $\mathrm{z}$ wyjątkiem [błędnego] postrzegania trwałych rzeczy w świecie. Przemyślawszy racjonalnie poglądy, ogłosili naukę o parze - prawdzie i fałszu.

Jedyna wielość prawd, z jaką mamy na co dzień do czynienia, bierze się z błędu poznawczego, który polega na „postrzeganiu” trwałych rzeczy w świecie. Trwałych znaczy tutaj będących w domniemaniu realnymi bytami. W tle tej wypowiedzi daje się dostrzec przesłanie Kazania do Katjajany - przeświadczenie o trwałości jest przeświadczeniem o istnieniu. Ci, którzy szukają bytu, ostatecznie szukają go jako czegoś trwałego. Prawda i fałsz okazuje się zatem poznawczym korelatem bytu i niebytu. W związku z tym, tak jak Budda uniewaznia dystynkcję istnienia i nieistnienia, tak też będzie ostatecznie unieważniał dystynkcję prawdy i fałszu jako własności poglądów. Prawda i fałsz jako własności poglądów mają zastosowanie tylko w obszarze sansary, czyli błędu poznawczego. Prawdą jedyną, czyli wyzwalającą, 
jest prawda widzenia rzeczy, jakimi są. Jednak ci, którzy tkwią w błędzie, nie widzą rzeczy jako rzeczy, tzn. nie widzą formy jako formy, uczuć jako uczuć itd. Stąd też, głoszą oni to, co błędnie widzą. O tym zapewnia nas strofa Sn. 781:

sakam bi dițthim katham accayeyya

chandanunito ruciyā nivițtho

sayam samattāni pakubbamāno

yatha bi janeyya tathā vadeyya $\|$

Będąc pobudzanym pragnieniem, ulegając skłonności, robiąc, co się robi jako coś normalnego, jak można przekroczyć własny pogląd? Jak się bowiem poznaje, tak się twierdzi.

Budda, a za nim wczesna tradycja buddyjska wskazują na ścisły związek głoszonych poglądów ze sposobem postrzegania rzeczy. Mówiąc inaczej, poglądy stanowią ekspresję błędu poznawczego, który konstytuuje się na poziomie postrzegania. Myśl ta znalazła rozwinięcie w Kazaniu o miodowej kulce (Madbu-pindika-sutta; MN I, 108-113 [MN 18]). W mowie tej pewien arogancki młodzieniec znany jako Dandapani (p. Daṇdapāni $)^{88}$, przyjąwszy prowokacyjną postawę, zadał Buddzie pytanie: „Co asceta twierdzi, co głosi?” (kim vādī samano kimakkbāyi $t \imath$ ). W odpowiedzi usłyszał, ze Budda twierdzi i głosi $\mathrm{w}$ taki sposób, że ten, kto postępuje zgodnie $\mathrm{z}$ jego nauką z nikim nie spiera się w świecie (na kenaci loke viggayba tițthbatı) ${ }^{89}$, a co więcej, ko-

88 Imię to, a raczej przydomek, znaczy dosł. 'dzierizyciel kija', co wiązało się z faktem, iż jego właściciel chodził, wspierając się na złoconym kiju, tj. lasce. Ponieważ był młody i zdrowy, to akt ten traktowany jest $w$ tekście jako świadectwo jego pretensjonalności i wyraz pychy, gdyż poprzez to akcesorium, jak możemy sį̧ domyślić, chciał on sobie nadać oznaki godności charakteryzujące w jego mniemaniu starego mędrca.

${ }^{89}$ Odpowiedź ta koresponduje $\mathrm{z}$ inną słynną wypowiedzią Buddy z Kazania o kwiatach (Puppha-sutta; SN III, 138), którą przywoływałem już w pierwszej części tej pracy, a w której oznajmił, że nie on spiera się ze światem, tylko świat spiera się z nim. 
goś takiego nie pętają już jego postrzeżenia (sañ̃āa nānusenti; MN I, 108). Usłyszawszy to objaśnienie, Dandapani niczego już nie rzekł, tylko mimiką okazał swoją dezaprobatę i odszedł.

Wieczorem otoczony grupą młodych mnichów Budda powrócił do tej rozmowy. Wskazał na podstawę, na której dochodzi do spętania człowieka postrzeżeniami i pojęciami. Stwierdził, że jeżeli nie znajduje się niczego, co raduje, co zadowala, do czego się lgnie, to ustają wszystkie ukryte skłonności, w tym m.in. do poglądów (dițțhānusaya), do wątpienia (vicikicchānusaya), do pychy (mānānusaya), do pragnienia istnienia (bhava-rāgānusaya), do niewiedzy (avijjänusaya). Kończy to w jego opinii przemoc, pośród przejawów której wymienił także wzajemne obwinianie się, złośliwości, fałszywe oskarżenia i spory (vivāda) oraz kładzie kres wszelkim innym szkodliwym stanom umysłu (MN I, 109-110). Po tych słowach udał się na spoczynek.

Mnisi pozostawieni samym sobie mieli jednak poczucie, że nie zrozumieli tej nauki, dlatego postanowili udać się do powszechnie szanowanego i cenionego czcigodnego Mahakaczczany z prośbą o jej objaśnienie. Pytany o znaczenie słów Buddy Mahakaczczana odpowiedział, że mnisi powinni przede wszystkim spytać jego samego, gdyż: „On zna poznane, widzi widziane, jest okiem/widzeniem, jest wiedzą, jest dhammą, jest doskonałym, głosicielem, wskazującym, objaśniającym znaczenie, dawcą nieśmiertelności, panem dhammy, Tathagatą" (janam janati passam passati, cakkbu-bbūto ñāna-bbüto dhamma-bhūto brabma-bbūto, vattā pavattā, atthassa ninnetā amatassa dātā dhammassāmī tathägato; MN I, 111). Ostatecznie jednak Mahakaczczana zgodził się objaśnić naukę mistrza. Zrobił to w sposób, który począwszy od Kazania do Katjajany, będzie stale z nim kojarzony - wskazał na strukturę zależnego powstawania, w którą ujął proces kształtowania się myślenia i spekulacji. Stwierdził mianowicie, iż (MN I, 111-112):

cakkbuñ c' avuso pațicca rüpe ca uppajjati cakkbu-viññanam, tinnam sangati phasso, phassa-paccaya vedanā, yam vedeti tam 
sañjānäti, yam sañjanati tam vitakketi, yam vitakketi tam papañceti, yam papañceti tatonidānam purisam papañca-saññ̄a-sankkba samudäcaranti atītānägata-paccuppannesu cakkbu- viñneyyesu rūpesu.

W zależności od oka i formy materialnej, powstaje świadomość widzenia; spotkanie tych trzech to kontakt; uwarunkowane kontaktem jest uczucie; co ktoś czuje, to postrzega; co ktoś postrzega, o tym myśli; o czym ktoś myśli, o tym spekuluje [dosł. to umysłowo rozplenia]; o czym ktoś spekuluje, to jest podstawą, na której postrzeżenia i pojęcia skażone spekulacją/rozplenieniem osaczają człowieka odnośnie do przeszłych, teraźniejszych i przyszłych form poznawalnych okiem.

Tę samą uwage Mahakaczczana powtórzył w odniesieniu do pozostałych władz ujmowania, a następnie dodał, że „gdy istnieją oko, forma i świadomość, to możliwe jest wskazanie kontaktu; gdy istnieje manifestacja kontaktu, to możliwe jest wskazanie manifestacji uczucia”, i tak po kolei aż do stwierdzenia, że gdy „istnieje manifestacja myślenia, to możliwe jest wskazanie manifestacji bycia osaczonym przez postrzeżenia i pojęcia skażone spekulacją" (vitakka-paññatiyā sati papañca-sañña-sañkba-samudācarana-paññattim paññāpessatīti; MN I, 112). Wskazując na te zależności, Mahakaczczana mógt ostatecznie określić, brak czego prowadzi do braku przemocy i konfliktu, a tym samym i sporu. Jak widzimy, mamy tutaj do czynienia $z$ rozbudowaną koncepcją, która osadza spór w samym fakcie myślenia, a ten z kolei ostatecznie w postrzeganiu naznaczonym błędem.

\subsubsection{Wątpienie jako sposób wyrażania się lgnięcia}

Odrębnym zagadnieniem, którym powinniśmy się przez chwilę zająć, jest status wątpienia. Ustalanie się w postawie wątpienia w możliwość uzyskania poznawczych rozstrzygnięć wydaje się konstytutywną cechą starożytnego sceptycyzmu. Nie od rzeczy zatem będzie przyjrzeć 
się temu, jak kwestia ta traktowana jest w tekście cieszącym się ze wszystkich buddyjskich tekstów opinią najbardziej sceptycznego.

W tekstach palijskich stan wątpienia określany jest standardowo dwoma terminami: vicikicchā oraz katham-kathā, oba można thumaczyć jako 'wątpienie, niepewność', przy czym ten drugi odnosi się do wątpienia, wskazując dosłownie na sytuację nieustannego wypowiadania/zadawania (katbā) pytania ,jak?” (katham). Wątpiący to zatem ten, który pozostaje w stanie nieustannego zapytywania. W czwartym rozdziale Suttanipaty wątpienie przywołane zostało tylko w dwóch strofach, tj. w Sn. 866 i 868, przy użyciu drugiego z tych terminów.

W Sn. 866 (Sn. IV.11.5) postawione zostaje pytanie o to, w czym swój początek mają różne stany umysłu, o których mówi Asceta, tj. Budda, takie jak pragnienie (chanda), irytacja (kodba), kłamliwość (mosa-vajja), formułowanie opinii (vinicchaya) i właśnie niepewność (katham-kathā). Strofa Sn. 867 udziela odpowiedzi na pytanie o to, w czym początek ma pragnienie. Źródłem pragnienia, oznajmia sį̨ tam, jest doświadczanie przyjemności i nieprzyjemności, co z kolei pozostaje $\mathrm{w}$ związku $\mathrm{z}$ ujmowaniem przedmiotów doświadczenia jako istniejących lub nieistniejących, a to znajduje wyraz $\mathrm{w}$ formułowaniu opinii o tym, co wartościowe i bezwartościowe. Strofa Sn. 868 (Sn. IV.11.7) udziela odpowiedzi o początek pozostałych stanów umysłu:

kodho mosa-vajjañ ca katham-katba ca ete pi dhammä dvaya-m-eva sante katham-kathi ñana-pathaya sikkbe natvä pavutta samanena dhamma $\|$

Irytacja, kłamliwość, niepewność oraz także te [inne] stany umysłu [powstają], gdy owa para [przyjemność i nieprzyjemność] istnieje. Niechaj niepewny wprawia się w ścieżce poznania. Asceta wypowiedział się o stanach umysłu, poznawszy [je].

Można powiedzieć, że pozostałe stany umysłu swój początek mają dokładnie w tym samym miejscu co pragnienie - czyli w doświadcza- 
niu przyjemności i nieprzyjemności. Uwaga ta jest o tyle ważna, że klarownie pokazuje, jak stan niepewności, wątpienia kategoryzowany jest $\mathrm{w}$ buddyjskiej praktyce podążania do dobrostanu. Jest takim samym szkodliwym stanem umystu, jak pozostałe wskazane stany. Należy się go pozbyć poprzez wprawianie się w poznaniu. Owo poznanie dotyczy właśnie kształtowania się szkodliwych stanów umysłu ${ }^{90}$.

Jeszcze raz powinienem podkreślić, jak zrobiłem to w pierwszym rozdziale tej części, iż, wskazując na potrzebę wyzbycia się wątpienia, nie chodzi tutaj o krytykę poznawczej otwartości i dociekliwości w obronie znaczenia wiary i zaufania do duchowego autorytetu. W świetle omawianych wcześniej zaleceń Buddy nawołujących uczniów do bycia wyspą i schronieniem dla samych siebie, które doskonale korespondują z przesłaniem przywoływanego już Kazania do Kalamów (Kãläma-sutta; AN I, 188-193), takie ujęcie tej kwestii jest całkowicie pozbawione sensu. W nauczaniu Buddy pozostawanie w stanie permanentnego wątpienia spotyka się z krytyką, gdyż postrzegane jest przede wszystkim jako stan poznawczej ociężałości, bardziej jako świadectwo poznawczej bierności i niemocy, niż poznawczej aktywności i dociekliwości.

Tak więc, oznajmia się w Suttanipacie, żeby zaniechać poglądu, nie należy popadać w zwątpienie, tylko „wprawiać się w ścieżce poznania” (ñāna-patbaya sikkbe). W Kazaniu o usuwaniu (Sallekba-sutta; MN I, 40-46) Budda przedstawia wątpienie jako jedną z wielu szkodliwych postaw umysłowych, które należy przekroczyć. Mnisi powinni ustalać się w następującym postanowieniu: „Inni będą wątpiący, my tutaj przekroczymy wątpienie" (pare vecikicchi bbavissanti, mayam ettba tinna-vicikicchä bbavissāmā; MN I, 42).

Stosownie do tego postanowienia w drugim rozdziale Suttanipaty zapewnia się (Sn. 231ab [Sn. II.1.10ab]):

90 W całej Suttanipacie odniesienie do wątpienia pojawia się w sumie siedemnaście razy (Sn. 17, 86, 231, 343, 346, 347, 667, 500, 534, 540, 638, 866, 868, $1063,1064,1088$ i 1089). Używane są oba terminy lub ich derywaty. W zasadzie we wszystkich wypadkach mowa jest o przekraczaniu wątpienia. 
saba v' assa dassana-sampadaya tayas su dhammā jabita bbavanti sakkãya-dițthi vicikiccbitañ ca silabbatam vā pi yad attbi kiñci

Wraz z osiągnięciem wglądu trzy rzeczy zostają porzucone: poczucie indywidualnego istnienia (sakkāya-dițthi), wątpienie (vicikiccbita) oraz reguły moralne i śluby religijne (sìlabbata).

Gdy mówimy o zagadnieniu wątpienia w kontekście myśli buddyjskiej, musimy zwrócić uwagę jeszcze na jedną kwestię. Otóż w nikajach pozycja opartych na nim poglądów jest bardzo dobrze rozpoznana. W kazaniach nie tylko wspomina się o wątpieniu jako jednym ze szkodliwych czynników umysłowych, ale wiele uwagi poświęca się stanowiskom filozoficznym, których reprezentanci dowartościowują taką postawę. Wszystkie te poglądy zostają zakwestionowane, mimo iż są wśród nich takie, w wypadku których zostaje zauważone zewnętrzne podobieństwo do postawy Buddy.

Ze wspomnianą tu sytuacją mamy do czynienia np. w Kazaniu do Dighanakbi (Dighanakba-sutta; MN 74). Asceta Dighanakha, zwany też Aggiwessaną (p. Aggivessana), oznajmia w MN I, 497: „Mistrzu Gotamo, w rzeczy samej moją doktryną i poglądem jest: «niczego nie uznaję" (abam bi bho gotama evamvuādì evamdițthi: sabbam me na kbamatìti). Dighanakha przyznaje się tym samym, że nie akceptuje i nie głosi żadnego poglądu.

W odpowiedzi Budda zwraca uwag̨̨ na sprzeczność tkwiącą w postawie Aggiwessany - mianowicie uznaje pogląd o nieuznawaniu poglądów. Tekst nie wyjaśnia, na jakiej podstawie ten sformułował swoje stanowisko. Możemy się tylko domyślać, że uznał on za słuszne wątpić w prawdziwość wszelkich poglądów. Dlatego Budda wytyka mu sprzeczność - Dighanakha nie uznaje żadnych poglądów, gdyż uznaje za słuszne nie uznawać żadnych poglądów, czyli owo nieuznawanie poglądów musi opierać się na dokonaniu jakiegoś rozpoznania w kwestii tego, co jest stuszne, a co nie. 
Następnie Budda wyróżnia trzy możliwe postawy wobec poglądów: uznawanie wszystkich, nieuznawanie żadnych, uznawanie niektórych i nieuznawanie pewnych (MN I, 498). Z tych trzech, przyznaje, nieuznawanie żadnych wydaje się bliskie głoszonej przez niego samego postawie nielgnięcia do poglądów. Wzmianka ta wywołuje niekłamaną radość u Aggiwessany, który z zachwytem stwierdza: „Mistrz Gotama pochwala moje stanowisko, mistrz Gotama rekomenduje moje stanowisko" (ukkamsati me bhavam gotamo dițthigatam, samukkamsati me bhavam gotamo dițthigatanti). Budda puszcza tę uwagę mimo uszu i zaczyna demonstrować, że każde $\mathrm{z}$ tych trzech stanowisk prowadzi do konfliktu i sporu. Jeśli sobie to uświadomimy, możemy zrezygnować $\mathrm{z}$ każdej $\mathrm{z}$ tych postaw, czyli zrezygnować ze wszystkich poglądów i całkowicie je porzucić i zaniechać (MN I, 499). W rezultacie Budda uczy o nietrwałości oraz warunkowaniu ciała i uczuć. Kto widzi nietrwałość i zależność, ten rozczarowuje się uczuciami, kto rozczarowuje się wszelkimi uczuciami, ten przestaje pragnąć, a kto przestaje pragnąć, ten ostatecznie się wyzwala (MN I, 500). Przedstawiając stanowisko wyzwolonego, Budda oświadcza: „Mnich, którego umyst jest w ten sposób wyzwolony, z nikim się nie zgadza, z nikim się nie spiera. Używa mowy obecnej w świecie bez przywiązania" (evam vimutta- citto kbo aggivessana bbikkbu na kenaci samvadati na kenaci vivadati, yañ ca loke vuttam tena vobarati aparāmasan ti). Zbieżność postawy Buddy z postawą prezentowaną przez Dighanakhę, który gtosit, że nie uznaje żadnych poglądów, okazuje się pozorna. Postawa Przebudzonego faktycznie jest całkowicie odmienna od trzech postaw przez niego wyliczonych i co ważniejsze z nimi niewspółmierna. Owe trzy stanowiska formułowane są w relacji do kwestii prawdy i fałszu, tym samym pozostają względem siebie w konflikcie. Stanowisko Buddy natomiast zostaje sformułowane w relacji do tego konfliktu. Na tym właśnie polega jego niewspółmierność ${ }^{11}$.

91 Więcej na ten temat zob. P. Fuller, The Notion of Ditthi in Theravada Buddhism. The Point of View, London-New York 2005, s. 155; zob. takzie 
Szczególnie wiele miejsca kwestii stanowisk wyrastających z wątpienia poświęca się w Kazaniu o sieci Brabmy, pierwszej mowie Zbioru dtugich kazań (DN I, 2-46). Ogólnie w całym tym kazaniu Budda analizuje sześćdziesiąt dwie błędne koncepcje pogrupowane w osiem zestawów powiązanych ze sobą tematycznie poglądów. Po każdym takim zestawie oraz w kilku ogólnych podsumowaniach, w sumie trzynaście razy, oznajmia, że nie tylko zna konsekwencje takich poglądów związane $z$ odradzaniem się $w$ konkretnej sferze, ale też że wie znacznie więcej. Niemniej oznajmia, że nie chwyta się tej wiedzy (DN I, 22: tañ ca pajānanam na parāmasati) ${ }^{92}$, a będąc nieprzywiązanym, osobiście (paccatta) ${ }^{93}$ poznat spokój (aparämasato c' assa paccattam yeva nibbuti vidita) oraz poznawszy takimi, jakimi są, powstawanie i zanik uczuć, ich smak i niebezpieczeństwo oraz ich zaniechanie, Tathagata jest całkowicie wyzwolony (vedananam samudayañ ca atthañgamañ ca assādañ ca adīnavañ ca nissaranañ ca yathā-bbūtam viditvā anupädā vimutto bbikkbave tathagato).

C. S. Anderson, op. cit., s. 37; N. Katz, Buddhist Images of Human Perfection, Delhi 1989, s. 218.

92 Określenia paramasana - 'pochwycenie, podjęcie, pojęcie', oraz gabita 'uchwycony, ujęty; ujęcie, uchwycenie' są ewidentnie synonimami.

93 Poznanie przebudzonego jest poznaniem osobistym (paccatta) i Budda za cel stawia sobie doprowadzenie uczniów do powtórzenia tego poznania. Doskonały tego przykład znajdziemy w Kazaniu do Bhaddiji (Bhaddiya-sutta) zamieszczonym w Anguttaranikaji (AN II, 190-194). Bhaddija odwiedził Budde, gdyz chciał się upewnić, czy to prawda, co słyszał, że ten przy użyciu magii nawraca uczniów innych nauczycieli. Przebudzony w duchu Kazania do Kalamów oświadczył, aby Bhaddija nie szedł za nim (czyli nie porzucał innych nauczycieli, nie porzucał dotychczasowego życia), kierując się ustną tradycją, kierując się linią nauczycieli, pogłoską, argumentami rozumu, wnioskowaniem, rozwagą, uznaniem poglądów po ich rozpatrzeniu, wiarygodnością [nauczyciela] czy też utrwalonym mniemaniem, że ten asceta jest naszym nauczycielem. Następnie Budda oznajmit: „Lecz kiedy poznasz, Bhaddijo, samemu” (yadā tumbe bhaddiya attanā va jāneyyātha; AN II, 191), jak się rzeczy mają, wówczas je porzucisz. 
Budda pokazuje, że różne przekonania mają podstawy w błędnych interpretacjach doświadczeń, np. przekonanie o trwałości jaźni opiera się na medytacyjnym doświadczeniu przeszłych żywotów. W znamienny jednak sposób odnosi się do tych, którzy tak jak on milczą na temat wieczności bądź skończoności świata. Ich postawę przyrównuje do „wicia się węgorza” (amarā-vikkhepa). Chociaż oceniana z zewnętrznej perspektywy wydaje się ona taka jak Buddy, ten uznaje, że między nim a nimi zachodzi zasadnicza różnica związana $z$ odmiennością powodów milczenia.

W pierwszym ze wskazanych przez niego tego rodzaju stanowisk jego zwolennicy milczą z powodu lęku przed udzieleniem złej odpowiedzi; nie znając odpowiedzi, obawiają się popadnięcia w fałsz, w błąd; chcąc uniknąć oskarżeń o niewiedzę, dla poczucia bezpieczeństwa wolą zachować milczenie bądź kluczą (DN I, 24-25)94. Budda natomiast nie odpowiada na te pytania dlatego, iż wie, że są duchowo bezużyteczne. Odpowiedź na nie nie przybliża do wyzwolenia, zajmowanie się nimi, spekulowanie na ich temat jest zajęciem nie tylko czczym, próżnym, ale też szkodliwym.

Niezwykle ciekawe jest stanowisko drugie. Budda dopuszcza bowiem, że jego zwolennicy motywowani są obawą przed popadnięciem w lgnięcie (upädāna). Nie orzekają zatem, co jest dobre, a co złe, aby uchronić się przed szkodliwymi postawami, takimi jak pragnienie i awersja, które się na lgnięciu nabudowują. Milczą w związku z tym bądź kluczą tak jak przedstawiciele pierwszej grupy (DN I, 25-26). Jayatilleke zasugerował, że powodem, dla którego Budda odrzucił to stanowisko, było odmienne rozumienie lgnięcia' ${ }^{95}$ Nic jednak w tekście nie wskazuje, aby ta opinia była trafna. Uważam wręcz, że

94 Przedstawiciele tej grupy odmawiają stwierdzania, co jest dobre, a co jest złe, gdyż obawiają się błędu. Żeby nie błądzić, wolą nic nie twierdzić. Ten opis kontrastuje wyraźnie z modelem greckim. Neopirroniści, nie mając wiedzy o tym, co dobre i złe, nie boją się oznajmiać, co im sį̨ takie wydaje i tym sį̨ kierować $w$ działaniu.

95 Zob. K. N. Jayatilleke, op. cit., s. 126-127. 
powodem, dla którego przedstawiciele tego stanowiska milczą bądź kluczą, nie jest obawa przed lgnięciem jako takim, a przed lgnięciem do niewłaściwych rzeczy. Nie znając stanu faktycznego, lękają się, że przylgną do rzeczy, do których lgnąć nie należy. Żeby się zabezpieczyć przed takim nieszczęściem, wybierają wątpienie. Zatem krytyka tego stanowiska nie jest związana $\mathrm{z}$ rozumieniem lgnięcia, a $\mathrm{z}$ wątpieniem. Oni powstrzymują się od żywienia opinii, aby nie lgnąć i w ten sposób zabezpieczyć się przed nieszczęściem. Budda natomiast nie lgnie i dlatego nie żywi opinii.

Jeszcze inna motywacja kieruje postępowaniem przedstawicieli grupy trzeciej. Nie udzielają oni żadnych odpowiedzi bądź kluczą, gdyż obawiają się przegranej w sporze. Doświadczenie życiowe każe im wierzyć, że istnieją zręczni dyskutanci, którzy swoimi pytaniami i argumentami będą potrafili obnażyć słabość dokonanych przez nich rozstrzygnięć. Obawiając się utraty prestiżu społecznego, wolą milczeć bądź kluczyć (DN I, 26).

Listę tych, którzy pytani zachowują milczenie bądź kluczą w swoich odpowiedziach zamykają przedstawiciele grupy czwartej (DN I, 27). O nich mówi się w kazaniu, że powodem, dla którego postępują tak, a nie inaczej, jest ich tępota (mandatta) i głupota (momübatta). Nie udzielają oni żadnych odpowiedzi, gdyż żadnych nie posiadają. Można powiedzieć, że z nieposiadania odpowiedzi uczynili cnotę. Wydaje się, iż skojarzenie tej grupy z neopirronizmem jest najtrafniejsze. Jej przedstawiciele w swoim postępowaniu kierują się samym przekonaniem, iż niczego w sposób wiążący nie można rozstrzygnąć, nie sposób uzasadnić ani prawdy, ani fałszu żadnych przekonań. Przedstawicielami trzech wcześniej wspomnianych grup kieruje odmienna motywacja. Zdają oni sobie sprawę ze swojej niewiedzy i widzą w tym swoją słabość, której próbują jakoś zaradzić. Dla przedstawicieli grupy czwartej brak wiedzy nie stanowi żadnego problemu. Można się wręcz domyślać, że według nich mają go ci, którzy zgłaszają pretensje do prawdy. Za klasycznego przedstawiciela tego stanowiska w kazaniach uchodzi Sańdżaja Belatthiputta (p. Sañjaya Belațțhipuțta). Jego 
postać została przywołana w Kazaniu o owocach ascezy (Sämañña-pbala-sutta; DN I, 58-59), w którym król Adżatasattu (p. Ajātasattu) opowiada Buddzie o swoich spotkaniach $z$ różnymi ascetami i o ich opinii na temat owoców ascetycznego życia. Sańdżaja był jedynym, który w tej kwestii wypowiadał się wymijająco, nie udzielając żadnej odpowiedzi. Król przyznał, że ze wszystkich ascetów i braminów Sańdżaja wydał mu się najgłupszy i najbardziej zaślepiony (DN I, 59). Opinię tę można uznać za komentarz, jakim buddyjska tradycja opatrywała postawę sceptyczną.

Postawa Buddy, mimo pozornego podobieństwa, zdecydowanie odbiega od postaw wyrastających z wątpienia. Podejrzewający ten fakt Waczczha spytat raz Mahamoggallanę (p. Mahāmoggallāna), słynnego ucznia Buddy, dlaczego inni nauczyciele nie nauczają tego samego, co Przebudzony (SN IV, 394). W odpowiedzi usłyszał, że jest to związane $\mathrm{z}$ tym, iz ich perspektywa zakorzeniona jest w pojęciu ,ja”. Budda pozbawiony jest tej perspektywy, dlatego nie odpowiada na pytania, które standardowo pozostawiał bez odpowiedzi. Waczczha udał się następnie do samego Buddy, aby zadać mu owe pytania. Mędrzec nie udzielił na nie odpowiedzi, w związku z tym Waczczha zainteresowat się, dlaczego on na te pytania nie odpowiada, podczas gdy inni nauczyciele nie mają takich oporów. Wówczas ustyszat tę samą odpowiedź, której udzielił mu Moggallana - jego perspektywa, w przeciwieństwie do perspektywy innych nauczycieli, wolna jest od pojęcia „ja”. Będąc świadkiem takiej zbieżności objaśnień mistrza i ucznia, Waczczha wpadł w zachwyt nad tą zgodnością. Na ironię zakrawa fakt, że Moggallana zanim został uczniem Buddy, miał wcześniej pobierać nauki u Sańdżaji.

$\mathrm{Za}$ podsumowanie rozważań o wątpieniu $\mathrm{w}$ tradycji buddyjskiej może posłużyć kazanie, jakie uczeń Buddy Ananda udzielił ascecie Sandace (p. Sandaka). Streszcza w nim naukę Buddy m.in. o czterech formach świątobliwego życia, które jednak nie dają ostatecznego schronienia czy też pociechy (anassasika brabma-cariya). Na pierwszym miejscu Ananda wskazuje tych, którzy zgłaszają pretensje do 
wszechwiedzy, twierdząc, że niezależnie od tego, w jakim są stanie świadomości, czy to we śnie, czy na jawie, zawsze dysponują wiedzą. Każdą sytuację tłumaczą - nawet tę, w której przydarza im się nieszczęście lub dopytują się o coś - że oni wiedzieli, iż tak musiało się stać, dlatego postępowali zgodnie z tą wiedzą (MN I, 519). Ananda nie komentuje bezpośrednio poznawczej wartości tej postawy. Można sį̨ jednak domyślić, iż nie jest ona wielka, a nawet jest niższa niż trzech pozostałych, gdyż w wypadku tych ostatnich Ananda dopuszcza możliwość, że ich reprezentantom zdarza się czasami powiedzieć coś prawdziwego. W pierwszym wypadku tego jednak nie sugeruje. Oznajmia tylko standardowo, że gdy przedstawiciel takiej postawy dostrzeże, że nie daje ona schronienia, to ją zostawia. To samo zresztą mówi o przedstawicielach trzech pozostałych form świątobliwego życia. Formę drugą wyznaczają ci, którzy opierają się na ustnym przekazie i tradycji, czyli wedyjscy kapłani. Ponieważ zależą w swoim przekazie od pamięci, to zwykle się mylą, chociaż czasami zdarza im się powiedzieć coś zgodnego z prawdą (MN I, 520). Trzecia forma świątobliwego życia charakterystyczna jest dla filozofa, którego Ananda nazywa racjonalistą/logikiem (takkī) oraz badaczem (vimamsī). Przekazuje on naukę wypracowaną na drodze rozumowania, podążając za wynikiem dociekania, jaki mu się jawi. Ale w takim wypadku zawsze pewne wnioski są prawdziwe/trafne, a inne nie. Postawa ta nie gwarantuje prawdziwości (MN I, 520). Czwarta forma jest formą nauczyciela tępego (manda) i głupiego (momuba). Taki nauczyciel pytany, ucieka się do wymijających odpowiedzi, wije się jak węgorz, mówiąc: „Nie głoszę tego, nie głoszę tamtego, nie głoszę czegoś innego. Nie głoszę, że tak nie jest. Nie głoszę, że tak nie nie jest" (evam pi me no, tatbā pi me no, añnatbā pi me no, no ti pi me no, no no ti pi me no ti; MN I, 520-521). Ananda powtarza w ten sposób charakterystykę sceptyka z Kazania o sieci Brabmy (DN I, 27).

Budda wyznacza model świątobliwego życia, który jest alternatywny wobec wszystkich czterech modeli. Powiedzieć o nim, że jest to model piąty, byłoby niewłaściwe, gdyż nie jest on lokowany na tym 
samym poziomie. Tamte bowiem były formami życia, które nie dają ostatecznego schronienia, ten natomiast ma takie schronienie gwarantować. Cały czas mówi się o Buddzie w kontraście do przedstawicieli owych czterech form życia, że jest tym, który wie i widzi (jāna passa), i jest w pełni doskonale przebudzony (sammä-sambuddha). Owa wiedza i widzenie są tutaj jednak $z$ innego poziomu niż wiedza np. racjonalnego filozofa. Budda jedyny bowiem oczyścił swój umysł $\mathrm{z}$ wszelkiego wątpienia (MN I, 521, powtórzenie z MN I, 347). Ananda podkreśla: „porzuciwszy wątpienie, pozostaje wolny od wątpienia, nie kwestionując zdrowych stanów, oczyszcza umysł z wątpienia" (vicikiccham pabāya tinna-vicikiccho vibarati, akatham-katbi kusalesu dhammesu vicikicchāya cittam parisodheti). Właściwy model życia polega na powściągliwości, na niechwytaniu się żadnych przedmiotów zmysłowych i umysłowych oraz na pozostawaniu w stanie naocznej pewności.

\subsubsection{Zarzut wewnętrznej sprzeczności}

Deklaracja nieposiadania przez Doskonałego poglądów pojawia się w Suttanipacie wielokrotnie. Jednak jej powtórzenie przed Magandiją (p. Mãgandiya) przyniosło konsekwencje, którym powinniśmy się przyjrzeć nieco dokładniej, zwłaszcza że Magandija w swoim rozumieniu owej deklaracji poszedł szlakiem przetartym już przez starożytnych krytyków greckiego sceptycyzmu. Nie należy się temu dziwić o tyle, że słowa Buddy rozumiane literalnie i pozostawione bez komentarza brzmią jak wyznanie samego Pirrona. W strofie Sn. 837 (Sn. IV.9.3) czytamy, co następuje:

idam vadami ti na tassa boti

(mägandiyà ti bhagavā)

dhammesu niccheyya samuggabìtam

passañ ca dițțīisu anuggabāya

ajjhatta-santim pacinam adassam $\|$ 
(Czcigodny powiedział do Magandiji): Pośród wielu nauk nie istnieje żadna, którą bym po zbadaniu uznat [mówiąc] „to głoszę". Rozpatrując poglądy, nie chwytając żadnego, poszukując, dostrzegłem wewnętrzny spokój.

Odnoszę wrażenie, że w przywołanej poniżej (Sn. 838) wypowiedzi Magandiji będącej reakcją na słowa Buddy daje się dostrzec ironia, gdy potwierdza on, że Przebudzony formułuje swoje deklaracje, nie lgnąc do nich. Na tle tego potwierdzenia pytanie, jakie kieruje do Buddy, brzmi przewrotnie.

\section{vinicchaya yani pakappitani}

(iti Magandiyo)

te ve muni brüsi anuggabaya

ajjbatta-santī ti yam etam attham

kathan nu dhirebi paveditam tam $\|$

(Magandija powiedział): Doprawdy, te przemyślane opinie, mędrcze, wypowiadasz, nie chwytając ich. Odnośnie tego, co zwiesz "wewnętrznym spokojem", jak o tym, mędrcze, powiadamiasz?

Magandija dostrzega w postawie Buddy wewnętrzną sprzeczność. $\mathrm{Z}$ jednej strony bowiem nauczyciel zapewnia, iż niczego nie deklaruje, z drugiej zaś przyznaje się do osiągnięcia wewnętrznego spokoju. Magandija podnosi wątpliwość, czy można w ogóle cokolwiek prawomocnie i wiążąco mówić, gdy się niczego nie deklaruje, czyli gdy niczego nie uznaje się za prawdę. Jaką informacyjną wartość mają słowa w świetle oświadczenia dezawuującego dystynkcje prawdy i fałszu? Czy wypowiedź taka w ramach jej własnych założeń nie okazuje się pozbawiona sensu? To już pewnie lepiej byłoby nauczać, nic nie mówiąc. Na tę wątpliwość Budda odpowiedział w Sn. 839 następująco:

na dițthiya na sutiya na ñanena

(magandiyã ti bbagava)

silabbatenapi na suddbim äba 
aditthiya assutiya añ̄aña asilata abbata no pi tena, ete ca nissajja anuggabāya santo anissaya bbavam na jappe II

(Czcigodny rzekł do Magandiji): Nie dzięki poglądowi, nie dzięki zasłyszeniu/objawieniu, nie dzięki poznaniu, nie dzięki cnotliwym czynom i nakazom powiedziałem o czystości. Ale też nie dzięki brakowi: poglądów, zasłyszenia/objawienia, poznania, cnotliwych czynów i nakazów - w ten sposób też nie. Porzuciwszy je, nie chwytając niczego, będąc wyciszonym, niezależnym, nie należy pragnąć istnienia.

Replika Buddy jest szczególna. Można wręcz odnieść wrażenie, że nie odpowiedział on na wątpliwość Magandiji, gdyż nie odniósł się bezpośrednio do wskazanego przez swojego rozmówcę problemu wartości orzekania poza prawdą i fałszem. Wręcz przeciwnie, może się wydawać, że tylko tę trudność pogłębił. W pierwszym zdaniu bowiem przyznat, że osiągnięcia czystości, o której informuje, nie zawdzięcza poglądom, w tym w szczególności poglądom objawienia wedyjskiego, ani stosowaniu się do nakazów czystości. W zdaniu drugim dopowiedział jednak, że osiągnięcia tego nie zawdzięcza także odrzuceniu tych poglądów i praktyk. Czemu zatem je zawdzięcza?

W komentarzu do tej strofy, napisanym kilka wieków później96, poradzono sobie $z$ tą trudnością $\mathbf{w}$ ten sposób, iż dokonano segregacji poglądów na niewłaściwe i właściwe. W zdaniu pierwszym Budda

96 Niddesa jest komentarzem do czwartego i piątego rozdziału Suttanipaty, co świadczy o tym, iż funkcjonowały one pierwotnie jako odrębny zbiór. Sama zaliczana jest to tekstów kanonicznych, jako jeden z tekstów Khuddakanikaji (Kbuddaka-nikdya). Jej datowanie jest problematyczne. Kenneth R. Norman, uważał że "nie może być późniejsza od daty ustalenia kanonu” (cannot be later than the date of the fixing of the Canon), K. R. Norman, Introduction, [w:] The Group of Discourses (Sutta-nipata), trans. idem, Oxford 2001, s. XXXI. Ponieważ jednak zawiera ona odniesienia do innych sutt oraz zwłaszcza do tekstów abhidhammy świadczące o tym, że jej autorzy mieli już do czynienia 
miałby zatem wskazywać poglądy i praktyki, które nim nie kierowały w dążeniu do czystości. W zdaniu drugim zaś określałby poglądy i praktyki, którymi się kierowat" ${ }^{97}$. Niemniej takie objaśnienie całkowicie ignoruje wskazaną przez Magandiję trudność. Rozstrzygnięcie to przypomina w znacznym stopniu sposób, w jaki późniejsza abhidharmiczna tradycja radziła sobie z dylematem Katjajany - jak unikać istnienia i nieistnienia. Rozwiązaniem okazała się dystrybutywna wykładnia tego dylematu, czyli odrzucenie istnienia trwatej jaźni i uznanie istnienia dharm sklasyfikowanych w zespoły. Tak jak w wypadku Kazania do Katjajany uznałem dystrybutywną interpretację za nietrafną, tak też i objaśnienie tej strofy jest nieprzekonujące.

Faktyczne rozwiązanie tego dylematu znajduje się w trzecim zdaniu, w którym Budda wyprowadza dyskurs poza kwestię uznawania i odrzucenia, asercji i negacji. Problem nie polega na rozstrzygnięciu, co jest prawdą, a co fałszem, tylko na zaprzestaniu lgnięcia do obu, gdyż owa para, jak wcześniej było wzmiankowane, wiąże się z błędnym przywiązaniem do istnienia i nieistnienia. Dlatego Budda, postawiony przed dylematem epistemologicznym, zwrócił uwagę na kwestį̨ ontologiczną, oznajmiając: „Nie należy pragnąć istnienia”. Zalecenie to, jak wiemy już $z$ analizy Kazania do Katjajany, nie oznacza, że istnieniu należy się przeciwstawiać, opowiadając się za nieistnieniem. Znaczy ono, że należy istnienie unieważnić jako to, co przedstawiamy sobie o rzeczywistości w ramach błędu poznawczego. Niepragnienie istnienia oznacza wyjście poza istnienie i nieistnienie, czyli zaniechanie wszelkiego lgnięcia do tego, co błędnie doświadczamy jako istniejące i nieistniejące. Wyjście poza istnienie i nieistnienie jest równoważne wyjściu poza prawdę i fałsz.

Okazało się jednak, że Magandija nie jest w stanie trafnie ocenić nauczania Buddy, gdyż przyznał w Sn. 840, że taka nauka wydaje

z kanonem w kształcie, jaki dzisiaj znamy, prawdopodobnie powstała ona we wczesnym okresie po spisaniu kanonu, być może w I w.

97 Zob. The Suttanipäta. An Ancient Collection..., s. 1110-1111. 
mu się pogmatwana czy też wręcz głupia (momuba dhamma). Przebudzony oświadczył w Sn. 841, że opinia Magandiji wynika z jego zaślepienia tym, czego się chwyta. To jest powód, dla którego nie jest on w stanie zrozumieć nauczania Buddy. Ostatecznie Budda wieńczy wypowiedź do Magandiji stwierdzeniem (Sn. 847 [Sn. IV.9.13]):

sañña-virattassa na santi gantbā pañña-vimuttassa na santi mobä sañ̃añ ca dițthiñ ca ye aggabesum te ghatțayantà vicaranti loke till

Nie istnieją więzy dla tego, który oderwał się od postrzeżeń. Nie istnieje omroczenie dla tego, który wyzwolił się dzięki mądrości. Jednak ci, którzy uchwycili się postrzeżeń i poglądów, błąkają się w świecie, wzbudzając spory.

Być buddą to być całkowicie wolnym od wszelkich więzów charakterystycznych dla stanu cierpienia. Jednym z tych więzów jest przywiązanie do poglądów. Dlatego w kazaniach oderwanie od poglądów jest często wspominane, np. w AN I, 66 stwierdza się, że Budda „ominął, wyszedł poza” (samatikkanta) „przylgnięcie [do poglądu], opętanie [poglądem], żądzę [poglądu], zniewolenie [poglądem], przywiązanie [do poglądu], pragnienie poglądu" (dițthi-räga-vinivesa-vinibandba-paligedba-pariyutțhānaj̄hosāna). Podobnie w MN I, 486 zauważa się lapidarnie, ze Budda oddalił wszelkie dążenie do poglądów (dițţi-gatan ti kho vaccha apanìyam etam tathägatassa). Postawę doskonałego przybliza Sn. 803 (Sn. IV.5.8), gdzie czytamy:

na kappayanti na purekkbaronti dhammā pi tesam na pațicchitāse na bräbmano silavatena neyyo pāramgato na pacceti tādi till

Nie spekulują (na kappayanti), nie opowiadają się (na purekkbaronti), nie uznają żadnych nauk (dhammapi tesam na 
pațicchitase). Bramin [tj. doskonały] nie podąża za cnotliwymi czynami i nakazami. Osiągnąwszy drugi brzeg, nie powraca.

Rodzi się jednak pytanie, jak doskonały doświadcza w trakcie życia. Jak doświadcza ten, który nie lgnie? Tę kwestię próbuje naświetlić Sn. 874:

na sañna-sañ̃̄ĩ na visañ̃na-sañ̃ $i$

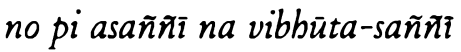

evam sametassa vibhoti rüpam

sañña-nidanā bi papañca-samkbā $\|$

Nie jest postrzegającym dzięki [zwykłemu] postrzeganiu, nie jest postrzegającym dzięki nadzwyczajnemu postrzeganiu, nie jest też niepostrzegającym, nie jest postrzegającym tego, co zanikło. Dla tego, który osiągnąt taki stan, forma zanika, albowiem pojęciowe rozplenienie [tj. spekulacja] ma podstawe w postrzeganiu.

Póki doskonały żyje, póty doświadcza, dlatego w strofie tej nazywa się go po prostu postrzegającym (sañ̃̄i). Jego postrzeganie jednak nie jest takie samo jak postrzeganie istot nieprzebudzonych. Istoty nieprzebudzone postrzegają $\mathrm{w}$ taki sposób, iż przedstawiają sobie to, co postrzegają. Znaczy to tyle, że postrzeganie istot nieprzebudzonych konstruowane jest jako ujmowanie przedmiotu przez jakieś „ja”. Postrzeganie doskonałego nie ma też nic wspólnego z postrzeganiem nadzwyczajnym (visañña-saññi). Komentarz sugeruje, że termin visañña oznacza świadomość zaburzoną, przyrównując ją do stanu umystu osoby niezrównoważonej ${ }^{8}$. Chodzi tu jednak o coś więcej niż o zwykłe szaleństwo. Jeżeli już mielibyśmy się trzymać tego odniesienia, to powinniśmy raczej powiedzieć o „szaleństwie bożym”, czyli o odmiennym stanie świadomości, co do którego niektórzy wierzą, że ujmuje on ostateczną, co w tym wypadku należy rozumieć jako 
transcendentną, pozaempiryczną, zwykle boską, rzeczywistość w jej faktycznym kształcie. Postrzeganie doskonałego nie jest w tym sensie odmiennym stanem świadomości. Nie jest też, jak zapewnia sį̨ w kolejnym sformułowaniu, stanem całkowitego niepostrzegania. Ostatecznie nie jest to też stan postrzegania tego, co zanikło ${ }^{99}$. Jedyne, co o tym stanie możemy powiedzieć pozytywnego, to to, że zanika w nim forma. Stwierdzenie to, ze względu na ostatnią część wypowiedzi, należy rozumieć tak, że postrzegający zaprzestaje postrzegania formy poprzez jej pojęciową reprezentację. Zaryzykuję hipotezę, że na ten opis możemy spojrzeć jako na próbę wysłowienia stanu czystej, tzn. bezprzedmiotowej, przytomności, w innym kontekście nazywanej właściwą mądrością (sammappañ̃̄a).

W MN I, 40 mówi się o niej:

n' etam mama, n' eso 'bam asmi, na me so attāti evametam yatbä-bbūtam sammappaññaya passato evam etasam dițțiñam pahãnam hoti, evam etāsam dițthinnam paținissaggo boti.

Gdy widzi się rzeczy, jakimi są, właściwą/doskonałą mądrością jako „to nie jest moje, to nie jestem ja, to nie jest moja jaźń", wówczas wszystkie poglądy [o jaźni i świecie] zostają zarzucone, zaniechane.

99 Określenie vibhūta-saññ ze wszystkich czterech określeń jest najbardziej niejasne. Norman sugeruje, że chodzi o stan umysłu tego, który nie wyszedł poza czwartą dżhanę w tzw. stany skupienia bezforemnego, ale jest bliski opuszczenia owej czwartej dihany, zob. The Group of Discourses..., s. 360-361. Bhikkhu Bodhi przywołuje chińską wersję tej strofy, zwracając uwag̨ na to, że w wersji tej pojawia sį̧ odmienne określenie niż w wersji palijskiej. Ściśle rzecz biorąc, to tylko dwa pierwsze określenia postrzegającego są analogiczne, dwa pozostałe są odmienne, zob. The Suttanipata. An Ancient Collection..., s. 1530, przyp. 1932. Sam jednak nie decyduje się na zaproponowanie własnej wykładni, poprzestając na konstatacji niejasności, która w jego opinii stanowiła problem juz dla autorów pierwszego komentarza. 


\subsubsection{Jaką rolę odgrywa pogląd jako przedstawienie?}

Dotychczas skupiałem się na wykazaniu, że deklaracja Buddy o nieposiadaniu własnych poglądów w swoim znaczeniu jest radykalnie odmienna od identycznej w wysłowieniu deklaracji starożytnego greckiego sceptyka. Uzyskany wynik mógłbym spuentować następująco: dla sceptyka brak poglądów jest początkiem drogi, która ma go zaprowadzić do dobrostanu, jest sposobem dążenia do dobrostanu; dla Buddy jest to punkt dojścia, jeden ze sposobów przejawiania się buddyjskiego dobrostanu.

Skoro dla sceptyka brak poglądów jest metodą osiągania dobrostanu, to $\mathrm{w}$ związku $\mathrm{z}$ tą różnicą $\mathrm{w}$ sposobie rozumienia braku poglądów można się spodziewać, że na buddyjskiej drodze do dobrostanu będzie się z poglądów czyniło użytek w sposób odmienny niż w sceptycyzmie. Potwierdzenie trafności tego przypuszczenia znajdziemy w Czankisutcie (Canki-sutta; MN II, 164-177).

Zanim przystąpimy do analizy przesłania tego kazania, warto w paru słowach naszkicować dość niezwykły kontekst, w jakim do niego doszło. Otóż Budda dotarł na obszar, którym zarządzał prominentny i bardzo szanowany bramin Czanki (p. Cañkī). Doszło tam do spotkania $\mathrm{z}$ bardzo dużą grupą braminów, podczas którego Budda prowadził z szacowną starszyzną uczoną konwersację. Rozmowę jednak co chwilę przerywał młody bramin, tekst mówi, że szesnastoletni, który próbował się w nią włączyć. Budda w końcu zareagowat, zwracając mu uwagę, żeby poczekał na swoją kolej, aż konwersacja ze starszyzną dobiegnie końca. Wówczas Czanki ujął się za młodym braminem, który na imię miał Kapathika (p. Kāpaṭhika), zapewniając o jego niezwykłej bystrości i ogromnej wiedzy, jaką ten już posiadł mimo młodego wieku. Tym sposobem Kapathika nie tylko został włączony do rozmowy, ale przejął jej ster, stając się głównym dyskutantem.

Młody bramin oznajmił, wyrażając życzenie poznania opinii Buddy w tej kwestii, iż bramini, w oparciu o utrwaloną ustną tradycję, głoszą, że "tylko to [tj. nauka zawarta w Wedach] jest prawdą, wszystko 
inne jest bezużyteczne" (idam eva saccam mogham aññan). Budda odpowiedział pytaniem, czy pośród owych braminów, łącznie z tymi, którzy dali początek przekazowi, łącznie z wieszczami, jest choć jeden, który głosi bądź głosił: „poznaję to, widzę to - tylko to jest prawdą, wszystko inne jest bezużyteczne" (aham etam jänāmi, abam etam passāmi: idam eva saccam mogham aññan; MN II, 169). Uzyskawszy negatywną odpowiedź, Przebudzony stwierdził, że postępowanie braminów przypomina korowód ślepców (andha-veni), którzy chwytaja się wzajemnie (paramparā-samsattä), choć żaden niczego nie widzi. W tej sytuacji "wiara braminów okazuje się bezpodstawna, nieugruntowana" (bräbmanānam amūlikā saddhā sampajjatı). Odwołanie się do oralnej tradycji niczego w tej kwestii nie zmienia.

Konstatację tę Budda wykorzystał jako pretekst do wskazania pięciu podstaw (pañca dhammā), na których kształtuje się pogląd: zaufanie/wiara (saddhä), upodobanie/skłonność [do poglądu, idei] (ruci), zasłyszenie (tj. tradycja ustna) (anussava), przemyślenie stanu rzeczy (äkära-parivitakka) oraz pogłębiona refleksja, czyli uznanie poglądu po gruntownym rozważeniu (dițthi-nijjhānakkhanti) (MN II, 170). Opierając swoją aktywność poznawczą na każdym z tych czynników, zaznacza Budda, sytuacja może rozwinąć się na dwa sposoby (dvidhā vipākāa). Innymi słowy, pogląd uzyskany w oparciu o każdy z tych czynników może okazać się prawdziwy bądź fałszywy.

Rozumienie trzech pierwszych podstaw nie sprawia większych trudności. Pewne jednak niejasności pojawiają się odnośnie do dwóch ostatnich czynników. W przypadku podstawy czwartej chodzi o przemyślenie racji, co ma wystarczyć do uzasadnionej wiary, lecz nie wie$\mathrm{d} z \mathrm{y}^{100}$. W przypadku piątym chodzi o akceptację poglądu w oparciu o uchwycenie jego faktycznego znaczenia ${ }^{101}$. Jest to akceptacja (kbanti) poglądu (dițthi) w oparciu o głęboką refleksje (nijjhāna) nad celem jego wygłoszenia. W tej akceptacji możemy się pomylić, błędnie

\footnotetext{
100 Zob. K. N. Jayatilleke, op. cit., s. 274-275, 393.

101 Ibidem, s. 275.
} 
rozpoznając cel nauczania, wówczas jesteśmy jak człowiek niewłaściwie chwytający węża. Opisując w Kitagirisutcie (Kịtāgiri-sutta; MN I, 473-481) stopniowy proces dochodzenia do ostatecznego poznania, Budda wskazał na kolejne etapy budowania wiedzy. Zaczął od żywienia zaufania, poprzez szacunek, słuchanie, zapamiętywanie, badanie znaczenia tego, co zapamiętano, po akceptację poglądu poprzez jego gruntowne przemyślenie (uchwycenie znaczenia) ${ }^{102}$. Zbudowanie akceptacji wpływa na kształtowanie się zapału, woli, badania na sobie, wysilania się (praktyki medytacyjnej), aby na końcu, pozostając w ciele, uświadomić sobie tę prawdę i zobaczyć ją we wglądzie poznawczym (MN I, 480). Samo jednak głębokie przemyślenie poglądu nie gwarantuje jeszcze rozpoznania jego prawdziwości (MN II, 171).

Filozofia jako pogtębiona refleksja mieściłaby się z perspektywy buddyjskiej w piątej kategorii. Mieściłby się w niej również sceptycyzm, gdyz jest to odmowa uznania prawdziwości jakiegokolwiek sądu w związku z pogłębioną refleksją nad podstawami uznawalności za prawdę. Sceptyk, wskazując powody i racje swojej postawy, nadaje jej sens i wartość.

Wróćmy jednak do Czankisutty. Usłyszawszy o tym, że przekaz tradycji wedyjskiej nie gwarantuje prawdy, młody bramin docieka dalej i zadaje w związku z tym pytanie: „W jaki sposób zatem, mistrzu Gotamo, ma miejsce strzeżenie prawdy? Jak należy strzec prawdy?" (kittāvatā pana, bho gotama, saccānurakkbana? kittāvatā saccam anurakkbati?; MN II, 171).

Odpowiedź Buddy jest znamienna. Powinniśmy się uważnie wczytać $\mathrm{w}$ jego słowa. Stwierdza on, że prawdy strzeże ten, kto wierząc w coś, zachowuje świadomość: „taka jest moja wiara” (evam me saddhā; MN II, 171). Nie twierdzi definitywnie: „tylko to jest prawdą, wszystko inne jest bezużyteczne" (idam eva saccam mogham añnan). Wiara nie jest jednak odkryciem prawdy (saccānubodha), tzn. nie jest przebu-

102 Pojawia się to samo określenie: dițțhi-nijjhānakkhanti; MN I, 480, zob. też AN I, 189. 
dzeniem się do prawdy, nie jest osobistym naocznym rozpoznaniem. W analogiczny sposób Budda wypowiada się o pozostałych czterech podstawach kształtowania się poglądu, tj. o upodobaniu/skłonności [do poglądu, idei], zasłyszeniu, przemyśleniu stanu rzeczy i pogłębionej refleksji. Musimy być świadomi, na jakiej podstawie żywimy jakiś pogląd. W ten sposób chronimy prawdę. W żadnym przypadku nie mamy jednak do czynienia $z$ odkryciem prawdy. Prawdę zatem chronimy nie wtedy, gdy w coś wierzymy, gdy coś uznajemy na takiej bądź innej podstawie, (i możemy dodać: gdy ją głosimy, argumentujemy na jej rzecz, walczymy za nią i za nią giniemy), tylko wtedy, gdy jesteśmy świadomi, na jakiej podstawie uznajemy jakąś rzecz za prawdziwą. Budda nie zaleca, jak czyni to sceptyk, całkowitego zawieszenia poglądu, zaleca on uważność wobec tego, w oparciu o co żywimy jakiś pogląd. Żywienie poglądu jest niezbędnym środkiem do praktyki zmierzającej do uzyskania osobistej naoczności, która pozwoli nam nie żywić żadnego poglądu. Jest środkiem niezbędnym, ponieważ stanowi podstawę zaangażowania w praktykę.

Kapathika w dalszym ciągu docieka: „W jaki sposób dochodzi do odkrycia prawdy? Jak odkrywa się prawdę?" (kittāvatā pana, bho gotama, saccãnubodho boti? kittavata saccam anubujjhati?; MN II, 171). Odpowiadając na to pytanie, Budda przedstawia droge wiodącą od zaufania do nauczyciela po widzenie prawdy, wskazując na dwanaście jej aspektów czy też etapów. Cały proces zaczyna się od zbudowania zaufania $(s a d d h \bar{a})$ do nauczyciela. Osiąga się je w ramach złożonego procesu, podczas którego adept bada (samannesati) nauczyciela pod kątem występowania w nim stanów ugruntowanych w trzech gtównych skalaniach: pragnieniu (lobba), awersji (dosa) oraz omroczeniu (moba), i rozpoznaje (jānati), że stany takie, a tym samym i owe skalania w nim nie występują. Podstawą wiary, tak jak rozumie się ją w buddyzmie, jest kultywowanie krytycznej postawy badania (samannesanā), dzięki której adept widzi (samanupassatı) czystość nauczyciela. Wiara w buddyzmie nie jest skokiem w nieznaną metafizyczną przestrzeń ubraną $\mathrm{w}$ zestaw przekonań, lecz stanowi ufność 
budowaną na krytycznym badaniu postawy tego, który owe przekonania głosi. Pokładając wiarę/zaufanie w nauczyciela, zbliża się do niego z szacunkiem; wyraziwszy szacunek, daje posłuch; dając posłuch, słyszy naukę; słysząc naukę, zapamiętuje ją; pamiętając ją, bada jej znaczenie; zbadawszy jej znaczenie, rozważnie ją akceptuje; rozważnie ją zaakceptowawszy, ulega intencji/pragnieniu uważności; zapragnąwszy, wysila się; wysilając się, uważnie bada; badając, dąży; „dążąc stanowczo, urzeczywistnia ciałem ostateczną prawdę oraz widzi ją przenikając ją mądrością" (pabitatto samãno kāyena c' eva parama-saccam sacchikaroti, pañ̃āya ca tam ativijjha passati; MN II, 173). Ważnym momentem $w$ tym opisie jest zwrócenie uwagi na rolę refleksyjnego badania treści przekonań (bada znaczenie). Uchwycenie znaczenia stwarza sposobność, aby odnieść się do nauki pozytywnie, akceptując ją, bądź negatywnie, odrzucając ją. Akceptacja nauki stanowi kontekst dla pojawienia się wysiłku w dążeniu do pracy medytacyjnej ${ }^{103}$.

Zagadnienie pięciu podstaw poznania powraca w Kazaniu o pięciu $i$ trzech (Pañcattaya-sutta; MN II, 228-238). W tekście w skróconej wersji przywołane zostało wyliczenie sześćdziesięciu dwóch błędnych poglądów obszernie omówionych w Brabamadżalasutcie. Odnosząc się do ascetów i braminów, którzy dyskutując zagadnienie przeszłości, głoszą różne kombinacje poglądów na temat jaźni i świata, Budda podkreśla zgodnie z nauką wyrażoną w Czankisutcie (MN II, 170), że poglądy te formułowane są w oparciu o pięć czynników. Poza oparciem o nie nie posiadają oni osobistego poznania (paccatta ñāna; MN II, 234), które byłoby czyste (parisuddha) i klarowne (pariyidāta). Nie mając takiego poznania, bazują na poznaniu fragmentarycznym, które uważa się za lgnięcie (upädäna) ${ }^{104}$. Innymi słowy, lgną do tego,

$103 \mathrm{Na}$ temat właściwych metod badania Buddy zob. Vimamsaka-sutta (MN I, 317-320).

104 Doskonały przykład takiego fragmentarycznego poznania daje słynna przypowieść o ślepcach i słoniu (Ud. 66-69). O tej kwestii wspominam jeszcze w podrozdziale 1.7 tej części. 
co głoszą. Zgodnie jednak z Czankisutta takie poznanie co do swej treści może okazać się prawdziwe. Pogląd taki jest jednak niewłaściwy ze względu na lgnięcie. Tathagata wyszedł poza to (tathägato tad upātivatto).

Kończąc przegląd wypowiedzi Buddy na temat względnej wartości poglądów w dochodzeniu do stanu braku poglądów, warto przywołać jeszcze jedną dystynkcję poczynioną w Kazaniu do Sangarawy (Sañgārava-sutta; MN II, 209-213). W mowie tej Budda wyróżnił trzy kategorie świątobliwych mężów ze względu na sposób, w jaki dokonują poznania. Grupe pierwszą stanowią tradycjonaliści (anussavika), którzy głoszą zasady świątobliwego życia, dharmę, opierając się o to, co zasłyszeli, tj. bramini gtoszący nauki Wed. Do drugiej grupy należą racjonaliści i badacze (takkī vimamsī) czy też racjonalistyczni badacze, którzy oddają się refleksji, czyli racjonalnej spekulacji, wykazując słuszność swoich ugruntowanych w wierze przekonań. Chociaż kultywują krytyczną refleksyjną postawę, Budda mówi o nich, że "opierają się całkowicie na wierze" (kevalam saddhä-mattakena). Do tej grupy można by bez wątpienia zaliczyć sceptyków. Bhikkhu Bodhi, komentując ten fragment, zauważa, że stwierdzenie, iż przedstawiciele tej grupy opierają się całkowicie na wierze, jest intrygujące ${ }^{105}$, zwłaszcza że w innych miejscach rozróżnia się wiarę i racjonalną refleksję jako dwie podstawy tworzenia przekonań (np. MN II, 170; MN II, 218; MN II, 234). Możliwe jednak, że skojarzenie to nie jest aż tak zaskakujące, jak na pierwszy rzut oka może się wydawać. Każde rozumowanie musi wychodzić $z$ jakiejś podstawy, nie ma rozumowań bezzałożeniowych. Jeżeli punktem wyjścia nie jest bezpośrednia naoczność, pozostaje zracjonalizowana wiara, czyli wiara przebrana np. za oczywistość. Grupe trzecią tworzą „wglądowcy”, czyli ci, którzy głoszą naukę, opierając się na własnym doskonałym poznaniu dharmy (samam yeva dhammam abbiññaya) uzyskanym dzięki praktyce medytacyjnej. Do tej kategorii Budda zaliczył siebie.

105 The Middle Length Discourses..., s. 1300, przyp. 919. 
Podział ten odpowiada w późniejszym buddyzmie często przywoływanemu rozróżnieniu trzech rodzajów mądrości, które przeprowadzone zostało w DN III, 219. Te trzy rodzaje to mądrość uzyskana dzięki: refleksji (cintāmaya-pañña), słuchaniu (sutamaya-paññā) i medytacji (bhāvanāmaya-paññā), chociaż poszczególne elementy w Kazaniu do Sangarawy wymienione zostały w odmiennej kolejności.

\subsubsection{O języku nauczania}

Zwracałem wcześniej uwage na wątpliwość Magandiji dotyczącą tego, czy Budda deklarujący nieposiadanie żadnych poglądów może o czymkolwiek prawomocnie orzekać. Problem jednak jest znacznie głębszy i wygląda następująco. Jeżeli nieposiadanie poglądów polega na widzeniu, w którym nie ma pojęcia nja", to po pierwsze, jaki sens mają wypowiedzi, w których wyzwolony wypowiada się w pierwszej osobie, a po drugie, czy takie wypowiadanie się nie przeczy przekonaniu, że jego widzenie jest faktycznie nieegotyczne. Kwestia ta w nikajach powraca kilkakrotnie i zasługuje na to, żeby poświęcić jej znacznie więcej uwagi, niż w tym momencie to uczynię.

W SN I, 14-15 tekst zapewnia, że arahant, doskonaty, który zniszczył skazy, może używać wypowiedzi w rodzaju „ja mówię" (abam vadami), „oni mówią do mnie” (mamam vadanti)” i że nie wiąże się to z pychą (mäna), z którą on się z sukcesem zmierzył. Zatem mowa tego, który skaz jeszcze nie zniszczył, zawsze wiąże się z pychą i naznaczona jest lgnięciem. Wyzwolony używa mowy zgodnie $z$ obowiązującą konwencją jako instrumentu oddziaływania na innych, a nie jako narzędzia głoszenia prawdy. Tekst oświadcza (SN I, 14-15):

pabina-manassa na santi gantba |

vidbüpita mäna-ganthassa sabbe |

sa vitivatto yamatam sumedho |

abam vadamiti $p i$ so vadeyya $\mid$

mamam vadantiti $i$ pi so vadeyya $\mid$ 
loke samañ̃nam kusalo viditvā vobära-mattena so vobareyyati $\|$

Dla tego, który usunął pychę, nie istnieją żadne więzy, wszystkie więzy pychy zostały zniszczone. Chociaż mędrzec przekroczył myśl, może mówić „Ja mówię", może mówić "Oni mówią do mnie". Zręczny, znając światową [tj. codzienną, potoczną] mowę, wypowiada się jedynie konwencjonalnie.

Podobnie w DN I, 202 Budda wspomina o sytuacjach, w których mowa jest o „jaźni” (atta). Dla Przebudzonego za tym określeniem, jak i za wszystkimi innymi, nie kryją się jednak żadne realne desygnaty. Budda oznajmia: „Są to, Czitto, tylko światowe [tj. zwykłe, potoczne] nazwy, zwykłe wyrażenia, potoczne sposoby mówienia, zwykłe określenia, które Tathagata wypowiada bez przywiązania" (itimā kbo citta loka-samañ̃ā loka-niruttiyo loka-vohārā loka-pañ̃attiyo yābi tathāgato vobarati aparāmasan ti).

$\mathrm{Z}$ perspektywy buddyjskiej język jest obszarem sansary. Sfera jezyka (pojecć i rozumienia) rozciąga się tak daleko, stwierdza Budda, pouczając Anandę, jak sfera sansary (DN II, 63-64). Cechuje go zatem, można by tak powiedzieć, swoisty sansaryczny izomorfizm - jest opisem przedmiotów, które istnieją dla naszego naznaczonego błędem poznania, czyli jako przedmioty naszego lgnięcia. To jest powód, oznajmia Budda, dla którego opis sytuacji Tathagaty po śmierci jest niemożliwy dla wyzwolonego (DN II, 68). Owo uzasadnienie warto przytoczyć.

yàvat' ananda adbivacanam yavatā adbivacana-patho, yāvatā nirutti yāvatā nirutti-patho, yàvatā pañnatti yāvatā pañ̃atti-

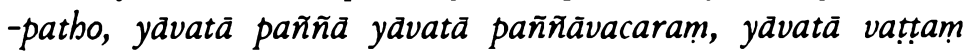
yâuatā vatțam vațtati, tad abbiñ̄na vimutto bbikkbu, tad abbiñña vimutto bbikkbu na janati na passati iti 'ssa dițthitit tad akallam.

Tak daleko, Anando, jak sięga nazwa i zakres nazwy, tak daleko, jak sięga język i zakres języka, tak daleko, jak się- 
ga pojęcie i zakres pojęcia, tak daleko, jak sięga rozumienie i zakres rozumienia, tak daleko, jak sięga i toczy się cykl odrodzeń - ten mnich jest wyzwolony dzięki wyższemu poznaniu; powiedzenie o nim, że nie poznaje i nie widzi, będzie niestosownym poglądem.

Mnich, którego umysł uwolniony jest od lgnięcia, nie lgnie do niczego w świecie, każdą z czterech opinii na temat sytuacji Tathagaty po śmierci uważa za błędną, niewłaściwą. Budda podkreśla, iż czymś nietrafnym, niewłaściwym byłoby powiedzenie o takim mnichu, że on nie wie i nie widzi. Mnich taki jest wyzwolony przez wyższe poznanie (abbiñña).

$* * *$

W rozdziale tym starałem się pokazać, że zgodnie z naukami wczesnego buddyzmu mędrzec nie powinien utożsamiać się z poglądami, nawet prawdziwymi, gdyż prowadzi to do zniewolenia i uniemożliwia osiągnięcie wyzwolenia.

$\mathrm{Na}$ istnienie potencjalnych związków między treścią Suttanipaty, zwłaszcza czwartego rozdziału, a myślą Nagardżuny zwrócił uwage ponad czterdzieści lat temu Luis O. Gómez ${ }^{106}$. Chociaż jego opinia bywa standardowo powtarzana w ogólnych opracowaniach, nie została przez nikogo podjęta jako obiecująca wskazówka, za którą warto podążyć, czyniąc z niej wyznacznik badawczej metody. Autor ten uznat, że Atțbaka-vagga głosi, iż należy porzucić wszelkie poglądy na rzecz bezpośredniego poznania rzeczywistości samej ${ }^{107}$. Uważa, że wyraźnie obecna w tym tekście zachęta do odrzucenia wszelkich poglądów daje wyraz typowej dla wielu tradycji religijnych i obecnej również w nauce

106 L. O. Gómez, Proto-Madbyamika in the Păli Canon, PEW 26/2 (1976), s. 137-165.

107 Ibidem, s. 140. 
buddyjskiej postawie mistycznej apofazy, która swoją filozoficzną kulminację znalazła następnie w filozofii Nagardżuny. Trzeba być jednak ostrożnym w użyciu kategorii mistycyzmu. Nauka o bezpośrednim poznaniu rzeczywistości nie jest jeszcze mistycyzmem. Mistycyzmem staje się wówczas, gdy owa rzeczywistość, która ma być w ten sposób poznana, zostaje pojęta jako jakaś forma absolutnego bytu, co zarówno we wczesnym buddyzmie, jak i w madhjamace nie ma miejsca ${ }^{108}$.

Chociaż w kwestii mistycyzmu zdecydowanie nie zgadzam sį̨ z Gómezem, czemu wyraz daję w ostatnim rozdziale tej części, to sądzę, iz myśl Nagardżuny faktycznie pozostaje w silnym związku z przekazem Suttanipaty i że w tekście tym znajduje się ważna wskazówka dla jej zrozumienia, co postaram się pokazać w następnym rozdziale.

\subsection{Dlaczego Nagardżuna nie posiada własnych poglądów?}

Buddyjskim filozofem, który najdobitniej podkreślał znaczenie takiej nieegotycznej postawy względem poglądów, był twórca szkoły madhjamaki - Nagardżuna (II w.). Zanim wykażę słuszność tego twierdzenia, zaznaczę, że takiej interpretacji postawy Nagardżuny trudno szukać w różnych opracowaniach myśli tego filozofa. Zwykle bowiem Nagardżunę przedstawia się jako myśliciela rewolucyjnego, nieucieleśniającego wcześniejszej tradycji, ma on ją wręcz burzyć, ma się jej przeciwstawiać. W związku z tym jego myśl, jeżeli nie odrzuca się jej jako nihilizmu, będzie się zwykle pozytywnie interpretowało w kontekstach charakterystycznych bardziej nawet dla filozofii europejskiej niż indyjskiej - z jednej strony w kontekście, który można by określić

${ }^{108}$ Chociaż Luis Gómez nie mówi o buddyjskim absolucie wprost, to obszeme odwołania do mistycznej narracji oraz zestawienia $z$ tradycją chrześcijańską sprawiają, że niektórzy badacze, czytając jego tekst, traktują ostateczną rzeczywistość poznawaną w sposób mistyczny jako rzeczywistość absolutu, zob. E. Fallick, Two Small Remnants of "Pre-Hinayanist” Buddhism in the Päli Nikayas, BSR 17/1 (2000), s. 38. 
sceptyczno-mistycznym, z drugiej zaś w kontekście krytyczno-analitycznym. Sprzyjanie którejś z tych wykładni w znacznym stopniu koreluje z kręgiem filozoficznym, z jakim związany pozostaje badacz. Uczeni anglosascy będą chcieli pokazać, że jest to myśliciel krytyczno-analityczny, uczeni z Europy Środkowo-Wschodniej będą zwracali uwagę na to, że był to myśliciel mistyczny, łączący ewentualnie sceptycyzm z mistycyzmem, czyli kroczący drogą apofazy i doświadczenia mistycznego. Obie te wykładnie uważam za fatalne dla interpretacji Nagardżuny i jestem przekonany, że filozofa tego należy czytać przede wszystkim w kontekście wczesnych tekstów buddyjskich, czyli w szczególności w kontekście owej postawy wyrażanej w tych tekstach względem wszelkich poglądów, w tym także poglądów prawdziwych.

Filozofię Nagardżuny można zwięźle podsumować w dwóch podstawowych tezach. Pierwsza głosi: „Wszystko jest puste” (sarvam śúnyam), co m.in. można przełożyć na twierdzenie: „Istnieć, to nie znaczy być w sobie określonym". Jest to całkowita desubstancjalizacja i deesencjalizacja istnienia, którą Nagardżuna w punkcie wyjścia neguje przekonania takich filozofów jak Platon, Arystoteles czy Husserl. W tezie drugiej zaś Nagardżuna odnosi się do tego, co faktycznie głosi, i na poziomie literalnego wysłowienia przyznaje się, że faktycznie nie głosi niczego. To słynne wyznanie buddyjskiego filozofa poczynione w VV 29 wzbudza ogromne kontrowersje. Brzmi ona następująco:

yadi kacana pratijña syän me tata eșa me bhaved doșaḅ | nāsti ca mama pratijña tasmān naivāsti me dọ̣ạ̣ \|

Gdybym głosił jakąs tezę (pratijñā), wtedy popełniałbym błąd. Jednakże nie posiadam żadnej własnej tezy, dlatego nie popełniam błędu.

Wypowiedź ta jest problematyczna w świetle pierwszego twierdzenia o pustce wszystkich rzeczy. Pogodzenie tych dwóch wypowiedzi, z których jedna głosi nieesencjonalność i niesubstancjalność rzeczy, druga zaś oznajmia, że Nagardżuna niczego nie głosi, stanowiło 
zawsze dużą trudność dla badaczy, jak też i dla późniejszych myślicieli buddyjskich, w tym także szkoły madhjamaki ${ }^{109}$.

Sądzę, że ważnej wskazówki do interpretacji tej deklaracji dostarcza uczeń Nagardzuny - Arjadewa, który w Czterystu strofach pisze (CŚ VIII, 7):

násünyam śūnya-vad drștam nirvānam me bhavatv iti $\mid$ mithya-drșter na nirvãnam vamayanti tathagatāạ $\|$

Niepustego (aśūnya) nie należy uważać za puste (śünya) [tylko z powodu pragnienia:] „Obym osiągnąt nirwanę". Tathagatowie głoszą, że nirwany nie [osiąga się] dzięki błędnemu poglądowi ${ }^{110}$.

Na pierwszy rzut oka wydaje się, że mamy poważny problem. Arjadewa jest uczniem Nagardzuny, który głosi: wszystko jest puste. Jak zatem rozumieć sformułowanie: „Niepustego nie należy uważać za puste" tylko dlatego, że pragnie się nirwany, czyli podejmuje się działanie powodowane pragnieniem jej osiągnięcia. Moje pragnienie

109 Zob. R. H. Robinson, Did Nagarjuna Really Refute All Pbilosopbical Views?, PEW 22 (1972), s. 325-331; D. S. Ruegg, Does the Madbyamika Have a Thesis and Pbilosophical Position?, [w:] Buddhist Logic and Epistemology. Studies in the Buddhist Analysis of Inference and Language, ed. B. K. Matilal, R. D. Evans, Dordrecht 1986, s. 229-237; I. Mabbett, Is There a Devadatta in the House? Nagarjuna's Vigrabavyavartani and the Liar Paradox, JIP 24 (1996), s. 295-320; J. L. Garfield, Emptiness and Positionlessness. Do the Mädbyamikas Relinquish All Views?, [w:] idem, Empty Words. Buddhist Philosopby and Cross-Cultural Interpretation, Oxford 2002, s. 46-68; J. Westerhoff, The No-Thesis View. Making Sense of Verse 29 of Nagarjuna's Vigrahavyāvartanī, [w:] Pointing at the Moon. Buddhism, Logic, Analytic Philosophy, ed. M. D'A mato, J. L. Garfield, T. J. F. Tillemans, Oxford 2009, s. 25-39.

110 Arjadewa nawiązuje do starego przekonania przypisywanego jeszcze Buddzie, a utrwalonego w sutcie Väsijațopama z SN III, 152-155 i powtórzonego w sutcie Bhavananuyutta z AN IV, 126-127, gdzie Budda stwierdza, że życzenie zajścia jakiegoś pozytywnego stanu (nielgnięcia, wyzwolenia) nie prowadzi do jego realizacji, gdyż można go uzyskać wyłącznie na drodze praktyki medytacyjnej. 
nie może decydować o tym, co głoszę jako prawdę. Ta wyprzedza owo pragnienie osiągnięcia nirwany. Głoszę, że wszystko jest puste nie dlatego, że pragnę nirwany, tylko dlatego, że to jest prawda. Arjadewa kończy słowami: „Tathagatowie głoszą, że nirwany nie [osiąga się] dzięki błędnemu poglądowi”. Musimy zapytać, gdzie tkwi błąd w stwierdzeniu, że wszystko jest puste z perspektywy filozofii, która głosi, że wszystko jest puste. Otóż błąd tkwi w postawie względem tego poglądu. Jeżeli lgnę do niego, jeżeli chwytam się go w sposób egotyczny, to nie osiągnę wyzwolenia.

Uczeń Nagardżuny podkreśla, że racją dla orzekania pustki, które to twierdzenie określa postawę madhjamaki, nie może być pragnienie osiągnięcia nirwany, czyli lgnięcie do myśli o nirwanie. Błędność poglądu w tym wypadku nie polega na niewłaściwej treści poglądu, tylko na niewłaściwym stosunku do skądinąd trafnego poglądu. Problemem zatem jest motywacja, a nie treść.

Co w związku z tym znaczy twierdzenie Nagardżuny, że nie głosi żadnego poglądu? Otóż nie głosić żadnej tezy, nie mieć poglądu, to nie znaczy wcale nie mieć niczego do powiedzenia, nie mieć żadnej propozycjonalnej treści do przekazania, jak to się często utrzymuje w zgodzie z przekonaniem, że Nagardżuna jest sceptykiem. Nie mieć poglądu to znaczy nie mieć do niego egotycznego stosunku. Nagardżuna przyznaje się, że nie żywi egotycznej postawy względem żadnego poglądu. Żaden nie jest jego, o żadnym nie może powiedzieć „mój” (mama), określając $\mathrm{w}$ ten sposób własną emocjonalną więź z jakimś przekonaniem. Nie twierdzi zaś, że żadnej propozycjonalnej treści dającej się dyskursywnie wyrazić w sądzie nie można przypisać wartości prawdy. On sam przecież uznaje za prawdziwy sąd o pustce.

Znamienne jest, że $w$ odniesieniu do rozumienia idei pustki $\mathrm{Na}-$ gardżuna przywołuje przypowieść o niewłaściwie chwytanym wężu, którą analizowaliśmy wcześniej. W MMK XXIV, 11 zauważa, że źle ujęta pustka niszczy jak źle uchwycony wą̇. Nie widzę powodu, aby uważać, że błąd w ujmowaniu pustki polega według Nagardżuny na wkładaniu w tę kategorię znaczeń temu filozofowi obcych. W przy- 
wołanej przypowieści nie chodziło bowiem o błąd, który pojawia sį̨ na poziomie semantycznym i polega na niezrozumieniu znaczenia idei czy sensu wypowiedzi. Błąd, o którym mówi Nagardżuna, polega na niezrozumieniu intencji stojącej za nauką o pustce. Problemem jest stosunek do koncepcji pustki, a nie semantyczna wartość twierdzenia o pustce rzeczy.

Postawę Nagardżuny wyraża stwierdzenie: nie mam poglądów, czyli nie lgnę. Jest ono radykalnie odmienne od: nie mam poglądów, dlatego nie lgnę. Nieposiadanie poglądów jest pochodne względem braku lgnięcia, a nie odwrotnie. Nagardżuna mówi: nie lgnę, dlatego nie posiadam własnych poglądów. Postawę tę należy zatem wyraźnie odróżnić od postawy sceptyka, który w zawieszeniu wszelkich poglądów widzi sposób na osiągnięcie spokoju umysłu, czyli w nomenklaturze buddyjskiej nielgnięcia.

Postawa Nagardżuny koresponduje z inną wypowiedzią z Dhammapady (DhP 97) gtoszącą, że przebudzony, czyli arahant (s. arbant), nie ma wierzeń (p. assaddba). Stwierdzenie to głosi, że przebudzony nie pozostaje $z$ żadnymi przekonaniami, z żadnymi poglądami $w$ relacji egotycznej, o żadnym poglądzie nie może powiedzieć „mój”. Nie oznacza to jednak, że przebudzony nie ma niczego prawdziwego do powiedzenia na temat rzeczywistości. Wszystko jednak co mówi, mówi w oparciu o widzenie rzeczy, jakimi one są, a nie w oparciu o mniemanie, przeświadczenie, zaufanie czy też wiarę, i co nie mniej ważne, a nawet najważniejsze, mówi kierowany intencją niesienia korzyści innym.

Zapewne wielu zada pytanie: czy istnieją wyraźne przesłanki, aby twierdzić, że Nagardżuna podąża za wcześniejszą tradycją, że wraca do wczesnej myśli buddyjskiej? Odpowiem na nie, przekształcając je: czy istnieją wystarczające przesłanki, aby twierdzić, że Nagardżuna nie podąża za wcześniejszą tradycją, czy potrafimy znaleźć świadectwa na to, że wytycza nowy szlak? Czy za taką przesłankę można uznać przyznanie się do nieposiadania żadnej tezy? Czy oznajmiając brak tezy, Nagardżuna zrywa $z$ wcześniejszą tradycją kładącą nacisk na range 
prawdy oraz prawdziwego poznania i przechodzi na pozycję radykalnego pirrońskiego sceptycyzmu?

Zanim zaczniemy wmawiać Nagardżunie sceptycyzm, warto zdać sobie sprawę, że najmocniejszą przesłanką dla tej interpretacji jest ta jedna strofa wypowiedziana w tekście ważnym, ale pomniejszym, dla którego punktem wyjścia jest obrona przekonania sformułowanego w MMK o pustce wszystkich rzeczy. Tylko jeden raz Nagardżuna przyznaje się w pierwszej osobie, że nie posiada żadnej tezy. Wyobraźmy sobie, że ta strofa się nie pojawiła. Czy wówczas równie ochoczo skłonni byśmy byli utrzymywać tę interpretację?

Najbardziej zagorzali zwolennicy interpretacji przypisującej twórcy madhjamaki sceptycyzm zapewne przywołaliby dwie strofy z MMK, w których wspomina się o leczeniu $z$ wszelkich poglądów (MMK XIII, 8) oraz porzucaniu wszelkich poglądów (MMK XXVII, 30). W wypadku pierwszym tym, co ma leczyć $z$ wszelkich poglądów, jest pustka, w wypadku drugim porzucenie wszelkich poglądów przedstawione jest jako cel ogłoszenia dobrej nauki. W obu wypadkach autorem owej dobroczynnej aktywności jest Budda. Stwierdzenie, że nie posiada on żadnych poglądów oraz że jego aktywność motywowana jest ich porzuceniem nie jest niczym nowym, zakorzenione jest we wczesnej tradycji i znajduje tam swoje uzasadnienie, jak to pokazywałem, przywołując strofy Suttanipaty. Gdyby Nagardżuna poprzestał na tych wypowiedziach, powtórzyłby coś, co było dobrze znane. $\mathrm{Za}$ jedyne novum $\mathrm{w}$ jego słowach należałoby uznać położenie silnego nacisku w nauczaniu Buddy na idę̧ pustki. Tym zatem, co prowokuje do interpretacji madhjamaki w duchu sceptycyzmu, jest fakt, iż Nagardżuna, po pierwsze, wypowiedź swoją sformułował w pierwszej osobie, a po drugie obudował ją krytyką kryteriów poznawczych. Nie wystarcza to jednak, aby uzasadnić tę interpretację. Wypowiadając się w pierwszej osobie, Nagardżuna wypowiedział się z pozycji przebudzonego. Widzi on pustkę rzeczy, nie lgnie do nich i w związku $\mathrm{z}$ tym nie posiada żadnego poglądu. Żadne jego twierdzenie nie jest oparte na domniemaniu, zaufaniu czy nawet wnioskowaniu. Możemy 
kwestionować, czy Nagardżuna był przebudzony, jest to jednak problem historyczny, a nie epistemologiczny. Rozwijając zaś krytykę kryteriów, Nagardżuna podważa przekonanie o ich szczególnym ontycznym statusie, a nie ich wartość epistemologiczną, tę bowiem uznawał, ale tylko w ramach codziennego doświadczenia i z tego powodu nie miały dla niego wielkiego znaczenia.

Wyraźne echo stów Suttanipaty pobrzmiewa także w strofie VV 30:

yadi kimcid upalabbeyam pravartayeyam nivartayeyam vā pratyaksādibbir arthais tad abbavān me 'nupalambhab ॥

Gdybym coś uchwytywał dzięki percepcji itd., wówczas stwierdzałbym to lub temu przeczył. Ponieważ jednak te rzeczy [tzn. kryteria poznawcze i przedmioty poznania] nie istnieją, krytyka ta nie odnosi się do mnie.

Czyż twórca madhjamaki nie stara się tutaj powiedzieć, że ponieważ pozostaje poza poglądami, jako że $w$ relacji do żadnego nie tworzy egotycznego stosunku, wspierając się czy to o postrzeganie, czy o wnioskowanie, czy o inne kryterium poznawcze, to nie wchodzi w żaden spór? Nawiązuje w ten sposób bezpośrednio do wczesnej buddyjskiej teorii postrzegania i spekulatywnego myślenia, która myślenie zakotwicza w postrzeganiu. Klasyczny opis, który już przywoływałem, znajdziemy w MN I, 111-112, gdzie właśnie Mahakaczczana, adresat jedynego przywoływanego przez Nagardżunę kazania, objaśnia naukę Buddy: „W zależności od oka i formy materialnej powstaje świadomość widzenia; spotkanie tych trzech to kontakt; uwarunkowane kontaktem jest uczucie; co ktoś czuje, to postrzega; co ktoś postrzega, o tym myśli; o czym ktoś myśli, o tym spekuluje; o czym ktoś spekuluje, to jest podstawą, na której postrzeżenia i pojęcia skażone spekulacją osaczają człowieka odnośnie przeszłych, teraźniejszych i przyszłych form poznawalnych okiem".

Również w poniższej wypowiedzi Nagardżuny pochodzącej z Ratnawali (RV II, 4), możemy wyraźnie usłyszeć echo nauki z Suttanipaty: 
drșta-śrutadyam muninā na satyam na mrșoditam | pakșäd dhi pratipakșạ̣ syād ubhayam tac ca nārthatab ॥

Mędrzec stwierdził, że to, co jest widziane, słyszane itd. nie jest ani prawdziwe, ani fałszywe. Jeśli istnieje teza, to istnieje antyteza, obie jednak są nierealne.

Dla istoty nieprzebudzonej orzekanie prawdy bądź fałszu o tym, czego się doświadcza, jest wyrazem błędu polegającego na przedstawianiu sobie tego, czego się doświadcza, w relacji do „ja”. Nie ma asercji bez negacji. Jeżeli głoszę jakiś pogląd, to jest on ze swej natury uwikłany $\mathbf{w}$ zaprzeczenie, a tym samym w spór. Z perspektywy Buddy, który widzi, jak pamiętamy, formę jako formę itd., asercja i negacja będące ekspresją „ja" nie mają żadnej wartości, a tym samym są nierealne. $Z$ perspektywy tego, który żywi poglądy, widzenie Buddy jest niewidzeniem, gdyż niczego nie uchwytuje on jako jakieś. Doskonale to potwierdza poniższy cytat z Aszty. W AS 137 czytamy:

subbūtir aba - katbam bhagavan rūpasyādrștata bhavati? katham vedanāyāb samjñāyạ samskārānām? katham bhagavan vijñanasyadrștatā bhavati? bhagavān aba - yadi subbüte na rūparambanam vijñanam utpadyate, evam rüpasyadrștata bbavati | evam vedanā samjñ̄a samskārāḅ | yadi subbūte na vijñānärambanam vijñānam utpadyate, evam vijñanasyädrștatā bhavati | ya ca subbūte rüpasyadrștatāa, ya ca vedanāyāḅ

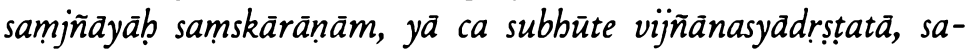
iva lokasya drștatā bhavati | evam bi subbüte lokas tathägatena drsțo bhavati $\mid$

Subhuti: Jak, Czcigodny, powstaje stan niewidzenia formy? [Analogiczne pytanie $\mathbf{w}$ odniesieniu do pozostałych zespołów.]

Czcigodny odparł: Gdy powstaje świadomość nie mająca podstawy w formie, wówczas zachodzi stan niewidzenia formy. [Analogiczna odpowiedź w odniesieniu do pozostałych zespołów.] Owo niewidzenie formy i pozostałych zespołów, 
jest widzeniem świata. W ten sposób, Subhuti, świat widzą tathagatowie.

Dokładnie to samo oznajmia Nagardżuna. Gdybym coś zmysłowo uchwytywał, czyli gdybym ujmował coś jako przedstawienie własnego „ja", wówczas orzekałbym o tym twierdząco bądź przecząco. Ja jednak niczego w ten sposób nie widzę, podkreśla twórca madhjamaki, czyli nie widzę niczego za sprawą kryteriów poznawczych, gdyż są to konwencjonalne instrumenty poznania, funkcjonujące w obszarze błędu poznawczego, czyli w obszarze perspektywy egotycznej. $\mathrm{Z}$ perspektywy owych instrumentów poznawczych, niczego nie wskazuję, nie mówię niczego, co domagałoby się zrozumienia. Jeśli tak zinterpretujemy stwierdzenia Nagardżuny, a sądzę, że mamy wszelkie ku temu przesłanki, to okaże się, że jego wypowiedź współbrzmi z poniższymi słowami zaczerpniętymi z Aszty (AS 19), włożonymi w usta Subhutiego:

na vijñāyate na vijñāyate idam devaputrāḅ | tathä bi nātra kimcit sūcyate, nätra kiṃcit śrūyate \|

Nie ma tu, bogowie, niczego do zrozumienia, zupełnie niczego. Albowiem nic nie zostało tu wskazane, nic nie zostało tu stwierdzone.

Poniższa strofa pochodząca z Ratny mogłaby posłużyć Nagardżunie za motto określające jego postawę. W RGS XXII, 7 oznajmia się:

yatha udgrabo tatba prakásitu samkileśo vyodāna ukta abu mabya anopalabdbi

na bi atra kaści yo kliśyati sudbyate vã prajñãya pāramita budbyati bodbisattve II

Gdy zwraca się uwage [tj. gdy się chwyta], wówczas ujawnia się splamienie. Niepostrzeganie [tj. niechwytanie się] " $\mathrm{Ja}^{\text {" }}$ i "moje" zwie się oczyszczeniem. Doprawdy nie ma tutaj nikogo, kto podlegałby splamieniu lub oczyszczeniu. Doskonałość mądrości budzi się w bodhisattwie, [gdy to pojmie]. 
Doskonałe objaśnienie epistemologicznej pozycji madhjamaki daje Czandrakirti w PP 57. Wybitny komentator stawia tam kwestię: jaki jest poznawczy status twierdzenia, że rzeczy nie powstają dzięki sobie, dzięki czemuś innemu, dzięki obu możliwościom łącznie i całkowicie bez przyczyny? W odpowiedzi zauważa, że to twierdzenie zostało sformułowane na potrzeby zwykłego człowieka w oparciu o podzielane przez niego przekonania, czyli ma status wypowiedzi konwencjonalnej. Jego sens zakotwiczony jest w przekonaniach będących wyrazem błędu poznawczego. Dla Buddy natomiast, zauważa Czandrakirti, nie ma żadnej wartości. Innymi słowy, poza tymi przekonaniami, poza tym błędnym sposobem ujmowania twierdzenie to nie ma sensu. Pojawia się więc kolejne pytanie o to, czy dla mędrca, czyli przebudzonego, nie istnieją żadne racjonalne argumenty. Na tę wątpliwość madhjamik odpowiada pytaniem: jak w ogóle możemy stwierdzić, czy istnieją, czy nie istnieją? Dokładnie tę samą wątpliwość wyraził Budda odnośnie do orzekania statusu Tathagaty po śmierci. Wszelkie orzekanie istnienia, pamiętamy, ma wartość tylko w obszarze sansarycznego doświadczenia. Wyzwolenie polega na unieważnieniu tego ostatniego, a tym samym ukonstytuowanego na nim języka orzekającego istnienie i nieistnienie. Dlatego Czandrakirti oznajmia: „To, co ostateczne, jest milczeniem szlachetnych" (paramārtho by āryānām tūṣinim-bhāvaḅ). Jaką wartość ma dla niego codzienny język, bez względu na to czy rozumny, czy nierozumny?

Ponieważ Nagardżuna niczego nie chwyta, nie można wymierzyć w niego żadnej krytyki, gdyż nie posiada żadnych poglądów, w których ujmuje rzeczy jako jakieś. Powtórzmy jeszcze raz za Suttanipata (Sn. 787):

Z tymi, którzy nie angażują się $\mathrm{w}$ dyskusję, nie sposób sį̨ spierać. Tacy bowiem niczego nie przyjmują ani nie odrzucają, wyzbyli się wszelkich poglądów.

W identycznym tonie twórca madhjamaki wypowiedział się w Sześ́́dziesięciu strofacb rozumowania (YṢ 50): 
| che ba'i bdag nyid can de dag || rnams la pbyogs med rtsod pa med I

| gang rnams la ni pbyogs med pa || de la gzban pbyogs ga la yod 1

Dla wielkich istot nie istnieje teza (t. phyogs, s. paksa) ani spór (t. rtsod pa, s. viväda). Jak może istnieć przeciwna teza (t. gzban pbyogs, s. para-pakșa) dla tych, którzy nie posiadają tezy?

Przekonanie o tym, że istoty, które przekroczyły sansarę, funkcjonują w odmienny sposób od tych, których działanie naznaczone jest błędem, od momentu powstania czwartego rozdziału Suttanipaty powtarzane było często. Jest to też motyw wyraźnie obecny w Ratnie. W RGS XVII, 6 zauważa się, że bodhisattwowie są „wolni od kłótni i sporów" (kalabā-vivāda-vigatā), a w RGS XXIV, 3 podkreśla się, że bodhisattwa, który uczestniczy w kłótniach i sporach, jest odległy od poznania. Opinia Nagardżuny w tej kwestii zgodna jest z wcześniejszą tradycją sięgającą Attbakawaggi. Było to przekonanie istotne takze dla Czandrakirtiego. W pierwszej części tej książki przytoczyłem strofę pochodzącą z Samadbiradżasutry (IX, 35), którą wybitny komentator w Prasannapadzie przywołał dwukrotnie. Strofa ta jest ważna, gdyz w jednoznaczny sposób wiąże spór z zagadnieniem istnienia. Przypomnijmy zatem (PP 135 i 270):

astīti nastīti vivāda eṣaḅ śuddhī aśuddbìti ayam vivādạ̣ | vivādaprāptyā na duḅkbam praśāmyati avivädaprāptyā ca dubkbam nirudbyate $\|$

"Istnienie” i „nieistnienie” tworzą spór. "Czystość” i „nieczystość" tworzą spór. Gdy się tkwi w sporze, cierpienie nie może zostać wyciszone. Gdy się nie tkwi w sporze, cierpienie zostaje usunięte.

Nagardżuna, a za nim wielu przedstawicieli madhjamaki, wpisuje się w tę postawę. Piszę „wielu”, a nie „wszyscy”, gdyż mam wątpli- 
wości, czy faktycznie wszyscy madhjamikowie dochowali wierności tej deklaracji. Klasycznym problemem dotyczącym wewnętrznego zróżnicowania indyjskiej madhjamaki dyskutowanym w Tybecie oraz współcześnie przez badaczy jest różnica między jej formami nazywanymi swatantriką (svātantrika) i prasangiką (präsañgika). Odnoszę nieodparte wrażenie, że różnica ta sięga Kazania do Kosambijczyków (Kosambiya-sutta; MN I, 320-325). Przedstawiciele obu wykładni madhjamaki głoszą, że ostatecznie rzeczy są puste. Jednak swatantrikowie utrzymują, że owego sądu o pustce rzeczy można i należy bronić przy pomocy metod rozumowania i argumentowania, które znajdują się w powszechnym użyciu. Zdają się oni przypominać tych mnichów z Kosambi, którzy uważali za stosowne angażować się w spory o prawdę. Prasangikowie natomiast, z Czandrakirtim na czele, podążają za intencją Buddy, oni tylko powiadamiają, aby ukierunkować innych na zobaczenie. Nie są zainteresowani obroną prawdy rozumianą jako zgodność sądu z rzeczywistością, gdyż ostatecznie o istnieniu żadnej rzeczywistości poza samym doświadczeniem nie sposób sensownie mówic ${ }^{111}$.

Postawę Nagardżuny i prasangików dobrze opisuje poniższa strofa z Ratny (RGS XXV, 1):

yo śikșamạnu na upaiti kabiṃci śikșạm na ca śikșakam labbati näpi ca śikșa-dbarmān |

sikșa aśikṣa ubbayo avikalpamano yo sikșate sa iba sikșati buddha-dbarme $\|$

Kto wprawia się w nauce i nie podejmuje żadnej nauki, nie chwyta się nauczyciela ani [wyobrażeń o] jakościach/wartościach nauki, kto wprawia się $w$ nauce, nie rozróżniając obu, tj. nauki i nie-nauki, ten oto wprawia się $w$ dharmie Buddy.

111 Zob. na ten temat doskonały zbiór tekstów: The Svatantrika-Präsangika Distinction. What Difference Does a Difference Make?, ed. G. B. J. Dreyfus, S. L. McClintock, Boston 2003. 
Ten, kto w ten sposób wprawia się w nauce, nie ma niczego do powiedzenia od siebie, ktoś taki nie zajmuje żadnego stanowiska, gdyż rozumie, że ostatecznie nie ma żadnego, które mogłoby być zajęte, ani też nikogo, kto mógtby zająć jakiekolwiek. Jego postawę opisuje stwierdzenie z RGS II, 3: „Stanowisko bez stanowiska Zwycięzca nazwał stanowiskiem" (astbānu stbānu ayu stbānu jinena ukto).

Niektórym badaczom ten charakterystyczny dla Buddy i madhjamików brak stanowiska kojarzy się ze sceptycyzmem tak bardzo, iż nie wnikając w specyfikę buddyjskiej myśli, ustawiają ją pochopnie na jednej półce wraz z greckim sceptycyzmem. Dla takiego podejścia znamienne są słowa Thomasa McEvilleya. Pisze on:

Ogólna postawa wobec życia madhjamików i pirronistów była podobna, niemal wręcz identyczna; dialektyka leżąca u podłoża tej postawy była podobna, niemal wręcz identyczna; oraz cel, dla realizacji którego przybrano ową postawę i praktykowano ową dialektykę, był podobny, niemal wręcz identyczny $^{112}$.

Żeby nie powtarzać myśli, które wypowiadałem już w tej części książki, odniosę się do powyższego stwierdzenia, oddając po raz kolejny głos Czandrakirtiemu. Broniąc madhjamaki przed zarzutem nihilizmu, wybitny komentator opowiedział wielce pouczającą historyjkę, którą tu przytocz $\xi^{113}$. Wyobraźmy sobie - pisze madhjamik - nastę-

112 Th. McEvilley, op. cit., s. 491: The overall stance toward life of Madbyamikas and Pyrrbonists was similar, indeed nearly identical; the dialectic which supported this stance was similar, indeed nearly identical; and the purpose for which this stance was adopted and this dialectic practiced was similar, indeed nearly identical. Por. A. Kuzminski, Pyrrbonism and the Madbyamaka, PEW 57/4 (2007), s. 482-511 oraz ide m, Pyrrbonism. How the Ancient Greeks Reinvented Buddhism, Lanham 2008; zob. także B. K. Matilal, Perception..., s. 46-57; Sh. Biderman, Scepticism and Religion. On the Interpretation of Nagarjuna, [w: Indian Pbilosopby of Religion, ed. R. W. Perrett, Dordrecht-BostonLondon 1989, s. 61-74.

113 Zob. PP 368-369. 
pującą sytuację. Pewien człowiek popełnił ciężką zbrodnię. Przeciwko niemu występuje dwóch świadków. Jeden, który nie miał pewności, kto tę zbrodnię faktycznie popełnit, ale ulegt namowie człowieka wrogiego owemu domniemanemu zbrodniarzowi i świadczy przeciwko niemu. Drugi, który widział zbrodniarza i ma pewność, że się nie myli. Obaj świadkowie zeznają to samo, trafnie wskazując zbrodniarza. W trakcie rozprawy jednak wychodzi na jaw, że pierwszy świadek go nie widział. Skutek jest taki, że spotyka go zarzut nikczemności i krzywoprzysięstwa.

Jaki płynie $z$ tej opowiastki morał? Otóż taki, że chociaż w sensie semantycznym obaj mówią to samo, to jeden z nich mówi prawdę, gdyż mówi zgodnie z tym, co zobaczył, podczas gdy drugi kłamie, gdyż nie widział tego, o czym mówi, a zatem mówi w oparciu o pobudki niepozostające w zgodzie z tym, jakie rzeczy są. Innymi słowy, gdy madhjamik oznajmia, że rzeczy nie istnieją, to znaczy to dla niego coś całkiem innego niż dla nihilisty głoszącego nieistnienie bytu, czyli w konsekwencji bezsensowność wszelkiego działania. Tak samo, gdy madhjamik przyznaje się, że niczego nie poznaje, to oświadcza coś całkiem innego niż mówiący to samo sceptyk. Pierwszy, poznawszy naturę rzeczy, ogłasza, że nie ma nic do poznania (w sensie realistycznym), drugi natomiast stwierdza tylko tyle, że niczego poznać nie chce.

Przypowieścią tą Czandrakirti nawiązuje do uwagi dobrze w tradycji buddyjskiej zakorzenionej i utrwalonej w Kazaniu o tym, co bezsporne (Apannaka-sutta; MN I, 400-413), aczkolwiek sytuacja przedstawiona w kazaniu jest nieco ciekawsza i bogatsza w znaczenie. W kazaniu tym Budda opowiada o cnotliwych ascetach i braminach, którzy pozostają ze sobą w sporze, głosząc przeciwne poglądy (MN I, 411). Jedni twierdzą: „z całą pewnością istnieje ustanie bytowania” (atthi sabbaso bbava-nirodho), czyli nirwana, inni zaś utrzymują: „z całą pewnością nie istnieje ustanie bytowania" (natthi sabbaso bbava-nirodbo). Budda nie opowiada się po stronie tych, którzy głoszą, że nie istnieje ustanie bytowania, gdyż, jak zauważa, „tego nie zobaczył [dost. to nie było 
przez niego widziane]" (idam me adițtham). Paradoksalnie, nie opowiada się też po stronie tych, którzy głoszą, że istnieje ustanie bytowania, gdyż, jak oznajmia, "tego nie poznałem” (idam me aviditam). Następnie zauważa:

abañc' eva kho pana ajānanto apassanto ekamsena ädāya vohareyyam: idam eva saccam moghamañnanti, na me tam assa patirūpam.

Gdybym teraz, nie poznawszy i nie zobaczywszy, opowiedział się po jednej stronie i gtosit: „tylko to jest prawdą, [wszystko] inne jest głupie", nie byłoby to dla mnie właściwe.

Tym, co dla Buddy właściwe (patirūpa), jest wypowiadanie się z pozycji poznania i widzenia faktycznego stanu rzeczy, a nie domniemywania istnienia i nieistnienia. Widzenie i poznanie Buddy nie jest widzeniem i poznaniem istnienia i nieistnienia. Jego widzenie i poznanie obie te kategorie unieważnia.

Wspomniałem, iż opowieść ta jest bogatsza w znaczenie, gdyż sama sytuacja jest bardziej złożona i ma też ona swoją kontynuację. Budda przyznaje bowiem, iż chociaż nie zgadza się z żadną ze stron, to istnieje między nimi pewna ważna różnica. Otóż stanowisko tych, którzy przeczą istnieniu nirwany, naznaczone jest żądzą (sārāga), uwiązaniem (samyoga), znajdywaniem upodobania (abbinandana), przywiązaniem (ajjhosāna) i lgnięciem (upädāna). Podczas gdy stanowisko drugich bliskie jest wyzbycia się żądzy, nieuwiązania, nieznajdywania upodobania, nieprzywiązania i nielgnięcia. „Bliskie” jednak nie znaczy „tożsame", tak jak postawa buddysty nie jest tożsama z postawą Buddy.

Nagardżuna nie był rewolucjonistą. Wręcz przekonany jestem, iz świadomie dbał o to, aby takiego zarzutu uniknąć. Dlatego w swoich tekstach przywołuje tylko wczesne, dobrze w tradycji zakorzenione metafory, a $z$ tytułu tylko jeden wczesny tekst - Katjajanawawade, którą, sądząc po przywoływanej treści, należy utożsamić z Katjajanasutrą (NidSa 19; SĀ 301), a w wersji palijskiej (przy uwzględnieniu zastrzeżeń, jakie miałem w pierwszej części książki) z Kaczczajanagot- 
tasutta (SN II, 16). Po drugie zaś należy podkreślić, że nie przywołuje Aszty, która w jego czasach była już tekstem znanym i popularnym, o czym może świadczyć data jej przekładu na chiński, i która mogłaby stanowić doskonałe źródło odniesień dla uprawomocnienia jego myśli. Status tego tekstu był jednak lokalny, jego przywoływanie narażało go na zarzut nieuprawnionej reinterpretacji myśli Buddy. Spostrzeżenia te wzięte łącznie wiążą Nagardżunę $\mathrm{z}$ wczesną tradycją, każąc patrzeć na niego jako na jej rzecznika i obrońcę, który przeciwstawia się dominującej w owym czasie naznaczonej skłonnością do petryfikacji doświadczenia tradycji abhidharmy. Kilka wieków później nie był to już jednak problem i Czandrakirti mógt korzystać z całego spektrum tekstów mahajanistycznych.

Kojarzenie madhjamaki ze sceptycyzmem jest konsekwencją czytania tekstów Nagardżuny w oderwaniu od tekstów wczesnej tradycji. Podejście to było szeroko rozpowszechnione i znajdowało swoje uprawomocnienie $w$ przekonaniu wiążącym twórcę madhjamaki z tradycją mahajany, a tę przeciwstawiało tzw. hinajanie pod względem zarówno ideału soteriologicznego, jak też i ogólnych przekonań ontologicznych. Przeświadczenie, iż abhidharma zarówno w warstwie merytorycznej, jak i z powodów chronologicznych, a może właśnie gtównie z powodów chronologicznych, jest najbardziej naturalną i reprezentatywną wykładnią myśli Buddy, dawało podstawy do traktowania nauki o pustce wszystkich rzeczy jako przewrotu dokonanego u samych źródeł buddyjskich intuicji. Dla autora tej pracy przeświadczenie to jest jedną z największych metodologicznych pomyłek, jakie zostały popełnione $\mathrm{w}$ interpretowaniu historii buddyjskich idei. Tak jak idę̨ pustki wszystkiego należy lokować w kontekście nauki Buddy o porzuceniu istnienia i nieistnienia, tak też deklarację nieposiadania poglądów należy rozpatrywać w kontekście jego nauki o porzuceniu prawdy i fałszu. Oglądana z tej perspektywy krytyka kryteriów poznawczych nie ma nic wspólnego z neopirrońską krytyką możliwości poznania. Są one względem siebie po prostu niewspółmierne. 
Fakt ten do pewnego stopnia uświadomił sobie Ethan Mills, który określa refleksję Nagardżuny mianem metafilozoficznego sceptycy$\mathrm{zmu}^{114}$. Piszę „do pewnego stopnia” właśnie ze względu na to, iż nie wyzwolił się od samego stosowania miana sceptycyzmu. Termin ten użyty w tym kontekście jest mylący ze względu na jego historyczne obciążenie. Określa on bowiem zasadniczo przekonanie odnośnie do możliwości uzyskania pewności poznawczej w kwestii prawdy wyrażonej w sądzie.

Twierdzę, że Nagardżuna nie przeczy możliwości uzyskania poznania prawdziwego i to w podwójnym sensie. Akceptuje on możliwość uzyskania pewności poznawczej w obszarze zarówno doświadczenia codziennego, jak też i poznania wyzwalającego, tyle tylko, że w obu wypadkach charakter tej pewności i jej doniosłość ma różną naturę. Temu, czemu Nagardżuna się przeciwstawia, jest przekonanie, że poznanie uzyskane $\mathrm{w}$ obszarze codziennego doświadczenia ma cokolwiek wspólnego z poznaniem wyzwalającym. Są to dwa różne i catkowicie nieprzekładalne porządki poznawcze. Czytelnikom Vigraba-vyavartanī będącym po pierwszej lekturze tego dzieła stwierdzenie, iż Nagardżuna nie przeczy możliwości orzekania prawdy w obszarze codziennego doświadczenia, może wydawać się zaskakujące w świetle dokonanej tam radykalnej krytyki kryteriów poznawczych ${ }^{115}$. Dlatego w kilku słowach wskażę podstawy tego przekonania.

Określając sens przeprowadzonej krytyki kryteriów poznawczych, twórca madhjamaki stwierdził w VV 64:

yac caharte vacanad asatạ pratisedha-vacana-siddhir iti $\mid$ atra jñapayate väg asad iti tan na pratinibanti $\|$

114 E. Mills, Three Pillars of Skepticism..., rozdz. 2-3. Por. takie S. Gandolfo, The Positionless Middle Way. Weak Pbilosophical Deflationism in Madbyamaka, JIP 44 (2016), s. 207-228.

115 Zwięźle na temat owej krytyki zob. K. Jakubczak, Madbjamaka Nagardżuny. Filozofia czy terapia?, Kraków 2010, s. 200. 
Co się tyczy twego oświadczenia, że „stwierdzenie negacji tego, co nie istnieje, zostaje wykazane bez słów". W tym przypadku mowa powiadamia (jñāpayate) o nieistnieniu [rzeczy], nie niszczy (pratinibantı) jej [jednak, tzn. nie unicestwia jej].

Pozostawiając na boku samo podejrzenie o to, że mowa mogłaby niszczyć obecność jakiegoś przedmiotu, widzimy wyraźnie, iż Nagardżuna akceptuje możliwość orzekania prawdy w obszarze codziennego doświadczenia. Taki bowiem jest sens stwierdzenia, że mowa powiadamia (jñapayate) o nieistnieniu danego przedmiotu. Możliwe jest zatem orzeczenie sądu zgodnie ze stanem faktycznym. Problemem jest rozumienie owego stanu faktycznego, a nie możliwości orzekania. W tym wypadku jest nim nasze codzienne doświadczenie czy też może lepiej byłoby powiedzieć, ze jest nim stan rzeczy taki, jaki jawi się w naszym codziennym doświadczeniu. W obszarze naszego codziennego doświadczenia jawi nam się np. nieobecność Dewadatty w pomieszczeniu albo obecność w tym samym pomieszczeniu stołu. Nagardzuna nie przeczy możliwości orzeczenia tego stanu w zgodzie z tym, co nam się jawi. Na tym właśnie polega powiadamiająca funkcja mowy. Tym, co Nagardzuna odrzuca, jest przekonanie głoszące, że przy pomocy owych codziennych środków poznawczych jesteśmy w stanie uzyskać sukces soteryczny, czyli spojrzeć na codzienne doświadczenie z zewnątrz, dostrzegając jego uwarunkowania, i w ten sposób się z nich wyzwolić. Codzienne środki poznawcze wystarczają tylko do tego, żeby owocnie poruszać się w obszarze codzienności, czyli żeby z wieżowca wychodzić drzwiami, a nie oknem. Owa codzienność jednak naznaczona jest cierpieniem i tego stanu rzeczy przy pomocy owych codziennych środków poznawczych zmienić nie możemy. Taki jest sens krytyki kryteriów poznawczych. Jeżeli chcemy osiągnąć sukces soteryczny, musimy wyjść w poznaniu poza perspektywę codziennego doświadczenia. Że jest to możliwe i na czym polega owo wyjście, o tym Nagardżuna nauczał w swoim głównym dziele, czyli w Podstawowych strofach madbjamaki. Krótko zatem. Uważam, 
że określanie madhjamaki metafilozoficznym sceptycyzmem więcej zaciemnia, niż rozjaśnia.

\subsection{Dlaczego buddyzm nie ma nic wspólnego ze sceptycyzmem?}

Dla buddyzmu, którego najwcześniejsza postać wyraziła się w Suttanipacie, a późniejsza $\mathrm{w}$ madhjamace, problemem, z jakim musimy się zmierzyć i uporać, jest nasz egotyzm, przejawiający się na różne sposoby we wszystkich sferach naszego istnienia, w tym także w sferze poznawczej, a nie pytanie o to, czy możliwe jest poznanie prawdziwe. Stąd pogląd w rozumieniu buddyjskim to nie jest po prostu sąd wyrażający propozycjonalną treść, lecz sąd wyrażający propozycjonalną treść, wobec którego zajmuje się afektywną, czyli egotyczną postawę. $\mathrm{Z}$ buddyjskiej perspektywy pogląd to sąd, którego wartość domniemujemy. Ten sam co do treści sąd, który jest ekspresją widzenia rzeczy, jakimi są, poglądem już nie jest. Inaczej mówiąc, w myśli buddyjskiej pojęcie poglądu nie jest formułowane wyłącznie w kontekście epistemologicznym, lecz także, a może nawet przede wszystkim, w kontekście psychologiczno-terapeutycznym, czyli soteriologicznym. Dla istoty sansarycznej sąd, czyli pewna treść umysłowa, tak jak każdy inny przedmiot doświadczenia, w tym zwłaszcza zmysłowego, zawsze jest i musi być przedmiotem afektywnego odniesienia, zawsze napiętnowany jest emocjonalnym stosunkiem (vedanā), nawet jeżeli jest to sąd prawdziwy. Zatem pogląd to jest sąd, wobec którego człowiek nie może nie zająć emocjonalnego stosunku, który wyraża się na jeden $\mathrm{z}$ trzech sposobów wyrażania się wedany - przyjemności, przykrości i obojętności.

Dlatego DhP 79cd, dając charakterystykę uczonego mędrca (pandita), czyli tego, który dopiero dąíy do wyzwolenia, zaznacza, że w jego wypadku stosunek do nauki Buddy określa uczucie zachwytu: „mędrzec zawsze znajduje upodobanie w nauce głoszonej przez Szla- 
chetnego" (ariyappavedite dhamme sadà ramati pandito). Pogląd zatem to jest sąd, wobec którego sansaryczna istota właśnie ze względu na swoją sansaryczną konstytucję skazana jest na odniesienie emocjonalne, czyli takie, w którym wyraża się jej egotyzm - i właśnie takich poglądów wyzwolony nie posiada. Brak poglądów to brak egotycznego odniesienia do jakichkolwiek sądów. Budda nie odrzuca poglądów z powodu trudności z określeniem ich epistemicznej wartości. Odrzuca on poglądy, ponieważ ich posiadanie czy żywienie jest dla niego formą lgnięcia, czyli jest szkodliwą postawą umysłu generującą cierpienie.

Ponieważ z perspektywy buddyjskiej poglądem nie jest po prostu sąd na temat rzeczywistości, lecz sąd, którego prawdziwość jest domniemywana, dlatego gdy Budda wypowiada sąd na temat rzeczywistości, to nie głosi poglądu, gdyż nie domniemuje prawdziwości owego sądu, on daje tylko ekspresję swojego widzenia rzeczy, jakimi one są. Ten sam sąd dla nie-buddów będzie już jednak poglądem, gdyż oni mogą dopóty, dopóki nie są buddami, tylko domniemywać wartość tego sądu, czyli jego prawdziwość bądź fałszywość.

Zatem lgnięcie do poglądu jest formą wyrażania się „ja". "Ja" wyraża się poprzez pogląd, konstytuuje sį w tymże. Taki jest sens przypowieści o ślepcach i słoniu. Chodzi w niej w pierwszym rzędzie nie o to, że poznanie istot sansarycznych jest cząstkowe, niepełne, lecz o to, że jest egotyczne. Dodajmy, że póki są istotami sansaryczny$\mathrm{mi}$, to ich poznanie nie może nie być egotyczne. Zatem „niegłoszenie poglądów" jest określeniem z poziomu nie epistemologicznego, lecz psychologicznego czy może kognitywistycznego. Gdy Budda mówi, jakie rzeczy są, to nie głosi żadnego poglądu, gdyż mówi z perspektywy widzenia, z perspektywy, w której jest tylko widzenie i to, co widziane, nie ma jednak żadnego widzącego. Zatem nie ma żadnego domniemania prawdy. W kontekście buddyjskim głoszenie jakiegoś poglądu to sposób wyrażania domniemania prawdy danej jakiemuś „ja”, zatem prawdy egotycznej. Wypowiedzi Buddy są asercjami w sensie semantycznym, nie są jednak poglądami w buddyjskim rozumieniu 
tego terminu. Dopóki wyraźnie sobie tego nie uświadomimy, dopóty będziemy powtarzać bajki o buddyjskim sceptycyzmie.

$\mathrm{Na}$ kwestię nieposiadania poglądów przez buddów w Suttanipacie należy patrzeć dokładnie tak samo, jak na kwestię daru w sutrach mądrości. W obu wypadkach mamy dokładnie tę samą intuicję. Sutra diamentowa oznajmia, że bodhisattwą można nazwać tylko tego, kto uświadamia sobie, że w sytuacji darowania nie ma dającego, obdarowywanego i daru. Tego, kto wspiera się na wyobrażeniu dającego, obdarowywanego i daru, nie można nazwać bodhisattwą ${ }^{116}$. Na tej samej zasadzie Suttanipata stwierdza, że buddowie nie posiadają poglądów. Dla buddy nie ma bowiem tego, kto głosi pogląd, komu głoszony jest pogląd oraz nie ma samego poglądu jako tego, co jest gtoszone, czyli jako integralnej treści wyrażonej w zwartej wypowiedzi, do której budda miałby egotyczny stosunek. Budda nie głosi poglądów, tylko daje adekwatną ekspresję swojego poznania i widzenia. Daje ekspresję w sytuacji nauczania. Poza tą sytuacją budda wewnętrznie milczy, gdyż nie spekuluje, nie rozważa, nie wyobraża sobie, nie przedstawia sobie - on wie i widzi, i dlatego jest poza sporem.

$\mathrm{Ci}$, którzy wchodzą w dyskusję wsparci o prawdę, są jak ci, którzy składają śluby bodhisattwy, wierząc, że mają komu pomagać, że mają coś, co mogą komuś ofiarować, zatem zakotwiczeni są w pojęciu „ja”. Oni wspierają się o prawdziwe poglądy, ale nie są buddami, gdyż mają egotyczne odniesienie do treści w tych poglądach zawartych - znajdują w nich zachwyt, wierzą, że są prawdziwe, gdyż wypowiedziane przez buddę, dowodzą, że są prawdziwe, gdyż przekazane przez buddę. Nie są zatem buddami, gdyż jeszcze w sposób nieegotyczny nie poznali i nie zobaczyli. Jeżeli filozofia to umiłowanie mądrości, dążenie do mądrości, poszukiwanie mądrości, to należy powiedzieć, że nauka buddów filozofią nie jest ${ }^{117}$, filozofią jest jednak nauka buddystów.

116 VC 4.

117 W DN I, 11 zauważa się, że Budda powstrzymuje się od takich niskich/marnych sztuk/nauk (tiracchana-vijja), jak (popularna) filozofia (lokayata). Na temat dyskusji dotyczącej zagadnienia charakteru nauki Buddy w aspekcie jej 
Paradoks polega na tym, że w warstwie semantycznej obie nauki moga być identyczne. Tym, co je różni, nie jest ich treść czy stosunek do tzw. rzeczywistości, ale relacja, w jakiej pozostają do nich ci, którzy je wypowiadają.

Rozróżnienie to może przywodzić na myśl Platońską dystynkcje na poznanie (episteme) i mniemanie (doxa). Podobieństwo jest jednak pozorne. Platońska dystynkcja jest rozróżnieniem między poznaniem prawdziwym ujmującym realny, gdyż doskonały, czyli niezmienny byt, a mniemaniem skazanym na nieustanne popadanie $w$ fałsz w związku z tym, iż celuje w obszar zmiany, który nie sposób bytem nazwać. Ostatecznie jest to rozróżnienie między rozumem a zmysłami. W dystynkcji buddyjskiej nacisk położony jest na rozróżnienie sposobu odnoszenia się do stwierdzanych treści, które w obu wypadkach pretendują do ujmowania tej samej rzeczywistości. W dystynkcji tej chodzi nie o poznanie prawdziwe i fałszywe, lecz o poznanie właściwe (sammāalsamyañc) i niewłaściwe (micchä/mithyā). W buddyjskiej epistemologii warunkiem uzyskania właściwego poznania jest nie tylko adekwatne ujmowanie rzeczywistości, ale przede wszystkim neutralizacja ego. Ten postulat odróżnia buddyjską epistemologį̨ od zarówno platonizmu, jak i sceptycyzmu. Podkreślić ponadto należy, że buddyjska dystynkcja jest trójdzielna, a nie dwudzielna - jest to podział na fałsz, prawdę i brak poglądów, czyli na lgnięcie do fałszu, lgnięcie do prawdy i nielgnięcie. Lgnięcie do fałszu jest szkodliwe zarówno pod względem epistemologicznym, jak i terapeutycznym/ soteriologicznym. Lgnięcie do prawdy, właściwe pod względem epistemologicznym, chociaż pomocne w początkowym okresie praktyki, jest szkodliwe pod względem terapeutycznym/soteriologicznym i dlatego musi być ostatecznie porzucone. Nielgnięcie do poglądów jest

filozoficzności zob. D. S. Ruegg, Some Reflections on the Place of Philosophy in the Study of Buddhism, [w:] idem, The Buddhist Philosophy of the Middle. Essays on Indian and Tibetan Madhyamaka, Boston 2010, s. 221-224; D. Smith, J. Whitaker, Reading the Buddha as a Philosopher, PEW 66/2 (2016), s. 515-538. 
właściwe zarówno pod względem epistemologicznym, jak i terapeutycznym/soteriologicznym.

Zatem podział wchodzących $w$ dyskusję na tych, którzy wspierają się o fałsz, oraz tych wspartych o prawdę nie jest podziałem na dogmatyków negatywnych i pozytywnych. Wsparci o fałsz nie głoszą, że nie ma prawdy, że wiedza jest niemożliwa. Wsparci o prawdę nie głoszą po prostu, że posiadają do prawdy dostęp. Obie strony wchodzą $\mathrm{w}$ dyskusję $\mathrm{w}$ przekonaniu, że posiadają prawdę. Opinie jednych jednak są fałszywe, opinie drugich zaś są prawdziwe. Obie jednak strony pozostają w egotycznym odniesieniu do owych opinii i dlatego nie są buddami. Budda nie ma opinii nie dlatego, że uznaje niemożliwość rozstrzygnięcia między prawdą i fałszem, tylko dlatego, że widzi rzeczy, jakimi są w sposób nieegotyczny. Nie musi niczego domniemywać. Gdy Budda się wypowiada o rzeczach, to nie wyraża żadnej opinii, nie głosi żadnego poglądu, tylko - używając określenia Nagardżuny - powiadamia (jñāpayate) o tym, jak rzeczy się mają.

Niewłaściwy pogląd jest zawsze niewłaściwy na dwa sposoby - pod względem „co" i ,jak” (za Rupertem Gethinem można te dwa aspekty nazwać kognitywnym i afektywnym) $)^{118}$. Pod względem "co", gdyi błędnie ujmuje rzeczywistość, pod względem „jak”, gdyż jest przedmiotem lgnięcia. Właściwy pogląd jest zawsze właściwy pod względem "co", natomiast jaki jest pod względem „jak”, zależy od tego, czyim jest poglądem. Jako właściwy pogląd dążącego do przebudzenia jest przedmiotem lgnięcia i skutkuje pozytywnym karmanem. Jako pogląd przebudzonego wolny jest od lgnięcia i polega na widzeniu rzeczy, jakimi one są. W przypadku osoby dąząacej do przebudzenia właściwy pogląd koryguje pogląd niewłaściwy i jest w liczbie mnogiej, tzn. w postaci licznych przekonań.

Jeżeli wada (vāda) jest dyskusją ukierunkowaną na poszukiwanie prawdy ${ }^{119}$, to buddowie w dyskusji udziału nie biorą, gdyż oni niczego

118 Zob. R. Gethin, Wrong View..., s. 20-23.

$119 \mathrm{Na}$ temat różnych rodzajów dyskusji w filozofii indyjskiej zob. K. Jakubczak, op. cit., s. 60-62. 
już nie szukają. Z perspektywy buddyjskiej każda forma dyskusji jest zajęciem sansarycznym, obarczonym wszystkimi przywarami pozostawania w stanie sansary, czyli przede wszystkim emocjonalną, egotyczną reakcją na opinie pojawiające się $w$ dyskusji. Buddowie tylko manifestują prawdę, dają tejże świadectwo, ale jej nie dociekają. Samo dociekanie prawdy ma jednak wartość dla istot sansarycznych. Buddyzm nie tylko tego faktu nie negował, ale, przeciwnie, afirmował go, czego przykładem jest przywiązywanie wagi do trzech rodzajów mądrości, uzyskiwanej metodami, które poza sansarę nie wyprowadzają, ale odgrywają ważną rolę we wzbudzaniu motywacji do wyjścia poza nią - mądrości uzyskanej na drodze stuchania ('śruta-mayī-prajñāa),

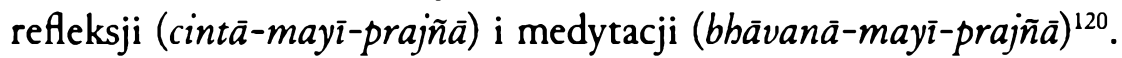

Dla buddyzmu, powtórzmy to raz jeszcze, brak poglądów to postawa psychologiczno-kognitywistyczna - brak egotycznego odniesienia do sądów, czyli nielgnięcie do nich, dla sceptyków zaś brak poglądów to postawa epistemologiczno-pragmatyczna - to brak asercji $\mathrm{i}$ odrzucenia, brak zgody na to, że sąd może posiadać wartość prawdy bądź fałszu ${ }^{121}$.

120 Uwaga o tym, że mądrość uzyskana dzięki medytacji nie wyprowadza poza sansare, wymaga komentarza, zwłaszcza w świetle dalszej mojej wypowiedzi na temat roli medytacji w tradycji buddyjskiej. Medytacja jest długotrwałym procesem badania i przekształcania własnego umysłu, podczas którego zdobywamy na temat jego funkcjonowania wiedzę, wcześniej nieposiadaną. Nie ma ona charakteru wyzwalającego, podobnie jak wiedza psychologa. Doświadczenie związane $z$ jej odkryciem, jak i sama jej treść umacniają jednak w motywacji dalszego wydatkowania energii w dążeniu do wyzwolenia. W późniejszej tradycji rozróżniano $\mathrm{w}$ związku z tym mądrość uzyskaną dzięki medytacji, która nie wyzwala, od mądrości wyzwalającej. Wasubandhu na przykład pierwszy rodzaj mądrości zaliczał do mądrości ze skazą, pomocnej w dążeniu do wyzwolenia, ale niewyzwalającej, i odróżniał ją od wyzwalającej mądrości ujmującej naturę rzeczy, którą nazywał abhidharmą, zob. AKB I, 2 b.

${ }^{121} \mathrm{O}$ asercji zob. D. Vernant, The Limits of a Logical Treatment of Assertion, [w:] Logic, Thought and Action, ed. D. Vanderveken, Dordrecht 2005, s. $267-288$. 
Pirron głosi, że niezmącony spokój (ataraxia), czyli stan najdoskonalszego dobrostanu (eudaimonia), bierze się z niemniemania (adoxastoi), czyli z nieroztrząsania kwestii prawdy i fałszu, z nieprzechylania się na żadną stronę (aklinesis), z nieulegania żadnym wzruszeniom (akradantoi). Ci, którzy ćwiczą się w ten sposób, osiągają zdolność niewyrokowania (aphasia), rozumianą jako trwała dyspozycja umysłowa, i ona właśnie prowadzi do niezmąconego spokoju (ataraxia).

Budda głosi, iż najwyższy dobrostan, czyli nirwana, osiągany jest dzięki zaprzestaniu lgnięcia, w którym to stanie może dokonać się przejście od myślenia prawdy, czyli mojego (egotycznego) pojęciowego przedstawiania sobie prawdy, tj. rzeczy, jakimi one są, do widzenia prawdy, czyli widzenia rzeczywistości własnego doświadczenia. Innymi słowy, może dokonać się przejście od prawdziwego poglądu do właściwego wglądu. Pirroński sceptycyzm postuluje zawieszenie poglądów (epocbē) w obliczu niemożliwości rozstrzygnięcia ich wartości prawdy i fałszu. Gdy Pirron zawiesił w ten sposób poglądy, przypadkowo uzyskał spokój umysłu. Pozwala to sceptykom żywić nadzieję, że i im się to przydarzy, chociaż pewności mieć nie mogą, gdyż przecież nie sposób poznać żadnych stałych prawideł rządzących rzeczywistością, w tym również prawideł wiążących stan uspokojenia umysłu ze stanem niewyrokowania. Buddyzm natomiast postuluje zawieszenie i neutralizację ego. Bez szczególnej formy praktyki umysłowej, jaką jest medytacja, dokonać tego jednak nie można. Perspektywa sceptyczna jest epistemologiczna, perspektywa buddyjska - psychologiczno-kognitywistyczna. Dla Pirrona i Sekstusa brak poglądów jest podstawą i warunkiem dobrostanu, dla Buddy i Nagardżuny brak poglądów jest wyrazem, ekspresją dobrostanu.

Sceptyk zaleca: przestań żywić poglądy poprzez rozpoznanie izostenii (niemożliwości rozstrzygnięcia między prawdą a fałszem jakiegokolwiek poglądu), dokonaj epochē, a osiągniesz ataraksję, spokój umysłu, czyli pełnię szczęścia (eudaimonia). Budda zaleca: osiągnij spokój umysłu poprzez poznanie i widzenie rzeczy, a nie będziesz 
żywił poglądów (przestaniesz lgnąć do wszelkich treści propozycjonalnych, przestaniesz zajmować propozycjonalne postawy).

Z buddyjskiej perspektywy postawę sceptyka można przyrównać do postawy tego, kto głositby, że ponieważ $w$ oparciu o doznanie przyjemności rozwija się pragnienie, a w oparciu o doznanie przykrości rozwija się awersja, to on będzie pielęgnował doznania obojętne. Budda doznania obojętne uznaje za szkodliwe, gdyi na ich podstawie rozwija się gnuśność, niepodejmowanie żadnej próby zaradzenia problemowi.

Kolejna różnica między sceptycyzmem a nauką Buddy uwidacznia się $\mathrm{w}$ sposobie rozumienia dobrostanu. W podrozdziale 1.2 części drugiej zwracatem uwagę na problem związany z rozumieniem natury ataraksji oraz jej trwałości. Wydaje się, że ataraksja sceptyka nie jest stanem trwałym, zależy od utrzymywania postawy powstrzymania się od sądzenia. Odejście od tej postawy skutkować powinno, w zgodzie ze sceptycką narracją, utratą owego spokoju umystu. Realizacja buddyjskiego kresu wiąże się $\mathrm{z}$ radykalną przemianą, po której nie jest możliwy powrót do człowieka sansarycznego. Trwałość tej przemiany ma swoją podstawę w praktyce medytacji - długotrwałym i żmudnym procesie świadomego kształtowania umysłu, opisywanym w kategoriach jego oczyszczania $z$ egotycznych postaw, w wyniku którego umyst ma uzyskać zdolność do przeprowadzenia wolnego od egotyzmu rozpoznania, tj. zobaczenia rzeczy, jakimi są. W sceptycyzmie nie znajdziemy odniesień do medytacji jako instrumentu generowania zmiany postawy. Dla Buddy gwarancją sukcesu jest widzenie i poznanie. Sceptycy gwarancji sukcesu upatrują $w$ świadomej zgodzie na brak poznania. Pirronizm przypomina postawę tego, który aktem deklaracji chce powstrzymać żywienie poglądów. Postawę taką Budda uznał za całkowicie nieskuteczna.

Następnym momentem, w którym dostrzec możemy odmienność obu postaw, jest sposób rozumienia konwencji i naturalności. Tradycje te żywią radykalnie odmienne przekonania odnośnie do konwencji i kierowania się nią. Sceptyk podejmuje działanie, odnosząc się 
do konwencji, czyli ustanowionych praw, obyczajów, tradycji, zdając sobie sprawę z tego, że nie stoją za nimi żadne naturalne dobra. Buddyjskie rozumienie konwencji jest całkowicie odmienne, gdyż wiąże się nie ze sferą kulturowych ustanowień, lecz z narzucającym się sposobem doświadczania rzeczy. Buddyzm i sceptycyzm posługują się radykalnie odmiennym sposobem rozumienia doświadczenia, a co za tym idzie, odmiennym sposobem rozumienia tego, co naturalne. Sceptyk uważa, że zjawiska mu się narzucają, gdyż polegają „na biernym doznaniu bez udziału woli" (PH I, 22) i kwestionuje tylko, czy rzeczy są faktycznie takie, jakie mu się jawią ${ }^{122}$. Innymi słowy, z tego, że miód wydaje się słodki (zjawisko), nie można wyciągać wniosku, że jest on faktycznie, ze swej natury, stodki (opinia). Taki wniosek jest dogmatycznym uroszczeniem. Buddyzm operuje całkowicie odmiennym pojęciem doświadczenia, zgodnie $\mathrm{z}$ którym zjawisko nie polega na biernym doznaniu, lecz samo jest już współkonstruowane przez poznający „podmiot”, również w sensie emocjonalnej na nie reakcji. Doświadczamy zjawiska jako przyjemnego bądź nieprzyjemnego i tu zaczyna się problem dla buddyzmu. Sceptyk zaś w zgodzie ze swoją koncepcją doświadczenia uważa jego emocjonalną jakość za coś naturalnego, co mu się narzuca i za czym w związku z tym może swobodnie podążać.

Sceptycy nie mają poglądów, gdyż ich mieć nie mogą. Buddowie nie mają poglądów, gdyż ich mieć nie potrzebują. To stanowi fundamentalną między nimi różnicę.

122 Zob. też PH I, 23-24, gdzie mowa jest o tym, że żyjemy zgodnie ze wskazówkami natury. Zob. także P. S. Fosl, Skepticism and the Possibility of Nature, [w:] Pyrrbonism in Ancient..., s. 145-169. 


\section{Widzenie pustki a doświadczenie mistyczne ${ }^{123}$}

\subsection{Buddyzm jako mistycyzm}

„Buddyzm [...] uważać można za najbardziej mistyczną religię”. Tymi słowami znany brytyjski badacz religii Ninian Smart zaczął swój artykuł o mistyce w buddyzmie therawady ${ }^{124}$. Nie był on oczywiście pierwszym głoszącym tak jednoznaczny pogląd. Można tu przywołać francuskiego badacza André Bareau, który w pracy o buddyjskim absolucie twierdził: „Nigdy nie należy zapominać, iż buddyzm jest przede wszystkim mistyką" ${ }^{125}$. Dużą rolę w popularyzacji przekonania o mistyczności buddyzmu odegrał przed II wojną światową Louis de la Vallée Poussin. W tekście poświęconym nirwanie utrzymywat, że w buddyzmie wiodą do niej dwie przeciwstawne drogi: droga

123 Niniejszy rozdział, chociaż ostatni w książce, był pierwszym, jaki napisałem ponad trzy lata temu. Zasadniczą jego część miałem okazję już publikować jako artykuł w tematycznym tomie poświęconym kwestiom buddyjskim, który redagowałem w czasopiśmie „Argument. Biannual Philosophical Journal” 7/1 (2017), s. 71-96.

124 N. Smart, Mysticism and Scripture in Theraväda Buddhism, [w:] Mysticism and Sacred Scripture, ed. S. T. Katz, Oxford 2000, s. 232: Buddbism [...] can be considered the most mystical of religions.

125. A. Bareau, L'absolu en philosophie boudbique, Paris 1951, cytuję za: I. Pyysiäine n, Beyond Language and Reason. Mysticism in Indian Buddbism, Helsinki 1993, s. 14: One should never forget that Buddhism is above all mysticism. 
racjonalnej analizy wyrażająca się w rozróżnianiu i wyliczaniu dharm oraz droga mistyki, tj. medytacyjnego skupienia ${ }^{126}$. Mistyki w buddyzmie dopatrywat się Theodor Stcherbatsky ${ }^{127}$. W Polsce stanowisko takie upowszechniał Stanisław Schayer i jego uczniowie ${ }^{128}$. Opinie owych wybitnych badaczy utrwality przekonanie o mistycznym charakterze buddyzmu do tego stopnia, że wielu współczesnych autorów piszących o różnych aspektach kultury buddyjskiej przyjmuje owo przekonanie w sposób całkowicie bezkrytyczny, uważając je za niekwestionowalne ${ }^{129}$.

Szczególną popularność pogląd ten uzyskał w Indiach, gdyż pozwalał niejako na powrót, wbrew oficjalnemu buddyjskiemu stanowisku, wpisać buddyzm w nadrzędną tradycję upaniszadowo-wedantyczną. Najbardziej znanym jego rzecznikiem był Tirupattur R. V. Murti, autor swego czasu bardzo poczytnej książki o madhjamace The Central Pbilosopby of Buddbism ${ }^{130}$. Ogromną popularnością cieszyły się pu-

126 Wyróżniając te dwie drogi, de la Vallée Poussin konstatował napięcie, jakie uwidacznia się w myśli buddyjskiej między tzw. wglądem (vipaśyanā) a wyciszeniem (śamatha), zob. L. de la Vallée Poussin, Musila and Narada..., s. 1. Mimo upływu lat kwestia ta ciągle budzi kontrowersje i przykuwa uwage badaczy. Por. także E. Shulma n, Mindful Wisdom. The Sati-pațthāna-sutta on Mindfulness, Memory, and Liberation, HR 49/4 (2010), s. 393-420.

127 Zob. T. Stcherbatsky, The Conception of Buddhist Nirvāna, Leningrad 1927, s. 16-19.

${ }_{128}$ Zob. S. Schayer, Ausgewäblte Kapitel aus der Prasannapadā, Kraków 1931, s. XXX-XXXIII.

129 Zob. np. D. Collinson, K. Plant, R. Wilkinson, Fifty Eastern Thinkers, London-New York 2002, s. 379: At the beart of Buddhism in all its forms, and so of Zen, is the experience of enlightenment, and this experience is mystical in character. Zob. także D. B. Gray, The Mystical Dimensions in Buddhism, [w:] Teaching Mysticism, ed. W. B. Parsons, Oxford 2011, s. 67-87; G. Parrinder, Mysticism in the World's Religions, Oxford 1995, s. 54-65.

$130 \mathrm{Za}$ zasadniczy aspekt koncepcji filozofii sformułowanej w buddyjskiej szkole madhjamaki T. R. V. Murti uważał idę̨ doskonałości mądrości (prajña-päramita), przez którą rozumiał niedualną, beztreściową intuicje ujmującą ponadracjonalny Absolut, zob. T. R. V. Murti, The Central Philosophy of Buddhism, London 1955, s. 218-220. 
blikacje Daisetzu Suzukiego ${ }^{131}$, przesiąknięte szlachetnym aromatem buddyjskiej mistyki unoszącym się wraz z dymem japońskich kadzideł w klasztorach zen.

Sądząc po tym, jak wielu badaczy religii i samego buddyzmu w XX w. wyrażało opinie w kwestii buddyjskiej mistyki, uznać można, że zagadnienie to mocno skupiało na sobie uwage badawczego środowiska. Tym bardziej zaskakuje fakt, iż doczekało sį̨ tak niewielu gruntownych opracowań. Najbardziej kompleksowe i ambitne studium tego zagadnienia pojawiło się dopiero w 1993. Jest to książka Beyond Language and Reason. Mysticism in Indian Buddhism fińskiego badacza Ilkki Pyysiainena - praca cenna ze względu na jasno, aczkolwiek dość tendencyjnie (wąsko) sformułowaną perspektywę badawczą i dobór cytatów oraz niezwykle irytująca ze względu na wiele powierzchownych i nietrafnych opinii ${ }^{132}$.

Zagadnienie buddyjskiej mistyki przyciągato uwagę, gdyż jego pozytywne rozstrzygnięcie dawało nadzieję na to, iż uda się obejść problem, jaki stwarzał buddyzm swoją powszechnie znaną krytyką idei atmana (jaźni, duszy, substancjalnego podmiotu) i nieco mniej znaną krytyką idei boga kreatora. Negacja ich obu, zwłaszcza zaś tej drugiej, stawiała buddyzm poza wszelkimi esencjalistycznymi definicjami religii, które za fundamentalny aspekt wszelkiej religijności uznawały odniesienie się człowieka do boga. Całkowite dezawuowanie boskości, filozoficzna krytyka idei boskości oraz zupełne wykluczenie

131 Zob. np. D. T. Suzuki, Wprowadzenie do buddyzmu zen, thum. M. i A. Grabowscy, Warszawa 1992, s. 31-33, a także idem, Zen $i$ kultura japońska, tłum. B. Szymańska et al., Kraków 2009, s. 244 oraz idem, Mysticism. Cbristian and Buddbist, London-New York 2002. Wypada zauważyć, że przekonanie o mistyczności buddyzmu, w tym zwłaszcza buddyzmu zen, Suzuki powtarza w pracach publikowanych po $1945 \mathrm{r}$. We wcześniejszych tekstach zdecydowanie temu zaprzeczat, zob. np. ide m, An Interpretation of Zen-Experience (1939), [w:] idem, Studies in Zen, New York 1955, s. 74.

132 I. Pyysiäinen, op. cit.; zob. także J. Bronkhorst, Review of Ilkka Pyysiäinen, "Beyond Language and Reason. Mysticism in Indian Buddbism”, „Asiatische Studien / Études Asiatiques" 47/4 (1993), s. 709-715. 
boskości z praktyki życiowej przy jednoczesnej afirmacji „duchowości” odbierało badaczom wygodną etykietę i burzyło utrwalone przekonania odnośnie do tego, czym jest religia. Konieczność zmierzenia sį̨ $\mathrm{z}$ trudnościami stwarzanymi przez buddyzm była jednym z tych kilku czynników, które wpływały na przesunięcie się uwagi badaczy religii z kwestii boga i społecznych praktyk instytucjonalizujących relacje człowieka do boga na kwestį̧ osobistego doświadczenia duchowego i jednostkowej świadomości. Ten ruch doprowadził do utrwalenia się przekonania, że sednem religijności, jej witalną energią nie są społeczne instytucje, a osobiste, niezwykle enigmatyczne doświadczenie mistyczne. Zgodnie $\mathrm{z}$ tym przekonaniem u źródeł wszelkiego doświadczenia religijnego ma zatem leżeć doświadczenie mistyczne. Jeżeli więc odkryjemy takie doświadczenie w tradycji buddyjskiej, to odkryjemy podstawę, w oparciu o którą będziemy mogli snuć porównawcze spekulacje z filozoficzno-religijnymi tradycjami wywodzącymi się z obszaru Morza Śródziemnego, znajdziemy zatem punkt oparcia dla uniwersalnej generalizacji.

Zdaniem wielu badaczy spełnieniem mistycznych aspiracji buddyzmu jest mahajana $\mathrm{z}$ jej dwiema szkołami - madhjamaką (madbyamaka) i jogaczarą (yogācara). Obie owo spełnienie mają osiągać w odmienny, charakterystyczny dla siebie sposób. $\mathrm{Na}$ marginesie warto zaznaczyć, że mistyczność mahajany afirmują nawet ci badacze, którzy tak jak Bimal K. Matilal, kwestionują mistyczny charakter przesłania samego Buddy i wczesnych szkół buddyjskich $z$ therawadą na czele czy też przynajmniej w nie powątpiewają ${ }^{133}$. A nawet wtedy afirmacja ta na zasadzie kontrastu nabiera dodatkowego znaczenia, uwypuklając zdaniem tych badaczy heterodoksyjność mahajany ${ }^{134}$.

133 Zob. B. K. Matilal, Mysticism and Reality. Ineffability, JIP 3 (1975), s. 231-233.

134 W. T. Stace w swojej poczytnej książce z lat sześćdziesiąrych ubiegłego wieku utrzymywał, że różnice między mistycyzmem mahajany a mistycyzmem innych religii są wyłącznie różnicami interpretacji, a nie doświadczenia. Czy opinię tę można odnieść do tradycji hinajany, autor uważał już jednak za co 
W dalszym ciągu zamierzam się skupić wyłącznie na szkole madhjamaki. Wskażę te miejsca w pismach twórcy szkoły, Nagardżuny, oraz w fundującej jego filozofię literaturze doskonałości mądrości, które pozwalały badaczom takie przekonanie formułować, i postaram się wykazać, że jest to przekonanie z gruntu fałszywe ${ }^{135}$.

\subsection{Cechy doświadczenia mistycznego}

Wcześniej jednak wypada doprecyzować znaczenie kategorii „doświadczenia mistycznego", które tutaj będę miał na uwadze. Należy podkreślić, iż nie ma wśród badaczy mistyki zgody co do tego, czy wszystkie doświadczenia mistyczne mają tę samą naturę. Nie wszyscy akceptują spopularyzowane przez Williama Jamesa i dominujące od czasu publikacji jego Doświadczeń religijnych (1902) przekonanie o ich jedności ${ }^{136}$. W latach trzydziestych Rudolf Otto wyróżniał mistykę introwertyczną i ekstrawertyczną ${ }^{137}$. Pod koniec lat pięćdziesiątych XX w. Robert Ch. Zaehner zaproponował podział na mistykę natury (pan-en-heniczną), monistyczną i teistyczną ${ }^{138}$. Jeszcze inni, jak Gershom Scholem, podkreślali, iż mistyka przede wszystkim przynależy do określonej religii i stanowi wyraz dojrzałej religijnej świadomości,

najmniej problematyczne, zob. W. T. Stace, Mysticism and Philosophy, London 1961, s. 123.

$135 \mathrm{Na}$ temat mistyczności szkoły jogaczary, przynajmniej w aspekcie zagadnienia niewyrażalności ostatecznej rzeczywistości zob. D. Burton, Wisdom beyond Words? Ineffability in Yogàcāra and Madhyamaka Buddhism, CB 1/1 (2000), s. 53-76.

136 Zob. polskie wydanie: W. Ja mes, Doswiadczenia religijne, thum. J. Hempel, Kraków 2001, s. 292-331, zwł. s. 330.

${ }_{137}$ Ściśle rzecz ujmując, R. Otto mówił o mistyce "oglądu wewnętrznego" i mistyce "oglądu jedności”, zob. R. Otto, Mistyka Wschodu i Zachodu. Analogie i różnice wyjaśniające jej istotę, thum. T. Dulińs ki, Warszawa 2000, s. 52-57. W póżniejszych pracach przyjął się podział na mistykę introwertyczną i ekstrawertyczną, zob. W. T. S tace, op. cit., s. 131-132.

${ }^{138}$ R. Ch. Zaehner, Mysticism, Sacred and Profane, Oxford 1971, s. 168. 
wszelkie zatem ogólne typizacje, które mistykę wyrywają z jej właściwego religijnego kontekstu, popadają nadmiernie w spekulację ${ }^{139}$.

Wreszcie należy zaznaczyć, iż nie ma również jasności co do tego, czy mistyka jest udziałem wyłącznie doświadczenia religijnego. Po eksperymentach $\mathrm{z}$ halucynogenami w latach pięćdziesiątych XX w. Aldous Huxley uznał, iż kontekst religijny nie jest konieczny do tego, aby wygenerować doświadczenie mistyczne, można to zrobić środkami chemicznymi ${ }^{140}$. Mimo iż stanowisko Huxleya spotkało się z ostrą krytyką ze strony religioznawców, wpłynęło na rozwój w latach sześćdziesiątych ubiegłego stulecia psychologicznych badań nad doświadczeniem mistycznym. W ich efekcie pojawił się nowy język badawczy (m.in. zamiast o doświadczeniu mistycznym zaczęto mówić o odmiennych stanach świadomości), a do obiegu trafiła kategoria „mistyki halucynogenów". Szybko jednak okazało się, że chociaż badania te wiele wnoszą do wiedzy o subiektywnych i fizjologicznych aspektach odmiennych stanów świadomości, to nie są w stanie niczego rozstrzygnąć w kwestii tego, co można by określić jako obiektywne aspekty doświadczenia mistycznego, a co gorsze sam przedmiot badawczy, jakim jest doświadczenie mistyczne, zatracił wyrazistość.

Bez wątpienia doświadczenie mistyczne jest rodzajem odmiennego stanu świadomości, nie każdy jednak odmienny stan świadomości jest doświadczeniem mistycznym. Badania psychologiczne okazały się niezdolne do określenia specyfiki tego zjawiska na tle odmiennych stanów świadomości. Uczynić to można wyłącznie, powracając do starej procedury wskazywania cech charakterystycznych, której zasadniczą wadą jest to, iż wydaje się zanadto zależna od kontekstu społeczno-kulturowego. Dla realizacji celu, jaki wyznaczyłem sobie w tym rozdziale, to powinno jednak wystarczyć.

139 Zob. G. Schole m, Mistycyzm żydowski i jego główne kierunki, tłum. I. Ka nia, Warszawa 2007, s. 18, 22-23.

140 A. Huxley, Drzwi percepcji, thum. P. Kołyszko, Warszawa 1991. Na temat różnicy w podejściu do kwestii natury i generowania doświadczenia mistycznego zob. J. Kellenberger, Mysticism and Drugs, "Religious Studies" 14/2 (1978), s. 175-191. 
Wyliczanie cech charakterystycznych religijnego doświadczenia mistycznego zwykle rozpoczyna się od przypomnienia charakterystyki Jamesa. Spośród czterech cech wskazanych przez amerykańskiego flozofa dwie pierwsze spotkały się z powszechnym uznaniem i do dnia dzisiejszego przywoływane są jako najbardziej standardowe cechy tego doświadczenia ${ }^{141}$.

Jako pierwszą z cech wymienia się zwykle niewyrażalność. Sam James uważał ją za "najbardziej poręczną" cechę doświadczenia mistycznego, coś w rodzaju jego kamienia probierczego czy też papierka lakmusowego. Nie jest jednak jasne, jak należy ją rozumieć. Bimal K. Matilal podkreślał, iż w grę wchodzą dwie możliwości: albo kwestionujemy możliwość wyrażenia subiektywnej warstwy czy też strony doświadczenia, co wydaje się rzeczą banalną, gdyż z sytuacją taką mamy do czynienia w przypadku każdego doświadczenia zmysłowego, albo też uznajemy, że niewyrażalny jest przedmiot tego doświadczenia, i to jest zdaniem indyjskiego badacza sytuacja znacznie ciekawsza ${ }^{142}$. Tak czy inaczej, niewielu późniejszych myślicieli było gotowych podawać w wątpliwość przekonanie Jamesa, a ci, którzy to robili, albo popadali w banał, zwracając uwagę na aspekt subiektywny ${ }^{143}$, albo kwestionowali w ogóle, tak jak Matilal ${ }^{144}$, poznawczą skuteczność doświadczenia mistycznego, czyli cechę, którą James wymieniał jako drugą. Doświadczenie mistyczne bowiem, twierdził amerykański uczony, odznacza się jakością noetyczną, tj. intuicyjnym poznawczym wglądem w rzeczywistość. Obie te cechy mają wystarczać do zidentyfikowania doświadczenia mistycznego. Ponadto James dodawał jeszcze dalsze dwie drugorzędne cechy: chwilowość i pasywność.

141 W. James, op. cit., s. 293-294.

142 B. K. Matilal, Mysticism and..., s. 218-228. O różnych rodzajach niewyrażalności zob. A. Kukla, Ineffability and Pbilosopby, London-New York 2005, s. $135-157$.

${ }^{143} \mathrm{Na}$ ten temat zob. np. W. T. Stace, op. cit., s. 283-284.

Ift B. K. Matilal, Mysticism and..., s. 246-247. Matilal w swojej krytyce podąza za fundamentalnym przeświadczeniem filozofii njaji, że wszystko, co istnieje, jest poznawalne i nazywalne. 
Niewyrażalność doświadczenia mistycznego manifestować się ma w wypowiedziach mistyków na wiele różnych sposobów. Często wskazują oni na pozakonceptualną naturę doświadczanego przedmiotu. Ponieważ jest ona niedostępna pojęciom, najwłaściwszym sposobem wypowiadania się o niej jest zachowanie milczenia. Mimo pochwał pod adresem jezzykowej abstynencji mistycy z racji swojego społecznego uwikłania naruszają własne deklaracje i podejmują wysiłek nakierowania innych na drogę prowadzącą do powtórzenia ich doświadczenia. Chociaż jeszcze ważniejszym powodem wydaje się potrzeba ulokowania opartych na doświadczeniu mistycznym przekonań w obszarze dominujących modeli światopoglądowych. Czynią to, zwykle używając języka na tak dobrze znane niestandardowe sposoby: preferują negację, która choć nie wprost, to przybliżać ma nasze zrozumienie do celu, zamykając fałszywe ścieżki myśli, co jest drogą apofatyczną; orzekają sprzeczne predykaty, tak jakby logiczne przepetnienie było najstosowniejszym znakiem na oznaczenie doskonałości bytowej pełni doświadczanego przedmiotu, wyrażają się więc paradoksalnie; ubierają przedmiot doświadczenia w słowa, którym przesuwają bądź rozszerzają znaczenia, tworzą zatem retorycznie aplikowany język metafor, niepoddający się jednoznacznej wykładni ${ }^{145}$. W zabiegach tych manifestować się ma, zdaniem badaczy, charakterystyczne dla doświadczenia mistycznego poczucie jedności $z$ doświadczanym przedmiotem, bez względu na to, czy będzie to osobowy bóg, bezosobowy absolut czy natura, poczucie jego doskonałości oraz pełni.

\subsection{Madhjamaka jako mistyka}

Które $\mathrm{z}$ tych cech, wypada w końcu zapytać, przysługują madhjamace? Matilal, który mistyce madhjamaki poświęcił stosunkowo wiele

$145 \mathrm{Na}$ temat różnych sposobów użycia języka w kontekście doświadczenia mistycznego zob. R. H. Jones, Mysticism Examined. Philosophical Inquiries into Mysticism, Albany 1993, zwt. s. 101-123 oraz ide m, Philosophy of Mysticism. Raids on the Ineffable, Albany 2016, zwł. s. 203-231. 
uwagi, uznat, iż w charakterystyce tej szkoły dominują trzy cechy mistycyzmu: (1) poznanie intuicyjne bezpośrednio ujmujące ostateczną rzeczywistość, nadrzędne względem zmysłowo-pojęciowego poznania zjawisk (sfery konwencjonalnej), (2) koncepcja niedualnej (advaya) rzeczywistości leżącej poza wielością zjawisk oraz (3) idea niewyrażalności tego, co ostateczne ${ }^{146}$. Owa niewyrażalność ostatecznej rzeczywistości ma być zdaniem Matilala „wyrażana” w madhjamace pośrednio poprzez zastosowanie wspomnianych wyżej metod: via negativa, coincidentia oppositorum i jezzyk metafor ${ }^{147}$.

$\mathrm{Na}$ poziomie literalnego czytania pism Nagardżuny łatwo wskazać fragmenty, w których metody te zdają się znajdować zastosowanie. Pisma twórcy szkoły oraz późniejszych madhjamików roją się od negacji, sprzecznych orzeczeń i określeń, których bezpośrednie znaczenie może się wydawać trudno identyfikowalne.

Już w tak zwanej mangalaśloce, czyli strofach otwierających Podstawowe strofy madhjamaki, dają się rozpoznać wszystkie te cechy. Nagardżuna składa w nich hołd Buddzie jako Doskonałemu Nauczycie-

146 B. K. Matilal, Epistemology, Logic, and Grammar in Indian Pbilosophical Analysis, ed. J. Ga neri, Oxford 2005, s. 130-131; zob. również R. H. Sharf, The Rbetoric of Experience and the Study of Religion, "Journal of Consciousness Studies" 7/11-12 (2000), s. 267-287.

147 K. Matilal, Mysticism and Reality..., s. 237-244. L. S. Betty uważał, że to, co można nazwać logiczną słabością tekstów Nagardżuny, wynika z błędnej perspektywy, z jakiej madhjamaka jest oceniana. Gdy spojrzymy na madhjamakę z właściwej dla niej perspektywy, czyli z perspektywy doświadczenia mistycznego, a nie racjonalistycznej filozofii, to owa logiczna słabość nabierze odmiennego charakteru, zob. L. S. Betty, Nagärjuna's Masterpiece - Logical Mystical, Both or Neither?, PEW 33 (1983), zwt. s. 133-135. Odnośnie do ostatniego tekstu zob. także D. Loy, How Not to Criticize Nagärjuna. A Response to L. Stafford Betty, PEW 34/4 (1984), s. 437-445; L. S. Betty, Is Nagarjuna a Philosopher? Response to Professor Loy, PEW 34/4 (1984), s. 447-450. Według niektórych badaczy o mistycznym charakterze madhjamaki świadczy teoria dwóch prawd, zob. J. S. O'Leary, Ultimacy and Conventionality in Religious Experience, [w:] Religious Experience and the End of Metaphysics, ed. J. Bloechl, Bloomington-Indianapolis 2003, s. 174-199. 
lowi, który oprócz nauki o zależnym powstawaniu przekazywał wiedzę o „tagodnym uciszeniu rozplenienia [tj. języka], niezanikaniu, niepowstawaniu, nieunicestwieniu, nietrwałości, nietożsamości, niezróżnicowaniu, nieprzychodzeniu, nieodchodzeniu" (anirodham anutpädam anucchedam aśáśvatam, anekārtham anānārtham anāgamam anirgamam, yạ pratītya-samutpādam prapañcopaśamam śivam $)^{148}$.

W tym samym duchu w MMK XVIII, 9 twórca madhjamaki oznajmia:

apara-pratyayam śantam prapañcair aprapañcitam | nirvikalpam anānārtham etat tattvasya laksanam ||

Niczym nieuwarunkowana, spokojna, pojęciowo nierozpleniona, [językowo] niezróżnicowana, bez dystynkcji - oto cecha ostatecznego [„tości” (tattvasya lakșanam)].

Jakby tego było mało, w rozdziale XXV traktującym o nirwanie dodaje w sposób, który zdaje się kłócić z mangalaśloką (MMK XXV, 24):

sarvopalambhopaśamạ prapañcopaśamạ śivạ $\mid$ na kvacit kasyacit kaścid dharmo buddhena desita \|

Nikogo i nigdzie Budda nie nauczał o uciszeniu postrzegania i łagodnym uciszeniu rozplenienia jako o czymś.

Z kolei Czandrakirti podkreśla w komentarzu: „To, co ostateczne, jest milczeniem szlachetnych" (paramārtho by ärjānāàm tūṣnīm-bbāvaḅ;;

148 Mangalaśloka bywa różnie traktowana $w$ różnych redakcjach. W uchodzącej za normatywną redakcji Louisa de La Vallée Poussina strofy te zostaty wyodrębnione $z$ pierwszego rozdziału, zob. L. de La Vallée Poussin, Mülamadhyamakakarikās (Mädhyamikasūtras) de Nagaarjuna avec la Prasannapada Commentaire de Candrakirti, St. Petersbourg 1903, s. 11, w. 13-16. Czasami jednak włącza się je do rozdziału pierwszego jako jego strofy otwierające, co jednak ze względu na ich treść wydaje się nieuzasadnione, zob. P. L. Vaidya, Madhyamakasastra of Nagariuna with the Commentary. Prasannapada by Candrakirti, Darbhanga 1960, s. 4. Czasami zaś strofy te w redakcji MMK są w ogóle pomijane, jak ma to miejsce w: J. W. de Jong, Mülamadhyamakakarikab, Madras 1977, s. 1. 
PP 57.7-8) ${ }^{149}$, a nauka o nim, jak dopowiada $w$ innym miejscu, jest niewysłowiona (anaksara; PP 264.6-7).

Owe standardowe dla mistyki formy wypowiedzi świadczące o niewyrażalności doświadczenia swoją kanoniczną podstawę mają znajdować w literaturze doskonałości mądrości. Klasycznym przykładem ma być następujący ustęp z Ratny (RGS XX, 20):

yatha nirmito purușa no va adrísakāyo nämena vā puna sa prajñapanaya śakyạ |

tatha bodhisattva caramānu vimokșadväram namena vā puna sa prajñapanaya śakyab $\|$

Tak jak człowieka stworzonego czarami bądź tego, który uczynił się niewidzialnym, nie można określić słowami, tak też przekraczającego próg wolności bodhisattwę nie można określić słowami.

Jak należy rozumieć takie wypowiedzi? Uprzedzając wypadki, stwierdzę, że przede wszystkim należy je staranniej czytać, uwzględniając ich własny kontekst, a nie pochopnie narzucać interpretacje, kojarząc je z utrwalonymi kulturowymi schematami. Stwierdzenie, iz osoby zrealizowanej (tutaj: bodhisattwy) nie można określić słowami, nie musi bowiem znaczyć, iż ontyczny stan takiej osoby jest w sensie dosłownym nieopisywalny. Podobne stwierdzenie pojawiło się już w Dhammapadzie odnośnie doskonałego. Głosi się tam, że jego droga jest nieuchwytna, gdyz nie zostawia on śladów karmicznych, tak jak ptak nie zostawia śladów w powietrzu (DhP 92). Nieopisywalność więc w pierwszym rzędzie nie dotyczy, a przynajmniej nie musi dotyczyć bodhisattwy, a faktu nietworzenia karmana - nie sposób opisać

149 Określenie "milczenie szlachetnych / szlachetne milczenie” jest w kulrurze buddyjskiej głęboko zakorzenione i możliwe, że posługiwał sį̨ nim Budda. W zbiorze sutt kanonu palijskiego pojawia się co najmniej trzykrotnie, zob. SN II, 273; AN IV, 153; MN I, 161. W madhjamace nabiera jednak szczególnego znaczenia. 
to, czego nie ma. Co ciekawe, owo porównanie zrealizowanego do ptaka pojawia się też w Ratnie/Aszcie, i to w tym samym rozdziale, co przytoczona strofa (RGS XX, 8 / AS 374), i to ono wyznacza kontekst dla rozumienia nieokreśloności bodhisattwy.

Wróćmy jednak jeszcze na moment do dalszych przykładów paradoksalnego orzekania w sutrach doskonałości mądrości. Niezwykle ciekawe twierdzenie pojawia się w pierwszym rozdziale Aszty (AS 2122). W odpowiedzi na pytanie Subhutiego Budda wskazuje na szczególną i niezwykłą cechę postawy bodhisattwy związaną z treścią jego ślubowania. Jak wiadomo bodhisattwa zobowiązuje się do niesienia pomocy wszystkim sansarycznym istotom, celem doprowadzenia ich do nirwany. Doprowadzając jednak do nirwany niezliczone istoty stwierdza Budda - bodhisattwa nikogo do nirwany nie doprowadza. Co więcej, nie tylko nikt nie zostaje do nirwany doprowadzony, ale też nie istnieje nikt, kto mógtby kogokolwiek do nirwany doprowadzić. Na poziomie literalnym mamy więc klasyczną sprzeczność działanie, które domaga się podmiotu działania i przedmiotu działania ma być wykonane przez nieistniejący podmiot wobec nieistniejących przedmiotów.

Podobnych paradoksalnych wypowiedzi w sutrach doskonałości mądrości znajdujemy wiele: a to Tathagatę należy widzieć na podstawie nie-cech jako cech ${ }^{150}$, a to bodhisattwa nie powinien się chwytać ani dharmy (cnoty/cechy), ani nie-dharmy (nie-cnoty/nie-cechy) ${ }^{151}$, za to bodhisattwa powinien porzucic dharmy (cnoty/cechy) jeszcze bardziej niż nie-dharmy (nie-cnoty/nie-cechy) ${ }^{152}$ itd.

150 VC 5: lakșanalakṣanatastatbagato draștavyab. Por. też RGS I, 12c, gdzie oznajmia się, że "praktykę tę [bodhisattwa] rozpoznaje jako nie-praktykę" (caranam ca so acaranam ca prajanayituā), a także RGS II, 7d, gdzie po stwierdzeniu, że bodhisattwa ćwiczy sį̨ wyłącznie w nauce Buddy celem osiągnięcia wszechwiedzy, ogłasza się, że „jego [bodhisattwy] ćwiczeniem jest nie-ćwiczenie i nikt nie ćwiczy się w takim ćwiczeniu" (śikșaśsikșa na ya śikșati eșa śikșā).

151 VC 6: na [...] bodhisattvena mabasattvena dharma udgrabītavyo nddbarmab.

152 VC 6: dharma eva prabātavyă prägevadharma. Kwestia tłumaczenia terminu dharma w tym fragmencie, zwłaszcza, gdy pojawia się w liczbie mnogiej, bu- 
Wypowiedzi te pozostawione bez komentarza zdają się naruszać podstawową logiczną intuicję rządzącą naszym językiem - prawo niesprzeczności ${ }^{153}$. Czy faktycznie pozostaje nam tylko skonstatować ten fakt i uznać, że są rozpaczliwą próbą wysłowienia niewysławialnego? Zdecydowanie nie mogę na to przystać. Wczytajmy się ponownie w słowa obwieszczające beznadziejny los bodhisattwy - ma on do nirwany doprowadzić niezliczone istoty, nie doprowadzając żadnej. Sądzę, że rozwiązanie tego paradoksu, jakie proponuje Sutra diamentowa, należy przyjąć za paradygmatyczne. Stwierdza się w niej, iż nie można uznać za bodhisattwę tego, kto wciąż działa w oparciu o pojęcia ja/jaźni, żywej istoty, duszy, osoby ${ }^{154}$.

Zresztą nie jest to rozwiązanie oryginalne. Pojawia się już w Aszcie (AS 11-14), aczkolwiek w formie mniej wyrazistej, gdyż narracyjnie bardziej rozbudowanej. Po orzeczeniu powszechnej pustki (AS 10) Subhuti, uwzględniając fakt pustki, przystępuje do charakterystyki

dzi ogromne kontrowersje, a sam termin bywa różnie przekładany. Ponieważ rozstrzygnięcie tej kwestii $w$ tym miejscu nie jest ważne, to nie wdaję sį̨ $\mathrm{w}$ dyskusję. Por. też. słynne sformułowanie z VC 8, w którym oznajmia się, że Tathagata nauczat, iz cechy Buddy są nie-cechami Buddy i dlatego właśnie nazywane są cechami Buddy (buddha-dbarma buddha-dharma iti subbüte abuddha-dharmaśsaiva te tatbagatena bhasitäb, tenocyante buddha-dharma iti).

${ }^{153}$ Bez wątpienia tego typu wypowiedzi stanowią literalną podstawę dla sformułowanej przez japońskiego filozofa Kitaro Nishidę koncepcji absolutnej nicości i absolutnie sprzecznej samotożsamości, na ten temat zob. J. W. Heisig, Philosophers of Nothingness. An Essay on the Kyoto School, Honolulu 2001, zwt. s. 61-83, a takie A. Kozyra, Filozofia nicósi Nishidy Kitarō, Warszawa 2007, zwł. s. 29-70. Jak jednak wykazuję dalej, sprzeczności owe należy uważać za pozorne, a tym samym koncepcja Nishidy pochopnie i mylnie nadinterpretowuje sutry doskonałości mądrości.

154 VC 3: na sa [...] bodhisattvo vaktavyo yasya sattva-samjna pravarteta jiva-samjna vã pudgala-samjña va pravarteta. Por. RGS I, 24-25 - wielkie współczucie bodhisattwów jest wolne od pojęcia istoty/bytu; ten, kto myśli, że przekroczył cierpienie, myśli w kategoriach istot i jaźni - nie posiada mądrości. Por. RGS VII, 4 - kto myśli, że dąży do mądrości, aby uwolnić inne istoty, wyobraża sobie pojęcie istot i nie praktykuje tym samym doskonałości mądrości. 
postępowania bodhisattwy. Znamienne w owej prezentacji jest to, iz zaczyna od określenia niewłaściwej postawy umysłu tego, który aspiruje do ideału bodhisattwy. Nie zbliża się do realizacji tego ideału oznajmia Subhuti - ten, kto działa w oparciu o którykolwiek z pięciu zespołów czynników (skandha). Ten, kto tak działa, faktycznie działa w oparciu o znak (nimitta). W oparciu o znak działa każdy, kto działa w oparciu: o znak formy (rüpa-nimitta); o wyobrażenie, że „forma jest znakiem"; o powstawanie formy; o zanik formy; o zniszczenie formy; o wyobrażenie, że „forma jest pusta”; o wyobrażenie „ja działam”; czy też o wyobrażenie ,ja jestem bodhisattwą" i tak dalej odpowiednio do czterech pozostałych zespołów. Ten, kto w ten sposób działa mówi Subhuti - „faktycznie działa w oparciu o wyobrażenie «ja jestem bodhisattwą) [traktowanym] jako podstawa" (abam bodhisattva iti by upalambba eva sa carati; AS 11). Dopóki ktoś myśli o sobie, że działa w oparciu o doskonałość mądrości, dopóty działa w oparciu o znak. Ostatecznie Subhuti podsumowuje: „taki bodhisattwa znany jest jako niezręczny w środkach" (ayam bodhisattvo 'nupaaya-kuśalo veditavyab; AS 12).

Powyższa negatywna charakterystyka rodzi pytanie o to, jak od strony pozytywnej powinno wyglądać działanie tego, który działa w oparciu o doskonałość mądrości. W odpowiedzi Subhuti ponownie wylicza rzeczy, w oparciu o które nie należy działać, dodając, że ten, kto działa niewsparty o te rzeczy, nie powinien nawet myśleć, że działa w oparciu o doskonałość mądrości. Działając, nie tworzy wyobrażeń ,ja działam”, „ja nie działam", nja działam i nie działam”, „ja ani działam, ani nie działam". Właściwym stanem umysłu bodhisattwy jest "skupienie na nielgnięciu do żadnych dharm poprzez nazwę" (sarva-dharmānupādāno nāma samādhir; AS 13). Ostatecznie - stwierdza Subhuti - „kiedy trwa w tym skupieniu, bodhisattwa mahasattwa szybko osiągnie petne doskonałe przebudzenie" (anenaiva samädhinā vibaran bodhisattvo mabā-sattvạ̣ kșipram anuttarām samyak-sambodbim abbisambudbyate; AS 13), a trwając w tym skupieniu, nie myśli o sobie: „ja jestem skupiony” (aham samābitạ̣; AS 13). 
Co ciekawe, będąc tak skupionym - dodaje Subhuti - bodhisattwa nie jest w stanie takiego skupienia zademonstrować, gdyż go nie zna i nie postrzega, a nie zna go i nie postrzega, gdyż ono nie istnieje (AS 14). Oto mamy dramatyczny paradoks - żeby zrealizować postawę bodhisattwy, musimy wejść w skupienie, które nie istnieje. Jest to jednak paradoks pozorny, jak można wnosić z kolejnych stów, tym razem wypowiedzianych przez Buddę. Skupienie to nie istnieje w tym sensie - oznajmia Czcigodny - iż nie istnieje jako ontyczny czynnik (dharma), którego własną cechą, własną naturą byłaby jakość takiego skupienia. Skupienie to nie jest czynnikiem umysłu, dlatego, że w ogóle żadne czynniki, tj. dharmy w sensie ostatecznym, czyli jako obdarzone własną naturą i w sobie ugruntowane, nie istnieją. Ponieważ nie ma niczego, co tak by istniało, to niczego tak istniejącego nie można poznać i doświadczyć, a tym samym nie można tego pokazać. Trwanie w skupieniu na nielgnięciu do żadnych dharm nie polega na doświadczeniu szczególnej umysłowej jakości jako przynależnej pewnemu dharmie, lecz na uświadomieniu sobie, że nie istnieją żadne jakości jako przynależne dharmom ${ }^{155}$.

Zaproponowana w Aszcie i powtórzona zwięźle w Sutrze diamentowej wykładnia znosi sprzeczność, gdyż ujawnia jej pozorność. Wykluczające się orzeczenia nie dotyczą tego samego przedmiotu pod tym samym względem. Ślubowanie niesienia pomocy jest aktem sansarycznym, tzn. dokonującym się w oparciu o sansaryczny, tj. obarczony niewiedzą, sposób postrzegania istot. Aby jednak to ślubowanie wypełnić, ślubujący musi zmienić, musi przekształcić swój ogląd rzeczywistości ${ }^{156}$, musi rozpoznać podstawowy fakt buddyjskiej nauki w sensie ostatecznym nie ma żadnych istot ufundowanych na trwa-

${ }_{155} \mathrm{Na}$ tej samej zasadzie w Sutrze diamentowej oznajmia się, że pełne doskonate przebudzenie nie jest dharmą i dlatego właśnie, że nie można w nim znaleźć ani uchwycić żadnego dharmy, nazywane jest pełnym doskonałym przebudzeniem, zob. VC 22, por. też VC 7.

$156 \mathrm{Na}$ temat języka jako narzędzia soteriologicznej transformacji $\mathbf{w}$ tradycji buddyjskiej zob. Yao-Ming Tsai, Language as an Instrument of Soteriolo- 
łych, niezmiennych i substancjalnych jaźniach, żadnych atmanów, jak też i żadnych ostatecznych w sobie określonych i w sobie ufundowanych dharm. Pojęcie istoty, tak jak pojęcie dharmy, jest funkcjonalne wyłącznie $\mathbf{w}$ obszarze sansary, $t \mathrm{j}$. $\mathrm{w}$ obszarze doświadczenia sansare konstytuującego, rozpoznanie tego faktu jest warunkiem realizacji nirwany, a ta wiąże się z całkowitym zaprzestaniem lgnięcia i właśnie, jak stwierdza Aszta, „bodhisattwa mahasattwa jest tym, który ćwiczy się w nieprzywiązaniu do żadnych dharm" (sarva-dharmanạm bi subhūte bodhisattvo mabāsattvo 'saktatāyām siikșate; AS 18).

\subsection{Pustka a Nicość}

Madhjamaka głosi, iż wszystko, czego doświadczamy i czego doświadczyć możemy, jest puste, czyli nie posiada samobytu. Niewiedza, która warunkuje naznaczony cierpieniem stan sansaryczny, dotyczy tego właśnie faktu. Jedynym sposobem, aby tę sytuację zmienić na satysfakcjonującą, jest korekta owego poznawczego błędu, która może się dokonać wyłącznie poprzez bezpośredni ogląd stanu faktycznego. W Sześ́dziesięciu strofach rozumowania (YṢ 56cd) Nagardżuna oznajmia:

| sgyu ma'i skyes bu ltar dben par || mthong nas mya ngan 'da' bar' 'gyur |

Gdy widzi się, [że wszystko], tak jak człowiek stworzony czarami, jest puste [t. dben $p a=\mathrm{s}$. vivikta], osiąga się nirwanę.

Nie będę w tym miejscu objaśniał szczegółowo całego słownika madhjamaki, w którym kluczową rolę pełni termin "samobyt" (svabhâva). Nie będę tutaj eksplikował znaczenia "pustki" jako braku. Nie chcę się tutaj wdawać w dyskusję na temat dwóch aspektów

gical Transformation from the Madhyamaka Perspective, APh 24/4 (2014), s. $330-345$. 
samobytu - egzystencjalnego i esencjalnego - i ich wzajemnych powiązań. $\mathrm{O}$ tym wszystkim pisałem obszernie $w$ innym miejscu ${ }^{157}$ i nie chcę do tego wracać.

Tym, co mnie tutaj interesuje, nad czym chcę przez chwilę podywagować, są pytania: na czym faktycznie polega błąd istot sansarycznych? czym jest owo niewidzenie pustki?

W MMK XV, 6 Nagardżuna udzielił pewnej podpowiedzi. Czytamy tam:

svabhävam parabbavam ca bhavam cābhāvam eva ca | ye paśyanti na paśyanti te tattvam buddha-sásane \|

$\mathrm{Ci}$, którzy widzą samobyt $\mathrm{i}$ innobyt, byt i niebyt, nie dostrzegają istoty (tattva) nauki Buddy.

Zatem pustki nie widzą ci, którzy widzą samobyt i pozostałe ufundowane na nim kategorie. Czym jest jednak to widzenie samobytu, jak ono wyraża się w naszym codziennym doświadczeniu?

Właśnie siedzę za stołem, który, jak uważam, prezentuje mi sį̨ bezpośrednio w całej swojej solidności. Mogę się o niego oprzeć, ufając, że moje dłonie napotkają opór, mogę bezrefleksyjnie położyć na nim kolejną kartkę w przekonaniu, że pozostanie w zasięgu mojej dłoni, mogę dla gimnastyki zajrzeć pod spód, nie zadając sobie wcześniej pytania, czy w ogóle ten stół ma jakiś spód. Skąd we mnie to zaufanie, jakim obdarzam ten przedmiot? Dlaczego z podejrzeniem stucham madhjamika, gdy mówi mi, że to jest tylko byt nominalny (prajñapti-mätra) i co to właściwie miałoby znaczyć?

Sytuacja, którą próbuje tutaj opisać, została w dwudziestowiecznej filozofii poddana analizie przez Edmunda Husserla. Nazwat on ją "generalną tezą naturalnego nastawienia"158. Sądzę, że dokładnie ten

157 Zob. K. Jakubczak, op. cit., zwł. s. 173-177. Zob. także powyziej rozdz. 2.3 pierwszej części.

158 Zob. E. Husserl, Idee czystej fenomenologii i fenomenologicznej filozofii. Ksiega pierwsza, tłum. D. Gierulanka, Warszawa 1975, s. 86-88. 
sam aspekt naszego codziennego doświadczenia ma na myśli Nagardżuna, gdy mówi o "widzeniu samobytu”. Widzieć samobyt to doświadczać przedmiotu jako tego, co napotykam, jako tego, co znajduje w świecie, jako tego, przed czym staję, dążąc do odkrycia zamkniętej w nim samym jego własnej tajemnicy. Widzieć samobyt to wpisywać w przedmiot doświadczenia to poczucie naturalności jego bycia danym. Czandrakirti w Prasannapadzie sytuację tę określit mianem „nakładania/przypisania” (adbyāropa) fałszywej natury/fałszywego samobytu (viparìta-svarūpa = viparîta-svabbãva) $)^{159}$, dodając, iż właśnie ten akt nakładania samobytu poddał krytyce Nagardżuna w pierwszym rozdziale MMK, rozwijając filozofię pustki.

159 PP 58.10-11: „Dlatego pierwszy rozdział zaczyna się najpierw [stwierdzeniem] "rzeczy nie powstały", aby przeciwstawić się nakładaniu fałszywej natury" (tasmàd anutpanna bhāva ityevaì tâvad viparita-svarūpadbyaropa-pratipaksena pratbama-prakaranarambbab). Termin adbyaropa należy do grupy kilku równoznacznych terminów utworzonych na bazie rdzenia czasownikowego rub ('wznosić [się], wspinać się, nakładać, przypisywać'). W grupie mamy także aropa i samaropa. Wszystkie znaczą 'nałożenie'. Czandrakirti używał go wymiennie właśnie $z$ samaropa. Termin ten nie jest wyłączną własnością Czandrakirtiego i madhjamaki. Ważną rolę uzyskał we wcześniejszej widżnianawadzie (vijñana-vada). Z kolei dla Siankary (Śańkara) jest on synonimem terminu adbyasa również w znaczeniu 'nałożenie', który to termin należy do zestawu najbardziej podstawowych kategorii adwajtawedanty, gdzie używa się go do definiowania niewiedzy (avidya). Rację mają ci badacze, którzy twierdzą, że w zrozumieniu owego pojęcia kryje się klucz do istoty nauki o pustce rzeczy, zob. np. T. Tanji, On samäropa Probing the Relationship of the Buddha's Silence and His Teaching, [w:] Wisdom, Compassion, and the Search for Understanding. The Buddhist Studies Legacy of Gadjin M. Nagao, ed. J. Silk, Honolulu 2000, s. 353; zob. także T. J. F. Tille mans, Trying to be Fair to Madhyamika Buddhism, Calgary 2001, s. 16. Problem polega jednak na tym, że nie jest łatwo ten klucz wydobyć, gdyż kategoria „nakładania” może być i bywa różnie rozumiana. Późniejsi madhjamikowie, jak Kamalasila (Kamalaśila) i Di̇nianagarbha (Jñānagarbha) preferowali synonim samaropa, zapożyczony z filozofii widżnianawady, zob. T. Tanji, op. cit., s. 347-348; zob. także T. Tillemans, What Are Madbyamikas Refuting?' Säntarakșita, Kamalaśila et alii on Superimpositions (Samāropa), [w:] Three Mountains and Seven Rivers. Prof. Musashi Tachikawa's Felicitation Volume, ed. S. Hino, T. Wada, Delhi 2004, s. 225-237. 
Nominalność przedmiotu, zdaniem madhjamika, nie polega na tym, że wyprojektowuje go w całym jego jakościowym uposażeniu. To jest pogląd jogaczary i jest to pogląd idealistyczny. Nominalność przedmiotu polega na tym, iż ujmuje go jako samoistny. Zobaczyć pustkę przedmiotu, to utracić owo poczucie naturalności dania, ale nie sam przedmiot. Pustka madhjamaki nie jest zatem transcendentną rzeczywistością ukrytą pod płaszczem danej nam w doświadczeniu mnogości rzeczy.

Analiza, którą postuluje madhjamik, ujawniać ma, że konwencjonalne przedmioty, czyli przedmioty doświadczenia codziennego, nie istnieją tak, jak się jawią, czyli jako samoistne i samobytujące, ale nie, że nie istnieją w ogóle. Analiza ujawnia, że mylimy się co do ich sposobu istnienia, ale nie co do samego ich istnienia.

Odkrycie, że wszystko, co jest nam dane, istnieje tak samo, staje się podstawą orzekania jedności rzeczy. Ciekawy tego przykład odnajdujemy w Pańczawińsiatisabasrice (Pañca-vimśati-sābasrikā-prajñā-pāramitā-sūtra). Sutra stwierdza analogicznie do przywoływanej wcześniej Aszty (AS 13), że bodhisattwa, który zmierza do doskonałości mądrości, opierając się na formie (rūpa) i pozostałych zespołach (skandha), jest niewprawny w użyciu środków (anupāya-kuśala). Zręczny w środkach jest tylko ten, który nie opiera się na formie itd., tzn. ten, który widzi, że nic nie ma samobytu, łącznie z samą mądrością (PVS 1, 140). Zobaczyć, że nic nie ma samobytu, to zobaczyć, że ostatecznie, tzn. jako w sobie określone, nic nie istnieje, w szczególności nie istnieją żadne dharmy (sarva-dharma-avidyamānatva) jako nośniki własnych istotowych jakości. Zatem wszystkie dharmy, jako że są nierozróżnialne (avikalpatva) w oparciu o przynależne im cechy, ostatecznie są takożsame (sarva-dharma-samatā). Na tej podstawie formułowane jest również przekonanie o nierozróżnialności żadnych medytacji oraz o nierozróżnialności medytacji i bodhisattwy (medytacji i przebudzenia) (PVS 1, 145) $)^{160}$.

${ }^{160} \mathrm{~W}$ stwierdzeniach tego rodzaju należy dopatrywać się źródeł twierdzenia Dogena o jedności zazen i przebudzenia. Jedność zazen i przebudzenia jest jed- 
Podkreślić należy z naciskiem, iż pustka nie jest ostateczną rzeczywistością w takim sensie, jak bóg teistów, Jedno neoplatoników czy brahman wedantystów, nie jest gruntem w sensie ontycznej podstawy wszystkiego. Pustka jest ostateczną „jakością" wszelkiego możliwego przedmiotu doświadczenia, tzn. jest faktem nieposiadania domniemanego $\mathrm{w}$ naturalnym nastawieniu samobytu jakiejkolwiek rzeczy odkrywanym na drodze analizy. $\mathrm{Ci}$, którzy przypisują madhjamace mistycyzm (jak np. Matilal) ${ }^{161}$, ten fakt przeoczają, ulegając wedantyczno-neoplatońskim nawykom.

Tak rozumiana pustka nie ma nic wspólnego $z$ ideą nicości. Snucie na jej podstawie porównań między buddyzmem (madhjamaką) a chrześcijańską bądź wedantyczną mistyką jest w punkcie wyjścia skazane na porażkę ${ }^{162}$. W chrześcijańskim doświadczeniu mistycznym nicość pojawia się w dwóch postaciach, obie są spadkiem po tradycji neoplatońskiej (i Filona z Aleksandrii). Po pierwsze nicość Boga, czyli absolutnego bytu, który w swojej doskonałej absolutności wykracza poza pojęcie bytu ukształtowane w świecie codziennego doświadczenia. Będąc ostatecznym gruntem dla wszelkiego istnienia, nicość taka jest nicością nieokreśloności czy też nieokreślonej ponadracjonalności, nicość taka jest faktycznie Nicością. Po drugie nicość stworzenia, które w sobie jest nicością o tyle, o ile nie ma w nim niczego, co nie pochodziłoby od Boga. Jest to nicość $\mathbf{w}$ rozumieniu całkowitej pochodności istnienia. Chrześcijańskie doświadczenie mistyczne jest zwróceniem się ku boskiej Nicości poprzez odkrycie nicości świata.

Pustka madhjamaki jest podstawą wszelkich form w świecie nie w sensie gruntu, w którym zakotwiczony jest byt wszelkich form (rzeczy). Pustka nie jest tu ani nicością jako absolutnym przekreśle-

nością pustki, a nie pełni, jest jednością braku/negatywną, a nie posiadania/ pozytywną.

161 B. K. Matilal, Mysticism and Reality..., s. 220.

162 Niezwykle ciekawy przykład takiej porażki dostarczył: C. D. Sebastian, The Cloud of Notbingness. The Negative Way in Nägärjuna and Jobn of the Cross, New Delhi 2016. 
niem bytu, ani nicością jako nieokreślonością doskonałego absolutnego bytu. Pustka jest bezistotowością rzeczy (form) będącą wyrazem ich wzajemnej zależności/relacyjności. Pustka jest naturą rzeczy w sensie braku wszelkiej natury, tzn. w sensie niebycia określonym od wewnątrz, ze swej własnej strony ${ }^{163}$.

Buddyjskie rozumienie pustki jako niesubstancjalności wszelkiego istnienia nie ma też nic wspólnego $z$ hinduistycznym, tak ważnym $w$ tradycji wedanty rozumieniem pustki jako nieprzejawionym istnieniem Absolutu, a przez to istnieniem niepoznawalnym, zainicjowanym w Rigwedzie w hymnie Nasadija ${ }^{164}$. W idei pustki wyraża się buddyjskie rozumienie istnienia jako relacyjności: rzeczy są tym, czym są poprzez relacje, a nie są w relacji poprzez bycie tym, czym są. Tak rozumiana relacyjność przysługuje wszelkiemu istnieniu. Jest to jeden z powodów, dla których buddyzm odrzuca idę̨ Boga jako w sobie ugruntowanego gruntu wszelkiego różnego od siebie istnienia.

Czytając o ostatecznym, które ma się kryć pod takimi terminami jak paramärtha, tattva, tathatä czy dharmatā, badacze zbyt pochopnie ulegali neoplatońskim nawykom, które skłaniały ich do postulowania transcendencji jako faktycznego desygnatu owych terminów. Wskazując na to, co ostateczne, teksty madhjamaki i sutry doskonałości mądrości faktycznie wskazują na pustkę jako na brak samobytu. Znamienne tego potwierdzenie znajdziemy w Ratnie, która dobitnie określa, jak należy ową takość rozumieć. W RGS XII, 4abc czytamy:

163 Dlatego Tathagate, jak zauważa VC 5, należy widzieć na postawie nie-cech jako cech, czyli na podstawie braku natury jako natury. Czandrakirti tę myśl wyraził wprost: naturą rzeczy jest ich brak natury, tzn. tym, co ostateczne w rzeczach, jest fakt, iż nie posiadają one żadnej natury $w$ rozumieniu esencjalnym, zob. na ten temat W. L. A mes, The Notion of svabhāva in the Thought of Candrakirti, JIP 10/2 (1982), s. 161-177.

$164 \mathrm{Rg}$-veda X, 129, 3. W języku polskim hymn ten przekładany był co najmniej dziewięciokrotnie. Przegląd tłumaczeń, analizę tekstu wraz z własną propozycją translatorską daje: M. K. Byrski, Przekaz tekstów objawionych $i$ normatywnych w ttumaczeniach, czyli praktyka zależnego powstawania, "Przegląd Orientalistyczny" 226-227 (2008), s. 153-172. 
tișthantu loka-vidunām parinirvrtanām sthita eșa dharmata-niyàma śünya-dharmā |

tạm bodhisattva tathatäm anubuddhayanti $[. .$.

Bez względu na to czy mędrcy przebywają w świecie, czy weszli w ostateczną nirwanę, owa natura rzeczy [tj. dharmiczność] (dharmatä) pozostaje wykazana: „Dharmy są puste”. To jest owa takość (tathatā), którą pojmują bodhisattwowie.

Zatem jeżeli w ogóle możemy mówić z perspektywy nauki o pustce, że rzeczywistość jest niedualna (advaya), to nie w sensie substancjalnej tożsamości wszelkiego bytu, lecz w sensie jego esencjalnej takożsamości. Wszystko, co jest bądź może być dostępne w naszym doświadczeniu, w ten sam sposób pozbawione jest samobytu. Tak radykalne zaprzeczenie samobytu ma zdaniem wielu krytyków madhjamaki prowadzić do ekstremalnych konsekwencji - do nihilizmu. Badacze głoszący mistyczną wykładnię myśli madhjamaki wmawiają nam jednak, że lekarstwem na domniemany jej nihilizm jest absolutyzm. W ich opinii negatywna droga madhjamaki jest radykalna, ale tylko w dążeniu do ukrytej prawdy pełni bytu. Badacze ci nie chcą dostrzec, iż Nagardżuna w zgodzie z wczesnymi buddyjskimi intuicjami powtórzonymi w literaturze doskonałości mądrości twierdził, że obie postawy - nihilizm i absolutyzm - są objawami tej samej choroby, z której leczyć miała nauka o pustce.

Mistyczna apofaza kosztem ,jest" predykatywnego afirmuje ,jest" egzystencjalne (tj. boga, dla którego najodpowiedniejszym sposobem samoidentyfikacji jest oświadczenie „jestem, który jestem”; byt doskonały; absolut jako czyste bycie). Stwierdzenie, iz absolut nie jest bytem ani niebytem, znaczy w tym wypadku tyle, że nie jest określony, gdyz w swoim byciu wyprzedza wszelkie określenie. Postawa Buddy oraz madhjamaki jest radykalnie odmienna. Środkowa droga unika nie tylko ,jest" predykatywnego, ale też egzystencjalnego, jest wyjściem poza postawę tetyczną, jak wykazywałem w pierwszej części tej książki ${ }^{165}$.

${ }^{165}$ Por. M. D'A mato, Buddhism, Apophasis, Truth, Nournal for Cultural and Religious Theory" 9/2 (2008), s. 17-29. 


\subsection{Sens milczenia w madhjamace}

W tym miejscu musimy jednak zapytać, czy nauka o pustce jako o ostatecznym stanie rzeczy jest $\mathbf{w}$ ogóle wyrażalna. W kontekście różnych stwierdzeń sugerujących niewyrażalność buddyjskiej nauki czy też wręcz postulujących zachowanie milczenia w obliczu ostateczności, pytanie to nabiera szczególnej wagi.

W Sutrze diamentowej Budda oznajmił Subhutiemu (VC 7):

yo 'sau tathagatena dharmo desitab, agrabyab so 'nabbilapyab, na sa dharmo nädharmạ |

Ta dharma, nauczana przez Tathagatę, jest nieuchwytna (agrabya), jest niewyrażalna (anabbilapya). Nie jest to ani dharma ani nie-dharma.

Przekonanie o niemożliwości wysłowienia dharmy powtórzył Czandrakirti. W Prasannapadzie po stwierdzeniu, że własna natura (svarüpa) ani istnieje, ani nie istnieje, oznajmił, iż „na zasadzie konwencji i poprzez przypisanie mówimy, że "rzeczy istnieją», aby rozwiać u ludzi lęk" (tathāpi śrotrṇamuttrāsaparivarjanārtham samurtyā samāropya tadastīti brümaḅ; PP 264.4). W swoim postępowaniu - dodaje Czandrakirti, cytując niezidentyfikowaną sutrę - madhjamikowie postępują za Czcigodnym, który miał oznajmić (PP 264.6-7):

anakșarasya dharmasya śrutiḅ ka deśanā ca ka $\mid$ śrūyate deśsyate cäpi samarropad anakșarạ \|

Jak można przyswoić niewystowioną (anakșara) dharmę? Jak można nauczyć niewysłowionej dharmy? Niewystowiona prawda jest przyswajana i nauczana dzięki przypisaniu (samaropa).

Odpowiedź na pytanie o to, co znaczy, że nauka jest niewysłowiona, pokrywa się z odpowiedzią na pytanie o to, jaki jest sens milczenia w madhjamace. Aby się do niej zbliżyć, powinniśmy sobie w pierw- 
szym rzędzie uświadomić, że milczenie ze względu na kontekst, w jakim się pojawia, nie zawsze znaczy to samo. Uwzględniając to, proponuję roboczo wyróżnić i rozważyć cztery idee milczenia.

Milczenie (uświadomionej) niewiedzy - to milczenie, wskazujące na nieznajomość odpowiedzi. Milczę, gdyż uświadamiam sobie, że odpowiedź nie jest mi znana. Jego warunkiem jest zrozumienie pytania.

Milczenie sceptyka - milczenie to jest skutkiem decyzji o zawieszeniu wszelkich sądów na temat rzeczy ze względu na skonstatowanie niemożliwości rozstrzygnięcia prawdziwości ani fałszywości żadnego sądu asertywnego oraz sprzecznego $z$ nim sądu negatywnego. Jest ono wyrazem fundamentalnych ograniczeń poznawczych człowieka. Człowiek w swoim poznaniu nie jest w stanie wyjść poza sferę własnych, tj. subiektywnych wrażeń i doznań, a tym samym poza sferę mniemań. Milczenie to jest ostateczną konkluzją wypływającą z analizy zdolności poznawczych człowieka. Konsekwentny sceptyk powinien całkowicie milczeć na temat wszelkiego bytu różnego od jego własnych wrażeń. Za swoistą wersję takiego milczenia należałoby uznać milczenie postmodernisty (poststukturalisty, dekonstrukcjonisty), o ile ten w imię względności wszelkiej prawdy uznałby za stosowne zaprzestać wieszczenia owej „prawdy”166.

Milczenie mistyka - milczenie to wskazuje na całkowicie nieempiryczny charakter bytu transcendentnego. Tylko pozornie przypomina ono milczenie sceptyka. Bardziej niż świadectwem niemożliwości poznawczych człowieka jest ono wyrazem pozapojęciowej natury bytu transcendentnego. Rozpoznanie owej pozapojęciowej natury dokonuje się $\mathrm{w}$ procesie poznawczym skupionym na świecie poznawczo dostępnym, czyli świecie rzeczy. To rozpoznanie natury świata rzeczy każe nam uznać istnienie owej transcendencji jako ostatecznego gruntu dla świata rzeczy, w którym zakorzeniony jest byt

166 Zob. A. Szahaj, Teksty na wolności, „Kultura Współczesna” 2 (1993), s. 11-12. 
owego świata. Zatem mistyk wie coś istotnego o tym absolucie, wiedzę tę czerpie z poznania natury świata i analizy możliwości istnienia świata obdarzonego taką naturą. Milczenie mistyka jest nie tyle wyrazem słabości poznawczej człowieka, jego poznawczych ograniczeń, co nadzwyczajnego charakteru bytu absolutnego, „nadzwyczajnego”, czyli takiego, który przekracza zdefiniowaną empirycznie zwyczajność. Zatem mistyk wie wiele więcej od sceptyka. Wie, że absolut istnieje i wie, jaki i czym on nie jest. Milczenie mistyka jest najlepszym znakiem tego, co niewyrażalne. Każde inne słowo bowiem, ze względu na skończoność swojego znaczenia, użyte jako znak doświadczenia mistycznego musi ograniczyć treść tego doświadczenia.

Czwartą formą milczenia, różną od trzech wymienionych, jest milczenie madhjamika. Nim się teraz zajmiemy.

Twierdzę, że cechująca madhjamika rezerwa w stosunku do językowej artykulacji doświadczeń nie wynika z przyrodzonej ułomności języka niezdolnego do ujęcia Tajemnicy absolutnego Bytu, tylko z przeświadczenia, że każda, nawet trafna, tj. prawdziwa artykulacja językowa może stać się przedmiotem egoistycznego lgnięcia. Prawdziwy sąd o rzeczywistości, w przypadku madhjamaki sąd o pustce wszystkich rzeczy, może być tak samo podstawą szkodliwego lgnięcia, jak sąd fałszywy. Nagardżuna myśl tę wyraził, przyrównując sytuację niewłaściwego zrozumienia pustki do złego, niewprawnego uchwycenia żmii (MMK XXIV, 11). Problemem dla madhjamaki jest egotyczna postawa poznającego umysłu, a nie niewystarczalność czy też ułomność języka.

Wypada dodać, iż nie jest to jakaś szczególna cecha teorii madhjamaki. Jest to przekonanie utrwalone $w$ tradycji buddyjskiej na długo przed Nagardżuną. Zgrabną jego ilustrację znajdziemy choćby w Dhammapadzie, gdzie stwierdza się paradoksalnie, iż wiedza rozsadza głowę gtupca (DhP 72). Paradoks polega na tym, że przecież zgodnie $z$ naturalnym buddyjskim dążeniem do poznania prawdziwego w przekonaniu, iż ono wyzwala, wiedza powinna zmienić głupca w mędrca. Ona jednak działa na jego szkodę, czyli dostarczając mu 
pożywki dla trwalszego pogrążenia się w głupocie. Oczywiście nie jest to „wina” wiedzy, tylko samego głupca, jego niezdolności do jej właściwego, zgodnego $\mathrm{z}$ jej treścią ujęcia. Przekonanie o posiadaniu prawdy, o byciu jej depozytariuszem, pycha z jej posiadania są najbardziej subtelnymi formami egotyzmu, na które wskazuje buddyzm, i sądzę, że jednymi z najbardziej szkodliwych, a przynajmniej jednymi $\mathrm{z}$ najtrudniej usuwalnych ${ }^{167}$.

Wsparcie dla takiej wykładni postawy madhjamaki znajdziemy też w Aszcie. W prowadzonej w pierwszym rozdziale tego tekstu dyskusji między Buddą, Subhutim i Siariputrą pojawia się kwestia określania bodhisattwy mianem "wielkiej istoty”, tj. mahasattwy. Zostaje tam ustalone, że na miano to zasługuje tylko ten, który nie lgnie, nie przywiązuje się ani do myśli o przebudzeniu, ani do myśli o wszechwie$\mathrm{dzy}$, ani do innych doskonałych jakości. Myśl do niczego nie lgnąca stwierdza się tam - jest myślą, która myślą nie jest (cittam acittam). Co niezwykle ważne, w stanie owego braku myśli, owej „bezmyślności", czyli zupełnego nielgnięcia, a więc w stanie doskonałej upekszy nie pojawia się nawet myśl „istnieje” ani „nie istnieje” (AS 20) ${ }^{168}$.

Ustalenie to jest ważne dlatego, iż Aszta nawiązuje tutaj do znacznie wcześniejszego tekstu, mianowicie do Katjajanasutry/Kaczczanagottasutty zachowanej, jak zwracałem uwagę, w wersji sanskryckiej (NidSa 19) i palijskiej (SN II, 16-17). Jest to, powtórzmy, jedyny kanoniczny tekst buddyjski, do którego wprost $\mathrm{z}$ tytułu odwołuje się sam Nagardżuna w MMK. Dlatego sądzę, że filozofię madhjamaki nie

$167 \mathrm{Na}$ tle licznych przypowieści i uwag analogicznych do tej z Dhammapady łatwo dostrzec intelektualne impulsy, które popychały buddyjską refleksję z jednej strony w kierunku idei zręcznych środków, z drugiej zaś w kierunku idei bodhisattwy $\mathrm{z}$ jego ślubowaniem powstrzymania się od wejścia w ostateczną nirwanę.

168 Ratna dodaje w tym kontekście, że kto nie lgnie, musi porzucić wszystkie nazwy (RGS I, 27). W strofie II, 11 dodaje w podobnym duchu, że "postrzeżenia to tylko słowa" (samjñeti nama), a ci, którzy się ich wyzbyli, osiągnęli doskonałość (päramita). 
tylko można, ale wręcz należy odczytywać przez pryzmat przesłania zawartego w tej sutrze.

Nie wdając się w szczegóły, przypomnimy tylko, że w tekście tym w odpowiedzi na pytanie Katjajany Budda określa parametry właściwego poglądu (s. samyag-driști / p. sammā-dițthi). Właściwy pogląd to taki, w którym unika się orzekania dwóch ekstremów bytu/ istnienia i niebytu/nieistnienia. W pułapkę owego przeciwstawienia bytu i niebytu wpada się za sprawą egotycznego lgnięcia do przedmiotów doświadczenia codziennego. Widzący właściwie, jak przebiega łańcuch przyczynowego warunkowania, w którym nie ma miejsca na trwałą jaźń, unikają owej pułapki, kroczą środkową drogą. Istotne w tym tekście jest to, że Budda wiąże żywienie przekonania o bycie/ niebycie z postawą lgnięcia i sugeruje, iż widzenie rzeczy, jakimi one są, może się dokonać tylko w stanie całkowitego nielgnięcia, upekszy.

Dopiero w tym kontekście możemy uchwycić sens pozornie prostego przesłania Nagardzuny z MMK XV, 10:

astiti śásvata-grabo nästity uccheda-darsanam | tasmād astitva-nastitve nāśrīyeta vicaksanạ̣ \|

[Stwierdzenie] „istnieje” to pogląd eternalizmu. [Stwierdzenie] „nie istnieje” to pogląd anihilacjonizmu. Dlatego mędrzec nie powinien obstawać przy istnieniu i nieistnieniu.

Nagardżuna nie mówi tu niczego, czego nie bylibyśmy w stanie wyczytać z przywołanych tekstów sutrowych. Obstawanie przy istnieniu bądź nieistnieniu jest wyrazem lgnięcia, ugruntowanego w błędnym oglądzie rzeczy.

Jeszcze dobitniej i klarowniej stwierdza to jego uczeń Arjadewa. W Czterystu strofach pisze (CŚ VIII, 7):

násúnyam śünya-vad drștam nirvanạ̣ me bhavatviti | mithyā-drșțer na nirvānạm varnayanti tathägatāḅ $\|$

Niepustego (ásúnya) nie należy uważać za puste (śūnya), [tylko z powodu pragnienia:] "Obym osiągnąt nirwanę". Tatha- 
gatowie głoszą, że nirwany nie [osiąga się] dzięki błędnemu poglądowi.

Dlaczego Arjadewa oznajmia, że niepustego nie należy uważać za puste, skoro madhjamaka głosi właśnie, że wszystkie rzeczy są puste? Czym w ogóle miałoby być to niepuste, skoro wszystko jest puste? Dlaczego twierdzenie, że rzeczy są puste, zostaje tutaj uznane za błędny pogląd, który nie zbliża do nirwany? Otóż w strofie tej uczeń Nagardżuny podkreśla, że racją dla takiego orzekania nie może być pragnienie osiągnięcia nirwany, czyli lgnięcie do myśli o nirwanie. W tym wypadku błąd nie polega na głoszeniu poglądu niewłaściwego co do treści, tylko na niewłaściwym stosunku do poglądu, który $\mathrm{z}$ perspektywy madhjamaki w ramach reguł określających funkcjonowanie sansary jako błędu poznawczego trafnie ujmuje stan rzeczy. Problemem dla Arjadewy jest motywacja stojąca za poglądem, nie jego treść. Nikt nie jest $\mathrm{w}$ stanie zmusić się do tego, aby zmienić tezę naturalnego nastawienia, tj. aby uważać za puste rzeczy, które w naturalnym nastawieniu dane nam są jako obdarzone samobytem. Wyzwolenia nie osiąga się wolą, nie osiąga się decyzją, nie osiąga sį̨ wreszcie intencją, chociaż ta odgrywa niezwykle ważną rolę w buddyjskiej praktyce duchowej. Wyzwolenie osiąga się wiedzą uzyskaną poprzez bezpośredni ogląd rzeczy, jakimi one są. Rozpoznanie stanu rzeczy ma znosić potrzebę domniemywania, ma znosić potrzebę poszukiwania i przedstawiania sobie, gdyż trwale usuwa lgnięcie. Nie lgnąc, przebudzony milczy. Milczy nie dlatego, że chce milczeć, tak jak niektórzy asceci składający śluby milczenia, którzy przedstawiają sobie milczenie jako właściwy sposób postępowania, tylko dlatego że nie ma potrzeby mówić, nie ma już bowiem niczego, o czym chciałby samemu sobie jeszcze opowiedzieć. Przestał tworzyć świat. Jedyne, co może jeszcze zrobić, to powiedzieć innym, jak przestać tworzyć świat. Żeby mógt im to jednak powiedzieć, musi powrócić do ich świata poprzez język, który nie jest już jego.

Wypowiedź Arjadewy dostarcza doskonałego narzędzia do interpretacji innego słynnego stwierdzenia Nagardżuny, które już przy- 
woływałem, pochodzącego z Odwrócenia krytyki (Vigraba-vyāvartanī) o nieposiadaniu własnych poglądów. W VV 29 Nagardżuna stwierdził:

\section{yadi kācana pratijñã syān me tata eșa me bhaved doṣaḅ | nāsti ca mama pratijūã tasmān naivästi me doșab ॥}

Gdybym głosił jakąś tezę (pratijña), wtedy popełniałbym błąd. Jednakże nie posiadam żadnej własnej tezy, dlatego nie popełniam błędu ${ }^{169}$.

Nie głosić żadnej tezy, nie mieć poglądu, to nie znaczy nie mieć niczego do powiedzenia, nie mieć żadnej propozycjonalnej treści do przekazania. Nie posiadać poglądu, to znaczy, jak już wskazywałem, nie mieć egotycznego odniesienia do poglądu. Nagardżuna przyznaje, że żaden pogląd nie jest jego, żadnego nie nazywa „swoim”, z żadnym nie tworzy emocjonalnej więzi. Nie głosi natomiast, że żadnemu sądowi nie można przypisać wartości prawdy lub fałszu. Wszak sam za prawdziwy uznaje sąd o pustce. Pamiętać jednak musimy, jeszcze raz to podkreślę, że uznawanie za prawdę lub fałsz dokonuje się w ramach wewnętrznych reguł sansary. Rzeczywistość, do której odnosi się sąd, jest rzeczywistością sansarycznego doświadczenia. Gdy sąd prawdziwie orzeka pustkę rzeczy, to owa pustka jest tym, co ostatecznie moż-

169 Również w tym wypadku Nagardżuna pozostaje wierny wcześniejszej, ogólnobuddyjskiej tradycji. Bez wątpienia bowiem, za taką antycypacje jego postawy uznać można stwierdzenie z Dbammapady, że przebudzony, czyli arabant (s. arbant), nie ma wierzeń (p. assaddba) (DhP 97). Stwierdzenie to głosi, jak później czyni to Nagardżuna, że przebudzony nie pozostaje z żadnymi przekonaniami, z żadnymi poglądami w relacji egotycznej, o żadnym poglądzie nie może powiedzieć „mój”. Nie oznacza to jednak, że przebudzony nie ma niczego prawdziwego do powiedzenia na temat rzeczywistości. Wszystko jednak, co mówi, mówi w oparciu o widzenie rzeczy, jakimi one są, a nie w oparciu o mniemanie, przeświadczenie, czy też zaufanie. Dodam jeszcze tylko, że Matilal w wypowiedziach takich jak ta z VV 29 widział potwierdzenie przypuszczenia, ze madhjamaka jest mistycyzmem, zob. B. K. Matilal, The Logical Illumination of Indian Mysticism, [w:] Mind, Language and World. The Collected Essays of Bimal Krishna Matilal, ed. J. Ganeri, New Delhi 2002, s. 45. 
na powiedzieć o rzeczach doświadczenia na podstawie analizy owych przedmiotów i opisującego je języka, nie jest zaś deskrypcją transcendentnej wobec owych rzeczy realności. Żadnej pustki poza rzeczami i obok rzeczy po prostu nie ma.

Przyznając się do nieposiadania poglądów, autor MMK przedstawia siebie jako osobę przebudzoną. Drugorzędną sprawą pozostaje, czy mu w to uwierzymy. Nie ma znaczenia, czy Nagardżuna jest przebudzony, czy tylko kreśli ideał przebudzonego. Istotne jest to, że prezentowana postawa w niczym nie przypomina ani sceptycyzmu, ani mistycyzmu.

Zatem powiedzmy to dobitnie. Rezerwy madhjamaki w stosunku do języka nie należy interpretować w ten sposób, iż bierze się z tego, że doświadczenie rzeczy, jakimi one są, ujawnia ich pustkę (śūnyatā) "będącą podstawą wszelkich form w świecie", tożsamą z "nicością", „z której wszystko zostało powołane do bycia - mocą, której można dać imię: Nic jak Bóg"170. Pustki nie można interpretować jako Nicości, jako Tajemnicy Boga, jako nieokreśloności boskiego czy też absolutnego bytu. Interpretacja taka sprowadza naukę madhjamaki do formy negatywnej teologii, z którą nie ma ona nic wspólnego.

Rezerwa madhjamaki wobec języka manifestująca się w preferowaniu negatywnych określeń „takości”, odmowie uznania wykluczających się atrybucji, afirmacji milczenia jako najdoskonalszej postawy względem rzeczywistości jest świadectwem świadomości niebezpieczeństwa egotycznego lgnięcia do przekonań w języku wyrażonych. Rozpoznanie pustki, jako negatywnej własności rzeczy, co równoważne jest $z$ widzeniem rzeczy, jakimi one są, stanowi jedyny sposób zdaniem madhjamików - aby się przed tym niebezpieczeństwem uchronić.

Musimy zdać sobie sprawę, że milczenie nie zawsze "mówi” to samo. Jego sens ujawnia się tylko w szerszym kontekście afirmowanych i negowanych przekonań. Jeżeli chcemy zatem zrozumieć, co

${ }^{170} \mathrm{~J}$. Bolewski, Daleki Wschód na Zachodzie. Od reinkarnacji do regeneracji, Kraków 2006, s. 187. 
mówi milczenie madhjamików, musimy wsłuchać się w słowa, które je poprzedzają ${ }^{171}$.

Podsumujmy więc. Milczenie madhjamika - owo milczenie szlachetnego (arjānămi tūṣnìm-bhāvậ) zalecane przez Czandrakirtiego nie ma nic wspólnego ani z milczeniem sceptyka, ani mistyka, ani tym bardziej $z$ milczeniem (uświadomionej) niewiedzy. Milczenie to wyraża stan doskonałej równowagi umysłu, upekszy, stan doskonałego nielgnięcia, w którym nic nie pozostaje już do powiedzenia. Ale nie pozostaje nie dlatego, że nie ma już co powiedzieć, lecz dlatego, że nie ma już po co mówić. W sytuacji tej jedynym powodem zabierania głosu w jakiejkolwiek sprawie może być wyłącznie potrzeba niesienia pomocy innym utrwalona karmicznie poprzez złożenie ślubów bodhisattwy.

\subsection{Dlaczego poznawcze doświadczenie jogiczne nie jest doświadczeniem mistycznym?}

Buddyjskie doświadczenie nie odsyła do jakiejś tajemniczej Nicości przez odkrycie nicości stworzenia. Buddyjskie doświadczenie jogiczne

171 Milczenia madhjamika nie można rozpatrywać w oderwaniu od kwestii milczenia Buddy. Na ten temat zob. T. W. Organ, The Silence of the Buddha, PEW 4/2 (1954), s. 125-140; G. Nagao, The Silence of the Buddha and its Madbyamic Interpretation, [w:] idem, Mädbyamika and Yogäcära. A Study of Mabãyana Pbilosophies, ed. and trans. L. S. Kawamura, Albany 1991, s. 35-49; J. I. Cabezo n, Ineffability and the Silence of the Buddha, [w:] ide m, Buddhism and Language. A Study of Indo-Tibetan Scbolasticism, Albany 1994, s. 171-187; A. Vélez de Cea, The Silence of the Buddha and the Questions about the Tathdgata after Death, "The Indian International Journal of Buddhist Studies" 5 (2004), s. 119-141; K. Park, An Analysis of the Buddha's Paradoxical Silence. Neither the Positive nor Nibilistic View, "International Journal of Buddhist Thought \& Culture" 6 (2006), s. 243-264; J. Ganeri, The Concealed Art of the Soul. Theories of Self and Practices of Truth in Indian Ethics and Epistemology, Oxford 2007, s. 39-60. 
przynajmniej do czasów madhjamaki jest doświadczeniem tej samej rzeczywistości, o której prawda dostępna jest $\mathrm{w}$ racjonalnej analizie filozoficznej. Istotą buddyjskiego medytacyjnego, jogicznego („mistycznego") doświadczenia nie jest odsyłanie człowieka do Tajemnicy, tylko takie uprzystępnianie dostępnej inną drogą prawdy, które ma moc przemiany istnienia sansarycznego $w$ istnienie nirwaniczne poprzez wykorzenienie zalążków owego zafałszowanego sposobu istnienia mających charakter szkodliwych nawyków umysłowych.

Trzy rodzaje mądrości (prajñā) wyróżniane w buddyzmie nie dotyczą różnych sfer istnienia, nie dotyczą różnych postaw względem istnienia absolutnego/boskiego, lecz różnych form generowania mądrości: poprzez słuchanie (śruta-mayī), namysł (cintā-maȳi ) i medytacje (bhãvanā-mayī ${ }^{172}$. W swojej treści te trzy rodzaje mądrości nie różnią się od siebie, są jedną mądrością. Buddyjska medytacja zatem nie jest jakimś niezwykłym fundamentem, bez którego filozoficzne rozważania buddyjskie, np. na temat niejaźni, pozostają teorią, która nie tylko szkodzi, ale też nie jest w pełni racjonalna, jak sugerują niektórzy autorzy ${ }^{173}$. Buddyjska medytacja nie ujawnia jakiegoś ukrytego ontycznego dna niedostępnego buddyjskiej racjonalnej analizie, jakiegoś obszaru, „do którego rozum ze swoim światłem sięga tylko częściowo"174. Filozoficzna teoria, nawet będąc prawdziwa, może być szkodliwa o tyle, o ile może stać się $\mathrm{w}$ swoim werbalnym wyartykułowaniu przedmiotem lgnięcia, które wzmacnia poczucie ego. Poznanie medytacyjne przekształca medytującego w ten sposób, iż owa szkodliwa postawa lgnięcia nie może się pojawić. Dzięki temu takie poznanie wyzwala.

172 Podział ten jest powszechnie znany w tradycji buddyjskiej i przywoływany przez przedstawicieli różnych szkół, np. zarówno przez Wasubandhu (Abbidharma-kosa), jak i Kamalasile (Bhavana-krama).

${ }_{173} \mathrm{~J}$. Bolewski, op. cit., s. 149.

174 Ibidem. Zob. takie A. C. Klein, Mental Concentration and the Unconditioned. A Buddhist Case for Unmediated Experience, [w:] Patbs to Liberation. The Marga and Its Transformations in Buddhist Thought, ed. R. E. Buswell, R. M. Gimello, Honolulu 1992, s. 269-308. 
Wartość wglądu poznawczego uzyskanego na drodze medytacji nie wyraża się w tym, iż udostępnia on nową, doskonałą, ostateczną, w inny sposób niedostępną prawdę o rzeczywistości, tym bardziej nie wyraża się w tym, iż uchwytuje on inną, ukrytą pod mnogością zjawisk doskonalszą rzeczywistość, tylko w tym, iż trwale usuwa te czynniki umystowe o charakterze nawyków, które konstytuują naszą sansaryczną postawę wyrażającą się w egoistycznym lgnięciu wyrastającym z przedświadomego przeświadczenia o ostatecznej, w nich samych ufundowanej realności przedmiotów doświadczenia. To przeświadczenie nazwałem za Edmundem Husserlem "generalną tezą naturalnego nastawienia”. Pod tym względem postawa madhjamaki jest zgodna z postawą całej tradycji abhidharmicznej. Novum madhjamaki polega wyłącznie na tym, iż kładzie ona skrajnie intensywny nacisk na de-substancjalizację rzeczywistości przedmiotowej. Madhjamaka utrzymuje, iż dla uzyskania doskonałej równowagi umysłu (upekszy) wstępna de-substancjalizacja podmiotu poprzez rozłożenie go na skandhy (i dharmy) nie wystarcza.

Buddyjskie doświadczenie medytacyjne jest zatem inną formą poznania tej samej prawdy, która dostępna jest na drodze racjonalnej analizy. W przypadku madhjamaki można powiedzieć, że praktyka medytacyjna służy doskonaleniu owej analizy czy też, że wręcz ją stanowi.

Porównanie do fenomenologii Husserla uważam za wartościowe i nośne. Sytuacja, jaką opisuje madhjamaka, zdaje się być tą samą, która stanowi punkt wyjścia refleksji niemieckiego filozofa. Podkreślić jednak należy, że tam, gdzie Husserl zaczyna, tam madhjamaka kończy. Husserl sądzi, że aby zbudować obiektywną wiedzę, należy dotrzeć do tego dotychczas nieodkrytego miejsca, w którym dokonuje się sama konstytucja przedmiotu poznania. Temu ma służć redukcja fenomenologiczna, która w postaci epochē jest zawieszeniem obowiązywania tezy naturalnego nastawienia, czyli przeświadczenia o realności doświadczanych przedmiotów. Gdy ją przeprowadzimy, otworzy się nowy, dotychczas niezbadany obszar poznawczy. 
Z perspektywy madhjamaki projekt Husserla jawi się jako skrajnie naiwny. Niemiecki filozof traktuje błąd poznawczy jako coś, co nam się przytrafia. Co prawda do czasów Husserla przytrafiało się zawsze, ale dalej tylko przytrafiało. Madhjamaka zaś w zgodzie z całą poprzedzającą ją tradycją buddyjską uznaje, że błąd poznawczy jest tym, co nas konstytuuje jako poznające błędnie podmioty, jest tym, co funduje naszą sansaryczną empiryczną egzystencję. Zawiesić generalną tezę naturalnego nastawienia to z perspektywy madhjamaki zmienić naszą kondycję z sansarycznej na nirwaniczną. Husserl postuluje, aby zrobić to aktem teoretycznej decyzji1 ${ }^{175}$. Mówiąc językiem buddyjskiej teorii medytacji, Husserl wierzy, że do osiągnięcia upekszy wystarcza czysta intelektualna operacja.

Husserl jest jednym $\mathrm{z}$ wielu europejskich myślicieli mających swojego patrona w Kartezjuszu, którzy poznawczą praktykę wyrywali z praktyki życiowej. Wierzyli, iż proces poznawczy można skutecznie odizolować od umysłowych sił wpływających na charakter i jakość naszej życiowej praktyki, czyli na nasze zachowania, wybory, reakcje emocjonalne, skłonności itd., gdyż proces ten jest domeną odmiennej umysłowej/psychicznej władzy. Wyrwanie praktyki poznawczej z praktyki życiowej wiąże się z nadaniem temu obszarowi naszej osoby, który ową praktykę poznawczą funduje, czyli świadomości, szczególnego, wyróżnionego ontycznego statusu.

Rację mieli wszyscy ci krytycy koncepcji epochē, którzy dowodzili, iż spycha ona Husserla na stanowisko idealizmu, przesądzając na wstępie o nadzwyczajnym i nadrzędnym sposobie istnienia świadomości, o jej absolutności ${ }^{176}$.

Warto zwrócić na ten fakt uwagę, gdyż analogiczny proces zaobserwować można w późnym indyjskim buddyzmie. To samo zdają się robić zwolennicy literalnie pojmowanej idei tathagatagarbhy (tathägata-

175 E. Husserl, op. cit., s. 88-92.

176 Zob. np. R. Ingarden, Wstep do fenomenologii Husserla, thum. A. Półtawski, Warszawa 1974, s. 221-224. 
-garbha), którzy utożsamiają dobrze ugruntowaną w abhidharmicznej teorii dharm, wręcz naturalną dla tej teorii i nie budzącą wielkich kontrowersji idę̧ czystości świadomości z przekonaniem o jej absolutnym statusie ontycznym.

Te ogólne rozważania chciałbym zakończyć odniesieniem do współczesnego japońskiego autora buddyjskiego, który uzyskał popularność nie jako filozof, lecz jako mistrz duchowy tradycji soto zen, Shunryu Suzukiego. Mimo deklarowanej rezerwy w stosunku do wszelkiej filozofii, w tym także filozofii buddyjskiej, co pozostaje w zgodzie z potocznymi wyobrażeniami na temat postawy zen, stwierdza on z jednej strony: „Filozofia buddyjska jest tak uniwersalna i logiczna, że nie jest to filozofia buddyzmu, ale samego życia", z drugiej zaś zauważa: „W niektórych wypadkach buddyzm skłania się do polemiki [...], bowiem buddyści muszą zabezpieczyć swoją drog̨̨ przed mistycznymi czy magicznymi interpretacjami religii" ${ }^{177}$.

Filozoficzna wykładnia nie jest kwestią wtórną, co sugeruje wielu badaczy doświadczenia mistycznego. Zabezpieczając drog̨ każdej praktyki duchowej (religii), jest ona znakiem różnicy nie tylko filozoficzno-teologicznych interpretacji, ale także, a może przede wszystkim, różnicy samych doświadczeń leżących u podstaw owych wykładni ${ }^{178}$. Dla osiągnięcia przebudzenia istotne jest bowiem nie tylko jak się doświadcza/wierzy, ale także czego się doświadcza / w co się wierzy.

177 Sh. Suzuki, Umyst zen, umyst początkujacego, thum. J. Dobrowolski, A. Sobota, b.m. i r.w., s. 121.

178 W kontekście tych uwag warto sięgnąć do: M. T. Kapstein, Retbinking Religious Experience. Seeing the Light in the History of Religions, [w:] The Presence of Light. Divine Radiance and Religious Experience, ed. M. T. Kapste in, Chicago-London 2004, s. 265-299. 



\section{Uwagi końcowe}

W otwierających słowach niniejszej książki zwracałem uwagę na napięcie, jakie ujawniło się u samych źródeł filozoficznego myślenia w Grecji, między ideą istnienia/bytu a nieistnienia/niebytu. W Helladzie jego wyrazicielami byli Parmenides i Gorgiasz. Analogiczne napięcie, aczkolwiek ubrane w odmienne historyczne szaty, uwidoczniło się również w najstarszym filozoficznym tekście kultury indyjskiej, który początku wszystkiego doszukiwał się w stanie tak doskonałym, iż poprzedzać miał zarówno niebyt, jak i byt.

Budda uznał owo napięcie za konstytutywne dla naszego codziennego doświadczenia, a tym samym za powiązane $z$ zasadniczą jego cechą, jaką jest tzw. cierpienie. Błąd poznawczy wyraża się w traktowanym jako naturalne poczuciu istnienia. Bergson wykazywał, że pojęcie nicości, będąc wtórnym wobec naturalnego i pierwotnego pojęcia istnienia/bytu, jako wewnętrznie sprzeczne jest pojęciem pozornym. Absolutnej nicości nie jesteśmy w stanie w żaden sposób sobie przedstawić. Myśleć możemy jedynie niebyt względny, wykreślając z naszego doświadczenia wcześniej dany konkretny byt.

Budda wykazywał, a za nim czyniła to późniejsza tradycja madhjamaki, że nie mniej problematyczne jest myślenie bytu. Wszelkie bowiem myślenie bytu jest myśleniem istnienia czegoś, a zatem ufundowane jest na tożsamości, na przekonaniu o byciu wewnętrznie określonym. Tak jak nie sposób myśleć czystego nieistnienia, tak też nie sposób myśleć czystego istnienia. Myślenie czystego istnienia jest bowiem myśleniem istnienia niczego. Budda zgodziłby się zapewne, 
ze czysty byt i czyste nic są tym samym, ale nie w sensie heglowskiej syntezy, tylko w sensie własnej nauki o niejaźni, zgodnie z którą obie kategorie są wyrazem tego samego problemu, tej samej choroby.

$\mathrm{Z}$ jeszcze jedną klasyczną opinią wysłowioną przez Parmenidesa i podjętą przez Hegla Budda skłonny byłby się zgodzić, choć i w tym wypadku nadałby jej własny sens. Głosi ona, że byt i myśl są jednością. Dla Przebudzonego stwierdzenie to znaczy tyle, że wszelkie istnienie ugruntowane jest w myśleniu istnienia samego siebie. Sprowadza sį̧ to do przekonania, że u podstaw myślenia istnienia leży poczucie własnego „ja”, które jest paradygmatyczne dla myślenia istnienia. Myślenie bytu zatem, jak też i myślenie niebytu w punkcie wyjścia jest myśleniem egotycznym. Innymi słowy, jest myśleniem, które ze swej natury wyraża się w przeciwstawnych formach pragnienia - w żądzy i awersji. Stany te mają charakter kognitywny, a nie tylko psychologiczny, są przedświadomymi manifestacjami postaw afirmujących istnienie i nieistnienie. Dlatego dążenie do wyzwolenia, które wiąże się z koniecznością wyzbycia się pragnienia, wiąże się także z koniecznością zaniechania myślenia w kategoriach bytu i niebytu.

Postulat porzucenia bytu i niebytu sprowadził na Buddę zarzut nihilizmu. $Z$ perspektywy jego adresata zarzut ten czerpie swoją wartość $\mathrm{z}$ afirmacji obiektywnego istnienia. Wyraża się w nim przekonanie, że mimo tkwienia w fundującym nasze doświadczenie błędzie poznawczym samo istnienie ujmujemy w sposób wolny od tego błędu. Mamy tutaj do czynienia z sytuacją zaskakująco podobną do dylematu Kartezjusza: jak obronić się przed powszechną iluzją? Francuski filozof uznał, jak pamiętamy, że bastionem, nad którym iluzja nie jest w stanie zapanować, jest świadomość istnienia własnego „ja”. W świadomości tej dana nam jest pierwotna intuicja istnienia. Budda uznałby, że Kartezjusz wydobył tylko na powierzchnię świadomości najgłębszą strukturę naszego doświadczenia istnienia - doświadczać istnienia to w pierwszym rzędzie doświadczać istnienia własnego „ja”. To jest powód, dla którego twórca buddyzmu tak wiele uwagi poświęcił kwestii domniemanego istnienia jaźni. 
Odpowiedzią na ugruntowane w poczuciu własnej indywidualności pojęcia istnienia i nieistnienia, a tym samym na zarzut nihilizmu, jest nauka o środkowej drodze. W mowie do mnichów noszącej znamienny tytuł Kazanie do dziedziców dbammy (Dhamma-dāyāda-sutta; MN I, 12-16) Budda oświadczył (MN I, 15):

tatr' avuso lobbo ca päpako doso ca papako. lobbassa ca pabānaya dosassa ca pabānāya atthi majjbimã pațipadā cakkbu-karañi ñana-karañi upasamaya abbiñ̃ãaya sambodhaya nibbanaya samvattati.

Przyjaciele, tutaj żądza jest zła i awersja jest zła. Istnieje środkowa droga (majjhimā pațipadā) prowadząca do porzucenia żądzy i awersji, skutkująca widzeniem, skutkująca poznaniem, prowadząca do wyciszenia, do bezpośredniego poznania, do doskonałego przebudzenia, do nibbany.

Dalej dodaje, że ową środkową drogą jest szlachetna ośmioraka ścieżka (ariya atțhangika magga), czyli praktyka, która doprowadzić ma do bezpośredniego poznania (abbiñña). Przedmiotem owego bezpośredniego poznania jest środkowa droga w znaczeniu drugim, nauczana w Kazaniu do Katjajany, która unikać ma istnienia i nieistnienia, a która polega na widzeniu wszystkiego, co się w naszym doświadczeniu ujawnia, jako pozostającego w zależności.

Buddyjska mądrość polega na rozpoznaniu rangi owej zależności, tzn. na rozpoznaniu, że pojęcie bytu jako tożsamego z samym sobą, co musi oznaczać, iż w sobie niesie on własne istnienie, nie znajduje w naszym doświadczeniu żadnego zastosowania. Mówiąc inaczej, jest projekcją naszego ego. Celem buddyjskiej mądrości jest widzenie rzeczy, jakimi są, ale nie afirmacja owego widzenia w poglądach. Budda nie naucza po to, aby dawać wyraz swojemu widzeniu. Dawanie takiego wyrazu nie ma dla niego samo w sobie żadnej wartości. Nie chce być pasterzem ani bycia, ani prawdy. Naucza wyłącznie po to, aby innych do takiego widzenia przybliżć. Nauczanie poza kontekstem wyzwolenia ostatecznie okazuje się projekcją egotyzmu. Intencje 
Przebudzonego doskonale oddał Sariputta, jego stynny uczeń, który odniósł się do pytania o cel mądrości. W MN I, 293 czytamy:

paññā pan' avuso kimatthiya ti. paññā kbo àvuso abbiññattha pariññattha pabānattbā ti.

"Co, przyjacielu, jest celem mądrości?”

„Przyjacielu, celem mądrości jest bezpośrednie poznanie, petne poznanie, celem mądrości jest porzucenie". 


\section{Dodatki<smiles>C=IC=COC=CC=CC</smiles> 



\section{Apendyks 1}

\section{Kazanie do [pewnego] bramina (Bräbmaṇa-sūtra)}

\section{Nidāna-samyukta 18: Brābmaṇa-sūtra}

[18.1] anyataro brabmaṇo yena bhagavāms tenopajagāma | upetya bhagavatā sārdham sammodanīm samrañjanīm kathām vividham upasambrtyaikante nyașidat | ekāntanișannạ̣ sa brabmano bhagavantam idam avocat $\mid$

[18.2] kin nu bho gautama sa karoti sa pratisamvedayati | avyakrtam idam bräbmana mayā sa karoti sa pratisamvedayati $\mid$ [18.3] kin nu bho gautama anyab karoty anyab pratisamvedayati | etad api bräbmana avyākrtam maya anya ba karoty anya ḅ pratisamvedayati

[18.4] kin nu bbo gautama sa karoti sa pratisamvedayatīti prșto avyakrtam iti vadasi | anyab karoty anyab pratisamvedayatiti prșto avyākrtam iti vadasi

ko nu bho gautama asya bhāșitasyärtho draștavyạ̣ |

[18.5] sa karoti sa pratisamvedayatīti brābmana śáśatatve paraiti | anyab karoty anyab pratisamvedayatīty ucchede paraiti $\mid$

[18.6] ity etāv ubhāv antāv anupagamya madbyamayā pratipadā tathāgato dharmam deśayati |

[18.7] yadutasmin satīdam bhavaty asyotpādäd idam utpadyate | yadutāvidyāpratyayāḅ samskārā iti yāvat samudayo nirodhaś ca bhavati $\mid$ 


\section{Kazanie do [pewnego] bramina}

[18.1] Wówczas pewien bramin podszedł do Czcigodnego. Podszedtszy, wymienił z Czcigodnym życzliwe i uprzejme pozdrowienia i usiadł z boku. Usiadłszy z boku, tak powiedział do Czcigodnego:

[18.2] „Czy doprawdy, Mistrzu Gautamo, ten, kto działa, jest tym, kto doświadcza [skutków działania] ?”

„Tego, braminie, nie głoszę: ten, kto działa, jest tym, kto doświadcza [skutków działania]".

[18.3] „Czy zatem, Mistrzu Gautamo, kto inny działa, kto inny doświadcza [skutków działania]?”

„Tego też, braminie, nie głoszę: kto inny działa, kto inny doświadcza [skutków działania]".

[18.4] „Pytany, czy ten, kto działa, jest tym, kto doświadcza [skutków działania], oświadczasz, że tego nie głosisz. Pytany, czy kto inny działa, kto inny doświadcza [skutków działania], oświadczasz, że tego nie głosisz. Jak zatem, Mistrzu Gautamo, należy rozumieć znaczenie tej wypowiedzi?"

[18.5] [Twierdzenie]: „«Ten, kto działa, jest tym, kto doświadcza [skutków działania]", prowadzi, braminie, do [poglądu o] trwałości". [Twierdzenie]: „«Kto inny działa, kto inny doświadcza [skutków działania]", prowadzi, braminie, do [poglądu o] zniszczeniu". [18.6] „Zatem unikając tych dwóch krańców, Tathagata naucza dharmy poprzez środkową drogę: [18.7] mianowicie, gdy to istnieje, to się pojawia, gdy to powstało, to powstaje, $\mathrm{i}$ tak formacje wolicjonalne są uwarunkowane niewiedzą, jak powiedziano odnośnie do powstawania i ustawania". 


\section{Apendyks 2}

\section{Kazanie do Katjajany (Kātyāyana-sūtra)}

\section{Nidāna-samyukta 19: Kātyāyana-sūtra}

[19.1] bhagavān nādikāyām viharati guñjakā-vasathe |

[19.2] athāyuṣmān sandhäkātyāyano yena bhagavāms tenopajagāma | upetya bhagavat-pādau sirasā vanditvaikānte 'sthät | ekānta-sthita àyușmān sandhākātyāyano bhagavantam idam avocat |

[19.3] samyag-drștith samyag-drștir iti bhadanta ucyate | kiyatã samyag-drștir bhavati | kiyatā tathägatạ̣ samyag-drștim prajñapayamānạ̣ prajñapayati

[19.4] evam ukto bhagavān āyusmantam sandhäkātyāyanam idam avocat

[19.5.a] dvayam niśrito 'yam kạtyāyana loko yad bbūyasāstitāan ca niśrito nāstitāã ca | upadbyupādāna-vinibaddho 'yam kātyāyana loko yad utāstitāñ ca niśrito nāstitāñ ca | etāni ced upadbyupādānāni cetaso 'dhișthānābbiniveśānuśayān nopaiti nopādatte nādbitișțhati nābbiniviśaty atmā meti |

[19.5.b] dubkham idam utpadyamānam utpadyate | dubkbam nirudbyamānam nirudbyate | atra cen na kānkșati na vicikitsati | apara- pratyayam jñānam evāsya bbavati |

[19.6] iyatä kätyāyana samyag-drsțtir bhavati | iyatā tathägatậ samyag-drsțim prajñapaymānab prajñapayati $\mid$ 
[19.7] tat kasmäd dhetoḅ | loka-samudayam kātyāyana yathā-bbūtam samyak-prajñayã paśyato yā loke nāstitã sā na bhavati | loka-nirodham yathā-bbütam samyak-prajñayā pásyato yā loke 'stitā sā na bhavati $\mid$

[19.8] ity etāv ubhāv antāv anupagamya madhyamayā pratipadā tathägato dharmam deśayati $\mid$

[19.9] yad utāsmin satĩdam bhavaty asyotpādād idam utpadyate | yad utävidya-pratyayāḅ samskārā iti pūrvavad yāvat samudayo nirodhaś ca bbavati

[19.10] asmin kbalu dharma-paryāye bhäșamạna àyuṣmataḅ sandhäkā tyäyanasyānupādāyāsravebhyaś cittam vimuktam | 


\section{Kazanie do Katjajany}

[19.1] Czcigodny przebywat w Nadice w domu z cegiet.

[19.2] Wówczas dostojny Sandhakatjajana podszedł do Czcigodnego. Podszedłszy, głową uhonorował stopy Czcigodnego i stanął z boku. Stojąc z boku, dostojny Sandhakatjajana tak rzekł do Czcigodnego: [19.3] „Mówi się, Czcigodny, "Właściwy pogląd, właściwy pogląd». Jak istnieje właściwy pogląd? Jak Tathagata określa rozumienie właściwego poglądu?".

[19.4] Gdy tak powiedział, Czcigodny w ten sposób przemówił do dostojnego Sandhakatjajany:

[19.5a] „Ten świat, Katjajano, zasadniczo ufundowany jest na dwójni: na istnieniu i nieistnieniu. Ten świat, Katjajano, ufundowany na istnieniu i nieistnieniu, związany jest lgnięciem i przywiązaniem [ew. związany jest lgnięciem do podłoża/zespołów]. Jeśli nie oddaje się tym [postawom] lgnięcia i przywiązania, stanowiącym skłonność umysłu do uporu i związania, nie przyjmuje ich, nie obstaje przy nich, nie trzyma się ich [mówiąc] «moja jaźń», [19.5b] to powstające cierpienie powstaje, to ustające cierpienie ustaje. Jeśli w tej kwestii nie wątpi, nie waha się, to niezwłocznie pojawia się niezależne poznanie tego. [19.6] Właściwy pogląd, Katjajano, istnieje w ten sposób. Tak Tathagata określa rozumienie właściwego poglądu.

[19.7] Dlaczego tak jest? Kto, Katjajano, dzięki właściwemu poznaniu widzi powstawanie świata takim, jakim jest, ten nie postrzega w świecie nieistnienia. Kto dzięki właściwemu poznaniu widzi ustawanie świata takim, jakim jest, ten nie postrzega w świecie istnienia. [19.8] Zatem unikając tych dwóch krańców, Tathagata naucza dharmy poprzez środkową drogę: [19.9] mianowicie, gdy to istnieje, to sie pojawia, gdy to powstało, to powstaje, i tak formacje wolicjonalne są uwarunkowane niewiedzą, jak powiedziano wcześniej odnośnie do powstawania i ustawania".

[19.10] Gdy tylko ten wykład dharmy wybrzmiał, umysł dostojnego Sandhakatjajany wyzwolił się ze skaz poprzez nielgnięcie. 



\section{Bibliografia}

\section{Literatura źródłowa}

\section{Literatura buddyjska}

\section{Añguttara-nikāya}

- Añguttara-nikāya, ed. R. Morris, E. Hardy, vol. 1-5, Pali Text Society, London 1885-1900. [Redakcja.]

- The Book of Gradual Sayings, trans. F. L. Woodward, E. M. Hare, Pali Text Society, London 1932-1936. [Przekład.]

- The Numerical Discourses of the Buddha. A Translation of the Anguttara Nikaya, trans. Bhikkhu Bodhi, Wisdom Publications, Boston 2012. [Przekład.]

\section{Āryadeva [Arjadewa]}

\section{Catub-sataka}

- Arryadeva's Four Hundred Stanzas on the Middle Way, trans. R. Sonam, Snow Lion Publications, Ithaca 2008. [Przekład.]

- Lang K., Arryadeva's Catubśataka. On the Bodhisattva's Cultivation of Merit and Knowledge, Akademisk Forlag, Copenhagen 1986. [Redakcja i przekład.]

\section{Asanga [Asanga]}

Bodbi-sattva-bbümi

- The Bodbisattva Path to Unsurpassed Enlightenment. A Complete Translation of the Bodhisattvabbümi, trans. A. B. Engle, Snow Lion Publications, Boulder 2016. [Przekład.] 
- Bodbisattvabbumi, ed. N. Dutt, K. P. Jayaswal Research Institute, Patna 1966. [Redakcja.]

\section{Așta-sāhasrikā-prajñā-pāramitā-sūtra}

- Asbtasabasrika, ed. R. Mitra, The Asiatic Society of Bengal, Calcutta 1888. [Redakcja.]

- Asțasabasrika Prajñāpāramita, ed. P. L. Vaidya, The Mithila Institute, Darbhanga 1960. [Reprint: University of Oslo, Bibliotheca Poliglota: Thesaurus Literaturae Buddhicae: Aștasāhasrikā Prajñāpāramitā, http://www2.hf.uio.no/common/apps/permlink/permlink.php?app= polyglotta\&context $=$ volume \&uid $=71$ f3de9e-5528-11e4-856a-001cc4 ddFOf4 (dostęp: 11.07.2017).]

- Astasabasrika Prajñaparamita. The Perfection of Wisdom in Eight Thousand Ślokas, trans. E. Conze, The Asiatic Society, Calcutta 1958. [Przekład.]

- The Perfection of Wisdom in Eight Thousand Lines and Its Verse Summary, $2^{\text {nd }}$ ed., trans. E. Conze, Four Seasons Foundation, Bolinas 1975. [Przekład.]

\section{Buddhaghosa [Buddhaghosa]}

\section{Visuddbi-magga}

- The Path of Purification (Nisuddhimagga) by Bhadantācariya Buddhaghosa, $5^{\text {th }}$ ed., trans. Bhikkhu Ñ̄ṇamoli, Buddhist Publication Society, Kandy 1991. [Przekład.]

- The Path of Purity. Being a Translation of Buddhaghosa's Visuddbimagga, vol. 1-3, trans. Pe Maung Tin, Pali Tex Society, London 1923-1931. [Przekład.]

- The Visuddhi-magga of Buddhaghosa, vol. 1-2, ed. C. A. F. Rhys Davids, Pali Text Society, London 1920-1921. [Redakcja.]

\section{Candrakïri [Czandrakirti]}

\section{Prasanna-padā}

- MacDonald A., In Clear Words. The Prasannapadā, Chapter One, vol. I: Introduction, Manuscript Description, Sanskrit Text, Verlag der Österreichische Akademie der Wissenschaften, Wien 2015. [Redakcja.] 
- MacDonald A., In Clear Words. The Prasannapada, Chapter One, vol. II: Annotated Translation, Tibetan Text, Verlag der Österreichischen Akademie der Wissenschaften, Wien 2015. [Przekład.]

- Madhyamakasastra of Nagarjuna. With the commentary: Prasannapada by Candrakirti, ed. P. L. Vaidya, The Mithila Institute, Darbhanga 1960. [Redakcja.]

- Mũlamadbyamakakärikās (Madbyamikasūtras) de Nägārjuna avec la Prasannapada Commentaire de Candrakirti, ed. L. de La Vallée Poussin, L’Académie Impériale des Sciences, St. Petersbourg 1903. [Redakcja.]

- Schayer S., Ausgewäblte Kapitel aus der Prasannapadā, PAU, Kraków 1931. [Przekład.]

- Sprung M., Lucid Exposition of the Middle Way, Prajñā Press, Boulder 1979. [Przekład.]

- Stcherbatsky T., The Conception of Buddhist Nirvanna, The Academy of Sciences of the USSR, Leningrad 1927. [Przekład.]

\section{Dhamma-pada}

- Dhammapada, [w:] The Minor Antbologies of the Pali Canon, vol. 1, ed. and trans. C. A. F. Rhys Davids, Humphrey Milford, London 1931. [Redakcja i przekład.]

- The Dhammapada, trans., intr., notes J. R. Carter, M. Palihawadana, Oxford University Press, Oxford 2000. [Przekład.]

- The Dhammapada, with Introductory Essays, Pāli Text, English Translation and Notes by S. Radhakrishnan, Oxford University Press, London-New York-Toronto 1950. [Tekst i przekład.]

- The Dhammapada. The Buddha's Patb of Wisdom, trans. Acharya Buddharakkhita, Buddhist Publication Society, Kandy 1996 (1 wyd. 1985). [Tekst i przekład.]

- The Dhammapada. The Path of the Dhamma, trans. A. R. Bomhard, Charleston Buddhist Fellowship, Charleston 2013. [Przekład.]

- Dhammapada. Wisdom of the Buddha, trans. H. Kaviratna, Theosophical University Press, Pasadena 1980. [Tekst i przekład.]

- Dhammapadam czyli Ścieżka Prawdy. Podstawy moralności buddyjkiej, tłum. S. F. Michalski, Pracownia „Borgis”, Wrocław 1996 (1 wyd. 1925). 


\section{Dhamma-sañgani}

- A Buddbist Manual of Psychological Etbics, $3^{\text {rd }}$ ed., trans., intr., notes C. A. F. Rhys Davids, Pali Text Society, Oxford 2004 (1 wyd. 1900). [Przekład.]

- The Dhammasangani, ed. E. Müller, Pali Text Society, London 1885. [Redakcja.]

\section{Digha-nikāya}

- Dialogues of the Buddha, vol. 1-3, trans. T. W. Rhys Davids, C. A. F. Rhys Davids, Pali Text Society, London 1899-1921. [Przekład.]

- Digha-nikaya, vol. 1-3, ed. T. W. Rhys Davids, J. E. Carpenter, Pali Text Society, London 1889-1910. [Redakcja.]

- The Long Discourses of the Buddha. A Translation of the Digha Nikâya, trans. M. Walshe, Wisdom Publications, Boston 1995. [Przekład.]

\section{Iti-vuttaka}

- Iti-vuttaka, ed. E. Windisch, Pali Text Society, London 1889. [Redakcja.]

- The Itivuttaka, trans. P. Masefield, Pali Text Society, Oxford 2000. [Przekład.]

\section{Kāśyapa-parivarta-sutra}

- Käśyapaparivarta, ed. A. von Staël-Holstein, Meicho-Fukyū-Kai, Peking 1925. [Reprint: University of Oslo, Biblitheca Poliglota: Thesaurus Literaturae Buddhicae: Așțasāhasrikā Prajn̄āpāramitā, https:// www2.hf.uio.no/polyglotta/index.php?page=volume\&vid=21 (dostęp: 8.09.2019).] [Redakcja.]

- The Kaśyapaparivarta, ed. \& trans. Bhikkhu Pāsādika, Aditya Prakashan, New Delhi 2015. [Tekst i przekład.]

- The Kasyapaparivarta. Romanized Text and Facsimiles, ed. M. I. Vorobyova-Desyatovskaya, IRIAB, Tokyo 2002. [Reprint: GRETIL - Göttingen Register of Electronic Texts in Indian Languages, http://gretil. sub.uni-goettingen.de/gretil/1_sanskr/4_rellit/buddh/kasyparu.htm (dostęp: 8.09.2019).] [Redakcja.] 


\section{Majjhima-nikāya}

- The Collection of the Middle Length Sayings, vol. 1-3, trans. I. B. Horner, Pali Text Society, London 1954-1959. [Przekład.]

- Further Dialogues of the Buddha, vol. 1-2, trans. R. Chalmers, Humphrey Milford, London 1926-1927. [Przekład.]

- Majjhima-nikaya, vol. 1-3, ed. V. Trenckner, R. Chalmers, Pali Text Society, London 1888-1902. [Redakcja.]

- The Middle Length Discourses of the Buddha. A New Translation of the Majjhima Nikaya, trans. Bhikkhu N̄ānamoli, ed. Bhikkhu Bodhi, Wisdom Publications, Boston 1995. [Przekład.]

\section{Nāgārjuna [Nagardżuna]}

Catub-stava

- Lindtner Ch., Nagarjuniana. Studies in the Writings and Pbilosophy of Nagärjuna, Motilal Banarsidass Publ., Delhi 1990. [Redakcja i przekład hymnów Lokatīta-stava i Acintya-stava.]

- Tola F., Dragonetti C., On Voidness. A Study on Buddhist Nibilism, Motilal Banarsidass Publ., Delhi 1995. [Przekład.]

- Tucci G., Two Hymns of the Catubstava of Nagarjuna, JRAS 1932, s. 309-325. [Przedruk w: Tola F., Dragonetti C., On Voidness. A Study on Buddhist Nibilism, Motilal Banarsidass Publ., Delhi 1995.] [Redakcja i przekład hymnów Niraupamya-stava i Paramartha-stava.]

Müla-madbyamaka-karika

- Bocking B., Nagarijuna in China. A Translation of the Middle Treatise, The Edwin Mellen Press, Lewiston 1995. [Przekład.]

- Garfield J. L., The Fundamental Wisdom of the Middle Way. Nagarjun a's „Mülamadhyamakakärika”, Oxford University Press, Oxford 1995. [Przekład.]

- Inada K. K., Nagarjuna. A Translation of His Mülamadbyamakakärika with an Introductory Essay, The Hokuseido Press, Tokyo 1970. [Przekład.]

- Jong J. W. de, Mülamadhyamakakarikah, The Adyar Library and Research Centre, Madras 1977. [Redakcja.]

- Kalupahana D. J., Nagārjuna. The Philosophy of the Middle Way, SUNY Press, Albany 1986. [Przekład.] 
- Madhyamakaśastra of Nägärjuna. With the Commentary: Prasannapadā by Candrakirti, ed. P. L. Vaidya, Mithila Institute, Darbhanga 1960. [Redakcja.]

- McCagney N., Nägäriuna and the Philosophy of Openness, Rowman \& Littlefield Publishers, Lanham 1997. [Przekład.]

- Mũlamadhyamakakarikas (Mädbyamikasūtras) de Nägärjuna avec la Prasannapadā Commentaire de Candrakìti, ed. L. de La Vallée Poussin, St. Petersbourg 1903. [Redakcja.]

- Pandeya R. C., Manju, Nägärjuna's Philosopby of No-Identity, Eastern Book Linkers, Delhi 1991. [Przekład.]

- The Root Stanzas of the Middle Way, The Mulamadhyamakakārikā, trans. Padmakara Translation Group, Shambhala, Boulder 2016. [Przekład.]

- Siderits M., Katsura Sh., Nagärjuna's Middle Way. The Mülamadbyamakakarikā, Wisdom Publications, Boston 2013. [Przekład.]

- Streng F. J., Emptiness. A Study in Religious Meaning, Abingdon Press, Nashville 1967. [Przekład.]

\section{Ratnāvalī}

- Hahn M., Nagarjuna's Ratnavalī, Bonn 1982. [Redakcja.]

- Hopkins J., The Precious Garland and the Song of the Four Mindfulness, [w:] The Buddbism of Tibet. Combined Volume, George Allen \& Unwin, London 1984 (1 wyd. 1975). [Przekład.]

- Tucci G., The Ratnavali of Nagarjuna, JRAS 66/2 (1934), s. 307-325; 68/2 (1936), s. 237-252; 68/3 (1936), s. 423-435. [Przekład.]

\section{Súnyata-saptati}

- Komito D. R., Nägarjuna's Seventy Stanzas. A Buddhist Psychology of Emptiness, Snow Lion Publications, Ithaca 1987. [Przekład.]

- Lindtner Ch., Nagarjuniana. Studies in the Writings and Pbilosophy of Nagarjuna, Motilal Banarsidass Publ., Delhi 1990. [Redakcja i przekład.]

- Tola F., Dragonetti C., On Voidness. A Study on Buddhist Nibilism, Motilal Banarsidass Publ., Delhi 1995. [Przekład.] 
Vigraba-vydvartani

- Bhattacharya K., The Dialectical Method of Nagarjuna. Vigrabavyavartanī, Motilal Banarsidass Publ., Delhi 1990 (rep.). [Przekład.]

- Jakubczak K., Madbjamaka Nagardżuny. Filozofia czy terapia?, Księgarnia Akademicka, Kraków 2010. [Przekład.]

- Johnston E. H., Kunst A., Vigrabavyāvartanī of Nägarjuna, „Mélanges chinois et bouddhiques" 9 (1948-1951), s. 99-152. [Redakcja.] [Przedruk w: Bhattacharya K., The Dialectical Method of Nägarjuna. Vigrabavyāvartani, Motilal Banarsidass Publ., Delhi 1990 (rep.).]

- Lindtner Ch., Nagarjuniana. Studies in the Writings and Pbilosopby of Nagärjuna, Motilal Banarsidass Publ., Delhi 1990. [Redakcja.]

- Pandeya R. C., Manju, Nägärjuna's Philosophy of No-Identity, Eastern Book Linkers, Delhi 1991. [Przekład.]

- Streng F. J., Emptiness. A Study in Religious Meaning, Abingdon Press, Nashville 1967. [Przekład.]

- Westerhoff J., The Dispeller of Disputes. Nägāriuna's Vigrahavyāvartanī, Oxford University Press, Oxford-New York 2010. [Przekład.]

- Wood T. E., Nagarjunian Disputations. A Pbilosophical Journey through an Indian Looking-Glass, University of Hawai'i Press, Honolulu 1994. [Przekład.]

Yukti-sasțika

- Lindtner Ch., Nagarjuniana. Studies in the Writings and Pbilosopby of Nagarjuna, Motilal Banarsidass Publ., Delhi 1990. [Redakcja i przekład.]

- Tola F., Dragonetti C., On Voidness. A Study on Buddhist Nibilism, Motilal Banarsidass Publ., Delhi 1995. [Przekład.]

\section{Nidāna-samyukta}

- Fünfundzwanzig Sūtras des Nidanasamyukta, hrsg C. Tripāṭhī, Akademie Verlag, Berlin 1962. [Reprint: GRETIL - Göttingen Register of Electronic Texts in Indian Languages, http:/gretil.sub.uni-goettingen. de/gretil/1_sanskr/4_rellit/buddh/nidansyu.htm (dostęp: 18.12.2019).] [Redakcja.] 


\section{Pañca-vimisati-sāhasrikā-prajñ̄a-pāramitā-sūtra}

- Pañcavimśatisabasrika Prajñapāramita Sūtra, ed. N. Dutt, Luzac \& Co, London 1943. [Reprint: GRETIL - Göttingen Register of Electronic Texts in Indian Languages, http://gretil.sub.uni-goettingen.de/gretil/ 1_sanskr/4_rellit/buddh/pspduttu.htm (dostęp: 28.09.2019).] [Redakcja.]

\section{Prajñā-pāramitā-ratna-guna-samcaya-gāthā}

- Mabayana-sütra-samgrabab, part 1, ed. P. L. Vaidya, The Mithila Institute, Darbhanga 1961. [Reprint: Digital Sanskrit Buddhist Canon, http://www.dsbcproject.org/canon-text/book/72 (dostęp: 11.07.2017).] [Redakcja.]

- The Perfection of Wisdom in Eight Thousand Lines and Its Verse Summary, $2^{\text {nd }}$ ed., trans. E. Conze, Four Seasons Foundation, Bolinas 1975. [Przekład.]

\section{Samāahi-rāja-sūtra}

- The King of Samadhis Sütra, trans. P. A Roberts, 2018, http://read.84 000.co/translation/toh127.html (dostęp: 31.10.2019). [Przekład.]

- Samädhiräjasūtra, ed. N. Dutt, The Mithila Institute, Darbhanga 1961. [Redakcja.]

\section{Samyutta-nikāya}

- The Book of the Kindred Sayings, vol. 1-5, trans. C. A. F. Rhys Davids, F. L. Woodward, Pali Text Society, London 1917-1930. [Przekład.]

- The Connected Discourses of the Buddha. A New Translation of the Samyutta Nikāya, trans. Bhikkhu Bodhi, Wisdom Publications, Boston 2000. [Przekład.]

- Kaccāyanagotta Sutta, trans. J. D. Ireland, BSR 14/2 (1997), s. 107108.

- Samyutta-nikaya, vol. 1-6, ed. M. L. Feer, Pali Text Society, London 1884-1904. [Redakcja.]

\section{Sutta-nipäta}

- The Atțhakavagga, trans. Bhikkhu Paññobhāsa, Path Press Publications, b.m.w. 2012. [Tekst i przekład.] 
- The Buddha before Buddhism. Wisdom from the Early Teachings. A Translation of the Atthakavagga with Commentary, trans. G. Fronsdal, Shambhala, Boulder 2016. [Przekład.]

- Buddha's Teachings Being the Sutta-nipāta or Discourse-Collection, trans. L. Chalmers, Harvard University Press, Cambridge 1932. [Tekst i przekład.]

- The Group of Discourses (Sutta-nipäta), $2^{\text {nd }}$ ed., trans. K. R. Norman, Pali Text Society, Oxford 2001. [Przekład.]

- Sutta Nipata, trans. L. Kh. Mills, SuttaCentral, b.m.w. 2015. [Przekład.]

- Sutta-nipāta, ed. D. Andersen, H. Smith, Pali Text Society, Oxford 1913. [Redakcja.]

- The Sutta-nipata. A Collection of Discourses, trans. V. Fausböll, The Clarendon Press, Oxford 1898. [Przekład.]

- The Suttanipata. An Ancient Collection of the Buddha's Discourses Together with Its Commentaires, trans. Bhikkhu Bodhi, Wisdom Publications, Somerville 2017. [Przekład.]

\section{Vajracchedikā-prajñāa-pāramitā-sütra}

- Diamentowa Sutra, tłum. M. Mejor, Ksiąinica Pomorska, Szczecin 2004. [Przekład.]

- The Diamond Sutra, [w:] Perfect Wisdom. The Short Prajñaparamita Texts, trans. E. Conze, Buddhist Publishing Group, Totnes 1993, s. 122-139 (1 wyd. 1973). [Przekład.]

- Vajracchedika Prajñaparamita, ed. P. Harrison, Sh. Watanabe, [w:] Manuscripts in the Schoyen Collection. Buddhist Manuscripts, vol. 3, ed. J. Braarvig, Hermes Academic Publishing, Oslo 2006, s. 89-132. [Reprint: University of Oslo. Biblitheca Poliglota: Thesaurus Literaturae Buddhicae: Vajracchedikā Prajñāpāramitā, http://www2.hf.uio.no/com mon/apps/permlink/permlink.php?app=polyglotta\&context $=$ volume\& uid=21 af821c-0cb2-11df-9e60-00215aecadea (dostęp: 11.07.2017).] [Redakcja.]

- Vajracchedika Prajnaparamita. A New English Translation of the Sanskrit Text Based on Two Manuscripts from Greater Gandbara, trans. P. Harrison, [w:] Manuscripts in the Schøyen Collection. Buddhist Manuscripts, vol. 3, ed. J. Braarvig, Hermes Academic Publishing, Oslo 2006, s. 133159. [Przekład.] 


\section{Vasubandhu [Wasubandhu]}

Abhidbarma-kośa-bbasya

- Abbidharmakośabhasyam, ed. P. Pradhan, K. P. Jayaswal, Research Institute, Patna 1975. [Redakcja.]

- Abbidbarmakośabbasyam, French trans. L. de la Vallée Poussin, English trans. L. M. Pruden, vol. 1-4, Asian Humanities Press, Berkeley 1991. [Przekład.]

\section{Vinaya-pitaka}

- The Book of the Discipline (Vinaya-pitaka), vol. 1-6, trans. I. B. Horner, Pali Text Society, London 1938-1966. [Przekład.]

- The Vinaya Pitakam, vol. 1-4, ed. H. Oldenberg, Williams and Norgate, London-Edinburgh 1879-1882. [Redakcja.]

\section{Indyjska literatura niebuddyjska}

\section{Iśvarakrș̣na [Iśwarakriszna]}

Samkbya-karika

- Iśwarakriszna, Sankbjakarika, thum. M. Jakubczak, [w:] Filozofia Wschodu. Wybór tekstów, red. M. Kudelska, Wydawnictwo Uniwersytetu Jagiellońskiego, Kraków 2002, s. 81-98. [Przekład.]

- Larson G. J., Classical Sämkbya. An Interpretation of Its History and Meaning, Motilal Banarsidass Publ., Delhi 1979. [Tekst i przekład.]

\section{Upanişad}

- The Early Upanișads, trans., ed. P. Olivelle, Oxford University Press, Oxford 1998. [Redakcja i przekład.]

- Mänūkeyopanișad, tłum. B. Śliwczyńska, SI 3 (1996), s. 130-134. [Tekst i przekład.]

- The Principal Upanișads, ed., trans. S. Radhakrishnan, George Allen \& Unwin, London 1953. [Redakcja i przekład.]

- Upaniszady, tłum. M. Kudelska, Wydawnictwo Uniwersytetu Jagiellońskiego, Kraków 2004. [Przekład.] 


\section{Rg-veda}

- Hymny Rigwedy, thum. F. Michalski, Ossolineum, Wrocław 1971. [Przekład.]

- The Rigueda. The Earliest Religious Poetry of India, vol. 1-3, trans. S. W. Jamison, J. P. Brereton, Oxford University Press, Oxford 2014. [Przekład.]

\section{Nieindyjska literatura}

Sekstus Empiryk, Przeciw fizykom. Przeciw etykom (Adversus mathemati$\cos I X-X I)$, tłum. Z. Nerczuk, Wydawnictwo Marek Derewiecki, Kęty 2010.

Sekstus Empiryk, Przeciw logikom, thum. I. Dąmbska, Państwowe Wydawnictwo Naukowe, Warszawa 1970.

Sextus Empiryk, Zarysy pirrońskie, tłum. A. Krokiewicz, Wydawnictwo AKME, Warszawa 1998.

\section{Literatura ogólna}

Albahari M., Analytical Buddhism. The Two-Tiered Illusion of Self, Palgrave Macmillan, New York 2006, https://doi.org/10.1057/978023 0800540_10.

Ames W. L., The Notion of svabhāva in the Thought of Candrakirti, JIP 10/2 (1982), s. 161-177, https://doi.org/10.1007/bf00160628.

Anālayo, Sakkayadițţbi, [w:] Encyclopaedia of Buddhism, vol. 7, fasc. 4, ed. W. G. Weeraratne, Department of Buddhist Affairs, Colombo 2006, s. 641-644, https://doi.org/10.1515/9783110804164.227.

Anālayo, The Mahācattārīsaka-sutta in the Light of its Parallels - Tracing the Beginnings of Abbidharmic Thought, "Journal of the Centre for Buddhist Studies, Sri Lanka" 8 (2010), s. 59-93.

Anderson C. S., Pain and Its Ending. The Four Noble Trutbs in the Theraväda Buddhist Canon, Routledge, London-New York 2013 (1 wyd. 1999), https://doi.org/10.4324/9781315027401.

Annas J., The Morality of Happiness, Oxford University Press, New YorkOxford 1993, https://doi.org/10.1093/0195096525.001.0001. 
Apple J. B., The Old Tibetan Version of the Kāsyapaparivarta preserved in Fragments from Dunbuang (1), ARIRIAB 20 (2017), s. 205-230.

Arnold D., How to Do Things with Candrakirti. A Comparative Study in Anti-Skepticism, PEW 51/2 (2001), s. 247-279, https://doi.org/10.1353/ pew.2001.0019.

Arnold D., Materials for a Mädbyamika Critique of Foundationalism. An Annotated Translation of Prasannapada 55.11-75.13, JIABS 28/2 (2005), s. 411-467.

Arnold D., Nägarjuna's „Middle Way”. A Non-eliminative Understanding of Selflessness, "Revue internationale de philosophie" 3/253 (2010), s. 367395.

Ausland H. W., On the Moral Origin of the Pyrrhonian Philosophy, ${ }_{\text {Elen- }}$ chos" 10 (1989), s. 359-434.

Balcerowicz P., Dżinizm. Starożytna religia Indii, Wydawnictwo Akademickie Dialog, Warszawa 2003.

Balcerowicz P., Early Asceticism in India. Ajivivikism and Jainism, Routledge, London-New York 2016, https://doi.org/10.4324/9781315726977.

Bareau A., L'absolu en philosophie boudbique, Centre de Documentation Universitaire, Paris 1951.

Barnes J., Introduction, [w:] Sextus Empiricus, Outlines of Scepticism, ed. J. Annas, J. Barnes, Cambridge University Press, Cambridge 2000, s. XI-XXXI.

Beckwith Ch. I., Greek Buddha. Pyrrbo's Encounter with Early Buddhism in Central Asia, Princeton University Press, Princeton-Oxford 2015.

Berger D. L., Acquiring Emptiness. Interpreting Nägärjuna's $M M K$ 24:18, PEW 60/1 (2010), s. 40-64, https://doi.org/10.1353/pew.0.0088.

Berger D. L., Illocution, No-Theory and Practice in Nagarjuna's Skepticism. Reflections on the "Vigrabavyavartani”, [w:] Online Proceedings of the 20th Annual World Congress of Philosophy, Boston, Massachusetts, 10-15.08.1998, http://www.bu.edu/wcp/Papers/Asia/AsiaBerg.htm (dostęp 25.05.2010).

Bergson H., Ewolucja twórcza, tłum. F. Znaniecki, Wydawnictwo Zielona Sowa, Kraków 2005 (1 wyd. 1907).

Bett R., How Ethical Can an Ancient Skeptic Be?, [w:] Pyrrhonism in Ancient, Modern, and Contemporary Philosophy, ed. D. Machuca, Springer, 
Dordrecht 2011, s. 3-17, https://doi.org/10.1007/978-94-007-19910_1.

Bett R., Pyrrbo, [w:] The Stanford Encyclopedia of Pbilosophy, ed. E. N. Zalta, https://plato.stanford.edu/archives/win2014/entries/pyrrho/ (dostęp: 2.08.2018).

Bett R., Pyrrbo, His Antecedents, and His Legacy, Oxford University Press, Oxford 2000, https://doi.org/10.1093/acprof:oso/9780199256617.001. 0001.

Betty L. S., Näārjuna's Masterpiece - Logical Mystical, Both or Neither?, PEW 33/2 (1983), s. 123-138, https://doi.org/10.2307/1399097.

Betty S. L., Is Nägärjuna a Pbilosopher? Response to Professor Loy, PEW 34/4 (1984), s. 447-450, https://doi.org/10.2307/1399178.

Bhattacharya K., The Dialectical Method of Nägärjuna. Vigrabavyãvartanī, Motilal Banarsidass Publ., Delhi 1990 (rep.).

Biderman Sh., Scepticism and Religion. On the Interpretation of Nägarjuna, [w:] Indian Pbilosophy of Religion, ed. R. W. Perrett, Kluwer Academic Publishers, Dordrecht-Boston-London 1989, s. 61-74, https://doi.org/ 10.1007/978-94-009-2458-1_5.

Bocking B., Näaarjuna in China. A Translation of the Middle Treatise, The Edwin Mellen Press, Lewiston 1995.

Bolewski J., Daleki Wschód na Zachodzie. Od reinkarnacji do regeneracji, WAM, Kraków 2006.

Bosch L. P. van den, Some Reflections on the Concept of Person in Ancient Indian Texts, [w:] Concepts of Person in Religion and Thought, ed. H. G. Kippenberg et al., Mouton de Gruyter, Berlin-New York 1990. Brennan T., Ethics and Epistemology in Sextus Empiricus, Routledge, New York-London 1999, https://doi.org/10.1515/9783110874372.229.

Bronkhorst J., Buddhist Teaching in India, Wisdom Publications, Boston 2009.

Bronkhorst J., Language and Reality. On an Episode in Indian Thought, trans. from the French M. S. Allen, R. Raghunathan, Brill, LeidenBoston 2011.

Bronkhorst J., Review of Ilkka Pyysiäinen, „Beyond Language and Reason. Mysticism in Indian Buddhism”, "Asiatische Studien / Études Asiatiques" 47/4 (1993), s. 709-715. 
Brunschwig J., Papers in Hellenistic Philosophy, Cambridge University Press,

Cambridge 1994, https://doi.org/10.1017/cbo9780511518393.

Buescher J. B., Echoes from an Empty Sky. The Origins of the Buddhist Doctrine of the Two Trutbs, Snow Lion Publications, Ithaca-Boulder 2005. Burford G. G., Cülaniddesa, [w:] Encyclopedia of Indian Philosopbies. Abbidharma Buddhism to 150 A. D., ed. K. H. Potter, Motilal Banarsidass Publ., Delhi 1996, s. 313-316.

Burford G. G., Mabāniddesa, [w:] Encyclopedia of Indian Pbilosopbies. Abbidharma Buddhism to 150 A. D., ed. K. H. Potter, Motilal Banarsidass Publ., Delhi 1996, s. 305-312.

Burford G. G., Theravada Buddhist Soteriology and the Paradox of Desire, [w:] Paths to Liberation. The Märga and Its Transformations in Buddhist Thought, ed. R. E. Buswell, R. M. Gimello, University of Hawai i Press, Honolulu 1992, s. 37-61.

Burnet J., Sceptics, [w:] Encyclopaedia of Religion and Ethics, ed. J. Hastings, vol. 11, Charles Scribner's Sons, New York 1908, s. 228-231.

Burnouf E., Introduction to the History of Indian Buddhism, trans. K. Buffetrille, D. S. Lopez, The University of Chicago Press, Chicago-London 2010 (1 wyd. 1844), https://doi.org/ 10.7208/chicago/9780226081250. 001.0001.

Burton D., Buddhism, Knowledge and Liberation. A Philosophical Study, Ashgate, Aldershot-Burlington 2004, https://doi.org/10.4324/97813 15261201.

Burton D., Emptiness Appraised. A Critical Study of Nagarjuna's Philosophy, Curzon, Richmond 1999, https://doi.org/10.4324/9781315787343.

Burton D., Is Madhyamaka Buddhism Really the Middle Way? Emptiness and the Problem of Nibilism, CB 2/2 (2001), s. 177-190, https://doi. org/10.1080/146399401085737.49.

Burton D., Wisdom beyond Words? Ineffability in Yogãcāra and Madbyamaka Buddhism, CB 1/1 (2000), s. 53-76, https://doi.org/10.1080/146 39940008573721.

Buswell R. E., Lopez D. S., The Princeton Dictionary of Buddhism, Princeton University Press, Princeton 2014, https://doi.org/10.1093/acref/ 9780190681159.001.0001.

Byrski M. K., Przekaz tekstów objawionych i normatywnych $w$ ttumaczeniach, czyli praktyka zależnego powstawania, "Przegląd Orientalistyczny” 226-227 (2008), s. 153-172. 
Cabezón J. I., Ineffability and the Silence of the Buddha, [w:] J. I. Cabezón, Buddhism and Language. A Study of Indo-Tibetan Scholasticism, SUNY Press, Albany 1994, s. 171-187.

Carr K. L., The Banalization of Nibilism. Twentieth-Century Responses to Meaninglessnes, SUNY Press, Albany 1992.

Castagnoli L., Aporia and Enquiry in Ancient Pyrrbonism, [w:] The Aporetic Tradition in Ancient Philosophy, ed. G. Karamanolis, V. Politis, Cambridge University Press, Cambridge 2018, s. 205-226, https://doi. org/10.1017/9781316274293.012.

Chatterjee D., Skepticism and Indian Philosopby, PEW 27/2 (1977), s. 195209, https://doi.org/10.2307/1397616.

Cheng Hsueh-Li, Causality as Soteriology. An Analysis of the Central Philosopby of Buddhism, JChP 9 (1982), s. 423-440, https://doi.org/10. 1111/j.1540-6253.1982.tb00583.x.

Chinn E., Nagarjuna's Fundamental Principle of Pratitysamutpada, PEW 51/1 (2001), s. 54-72, https://doi.org/10.1353/pew.2001.0005.

Choong M.-k., Annotated Translation of Sūtras from the Chinese Samyuktagama relevant to the Early Buddhist Teachings on Emptiness and the Middle Way, $2^{\text {nd }}$ ed., International Buddhist College, Songkhla 2010.

Choong M.-k., The Fundamental Teachings of Early Buddhism, Harrassowitz Verlag, Wiesbaden 2000.

Choong M.-k., The Notion of Emptiness in Early Buddhism, Motilal Banarsidass Publ., Delhi 1999.

Collins S., Selfless Persons. Imagery and Thought in Theravāda Buddhism, Cambridge University Press, Cambridge 1982, https://doi.org/10.1017/ cbo9780511621499.

Collins S., What Are Buddhists Doing When They Deny the Self?, [w:] Religion and Practical Reason. New Essays in the Comparative Pbilosophy of Religions, ed. F. E. Reynolds, D. Tracy, SUNY Press, Albany 1994, s. 59-86.

Collinson D., Plant K., Wilkinson R., Fifty Eastern Thinkers, Routledge, London-New York 2000, https://doi.org/10.4324/9780203005408.

Conze E., Buddhist Thought in India, George Allen \& Unwin, London 1962, https://doi.org/10.3998/mpub.23908. 
Conze E., The Composition of the Asțasahasrika Prajñäpäramitā, [w:] E. Conze, Thirty Years of Buddhist Studies. Selected Essays, Oxford 1967, s. $168-184$.

Conze E., The Prajñaparamita Literature, The Reiyukai, Tokyo 1978. Conze E., The Prajñaparamitä-brdaya Sütra, [w:] E. Conze, Thirty Years of Buddhist Studies. Selected Essays, Bruno Cassirer, Oxford 1967, s. 148167.

Conze E., The Composition of the Astasāhasrika Prajñapaaramitā, BSOAS 14/2 (1952), s. 251-262, https://doi.org/10.1017/s0041977x00083865. Cox C., Dependent Origination. Its Elaboration in Early Sarvastivada Abbidharma Texts, [w:] Researches in Indian and Buddhist Philosophy. Essays in Honour of Professor Alex Wayman, ed. R. K. Sharma, Motilal Banarsidass Publ., Delhi 1993, s. 119-141.

Cox C., Disputed Dharmas. Early Buddhist Theories on Existence, The International Institute of Buddhist Studies, Tokyo 1995.

Cox C., From Category to Ontology. The Changing Role of Dharma in Sarvastivada Abbidharma, JIP 32 (2004), s. 543-597, https://doi.org/ 10.1007/s10781-004-8635-4.

Craig E., Realism and Antirealism, [w:] Routledge Encyclopedia of Philosophy, vol. 8, ed. E. Craig, Routledge, London-New York 1998, s. 115119, https://doi.org/10.4324/9780415249126-n049-1.

D'Amato M., Buddhism, Apophasis, Truth, "Journal for Cultural and Religious Theory" 9/2 (2008), s. 17-29.

Darling G. J., An Evaluation of the Vedāntic Critique of Buddhism, Motilal Banarsidass Publ., Delhi 1987.

Dębicki W. M., Filozofia nicości. Rzecz o istocie buddyzmu, Gebethner i Wolf, Warszawa 1896.

Dhammajothi M., The Concept of Emptiness in Pali Literature, The Corporate Body of the Buddha Educational Foundation, Taipei 2008.

Dhammajoti K. L., Sarvastivada Abbidharma, University of Hong Kong, Hong Kong 2007.

Diogenes Laertios, Żywoty i poglady stynnych filozofów, tłum. I. Krońska, W. Olszewski, B. Kupis, Państwowe Wydawnictwo Naukowe, Warszawa 1988.

Dreyfus G., Garfield J. L., Madhyamaka and Classical Greek Skepticism, [w:] Moonshadows. Conventional Truth in Buddhist Pbilosopby, ed. The Cowherds, Oxford University Press, Oxford 2011, s. 115-130. 
Droit R.-P., The Cult of Notbingness. The Pbilosophers and the Buddha, trans. D. Streight, P. Vohnson, The University of North Carolina Press, Chapel Hill 2003.

Duerlinger J., Indian Buddbist Theories of Persons. Vasubandbu's "Refutation of the Theory of a Self", RoutledgeCurzon, London-New York 2003, https://doi.org/10.4324/9780203607640.

Duerlinger J., The Refutation of the Self in Indian Buddbism. Candrakirti on the Selflessness of Persons, Routledge, London-New York 2013, https:// doi.org/10.4324/9780203074718.

Dummett M., Logiczna podstawa metafizyki, thum. W. Sady, Wydawnictwo Naukowe PWN, Warszawa 1998.

Encyclopedia of Indian Pbilosopbies, vol. 2: Indian Metaphysics and Epistemology. The Tradition of Nyaya-Vaisesika up to Gangeśa, ed. K. H. Potter, Motilal Banarsidass Publ., Delhi 1977, https://doi.org/10.1515/97814 00870752.

Falk H., The 'Split' Collection of Kharoșthi Texts, ARIRIAB 14 (2011), s. 13-23.

Falk H., Karashima S., A First-century Prajñāpāramitā Manuscript from Gandhara - parivarta 1 (Texts from the Split Collection 1), ARIRIAB 15 (2012), s. 19-61.

Fallick E., Two Small Remnants of "Pre-Hinayanist” Buddbism in the Pali Nikāyas, BSR 17/1 (2000), s. 35-38.

Ferraro G., A Criticism of $M$. Siderits and J. L. Garfield's „Semantic Interpretation" of Nägäriuna's Theory of Two Trutbs, JIP 41 (2013), s. 195219, https://doi.org/10.1007/s10781-013-9179-2.

Ferraro G., Realistic-Antimetaphysical Reading $V_{s}$ Any Nibilistic Interpretation of Madbyamaka, JIP 45 (2017), s. 73-98, https://doi.org/10.1007/ s10781-016-9299-6.

Fink Ch. K., Clinging to Notbing. The Phenomenology and Metapbysics of Upädana in Early Buddhism, APh 25/1 (2015), s. 15-33, https://doi.or $\mathrm{g} / 10.1080 / 09552367.2015 .1016734$.

Flintoff E., Pyrrbo and India, „Phronesis” 25/1 (1980), s. 88-108, https:// doi.org/10.1163/156852880x00052.

Fosl P. S., Skepticism and the Possibility of Nature, [w:] Pyrrbonism in Ancient, Modern, and Contemporary Pbilosophy, ed. D. E. Machuca, Sprin- 
ger, Dordrecht 2011, s. 145-169, https://doi.org/10.1007/978-94-0071991-0_8.

Franke R. O., Der „Negativismus” in der alten Buddbalebre, [w:] Aufsätze zur Kultur- und Sprachgeschichte vornebmlich des Orients. Ernst Kubn zum 70. Geburtstage, Von M. und H. Marcus, Breslau 1916, s. 336-344. Frauwallner E., Studies in Abbidharma Literature and the Origins of Buddhist Philosophical Systems, SUNY Press, Albany 1995.

Frenkian A. F., Der griechische Skeptizismus und die indische Philosophie, „Bibliotheca Classica Orientalis” 4 (1958), s. 211-250.

Fuller P., The Notion of Dittthi in Theravada Buddhism. The Point of View, RoutledgeCurzon, London-New York 2005, https://doi.org/10. 4324/9780203010433.

Gajda J., Sofisci, Wiedza Powszechna, Warszawa 1989.

Ganeri J., The Concealed Art of the Soul. Theories of Self and Practices of Truth in Indian Ethics and Epistemology, Oxford University Press, Oxford 2007.

Gangopadhyaya M., Indian Atomism. History and Sources, K. P. Bagchi \& Company, Calcutta 1980.

Garfield J. L., Dependent Arising and the Emptiness of Emptiness. Why did Nagarjuna Start with Causation?, PEW 44/2 (1994), s. 219-250, https:// doi.org/10.2307/1399593.

Garfield J. L., Emptiness and Positionlessness. Do the Mädhyamikas Relinquish All Views?, [w:] J. L. Garfield, Empty Words. Buddhist Philosophy and Cross-Cultural Interpretation, Oxford University Press, Oxford 2002, s. 46-68.

Garfield J. L., Epoche and Śünyatā. Skepticism East and West, PEW 40/3 (1990), s. 285-307, https://doi.org/10.2307/1399425.

Garfield J. L., Madhyamaka, Nibilism, and the Emptiness of Emptiness, [w:] Nothingness in Asian Philosophy, ed. JeeLoo Liu, D. L. Berger, Routledge, New York-London 2014, s. 44-54, https://doi.org/10.4324/ 9781315774244.

Garfield J. L., Nagarjuna's Theory of Causality. Implications Sacred and Profane, PEW 51/4 (2001), s. 507-524, https://doi.org/10.1353/pew. 2001.0055.

Garfield J. L., Taking Conventional Truth Seriously. Authority Regarding Deceptive Reality, PEW 60/3 (2010), s. 341-354, https://doi.org/10. 1353/pew.0.0113. 
Garfield J. L., Priest G., Nägārjuna and the Limits of Thought, PEW 53/1 (2003), s. 1-21, https://doi.org/10.1353/pew.2003.0004.

Gethin R., He Who Sees Dhamma Sees Dhammas. Dhamma in Early Buddhism, JIP 32 (2004), s. 513-542, https://doi.org/10.1007/s10781-0048633-6.

Gethin R., The Foundations of Buddhism, Oxford University Press, Oxford 1998.

Gethin R., Wrong View (micchā-dițthi) and Right View (sammā-dițthi) in the Theravada Abbidbamma, CB 5/1 (2004), s. 15-28, https://doi.org/ 10.1080/1463994042000249571.

Gombrich R. F., How Buddbism Began. The Conditioned Genesis of the Early Teachings, $2^{\text {nd }}$ ed., Routledge, London-New York 2006, https:// doi.org/10.4324/9780203098738.

Gombrich R. F., The Buddha's Thought, „Revue internationale de philosophie" 3/253 (2010), s. 315-339.

Gombrich R. F., What the Buddha Thought, Equinox, London-Oakville 2009.

Gómez L. O., Proto-Madbyamika in the Päli Canon, PEW 26/2 (1976), s. 137-165, https://doi.org/10.2307/1398186.

Goodman N., Jak tworzymy świat, thum. M. Szczubiałka, Fundacja Aletheia, Warszawa 1997.

Gray D. B., The Mystical Dimensions in Buddhism, [w:] Teaching Mysticism, ed. W. B. Parsons, Oxford University Press, Oxford 2011, s. 6787, https://doi.org/10.1093/acprof:oso/9780199751198.003.0005.

Grgić F., Sextus Empiricus on the Goal of Skepticism, „Ancient Philosophy” 26 (2006), s. 141-160, https://doi.org/10.5840/ancientphil200626138. Gupta R., The Buddhist Doctrine of Momentariness and Its Presuppositions, JIP 8 (1980), s. 47-68, https://doi.org/10.1007/bf02539786.

Halkias G. T., When the Greeks Converted the Buddha. Asymmetrical Transfers of Knowledge in Indo-Greek Cultures, [w:] Religions and Trade, ed. P. Wick, V. Rabens, Brill, Leiden-Boston 2014, s. 65-115, https://doi. org/10.1163/9789004255302_005.

Hamilton S., Early Buddhism. A New Approach. The I of the Bebolder, Curzon Press, Richmond 2000, https://doi.org/10.4324/9781315028460. Hamilton S., Identity and Experience. The Constitution of the Human Being According to Early Buddhism, Luzac Oriental, London 1996. 
Hamilton S., The "External World". Its Status and Relevance in the Pali Nikayas, „Religion” 29 (1999), s. 73-90, https://doi.org/10.1006/ reli.1999.0166.

Hankinson R. J., The Sceptics, Routledge, London-New York 1995.

Harris E. J., Buddhism - Liberating Ethical Path or Journey into Apathy? A Study of T. W. Rhys Davids and Bishop R. S. Copleston, [w:] Recent Researches in Buddhist Studies. Essays in Honour of Professor Y. Karunadasa, ed. K. L. Dhammajoti et al., Felicitation Committee, Colombo 1997, s. 300-335.

Harris E. J., Detacbment and Compassion in Early Buddhism, Buddhist Publication Society, Kandy 1997.

Harvey P., Dukkha, Non-Self, and the Teaching on the Four "Noble Trutbs", [w:] A Companion to Buddhist Philosophy, ed. S. M. Emmanuel, Wiley-Blackwell, Chichester 2013, s. 26-45, https://doi.org/10.1002/978111 8324004.ch2.

Harvey P., The Selfless Mind. Personality, Consciousness and Nirvana in Early Buddhism, Curzon Press, Richmond 1995, https://doi.org/10. 4324/9781315026336.

Hayes R. P., Dignaga on the Interpretation of Signs, Kluwer Academic Publishers, Dordrecht-Boston-London 1988, https://doi.org/10.1007/ 978-94-009-2899-2.

Hayes R. P., Nãgārjuna's Appeal, JIP 22 (1994), s. 299-378, https://doi. org/10.1007/bf01095223.

Heisig W., Philosophers of Nothingness. An Essay on the Kyoto School, University of Hawai'i Press, Honolulu 2001, https://doi.org/10.1515/978082 4863944.

Hirakawa A., A History of Indian Buddhism. From Śäkyamuni to Early Mabãyana, University of Hawai'i Press, Honolulu 1990.

Huifeng S., "Dependent Origination = Emptiness" - Nagarjuna's Innovation? An Examination of the Early and Mainstream Sectarian Textual Sources, JCBSSL 11 (2013), s. 175-228.

Husserl E., Idee czystej fenomenologii $i$ fenomenologicznej filozofii. Ksiega pierwsza, tłum. D. Gierulanka, Państwowe Wydawnictwo Naukowe, Warszawa 1975.

Huxley A., Drzwi percepcji, tłum. P. Kołyszko, Wydawnictwo Przedświt, Warszawa 1991. 
Hwang S., Metaphor and Literalism in Buddhism. The Doctrinal History of Nirvana, Routledge, London-New York 2006.

Ingarden R., Spór o istnienie świata, t. 1-3, wyd. 3, Państwowe Wydawnictwo Naukowe, Warszawa 1987.

Ingarden R., Wstep do fenomenologii Husserla, tłum. A. Półtawski, Państwowe Wydawnictwo Naukowe, Warszawa 1974.

Jakubczak K., Doswiadczenie mistyczne $w$ tradycji buddyjskiej, [w:] Miedzy wiara a gnozq. Doswiadczenie mistyczne $w$ tradycjacb Orientu, red.

M. Jakubczak, M. Sacha-Piekło, Universitas, Kraków 2003, s. 175-240. Jakubczak K., Madbjamaka Nagardżuny. Filozofia czy terapia?, Księgarnia Akademicka, Kraków 2010.

James W., Doswiadczenia religijne, thum. J. Hempel, Zakład Wydawniczy NOMOS, Kraków 2001.

Jayatilleke K. N., Early Buddhist Theory of Knowledge, George Allen \& Unwin, London 1963, https://doi.org/10.4324/9781315888347. Joachimowicz L., Sceptycyzm grecki, Wiedza Powszechna, Warszawa 1972. Jones R. H., Mysticism Examined. Philosophical Inquiries into Mysticism, SUNY Press, Albany 1993.

Jones R. H., Philosophy of Mysticism. Raids on the Ineffable, SUNY Press, Albany 2016.

Jong J. W. de, Absolut w myśli buddyjkiej, tłum. K. Jakubczak, „Nomos” 18/19 (1997), s. 23-30.

Jong J. W. de, Emptiness, JIP 2 (1972), s. 7-15, https://doi.org/10.1007/ bf00207467.

Jurewicz J., Playing with Fire. The pratityasamutpada from the Perspective of Vedic Thought, JPTS 26 (2000), s. 77-103. [Reprint w: Buddhism. Critical Concepts in Religious Studies, vol. 1, ed. P. Williams, Routledge, London-New York 2005, s. 169-187.]

Kalupahana D. J., Causality. The Central Pbilosophy of Buddhism, The University of Hawai'i Press, Honolulu 1975.

Kalupahana D. J., Nagarjuna. The Philosophy of the Middle Way, SUNY Press, Albany 1986.

Kalupahana D. J., The Early Buddhist Notion of the Middle Path, JChP 7/1 (1980), s. 73-90, https://doi.org/10.1111/j.1540-6253.1980.tb00234.x. Kalupahana D. J., The Philosophy of Relations in Buddhism (1), „University of Ceylon Reviewn 20 (1962), s. 19-54. 
Kapstein M. T., Retbinking Religious Experience. Seeing the Light in the History of Religions, [w:] The Presence of Light. Divine Radiance and Religious Experience, ed. M. T. Kapstein, The University of Chicago Press, Chicago-London 2004, s. 265-299.

Karambelkar V. W., The Problem of Nagarjuna, JIH 30/1 (1952), s. 21-33. Karunadasa Y., The Dhamma Theory. Philosophical Cornerstone of the Abbidhamma, Buddhist Publication Society, Kandy 1996.

Kasulis Th. P., The Buddhist Concept of Self, [w:] Companion to World

Philosophy, ed. E. Deutsch, R. Bontekoe, Blackwell Publishing, Oxford 1997, s. 400-409, https://doi.org/10.1002/9781405164566.ch29.

Katz N., Buddhist Images of Human Perfection, Motilal Banarsidass Publ., Delhi 1989 (1 wyd. 1982).

Katz N., Does the "Cessation of the World" Entail the Cessation of Emotions?

The Psychology of the Arabant, PBR 4/3 (1979), s. 53-65.

Keith A. B., Buddhist Philosophy in India and Ceylon, Clarendon Press, Oxford 1923.

Kellenberger J., Mysticism and Drugs, „Religious Studies” 14/2 (1978), s. 175-191, https://doi.org/10.1017/s0034412500010660.

Kern H., Manual of Indian Buddhism, Verlag von Karl J. Trübner, Strassburg 1896.

Klein A. C., Mental Concentration and the Unconditioned. A Buddhist Case for Unmediated Experience, [w:] Paths to Liberation. The Marga and Its Transformations in Buddhist Thought, ed. R. E. Buswell, R. M. Gimello, University of Hawai'i Press, Honolulu 1992, s. 269-308.

Kosior K., Droga środkowa $w$ nikajach, Wydawnictwo UMCS, Lublin 1999.

Kozyra A., Filozofia nicości Nishidy Kitarō, Nozomi, Warszawa 2007.

Krokiewicz A., Sceptycyzm grecki (od Pirrona do Karneadesa), Instytut Wydawniczy PAX, Warszawa 1984.

Kuan Tse-fu, Abbidbamma Interpretations of „Persons” (puggala): with Particular Reference to the Anguttara Nikaya, JIP 43 (2015), s. 31-60, https:// doi.org/10.1007/s10781-014-9228-5.

Kukla A., Ineffability and Philosopby, Routledge, London-New York 2005, https://doi.org/10.4324/9780203325070.

Kuzminski A., Pyrrbonism and the Madhyamaka, PEW 57/4 (2007), s. 482-511, https://doi.org/10.1353/pew.2007.0052. 
Kuzminski A., Pyrrbonism. How the Ancient Greeks Reinvented Buddhism, Lexington Books, Lanham 2008.

La Vallée Poussin L. de, Scepticism (Buddhist), [w:] Encyclopaedia of Religion and Ethics, ed. J. Hastings, vol. 11, Charles Scribner's Sons, New York 1908, s. 231-232.

La Vallée Poussin L. de, Musila et Narada. Le chemin du nirvãna, "Mélanges chinois et bouddhiques" 5 (1936-1937), s. 189-222. [Przekład na angielski: Musila and Närada. The Path of Nirvāna, trans. G. M. Chödrön, G. L. Sangpo, http://www.gampoabbey.org/kosharesources.php (dostęp: 10.03.2015).]

Lamotte É., Three Sütras from the Samyuktagama concerning Emptiness, trans. S. Boin-Webb, BSR 10/1 (1993), s. 1-23.

Lang K. C., Candrakirti on the Limits of Language and Logic, [w:] A Companion to Buddhist Philosophy, ed. S. M. Emmanuel, Wiley-Blackwell, Chichester 2013, s. 331-348, https://doi.org/10.1002/9781118324004.ch21. Lennon T. M., The Rationalist Conception of Substance, [w:] A Companion to Rationalism, ed. A. Nelson, Blackwell Publishing, Oxford 2005, s. 12-30, https://doi.org/10.1002/9780470996904.ch2.

Lindtner Ch., Nagariuniana. Studies in the Writings and Philosopby of $\mathrm{Na}$ gārina, Motilal Banarsidass Publ., Delhi 1990.

Loy D., How Not to Criticize Nagarjuna. A Response to L. Stafford Betty, PEW 34/4 (1984), s. 437-445, https://doi.org/10.2307/1399177.

Mabbett I., Is There a Devadatta in the House? Nagaryuna's Vigrabavyavartani and the Liar Paradox, JIP 24 (1996), s. 295-320, https://doi.org/10.1007/ bf01792028.

Mabbett I., The Problem of the Historical Nägārjuna Revisited, JAOS 118/3 (1998), s. 332-346, https://doi.org/10.2307/606062.

MacDonald A., Knowing Notbing. Candrakirti and Yogic Perception, [w:] Yogic Perception, Meditation and Altered States of Consciouness, ed. E. Franco, Verlag der Österreichische Akademie der Wissenschaften, Wien 2009, s. 133-168.

Machuca D. E., Ancient Skepticism. Pyrrbonism, „Philosophy Compass” 6/4 (2011), s. 246-258, https://doi.org/10.1111/j.1747-9991.2011.00391.x.

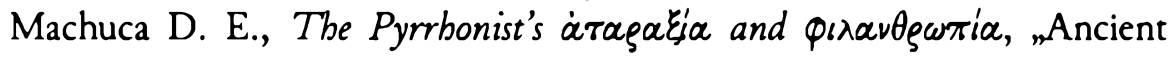
Philosophy" 26 (2006), s. 111-139, https://doi.org/10.5840/ancientphil200626141. 
Madhyamaka and Yogācära. Allies or Rivals?, ed. J. L. Garfield, J. Westerhoff, Oxford University Press, Oxford 2015.

Massie P., Ataraxia. Tranquility at the End, [w:] A Companion to Ancient Philosopby, ed. S. D. Kirkland, E. Sanday, Northwestern University Press, Evanston 2018, s. 245-262, https://doi.org/10.2307/j.ctv75d7 w6.23.

Massie P., Pbilosophy and Ataraxia in Sextus Empiricus, "Peitho / Examina Antiqua" 1/4 (2013), s. 211-234, https://doi.org/10.14746/pea.2013. 1.10 .

Matial B. K., Epistemology, Logic, and Grammar in Indian Philosopbical Analysis, ed. J. Ganeri, Oxford University Press, Oxford 2005, https:// doi.org/10.1515/9783110813562.

Matilal B. K., Mysticism and Reality. Ineffability, JIP 3 (1975), s. 217-252, https://doi.org/10.1007/bf02629145.

Matilal B. K., Perception. An Essay on Classical Indian Theories of Knowledge, Clarendon Press, Oxford 1985, https://doi.org/10.1093/acprof:o so/9780198239765.001.0001.

Matilal B. K., Scepticism and Mysticism, JAOS 105/3 (1985), s. 479-484, https://doi.org/10.2307/601523.

Matilal B. K., The Logical Illumination of Indian Mysticism, [w:] Mind, Language and World. The Collected Essays of Bimal Krishna Matilal, ed. J. Ganeri, Oxford University Press, New Delhi 2002, s. 38-64.

McCagney N., Nägärjuna and the Philosophy of Openness, Rowman \& Littlefield Publishers, Lanham 1997.

McEvilley Th., The Shape of Ancient Thought. Comparative Studies in Greek and Indian Philosopbies, Allworth Press, New York 2001.

McPherran M. L., Ataraxia and Eudaimonia in Ancient Pyrrbonism. Is the Skeptic Really Happy?, „Proceedings of the Boston Area Colloquium in Ancient Philosophy" 5 (1989), s. 135-171.

McPherran M. L., Skeptical Homeopathy and Self-refutation, „Phronesis” 32 (1987), s. 290-328, https://doi.org/10.1163/156852887x00172.

Mejor M., Buddyjska doktryna o powstawaniu $w$ zależności (pratitya-samutpāda) - oryginalna koncepcja samego Buddy czy późniejszy jej rozwój?, SI 3 (1996), s. 118-129.

Mejor M., Buddyzm. Zarys historii buddyzmu w Indiach, Prószyński i S-ka, Warszawa 2001. 
Mills E., Skepticism and Religious Practice in Sextus and Nagarjuna, [w:] Ethics without Self, Dharma without Atman. Western and Buddhist Philosophical Traditions in Dialogue, ed. G. F. Davis, Springer, Cham 2018, s. 91-106, https://doi.org/10.1007/978-3-319-67407-0_4.

Mills E., The Dependent Origination of Skepticism in Classical India. An Experiment in Cross-Cultural Philosophy, [rozpr. dokt.], The University of New Mexico, Albuquerque 2013.

Mills E., Three Pillars of Skepticism in Classical India. Nägārjuna, Jayarāíi, and Śrī Harṣa, Lexington Books, Lanham 2018.

Murti T. R. V., The Central Philosophy of Buddhism, George Allen \& Unwin, London 1955, https://doi.org/10.4324/9780203706701.

Murty K. S., Nagarjuna, National Book Trust, New Delhi 1983 (rep.). Nagao G., The Silence of the Buddha and Its Madhyamic Interpretation, [w:]

G. Nagao, Madbyamika and Yogacara. A Study of Mabãyāna Pbilosophies, ed., trans. L. S. Kawamura, SUNY Press, Albany 1991, s. 35-49. Nakamura H., Indian Buddhism. A Survey with Bibliographical Notes, Motilal Banarsidass Publ., Delhi 1996.

Narain H., Súnyavada. A Reinterpretation, PEW 13/4 (1963), s. 311-338, https://doi.org/10.2307/1396920.

Narain H., The Madbyamika Mind, Motilal Banarsidass Publ., Delhi 1997. Narain H., The Nature of Mädbyamika Thought, [w:] Maadbyamika Dialectic and the Philosopby of Nägarjuna, ed. Samdhong Rinpoche, Central Institute of Higher Tibetan Studies, Sarnath 1985, s. 227-256.

Nietzsche F., Wola mocy, ttum. S. Frycz, K. Drzewiecki, Nakład Jakóba Mortkiewicza, Warszawa 1910-1911.

Norman K. R., The Atthakavagga and Early Buddhism, [w:] Jainism and Early Buddhism. Essays in Honour of Padmanabb S. Jaini, vol. 2, ed. O. Qvarnström, Asian Humanities Press, Fremont 2003, s. 511-522.

Norman K. R., Pali Literature. Including the Canonical Literature in Prakrit and Sanskrit of All the Hinayana Schools of Buddhism, Otto Harrassowitz, Wiesbaden 1983.

Norman K. R., On Translating the Dhammapada, BSR 6/2 (1989), s. 153165.

Nussbaum M. C., The Therapy of Desire. Theory and Practice in Hellenistic Ethics, Princeton University Press, Princeton-Oxford 1994, https://doi. org/10.2307/j.ctt2tt8tt. 
Oetke C., „Nibilist” and "Non-nibilist” Interpretations of Madbyamaka. Review article of: Thomas E. Wood, Nägärjunian Disputations, Honolulu 1994, AO 57 (1996), s. 57-104.

O'Leary J. S., Ultimacy and Conventionality in Religious Experience, [w:] Religious Experience and the End of Metaphysics, ed. J. Bloechl, Indiana University Press, Bloomington-Indianapolis 2003, s. 174-199.

Organ T. W., The Silence of the Buddba, PEW 4/2 (1954), s. 125-140, https://doi.org/10.2307/1397523.

Orsborn M. B., Chiasmus in the Early Prajn̄āpāramitā. Literary Parallelism Connecting Criticism and Hermeneutics in an Early Mahāyāna Sūtra, [rozpr. dokt.], The University of Hong Kong, Hong Kong 2012.

Otto R., Mistyka Wschodu i Zachodu. Analogie i różnice wyjaśniające jej istotę, tłum. T. Duliński, Wydawnictwo KR, Warszawa 2000.

Pali-English Dictionary, ed. T. W. Rhys Davids, W. Stede, Motilal Banarsidass Publ., Delhi 1993.

Pande G. C., Causality in Buddbist Pbilosopby, [w:] A Companion to World Philosopbies, ed. E. Deutsch, R. Bontekoe, Blackwell Publishers, Oxford 1999, s. 370-380, https://doi.org/10.1002/9781405164566.ch26. Park K., An Analysis of the Buddha's Paradoxical Silence. Neither the Positive nor Nibilistic View, „International Journal of Buddhist Thought \& Culture" 6 (2006), s. 243-264.

Parrinder G., Mysticism in the World's Religions, $2^{\text {nd }}$ ed., Oneworld, Oxford 1995.

Pāsādika, Bhikkhu, The Kāśyapaparivarta (Od-srung-gi le'u) - Prolegomena, TJ 5/4 (1980), s. 48-58.

Pathak S. K., Life of Nāgārjuna, IHQ 30/1 (1954), s. 93-95.

Pérez-Remón J., Self and Non-Self in Early Buddbism, Mouton Publishers,

The Hague 1980, https://doi.org/10.1515/9783110804164.

Perin C., Pyrrbonian Scepticism and the Search for Truth, „Oxford Studies in Ancient Philosophy" 30 (2006), s. 337-360.

Polak G., Language, Conscious Experience and the Self in Early Buddhism. A Cross-cultural Interdisciplinary Study, JOCBS 14 (2018), s. 37-76.

Premasiri P. D., The Pbilosopby of the Atthakavagga, Buddhist Publication Society (online edition), Kandy 2008.

Putnam H., Wiele twarzy realizmu i inne eseje, wybór i tłum. A. Grobler, Wydawnictwo Naukowe PWN, Warszawa 1998. 
Pyysiäinen I., Beyond Language and Reason. Mysticism in Indian Buddhism, Suomalainen Tiedeakatemia, Helsinki 1993.

Question of Being. East-West Perspectives, ed. M. Sprung, Pennsylvania State University Press, University Park 1978.

Radich M. D., The Somatics of Liberation. Ideas about Embodiment in Buddhism from Its Origins to the Fifth Century C.E., [rozpr. dokt.], Harvard University, Cambridge 2007.

Rhys Davids C. A. F., On the Will in Buddhism, JRAS 1 (1898), s. 47-59. Rhys Davids C. A. F., To Become or Not to Become, Luzac \& Co., London 1937.

Robinson R. H., Did Nagarjuna Really Refute All Pbilosophical Views?, PEW 22 (1972), s. 325-331, https://doi.org/10.2307/1397681.

Ronkin N., Early Buddbist Metaphysics. The Making of a Pbilosophical Tradition, RoutledgeCurzon, London-New York 2005, https://doi.org/ 10.4324/9780203537060.

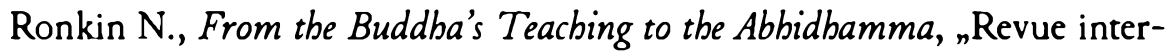
nationale de philosophie" 3/253 (2010), s. 341-365.

Rospatt A. von, The Buddhist Doctrine of Momentariness, Steiner, Stuttgart 1995.

Ruegg D. S., Does the Mädhyamika Have a Thesis and Philosophical Position?, [w:] Buddhist Logic and Epistemology. Studies in the Buddhist Analysis of Inference and Language, ed. B. K. Matilal, R. D. Evans, Kluwer Academic Publishers, Dordrecht 1986, s. 229-237, https://doi.org/ 10.1007/978-94-009-4644-6_14.

Ruegg D. S., Some Reflections on the Place of Philosophy in the Study of Buddhism, [w:] D. S. Ruegg, The Buddhist Philosophy of the Middle. Essays on Indian and Tibetan Madhyamaka, Wisdom Publications, Boston 2010, s. 217-252.

Ruegg D. S., The Literature of the Madhyamaka School of Philosophy in India, Otto Harrassowitz, Wiesbaden 1981.

Salomon R., Buddhist Literature of Ancient Gandbara. An Introduction with Selected Translations, Wisdom Publications, Somerville 2018.

Salvini M., Dependent Arising, Non-arising, and the Mind. MMK1 and the Abbidharma, JIP 42 (2014), s. 471-497, https://doi.org/10.1007/s10 781-014-9219-6. 
Salvini M., Language and Existence in Madhyamaka and Yogäcāra. Preliminary Reflections, [w:] Madbyamaka and Yogacära. Allies or Rivals?, ed. J. L. Garfield, J. Westerhoff, Oxford University Press, Oxford 2015, s. 29-71, https://doi.org/10.1093/acprof:oso/9780190231286.003.0003. Salvini M., The Nidannasamyukta and the Mülamadhyamakakarika. Understanding the Middle Way through Comparison and Exegesis, TIJBS 2 (2011), s. 57-95.

Sayādaw M., A Discourse on Dependent Origination, trans. U Aye Maung, ed. Bhikkhu Pesala, Association for Insight Meditation, Middlesex 2013.

Scarborough M., Comparative Theories of Nonduality. The Searcb for a Middle Way, Continuum, London-New York 2009.

Schayer S., Anityatā. Zagadnienie nietrwałości bytu w filozofii buddyjskiej, [w:] S. Schayer, O filozofowaniu Hindusów, red. M. Mejor, Państwowe Wydawnictwo Naukowe, Warszawa 1988, s. 230-312.

Schayer S., Ausgewäblte Kapitel aus der Prasannapada, PAU, Kraków 1931. Schlingloff D., Buddyzm, thum. L. Żylicz, Wydawnictwo Akademickie Dialog, Warszawa 2004.

Schmithausen L., On Some Aspects of Descriptions or Theories of "Liberating Insight" and "Enlightenment" in Early Buddhism, [w:] Studien zum Jainismus und Buddhismus. Gedenkscbrift für Ludwig Alsdorf, hrsg. K. Bruhn,

A. Wezler, Franz Steiner Verlag GmbH, Wiesbaden 1981, s. 199-250. Schmithausen L., On the Problem of the Relation of Spiritual Practice and Philosophical Theory in Buddhism, [w:] German Scholars on India II, ed. Cultural Department of the Embassy of the Federal Republic of Germany, Bombay 1976, s. 235-251.

Scholem G., Mistycyzm żydowski i jego główne kierunki, tłum. I. Kania, Wydawnictwo Aletheia, Warszawa 2007.

Schopen G., The Phrase "sa prthivipradeśaś caityabhūto bhavet" in the Vajracchedikā. Notes on the Cult of the Book in Mabayana, IIJ 17 (1975), s. 147-181, https://doi.org/10.1163/000000075790079574.

Sebastian C. D., The Cloud of Nothingness. The Negative Way in Nagariuna and Jobn of the Cross, Springer India, New Delhi 2016, https://doi.org/ 10.1007/978-81-322-3646-7.

Sharf R. H., The Rhetoric of Experience and the Study of Religion, $n$ Journal of Consciousness Studies" 7/11-12 (2000), s. 267-287. 
Shulman E., Early Buddhist Imagination. The Atțhakavagga as Buddhist Poetry, JLABS 35/1-2 (2012), s. 363-411.

Shulman E., Early Meanings of Dependent Origination, JIP 36 (2008), s. 297-317.

Shulman E., Language, Understanding and Reality. A Study of Their Relation in a Foundational Indian Metaphysical Debate, JIP 40 (2012), s. 339-369, https://doi.org/10.1007/s10781-012-9158-z.

Shulman E., Mindful Wisdom. The Sati-patṭhāna-sutta on Mindfulness, Memory, and Liberation, HR 49/4 (2010), s. 393-420, https://doi. org/10.1086/649856.

Siderits M., Buddhism as Philosophy. An Introduction, Hackett Pub., Indianapolis 2007, https://doi.org/10.4324/9781315261225.

Siderits M., Buddhist Reductionism, PEW 47/4 (1997), s. 455-478, https:// doi.org/10.2307/1400298.

Siderits M., Causation and Emptiness in Early Madbyamaka, JIP 32 (2004), s. 393-419, https://doi.org/10.1023/b:indi.0000044422.42295.6a.

Siderits M., Indian Philosophy of Language. Studies in Selected Issues, Kluwer Academic Pub., Dordrecht 1991, https://doi.org/10.1007/978-94-0113234-3.

Siderits M., Madhyamaka Emptiness and Buddhist Ethics, [w:] Nothingness in Asian Pbilosophy, ed. JeeLoo Liu, D. L. Berger, Routledge, New York-London 2014, s. 64-77, https://doi.org/10.4324/9781315774244. Siderits M., Katsura Sh., Nãgārjuna's Middle Way. The Mülamadhyamakakārikā, Wisdom Publications, Boston 2013.

Silk J. A., The Nature of the Verses of the Kāsyapaparivarta, „Bulletin of the Asia Institute" 23 (2009), s. 181-190.

Skilton A., Dating the Samädhirāja Sütra, JIP 7 (1999), s. 635-652, https:// doi.org/10.1023/A:1004633623956.

Slocombe W., Nibilism and the Sublime Postmodern. The (Hi)Story of a Difficult Relationship from Romanticism to Postmodernism, Routledge, New York-London 2006, https://doi.org/10.4324/9780203959206.

Smart N., Mysticism and Scripture in Theravāda Buddhism, [w:] Mysticism and Sacred Scripture, ed. S. T. Katz, Oxford University Press, Oxford 2000, s. 232-241, https://doi.org/10.1093/acprof:oso/9780195097030. 003.0012 . 
Smart N., Transcendence in a Pluralistic Context, [w:] Religion without Transcendence, ed. D. Z. Phillips, T. Tessin, Macmillan Press, Hampshire-London 1997, s. 113-121, https://doi.org/10.1007/978-1-34925915-1_8.

Smith D., Was the Buddha an Anti-Realist?, JOCBS 11 (2015), s. 143-178. Smith D., Whitaker J., Reading the Buddha as a Pbilosopher, PEW 66/2 (2016), s. 515-538, https://doi.org/10.1353/pew.2016.0026.

Sprung M., Being and the Middle Way, [w:] Question of Being. East-West Perspectives, ed. M. Sprung, Pennsylvania State University Press, University Park 1978, s. 127-139.

Stace W. T., Mysticism and Pbilosopby, Macmillan and Co., London 1961. Stcherbatsky T., The Conception of Buddbist Nirvana, The Academy of Sciences of the USSR, Leningrad 1927.

Striker G., Ataraxia. Happiness as Tranquillity, [w:] G. Striker, Essays on Hellenistic Epistemology and Ethics, Cambridge University Press, Cambridge 1996, s. 183-195, https://doi.org/10.1017/cbo9781139172783.010.

Stróżewski W., Ontologia, Wydawnictwo Aureus - Wydawnictwo Znak, Kraków 2003.

Studies in the Literature of the Great Vebicle. Three Mabāyana Buddbist Texts, ed. L. O. Gomez, J. A. Silk, The University of Michigan, Ann Arbor 1989.

Suzuki D. T., An Interpretation of Zen Experience (1939), [w:] D. T. Suzuki, Studies in Zen, A Delta Book, New York 1955, s. 61-84.

Suzuki D. T., Mysticism. Christian and Buddbist, Routledge, London-New York 2002 (1 wyd. 1957), https://doi.org/10.4324/9780203217856.

Suzuki D. T., Outlines of Mabayana Buddhism, Luzac and Company, London 1907.

Suzuki D. T., Wprowadzenie do buddyzmu zen, tłum. M. i A. Grabowscy, Wydawnictwo Przedświt, Warszawa 1992.

Suzuki D. T., Zen i kultura japońska, tłum. B. Szymańska et al., Wydawnictwo UJ, Kraków 2009.

Suzuki Sh., Umyst zen, umyst początkujacego, thum. J. Dobrowolski, A. Sobota, b.m.w., b.r.w.

The Svatantrika-Prāsangika Distinction. What Difference Does a Difference Make?, ed. G. B. J. Dreyfus, S. L. McClintock, Wisdom Publications, Boston 2003. 
Svavarsson S. H., The Pyrrbonian Idea of a Good Life, [w:] The Quest for the Good Life. Ancient Philosophers on Happiness, ed. Ø. Rabbås et al., Oxford University Press, Oxford 2015, s. 197-211, https://doi.org/10. 1093/acprof:oso/9780198746980.003.0011.

Svavarsson S. H., Two Kinds of Tranquility. Sextus Empiricus on Ataraxia, [w:] Pyrrhonism in Ancient, Modern, and Contemporary Pbilosophy, ed. D. E. Machuca, Springer, Dordrecht 2011, s. 19-31, https://doi.org/ 10.1007/978-94-007-1991-0_2.

Szahaj A., Teksty na wolności, „Kultura Współczesna” 2 (1993), s. 5-13. Szubka T., Trzy formy wspótczesnego antyrealizmu, "Kwartalnik Filozoficzny" XXVI/1 (1998), s. 5-33.

Tamblyn N., Parmenides and Nägarjuna. A Buddhist Interpretation of Ancient Greek Philosophy, JOCBS 4 (2013), s. 134-146.

Tanaka K., In Search of the Semantics of Emptiness, [w:] Notbingness in Asian Philosophy, ed. JeeLoo Liu, D. L. Berger, Routledge, New York-London 2014, s. 55-63, https://doi.org/10.4324/9781315774244.

Tanji T., On Samaropa. Probing the Relationship of the Buddha's Silence and His Teaching, [w:] Wisdom, Compassion, and the Search for Understanding. The Buddhist Studies Legacy of Gadjin M. Nagao, ed. J. A. Silk, University of Hawaii Press, Honolulu 2000, s. 347-368.

Thomas E. J., The History of Buddhist Thought, Kegan Paul, Trench, Trubner \& Co., London 1933, https://doi.org/10.2307/2015503.

Thomas E. J., The Life of Buddha as Legend and History, Kegan Paul, Trench, Trubner \& Co., London 1927, https://doi.org/10.1038/12015 $2 \mathrm{~b} 0$.

Tilakaratne A., Excursus. The Buddhist Concept of Truth(Sacca), [w:] Mindful Journalism and News Ethics in the Digital Era. A Buddhist Approach, ed. Sh. A. Gunaratne, M. Pearson, S. Senarath, Routledge, New YorkLondon 2015, s. 125-129, https://doi.org/10.4324/9781315723341.

Tillemans T. J. F., Metaphysics for Madhyamikas, [w:] The Svātantrika- Prasangika Distinction. What Difference Does a Difference Make?, ed. G. Dreyfus, S. McClintock, Wisdom Publications, Boston 2003, s. 93123.

Tillemans T. J. F., Trying to Be Fair to Mädbyamika Buddhism, Winter 2001, University of Calgary, Calgary 2001, s. 1-29. 
Tillemans T. J. F., What Are Madbyamikas Refuting? Sāntarakșita, Kamalaśila et alii on Superimpositions (Samāropa), [w:] Three Mountains and Seven Rivers. Prof. Musashi Tacbikawa's Felicitation Volume, ed. S. Hino, T. Wada, Motilal Banarsidass Publ., Delhi 2004, s. 225-237. Tola F., Dragonetti C., On Voidness. A Study on Buddhist Nibilism, Motilal Banarsidass Publ., Delhi 1995.

Tsai Yao-ming, Language as an Instrument of Soteriological Transformation from the Madhyamaka Perspective, APh 24/4 (2014), s. 330-345, https://doi.org/10.1080/09552367.2014.984484.

Vélez de Cea A., Emptiness in the Pali Suttas and the Question of Nāgārjuna's Orthodoxy, PEW 55/4 (2005), s. 507-528, https://doi.org/ 10.1353/pew.2005.0043.

Vélez de Cea A., The Silence of the Buddha and the Questions about the Tathägata after Death, "The Indian International Journal of Buddhist Studies" 5 (2004), s. 119-141.

Vernant D., The Limits of a Logical Treatment of Assertion, [w:] Logic, Thought and Action, ed. D. Vanderveken, Springer, Dordrecht 2005, s. 267-288, https://doi.org/10.1007/1-4020-3167-x_13.

Vetter T., Some Remarks on Older Parts of the Suttanipāta, [w:] Earliest Buddhism and Madhyamaka, ed. D. S. Ruegg, L. Schmithausen, E. J. Brill, Leiden 1990, s. 36-56.

Vogt K. M., The Aims of Skeptical Investigation, [w:] Pyrrbonism in Ancient, Modern, and Contemporary Pbilosophy, ed. D. E. Machuca, Springer, Dordrecht 2011, s. 33-49, https://doi.org/10.1093/acprof:oso/97801 99916818.003.0006.

Waghorn N., Nothingness and the Meaning of Life. Philosophical Approaches to Ultimate Meaning Through Notbing and Reflexivity, Bloomsbury Academic, London 2014, https://doi.org/10.5040/9781472594334.

Walleser M., The Life of Nägärjuna from Tibetan and Chinese Sources, trans. from the German A. A. Probsthain, AM 1 (1923), s. 421-455. Walser J., Nagarjuna and the Ratnavali. New Days to Date an Old Philosopher, JLABS 25/1-2 (2002), s. 209-262.

Walser J., Nägärjuna in Context. Mabāyāna Buddhism and Early Indian Culture, Columbia University Press, New York 2005, https://doi.org/ 10.7312/wals13164. 
Warder A. K., A Course in Indian Pbilosophy, Motilal Banarsidass Publ., Delhi 1998.

Warder A. K., Is Nagarjuna a Mabayanist?, [w:] The Problem of Two Trutbs in Buddhism and Vedanta, ed. M. Sprung, D. Reidel Publishing Company, Dordrecht-Boston 1973, s. 78-88, https://doi.org/10.1007/ 978-94-010-2582-9_7.

Watts J. D., Necessity and Sufficiency in the Buddhist Causal Schema, PEW 32/4 (1982), s. 407-423, https://doi.org/10.2307/1398613.

Wayman A., The Twenty Reifying Views (sakkayadittbi), [w:] Studies in Pali and Buddhism: A Memorial Volume in Honor of Bbikkbu Jagdish Kashyap, $2^{\text {nd }}$ ed., ed. A. K. Narain, B. R. Publishing Corporation, Delhi 2006, s. $375-380$.

Welbon G. R., On Understanding the Buddhist Nirvāna, HR 5/2 (1966), s. 300-326, https://doi.org/10.1086/462528.

Westerhoff J., Madbyamaka. Conventional Categories in Madhyamaka Pbilosophy, [w:] Categorisation in Indian Philosopby. Thinking Inside the Box, ed. J. Frazier, Ashgate Publishing, Surrey 2014, s. 115-131, https:// doi.org/10.4324/9781315570976.

Westerhoff J., Metaphysical Issues in Indian Buddhist Thought, [w:] A Companion to Buddhist Philosophy, ed. S. M. Emmanuel, Wiley-Blackwell, Chichester 2013, s. 129-150, https://doi.org/10.1002/97811183240 04.ch8.

Westerhoff J., Nãgārjuna's Madhyamaka. A Philosophical Introduction, Oxford University Press, Oxford-New York 2009, https://doi.org/10.1093/ acprof:oso/9780195375213.001.0001.

Westerhoff J., On the Nibilist Interpretation of Madbyamaka, JIP 44 (2016), s. 337-376, https://doi.org/10.1007/s10781-014-9266-z.

Westerhoff J., The Madhyamaka Concept of Svabhāva. Ontological and Cognitive Aspects, APh 17/1 (2007), s. 17-45, https://doi.org/10.1080/ 09552360701201122.

Westerhoff J., The Merely Conventional Existence of the World, [w:] Moonshadows. Conventional Truth in Buddhist Philosophy, ed. The Cowherds, Oxford University Press, Oxford 2011, s. 189-212, https://doi.org/10. 1093/acprof:oso/9780199751426.003.0012.

Westerhoff J., The No-Thesis View. Making Sense of Verse 29 of Nagarjuna's Vigrahavyāvartanī, [w:] Pointing at the Moon. Buddhism, Logic, 
Analytic Pbilosophy, ed. M. D'Amato, J. L. Garfield, T. J. L. Tillemans, Oxford University Press, Oxford 2009, s. 25-39, https://doi. org/10.1093/acprof:oso/9780195381559.003.0003.

Whitney W. D., The Roots, Verb-Forms, and Primary Derivatives of the Sanskrit Language, Breitkopf and Härtel, Leipzig 1885.

Williams P. M., Mabayāna Buddhism. The Doctrinal Foundations, Routledge, New York 1989, https://doi.org/10.4324/9780203428474.

Williams P. M., On the Abbidharma Ontology, JIP 9 (1981), s. 227-257, https://doi.org/10.1007/bf00235381.

Williams P. M., Some Aspects of Language and Construction in the Madhyamaka, JIP 8 (1980), s. 1-45, https://doi.org/10.1007/bf02539785.

Wong A. D., Unmitigated Skepticism. The Nature and Scope of Pyrrhonism, [rozpr. dokt.], University of California, San Diego 2017.

Wood T. E., Nagārjunian Disputations. A Philosophical Journey through an Indian Looking-Glass, University of Hawai'i Press, Honolulu 1994.

Wynne A., Buddhism. An Introduction, I.B. Tauris, London-New York 2015.

Wynne A., Early Buddhist Teachings as Proto-śūnyavāda, JOCBS 11 (2015), s. 213-241.

Wynne A., Early Evidence for the "No Self” Doctrine? A Note on the Second anātman Teaching of the Second Sermon, TIJBS 1 (2009), s. 64-84.

Wynne A., Miraculous Transformation and Personal Identity. A Note on the First anātman Teaching of the Second Sermon, TIJBS 1 (2009), s. 85-113.

Wynne A., The ātman and Its Negation. A Conceptual and Chronological Analysis of Early Buddhist Thought, JLABS 33/1-2 (2010), s. 103-171. Wynne A., The Origin of Buddhist Meditation, Routledge, London-New York 2007, https://doi.org/10.4324/9780203963005.

Yoshimizu Ch., Causal Efficacy and Spatiotemporal Restriction. An Analitical Study of the Sautrāntika Philosophy, [w:] Pramanakinitith. Papers dedicated to Ernst Steinkellner on the occasion of bis 70th birthday, part 2, ed. B. Kellner et al., Wien 2007, s. 1049-1078 (Wiener Studien zur Tibetologie und Buddhismuskunde 70.2).

Yün-hua J., Nagarjuna, One or More?' A New Interpretation of Buddhist Hagiography, HR 10/2 (1970), s. 139-155, https://doi.org/10.1086/462624. 
Zaehner R. Ch., Mysticism, Sacred and Profane, Oxford University Press, Oxford 1971.

Ziemińska R., Czy Pirron byt sceptykiem? Nowe interpretacje starożytnego sceptycyzmu, „Studia Philosophica Wratislaviensia” 6/1 (2011), s. 169175.

Ziemińska R., Historia sceptycyzmu. W poszukiwaniu spónności, Wydawnictwo Naukowe UMK, Toruń 2013. 



\section{Indeks osobowy}

Postaci mityczne zaznaczone kursywą

Adżatasattu (p. Ajātasattu) 320

Aggiwessana (p. Aggivessana) 104,

315-316

Ainezydem 238

Albahari Miri 113

Ames William L. 385

Anālayo 78

Ananda (p. Ānanda) 59, 61, 73, $130,137-139,141,215,272$,

$$
\text { 284, 320-322, } 336
$$

Anderson Carol 301, 317

Antygonos z Karystos 231

Annas Julia 264-265

Apelles 248

Apple James 155

Arjadewa (s. Āryadeva) 49, 210,

224, 340-341, 391-392

Arkezylaos 239-240

Arystokles z Messyny 240

Arystoteles 276, 339

Asanga (s. Asanga) 36-37

Assadżi (p. Assaji) 124, 149

Ausland Hayden W. 242
Balcerowicz Piotr 129

Bareau André 365

Barnes Jonathan 265

Beckwith Christopher I. 233-234, 242-243

Bergson Henri 23-24, 401

Berkeley George 33

Bett Richard 241, 245, 253, 258

Betty L. Stafford 373

Bhaddija (p. Bhaddiya) 317

Bhawawiweka (s. Bhāvaviveka) 153, 193-194

Bhumidża (p. Bhūmija) 137

Biderman Shlomo 350

Bloechl Jeffrey 373

Bodhi, Bhikkhu 65, 77, 98-100, 104-106, 236, 294, 308, 328, 334

Boin-Webb Sara 309

Bolewski Jacek 394, 396

Bosch Lourens van den 54

Brennan Tad 260-261

Bronkhorst Johannes 367

Bruhn Klaus 278 
Brunschwig Jacques 242

Budda (p., s. Buddha) passim

Buddhaghosa (p. Buddhaghosa) 49,

57, 65-66, 130, 208, 286

Buddhapalita (s. Buddhapālita) 153

Buffetrille Katia 38

Burnet John 231

Burnouf Eugène 38

Burton David 40, 369

Buswell Robert 155, 396

Byrski Maria Krzysztof 385

Cabezón José Ignacio 395

Carr Karen Leslie 29-30

Castagnoli Luca 249

Chalmers Robert 285

Chödrön Gelongma Migme 278

Choong Mun-keat 209, 211-212, 218-219, 221, 235

Collins Steven 113, 275

Collinson Diané 366

Conze Edward 156, 166-168, 180, 292

Craig Edward 109

Czandrakirti (s. Candrakìrti) 49, 54, 193-198, 200, 205-206, 220, 347-351, 353, 374, 382, 387, 395 Czanki (p. Cañkī) 329

Czhanda/Czhanna (s. Chanda, p. Channa) 220-221

Czitta (p. Citta) 104, 214

D'Amato Mario 340, 386

Dandapani (p. Daṇḍapāni) 310-311

Darling Gregory Joseph 37

Davis Gordon F. 276
Dąmbska Izydora 265

Dewadatta 355

Dębicki Władysław M. 34

Dhammadinna (p. Dhammadinnā)

$$
\text { 73-74 }
$$

Dhammajothi Medawachchiye 212

Dhammajoti K. L. 203

Dighanakha (p. Dïghanakha), zob. Aggiwessana

Diogenes Laertios 243, 254

Dobrowolski Jacek 399

Dogen 383

Dreyfus Georges 349

Droit Roger-Pol 38

Drzewiecki Konrad 231

Duliński Tomasz 369

Dummett Michael 117

Dutt Nalinaksha 36

Di̇nianagarbha (s. Jñãnagarbha)

382

Emmanuel Steven M. 113

Euzebiusz z Cezarei 241

Evans Robert D. 340

Falk Harry 15

Fallick Eric 338

Ferraro Giuseppe 41

Filon z Aleksandrii 384

Fink Charles K. 284

Flintoff Everard 232

Fosl Peter S. 365

Franke Otto 33

Frenkian Aram M. 232

Frycz Stefan 231

Fuller Paul 90, 316 
Gajda Janina 21-22

Gandolfo Stefano 354

Ganeri Jonardon 372, 393, 395

Gangopadhyaya Mrinalkanti 122

Garfield Jay 201-202, 232, 340

Gethin Rupert 77, 135, 360

Gierulanka Danuta 381

Gimello Robert M. 396

Godatta (p. Godatta) 214

Gombrich Richard Francis 278

Gómez Luis Oscar 197, 337-338

Goodman Nelson 116

Gorgiasz z Leontinoi 21, 29, 401 Gotama (p. Gotama), zob. Budda Grabowska Małgorzata 367

Grabowski Andrzej 367

Gray David B. 366

Grela Joanna 164

Grgić Filip 265

Grobler Adam 117

Gupta Rita 149

Halkias Georgios T. 233

Hamilton Sue 57, 66, 106-111, 116, 149

Hankinson R. Jim 263

Harvey Peter 113

Hastings James 231-232

Hayes Richard P. 39, 232-233

Hegel Georg Wilhelm Friedrich 402

Heisig James 377

Hempel Jan 369

Hino Shoun 382

Hirakawa Akira 149, 155

Horner Isaline Blew 124, 285-286
Hsueh-Li Cheng 147

Huifeng Shì 208, 211

Husserl Edmund 339, 381, 397-398

Huxley Aldous 370

Hwang Soonil 284

Ingarden Roman 172, 398

Isidatta (p. Isidatta) 72

Jacobi Friedrich Heinrich 27

Jakubczak Krzysztof 39, 103, 191, 354, 360, 381

Jakubczak Marzenna 103

James William 369, 371

Jayatilleke Kulatissa Nanda 45, 103, 285, 318, 330

Joachimowicz Leon 265

Jones Richard H. 372

Jong Jan Willem de 15, 38, 374

Jurewicz Joanna 148

Kaczczana / Kaczczanagotta / Kaczczajanagotta / Mahakaczczana (p. Kaccāna, Kaccānagotta, Kaccāyanagotta, Mahākaccāna), zob. Katjajana

Kalupahana David J. 53-54, 129, $131,133,146-147,149,158-$ $160,195-196$

Kamalasila (s. Kamalaśîla) 197, 382, 396

Kania Ireneusz 370

Kant Immanuel 24, 39, 106-107, 116, 277

Kapathika (p. Kāpațhika) 329

Kapstein Matthew T. 399 
Karamanolis George E. 249

Karambelkar V. W. 210

Karashima Seishi 155

Kartezjusz 398, 402

Kassapa/Kaśjapa (p. Kassapa, s. Kāśyapa) $84-85,128,157,159,161$, 163-164, 196

Katjajana / Mahakatjajana / Sandhakatjajana (s. Kātyāyana, Mahākātyāyana, Sandhākātyāyana) 43, 53-55, 82, 89, 92, 94, 123, 152, $273,306-307,311-312,325$, 344,391

Katsura Shōryū 154, 193-194, 204 Katz Nathan 56, 317

Katz Steven T. 365

Kausika/Siakra (s. Kauśika, Śakra) 183-184, 186

Kawamura Leslie S. 395

Keith Arthur Berriedale 38

Kellenberger James 370

Kern Hendrik 33, 38

Khema (p. Khemā) 81

Kippenberg Hans G. 54

Kirkland Sean D. 253

Klein Anne Carolyn 396

Kołyszko Piotr 370

Kosior Krzysztof 93, 104, 113

Kozyra Agnieszka 377

Krokiewicz Adam 239, 241

Krońska Irena 243

Kudelska Marta 127

Kukla André 371

Kupis Bogdan 243

Kuzminski Adrian 232, 350
Lamotte Étienne 209, 219

Lang Karen C. 226

Lindtner Christian 15

Lokakszema (s. Lokakṣema) 155156

Lopez Donald S. 38, 155

Loy David 373

Mabbett Ian 210, 340

Machuca Diego E. 245, 249, 265, 268

Magandija (p. Māgandiya) 274, 280-281, 283, 285, 322-326, 335 Mahakotthita (p. Mahākoțțhita) 214

Mahakaczczana, zob. Kaczczana

Mahakatjajana, zob. Katjajana

Mahamoggallana, zob. Moggallana Malunkjaputta (p. Mālunikyaputta) 272-273

Mara (p. Māra) 88, 119, 146

Massie Pascal 249, 253, 260, 269

Matilal Bimal Krishna 232, 340, 350, 368, 371-373, 384, 393

Maung U Aye 286

McCagney Nancy 214

McClintock Sara 349

McEvilley Thomas 233-234, 350

McPherran Mark L. 264

Mejor Marek 39, 75, 136, 141

Michalski Stanisław Franciszek 288

Mills Ethan 275, 354

Mitra Rājendralāla 15, 166

Moggalana/Mahamoggallana (p. Moggallāna, Mahāmoggallāna) 320 
Mogharadża (p. Mogharāja) 216217

Molijaphagguna (p. Moliyaphagguna) 87

Murti Tirupattur Ramaseshayyer

Venkatachala 39, 208, 366

Murty Kotha Satchidananda 210

Nagao Gadjin 395

Nagardżuna (s. Nāgārjuna) 15, 17, $35,38,40,46-49,53-54,97$, $101,149,153-155,157,162$, $170-171,188,190-192,194-$ 196, 198-212, 214. 216-217, 221-227, 233-234, 275, 287, 337-344, 346-349, 352-355, $360,362,369,373,380-382$, 386, 389-394

Nakamura Hajime 293

N̄āṇamoli, Bhikkhu 77, 236

Narain Harsh 39

Nerczuk Zbigniew 258

Nietzsche Friedrich 231

Nishida Kitaro 377

Norman Kenneth Roy 288, 293, 324, 328

Nussbaum Martha 264

O'Leary Joseph Stephen 373

Oetke Claus 40

Olivelle Patrick 127

Olszewski Witold 243

Organ Troy Wilson 395

Orsborn Matthew 167

Otto Rudolf 369
Paharada (p. Pahārāda) 225

Pakudha Kaczczajana (p. Pakudha Kaccāyana) 128

Park Kwangsoo 395

Parmenides 22, 24, 199, 227, 401-402

Parrinder Geoffrey 366

Parsons William B. 366

Pāsādika, Bhikkhu 155

Pasenadi (p. Pasenadi) 81

Pathak Sunitikumar 210

Perez-Remon Joaquin 113

Perin Casey 268

Perrett Roy W. 350

Pesala, Bhikkhu 286

Pirron z Elidy 231-234, 240-248, 253-254, 256, 262, 266, 322, 362

Plant Kathryn 366

Platon 22, 100, 225, 339, 359

Polak Grzegorz 104

Politis Vasilis 249

Potter Karl Harrington 122

Półtawski Andrzej 398

Probsthain A. A. 210

Pruden Leo M. 36

Punna Mantaniputta (p. Punnna Mantāniputta) 73, 284

Purusza (s. Purușa) 127

Putnam Hilary 117

Pyysiäinen Ilkka 365, 367

Qvarnström Olle 293

Rabbås Oyvind 249

Rabens Volker 233

Radich Michael David 78 
Reynolds Frank E. 113

Rhys Davids Caroline Augusta Foley 25-26, 34, 285

Rhys Davids Thomas William 77, 270, 285

Robinson Richard H. 340

Rohitassa (p. Rohitassa) 60-61

Ronkin Noa 111, 126, 130

Ruegg David Seyfort 210, 340, 359

Sacha-Piekło Małgorzata 103

Sady Wojciech 117

Sakka (p. Sakka) 273

Salomon Richard 156

Salvini Mattia 94

Samdhong Rinpoche 39

Samiddhi (p. Samiddhi) 58-59

Sandaka (p. Sandaka) 320

Sanday Eric 253

Sandhakatjajana, zob. Katjajana

Sangpo Gelong Lodrö 278

Sańdżaja Belatthiputta (p. Sañjaya

Belatthhiputța) 319-320

Sariputta (p. Sāriputta) 74, 124, 137, $165,167-169,173-175,184,213-$ $214,301,390,404$

Sayādaw Mahasi 286

Scarborough Milton 38

Schayer Stanisław 39, 208, 366

Schlingloff Dieter 279

Schmithausen Lambert 278

Scholem Gershom 369-370

Schopen Gregory 292

Sebastian C. D. 384

Sekstus Empiryk 238-240, 245, 247-

$250,252-258,262-263,265-269$
Shaoyong Ye 204

Sharf Robert H. 373

Shulman Eviatar 366

Siakra, zob. Kausika

Siankara (s. Śañkara) 382

Siantidewa (s. Śāntideva) 197

Siariputra (s. Sāriputra), zob. Sariputta

Siderits Mark 122, 154, 188, 193194, 204

Silk Jonathan A. 155, 197, 382

Skilton Andrew 197

Slocombe William 28-29

Smart Ninian 365

Smith Douglass 117-121, 359

Sobota Adam 399

Sokrates 242

Sprung Mervyn 209

Stace Walter Terence 368-369, 371

Staël-Holstein Alexander von 15

Stcherbatsky Theodor 38-39, 208, 366

Stede William 77, 270

Streight David 38

Striker Gisela 253

Stróżewski Władysław 24

Subhuti (s. Subhūti) 165-166, 168-

$170,172-173,179-186,190,345-$

$$
\text { 346, 376, 378-379, 387, } 390
$$

Suzuki Daisetsu Teitaro 39, 367

Suzuki Shunryū 399

Svavarsson Svavar Hrafn 249, 258

Szahaj Andrzej 388

Szczubiałka Michał 116

Szubka Tadeusz 109

Szymańska Beata 367 
Śliwczyńska Bożena 128

Tanji Teruyoshi 382

Tathagata (s., p. Tathāgata), zob. Budda

Thomas Edward J. 34, 285

Tillemans Tom J. F. 340, 382

Timbaruka (p. Timbaruka) 86

Tracy David 113

Tymon z Fliuntu 241, 246-248, 267

Upasiwa (p. Upasiva) 81

Vaidya Paraśurāma Lakshmaṇa 16, 166, 374

Vallée Poussin Louis de la 15, 34, $36,204,232,278,365-366,374$ Vanderveken Daniel 361

Vélez de Cea J. Abraham 211-212, 395

Vernant Denis 361

Vogt Katja Maria 268

Vohnson Pamela 38

Waczczhagotta (p. Vacchagotta) 72,

$80-81,113,139,160,272,320$

Wada Toshihiro 382

Wadziira (p. Vajirā) 88, 91

Walleser Max 210

Walshe Maurice 77
Warder Anthony Kennedy 209-210

Wasubandhu (s. Vasubandhu) 36, 49, 56, 396

Watts Jeffrey Douglas 149

Weeraratne W. G. 78

Welbon Guy Richard 33-34

Westerhoff Jan 37, 40, 204, 340

Wezler Albrecht 278

Whitaker Justin 359

Whitney William Dwight 176

Wick Peter 233

Wilkinson Robert 366

Williams Paul M. 123, 148, 292

Wisakha (p. Visākha) 73-75

Wong Andrew D. 255

Wood Thomas E. 40, 45

Woodward Frank Lee 65

Wynne Alexander 32, 66, 111-116,

$119,122,211,278$

Yao-Ming Tsai 379

Yün-hua Jan 210

Zaehner Robert Charles 369

Zalta Edward N. 253

Ziemińska Renata 238-240

Znaniecki Florian 23

Żylicz Leon 279 



\section{Indeks rzeczowy}

Indeks obejmuje wyłącznie istotne wystąpienia terminów w ich znaczeniu technicznym

abhidharma 36, 44, 46, 49, 100, apatheia 26, 240, 252; zob. bezna$101,113,122-123,131,143, \quad$ miętność

203, 208-209, 216, 353, 361

abhidharmicy 100, 104

abhidharmiczny/abhidharmiczna

$35,44-46,95,97-98,100-101$, $103,113,117,122,133,149$,

$177,181,202,208,286,325$, 397,399

adiaphora 241

adwajtawedanta (s. advaita-vedānta)

$37,126,382$

adżiwika (p., s. ajìvika) 129

afirmacja (p., s. abbivadana) 70, 77,

$81,99,102,114,124,402-403$;

$z o b$. afirmacja istnienia

anepikrita 241

anihilacjonista (p., s. uccheda-vādin)

32,86

anihilacjonizm (s., p. uccheda-vāda)

32 , 86-87, 100, 104, 128, 202-

203, 391; por. unicestwienie

antyrealizm 65, 104-123; por. realizm apbasia 239, 243, 246, 267, 362;

zob. niewyrokowanie

apofatyczny 108, 119, 121, 124, 159,372

astatbmēta 241, 243

ataraxia 233, 240, 243-244, 247, $249,252-253,258,267,362-$ 363 ; zob. spokój umystu; uspokojenie umystu

ateizm 26-27

atman (ätman) 127, 367, 380; zob. jaźń

awersja (s. dvesa, p. dosa) 31, 75, $302,318,332,363,402-403$

badacz

badacz w sceptycyzmie (skeptikos) 239

badacz w buddyzmie (p. vimamsī) 321, 334

bezjaźniowość (s. anātman) 113, 242; zob. niejaźń 
beznamiętność (apatbeia) 240, 266 bezpragnieniowość (p. viragga) 220, 298

błąd poznawczy $62,70,80-81,87$, $96-97,103,106,123,145,160$, $187,218,223,225,308-310$, $312,325,336,345-348,380-$ 381, 392, 398, 401-402; zob. niewiedza

bóg 24, 33-34, 100, 114, 119, 126$127,165,180,183,185,187$, $273,346,367-368,372,384$ jako byt konieczny 26-27, 385386, 394

brahman (s. brabman) jako absolut w tradycji wedyjskiej 127, 384 brak samobytu (s. nibsvabbava) 3536, 162-163, 192, 385; por. samobyt

byt (s. sat, p. sant, s., p. bbãva) 22, 24-25, 32, 39, 44, 70-71, 76-77, $97,99,101,122-123,126-127$, $144-145,154,163,179-180$, $183,186-190,192,195-196$, 199-200, 206-207, 211, 216, 222, 226-227, 232, 242, 271, 297, 309, 351, 359, 377, 381, 384, 386, 401-403; por. istnienie; niebyt

absolut 38, 100, 126, 338, 366, 372, 385-386, 389

absolutny 33, 37-38, 338, 384$385,389,394$

bytowa pierwotność 171-172 bytowa pochodność/zależność 101,136 nominalny (s. prajñapti-sat) 381 opozycja bytu i niebytu 216, 222,391 ; zob. opozycja istnienia i nieistnienia

transcendentny 388

całkowita zależność (s. idam-pratyayata-matra) 206; zob. fakt warunkowania

cecha/znak (s. lakṣana) 178, 200, 242, 374, 376, 385

akcydentalna 195

istotna 195

chwytanie (p. gabana, pariggaba) 139, 274, 282, 292, 300; zob. Ignięcie

codzienna praktyka (s. saṃvyavabära, vyavabāra) 25, 207-208

czternaście kwestii pozostawionych bez odpowiedzi (s. avyākrta-vastūni) 72, 113, 121, 273, 286, 320

cztery szlachetne prawdy (s. catväry arya-satyāni) 48, 60, 74, 146, 227, 279, 301

czujność (p. sampajana) 300

dharma (s. dharma, p. dbamma); zob. natura rzeczy; podstawa rzeczy

jako cnota 376-377

jako dobra/prawdziwa nauka/prawo (s. sad-dbarma, p. sad-dbamma) 53, 87, 93, 152, 174, 198, 202, 219-220, 225, 290, 334, $349,374,387,408,411$ 
jako ostateczny czynnik rzeczywistości / jakość 36, 44, 95, 97, $101,122-123,165,170-175$, 178-182, 186, 190, 212-213, $325,366,383,386,397,399$

jako zjawisko 157, 159, 161, 216-217, 378-380

dogmatyk 247, 252-253, 256-257, 259-260, 262-263, 265, 360 dogmatyk (p. nivissa-vädin) według tradycji buddyjskiej 296 leczenie dogmatyków 263 szaleństwo/szał dogmatyków 263, 267-268

dogmatyzm 239, 245, 251, 253, 256, 263-264, 269

doskonałość mądrości (s. prajña-päramita) 49, 156, 165-167, 169-173, 178-179, 182-184, 187$188,210,292,346,366,369$, $375-378,383,385-386$ doświadczenie mistyczne 278, 339, $365,368-373,384,389,395-$

396, 399; por. niewyrażalność doznanie/uczucie (s., p. vedana) 73, $88,125,128,134,138-139,144$, $184,215,219,272,284,300$, $312,316-317,344-345,356,363$ droga środka (s. madhyamā pratipad) 53, 153; zob. środkowa droga dyskusja (p., s. vada) 91, 297, 305,

307, 347, 358, 360-361; zob. spór dyspozycje/formacje wolicjonalne

(p. samkbara) 73, 90, 93, 134$135,144,219,236,284,408,411$ energia (p. virya, s. virya) 238, 361 epoché 239, 246, 252, 267, 362 epochē według fenomenologii 397-398

eternalizm (s. śásvata-vada, p. sassata-vāda) 71, 85-87, 100, 104, 128-129, 202-203, 391; por. trwanie

fakt warunkowania (p.idappaccayatā, s. idam-pratyayata) 147; zob. stan bycia tym uwarunkowanym falibilizm 29

fałsz (s. anrta, p. musā) 48, 198, 290, 297, 309, 316, 318-319, $323-325,345,353,359-360,393$ w sceptycyzmie $239,241,243-$ 244, 246, 248, 250, 252, 257, 361-362

fatalizm (p. niyati-vada) 128 filozofia pustki (s. śúnyatā-vada) 40, 153, 382; zob. madhjamaka forma (materialna) (p., s. rūpa) 58$59,67,72-73,76,78-79,81,90$, $118,134,144,170,172,175$, $179,184,215,219,282,284$, $310,312,327-328,344-345$, $378,383-385,389,393-394$ fundament $37,98,100,191,226$ generalna teza naturalnego nastawienia $381,392,397-398$ ghupiec (p. bāla) 175, 177-178, 288290, 308, 389-390 
iluzja (s., p. maya) 179-180, 219, 402

indywidualne istnienie (p. sakkaya) 73-74; zob. poczucie indywidualnego istnienia

innobyt (s. parabhāva) 192-195, 204, 381; por. samobyt

istnienie (s. astita, p. atthita) 24, 29 ,

32-33, 35-38, 43-49, 54-56, 64, 67-68, 70-71, 73, 76, 79-80, 82, $86,89,92-100,102-103,109$, $114,116,118,120-121,124-$ $125,130,144-146,149,154$, $157-158,160,163-164,168-$ $169,175,177-178,185,187$, $189,191-192,195-203,205$, $212-213,216,221-223,225-$ 227, 283-284, 288, 309, 311, $324-325,339, \quad 347-348,352-$ $353,383-385,391,396,401-$ 403; por. byt

afirmacja istnienia 70, 77, 81, 99 dwójnia (s., p. dvaya) istnienia i nieistnienia 55-56, 67, 83, 411 intuicja istnienia $71,97,105$, $158,160,190,200,211,402$ opozycja istnienia i nieistnienia 75, 154, 158, 160, 177, 198-199; por. opozycja bytu i niebytu pragnienie istnienia (p. bhava-tanba) 74

transcendentne $111,116,143$

jaźń (s. atman, p. attan) 32, 34, 44, 71-73, 75-77, 83, 85-87, 91-93, $100,112-114,116,122,127$,
$157,159-160,179-180,182$, $184-185,188,190,214-218$, $221,223,271-272,288,318$, $325,328,333,336,367,377$, 380, 391, 402, 411; zob. atman język (p. nirutti) 103-104, 111, 335-336, 347, 379, 389, 392, 394; por. codzienna praktyka jogaczara (s. yogäcara) 35, 38, 368369,383

karman (s. karman) 44, 57, 79, 135 , 235, 286, 360, 375

katafatyczny 119

koncepcja "niejednostronności”

[prawdy] (s. anekānta-vāda) 129 konieczność 27, 129, 146, 188

konieczność przyczyny 133, 140143, 149; por. wystarczalność przyczyny

kontakt (p. phassa) 80, 87-88, 118, $120-121,125,134,137,144$, $184,215,295,312,344$

konwencja (s. samvrti, p. samvuti) 103-104, 206, 208, 283, 335, 363-364, 387; zob. prawda konwencjonalna

konwencjonalny/konwencjonalnie $88,110,201,206,220,336$, 346-347, 373, 383

w sceptycyzmie 254, 363-364 kraniec/kres (p., s. anta) 61-62, 67, 86-87, 93-94, 96, 100, 157, 159$160,175-176,196-197,199-$ $200,202,408,411$ 
kryterium poznawcze (s. pramāna) 344

w sceptycyzmie 257

kwietyzm 26, 275

leczenie; por. terapia

dogmatyków wedhug sceptycyzmu 263

z poglądów według madhjamaki 343

Ignięcie (p., s. upādāna) 43, 55-56, 71, 73-76, 79, 82-84, 90, 134, $144,181,220,226,236,272$, 282-287, 289, 303, 306-307, $318-319, \quad 325-326, \quad 333-337$, $341,352,357,359-360,362$, 380, 389, 391-392, 394, 396397, 411; zob. chwytanie

lgnięcie do poglądów (p. dițţbupādāna) 284-287, 290, 292293, 298, 303

madhjamaka (s. madbyamaka) 3441, 45-46, 49, 53-54, 153-154, $162,183,187,191-192,195$, 197-198, 200, 202, 204, 206, 208-209, 211-212, 216, 218, $221,223,226,232,234,238$, $340-341, \quad 343-344,346-350$, $353-356,366,368-369,372-$ $374,380,382-387,389-390$, 392-394, 396-398, 401; zob. filozofia pustki

prasangika (s. prāsañgika) 349

swatantrika (s. svatantrika) 349 magia 278, 317 magiczny 278-280

magiczne rozumienie prawdy 279

mahajana/wielki pojazd (s. maba-yāna) 38, 46, 48, 62, 155, 157, 196, 209-211, 353, 368

mahajanistyczny 54, 154, 159, 166-167, 190, 197

materializm/materialiści (p., s. lokayata, s. cārvaka) 128-129

mądrość (s. prajñā, p. pañ̃̃a) 90, 151, 178, 210, 236-237, 274, $326,333,358,377,383,396$, 403-404; por. poznanie; doskonałość mądrości

oko mądrości (s. prajñāa-cakșu) 221

trzy rodzaje mądrości 335, 361, 396

właściwa mądrość (s. samyak-prajīā, p. sammappañ̃̄a) 90, 151, 291-292, 328; zob. właściwe poznanie

medytacja (bhāvanā) 57, 88, 118$119,212,278,335,361-363$, 383, 396-398

milczenie $114,160,199,272,318-$ $319,347,372,374-375,387-$ $389,392,394-395$

mimansa (s. mìmamssā) 37

mistycyzm 338-339, 365, 368, 373, 384, 393-394; por. mistyka mistyka 365-367, 369-370, 373, 375, 384; por. doświadczenie mistyczne

mistyka halucynogenów 370 
mniemanie $25,69-70,92,317,342$, 393

mniemanie w sceptycyzmie 255256

mniemanie według Platona (doxa) 359

moment (p. kbana, s. kṣana) 101 myśl o przebudzeniu (s. bodbi-citta) 166, 181-182, 390

myślenie (p. vitakka) 273, 312

nakładanie/przypisanie fałszywej natury (s. viparita-svarūpädbyāropa) 382,387

natura (s. prakrti) 143, 166

natura rzeczy (s. dharmatā) 184,

385-386; zob. porządek rzeczy naturalizm (s. svabbavva-vada) 128 nazwa (p. s. naman, p., s. adbivacana) 186, 336; por. pojęcie

nazwa jako całość psychiczna $w$ relacji do formy 134,175 negacja

jako przeciwieństwo asercji 305, 325,345

negatywizm 33

neopirronizm 234, 240, 246, 269-

270, 319; zob. sceptycyzm

nicość/Nicość 22-25, 28, 35, 37-

$38,76,100,163,200,226,377$, 384-385, 394-395, 401

niebyt (s., p. asat, abbàva) 22, 24$25,76,100,127,154,189,195-$ 196, 211, 216, 222, 297, 309, 381, 386, 391, 401-402; por. nicość; nieistnienie niechwytanie $179,322,346$

niechwytanie zadnych dharm (s. sarva-dbarmāparigrbìta) 170, 274 nieistnienie (s. nāstitā, p. n'attbitā) 21, 24, 33, 35-38, 43-44, 46-49, 54-56, 64, 67-68, 71, 73, 76-77, 79-82, 89, 91-100, 103, 111, $113-114,116,121,123-125$, $130,145,154,157-158,160$, $165,168-169,171,188-189$, 195-203, 211, 213, 216, 221$223,225-227,309,325,347-$ $348,351-353,355,391,401-$ 403, 411; por. niebyt

pragnienie nieistnienia (vibbava-tanba) 74-75

w relacji do niewiedzy (avidya) 175-178

niejaźń (s. anatman, p. anattā) 113, 185, 217, 223, 288, 396, 402; zob. bezjaźniowość

niejaźniowość (s. nairātmya) 113, 157, 159-160, 212-213, 216, 218-220, 288

nielgnięcie / brak lgnięcia 48, 120$121,152,165,180-182,316$, $340,342,352,359,361,378-$ 379, 390-391, 395, 411

niemyśl (s. acitta) 166-170, 181, 390

nieobecność niepokoju (taracbē) 252 nieodpowiednia uwaga (p. ayoniso manasikāra) 300; zob. odpowiednia uwaga niepowstawanie (s. anutpada) 183, 207, 374 
niesamobyt (s. asvabava) 162; por. brak samobytu

niesamobytność (s. asvabbavatva, nibsvabbavatva) 90, 188, 212, 217, 220; zob. niesubstancjalność niesubstancjalność (s. asvabbavatva, nibsvabbavatva) 161-162, 212, $219,339,385$; zob. niesamobytność

nietrwałość (s. anityatd) 56, 103, $122,136,147,157,160,183$, 207, 220, 242, 316, 374

niewiedza (s. avidya, p. avijja) 86, 93, 96, 124, 134-135, 137, 140, $142,144,147,164,172,190$, $200,216,223,235,280,282$, 288-290, 297, 311, 318-319, $379-380,382,388,395,408$, 411 ; por. błąd poznawczy

w relacji do nieistnienia (s. avidya) 175-178

niewyrażalność (jako cecha doświadczenia mistycznego) 369, $371-373,375,387$

niewyrokowanie (aphasia) 239-240, 243-244, 246-250, 253, 267, 362 niewzruszoność dhammy (p. dhamma-niyāmata) 147

nihilizm 21, 25-30, 33, 38-40, 89, 225, 338, 386

aleteologiczny 29-30

egzystencjalny 29-30

epistemologiczny 22, 29-30, 32, 36, 44, 271

etyczny/moralny 29-30, 44, 87 metafizyczny $22,29-30,32,36$, 117, 270-271

zarzut nihilizmu 21, 31-37, 44$45,199,234,350,402-403$

nirwana (s. nirvana; p. nibbana) 33, $35,38,107-108,115,175,180$, $199,212,214-215,220,222-$ $223,236,272,278,280-281$, 290, 293, 301-302, 340-341, $351-352,362,365,374,376-$ 377, 380, 386, 390-392, 403; por. wyzwolenie

njaja (s. nyaya) 37, 122, 371

oderwanie (p., s. viveka, s. viviktata) 224, 295, 326

odpowiednia uwaga (p. yoniso manasikära) 300

ogniwo (p., s. nidana) 132, 134138, 140-142, 144, 148, 157; zob. podstawa

omroczenie (p., s. moba) 31, 274, 302, 326, 332; por. niewiedza ontologia 27, 69-70, 96-98, 223

dystrybutywna 97-98, 158, 325 fundamentalna 97-98

typy ontologii 70 opozycja bytu i niebytu 216, 222; $z o b$. byt

opozycja istnienia i nieistnienia 75 , 154, 158, 160, 177, 198-199; $z o b$. istnienie osoba (s. pudgala) 36, 163-164, 180, 377 
panteizm 26

panteistyczna ontologia 70 paradoks 62-63, 171-172, 207, 377,

379

paradoksalny 185, 206, 372, 376

paradoksalność 185

pesymizm 26

podłoże/podstawa (s., p. upadbi) 55,

$82,144,236,411$

początek (s., p. samudaya) 130; zob.

powstawanie

poczucie indywidualnego istnienia /

poczucie nja" (p. sakkāya-ditțhi,

s. sat-kaya-drștil) 72-73, 75, 77-

79, 82, 106, 124, 190, 212, 284,

\section{5}

przeświadczenie o indywidualnym istnieniu 72,282

„pod włos” (p. patiloma, s. pratilo-

ma) 135,142

podstawa (p., s. nidana) 130, 132,

\section{7; zob. ogniwo}

pogląd (s. drșți, p. dițţbi, s. darśana)

71, 76-80, 85-86, 91-92, 101,

$104,114,119-120,126,128$,

$139,150,163,202,217,272-$

$275,279-281,285,287,289$, $292-301,303,305-311,314-$

$317,323-326,328-335,337-$

$339,341-345,347,351,353$,

356-362, 364, 391-394, 403,

408; por. teza

dążenie do poglądu (p. dițthi-gata) 296, 326; por. pragnienie posiadania poglądu

właściwy pogląd (s. samyag-drsțti,

p. sammä-ditṭi) 43, 48, 54-55,
79, 88-90, 176, 287, 290, 307, 391,411

niewłaściwy/błędny/fałszywy pogląd (s. mithyä-drșți, p. miccbā-dittbi) 71-72, 78-79, 176, 286287, 293, 330, 333-334, 340$341,360,392$

pogląd według sceptycyzmu 233, 244, 362-364

pojazd stuchaczy (s. śrāvaka-yãna) 210

pojęcie $36-37,67,74-75,77,87$, $92,114,203,212,216,270$, 298-299, 317, 320, 335, 337, $344,358,377,380$

pojęcie/określenie (p. paññatti, s. prajñapti) 58-59, 62, 104, 270, 312,$336 ; z o b$. względna nazwa pojęcie/postrzeżenie (s. samjiña, p. sañña) 118, 182, 184, 190, 273-274, 294, 299, 311-312, 326-327, 377

pojęcie/wyobrażenie (s. kalpana) 221

pojęciowe rozplenienie (s. prapañca, p. papañca) 207, 225, 273, $275,312,327,374$

pokarm (p. abara) 87, 131, 144 poszukiwacz (zetetikoi) 239

porządek rzeczy (s. dbarmata-niyāma) 189, 386

porzucenie (p. pabana) 6, 236, 328, 403-404

postrzeganie, percepcja (s. pratyakșa) 344 powód (p. kärana) 130 
powstawanie (s. samutpāda, p. samuppāda, s., p. samudaya) 60, 63-64, 74, 76, 84-91, 126, 144, 148, 183, 201, 207, 222, 227, 235, 291, 301, 317, 378, 411; zob. początek; zależne powstawanie

powstawanie indywidualnego istnienia (p. sakkāya-samudaya) 74

przypadkowe powstawanie (p. adbicca-samuppāda) 126

pozaświatowa (s. lokottara, p. lokuttara) 218-219

poznanie (s. jñana, p. ñāna) 89, 199, 313-314, 333, 403, 411; zob. wiedza

bezpośrednie/wyższe/doskonałe poznanie (p. abbiñna) 69, 236, 334, 337, 403-404

błędne, fałszywe poznanie (s. mitbya-jñana) 359

pełne poznanie (p. pariñna) 236 poznanie wedtug Platona (episteme) 359

właściwe poznanie/mądrość ( $p$. sammadañña, s. samyak-prajũa, p. sammappañña) 69, 89-90, 302, 359

pożądanie (p. icchā) 92, 119, 220, 283, 296

pragnienie

pragnienie (kama) 236; zob. przyjemność zmysłowa

pragnienie (p. taṇbā, p., s. rāga, p., s. lobba) $31,72,74,134,138-$
139, 144, 282, 298, 302, 332; por. żądza

pragnienie istnienia (p. bbava-rāga, bbava-tanhbā) 74, 146, 311 pragnienie nieistnienia ( $p$. vibbava-tanba) 74-75

pragnienie posiadania poglądu (p. ditțbi-rāga) 306, 326

pragnienie zmysłowe (p. kama-räga, p. kāma-taņba) 74, 306 pragnienie/intencja/pożądanie (p., s. chanda) 79, 273, 282, 296, 310,313

pożądanie przyjemności zmysłowej (p. kamacchanda) 282

prawda (s. satya, p. sacca) 198, 237, 297, 308-309, 329-333, 345, 352

koncepcja/teoria/idea dwóch prawd 62, 94, 104, 123, 373

konwencjonalna (s. samvrti-satya, p. samvuti-sacca) / codziennej praktyki (s. vyavabara-satya) 104, 123, 200, 206-207

ostateczna (s. paramartha-satya, p. paramattba-sacca) 123

strzezienie prawdy (p. saccānurakkbana) 331

przedstawienie (p. maññand) 90, 178, 280, 302, 308

przejrzysta (s. prabbāsvara) 166-167 przeświadczenie o indywidualnym istnieniu, zob. poczucie indywidualnego istnienia

przyczyna (s., p. betu) 125, 130-131, 133, 191, 203; por. związek przy- 
czynowo-skutkowy; teoria przyczynowości; zależne powstawanie przyjemność zmysłowa (kama) 74, 282, 284, 306 przywiązanie do praktyk i ślubów religijnych (p. sīlabbata-parāmasa) 282

pustka (s. śūnyatā, śūnyatva, p.

suñ̃ata, s. vivikta) 35-37, 39, $45-46,157,161-165,172,178-$ $179,181-185,187,199-201$, 207-215, 217-221, 225-227, $339,341-343,349,353,377$, 380-382, 386-387, 389, 393-394 pustka pustki (s. śūnyatā-śūnyatā) 163

pycha (p., s. mana) 166, 282, 311, 335-336, 390

racjonalista/logik (p. takkì) 321, 334

realizm $38,65,105-106,109,111$, $113,115,118,120-121$

realizm abstrakcyjny 109

realizm skonstruowany 115

równa siła uzasadnień / równosilność sądów (isostenia) 239-240, 246, 250-252, 260, 263, 266, 269, 297

równowaga umysłu (s. upekșa) 118, 182, 296, 395, 397

samobyt (s. svabbava) 35, 162, 171, $183,185,188,191-194,200-$ 201, 203-207, 380, 382-384, 386, 392; por. innobyt brak samobytu (s. nibssvabbāva) 35-36, 162-163, 192, 385 różne znaczenia „samobytu” 191, 380-381

samoistność 101, 171-172

sankhja (s. sämkbya) 126, 143, 204 sarwastiwada (s. sarvasti-väda) 95, 131, 149, 203, 208-209

sceptycyzm 48, 231-234, 238-240, 244-245, 250-253, 255, 259262, 264, 266-270, 273, 275, 285, 296-297, 304, 312, 322, $329,331,339,343,350,353-$ $354,356,358-359,362-364$, 394; zob. neopirronizm

sceptycyzm akademicki 238-240 sceptycyzm jako terapia 250, 267 skalanie (p. kilesa) 157, 236, 332 skaza/wyciek (p. asava, s. asrava) 69, 235-236, 282, 294, 296, 301302, 335, 361, 411; por. wylew; związanie

skaza bytowania / [skłaniania sį̧ ku] istnieniu (p. bhavasava) 235, 282

skaza niewiedzy (p. avijjasava) 235, 282

skaza przyjemności zmysłowej (p. kämāsava) 235

skaza żywienia poglądów / [skłaniania się ku] poglądowi (p. ditṭbasava) 235, 282, 286, 294

skłonność umysłu (p. cetaso adbitţbana, s. cetaso 'dbișthana) 83, 91-92, 411; zob. umystowe stanowisko 
skłonność do ideacji i rozpleniania myśli (p. papañca-sañña-sañkba) 273

skupienie (p., s. samadbi) 90, 170, 173, 213, 236, 328, 379

skupienie na pustce (p. suññato samādbi) 213

skupienie zwane "nielgnięciem do / niechwytaniem żadnych dharm" 170, 173, 378-379

skutek (p., s. phala) 82, 126, 128$129,133,140,142-143,145-$ 146, 204-205; zob. zdolność do wywoływania skutku

sofista (p. venayika) 31-32, 270-271 spokój umystu (p. santi) 237, 274,

$317,323,362$

spokój według sceptyków 243, 245-248, 252, 254-258, 260268,362 ; por. ataraxia; uspokojenie umystu; apatbeia spór (p., s. vada, viväda) 91, 118, 139, 197, 274, 290, 295, 301, $304-307,311-312,316,319$, $326,344-345,348-349,351$, 358; zob. dyskusja stałość dhammy (p. dhammațțitata) 147

stan bycia tym uwarunkowanym (p. idappaccayata, s. idam-pratyayatā) 146-147, 206; zob. fakt warunkowania

starość-i-śmierć (p., s. jarā-marana) 125, 134, 141, 283 szczęście (eudaimonia) 241, 362 ścieżka (s. märga, p. magga) 40, 174-175, 227

bodhisattwy 172

ośmioraka 90, 280, 287, 403

transcendentalna 140

środkowa droga (s. madhyama pratipad, p. majjbima patipada) 40, 54, 86-87, 92-93, 95, 100, 123, $151,154,157-159,165,175$, 190, 196, 201-202, 386, 391, 403, 408, 411; zob. droga środka idea środkowej drogi 96-98, 157, $160,164,211,218$

świadomość (s. vijñana, p. viñ̄āana) 58-59, 73, 76, 87-88, 90, 120, $125,134,144,184,215,219$, 284, 312, 344-345

świat (p., s. loka) 56-67, 74, 78, 89, 101, 187, 189, 199, 217, 411

świat formacji (p. sankkbara-loka) 57

świat istot czujących (s. sattva-loka, p. satta-loka) 57 świat-pojemnik (s. bbajana-loka) 57

świat przestrzenny (p. okasa-loka) 57

tathagatagarbha (s. tathägata-garbba) 398

takość (s., p. tathata) 147, 185, 188189, 385-386, 394

teoria/koncepcja przyczynowości 131, 143, 203, 208; por. związek przyczynowo-skutkowy terapia, por. leczenie 
w sceptycyzmie 250, 267

tetralemat (s. catuṣ-koți) 71-73, 86-

$119,126,129-130,168-169$,

186, 188-189

teza (s. pratijña, pakșa) 339, 345,

348, 393; por. pogląd

therawada ( $p$. thera-vãda) 65, 95,

106, 149, 365, 368

tożsamość/jedność (p. ekatta, s. eka-

tva) $69,96,125,145,179,191-$

192, 195, 200, 206-207, 216,

386, 401

trwanie (s. śāśvata) 71, 76, 86, 200,

288; por. eternalizm

trzy ćwiczenia 90

trzy znaki egzystencji (s. tri-lakṣana)

242

(umysłowe) stanowisko 92, 185,

316, 350; por. skłonność umystu unicestwienie/zniszczenie (s., p.

uccheda, s. vināsa, p. vināsa) 23, $31-32,85-87,163,183,199-$

200, 202, 207, 222, 271; por.

anihilacjonizm

upodobanie (p., s. abbinandana) 68-

69, 70, 92, 298, 301-302, 352

upodobanie/skłonność [do poglądu,

idei] (p., s. ruci) 330, 332

uspokojenie umystu (ataraxia) 240,

244, 246-247, 252, 257, 262

ustanie/ustawanie/unicestwienie/za-

nik (p., s. nirodba) 60, 63-64,

$74,89,93,132,150,172,227$,

408, 411

uważność (p. satima) 300, 332 wajsieszika (s. vaiśeșika) 37, 122

warunek (s. pratyaya, p. paccaya) $125,130-131,141-142,150$, 191, 204, 207, 291

wątpienie (p. katbam-katba, p. vicikiccha) 237-238, 282, 291, 311-315, 317, 319-320, 322

wenajika (p. venayika) 31-32, 270272; por. sofista

wgląd (s. vipaśyanā) 221, 278, 362, 366, 397

wiara/zaufanie (p. saddba, s. śraddbā) $140,175,281,300,314,330-$ 334, 342-343, 393

widzenie (s. paśya, p. passa, s. darśana) 83, 89, 92, 189, 196, 202, $235,299,301,311,322,332$, 346, 352, 357-358, 362-363, 403 widzenie jako bezpośrednia naoczność (s. darśana, p. dassana) 150, 301, 309

widzenie rzeczy, jaką jest (s. yatba-bbùta) 90-91, 146, 236-237, $299,307,310,328,342,356-$ $357,360,362-363,391-394,403$ widzenie samobytu 381-382 wiedza (p. ñāna, s. jñana,) 296, 303, 322; zob. poznanie

więzy/kajdany (p. samyojana, p. gantha) $217,238,274,282,300$, $302,326,336$

własna natura (s. svarūpa) 387

fałszywa natura (s. viparita-svarūpa) 382

wyciszanie (s. samatha, p. samatha,

p. upasama) $221,366,403$ 
wylew/rozlewisko (p. ogha) 33, 282, 294

wyrzeczenie (p. cāga) 237

występek (papa) 199; por. cnota

wyzwolenie (s. moksa; s. vimukti; p. vimutti) 43, 62, 64, 67, 92, 108$109,124,136,140-144,150-$ $152,161,164,197,199,214$, 216, 220-221, 225-226, 235, 238, 272, 276-277, 292, 309, $318,337,340-341,347,356$, $361,392,402-403$

względna nazwa (s. prajñaptir upadäya) 201

„2 włosem" (anuloma) 134, 142, 157; zob. zależne powstawanie zależne powstawanie (s. pratītya-samutpada, p. paticca-samuppāda) 48, 54, 96, 119, 124, 130$131,134-138,140-143,145-$ 151, 157-158, 201, 205, 207, $211,227,283,301,311$

zależne powstawanie $\mathrm{w}$ relacji do pustki 161-162, 201-203, 205, 208, 212, 227

zarzut bezczynności 254, 259

zawieszenie sądów (epochē) 239-240, 245-247, 250, 252-253, 256-
257, 263-268, 342, 362, 388; zob. epochē

zawieszenie opinii wedtug Buddy $125,272,332,362$

zdolność do wywoływania skutku (s. artba-kriya-karitva) 149 zespół (s. skandba, p. kbandba) 5556, 64-67, 72-79, 81-82, 90, 92, $99,101,103,106,112-113,122$, $134,139,170,172,179-180$, $184,188,215,220,235-236$, 271, 282-283, 325, 345, 378, 383,411

zespół warunków (p. betu-samūba) 133

znajdowanie upodobania (p., s. $a b$ binandana) 69-70, 298, 301302, 352

znak (s., p. nimitta) 172, 378

zręczne środki 94, 390

związanie/jarzmo/uwiązanie (p., s. yoga, samyoga) 282, 352

związek przyczynowo-skutkowy 131, 148; por. teoria przyczynowości żądza (s. trṣnā, raga, lobba) 139, 326, 352, 402-403; por. pragnienie 



\section{SUMMARY}

\section{Beyond being and non-being}

Buddhist philosophy against the charge of nihilism

The subject of this book is the so-called 'Buddhist nihilism'. I refer to it as 'so-called' because I view the category of nihilism as relative rather than absolute. In other words, a thought can be perceived as nihilist only in relation to another contrasting affirmatory thought. The Buddha teaches in the Kätyãyana-sūtra that one should give up the categories of existence and non-existence as they lack descriptive value. Therefore, from the point of view of a theory that affirms being (i.e. recognizes that the category of being/existence has a descriptive value), the Buddha's position may accurately be labelled as nihilism. Within that framework, the category of existence is treated as an objective one. However, this position loses its validity if it is considered from the perspective of the Buddha's teachings. According to the view of the Middle Way, treating being/existence as an objective category is a manifestation of a cognitive error. Undermining the objectivity of existence and non-existence, the Buddha revokes nihilism and affirmatism. He achieves this on two planes - the metaphysical and the epistemological.

The starting point of the work is a detailed analysis of the parallel Sanskrit and Pāli versions of the Discourse to Kätyäyana (Kätyāyana-sūtra / Kaccanagotta-sutta). I agree with the opinion of Mattia Salvini (Salvini, 2011) on the important potential consequences stemming 
from the seemingly small differences between these two versions in the expression of extremes that should be avoided. I argue that this is a difference between two types of ontologies, i.e. the fundamental and the distributive ontology. The first one is characteristic of the Sanskrit discourse, the second one of the Pâli version.

I maintain that the Buddha's understanding of existence and nonexistence is closely related to the way he approaches the issue of the self. The analysis of the self has a distinct character in the sense that the reflections pertaining to it are not analogous to those on the existence or non-existence of other objects. This analysis is meant to reveal the source of the very concept of existence, the moment at which the sense of existence is constituted. The Buddha shows that the concept of existence is constituted in the experience of one's own selfness. Sat-kaya-drsți is a paradigm for all existence. In that sense, the analysis of the self belongs to the fundamental ontology. We can also say that it is transcendental or phenomenological in its character. However, Abhidharma puts this analysis on an empirical plane. In other words, Abhidharma treats it as an inquiry into the question of whether the self exists. This contrasting perspective finds its reflection in the modification of the Pàli version of the Discourse to Katyayana through an introduction of a universal quantifier. While the opposition between existence and non-existence is fundamental in its character, the opposition between the judgments 'everything exists' and 'nothing exists' is formulated at the level of distributive ontology. The questions posed by the distributive ontology are not about understanding existence but about what exists. Within this ontology, the concept of existence is treated as a primary and objective concept. Therefore, from the perspective of philosophy which grasps our experience itself as a manifestation of a cognitive error, this means that the concept of existence is free from the aforementioned error. Here, Abhidharma departs from the message of the Discourse to Katyayana, in which understanding of the existence is treated as a problem. A sense of self, a sense of your own identity, is a paradigm 
for all concepts of existence and being (and thus of non-existence and non-being).

This understanding of existence corresponds to the understanding of the world as a phenomenon. In regard to the understanding of the world and the aggregates, I agree with the interpretation given by Sue Hamilton (Hamilton, 1999; Hamilton, 2000) and recently maintained by Alexander Wynne (Wynne, 2010; Wynne, 2015). At the same time, I point out the inconsistencies in the opinions of these researchers. On the one hand, they claim that the Buddha speaks only about phenomena; on the other hand, they state (Hamilton) or suggest (Wynne) that the Buddha accepts the existence of transcendent reality. Contrary to their assurances, they smuggle the concept of objective existence which describes this transcendent reality. Although this conviction can be found in contemporary anti-realism (e.g. in the works of authors such as Putnam or Dummett), I claim that it cannot be maintained with regard to the Buddha's position.

The question of understanding of dependent origination is a significant issue to which I devote a lot of attention in the first part of the book. In the Discourse to Kätyāyana, the seeing of dependent origination is a remedy for being stuck in both affirmation and negation of existence. Firstly, I show that the category of dependent origination relates only to experience, not to the alleged external world. Secondly, I show that the context for its assertion is a soteriological need, and thirdly, that according to this need, the Buddha is interested only in the aspect of necessity, not sufficiency of causal conditioning.

I further show that the approach revealed in the Sanskrit version of the Discourse to Katyayana was upheld in the early Mahāyāna sutras (Käśyapaparivarta-sūtra, Aștasāhasrikāa-prajñāpāramitāa-sūtra) and became the foundation for Nāgārjuna's texts. I claim that Nāgārjuna's critique of Abhidharma has its basis in a different way of understanding existence. Nāgārjuna opposes distributive ontology, according to which existence belongs to objects defined from their own site. His idea of emptiness is not revolutionary; it is a direct consequence of 
the analysis of the self which reveals that the concept of objective existence is constituted by a sense of selfness. In other words, the concept of dharma-nairatmya is not associated with the reinterpretation of the concept of pudgala-nairätmya by extending its meaning but a consequence of understanding existence as a transcendental category.

The second part of the book is devoted to the issue of the alleged scepticism of the Buddha and Nāgärjuna. In this part, I debate to the work of Christopher Beckwith (Beckwith, 2015). However, I am not discussing his historical thesis which claims that the inspiration for the thought of Pyrrho of Elis was early Buddhist thought. It cannot be ruled out with certainty that such inspiration did not take place. In turn, I focus on another much stronger thesis that Pyrrho's thought, in its content and structure, is a copy of the early Buddhist thought. In my work, I definitively reject this thesis.

I show that the analogies between the thought of Pyrrho and neoPyrrhonism and the early thought of the Buddha preserved in the Sutta-nipata (especially in the Atthaka-vagga) are superficial and apparent. I think that the main difference between Buddhist thought and Pyrrho's scepticism is, firstly, the orientation of the logical relations between the ideas that form the conceptual structures of both positions, and secondly, a completely different way of understanding the declaration of having no views. Although declarations of having no views seem to be similar in the literal expression, the meanings are not equivalent. This is due to several contrasting understandings of some of the key concepts. The first discrepancy is in the understanding of experience. In particular, it is in a difference of understanding what is natural: i.e. for a sceptic the experience of pleasure and unpleasantness is natural, and he or she can follow it making his or her decisions, whereas for the Buddha this is where the problem begins. Secondly, the traditions disagree in their understanding of the concept of the view. Classical scepticism comprehends the view only in an epistemological context, while for the early Buddhist thought the 
affective aspect is important. The psychological and cognitive context plays no role in classical scepticism. In contrast, in the Buddhist understanding, having a view is a manifestation of egotism and finds its expression in clinging. Furthermore, there is a divergence in the understanding of conventions and a different way of understanding of the final well-being.

In refuting Beckwith's thesis, the fundamental point of my reasoning is the distinction between the three types of people with regard to their attitude towards the discussion that appears in the Sutta- nipata IV.3.1. This distinction is important because it proves that for the early Buddhist thought the problem was clinging to every opinion as such (even to the true one) and not the ability to determine truthfulness or falsehood of a judgment. Finally, I argue that sceptics have no views, because they cannot have any. Buddhas have no views, because they don't need to have any. This is the principal difference between them.

Many scholars suggest that this sceptical attitude has become the most apparent in Madhyamaka philosophy. I reject this claim. In my opinion, Nāgārjuna's critique of cognitive criteria carried out in the Vigraba-vyavartani is not epistemological but ontological in its character. Nāgärjuna rejects not the idea of knowing as such, but the possibility of knowing in the world of things endowed with self-being. In the last chapter, I also reject the belief in the mystical nature of Madhyamaka philosophy. 


\section{Contents}

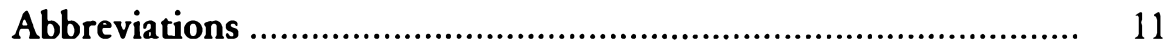

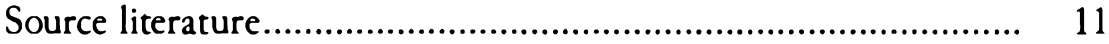

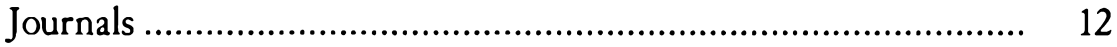

Other abbreviations.................................................................. 13

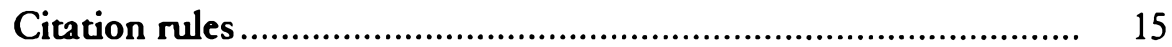

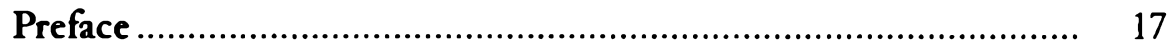

\section{Introduction}

1. The problem of nihilism .......................................................... 21

1.1. Nihilism as a descriptive and evaluative category.................. 25

1.2. Different concepts of nihilism ......................................... 28

2. The problem of Buddhist nihilism ............................................ 31

2.1. The Buddha as a nihilist ................................................... 31

2.2. Nihilism of Madhyamaka ................................................. 34

3. Methodological assumptions .................................................... 43

3.1. The aim of the work ........................................................ 43

3.2. What material will be studied............................................. 47

\section{Part one "IF THERE IS NO BEING..." BUDDHISM AS A PHILOSOPHY OF NOTHINGNESS?}

1. Beyond existence and non-existence, or how to understand the Buddha's Dharma 
1.1. The middle way in the Discourse to Kätyayana...................... 53

1.2. The idea of the world in the Buddha's thought ................... 56

1.3. Two extremes - existence and non-existence ........................ 67

1.4. The seeing of arising and ceasing as a remedy for existence and non-existence........................................................... 83

1.5. The principle of dependent origination as the middle way.... 92 1.5.1. Fundamental ontology and distributive ontology ........ 96 1.5.2. Anti-realism of the Buddha's thought........................ 104

1.5.3. Teaching on dependent origination............................ 123

2. Beyond being and non-being, or how to understand emptiness .... 153 2.1. The significance of the Discourse to Kätyāyana in Nāgārjun's thought

2.2. Existence and non-existence in early Mahāyāna literature ..... 155

2.3. The middle way as emptiness ............................................ 190

\section{Part two \\ TRUTH AS THE OBJECT OF CLINGING BEYOND EPISTEMOLOGICAL ABSOLUTISM AND NIHILISM}

1. The Buddha's teaching as scepticism...................................... 231

1.1. Knowledge, seeing, wisdom............................................. 231

1.2. What is scepticism?....................................................... 238

1.3. Sceptical tendencies in early Buddhism ............................. 270

1.4. Truth and the matter of cognitive attitude ......................... 276

1.5. Clinging to the truth as an epistemological problem ........... 285

1.5.1. Dispute as a way of expressing clinging..................... 304

1.5.2. Doubt as a way of expressing clinging...................... 312

1.5.3. The alleged internal contradiction .............................. 322

1.5.4. What is the role of a view as a representation? ........... 329

1.5.5. About the language of instruction ............................ 335

1.6. Why does Nāgārjuna not have his own views? .................... 338

1.7. Why does Buddhism have nothing to do with scepticism?.... 356

2. The seeing of emptiness and a mystical experience..................... 365

2.1. Buddhism as mysticism ..................................................... 365

2.2. Characteristics of a mystical experience................................ 369 
2.3. Madhyamaka as mysticism ............................................. 372

2.4. Emptiness and Nothingness ............................................ 380

2.5. The meaning of silence in Madhyamaka ........................... 387

2.6. Why is a yogic cognitive experience not a mystical experience?................................................................. 395

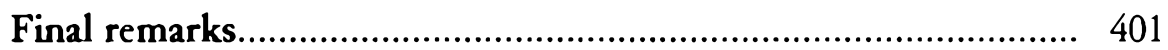

\section{Additions}

Appendix 1. The discourse to a brahmin (Brabmana-sūtra) ............. 407

Appendix 2. The discourse to Kātyāyana (Kätyāyana-sūtra) ............. 409

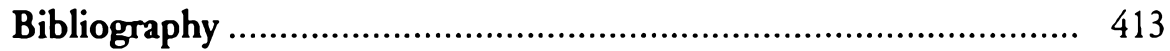

Primary source literature ...................................................... 413

Buddhist literature ….................................................... 413

Indian non-Buddhist literature ......................................... 422

Non-Indian literature .................................................... 423

Secondary source literature...................................................... 423

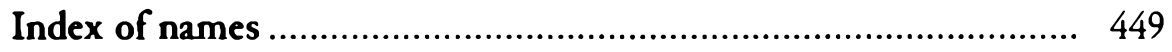

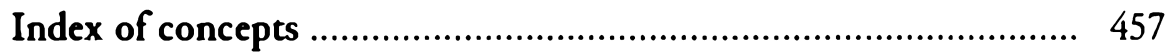

Summary. Beyond being and non-being. Buddhist philosophy against the charge of nihilism 



KRZYSZTOF JAKUBCZAK - filozof, kulturoznawca, wykłada w Instytucie Bliskiego i Dalekiego Wschodu Uniwersytetu Jagiellońskiego. Jego zainteresowania badawcze obejmuja ogólnie myśl i kulturę indo-buddyjska. W szczególności zajmuje go buddyjska filozofia, w tym tradycja madhjamaki - doktryna głoszq̨ca pustkę wszystkich rzeczy. Autor licznych publikacji poświęconych filozofii, a ostatnio także sztuce buddyjskiej.

Jeśli wartościowq ksiq̨żkq jest ta, w której przyłłaczajq̨ca większość zdań jest wartościowa, a te wartościowe zdania pojawiaja się w ksiq̨żce we właściwym miejscu, to Krzysztof Jakubczak napisał wartościowq ksiq̨żkę. Właściwe rozmieszczenie zdań oznacza zarówno ich usytuowanie w odpowiednich zbiorach, stanowiq̨cych części ksiq̨żki, jak i ich - zdań i zbiorów zdań - właściwe następstwo. To pierwsze oznacza, że ksiq̨żka jest wartościowa ze względu na udanq̨ konstrukcję, zaś to drugie, że jej treść jest spójna, co zapewnia tej konstrukcji zwartość. Natomiast za kryteria wartościowości samych zdań przyjmuję tu poprawność formalnq, sprawność językowq, a nade wszystko odkrywczość ich treści. Ta ostatnia oznacza nie tylko to, że treść zdań ujawnia czytelnikowi coś, czego przed ich lekturq̨ nie wiedział, ale i to, że owo coś nie było znane bqdź nie zostało w tak jasny sposób wyeksplikowane przez badaczy podejmujących rozważane w książce zagadnienia.

Z recenzji wydawniczej prof. Krzysztofa Kosiora
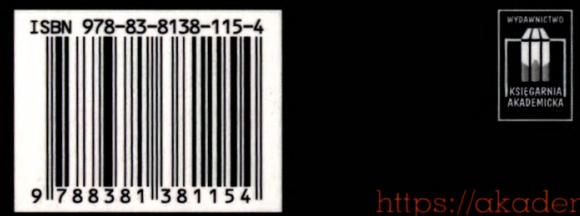